Portland State University

PDXScholar

Spring 9-5-2017

\title{
GIS Spatial Analysis of Arctic Settlement Patterns: A Case Study in Northwest Alaska
}

Justin Andrew Junge

Portland State University

Follow this and additional works at: https://pdxscholar.library.pdx.edu/open_access_etds

Part of the Anthropology Commons, and the Geographic Information Sciences Commons Let us know how access to this document benefits you.

\section{Recommended Citation}

Junge, Justin Andrew, "GIS Spatial Analysis of Arctic Settlement Patterns: A Case Study in Northwest Alaska" (2017). Dissertations and Theses. Paper 3878.

https://doi.org/10.15760/etd.5766

This Thesis is brought to you for free and open access. It has been accepted for inclusion in Dissertations and Theses by an authorized administrator of PDXScholar. Please contact us if we can make this document more accessible: pdxscholar@pdx.edu. 
GIS Spatial Analysis of Arctic Settlement Patterns:

A Case Study in Northwest Alaska

\title{
by
}

Justin Andrew Junge

A thesis submitted in partial fulfillment of the requirements for the degree of

\author{
Master of Science \\ in \\ Anthropology
}

Thesis Committee:

Shelby L. Anderson, Chair

Kenneth M. Ames

David Banis

\section{Portland State University \\ 2017}


(C) 2017 Justin Andrew Junge 


\begin{abstract}
Archaeologists have been interested in relationship between environmental variability and cultural change for the last six decades. By understanding how, when, and why humans adapt to environmental change, archaeologists and anthropologists can better understand the development and complexity of human cultures. In northwest Alaska, archaeologists hypothesize that environmental variability was a major factor in both growing coastal population density, with large aggregated villages and large houses, between 1000 and 500 years ago (ya), and subsequent decreasing population density between 500 ya and the contact era. After 500 ya people are thought to have dispersed to smaller settlements with smaller house sizes in coastal areas, and perhaps, upriver. This settlement pattern was identified through research at four site locations over 30 years ago. The changing geographic distribution of sites, associated settlement size, and house size has not been examined in detail. A more careful examination of changing northwest Alaskan settlement patterns is needed before larger questions about socio-economic organization can be addressed. I use Geographic Information Systems (GIS) to evaluate the evidence for a geographic redistribution of Arctic peoples during the Late Holocene.
\end{abstract}

I constructed a database of settlement location and site attribute information, specifically the number of houses within each settlement and the size $\left(\mathrm{m}^{2}\right)$. Data were collected from a dataset of Western Arctic National Parklands (WEAR), the Alaska Heritage Resource Survey (AHRS) database of archaeological sites in Alaska, 409 unpublished site reports and field notes curated by the National Park Service (NPS) and 
Bureau of Indian Affairs (BIA), and the results of recent fieldwork in northwest Alaska. A total of 486 settlements were identified within the northwest Alaska with 128 settlements having temporal and site attribute data.

I incorporated settlement size data into a GIS database and then carried out global, Moran's I, local Moran's I, and local Getis-Ord spatial analyses to test whether settlement redistribution occurred and if key settlement locations shifted after 500 ya. The site attribute data (number of houses and average size of houses) are used to test the additional aspects of the proposed settlement pattern change after 500 ya. A total of 83 settlements with 465 houses are used to test if the average size of settlements and average house size changed after 500 ya.

The results of the spatial analyses indicate no statistically significant patterns in the spatial distribution of settlements. Site attribute analysis shows no statistical difference in the average number of houses per village or the average size of houses before or after 500 ya. The results of this work build our understanding of regional settlement patterns during the late Holocene. By testing settlement pattern change, i.e. settlement distribution, settlement size, and house size, future research into settlement pattern change can begin to evaluate likely causes for the observed changes. My method, specifically the use of GIS as a method for testing settlement pattern change, can be applied to other regions and temporal scales. 


\section{Acknowledgments}

First and foremost, I would like to thank the members of my committee, starting with my advisor. Dr. Shelby Anderson, your consistent support, enthusiasm, and guidance throughout my graduate career and this thesis have been a valuable asset to me. This thesis was a long time coming and I am grateful you encouraged me to both participate in so many projects and keep me focused on my research. Dr. Ken Ames, thank you for always challenging me to "struggle harder" and providing me with the opportunities to grow and expand my interests in archaeology throughout the Pacific Northwest. Thanks to David Banis for always being available to chat about methods and giving me helpful directions to further my research. I would also like to thank the faculty in the Department of Anthropology for providing comments and thoughts on my initial proposal and their support while I completed this thesis. I would like to thank Connie Cash for always lending an ear, her endless help, and her dedication to the graduate students and faculty in the department.

I received funding from the Alaska Anthropological Association Thomas F. Ediel Graduate Scholarship and the Portland State Department of Anthropology Thomas M. Newman Fund. Additionally, the National Science Foundation (NSF), National Park Service (NPS), and the Bureau of Land Management (BLM) funded Dr. Anderson's fieldwork, providing me with the opportunity to collect thesis data. Thank you to Kenneth Pratt, Matt O’Leary, and Sean Mack at the Bureau of Indian Affairs, and to Jane Lakeman, Dr. Andrew Tremayne, Rhea Hood, and Adam Freeburg at the NPS for helping me access field data, reports, and site records. 
I am exceedingly grateful to my cohort and fellow students for all the late nights in the office, the adventures, and laughs throughout my graduate career. Thomas "TJ" Brown, thank you for all the research brainstorming and being able to bounce ideas off you. William Gardner-O'Kearny, thank you for being a midnight statistician, all the conversations about statistics and so many other nerdy things. Monica Mogilewsky, thank you for being an amazing officemate, always keeping me grounded, and the endless things you have done for me. Thank you to Pat Reed, Bill Cornett, and everyone else who commented on the early drafts of this thesis and helped shape it into what it has become.

I need to thank all of the friends and family that have supported through my research and put up with my constant distraction. The Junge and Hays families have done a lot to keep me going and have always been there for me. Lastly, to my parents Jeff and Joanna Junge, your lives inspired me to follow my dreams and your never wavering faith in me kept me moving to this goal. 


\section{Table of Contents}

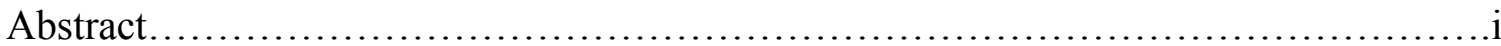

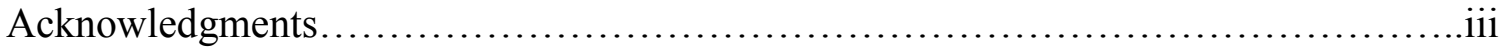

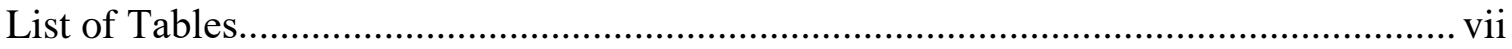

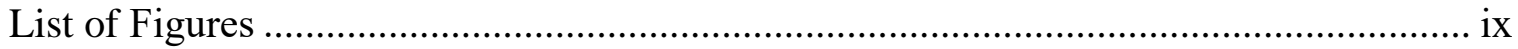

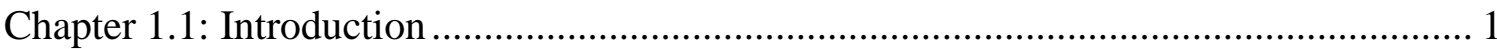

1.2 Development of Arctic Maritime Traditions in Northern Alaska .................... 4

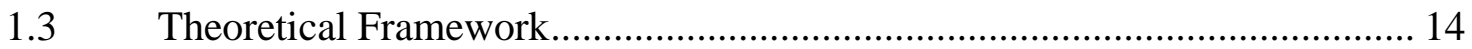

$1.4 \quad$ Research Questions and Hypotheses ....................................................... 16

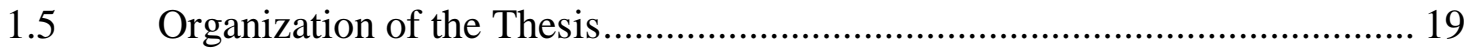

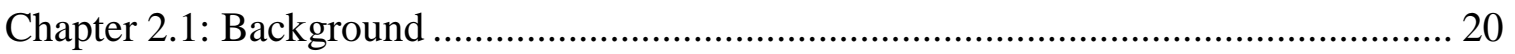

2.2 Spatial Analysis and Geographic Information Systems .............................. 20

2.3 Geographic Information Systems and Settlement Pattern Research .............. 22

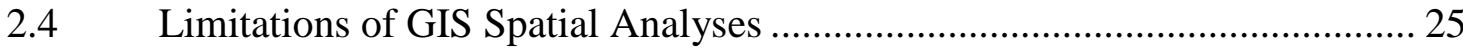

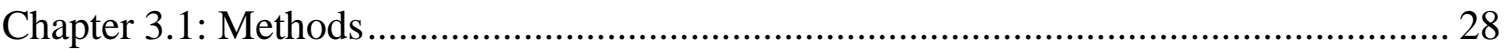

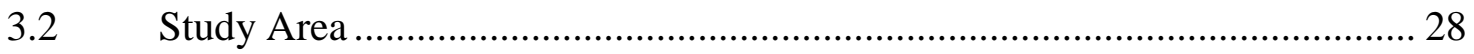

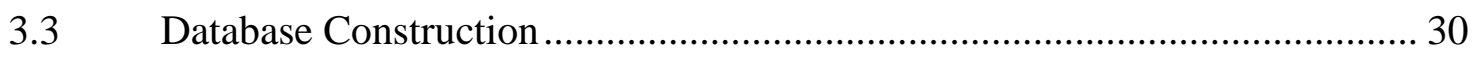

3.4.1 Spatial Distribution of Settlements with GIS ................................................ 44

3.4.2 Site Metric Analyses............................................................................. 49 
Chapter 4.1: Results

4.2 Nearest Neighbor Analysis ............................................................... 51

4.3 Global Moran's I Spatial Distribution Analysis .......................................... 52

4.3.2 Local Moran's I Spatial Analysis .............................................................. 53

4.3.3 Local Getis-Ord Gi* Spatial Analysis .................................................. 56

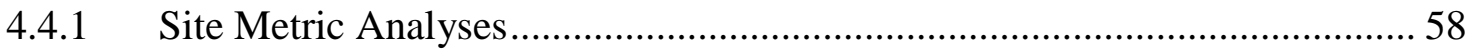

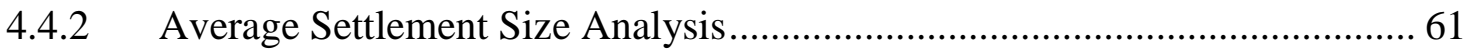

4.4.3 Average House Size Analysis................................................................ 61

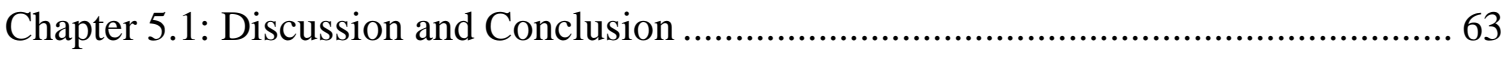

5.2 Testing Settlement Pattern Change in Northwest Alaska............................. 63

5.3 Broader Implications and Directions for Future Research .......................... 79

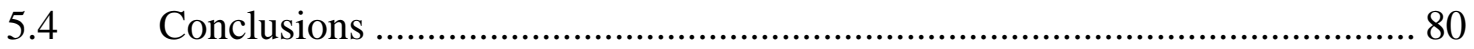

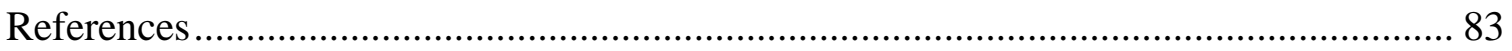

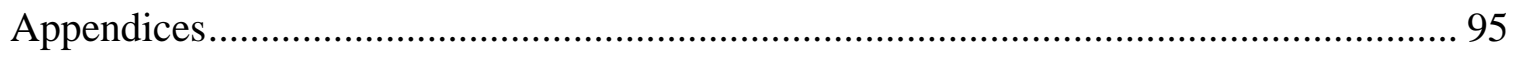

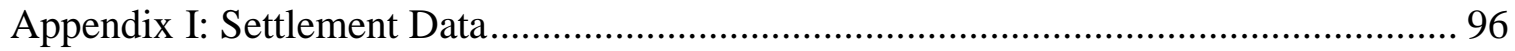

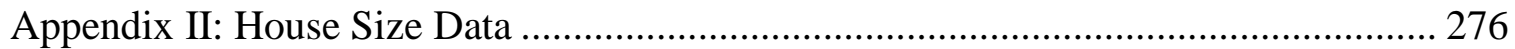




\section{List of Tables}

Table 1. Summary of settlement data, subsistence practices, and social organization in northwest Alaska and the Bering Strait region

Table 2. General cultural groups, climatic conditions, settlement patterns over the last 1200 years BP. 10

Table 3. Watershed groupings, original watersheds, and areas of the study area. 30

Table 4. Site types based on Anderson's (2011) site type designations. 34

Table 5. Criterion for each temporal grouping for the analyses. 35

Table 6. Site number, site name, site types, and number of houses of settlements that were occupied before $500 \mathrm{BP}$ 36

Table 7. Site number, site name, site types, and number of houses of settlements that were occupied after $500 \mathrm{BP}$

Table 8. Site number, site name, site types, and number of houses of settlements that were continuously occupied.

Table 9. Settlements and the number of measured houses before $500 \mathrm{BP}$. 42

Table 10. Settlements and the number of measured houses after $500 \mathrm{BP}$ 43

Table 11. Required features and parameters for Moran's I and Getis-Ord. 48

Table 12. The Nearest Neighbor Analysis for two temporal periods. 51

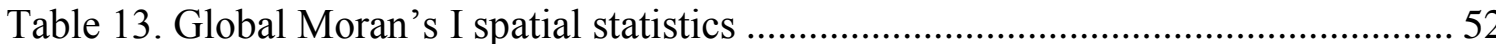

Table 14. Local Moran's I output descriptions. 53

Table 15. Observed values, expected values, and residuals of the number of settlements60 Table 16. Mann-Whitney U rank order values of the number of houses per settlement .. 61 
Table 17. Mann-Whitney U rank order values of the house size per settlement ............. 62

Table 18. The Nearest Neighbor Analysis for two temporal periods. ............................. 68 


\section{List of Figures}

Figure 1. Study area in Northwest Alaska. Key sites discussed in text ........................... 2

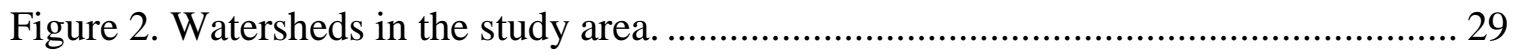

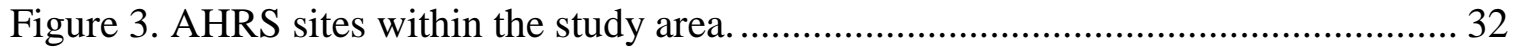

Figure 4. Nuluk and Port Clarence Project areas on the Seward Peninsula. ................... 33

Figure 5. Local Moran's I spatial statistics of settlements......................................... 55

Figure 6. Local Getis-Ord Gi* spatial statistics of settlements .................................. 57

Figure 7. Shapiro-Wilk test and distribution of settlement size before 500 BP. ............ 58

Figure 8. Shapiro-Wilk test and distribution of settlement size after 500 BP............... 59

Figure 9. Shapiro-Wilk test and distribution of house size (m2) before 500 BP............ 59

Figure 10. Shapiro-Wilk test and distribution of house size (m2) after 500 BP.............. 60

Figure 11. Exploratory local Moran's I and Getis-Ord Gi* analyses of settlements...... 71

Figure 12. Range of house sizes within settlement before 500 BP............................. 74

Figure 13. Range of house sizes within settlements after 500 BP............................. 75

Figure 14. Range of house sizes within settlements after 500 BP.............................. 76 


\section{Chapter 1.1: Introduction}

The last 5,000 years witnessed significant cultural and environmental changes in the Arctic with multiple migrations, expansion of maritime adaptations, the transition to a more sedentary lifestyle, and the rise of social inequality. Several studies have focused on the inter-relationship between a marine resource focus, increased sedentism, population growth, and the development of ranked societies (Anderson, et al. Forthcoming; Anderson and Freeburg 2014; Erlandson 2001; Fitzhugh 2003; Mason 1998; Yesner 1998) which characterized northern and northwestern Alaskan cultures during the late pre-contact era (Anderson 1984; Giddings 1952; Giddings and Anderson 1986; Tremayne 2015) (Figure 1). Many questions remain about why and how late precontact arctic maritime cultures developed. For example, what role, if any, did late Holocene environmental variability play in cultural change? Is there a link in northwest Alaska between food surplus, increased population density, and the emergence of inequality (Ingold 1983; Hayden 1995; Testart, et al. 1982; Twiss 2012; Wesson 1999)? But, before these questions can be addressed, new research is needed to better establish the underlying evidence for population growth, sedentism, and settlement pattern change over the last 5000 years. Therefore, the focus of this thesis research is on re-evaluating the archaeological evidence for one aspect of late pre-contact cultural change in the Arctic - settlement patterns. 


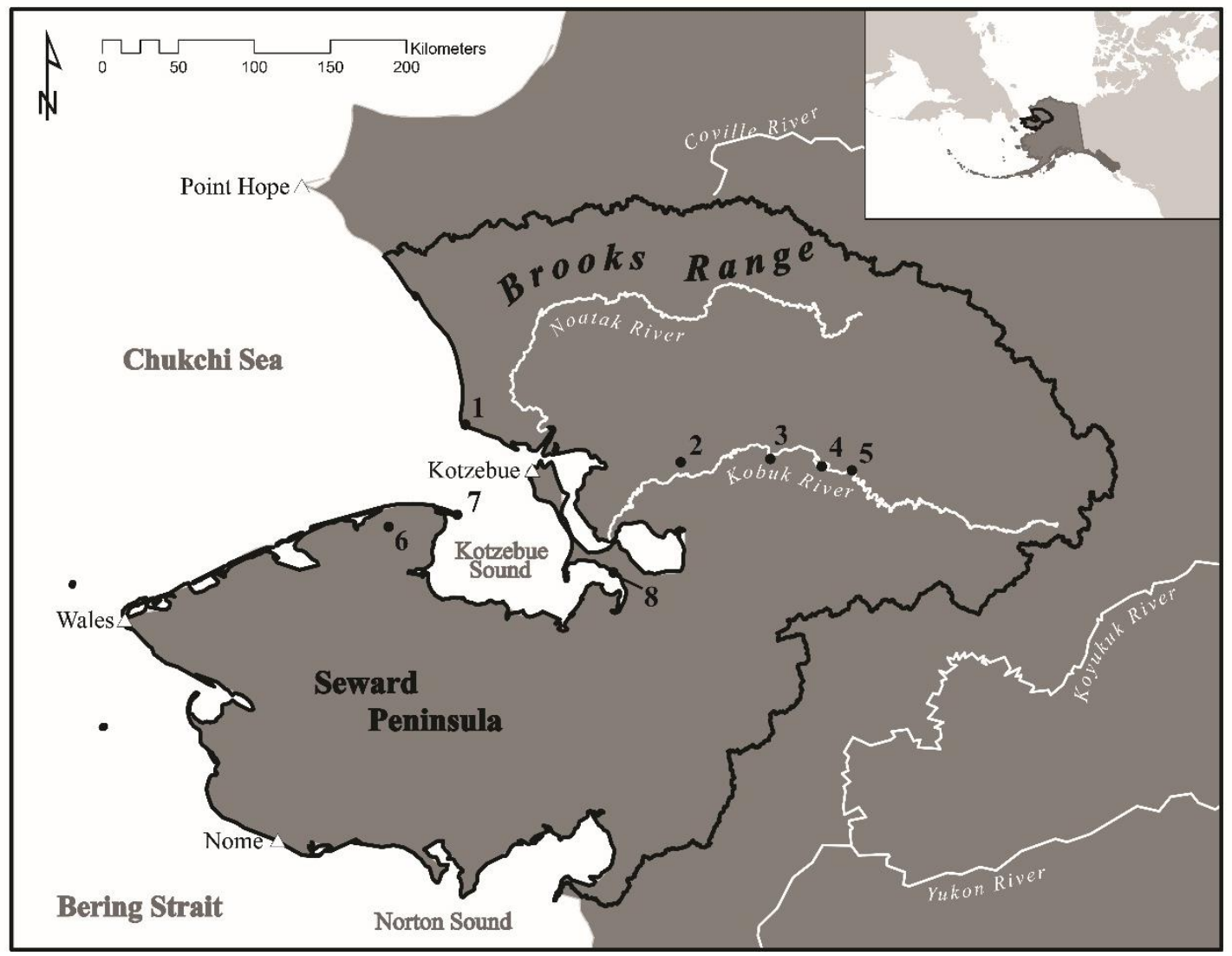

Figure 1. Study area in Northwest Alaska. Key sites discussed in text are: 1) Cape Krusenstern, 2) Eksiavik, 3) Ahteut, 4) Onion Portage, 5) Ambler Island, 6) KTZ-00052, 7) Cape Espenberg, and 8) Sisiivik.

Hunter-gatherer settlement patterns are defined by the group's mobility, subsistence, social organization, and settlement type (e.g. campsite, single house occupation, and villages). The observed or inferred shifts in settlement patterns that archaeologists study include changing settlement location, site density, and frequency of settlement movement. Archaeologists see these shifts as indicators of cultural change such as increased sedentism, changes in foraging practices, or shifts in mobility. These indicators are causally linked to broader changes in social organization and the 
development of complex hunter-gatherers worldwide (Binford 2001; Fitzhugh and Habu 2002; Rowley-Conwy 2001). In northwest Alaska (Figure 1) prior research indicates that most people living in this region prior to 2500 years before present (BP) were highly mobile and did not construct permanent dwellings (Anderson 1984; Giddings 1957; Giddings and Anderson 1986; Odess 2003). After 2500 BP, people's mobility likely shifted and permanent dwellings began to appear in coastal areas (Anderson 1984; Giddings and Anderson 1986). Starting around $1500 \mathrm{BP}$, there was an aggregation of large coastal settlements in areas with easy access to rich marine resources; archaeologists view this shift as key in the development of complex arctic huntergathering culture (Anderson 1984; Giddings and Anderson 1986; Mason and Gerlach 1995b). However, over the last 500 years, settlement patterns are less clear, with some research suggesting a dispersal of smaller settlements with smaller houses into the interior or to other, previously uninhabited, areas along the coast (Anderson 2011; Anderson and Freeburg 2014; Freeburg and Anderson 2012; Gerlach and Mason 1992; Mason 1998). Alternatively, some evidence indicates continued population growth and concentration of people in specific coastal areas (Schaaf 1988) over the last 500 years. Prior research relied primarily on number and size of houses within sites, and number of sites, to infer settlement patterns (e.g. Giddings and Anderson 1986; Gerlach and Mason; 1992; Mason 1998). Researchers determined site distribution by visual examination of maps; a formal spatial analysis of site density or patterning has yet to be undertaken.

The goals of this thesis were 1) to re-evaluate the evidence for settlement pattern change over the last 1000 years in northwest Alaska and 2) to conduct an analysis of 
spatial patterning. I focused on the last 1000 years because the archaeological dataset is richest for this time period, and because of the controversy over whether or not there were significant settlement pattern changes before and after 500 years ago. To achieve my goals I created a settlement pattern database that combines new, unpublished gray literature and recent survey data with existing settlement pattern datasets. I then used these data to test the distribution of settlements during the study period through spatial analysis using Geographic Information Systems (GIS). Additionally, I evaluated whether changes in population size are associated with the shifts in settlement patterns by testing whether the average number of houses per site and the average house size, measured in meters squared $\left(\mathrm{m}^{2}\right)$, changed during the same periods. I compared the results of this demographic analysis to the results of an on-going study of local demography through radiocarbon analysis (Anderson et al. Forthcoming).

\subsection{Development of Arctic Maritime Traditions in Northern Alaska}

While my focus is on the late pre-contact period, it is helpful to understand the broader cultural context in which late pre-contact settlement patterns emerged. There are several Paleoarctic (11500-6000 BP) and Northern Archaic (6500-4000 BP) sites in the interior areas of northwest Alaska (e.g. Anderson 1984, 1988; Esdale 2008; Goebel, et al. 2013), but the earliest coastal sites in northwest Alaska date to around 4500 B.P.; older coastal sites were inundated by early Holocene sea level rise, which did not stabilize until about 5,500 years ago. The early coastal occupation of the region, known locally as the Denbigh phase (4700-3200 BP) (Table 1), is characterized by small, highly mobile foraging groups that seasonally occupied both coastal and interior regions; subsistence 
included both marine and terrestrial resources (Anderson 1984; Anderson and Freeburg

2013; Giddings and Anderson 1986; Tremayne 2010, 2015). 
Table 1. Summary of settlement data, subsistence practices, and social organization in northwest Alaska and the Bering Strait region for the last 4,000 years (adapted from Mason 2009 and Anderson, et al. Forthcoming).

\begin{tabular}{|l|l|l|l|l|l|}
\hline $\begin{array}{l}\text { Cultural } \\
\text { Phases }\end{array}$ & $\begin{array}{l}\text { Date Ranges } \\
\text { (BP) }\end{array}$ & $\begin{array}{l}\text { Geographic } \\
\text { Distribution }\end{array}$ & Social Spaces & Settlement Locations & Subsistence Practices \\
\hline Denbigh & $4700-3200$ & $\begin{array}{l}\text { Brooks Range, } \\
\text { Kotzebue Sound, } \\
\text { Seward Peninsula, } \\
\text { Norton Sound }\end{array}$ & Unknown & $\begin{array}{l}\text { Inland settlements with } \\
\text { coastal campsites }\end{array}$ & $\begin{array}{l}\text { Varied with } \\
\text { predominately terrestrial } \\
\text { mammal hunting and } \\
\text { marine mammal hunting } \\
\text { at coastal campsites }\end{array}$ \\
\hline Choris & $2750-2250$ & $\begin{array}{l}\text { Brooks Range, } \\
\text { Kotzebue Sound, } \\
\text { Northern Yukon } \\
\text { Territory }\end{array}$ & $\begin{array}{l}\text { Large oval } \\
\text { structures, either } \\
\text { houses and/or } \\
\text { collective spaces }\end{array}$ & $\begin{array}{l}\text { Inland, riverine, and } \\
\text { coastal settlements }\end{array}$ & $\begin{array}{l}\text { Terrestrial and marine } \\
\text { hunting }\end{array}$ \\
\hline Ipiutak & $2250-1350$ & $\begin{array}{l}\text { Western Canada } \\
\text { through northwest } \\
\text { Alaska to the } \\
\text { southern Alaska } \\
\text { Peninsula }\end{array}$ & $\begin{array}{l}\text { Square house with } \\
\text { the presence of } \\
\text { community } \\
\text { structures at some } \\
\text { sites }\end{array}$ & $\begin{array}{l}\text { Increase in coastal } \\
\text { settlements with some } \\
\text { interior settlements } \\
\text { present }\end{array}$ & $\begin{array}{l}\text { Marine and terrestrial } \\
\text { mammal hunting (north } \\
\text { of Seward Peninsula), } \\
\text { fishing (south of Seward } \\
\text { Peninsula }\end{array}$ \\
\hline Birnirk & $1350-750$ & $\begin{array}{l}\text { Eastern and western } \\
\text { coasts of the } \\
\text { Chukchi Sea }\end{array}$ & $\begin{array}{l}\text { Small houses with } \\
\text { some larger } \\
\text { structures present }\end{array}$ & $\begin{array}{l}\text { Predominate coastal } \\
\text { settlements }\end{array}$ & $\begin{array}{l}\text { Marine with whale } \\
\text { specialization and } \\
\text { terrestrial mammal } \\
\text { hunting, possibly fishing }\end{array}$ \\
\hline
\end{tabular}




\begin{tabular}{|l|l|l|l|l|l|}
\hline $\begin{array}{l}\text { Cultural } \\
\text { Phases }\end{array}$ & $\begin{array}{l}\text { Date Ranges } \\
\text { (BP) }\end{array}$ & $\begin{array}{l}\text { Geographic } \\
\text { Distribution }\end{array}$ & Social Spaces & Settlement Locations & Subsistence Practices \\
\hline $\begin{array}{l}\text { Thule } \\
\text { Late) }\end{array}$ & $1200-550$ & $\begin{array}{l}\text { Bering Strait, } \\
\text { Northwest and } \\
\text { Northern Alaska, } \\
\text { Canadian Arctic, } \\
\text { Greenland }\end{array}$ & $\begin{array}{l}\text { Multi-room houses } \\
\text { with some larger } \\
\text { structures present }\end{array}$ & $\begin{array}{l}\text { Predominate coastal } \\
\text { settlements with } \\
\text { increased aggregation to } \\
\text { large villages }\end{array}$ & $\begin{array}{l}\text { Marine with whale } \\
\text { specialization and } \\
\text { terrestrial mammal } \\
\text { hunting, possibly fishing }\end{array}$ \\
\hline Kotzebue & $750-250$ & $\begin{array}{l}\text { Coastal areas of } \\
\text { Northwest Alaska }\end{array}$ & $\begin{array}{l}\text { Generally single } \\
\text { room houses with } \\
\text { some multi-room } \\
\text { houses, community } \\
\text { structures present }\end{array}$ & $\begin{array}{l}\text { Dispersed small } \\
\text { settlements or single } \\
\text { houses on the coast and } \\
\text { rivers, congregate trade } \\
\text { areas }\end{array}$ & $\begin{array}{l}\text { Marine and terrestrial } \\
\text { mammal hunting, fishing }\end{array}$ \\
\hline $\begin{array}{l}\text { Arctic } \\
\text { Woodland }\end{array}$ & $750-250$ & $\begin{array}{l}\text { Interior areas of } \\
\text { Northwest Alaska }\end{array}$ & $\begin{array}{l}\text { Generally single } \\
\text { room houses with } \\
\text { some multi-room } \\
\text { houses, community } \\
\text { structures present }\end{array}$ & $\begin{array}{l}\text { Dispersed small } \\
\text { settlements or single } \\
\text { houses in the interior, } \\
\text { campsites on the coast }\end{array}$ & $\begin{array}{l}\text { Terrestrial mammal } \\
\text { hunting, fishing, some } \\
\text { marine hunting near the } \\
\text { lower portion of rivers }\end{array}$ \\
\hline
\end{tabular}


A more sedentary lifestyle emerged around 2800-2500 years ago when several semi-subterranean house features associated with the Choris culture (2750-2250 BP) (Table 1) appear in coastal areas of northwest Alaska (Anderson 1984; Anderson and Freeburg 2013; Giddings and Anderson 1986; Mason and Gerlach 1995a). During this period, people lived in small mobile groups that continued to practice marine and terrestrial subsistence patterns established during the preceding Denbigh Phase. There are few interior Choris Phase sites but coastal settlements, campsites, and semi-subterranean houses have been identified around Kotzebue Sound, i.e. Cape Krusenstern, Choris Peninsula, and Cape Espenberg (Anderson 1984; Anderson and Freeburg 2013; Mason and Gerlach 1995a; Schaaf 1988).

Beginning with the Ipiutak Phase (2250-1350 BP) (Table 2), there is both an increase in the number and size of houses within coastal settlements. This, coupled with the presence of large communal structures and ornate burials, suggests that social organization changed during this period (Anderson 1984; Anderson and Freeburg 2013, 2014; Mason 1998, 2006, 2009b). Subsistence practices continue to focus on both marine mammals and caribou (Anderson 1984; Giddings and Anderson 1986). The cultural markers that define the "Ipiutak" people (1750-1150 BP) (Table 2) can be found at coastal sites such as Point Hope, Cape Krusenstern, and Deering (Bowers 2009; Giddings and Anderson 1986; Larsen and Rainey 1948; Mason 2006); interior Ipiutak sites are reported in a few instances, e.g. Onion Portage, Croxton (Anderson 1988; Gerlach 1989; Gerlach and Mason 1992). As with the previous phases, however, the settlement pattern for Ipiutak is not well defined. For example, it is not clear if people were moving 
seasonally between the coast and interior. Overall, during this period population density increases (Mason 1998).

Beginning approximately 2000 years ago new Arctic peoples with strong maritime hunting and fishing practices, referred to as the Neoeskimo culture, migrated into northwest Alaska. The Neoeskimo period encompasses the last 1500 years; Neoeskimo people are the direct ancestors of modern Yupik, Iñupiat, and other Inuit cultures that span the arctic region from Alaska to Greenland today. In northwest Alaska, the Arctic people who make up these archaeologically defined groups are the Birnirk, Thule, and Kotzebue phases (Table 1). Interactions and relationships between these different groups are not well understood (Anderson, et al. Forthcoming; Hoffecker 2005; Mason 2009b). These hunter-gatherer populations focused on aquatic subsistence practices and developed a pattern of near year-round settlements on the coasts. Whale hunting specialization developed during the Thule phase (Anderson 1984).

Some evidence points to an increase in coastal settlement during the Thule period beginning at approximately 1200 BP (Table 1). During this period there are larger settlements (i.e. more houses within each village) and more substantial house structures (i.e. as measured in $\mathrm{m}^{2}$ ) on the coast that were inhabited for longer periods of time (Giddings and Anderson 1986; Mason 1998). During this period of heightened sedentism and coastal aggregation, changing environmental conditions are associated with the cooler temperatures between 1200 and 900 BP (Bird, et al. 2009; Calkin, et al. 1998; Mann, et al. 2002; Mason and Jordan 1993, 2001). This was followed by a shift to warmer temperatures during the MCA (Bird, et al. 2009; Calkin, et al. 1998; Mann, et al. 
2002; Mason 2009a) (Table 2). While it is suggested that cooler conditions may have provided access to previously unavailable aquatic resources, such as whales, for the Neoeskimo people in Alaska (Dixon 2003; Gerlach and Mason 1995b; Mason 1998; Mason and Barber 2003), research into the migration of Thule people eastward into the Canadian Arctic indicates that migration occurred during warmer conditions, approximately 550 BP (Friesen and Arnold 2008: 534-537).

Table 2. General cultural groups, climatic conditions, settlement patterns over the last 1200 years BP (temporal periods associated with culture groups are defined in section 2.2).

\begin{tabular}{|c|c|c|c|}
\hline $\begin{array}{l}\text { Associated Culture } \\
\text { Groups }\end{array}$ & $\begin{array}{l}\text { Temporal } \\
\text { Period }\end{array}$ & $\begin{array}{l}\text { Climatic } \\
\text { Conditions }\end{array}$ & Settlement Patterns \\
\hline $\begin{array}{l}\text { Neoeskimo Traditions } \\
\text { (Birnirk, Punuk, and } \\
\text { Thule) }\end{array}$ & $\begin{array}{l}1200-900 \\
\text { BP }\end{array}$ & $\begin{array}{l}\text { Cooling } \\
\text { temperatures and } \\
\text { decreased } \\
\text { precipitation. }\end{array}$ & $\begin{array}{l}\text { Large villages with } \\
\text { large houses in key } \\
\text { resource locations. }\end{array}$ \\
\hline $\begin{array}{l}\text { Neoeskimo Traditions } \\
\text { (Thule), Kotzebue } \\
\text { Period, and Arctic } \\
\text { Woodland Culture }\end{array}$ & $900-300 \mathrm{BP}$ & $\begin{array}{l}\text { Warming } \\
\text { temperatures, the } \\
\text { Medieval Climatic } \\
\text { Anomaly. }\end{array}$ & $\begin{array}{l}\text { A transition from large } \\
\text { villages with large } \\
\text { houses in key resource } \\
\text { locations to smaller } \\
\text { settlement with smaller } \\
\text { houses disturbed across } \\
\text { the region. }\end{array}$ \\
\hline $\begin{array}{l}\text { Kotzebue Period, } \\
\text { Arctic Woodland } \\
\text { culture and contact } \\
\text { period/ethnographic } \\
\text { communities (nations) }\end{array}$ & $\begin{array}{l}500 / 300- \\
100 \mathrm{BP}\end{array}$ & $\begin{array}{l}\text { Cooling } \\
\text { temperatures, the } \\
\text { Little Ice Age. }\end{array}$ & $\begin{array}{l}\text { Smaller settlement with } \\
\text { smaller houses disturbed } \\
\text { across the region. }\end{array}$ \\
\hline
\end{tabular}

After $500 \mathrm{BP}$, settlement patterns in northwest Alaska are not as well understood because of limited research focusing on this time period. Initial work in the region (Giddings 1952; Giddings and Anderson 1986) suggested that settlement patterns shifted 
after about 500 years ago. Population decreased and settlements redistributed. People dispersed into smaller groups in new, previously uninhabited locations, and house structures were smaller across the region during this period (the Kotzebue and Arctic Woodland Phases) (Table 1 and 2). These changes in settlement patterns coincide with the shift from the MCA to cooler temperatures during the LIA beginning around $300 \mathrm{BP}$ (Table 1). Environmental change may have led to a decrease in the abundance of large bodied marine mammals (e.g. whales and seals) near their large coastal settlements that may have necessitated a shift by the arctic hunter-gatherers to the interior or other coastal locations for access to fish and terrestrial mammals for subsistence (Anderson 1984; Giddings 1952; Giddings and Anderson 1986).

During the contact era ( 350-250 BP), Native Alaskans had well-established subsistence practices and settlement patterns (Burch 1998, 2005, 2006; Fejes 1966; Ray 1975). Burch (1998) and Ray (1975) discuss in detail the roughly 19 independent societies or "nations" that inhabited northwest Alaska. Each nation followed unique seasonal rounds within their traditional boundaries (Burch 1998, 2006; Ray 1975). The settlement patterns for these nations indicate that small winter settlements were occupied during most of the year with seasonal subsistence logistical camps and meeting or "trade" areas for extended groups between spring and fall (Burch 1998). Subsistence practices focused on aquatic (e.g. marine mammals and fish) and terrestrial resources during specific seasons (Burch 1998).

The overall pattern is thought to be increasing population density, increased sedentism, and an increased focus on marine resources over time. Population may have 
decrease, and/or dispersed after about 500 BP for unknown reasons. Our understanding, however, of these patterns, is based on limited data. Our current understanding of preand post-500 BP settlement patterns is based primarily on research that focused on defining cultural periods of occupation from three key sites (i.e. Ahteut, Eksiavik, and Ambler Island) along the Kobuk River (Giddings 1952; Giddings and Anderson 1986) and Cape Krusenstern (Giddings and Anderson 1986). Significant elements of how archaeologists defined these periods were the house structural designs and settlement size at these locations. The pre- and post-500 BP settlement patterns are based on a total of 63 houses excavated or recorded; 17 houses at Cape Krusenstern (Giddings and Anderson 1986: 41-54, 59-79), 15 houses at Ambler Island (Giddings 195: 13-18), nine houses at Ekseavik (Giddings 1952: 25-26), and 22 houses at the Ahteut site (Giddings 1952: 27 31). The population estimates and change in population size pre- and post-500 BP are based on demographic studies that used radiocarbon dates and house size proxies for population estimates (Anderson and Freeburg 2013, 2014; Mason 1998; Mason and Gerlach 1995b). For example, recent work at Cape Krusenstern, Alaska (Anderson and Freeburg 2013; Freeburg and Anderson 2012) and northwest Alaska (Anderson 2011) provides more detail about regional settlement patterns and raises new questions about regional social networks and mobility during the study period. Anderson and Freeburg's studies indicate that populations increased prior to $800 \mathrm{BP}$ and decreased around $500 \mathrm{BP}$ (Anderson 2011; Anderson and Freeburg 2013, 2014; Freeburg and Anderson 2012). By $500 \mathrm{BP}$, settlement patterns appeared to shift in relation to the changes in population size; the new pattern was one of fewer sites and smaller houses (Anderson 2011: 167-168). 
This work supports the general trend that settlement size and density increase after 1000 BP and that some variations in settlement (e.g. shift in the distribution of sites or shorter site occupation periods) occurred after $500 \mathrm{BP}$; however, this research was limited to National Park Service (NPS) lands and only one systematically and intensively surveyed site complex.

Alternatively, research conducted on the Seward Peninsula within the Bering Land Bridge National Preserve by Schaaf (1988:212-213) led archaeologists to propose a fluid settlement pattern of coastal and interior occupations with little to no change in settlement size, house size, or house distribution after 500 BP. While the Seward Peninsula settlement pattern does not refute the widely accepted pattern, it does highlight the need to test the underlying spatial distribution and site metric attributes (average number of houses per site and the average house size) of settlements dating to the last 1000 years.

Archaeologists have not empirically evaluated the evidence for changing distribution of settlements over space or looked at site and house size data across the region. Firmly establishing the nature of settlement patterns over the last 5000 years is a critical step in evaluating larger arguments about the emergence of social complexity, maritime adaptations, and the possible role of demographic shifts, population packing, and environmental change in these social developments. It is the goal of this thesis to provide a GIS statistical analysis of the spatial distribution of settlement as a way to empirically test whether or not settlement patterns change in northwest Alaska over the last 1000 years. My aim is to resolve some of the discrepancies between different 
measures of settlement and population density (e.g. radiocarbon data versus analysis of dated cultural phases) (Anderson 2011) and to conduct the first spatial analysis of late Holocene settlement patterns in northwest Alaska.

\subsection{Theoretical Framework}

The theoretical framework for this work is evolutionary ecology and human behavioral ecology (HBE). The principal emphasis of HBE is on adaptation of a group of people through individual behavioral variability and evolutionary processes, primarily the evolutionary principals of natural selection (Kelly 2007; Trigger 1998). Though HBE has limitations in that it downplays culture and focuses on individual behavioral actions, this theoretical approach provides a framework for studying ecological interactions between humans and their environment (Fitzhugh 2003; Kennett 2005). For example, the attention HBE gives to the ecological interaction between humans and their environment is fundamental to the argument that changing climatic and environmental conditions led to settlement pattern change. In this thesis I draw on HBE as a way to understand the selection and change in settlement locations based on the environmental and climatic constraints the people living in northwest Alaska would have been experiencing in the late Holocene.

In addition to the theoretical foundation of HBE, I also utilize settlement pattern models developed by Lewis Binford. Binford (1980, 1990, 2001) drew on ethnographic data and categorized hunter-gatherer groups according to environmental constraints, settlement types, mobility, subsistence patterns, and technologies. Binford's forager- 
collector model is a continuum where people adjust their settlement patterns to resource availability and adaptive strategies. According to this model, foragers are huntergatherers whose adaptive strategies focus on spatially and temporally consistent resources within environments. This allows for lower settlement investment and higher residential mobility (Binford 1980, 1990; Kelly 2007). Whereas, collectors specialize in resources that are highly seasonal or inconsistent, requiring investment in specialized technology, storage, and mobility strategies that focus on logistical acquisition of resources that are collected and returned to the center settlement (Binford 1980, 1990, 2001; Kelly 2007). Based on these characteristics, we can categorize hunter-gatherers as foragers or collectors, but the fluid nature of human adaptive strategies means that a hunter-gatherer group can exhibit behavior that falls into both categories along the continuum of Binford's model.

The forager-collector model does not distinctly differentiate terrestrial and aquatic (referring to marine, riverine, and estuary locations) resource variability. In later work, however, Binford (1990, 2001) began to evaluate shifts in mobility, sedentism, and social organization among aquatic or maritime hunter-gatherers (see also Ames 2002; Erlandson 2001; Fitzhugh 2002; Yesner 1980). The two primary differences between aquatic and terrestrial resources are the clustered and heterogeneous nature of aquatic resources and the rich and abundant biomass found within aquatic environments compared to those of terrestrial environments (Binford 2001; see also Yesner 1980 for ten features of maritime adaptations). While archaeologists are still grappling with the history, origins, and development of aquatic hunter-gatherers (Erlandson 2001; Yesner 1980), aquatic 
resources and the development of collector settlement patterns are strongly correlated (Ames 1981, 1985, 2002).

Binford's forager-collector model offers a foundation for how I classify settlement types and the construction of my assumptions about settlement location. The rich and abundant biomass provided by aquatic resources informed my expectations for the aggregation of coastal settlements and the shift in settlement location to interior aquatic resources, i.e. lakes and rivers. In addition, I use Binford's (2001) extensive ethnographic dataset in my GIS analyses. I drew on Binford's regionally specific dataset for a measurement of average foraging radius per day. Overall, the application of these theoretical frameworks to this thesis strengthens my ability to test whether settlement patterns changed in northwest Alaska after $500 \mathrm{BP}$.

\subsection{Research Questions and Hypotheses}

This thesis investigates four questions about settlement pattern changing in northwest Alaska. These questions are:

I. Did the spatial distribution of settlements, villages and single house sites, change from a clustered to a dispersed pattern after $500 \mathrm{BP}$ ?

$\mathrm{H}_{0}$ : No statistically significant change in the spatial distribution and the locations key settlement do not change. 
$\mathrm{H}_{1}$ : If a pattern is present, then the spatial distribution of settlement locations before $500 \mathrm{BP}$ will be statistically different from the distribution after $500 \mathrm{BP}$.

II. Did the spatial distribution of settlement size, the number of houses per settlement, change after $500 \mathrm{BP}$ ?

$\mathrm{H}_{0}$ : No statistically significant change in the spatial distribution and the locations key settlement do not change.

$\mathrm{H}_{1}$ : If a pattern is present, then the spatial distribution of large aggregated and small dispersed settlement locations before $500 \mathrm{BP}$ will be statistically different from the distribution after $500 \mathrm{BP}$.

III. Did the size of settlements (average number houses per site) change after 500 BP? $\mathrm{H}_{0}$ : The difference between the average number of houses before and after $500 \mathrm{BP}$ is not statistically significant.

$\mathrm{H}_{1}$ : If a difference between the average number of houses per site is present, then the average number of houses per site will be statistically different before $500 \mathrm{BP}$ than after $500 \mathrm{BP}$.

IV. Did the average house size $\left(\mathrm{m}^{2}\right)$ change after $500 \mathrm{BP}$ ?

$\mathrm{H}_{0}: \quad$ The difference between the average house size before and after 500 $\mathrm{BP}$ is not statistically significant. 
$\mathrm{H}_{1}$ : If a difference between the average house size is present, then the average house size will be statistically different before 500 BP than after $500 \mathrm{BP}$.

I expect the spatial distribution of the settlements, the size of settlements, and the size of houses will correspond with the previously recorded settlement pattern and demographic changes in northwest Alaska. Specifically, I predict that a change in the spatial distribution will show a movement from a clustered pattern with a coastal aggregation of settlements (before $500 \mathrm{BP}$ ) to a dispersed pattern with the movement of settlements away from the coast into the interior or different locations along the coastline (after 500 BP). Additionally, the size of settlements and the average house size should decrease after $500 \mathrm{BP}$ as other demographic research suggests (Anderson, et al. Forthcoming; Anderson and Freeburg 2014; Mason 1998).

To test these hypotheses, I culled settlement data from previous research (Anderson 2011; Anderson and Freeburg 2013; Freeburg and Anderson 2012), statewide archaeological site data (AHRS 2015), and conducted grey literature research with the NPS and the Bureau of Indian Affairs (BIA). I also participated in fieldwork that contributed new settlement data to my database.

By integrating existing and new datasets, this thesis will expand our understanding of regional settlement patterns during the last 1200 years. This work will be the first spatial analysis of settlement patterns to evaluate regional trends that can be used to understand if and when arctic people shifted from large, densely populated 
coastal settlements and moved into the interior or migrated elsewhere along the coast. The goal of this thesis is to test the statistical significance of the generally held idea of settlement pattern change and the connection to shifts in the environment in northwest Alaska. In addition, this thesis will provide a model for testing the spatial distribution of settlements that can be used beyond northwest Alaska.

\subsection{Organization of the Thesis}

This thesis is organized into six chapters, with five chapters following this introduction. Chapter 2 is a literature review of settlement patterns and the application of GIS in this research. Chapter 3 consists of the methodology for the thesis. In Chapter 4, I present the results of GIS and site metric analyses. I discuss the results of broader

implications of this research in Chapter 5, followed by the conclusion of the thesis and directions for future research. 


\section{Chapter 2.1: Background}

This chapter provides information about the application of GIS to settlement studies in archaeology.

\subsection{Spatial Analysis and Geographic Information Systems}

To test whether the spatial distribution of settlements in northwest Alaska has changed over the last millennium, I used GIS software, ESRI ArcGIS 10.2, to evaluate spatial patterns before and after 500 BP. GIS is a method to capture, store, manipulate, analyze, manage, and present all types of geographic data (Bolstad 2012). Data stored within various software platforms are examined though the process of spatial analysis. Spatial analysis describes the basic study of spatial data but is subdivided into four perspectives; spatial data manipulation, spatial data analysis, spatial statistical analysis, and spatial modeling (O'Sullivan and Unwin 2014). Spatial data manipulation encompasses the basic editing and management techniques of GIS. Spatial data analysis is the descriptive and exploratory examination of spatial data. Spatial statistical analysis incorporates statistical tests to evaluate whether spatial data can be in statistical models. Spatial modeling includes the construction of models to test general assumptions and the

development of predictive models for future testing. These perspectives overlap greatly in practice and rely on similar data. Spatial analysis uses data incorporating aerial images, elevation data, environmental data, census data, or other information and is presented in nominal, ordinal, interval, or ratio scales (O'Sullivan and Unwin 2014). 
Spatial autocorrelation, the assumption that variables associated with locations that are closer together have more in common than those of locations that are further away, determines the degree to which spatial features are organized and if their attributes tend to cluster together or disperse across space (Bolstad 2012; O'Sullivan and Unwin 2014; Rogerson 2015; Wheatley and Gillings 2003). GIS platforms provide different analytical tools to test spatial autocorrelation. These analytical tools use different statistical formulas to measure the relationship between features and provide descriptive statistics for interpretation of data. A few of the analytical tools available in ESRI ArcGIS to test spatial statistics are the Average Nearest Neighbor, Moran's I, Geary's C, Getis-Ord, and Ripley's K function.

While each tool may be used to test specific attribute data or their relationships (see Mitchel 2005), Nearest Neighbor Analysis, Moran's I, and Getis-Ord are baselines for testing spatial pattern. Nearest Neighbor Analysis spatial statistic computes the observed average distance between a target feature and their nearest neighbor with the distance that would be expected between nearest neighbors in a random pattern (Mitchel 2005; O'Sullivan and Unwin 2014). The values produced through a Nearest Neighbor Analysis identifies whether the data has a clustered, dispersed, or random spatial pattern. Moran's I spatial statistic calculates the difference between the value at features and the mean of all features; it then compares the difference between the target feature and the neighboring features (Mitchel 2005; O'Sullivan and Unwin 2014). Based on the values, Moran's I will indicate whether data has a clustered, dispersed, or random spatial pattern. Getis-Ord spatial statistic measures whether the values are clustered and if these patterns 
concentrate in significantly high or low $(99 \%, 95 \%, 90 \%$ confidence value) locations (Mitchel 2005; O'Sullivan and Unwin 2014). Both of these spatial statistical tools have global and local applications. Global analysis, providing one value for the dataset, tests the statistical significance of the spatial autocorrelation or clustering values and generates z-scores and p-values of the locations of settlements. Local analysis tests the statistical significance for the same effects but does the calculations for each feature based on the adjacent neighboring features. Simply put, global spatial statistics are used to test general patterns while local spatial statistics are used to identify patterns among individual features. Overall, these spatial tools provide archaeologists with multiple ways of analyzing and interpreting their spatial datasets to understand past hunter-gatherer lifeways.

\subsection{Geographic Information Systems and Settlement Pattern Research}

Spatial analysis was used in archaeology prior to the incorporation of GIS into mainstream analysis (Kvamme 1999). With GIS, archaeologists are able to incorporate the four perspectives of spatial analysis (see section 2.3) to develop and test models of pre-historic lifeways. Archeologists use GIS to identify and interpret sites (Enloe, et al. 1994; Potter 2005), create predictive site models (Carlson 2012; Clark 2012; Warren and Asch 2003), evaluate settlement patterns (Henrikson 2002; Kennett 2005; Lovis, et al. 2005; Maschner 1996; Morgan 2009; Reeder-Myers 2014; Thompson and Turck 2009; Winterhalder, et al. 2010), and study the development of social complexity (Grier and Savelle 1994; Kennett, et al. 2009). Modeling and spatial analysis functions of GIS provide exceptional tools to present archaeological data for analysis and interpretation. 
One example of the application of GIS and settlement pattern analysis was conducted by Henrikson (2002) in evaluating settlement locations in relation to patch choice along the Snake River in Idaho. This research took into account geographic constraints (i.e. distance to water), technology present, and activities conducted at locations to assess the locations of residential sites and camps (i.e. short-term base camps and field camps) over the last 8000 years. While the lack of residential sites does hinder the overall analysis, the results do support the assumption of the settlement pattern models that residential sites were located within proximity of river corridors and camps were situated near ephemeral ponds.

Another example of GIS and settlement pattern analysis was Morgan's (2009) central place foraging model evaluation of settlements in the Sierra Nevada Mountains of California. This research classifies patches based on their ecozones (e.g. montane forest or alpine) and defines site types based on the number of bedrock mortars (used for acorn processing) at each site. Using Nearest Neighbor analysis, Morgan's research suggests that winter settlement aggregate below snowline ecozones and that seasonal sites are dispersed in ecozones where areas are clear of snow.

Additionally, Douglas Kennett used the Ideal Free Distribution (IFD) model to test the causes and effects of population growth and settlement selection on the Northern Channel Islands off the coast of southern California (Kennett 2005; Kennett et al. 2009; Winterhalder et al. 2010). Utilizing GIS, a model was constructed that ranked the habitats based on shoreline typology and kelp forest presence. The IFD model was applied to the settlement data to understand settlement distribution, territoriality, and social hierarchy 
on the northern Channel Islands. Incorporating this information, Kennett suggests that periods of larger villages were marked points in the adoption of social ranking and hierarchy in the societies. This interpretation was further supported by mortuary remains of this time period that indicate further demographic shifts and varied levels of health within the ranked society (Kennett 2005; Kennett et al. 2009).

In Alaska, the application of GIS models and spatial analysis in relation to settlement pattern change is limited. Work by Maschner (1996) focused on using evolutionary psychology and cognition to develop a model for the selection of prehistoric settlement locations in southeast Alaska based on environmental and geographic variables (i.e. climatic exposure, island size, and distance to water). While Maschner's research confirms the observed site formation patterns and supports a transition from a single-lineage to multi-lineage settlement pattern, it focuses more on spatial modeling of site locations than the change in spatial patterns over time.

Recent work by Michael Holt (2012) attempts to identify hunting practices based on cairn distribution and evaluates settlement patterns on the Seward Peninsula. Holt's results identified clustering of settlements through the use of Average Nearest Neighbor analysis. Holt associates these clusters with ethnographic settlement patterns. While his analysis is novel, his data do not incorporate temporal constraints and the undefined scale of his GIS analysis affected the results by indicating clustering or dispersal of settlements when these changes may not have been taking place. 
Overall, spatial analysis and settlement patterns research in Alaska are needed to test ideas archaeologists have regarding prehistoric lifeways during the late Holocene. For example, we cannot explore the reasons why population changed, mobility shifted, or how these both may have factored into changing social organization over the mid-to-late Holocene. Additionally, archaeologists will be able to test the statistical significance of their models using updated data and new tools, such as GIS, and move away from general interpretations of site locations.

\subsection{Limitations of GIS Spatial Analyses}

All the spatial statistics incorporated into GIS are powerful tools to explore spatial patterns, but these statistical approaches have inherent limitations. The first limitation of spatial analysis is spatial autocorrelation. Spatial autocorrelation assumes everything is related to everything else but this assumption negates the normal distribution assumed for non-spatial statistics (O'Sullivan and Unwin 2014). Even with this limitation, spatial analysis is a powerful way to identify and interpret spatial patterns. If initial spatial analysis shows strong spatial autocorrelation, the problem can be mitigated by bootstrapping, a method of resampling data to create a normal distribution and running the analysis again (O'Sullivan and Unwin 2014; Rogerson 2015). For this thesis, this limitation is not a hindrance to the analyses as the social relationships between the arctic people living in settlements that are closer to each other have more in common than people in settlements farther away. Additionally, the use of a bandwidth constraint (specifically the ethnographic bandwidth, see section 3.4.1) provides the analyses with a more accurate representation of interactions between the people living in the settlements. 
Other limitations of spatial analysis relate to scale of the analysis and confines of the study area. The limitations of scale are the modifiable areal unit problem (MAUP) and the ecological fallacy. The difficulty with MAUP and spatial analysis is that changes in the aggregation of data or how data are consolidated can change the relationship between the features and the statistical significance of data (O'Sullivan and Unwin 2014). To address limitations of MAUP, I trusted the original recorded data on number of houses per settlement and temporal distractions without aggregating or splitting into different classification or categories (i.e. splitting a large village with dispersed clusters of houses into two or more villages).

Lastly, limitations relating to the confines of the study area can occur because of the edge effect. The edge effect occurs from the construction of an artificial boundary or the use of a natural boundary, i.e. coastlines, for the study area. The problem arises because features near the edge may be affected by features outside the study area but can only be compared to features within the study area (O'Sullivan and Unwin 2014). This limitation can be diminished by providing an additional buffer around the study area or by defining the study area based on natural features, i.e. elevation boundaries and bodies of water. For this thesis, I attempt to mitigate the edge effect by using natural geographic boundaries (watersheds, see section 3.2) as the study area. Using watersheds provides a boundary that does not allow for direct interaction with people in settlements outside the study area as the terrain, i.e. opposite sides of a ridge or mountain, would general hinder movement across the terrain. Though GIS and spatial analysis have these limitations, 
together they are a powerful suite of tools to analyze geographic relationships and attribute correlations. 


\section{Chapter 3.1: Methods}

In this chapter, I present the study area of northwest Alaska. Then, I lay out the construction of the site database used for the spatial distribution and site metric analyses. Lastly, I outline analytical tools that are used to test the settlement pattern hypotheses.

\subsection{Study Area}

Prominent geologic features define northwest Alaska (Figure 1). It is widely accepted that the Alaskan coast between Cape Thompson and Cape Espenberg to the west and inland up the Noatak, Kobuk, Selawik, and Buckland rivers are the general boundaries of northwest Alaska (Burch 1998:4). For this thesis, I expanded the study area of northwest Alaska to encompass the Norton Sound as the southernmost boundary and the North Slope of the Brooks Range as the northernmost boundary of northwest Alaska. The eastern boundary is less distinct, but it generally includes the Kobuk River valley and the area south along the Kaltag Mountains. The Chukchi and Bering Seas define the western border. These geographic constraints of the region provide physical boundaries for my study area.

To address the issue of edge effects, described in the previous chapter (see section 2.5), I used the natural geographic boundaries of watersheds provided by the United States Geological Survey (USGS) as well as anadromous river data provided by the National Oceanic and Atmospheric Administration (NOAA) (Figure 2). Based on the watersheds, the study area is approximately 152 million $\mathrm{km}^{2}$. I aggregated the USGS 
watershed data and created four major watershed groupings: the Noatak, Kobuk, Northern Seward Peninsula, and Southern Seward Peninsula (Table 3).

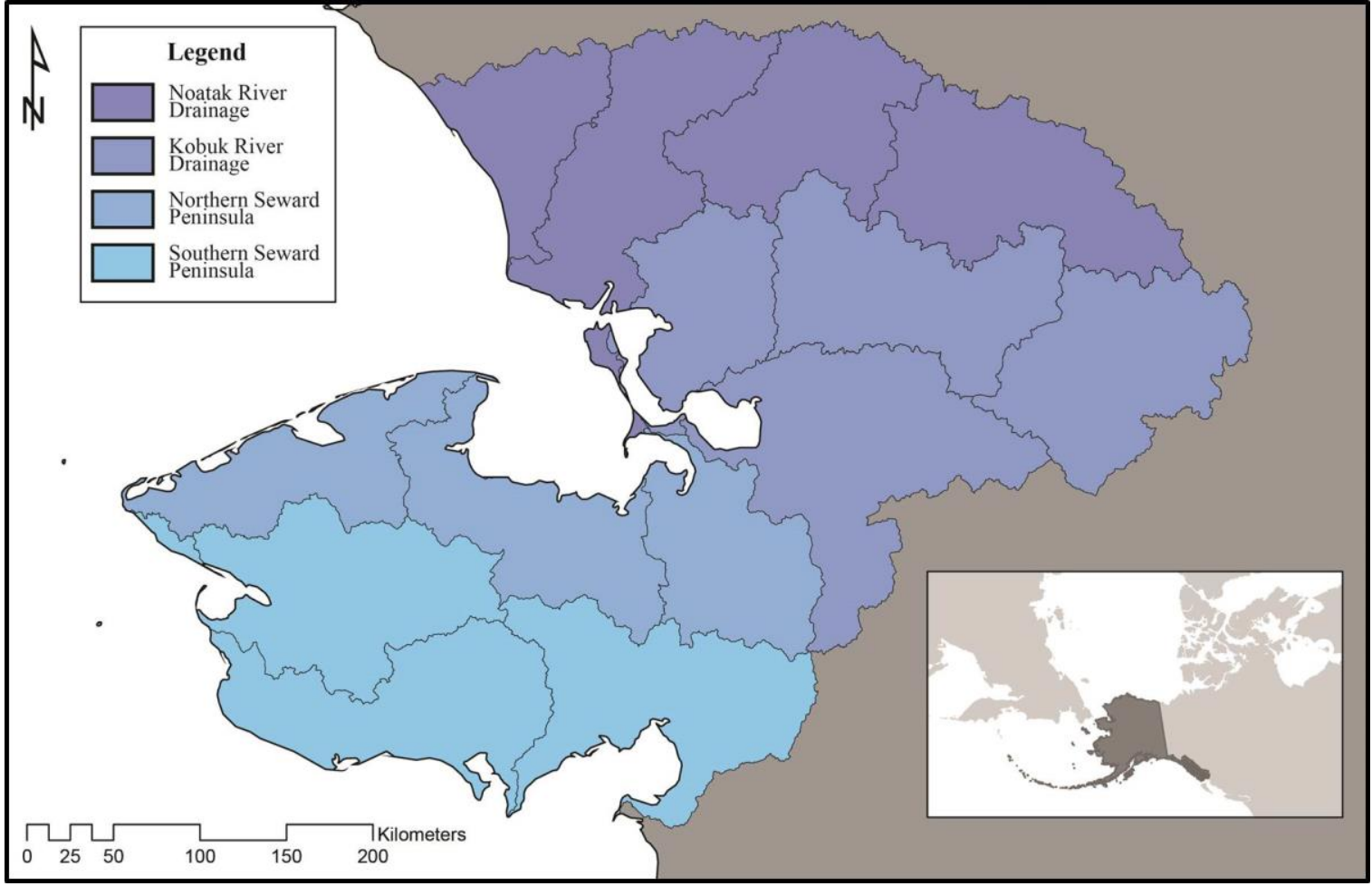

Figure 2. Watersheds in the study area. 
Table 3. Watershed groupings, original watersheds, and areas of the study area.

\begin{tabular}{|c|c|c|}
\hline Watershed Groupings & Watersheds & Area $\mathbf{k m}^{\mathbf{2}} \mathbf{)}$ \\
\hline \multirow{4}{*}{ Noatak } & Wulik-Kivalina & 7739.6 \\
\cline { 2 - 3 } & Lower Noatak & 12504.86 \\
\cline { 2 - 3 } & Middle Noatak & 10027.51 \\
\cline { 2 - 3 } & Upper Noatak & 12160.39 \\
\hline \multirow{4}{*}{ Kobuk } & Lower Kobuk & 8731.63 \\
\cline { 2 - 3 } & Middle Kobuk & 12464.74 \\
\cline { 2 - 3 } & Upper Kobuk & 12087.63 \\
\cline { 2 - 3 } & Selawik & 17160.56 \\
\hline \multirow{4}{*}{ Northern Seward Peninsula } & Buckland & 9138.05 \\
\cline { 2 - 3 } & Goodhope-Spafaried Bay & 10246.85 \\
\cline { 2 - 3 } & Shishmaref & 10730.82 \\
\hline \multirow{4}{*}{ Southern Seward Peninsula } & Norton Bay & 16176.77 \\
\cline { 2 - 3 } & Nome & 14753.27 \\
\cline { 2 - 3 } & Imuruk Basin & 12819.17 \\
\hline
\end{tabular}

\subsection{Database Construction}

I drew data from a total of four types of information sources to build my database for analysis. The first is a dataset of site locations and site metric data from the Western Arctic National Parklands (WEAR) administered by NPS, which are within my study area (Anderson 2011; Anderson and Freeburg 2013). The WEAR dataset was compiled by Anderson as part of her PhD research (Anderson 2011) and contained 371 archaeological sites, with 277 radiocarbon dates, that provided site metric and temporal data for my analysis. This dataset was generated in EXCEL and was provided by Anderson. The second dataset is the statewide historic and archaeological database managed by the Alaska State Historic Preservation Office (SHPO), which is available through the Alaska Heritage Resource Survey (AHRS) and maintained by Department of Natural Resources, Office of History and Archaeology (DNR). The AHRS dataset includes 2,968 sites within the study area (Figure 3). These sites range from 
paleontological sites to modern historic buildings. The AHRS database provides registered researchers with site location data as well as a general overview of the type of archaeological site recorded and a description of the material found. Data were available as PDF documents that are downloadable for archaeologists who are registered with the SHPO office.

After culling data from the AHRS and previous datasets, I was granted access to 409 unpublished site reports and field notes at the Anchorage field offices of the NPS and BIA to expand the description and site metric data within the database. All data were added to my thesis database with fields for the site number, latitude, longitude, site type, number of houses within the site, site area, occupation dates, cultural affiliation, references, site descriptions, alternative ID, and other data. 


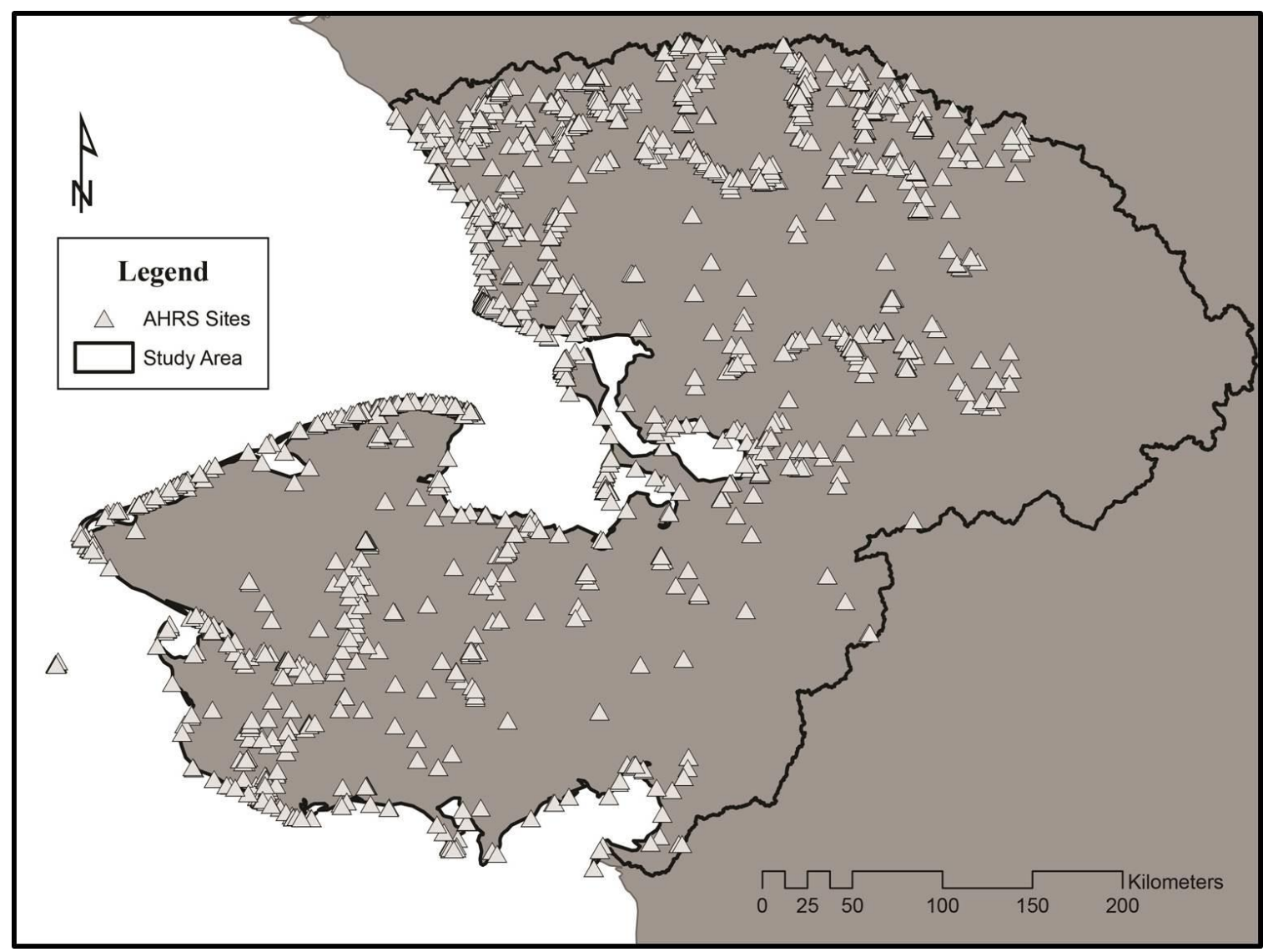

Figure 3. AHRS sites within the study area.

The last source of data for this thesis came from recent fieldwork in northwest Alaska. I participated in two separate projects lead by Dr. Shelby Anderson. The first project, conducted in 2013, was located in the western end of the Bering Land Bridge National Preserve (BELA) on the north coast of the Seward Peninsula (Figure 4). As part of this project, we identified 25 new sites and materials were collected that helped date and identify past human activities at the new and previously recorded sites within the study area. The second project was conducted in 2013 and 2015 around a closed Coast Guard station at Port Clarence, Alaska on the western coast of the Seward Peninsula (Figure 4). We identified a total of 15 new sites during the two years of field work and 
subsequently tested several sites to collect cultural and dateable material. Resulting settlement and house measurements were incorporated into my database for the analyses along with new radiocarbon dates.

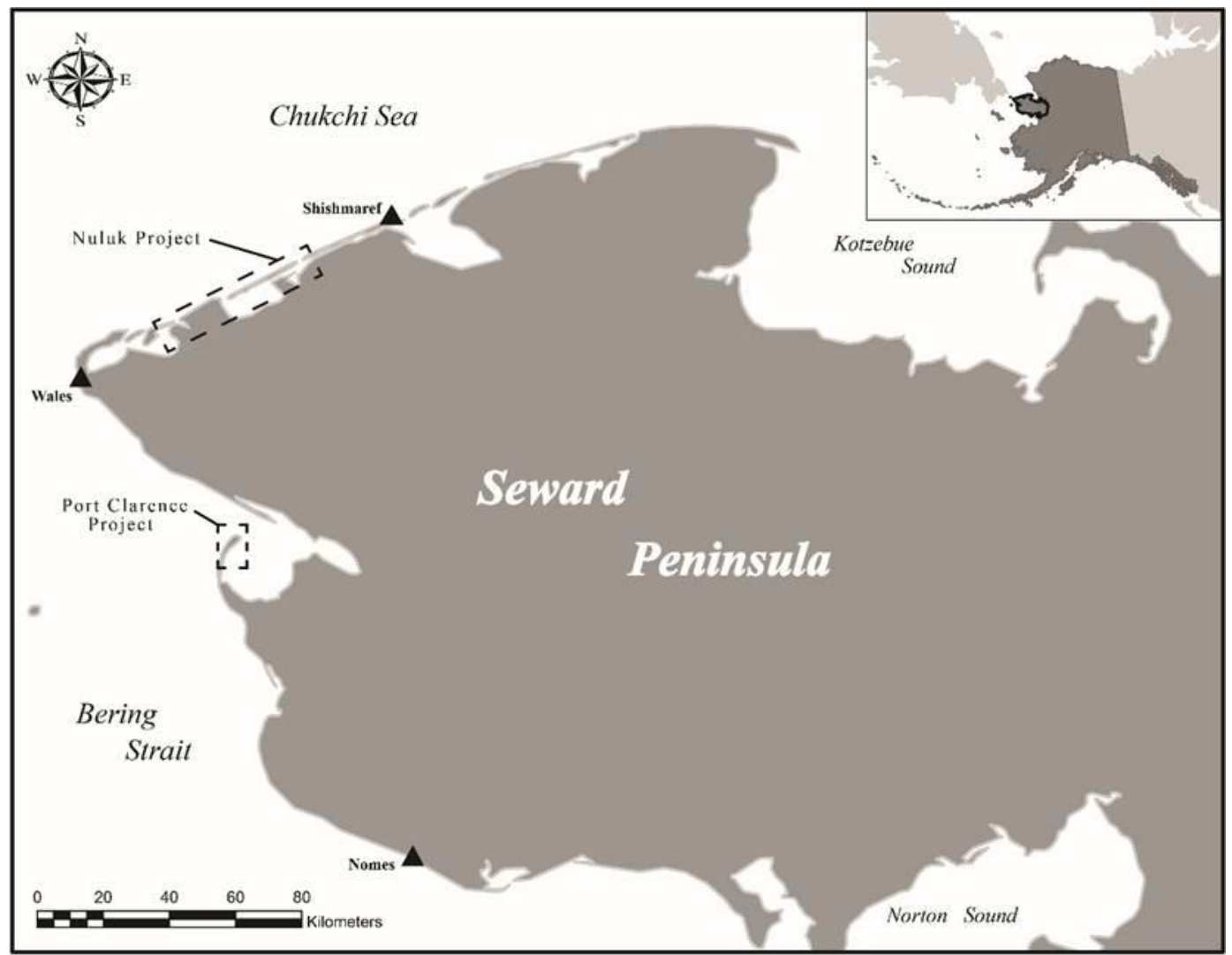

Figure 4. Nuluk and Port Clarence Project areas on the Seward Peninsula.

Site information from both databases and fieldwork were cross-referenced and checked to exclude duplicate data. A total of 2,968 sites were recorded in the AHRS (2015) within the study area. I categorized the sites into site types. Site types have been defined by the presence of features, i.e. house depressions or caches, surface artifacts, and other cultural material observed during the survey or recovered from excavations 
(Fitzhugh 2003; Martindale, et al. 2009). I used the site type definitions established by previous study in the region (Anderson 2011). Types include: large villages, villages, small villages, single houses, campsites, activity areas, cemeteries/burials, unknown, and other (Table 4). For my thesis, I focused solely on settlements, i.e. villages and single houses, to test the hypotheses related to settlement pattern change.

Table 4. Site types based on Anderson's (2011) site type designations.

\begin{tabular}{|l|l|l|}
\hline Site Type & Occupation & Description \\
\hline Activity Area & Seasonal & $\begin{array}{l}\text { Surface scatter (lithic, ceramic, bone, antler, } \\
\text { etc.) or hearths. No evidence of occupation } \\
\text { (tent elements, etc.) }\end{array}$ \\
\hline Campsite & Seasonal & $\begin{array}{l}\text { Evidence of features (surface or subsurface) } \\
\text { that indicate occupation or re-occupation in } \\
\text { addition to surface scatters (lithic, ceramic, } \\
\text { bone, antler, etc.) or hearths. }\end{array}$ \\
\hline Cemetery/Burial & N/A & $\begin{array}{l}\text { Human remains present, evidence of surface or } \\
\text { subsurface burials (burial markers, coffins, } \\
\text { burial artifacts), and/or other material } \\
\text { associated with human remains }\end{array}$ \\
\hline Large Village & Year-round or near year-round & $\begin{array}{l}\text { More than five houses (house depressions) with } \\
\text { associated features (caches, drying racks, etc.). }\end{array}$ \\
\hline Small Village & Year-round or near year-round & $\begin{array}{l}\text { Between two and five houses (house } \\
\text { depressions) with associated features (caches, } \\
\text { drying racks, etc.). }\end{array}$ \\
\hline Village & Year-round or near year-round & $\begin{array}{l}\text { Multiple houses reported but no definitive } \\
\text { number listed. }\end{array}$ \\
\hline Single House & Year-round or near year-round & $\begin{array}{l}\text { A single house (house depression) with } \\
\text { associated features (caches, drying racks, etc.). }\end{array}$ \\
\hline Unknown & Unknown & $\begin{array}{l}\text { Any description that does not fit the } \\
\text { aforementioned categories (historic sites, } \\
\text { mines, etc.). }\end{array}$ \\
\hline
\end{tabular}

I define settlements as large villages, villages, small villages, and single house occupations. A total of 486 settlements were identified within the study area and are presented in Appendix I. Of the total settlements, only 128 sites have temporal and site metric data required for incorporation into this thesis. For the temporal identification, I 
used available site occupation dates or cultural phase affiliations reported on site forms or in the literature. These dates and markers likely do not represent the full occupation history of each site in many cases. All of the 128 sites were subdivided into three temporal groups for the analyses. These temporal groups are occupations before $500 \mathrm{BP}$, after $500 \mathrm{BP}$, and continuously (Table 5).

Table 5. Criterion for each temporal grouping for the analyses.

\begin{tabular}{|l|l|}
\hline Temporal Grouping & Description \\
\hline Before 500 BP & $\begin{array}{l}\text { Sites with occupation dates between 1,000 and 500 BP } \\
\text { or associated with Thule or Birnirk cultural phases. }\end{array}$ \\
\hline After 500 BP & $\begin{array}{l}\text { Sites with occupation dates between 500 and 100 BP or } \\
\text { associated with Kotzebue, Arctic Woodland, or } \\
\text { proto/historic Iniupat. }\end{array}$ \\
\hline Continuously & $\begin{array}{l}\text { Sites that have dates that span the 500 BP boundary, } \\
\text { dates from both before and after 500 BP, or cultural } \\
\text { phases from both before and after 500 BP. }\end{array}$ \\
\hline
\end{tabular}

Based on these criteria, a total of 29 settlements have occupations that date before 500 BP (Table 6). A total 79 settlements are associated with occupations that date after 500 BP (Table 7). Lastly, 20 settlements were continuously occupied between 1,000 and 100 BP (Table 8). By including the continuously occupied settlements in both temporal periods, I will bolster the sample sizes of each group and provide more data for analysis. While the inclusion of the continuously occupied settlements may be masking finegrained settlement pattern change, it does provide a more robust dataset for analysis and removes researcher bias in the selection of excluding settlements that were occupied during the temporal periods. 
Table 6. Site number, site name, site types, and number of houses of settlements that were occupied before $500 \mathrm{BP}$.

\begin{tabular}{|l|l|l|c|}
\hline $\begin{array}{l}\text { AHRS Site } \\
\text { Number }\end{array}$ & Site Name & Site Type & Number of Houses \\
\hline BEN-00185 & & Single House & 1 \\
\hline KTZ-00008 & Kugruk Lagoon & Large Village & 20 \\
\hline KTZ-00023 & Deering Quargi & Single House & 1 \\
\hline KTZ-00031 & Old Kotzebue & Large Village & 200 \\
\hline KTZ-00068 & & Single House & 1 \\
\hline KTZ-00087 & & Large Village & 40 \\
\hline KTZ-00130 & & Large Village & 25 \\
\hline KTZ-00131 & & Large Village & 10 \\
\hline KTZ-00299 & & Single House & 1 \\
\hline KTZ-00300 & Deering Western Thule House 1 & Single House & 1 \\
\hline KTZ-00301 & Deering Western Thule House 2 & Single House & 1 \\
\hline NOA-00008 & & Small Village & 4 \\
\hline NOA-00158 & & Single House & 1 \\
\hline NOA-00170 & & Single House & 1 \\
\hline NOA-00274 & & Small Village & 3 \\
\hline NOA-00383 & & Large Village & 7 \\
\hline NOA-00468 & & Single House & 1 \\
\hline NOA-00473 & & Large Village & 7 \\
\hline NOA-00509 & & Small Village & 2 \\
\hline NOA-00531 & & Small Village & 2 \\
\hline NOA-00534 & & Small Village & 3 \\
\hline NOA-00555 & & Single House & 1 \\
\hline NOA-00556 & & Small Village & 3 \\
\hline NOA-00578 & & Small Village & 3 \\
\hline TEL-00093 & & Small Village & 3 \\
\hline TEL-00216 & & Small Village & 29 \\
\hline XBM-00002 & Ahteut Continuation & Small Village & 20 \\
\hline XBM-00003 & Ahteut Site & Large Village & \\
\hline XBM-00009 & Ekseavik (Eksiavik) & Large Village & \\
\hline & & & \\
\hline & & & \\
\hline & & & \\
\hline & & & \\
\hline
\end{tabular}


Table 7. Site number, site name, site types, and number of houses of settlements that were occupied after $500 \mathrm{BP}$.

\begin{tabular}{|c|c|c|c|}
\hline $\begin{array}{l}\text { AHRS Site Number / } \\
\text { Temporary Site Number }\end{array}$ & Site Name & Site Type & Number of Houses \\
\hline AMR-00001 & Onion Portage $(\mathrm{A})$ & Large Village & 20 \\
\hline AMR-00002 & Ambler Island & Large Village & 15 \\
\hline BEN-00029 & Kuzitrin Lake \#1 & Small Village & 3 \\
\hline BEN-00033 & Cloud Lake Village & Large Village & 9 \\
\hline BEN-00053 & Kuzitrin Lake West Village & Large Village & 35 \\
\hline CAN-00004 & Iqalugruaq & Small Village & 2 \\
\hline CAN-00025 & Kuluvachak & Large Village & 6 \\
\hline KTZ-00001 & & Village & 30 \\
\hline KTZ-00009 & Kividluk & Large Village & 32 \\
\hline KTZ-00020 & Kiplaut & Small Village & 4 \\
\hline KTZ-00053 & & Small Village & 3 \\
\hline KTZ-00054 & & Small Village & 2 \\
\hline KTZ-00055 & & Large Village & 12 \\
\hline KTZ-00056 & & Large Village & 16 \\
\hline KTZ-00060 & & Single Occupation & 1 \\
\hline KTZ-00090 & & Large Village & 10 \\
\hline KTZ-00101 & & Large Village & 10 \\
\hline KTZ-00138 & & Large Village & 15 \\
\hline KTZ-00148 & & Large Village & 11 \\
\hline KTZ-00171 & & Large Village & 10 \\
\hline KTZ-00298 & Aklaq & Large Village & 11 \\
\hline MIS-00032 & Lake Kaiyak & Large Village & 8 \\
\hline NOA-00003 & Aniyak & Large Village & 12 \\
\hline NOA-00140 & Anigaaq $\mathrm{C}$ & Large Village & 7 \\
\hline NOA-00161 & & Small Village & 3 \\
\hline NOA-00162 & & Single Occupation & 1 \\
\hline NOA-00163 & & Single Occupation & 1 \\
\hline NOA-00164 & & Small Village & 2 \\
\hline NOA-00188 & & Single Occupation & 1 \\
\hline NOA-00217 & Agiaguat & Small Village & 2 \\
\hline NOA-00284 & Atiligauraq & Small Village & 2 \\
\hline NOA-00301 & Igrugaivik Creek Camp & Small Village & 2 \\
\hline NOA-00474 & & Single Occupation & 1 \\
\hline NOA-00516 & & Large Village & 9 \\
\hline
\end{tabular}




\begin{tabular}{|c|c|c|c|}
\hline NOM-00146 & Snake River Spit Site & Small Village & 2 \\
\hline PSU-2013-006 (Nuluk) & & Single Occupation & 1 \\
\hline SHF-00043 & & Small Village & 2 \\
\hline SHU-00009 & Shungnak Site & Small Village & 5 \\
\hline SHU-00021 & Tekeahruguruk & Small Village & 5 \\
\hline SHU-00022 & Black River & Large Village & 8 \\
\hline SLK-00044 & & Single Occupation & 1 \\
\hline SLK-00102 & Dobuk & Single Occupation & 1 \\
\hline SOL-00068 & Okpiktulik & Large Village & 14 \\
\hline SOL-00093 & Nuglene Site & Large Village & 9 \\
\hline TEL-00001 & Sungiyorat & Small Village & 3 \\
\hline TEL-00006 & Amilrokmiut & Small Village & 5 \\
\hline TEL-00007 & Kauwerak & Large Village & 29 \\
\hline TEL-00060 & Metoktu & Large Village & 17 \\
\hline TEL-00061 & Igloo & Small Village & 4 \\
\hline TEL-00078 & Nutaat & Single Occupation & 1 \\
\hline TEL-00086 & & Large Village & 7 \\
\hline TEL-00087 & & Small Village & 2 \\
\hline TEL-00096 & & Small Village & 4 \\
\hline TEL-00099 & & Small Village & 4 \\
\hline TEL-00232 & & Small Village & 4 \\
\hline TEL-00233 & & Small Village & 2 \\
\hline TEL-00249 & & Small Village & 5 \\
\hline TEL-00250 & & Single Occupation & 1 \\
\hline TEL-00251 & & Single Occupation & 1 \\
\hline TEL-00252 & & Single Occupation & 1 \\
\hline TEL-00256 & & Single Occupation & 1 \\
\hline TEL-00257 & & Single Occupation & 1 \\
\hline TEL-00258 & & Small Village & 2 \\
\hline TEL-00260 & & Small Village & 2 \\
\hline TEL-00263 & & Small Village & 2 \\
\hline TEL-00264 & & Small Village & 3 \\
\hline TEL-00265 & & Small Village & 2 \\
\hline TEL-00269 & & Small Village & 4 \\
\hline TEL-00272 & & Small Village & 2 \\
\hline TEL-00273 & & Small Village & 3 \\
\hline TEL-00278 & & Small Village & 3 \\
\hline TEL-00280 & & Small Village & 3 \\
\hline XBM-00001 & Kavet Creek Site & Large Village & 28 \\
\hline
\end{tabular}




\begin{tabular}{|l|l|l|c|}
\hline XBM-00012 & Kangiguksuk & Single Occupation & 1 \\
\hline XBM-00028 & Killiktavik 2 & Large Village & 12 \\
\hline XBM-00030 & & Single Occupation & 1 \\
\hline XBM-00035 & Siesieaijak & Small Village & 4 \\
\hline XBM-00041 & Mitkotaylyuk & Single Occupation & 1 \\
\hline XHP-00017 & & Large Village & 24 \\
\hline
\end{tabular}

Table 8. Site number, site name, site types, and number of houses of settlements that were continuously occupied.

\begin{tabular}{|l|l|l|c|}
\hline AHRS Site Number & Site Name & Site Type & Number of Houses \\
\hline KTZ-00026 & Site East of Deering & Large Village & 18 \\
\hline KTZ-00030 & Intermediate Kotzebue & Large Village & 30 \\
\hline KTZ-00052 & & Large Village & 47 \\
\hline KTZ-00069 & & Large Village & 27 \\
\hline KTZ-00086 & & Large Village & 11 \\
\hline KTZ-00088 & & Small Village & 5 \\
\hline KTZ-00089 & & Small Village & 2 \\
\hline NOA-00513 & & Large Village & 45 \\
\hline NOA-00533 & & Large Village & 8 \\
\hline NOA-00558 & & Large Village & 6 \\
\hline SLK-00047 & Thule-Kotzebue Village & Large Village & 6 \\
\hline SLK-00049 & Sisiivik & Large Village & 160 \\
\hline SLK-00086 & & Single Occupation & 1 \\
\hline SOL-00065 & Kuvrawik & Large Village & 7 \\
\hline SOL-00131 & & Small Village & 2 \\
\hline SLK-00100 & Kiwalik Spit Village & Small Village & 5 \\
\hline TEL-00104 & & Large Village & 7 \\
\hline TEL-00105 & & Large Village & 8 \\
\hline TEL-00108 & & Single Occupation & 1 \\
\hline XBM-00131 & & Large Village & 9 \\
\hline
\end{tabular}

During the database construction, I identified three primary limitations within the data: a lack of systematic surveys within the study area, a lack of temporal specificity for site occupations, and an absence of site specific data. Fieldwork within the study area was directed towards cultural resource compliance, management of federal lands, or academic 
research. The majority of on-the-ground field work in northwest Alaska, with an emphasis on systematic survey, is limited to federal lands, e.g. Cape Krusenstern National Monument (Anderson 2011; Freeburg and Anderson 2012; McClenahan and Gibson 1990) and Bering Land Bridge National Preserve (BELA) (Anderson and Junge 2015; Hoffecker and Mason 2010; Powers, et al. 1982; Schaaf 1988; Tremayne 2014). This leaves large sections of the study area with only limited aerial reconnaissance survey, reconnaissance survey, or historic and ethnographic accounts of sites; large areas are also completely unsurveyed. While this limitation does hinder the full coverage of the study area and leaves sizeable gaps in my database, until more systematic surveys occur, the dataset I compiled is complete.

Archeologists recorded 2,968 paleontological, prehistoric, and historic sites within the study area but identified only 486 settlements, i.e. villages and single house sites. Of these settlements, 190 sites have temporal occupation dates or cultural affiliations. Additionally, many sites have only one date, have additional dates that are outside the study period, or are associated with multiple occupations that spans the last 1350 years (e.g. TEL-00105, XBM-00131, and SLK-00049 “Sisiivik”) and fall within both temporal periods. These dating issues point to the gaps in our knowledge. We need to obtain multiple dates from large sites with numerous houses. There is a lack of understanding of the complexities household occupations (i.e. multiple house occupations and reuse of older houses or structural elements). Only 128 sites have temporal markers to separate them into periods for the analysis. 
A general limitation in regards to site data is the lack of site metrics, i.e. the number of houses within the site and the size of houses. Unfortunately, this information is often not recorded for sites in northwest Alaska. As previously stated, much of the study area has not been surveyed and the surveyed areas were primarily aerial or reconnaissance surveys. This limited data is bolstered by ethnographic research (Burch 1998; Koutsky 1981a, 1981b, 1981c, 1981d, 1981e, 1981f; Ray 1975) and oral histories that indicate settlement locations and are listed in the AHRS database. While many of the ethnographic and oral history sites were relocated by archaeological fieldwork, some only have minimal site metric data for this analysis. Even when sites were surveyed and tested it can be difficult to identify feature type (e.g. house versus large storage cache) and feature measurements based on surface depressions and other markers. Many house structural layouts can be categorized based on the depression formations (see Darwent, et al. 2013), but no unified classification system or identification technique has been developed, beyond excavation, to completely identify specific size and shape of subsurface features. Likewise, measurements of surface features may not represent the actual size of the buried structures. The post-depositional and site formation processes may mask the physical dimensions of the structure and create larger, smaller, or merged surface depressions. Unless the measurements from a fully excavated house are provided (e.g. Giddings 1952; Giddings and Anderson 1986) the surface depression measurements were used as a proxy for the actual house size.

Of the 128 settlements that are associated with the two temporal groups, only 83 have corresponding house measurements; however, not all house features previously 
identified within these sites have measurement data. In some cases, there are discrepancies in house counts at large settlements, e.g. Giddings (1952) reported 200 houses at the Old Kotzebue site but only eight houses were ever excavated or depression measurements recorded (Giddings 1952; VanStone 1954). I have included all measurements that were accessible in data tables, figures, and GIS data into the house measurement database, see Appendix II. Of the 83 settlements with house measurement data, 25 are associated with an occupation before $500 \mathrm{BP}$ and have a total of 145 houses measured (Table 9). The remaining 58 settlements relate to an occupation after $500 \mathrm{BP}$ with a total of 320 houses measured (Table 10).

Table 9. Settlements and the number of measured houses before 500 BP.

\begin{tabular}{|l|c|c|}
\hline AHRS Site Number & Number of Houses Measured & Total Number of Houses \\
\hline BEN-00185 & 1 & 1 \\
\hline KTZ-00008 & 20 & 20 \\
\hline KTZ-00023 & 1 & 1 \\
\hline KTZ-00031 & 8 & 200 \\
\hline KTZ-00068 & 1 & 1 \\
\hline KTZ-00087 & 12 & 40 \\
\hline KTZ-00130 & 7 & 25 \\
\hline KTZ-00131 & 1 & 10 \\
\hline KTZ-00299 & 1 & 1 \\
\hline KTZ-00300 & 1 & 1 \\
\hline KTZ-00301 & 1 & 1 \\
\hline NOA-00158 & 3 & 3 \\
\hline NOA-00274 & 7 & 7 \\
\hline NOA-00383 & 1 & 1 \\
\hline NOA-00468 & 7 & 7 \\
\hline NOA-00473 & 2 & 2 \\
\hline NOA-00509 & 2 & 2 \\
\hline NOA-00531 & 3 & 3 \\
\hline NOA-00534 & 1 & 1 \\
\hline NOA-00555 & 3 & 3 \\
\hline NOA-00556 & 49 & \\
\hline & 7 & 1 \\
\hline & 1 & \\
\hline
\end{tabular}




\begin{tabular}{|l|c|c|}
\hline NOA-00578 & 5 & 5 \\
\hline TEL-00093 & 2 & 3 \\
\hline XBM-00003 & 22 & 29 \\
\hline XBM-00009 & 9 & 20 \\
\hline
\end{tabular}

Table 10. Settlements and the number of measured houses after $500 \mathrm{BP}$.

\begin{tabular}{|c|c|c|}
\hline $\begin{array}{l}\text { AHRS Site Number / } \\
\text { Temporary Site Number }\end{array}$ & Number of Houses Measured & Total Number of Houses \\
\hline AMR-00002 & 15 & 15 \\
\hline BEN-00029 & 2 & 3 \\
\hline BEN-00033 & 3 & 9 \\
\hline BEN-00053 & 9 & 35 \\
\hline CAN-0004 & 2 & 2 \\
\hline KTZ-00009 & 24 & 32 \\
\hline KTZ-00030 & 5 & 30 \\
\hline KTZ-00054 & 2 & 2 \\
\hline KTZ-00055 & 12 & 12 \\
\hline KTZ-00056 & 15 & 16 \\
\hline KTZ-00060 & 1 & 1 \\
\hline KTZ-00090 & 10 & 10 \\
\hline KTZ-00101 & 9 & 10 \\
\hline KTZ-00148 & 6 & 11 \\
\hline KTZ-00171 & 10 & 10 \\
\hline KTZ-00298 & 9 & 11 \\
\hline NOA-00003 & 12 & 12 \\
\hline NOA-00140 & 7 & 7 \\
\hline NOA-00161 & 2 & 3 \\
\hline NOA-00162 & 1 & 1 \\
\hline NOA-00163 & 1 & 1 \\
\hline NOA-00164 & 2 & 2 \\
\hline NOA-00188 & 1 & 1 \\
\hline NOA-00217 & 2 & 2 \\
\hline NOA-00284 & 2 & 2 \\
\hline NOA-00301 & 2 & 2 \\
\hline NOA-00474 & 1 & 1 \\
\hline PSU-2013-006 (Nuluk) & 1 & 1 \\
\hline SHF-00043 & 2 & 2 \\
\hline SHU-00009 & 1 & 5 \\
\hline SLK-00044 & 1 & 1 \\
\hline
\end{tabular}




\begin{tabular}{|c|c|c|}
\hline SLK-00102 & 1 & 1 \\
\hline SOL-00068 & 14 & 14 \\
\hline TEL-00007 & 28 & 29 \\
\hline TEL-00060 & 17 & 17 \\
\hline TEL-00086 & 6 & 7 \\
\hline TEL-00087 & 2 & 2 \\
\hline TEL-00096 & 4 & 4 \\
\hline TEL-00099 & 4 & 4 \\
\hline TEL-00232 & 4 & 4 \\
\hline TEL-00233 & 2 & 2 \\
\hline TEL-00249 & 4 & 5 \\
\hline TEL-00250 & 1 & 1 \\
\hline TEL-00251 & 1 & 1 \\
\hline TEL-00252 & 1 & 1 \\
\hline TEL-00256 & 1 & 1 \\
\hline TEL-00257 & 1 & 1 \\
\hline TEL-00258 & 1 & 2 \\
\hline TEL-00260 & 2 & 2 \\
\hline TEL-00263 & 2 & 2 \\
\hline TEL-00264 & 3 & 3 \\
\hline TEL-00269 & 4 & 4 \\
\hline TEL-00272 & 2 & 2 \\
\hline TEL-00273 & 3 & 3 \\
\hline TEL-00278 & 3 & 3 \\
\hline TEL-00280 & 3 & 3 \\
\hline XBM-00001 & 25 & 28 \\
\hline
\end{tabular}

\subsubsection{Spatial Distribution of Settlements with GIS}

I use three spatial analyses, Nearest Neighbor Analysis, Moran's I, and Getis-Ord, to ascertain whether settlement patterns changed pre- and post-500 BP. Nearest Neighbor Analysis measures the observed average distance of a target feature and the nearest neighbors and compares this value to the distance of the expected value between nearest neighbors in a random pattern (Bolstad 2012; O'Sullivan and Unwin 2014; Rogerson 2015; Wheatley and Gillings 2003). The Nearest Neighbor Analysis is used to evaluate 
the spatial distribution of settlements within the study area. Based on the output index of the Nearest Neighbor Analysis, the tool will identify whether the pattern being analyzed is clustered (i.e. a score < 1) or dispersed (i.e. a score > 1). The Nearest Neighbor Analysis provides z-scores and p-values for each output to indicate the significance of the results.

Moran's I measures the spatial autocorrelation, which is the degree to which spatial features cluster together or disperse, of the value associated with selected features and identifies whether their distributions cluster, order, or disperse (Bolstad 2012; O'Sullivan and Unwin 2014; Rogerson 2015; Wheatley and Gillings 2003). Both global and local Moran's I are used to evaluate the spatial distribution of size, the number of houses per settlement, of settlements and identify where clustering is occurring within the study area. As stated previously, the global Moran's I tests a single value against the entire dataset while the local Moran's I calculates a value and tests for each observation (O'Sullivan and Unwin 2014; Rogerson 2015). The global measure produces a numerical output that indicates a clustered (score of +1 ), dispersed (score of -1 ), or random pattern (score of -0.99-0.99). The local measure (Anselin Local Moran's I) creates an output feature class, i.e. points or polygons, that identifies locations that are clustered, dispersed, or outliers. The local Moran's I output will identify locations of High-High (large values near larger values) and Low-Low (small values near small values) clustering and outliers. The outliers indicate locations that are High-Low (large values near small values) and Low-High (small values near large values). Both Moran's I analyses list z-scores and pvalues for each output to indicate the significance of the results. 
Getis-Ord analysis is an examination of spatial density, but goes beyond density to locate statistically significant hot and cold spots, places of high value and low value, of clustered features (Bolstad 2012; Mitchel 2005; O'Sullivan and Unwin 2014; Rogerson 2015). Local Getis-Ord analysis is used to test the spatial distribution of the size of settlements and identify the location of settlements that are significantly large or small in size within the study area. The local Getis-Ord (Getis-Ord Gi* "hot-spot") creates an output feature class that visually discerns where the high and low value clustering is occurring within the study area. The output for the local Getis-Ord analysis presents pvalues and z-scores that specify the significance of the results.

These spatial analyses are used to test my expectations that the spatial pattern before $500 \mathrm{BP}$ was clustered with key settlements and the spatial pattern after $500 \mathrm{BP}$ was dispersed with key settlement locations shifting from aggregated locations. Each of these spatial analytical tools has required fields for the analyses to run in ArcGIS. The required fields for the Nearest Neighbor Analysis are feature class and distance method. The feature class is the shapefile, i.e. points or polygons, with which the analysis will be performed. The distance method is a pre-constructed method of measuring distance within the ESRI ArcGIS software (see ESRI ArcGIS for full description). The distance method has a default setting, Euclidean distance, that is suitable for exploratory analyses as Manhattan distance is designed for city street grid analysis.

The Moran's I and Getis-Ord analyses required fields include feature class, input value, minimum sample size, spatial relationship, distance method, and distance bandwidth (Table 11). The first three requirements are based on data being analyzed. The 
feature class, as described above, is the shapefile on which the analysis will be performed. The input values are the numeric values. In these analyses it is the number of houses per settlement for each feature being analyzed. Each tool requires a minimum sample size of 30 features for the analysis to be performed. The last three required fields for the spatial tools are parameters set on data while the analysis is being performed. Spatial relationships is a pre-constructed procedure within the ESRI ArcGIS software (see ESRI ArcGIS for full descriptions). The spatial relationship sets constants on how each feature is influenced by other features or the spatial environment. These relationships are inverse distance, inverse distance squared, fixed distance band, zone of indifference, contiguity edges only, contiguity edge corners, and spatial weights. As stated above, the distance method is how the distances are being measured for the analysis. The spatial relationship parameter has default setting that is suitable for exploratory analyses. 
Table 11. Required features and parameters used for global and local Moran's I and Getis-Ord.

\begin{tabular}{|l|l|}
\hline Required Field & Value or Parameter \\
\hline Feature Class & Point \\
\hline Input Value & Number of Houses \\
\hline Number of Entries & Temporal Period Dependent \\
\hline Spatial Relationship & Inverse Distance \\
\hline Distance Method & Euclidean Distance \\
\hline Bandwidth & 34 km (Ethnographic) $/ 113.576 \mathrm{~km}$ (Incremental) \\
\hline
\end{tabular}

The default for spatial relationship for most spatial analytical tools is Inverse Distance. Inverse Distance calculates the spatial autocorrelation value by adding more computational weighting to nearby neighboring features over other features that are further away. Bandwidth, the last parameter required for this analysis, has a functional application for the spatial relationship parameter. For the Inverse Distance relationship, the bandwidth specifies the cutoff distance at which the neighboring features are included in analysis of the target feature. The bandwidth can be selected based on specific information about the dataset or input data using Incremental Spatial Autocorrelation, a spatial analysis tool. For this analysis, I ran the spatial statistic tools with two bandwidths.

The two bandwidths used were based on 1) the ESRI ArcGIS spatial tool and regional ethnographic data. The first bandwidth was generated using the Incremental Spatial Autocorrelation tool in ArcGIS. The parameters for this tool required feature class, input value, and distance band in the output data, and a beginning distance. For this 
tool I used a beginning distance of $36 \mathrm{~km}$ and 20 segments based on the number of houses from all settlements within the complete database. These parameters were selected for an exploratory analysis to find the peak distance for spatial autocorrelation. A distance value of $113.576 \mathrm{~km}$ was used by the tool as the first and maximum peak based on the settlement data. The second bandwidth was selected based on the average foraging radius for male arctic hunters during the ethnographic period. The range of $34 \mathrm{~km}$ was calculated using Binford's (2001:238) compiled data stating that average round-trip distance is $26.4 \mathrm{~km}$ with a standard deviation of 7.93 . The value of $34 \mathrm{~km}$ was generated based on my assumption that hunter-gatherers would position settlements outside each other's round-trip distance range to minimize competition over resource access. While ethnographic data indicate that sharing of resources occurred, I feel that this bandwidth represents a more accurate relationship between settlements than using a larger or smaller bandwidth.

\subsubsection{Site Metric Analyses}

I use IBM SPSS Statistics 23 software to conduct site metric analysis. The goal of this analysis was to test whether there are significant differences in the mean measurements for settlement size and house size. For these analyses, I used a two sample t-test to identify if the difference between the two means is statistically significant (Fletcher and Lock 2005). The basic assumptions of these types of tests are that the sample sizes for the two populations are equal and that populations are normally distributed. 
The assumption of normality, an important aspect of statistical analysis, and tests, such as Kolmogorov-Smirnov and Shapiro-Wilk, was used to evaluate whether the populations are normally distributed. Depending upon whether the assumptions of normality hold, two types of analysis can be used to test for differences in the means (Fletcher and Lock 2005). For parametric samples, normal distribution, the basic pairedsample t-test was used. For non-parametric samples, non-normal distribution, the MannWhitney Test U was used. Before I tested the statistical difference between the average settlement size and average house size, I ran the Shapiro-Wilk test to identify the distribution of data. The Shapiro-Wilk test assumes a null hypothesis that the sample has a non-normal distribution and is recommended for datasets with small and large sample sizes (Razali and Wah 2011).

I also tested settlement data to explore the relationship between the number of settlements recorded for the two temporal datasets. Using a One-Sample Chi-Square test, I tested whether the observed frequencies match the expected theoretical frequencies (Fletcher and Lock 2005). The default expected frequencies in SPSS are 50\% of the total observed frequencies. The total observed frequencies is 108 settlements, 29 before 500 BP (Table 9) and 79 after 500 BP (Table 10), with expected frequencies of 54. ChiSquare test assumes a null hypothesis that no association between the frequencies was present (Fletcher and Lock 2005). 


\section{Chapter 4.1: Results}

In this chapter, I will present the results of the spatial distribution and site metric analyses. I will first show the results of the Nearest Neighbor Analysis. Then, I will present the global Moran's I followed by the output of the local Moran's I and local Getis-Ord analyses. I will then describe the results of the normality tests for the site metric data and identify the t-test used for the additional analyses. Lastly, I will present the results of the average settlement size and average house size t-test analyses.

\subsection{Nearest Neighbor Analysis}

As previously stated, the Nearest Neighbor Analysis tests the spatial distribution of settlements before and after 500 BP. Table 12 presents the Nearest Neighbor Analysis index value for the settlements in the two temporal periods. A Nearest Neighbor index of 0.562 with a p-value of 0.000 indicates that the spatial pattern before $500 \mathrm{BP}$ has a clustered distribution and is statistically significant. Similarly, a Nearest Neighbor index of 0.578 with a p-value of 0.000 indicates that the spatial pattern before $500 \mathrm{BP}$ has a clustered distribution and is statistically significant.

Table 12. The Nearest Neighbor Analysis for two temporal periods.

\begin{tabular}{lcccc}
\hline Analysis & Nearest Neighbor Index & Z-score & p-value & \multicolumn{2}{c}{ Significant } \\
Before 500 BP & 0.562 & -5.625 & 0.000 & Yes \\
After 500 BP & 0.578 & -7.919 & 0.000 & Yes \\
& & & & \\
\hline
\end{tabular}




\subsection{Global Moran's I Spatial Distribution Analysis}

As stated above, the global Moran's I evaluates the spatial distribution of the size settlements, the number of houses per settlement, before and after $500 \mathrm{BP}$. Table 13 lists the Moran's I spatial statistics for the size of settlements in the two temporal groups using both the ethnographic and incremental spatial bandwidth distances. Based on the statistical output values, the difference between the two bandwidths is marginal and shows no scale effects on data. With this in mind, I used the spatial statistic values associated with the ethnographic foraging distances for my analysis. A Moran's I value of 0.088 with a p-value of 0.679 indicates that the spatial pattern of the size of settlements before $500 \mathrm{BP}$ has a random distribution and is not statistically significant. Likewise, the Moran's I value of 0.042 with a p-value of 0.751 indicates that the spatial pattern of the size of settlements after $500 \mathrm{BP}$ is a random distribution and is not statistically significant.

Table 13. Global Moran's I spatial statistics for the two temporal groups separated into the ethnographic and incremental spatial bandwidth distances.

\begin{tabular}{lrcccc}
\hline Analysis & Bandwidth & Moran's I & Z-score & p-value & Significant \\
Before 500 BP & $34 \mathrm{~km}$ & 0.088 & 0.413 & 0.679 & No \\
& $113.576 \mathrm{~km}$ & 0.083 & 0.410 & 0.681 & No \\
After 500 BP & $34 \mathrm{~km}$ & 0.042 & 0.318 & 0.751 & No \\
& $113.576 \mathrm{~km}$ & 0.041 & 0.330 & 0.742 & No \\
\hline
\end{tabular}




\subsubsection{Local Moran's I Spatial Analysis}

Local Moran's I evaluates the spatial relationship of the size of settlements based on their corresponding size values within the study area to identify locations of high and low clustering of settlements before and after $500 \mathrm{BP}$ (Table 14). Using the ethnographic bandwidth distance, the local Moran's I before 500 BP (Figure 6:A1) identifies KTZ00030 (Intermediate Kotzebue site) and KTZ-00031 (Old Kotzebue site) as High-High clustered settlements and SLK-00049 (Sisiivik site) as a High-Low outlier. No other settlements during this temporal period are significantly clustered. After 500 BP (Figure 6:A2), the local Moran's I indicates that the Sisiivik site is still a High-Low outlier and that no other settlements are significantly clustered.

Table 14. Local Moran's I output descriptions.

\begin{tabular}{|l|l|}
\hline Output Type & Description \\
\hline Not Significant & $\begin{array}{l}\text { Settlement does not have a significantly high or low value } \\
\text { (number of houses) and is surrounded by similar settlements } \\
\text { within the distance bandwidth. }\end{array}$ \\
\hline High-High Clustering & $\begin{array}{l}\text { Settlement has high values (number of houses) and is located } \\
\text { near settlements within the distance bandwidth that also have } \\
\text { high values. }\end{array}$ \\
\hline High-Low Outlier & $\begin{array}{l}\text { Settlement has high values (number of houses) and is located } \\
\text { near settlements within the distance bandwidth that have low } \\
\text { values. }\end{array}$ \\
\hline Low-High Outlier & $\begin{array}{l}\text { Settlement has low values (number of houses) and is located } \\
\text { near settlements within the distance bandwidth that have high } \\
\text { values. }\end{array}$ \\
\hline Low-Low Clustering & $\begin{array}{l}\text { Settlement has low values (number of houses) and is located } \\
\text { near settlements within the distance bandwidth that also have } \\
\text { low values. }\end{array}$ \\
\hline
\end{tabular}

Based on the incremental spatial bandwidth distance, the local Moran's I before 500 BP (Figure 6:B1) identifies the Old Kotzebue site as the only High-High clustered settlement. No other settlements are significantly clustered. After 500 BP (Figure 6:B2), 
the local Moran's I indicates that the Intermediate Kotzebue site and KTZ-00001

(Kotzebue site) are High-High clustered settlements with the Sisiivik site as a High-Low outlier and SLK-00102 (Dobuk site) as a Low-High outlier. 


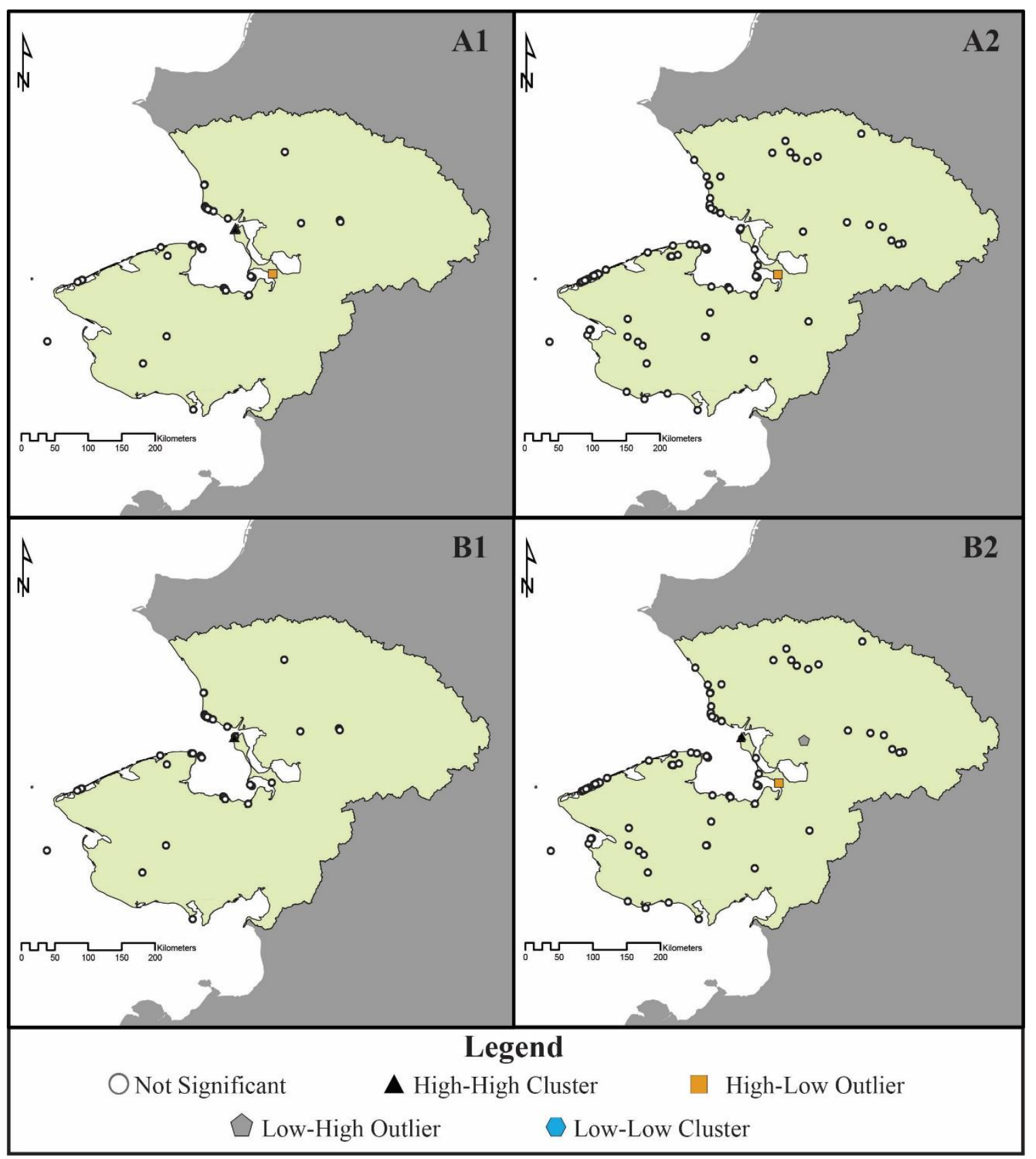

Figure 5. Local Moran's I spatial statistics of settlements before (1) and after (2) 500 BP using the ethnographic (A) and incremental spatial (B) bandwidth distances. 


\subsubsection{Local Getis-Ord Gi* Spatial Analysis}

Local Getis-Ord Gi* "hotspot analysis" evaluates the spatial relationship of the size of settlements, number of houses per settlement, based on their corresponding size values within the study area to identify statistically significant locations of settlements before and after 500 BP. Using the ethnographic bandwidth distance, the local Getis-Ord Gi* before 500 BP (Figure 7:A1) identifies the Old Kotzebue site and Sisiivik as statistically significant hotspots at a 99\% confidence level. After 500 BP (Figure 7:A2), the local Getis-Ord Gi* indicates that Sisiivik is still a hotspot (99\% confidence level) but now KTZ-00052 and NOA-00513 are statistically significant hotspots at a 95\% confidence level. These significance values indicate settlements that are uniquely larger or smaller in relation to the size (number of houses per settlements) of settlements surrounding the original settlement being analyzed. Based on the incremental spatial bandwidth, the Getis-Ord Gi* outputs for the settlements before 500 BP (Figure 7:B1) and after $500 \mathrm{BP}$ (Figure 7:B2) are the same as the ethnographic bandwidth. 


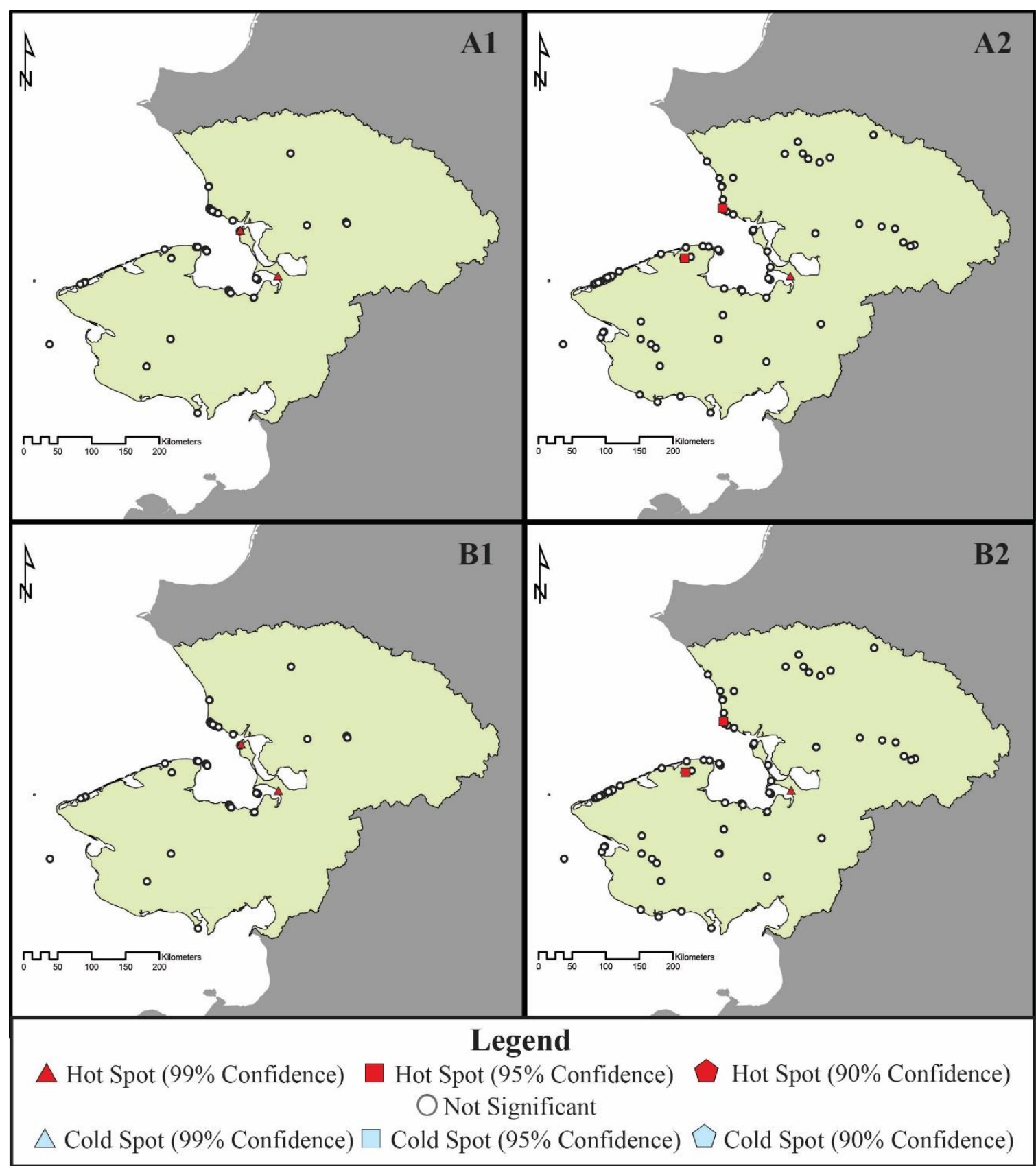

Figure 6. Local Getis-Ord Gi* spatial statistics of settlements before (1) and after (2) 500 $\mathrm{BP}$ using the ethnographic (A) and incremental spatial (B) bandwidth distances. 


\subsubsection{Site Metric Analyses}

Both site metric datasets, the average number of houses per site and the average house size, were tested for normality using the Shapiro-Wilk test. For the settlement size datasets, the samples for both before 500 BP (Figure 8) and after 500 BP (Figure 9) have p-values of $<0.001$. I cannot reject the null hypothesis and I therefore conclude the data have a non-normal distribution. For the house size datasets, the samples for both before 500 BP (Figure 10) and after 500 BP (Figure 11) have p-values of $<0.001$. I cannot reject the null hypothesis and I therefore conclude that data have a non-normal distribution. Because all four datasets have a non-normal distribution, I use the Mann-Whitney U test to compare the means of the average number of houses per site and the average house size.

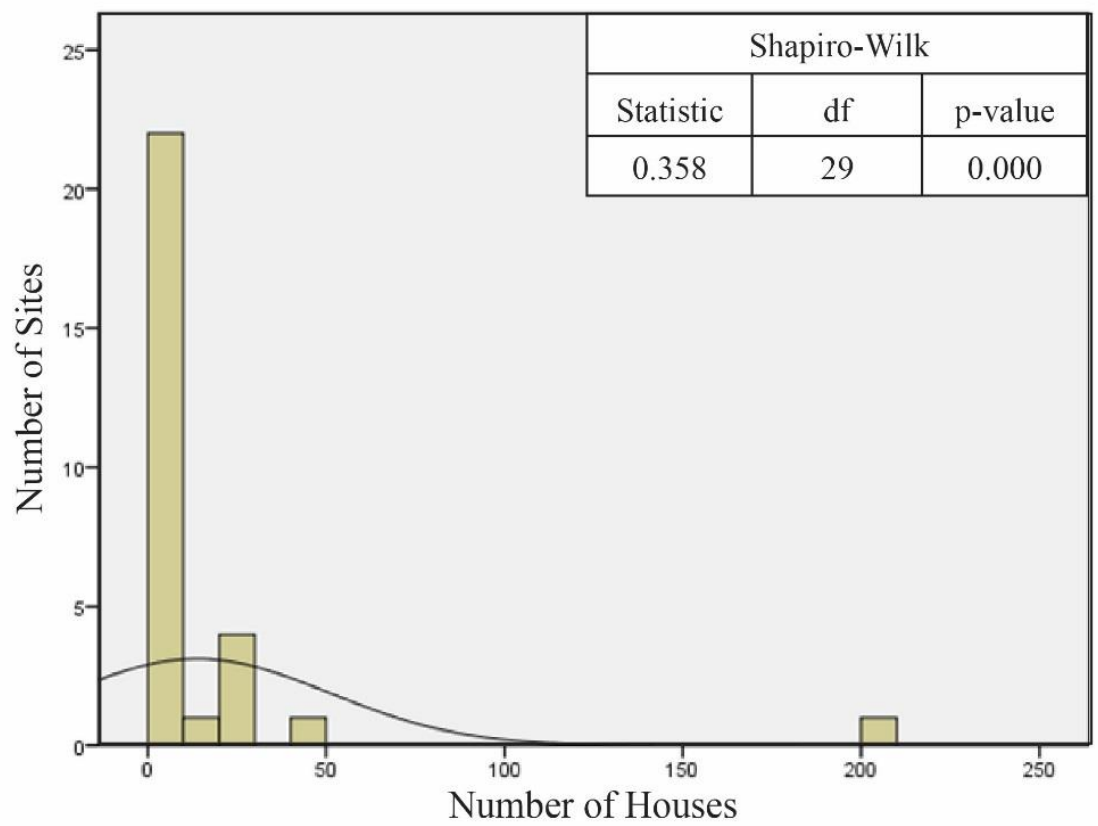

Figure 7. Shapiro-Wilk test and distribution of settlement size before 500 BP. 


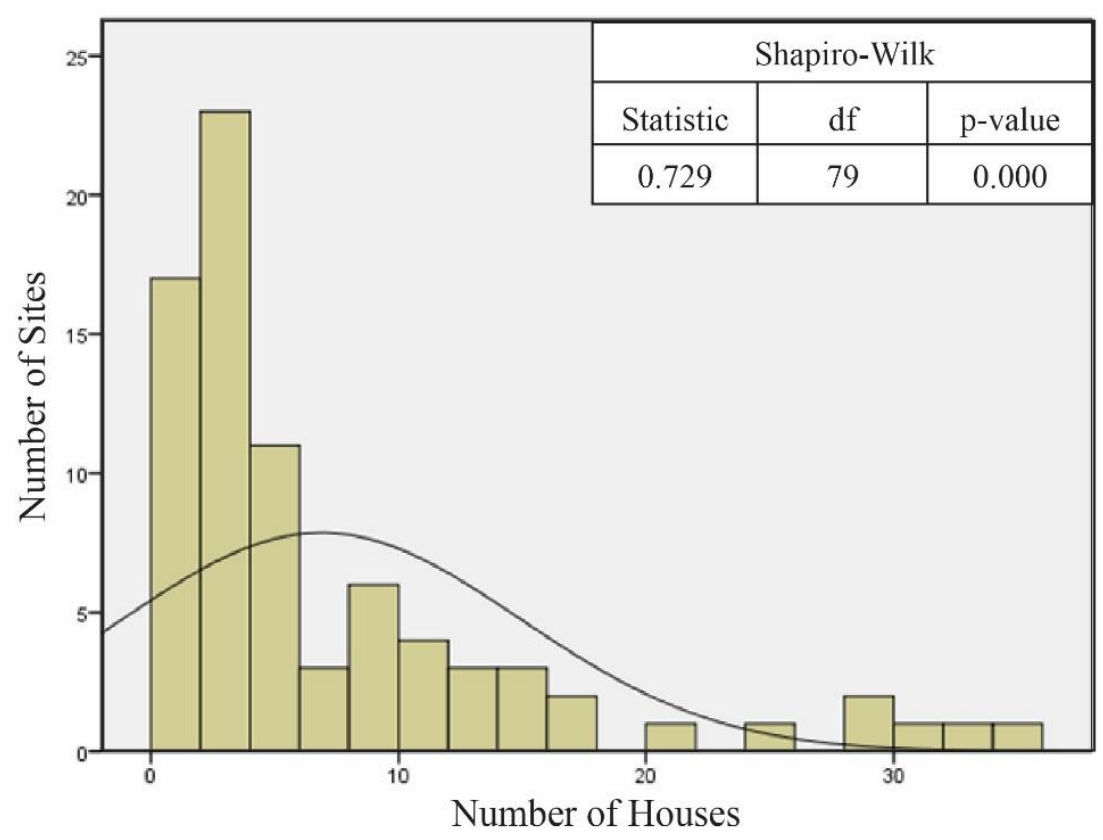

Figure 8. Shapiro-Wilk test and distribution of settlement size after $500 \mathrm{BP}$.

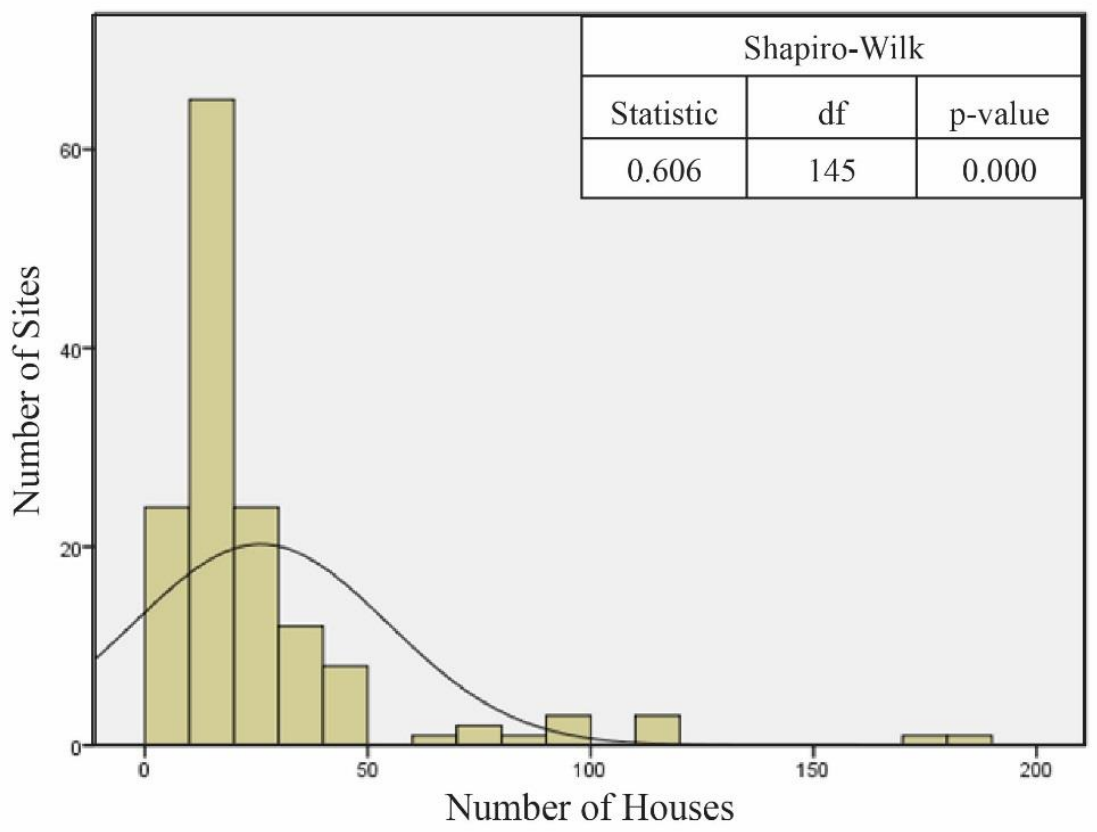

Figure 9. Shapiro-Wilk test and distribution of house size (m2) before $500 \mathrm{BP}$. 


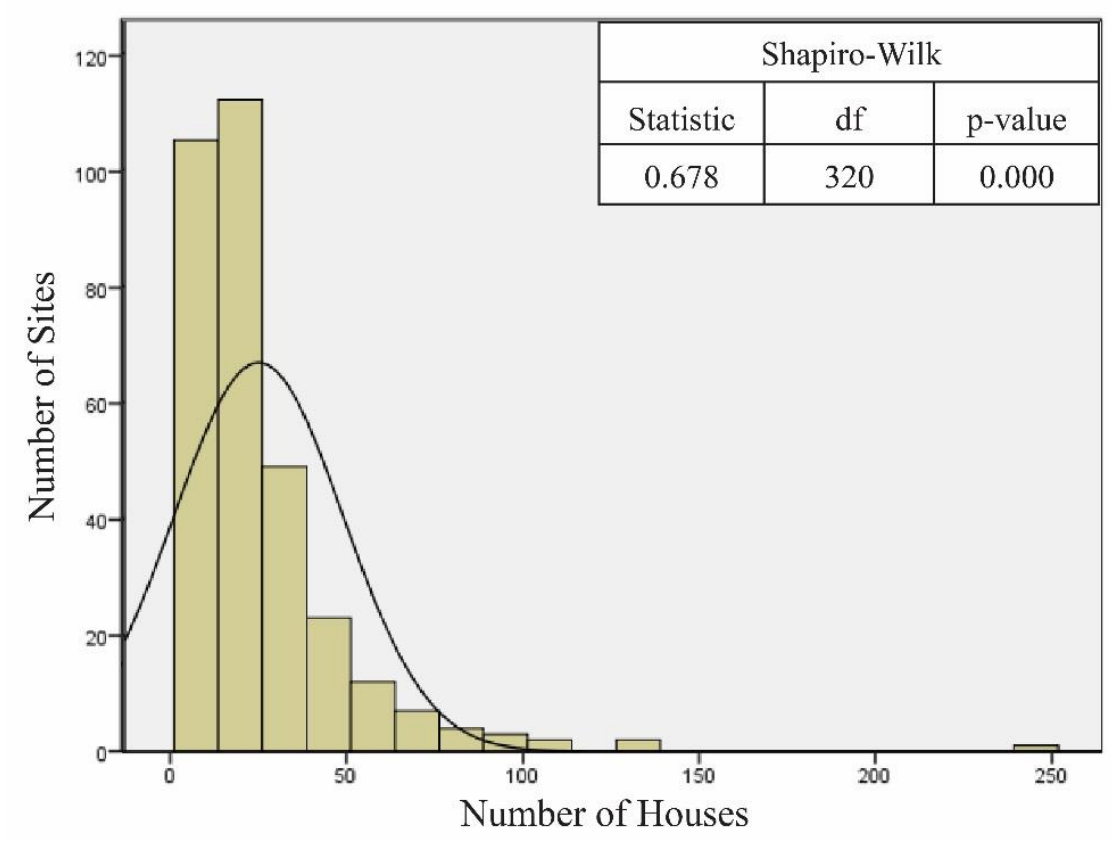

Figure 10. Shapiro-Wilk test and distribution of house size (m2) after 500 BP.

The relationship between the number of settlements before and after $500 \mathrm{BP}$ was tested using the One-Sample Chi-Square test (Table 15). Based on this data, there is a significant difference in the number of settlements when comparing the two temporal periods $(\chi 2=23.148$, df $=1, \mathrm{p}=<0.001)$.

Table 15. Observed values, expected values, and residuals of the number of settlements before and after $500 \mathrm{BP}$.

\begin{tabular}{|l|r|r|r|}
\hline & Observed N & Expected N & Residual \\
\hline After & 79 & 54.0 & 25.0 \\
Before & 29 & 54.0 & -25.0 \\
Total & 108 & & \\
\hline
\end{tabular}




\subsubsection{Average Settlement Size Analysis}

Based on the non-normal distribution of the datasets, the Mann-Whitney $U$ test was used to test the difference in the average number of houses per settlement before and after 500 BP. Mean values in the settlement before and after 500 BP (Table 16) were 51.88 and 55.46 houses, respectively; the average number of settlements in the two groups are not statistically significant (Mann-Whitney $\mathrm{U}=990.5, \mathrm{p}=0.408$ two-tailed).

Table 16. Mann-Whitney U rank order values of the number of houses per settlement before and after $500 \mathrm{BP}$.

\begin{tabular}{|rl|r|r|r|}
\hline & Period & \multicolumn{1}{|c|}{$\mathrm{N}$} & Mean Rank & Sum of Ranks \\
\hline \multirow{2}{*}{ Houses } & Before & 29 & 51.88 & 1504.50 \\
& After & 79 & 55.46 & 4381.50 \\
& Total & 108 & & \\
\hline
\end{tabular}

\subsubsection{Average House Size Analysis}

Based on the non-normal distribution of the datasets, the Mann-Whitney U test was used to test the difference in the average house size before and after $500 \mathrm{BP}$. Mean values in the settlement before and after $500 \mathrm{BP}$ (Table 17) were 236.74 and $231.30 \mathrm{~m}^{2}$,

respectively; the average house size $\left(\mathrm{m}^{2}\right)$ in the two groups are not statistically significant (Mann-Whitney $\mathrm{U}=22,657.0, \mathrm{p}=0.686$ two-tailed). 
Table 17. Mann-Whitney U rank order values of the house size per settlement before and after 500 BP.

\begin{tabular}{|rl|r|r|r|}
\hline & Period & \multicolumn{1}{|c|}{ N } & Mean Rank & Sum of Ranks \\
\hline Houses & Before & 145 & 236.74 & 34328.0 \\
& After & 320 & 231.30 & 74017.0 \\
& Total & 465 & & \\
\hline
\end{tabular}




\section{Chapter 5.1: Discussion and Conclusion}

In this chapter, I discuss the results of the analyses. First, I interpret the hypotheses based on the results and inferences of the spatial and site metric analyses. Then, I discuss the broader implications of the analyses and directions for future research. Lastly, I present my conclusions.

\subsection{Testing Settlement Pattern Change in Northwest Alaska}

Archaeologists' ideas about settlement patterns are prefaced on the belief that prior to $500 \mathrm{BP}$ larger populations were occupying large settlements aggregated on the coast at key resource procurement locations. Aafter 500 BP the settlement pattern changed to decreased populations occupying smaller settlements, single houses and small villages, and dispersed along the coast. It is also thought that groups moved these smaller settlements into the interior at this time. I tested this hypothesis by addressing three questions relating to the change in settlement patterns:

Did the spatial distribution of settlements, villages and single house sites, change from a clustered to a dispersed pattern after $500 \mathrm{BP}$ ?

Results: Reject the null hypothesis. The evidence shows that statistically significant clustering of settlements in the spatial distribution of settlement from 1000$500 \mathrm{BP}$ and after $500 \mathrm{BP}$.

Did the spatial distribution of settlement size, the number of houses per settlement, change after $500 \mathrm{BP}$ ? 
Results: Could not reject the null hypothesis. There is no evidence of a statistically significant change in the spatial distribution of settlement from 1000-500 BP and after $500 \mathrm{BP}$.

Did the size of settlements, average number houses per site, change after 500 BP?

Results: Could not reject the null hypothesis. There is no evidence of a statistically significant change in size of settlements from 1000-500 BP and after $500 \mathrm{BP}$.

Did the average house size $\left(\mathrm{m}^{2}\right)$ change after $500 \mathrm{BP}$ ?

Results: Could not reject the null hypothesis. There is no evidence of a statistically significant change in average house size from 1000-500 BP and after 500 BP.

Based on the results of the spatial analysis and site metric analysis, results do not indicate a major change in settlement patterns before and after $500 \mathrm{BP}$. The Nearest Neighbor Analysis indicates a statistically significant clustering of settlement during both temporal periods, but does not indicate a change in settlement patters before and after 500 BP. The global Moran's I spatial statistic failed to reject the null hypotheses. The random spatial distribution of the size of settlements before and after 500 BP indicates that settlements were not selectively organized or dispersed during either period. As no change occurred before and after $500 \mathrm{BP}$, I cannot reject my null hypothesis. There is no statistically significant change in settlement patterns based on the spatial distribution of sites. 
Next, I tested whether the local Moran's I and Getis-Ord Gi* spatial statistics would identify changes in the size of settlements based on their locations within the study area before and after $500 \mathrm{BP}$. Sites around Kotzebue Sound appear as stable settlements during both temporal periods. The only major change that the analyses indicated was a movement away from the Baldwin Peninsula; the location of Old Kotzebue, Intermediate Kotzebue, and Sisiivik; to significant hotspots at NOA-00513 on Cape Krusenstern and KTZ-00052 located around White Fish Lake, southwest of Cape Espenberg, after 500 BP. At first glance, this movement may indicate a change in settlement patterns based on the settlement locations away from previous hotspots along different portions of the coastline. Yet, the sites of NOA-00513 (located within $1 \mathrm{~km}$ of the coast) and KTZ00052 (located with $16 \mathrm{~km}$ of the coasts) showed continuous occupation through both temporal periods based on radiocarbon dates and other archaeological evidence.

One interesting result of the Getis-Ord Gi* analysis is that no cold spots, locations that have significant clustering of small villages or single house occupations, are indicated. The lack of cold spots is likely due to the fact that no locations of multiple single house occupations or small villages occur without some large villages nearby. If no small value, e.g. one to two houses per settlement, settlements are found near each other then no cold spots will occur. Two explanations for this fact are the way sites are defined or that some areas within the study region have been heavily studied and systematically surveyed.

Archaeologically, sites are defined by the evidence of cultural material found either by surface or subsurface testing. Generally, the site boundary is delineated if no 
cultural material is found 10-15 meters, based on state defined distances, away from the last artifact or feature. This process may create multiple sites that were once one larger site or, conversely, a site may be created that should be broken into smaller sites based on the distances between artifacts or features. The somewhat subjective nature of defining site boundaries is a fundamental problem in archaeology that is not easily resolved (Alaska Department of Natural Resources 2015).

The other possible explanation for no cold spots is that some areas within the study region have been heavily studied or surveyed systematically. Areas such as Cape Krusenstern, Cape Espenberg, and coastal and riverine areas within National Parks have had intensive research conducted. Within the intensive research and systematic survey, i.e. Cape Krusenstern and the Nuluk Project, more sites are identified and recorded. While these areas may increase the number of sites recorded, they are a mix of large villages, small villages, and single house occupations. It is possible that further survey, specifically systematic survey, may identify other settlements, either small or large, outside these heavily researched areas. While further research will provide more useful data, the current dataset does provide a range of data to conduct an exploratory analysis of settlement patterns in northwest Alaska.

As with any spatial or non-spatial analysis, the removal of outliers or changes in the parameters of the analysis can change the results of data analysis. The only differences between the two temporal datasets were the number of settlements included. The site metric analyses tested the normality of, and differences between, the two 
temporal datasets. The non-normal distribution and statistically significant difference between the sizes of the samples may be affecting the results.

The Nearest Neighbor Analysis yielded statistically significant clustered distributions of sites in both temporal periods. These patterns are interesting as prior research indicates that the distribution after $500 \mathrm{BP}$ should be dispersed. Exploring the data further, specific locations in both temporal periods may be driving the pattern based on the number of settlement within these locations. Before $500 \mathrm{BP}$, there are four locations that have multiple settlements within them. These locations include Cape Krusenstern ( $n=13)$, Cape Espenberg ( $n=6)$, Nuluk study area $(n=4)$, and the Deering area $(n=6)$. After $500 \mathrm{BP}$, there are five locations that have multiple settlements within them. These locations include Cape Krusenstern ( $\mathrm{n}=8$ ), Cape Espenberg ( $\mathrm{n}=9$ ), Nuluk study area $(n=20)$, White Fish Lake area $(n=5)$, and the Port Clarence study area $(n=6)$.

As an exploratory analysis of the results of my Nearest Neighbor Analysis, I ran an aggregation tool within ESRI ArcGIS to consolidate these areas into fewer settlements within specific locations. The aggregation tool uses a defined bandwidth to generate an area (polygon) around all settlements within that area. A limitation of this tool is that it starts with the closest settlements to each other and only creates a polygon around the nearest settlements to the initially delineated settlements. This will create areas that appear to exclude settlements that would be within the bandwidth of the newly generated area but are not included into the polygon, but remains as a settlement in the dataset. As my use of this tool is just a way of exploring data further, this limitation can be 
overlooked to see if the specific locations are driving the observed clustered pattern before and after $500 \mathrm{BP}$.

During this exploratory analysis, I started with bandwidths of 20 meters and 50 meters based on how archaeologists define site boundaries (Alaska Department of Natural Resources 2015). Using the starting bandwidth, no sites were aggregated. I expanded the bandwidth and I found two aggregations between 200-300 meters. I finally selected a large bandwidth, $16 \mathrm{~km}$, to see if this would identify the specific locations that I noted earlier. This bandwidth did identify the specific locations listed above as well as two other locations after 500 BP. These locations are in the area of Kivalina $(n=4)$ and on the Noatak river $(n=3)$. I aggregated these locations based on the areas defined by the tool and created single locations in the center of the polygons. Once all the data had been aggregated, I ran the Nearest Neighbor Analysis again to see if the pattern had changed. Table 18 presents the Nearest Neighbor Analysis of the aggregated settlement for the two temporal periods. The results of the Nearest Neighbor Analysis indicate that both temporal periods now have a random spatial distribution that is not statistically significant and that no change occurred before or after $500 \mathrm{BP}$. While the use of such a large bandwidth can be seen as manipulating the data to an extreme, it does highlight how site boundary definition can drive some of the patterning identified by spatial analysis.

Table 18. The Nearest Neighbor Analysis for two temporal periods.

\begin{tabular}{lcccc}
\hline Analysis & Nearest Neighbor Index & Z-score & p-value & Significant \\
Before 500 BP & 1.066 & 0.575 & 0.565 & No \\
After 500 BP & 0.899 & -1.370 & 0.171 & No \\
\hline
\end{tabular}


Of the settlements identified by the local Moran's I and Getis-Ord analyses, only the Old Kotzebue site, a 200 house village, and the Intermediate Kotzebue site, a 30 house village, show a change in High-High clustering (large sites located near each other) between the two temporal periods. The removal of any of the larger settlements (i.e. Old Kotzebue and Sisiivik) from the analysis changes the location of significantly clustered settlements and the statistical significance of their distribution, as they are now the largest sites. Both NOA-00513, a 45 house village, and KTZ-00052, a 47 house village, are the next largest villages following Sisiivik, a 160 house village, after 500 BP and appear significant based on the Local Getis-Ord Gi* analysis.

Likewise, the parameters used for the analyses influence the results, specifically the bandwidths I used when testing the spatial distribution of the settlement data. The ethnographic bandwidth, $34 \mathrm{~km}$, was based on foraging data of populations living in northwest Alaska, whereas the incremental spatial bandwidth, $113.576 \mathrm{~km}$, was a product of the dataset. The incremental distance tool generates the optimal distance bandwidth so that no individual settlement was without a neighboring settlement for the spatial analysis. The comparison of the bandwidths shows a marginal difference between the results. Only in the local Moran's I do the results change between the two bandwidths. The results of the analysis with the incremental spatial bandwidth indicate that Sisiivik, a High-Low outlier, before 500 BP, and SLK-00047, a Low-High outlier, after 500 BP, are the only noticeable changes in site distribution. It is likely that these changes are a result of parameters set upon the spatial analysis as we do not see this same pattern when using the ethnographic bandwidth to conduct the same analysis. 
The $34 \mathrm{~km}$ bandwidth was calculated based on the average daily foraging radius, $\sim 16 \mathrm{~km}$, of arctic populations (Binford 2001). Using Binford's estimated daily traveling distance, it could take a hunter-gatherer group up to seven days to travel between locations. This spatial distance and the energetic demand to travel that far would decrease the effective relationship between settlements at that distance. Even with the marginal differences between the results, it is possible that a refinement of the parameters and dataset could provide a clear picture of the interaction between settlements. Overall, the spatial analysis of settlements before and after $500 \mathrm{BP}$ could not reject the null hypotheses and indicate no change in the settlement patterns over the study period.

To explore the effect of changing the settlements that are included in the local Moran's I and Getis-Ord Gi* analyses. I adjusted the samples per temporal period to remove the continuously occupied settlements (with the exception of KTZ-00088 being included in the before $500 \mathrm{BP}$ period to reach the 30 sample threshold) and only tested the results of the ethnographic bandwidth. We can see that adjusting the samples to exclude Sisiivik, NOA-00513, and KTZ-00052 does affect the outcome and results of these analyses. The local Moran's I now indicate that Old Kotzebue is a High-Low outlier before $500 \mathrm{BP}$ with no other settlements significantly clustered (Figure 11:A1). 


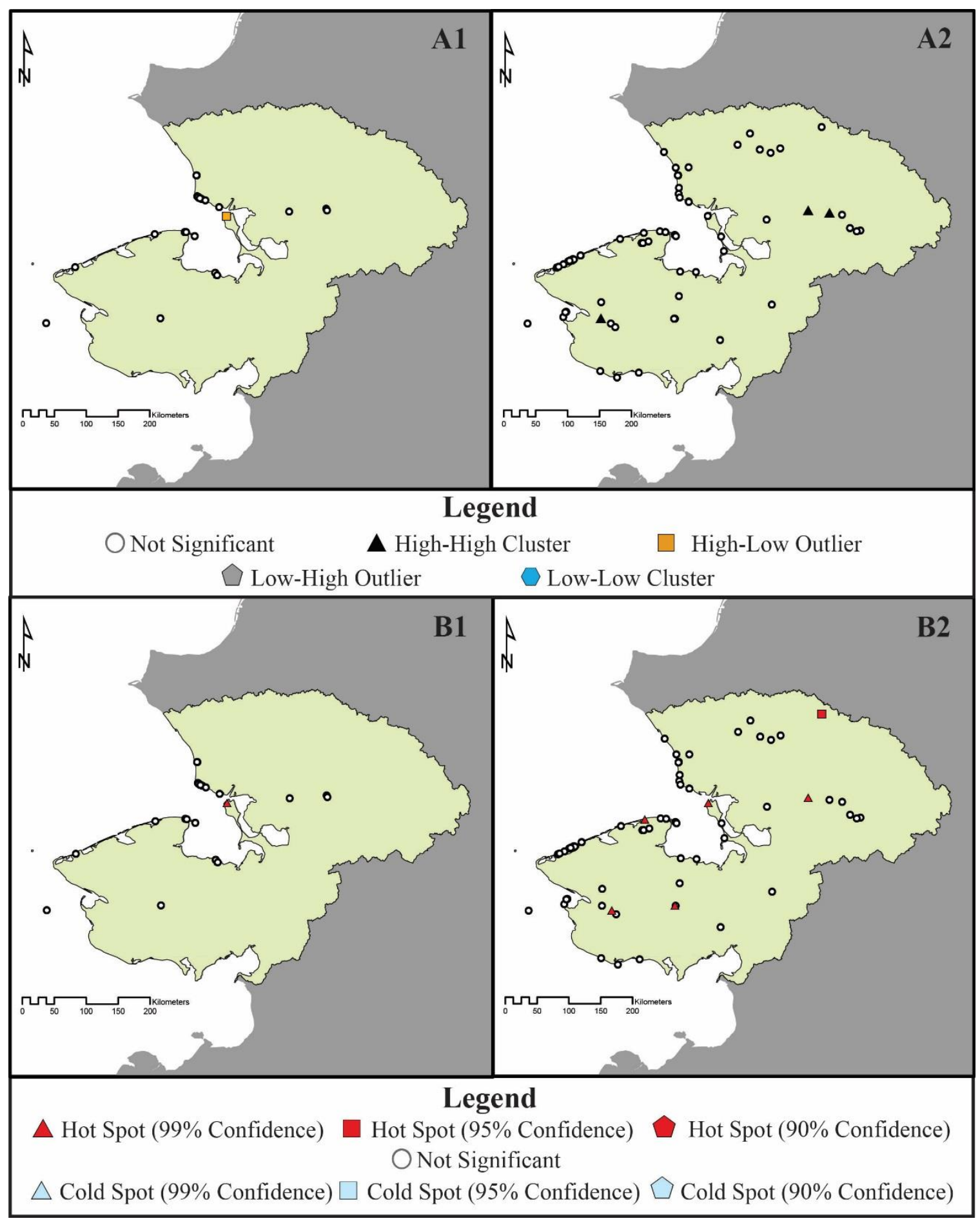

Figure 11. Exploratory local Moran's I (A) and Getis-Ord Gi* (B) analyses of settlements before (1) and after (2) 500 BP excluding the continuously occupied settlements. 
When the continuously occupied settlements are eliminated from analysis, the clustering of settlements changes dramatically after 500 BP. This is most apparent in the fact that the original analysis indicates Sisiivik as the only settlement of significant size (Figure 5:A2) while the new analysis indicates that Kavet Creek (XBM-00001), Onion Portage A (AMR-00001), and Metoktu (TEL-00060) are all High-High clustered settlements (Figure 11:A2). All three settlements are located in the interior with Kavet Creek and Onion Portage over $100 \mathrm{~km}$ from Kotzebue Sound on the Kobuk River and Metoktu just over $16 \mathrm{~km}$ from Grantley Harbor on the Agiapuk River. While the change in clustered settlements appears significant and suggests a shift into the interior, the overarching challenge of the dataset still persists. Kavet Creek, Onion Portage A, and Metoktu are similar to Old Kotzebue, Intermediate Kotzebue, and Sisiivik in that they are some of the largest settlements in the dataset and likely are driving the results of the analysis.

This effect is also present within the Getis-Ord Gi* spatial analyses (Figure 11:B1 \& B2). All of the sites that are significant hotspots are the largest sites within the dataset or appear to be far enough outside the distance bandwidth of other settlements to present a possible false significance. For example, XHP-00017 is a 24 house settlement and over $70 \mathrm{~km}$ away from the nearest settlement (Figure 11:B2). What these exploratory analyses reveal is that when using these tools we must be cautious to justify our parameters and also in interpreting the results.

Next, I tested the site metric data to evaluate whether average settlement size and average house size were different pre- and post-500 BP. Neither the average settlement 
size nor the average house size was statistically different between the two temporal periods. What the results indicate is a possible consistency in settlement formations, the range in single house to larger villages, and house sizes throughout the study period do not change even if more settlements are present after $500 \mathrm{BP}$. While the number of settlements occupied between the periods before and after $500 \mathrm{BP}$ are statistically different, that does not appear to affect either of the site metric analyses.

While the site metric analyses does not indicate a change in the settlement pattern before and after $500 \mathrm{BP}$ the house site analysis within each of the temporal periods may illustrate some variation in the range of house size. To explore the possible variations in house size within the temporal periods, I ran an exploratory box and whisker plot in IBM SPSS. The results of the exploratory research are presented in Figures 12-14. Overall the pattern before $500 \mathrm{BP}$ is of a wide variation in house size within some sites while the majority of the sites have an average house size below $50 \mathrm{~m}^{2}$. After $500 \mathrm{BP}$, the overall pattern shows a consistent average house size below $50 \mathrm{~m}^{2}$ with some large outliers or wide ranges. Initially comparing the two results would suggest that more large houses and large averages are present before $500 \mathrm{BP}$. Yet, the seven settlements with the larger houses and larger averages are all from Cape Krusenstern. This result is consistent with the pattern identified by prior research (Giddings 1952; Giddings and Anderson 1986) of large sized houses before $500 \mathrm{BP}$. But, since these houses were used to developed the settlement pattern may mean that Cape Krusenstern generally has large houses during this temporal period. One explanation for this pattern could lay geomorphology of the beachridge complex at Cape Krusenstern. 


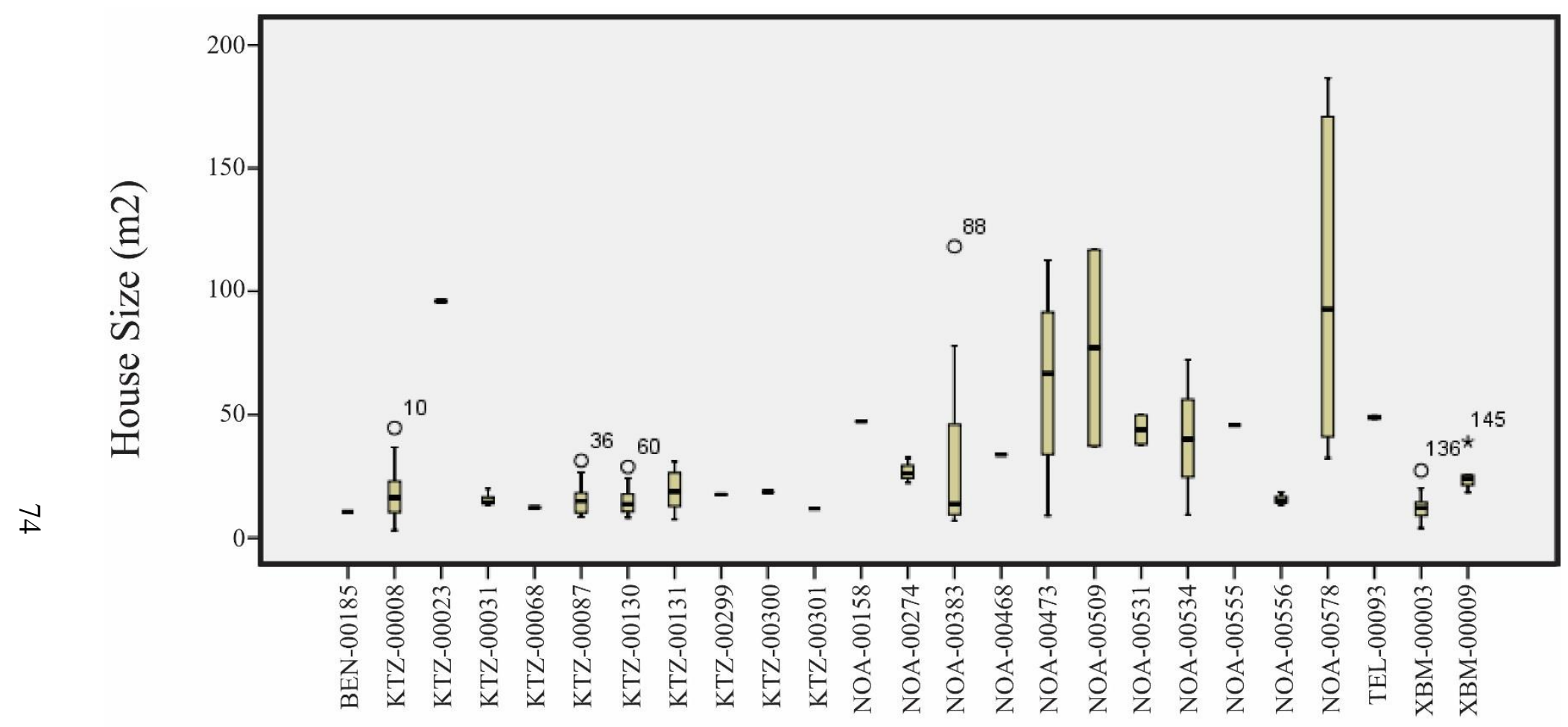

Site Before 500 BP

Figure 1. Range of house sizes within settlement before 500 BP. 


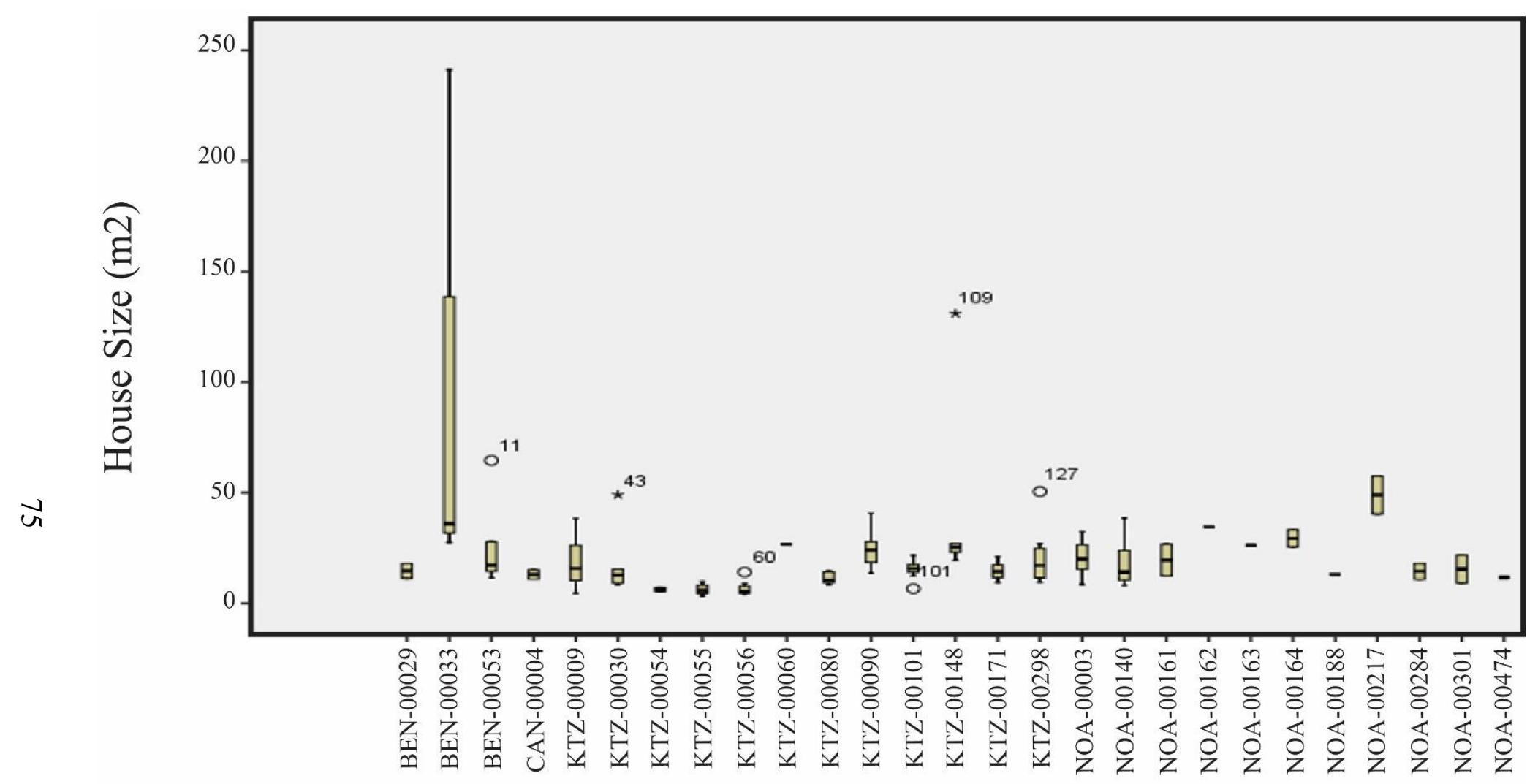

Site After 500 BP

Figure 2. Range of house sizes within settlements, between BEN-00029 and NOA-00474, after 500 BP. 


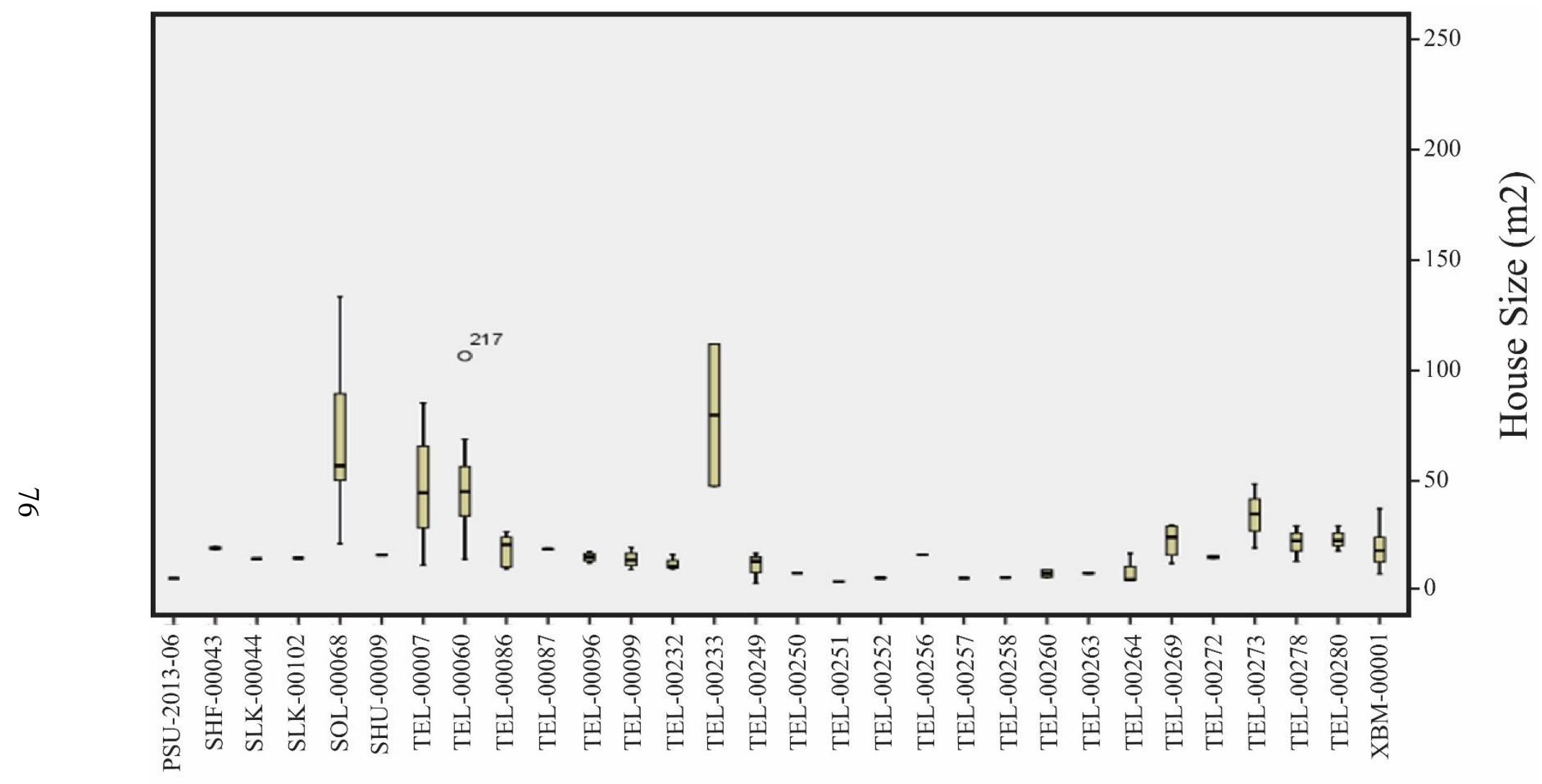

Site After 500 BP

Figure 3. Range of house sizes within settlements, between PSU-2013-06 and XBM-00001, after 500 BP. 
In the region, many sites are located on sand deposits or sediments that accumulated through aeolian, fluvial, or ocean processes. The primary deposits at Cape Krusenstern are gravels instead of other deposits. These gravel deposits may be contributing to the larger sizes of houses as the house depressions that were measured for the analysis may be bigger due to slumpage of the deposits over time. Whereas, the sand or other sediment deposits that make up the other sites in the region may hold the shape of the original collapsed semi-subterranean house better over time. While I currently cannot test whether this explanation is correct, the fact that without the Cape Krusenstern sites the average house sizes before and after $500 \mathrm{BP}$ are relatively consistent and are being smaller than $50 \mathrm{~m}^{2}$. What these site metrics do not address is the overall demographic change that is associated with the periods between 1200 - $500 \mathrm{BP}$ and 500 $100 \mathrm{BP}$.

A recent demographic study indicates a general trend of population growth during the late Holocene in northwest Alaska (Anderson, et al. Forthcoming). During the late Holocene, the observed trends fluctuate and may represent periods of population decline and growth. Bayesian analysis of 1034 radiocarbon dates indicate a period of population decline from approximately $1300 \mathrm{cal}$ BP to $1000 \mathrm{cal} \mathrm{BP}$. This is followed by a significant population increase between 1000 and $650 \mathrm{cal} \mathrm{BP}$. This is followed by a period of population decline starting at approximately $550 \mathrm{cal}$ BP. This study does evaluate possible alternative explanations for these patterns that include taphonomic effects, patterns in the calibration curve itself, archaeological biases, and large radiocarbon 
sample sizes from specific sites (e.g. Cape Krusenstern). Though an archaeological bias of not dating sites that indicate contact or post-contact material exists, the period of population decline after $550 \mathrm{cal}$ BP still appears in demographic studies that contain a robust sample of dates leading into the contact era (Anderson and Freeburg 2013, 2014). The results of this demographic analysis further lead us to expect a decline in the number of settlements, the average size of settlements, and average house sizes after $500 \mathrm{BP}$.

One explanation for the inconsistencies between the demographic study (Anderson et al. Forthcoming) and this thesis is that populations within in the region could have been more densely packed in settlements and houses before $500 \mathrm{BP}$ than after $500 \mathrm{BP}$. Alternatively, the houses occupied before $500 \mathrm{BP}$ may represent multi-use or multi-component activities where the people who used them would re-occupy a house rather than construct a new one. This argument is based on an assumption about house occupation that comes from the ethnographic record (Burch 2006; Giddings 1961). If more than eight people lived in a house (Burch 2006:97) or houses were occupied longer than one generation, the average number of houses per village would appear lower than the population living within the region. After $500 \mathrm{BP}$, the consistency in the number of houses and the size of houses with the overall decrease in expected populations could represent the generational movement of people or the construction of new houses within the settlement area rather than reoccupying a house. While these are plausible explanations, further analysis of multiple features per site to better understand house occupation histories is needed to test these idea. Until more data are collected, I can only say that site metric data do not appear consistent with the results of demographic analysis 
of the regional radiocarbon data and that site metrics do not change over the last 500 years.

\subsection{Broader Implications and Directions for Future Research}

Overall, the results of this thesis show no observable changes in settlement patterns in northwest Alaska before and after $500 \mathrm{BP}$. It is still plausible that small-scale changes in settlement patterns occurred at key sites, i.e. Cape Krusenstern and Cape Espenberg, or more localized study areas that do not represent a region-wide shift. As stated before, the prehistory of the region was defined by archaeologists conducting research at unique sites that provided data for the cultural phase designations. While these cultural phases may provide rough temporal associations and assumptions of settlement patterns to test against, we should not apply their localized settlement patterns to the region. We must continue to conduct research that expands our understanding of the late Holocene on a broader regional and temporal scale and move away from focusing on specific temporal periods or cultural phases.

In addition to expanding our understanding of the late Holocene on a broad scale, research must focus on a better understanding of intra-site dynamics and occupation history. Many of the sites used for this analysis were temporally defined by a small number of radiocarbon dates (an average of 2 dates for the 34 sites that have radiocarbon dates). The Sisiivik site is one of these temporally questionable settlements. A total of three radiocarbon dates have been run to date a 160 house village (BIA 2015, personal communication; O’Leary 2007). The disproportion between the number of radiocarbon 
dates and houses raises questions of the true site occupation history. Refined occupation chronology and settlement size data could provide a more developed analysis of settlement patterns across northwest Alaska and within sub-regions.

While testing the settlement patterns on a sub-region scale, e.g. within watershed or other smaller scales, would be beneficial to the study of settlement patterns in the region, I was unable to conduct this research at the time. As stated above, the original dataset of 486 settlements within the region may provide robust analysis of regional settlement patterns the current dataset does not have adequate data to run the spatial analytical tools, i.e. minimum of 30 per temporal period. Once that threshold is reached, further research can build on my analysis and test settlements at other scale to see if variation occurs within and between sub-regional areas.

\subsection{Conclusions}

The results of this study provide a comprehensive statistical and spatial analysis of regional settlement pattern change in Northwest Alaska over the last 1500 years. While archaeologists still cite the 30 year-old settlement pattern, when looking at the spatial distribution of settlement pre- and post-500 BP we see no significant change in the settlement pattern. I expected that the Moran's I and Getis-Ord Gi* analyses would indicate a clustering of large settlements in key coastal locations before $500 \mathrm{BP}$ and a dispersal of smaller settlements in different locations along the coast and into the interior after $500 \mathrm{BP}$. While the analyses did indicate large settlements in key locations along the coast, a shift to the interior and other locations does not appear to have occurred. It is 
entirely possible, however, that the limited sample size of before $500 \mathrm{BP}$, the exceedingly large villages (e.g. Sissivik and Old Kotzebue), or the lack of comprehensive dating of houses within each village may be masking subtle changes in the settlement patterns on a decade or generational scale.

Based on the site metric analyses, average number of houses per settlement and the average house size, I expected to see a shift from larger settlements and large houses to smaller settlements and smaller houses pre- and post-500 BP. However, the MannWhitney U test show no statistically significant difference between the two time period in both the average settlement size and the average house size. These analyses indicate that this aspect of settlement patterns stays constant throughout the study periods just as the spatial distribution analysis showed. However, similar to the spatial analysis, it is possible that lack of comprehensive dating of the houses within each village or the lack of complete measurements for every house within every settlement may be obscuring possible changes to site metrics on smaller temporal scales.

While both the spatial distribution analysis and the site metric analyses did not meet my expectations, these tools and methods can provide archaeologists with ways to test if settlement patterns have changed and provide a level of statistical significance. GIS is a powerful platform with ever increasing ways to test, analyze, and interpret data. Yet, as discussed above, researchers need to be cautious with what data they include and exclude in their analyses as well as be explicit in listing and justifying their test parameters. Only by conducting research with complete transparency of methods and 
data will other studies of settlement patterns and culture change comparable and replicable in other regions.

In addition to conducting transparent and replicable research within the region, more fieldwork is recommended to better understand the land use and activities in northwest Alaska. As pointed out previously in this thesis, much of northwest Alaska has not been systematically surveyed and specific ecoregions have likely only received aerial or photographic surveys because of many locations remote nature. By expanding systematic surveys beyond coastlines and rivers, archaeologists can gain begin to fully understand the complex interactions between humans and their environments and explore past hunter-gatherer land use within the region.

Furthermore, the statistical testing of settlement size and house size through time will broaden our understanding of other aspects of culture change. By looking at changes in settlement size and structure, researchers can expand our understanding of possible shifts in social organization through time. Similarly, additional research into changes in house size at small temporal or spatial scales may support current population reconstruction (Anderson, et al. Forthcoming) or indicate other shifts in regional population size. Through these steps we can continue to build upon current research and incorporate new and previously recorded data to expand our understanding of past human lifeways. It is a goal of future settlement pattern change research to further our knowledge of the complex nature of human-environmental interactions in northwest Alaska. 


\section{References}

AHRS

2015 Alaska Heritage Resource Survey. Department of Natural Resource, Alaska.

Alaska Department of Natural Resources

2015 What Types of Cultural Resources get an AHRS Number. Electonic document, http://dnr.alaska.gov/parks/oha/ahrs/ahrs.htm, accessed June 14, 2017.

Ames, Kenneth M

2000 Kennewick Man: Cultural Affiliation Report, Chapter 2: Review of the Archaeological Data. Anthropology Faculty Publications and Presentations.

2002 Going by Boat. Beyond Foraging and Collecting. Springer.

Anderson, Douglas D

1970 Athapaskans in the Kobuk Arctic Woodlands, Alaska? Bulletin (Canadian Archaeological Association) (2):3-12.

1984 Prehistory of North Alaska. In Handbook of North American Indians, edited by D. Dumas. vol. 5. Smithsonian Institution, Washington.

1988 Onion Portage: The Archaeology of a Stratified Site from the Kobuk River, Northwest Alaska. Anthropological Papers of the University of Alaska 22(1-2):1-163.

Anderson, Shelby L

2011 From Tundra to Forest: Ceramic Distribution and Social Interaction in Northwest Alaska. Dissretation, University of Washington, Seattle. 
Anderson, Shelby L, Thomas J Brown, Justin A Junge and Jonathan Duelks

Forthcoming Assesing the Role of Interaction and Competition in the Development and Spread of Arctic Maritime Traditions through Bayesian Radiocarbon Analysis.

Anderson, Shelby L and Adam K Freeburg

2013 A High-Resolution Chronology for the Cape Krusenstern Site Complex, Northwest Alaska. Arctic Anthropology 50(1):49-71.

2014 High Latitude Coastal Settlement Patterns: Cape Krusenstern, Alaska. Journal of Island and Coastal Archaeology 9(3):295-318.

Anderson, Shelby L and Justin A Junge

2015 Climate Change and Archaeology in Northwest Alasks: Nuluk Study. Report Sumbitted to the National Park Service, U.S. Department of Interior.

Binford, Lewis R

1980 Willow Smoke and Dogs' Tails: Hunter-Gatherer Settlement Systems and Archaeological Site Formation. American Antiquity:4-20.

1990 Mobility, Housing, and Environment: A Comparative Study. Journal of Anthropological Research:119-152.

2001 Constructing Frames of Reference: An Analytical Method for Archaeological Theory Building Using Ethnographic and Environmental Data Sets. Univ of California Press.

Bird, Broxton W, Mark B Abbott, Bruce P Finney and Barbara Kutchko 2009 A 2000 Year Varve-Based Climate Record from the Central Brooks Range, Alaska. Journal of Paleolimnology 41(1):25-41.

Bolstad, Paul

2012 GIS Fundamentals: A First Text on Geographic Information Systems. 4th ed. Eider Press, Saint Paul. 


\section{Bowers, Peter M}

2009 The Archaeology of Deering, Alaska: Final Report on the Village Safe Water Archaeological Program. Report Prepared for the Alaska Department of Environemntal Conservation and Native Village of Deering, Northern Land Use Research, Inc.

\section{Burch, Ernest $\mathrm{S}$}

1998 The Ińupiaq Eskimo Nations of Northwest Alaska. University of Alaska Press (Fairbanks).

2005 Alliance and Conflict: The World System of the Ińupiaq Eskimos 8. U of Nebraska Press.

2006 Social Life in Northwest Alaska: The Structure of Inupiaq Eskimo Nations. University of Alaska Press.

Calkin, Parker E, Darrell S Kaufman, Bruce J Przybyl, W Brett Whitford and Brian J Peck

1998 Glacier Regimes, Periglacial Landforms, and Holocene Climate Change in the Kigluaik Mountains, Seward Peninsula, Alaska, USA. Arctic and Alpine Research:154-165.

\section{Carlson, Risa $\mathbf{J}$}

2012 A Predictive Model for Early Holocene Archaeological Sites in Southeast Alaska Based on Elevated Palaeobeaches. Dissertation, University of Cambridge.

Clark, Catherine A

2012 Finding the Past in the Present: Modeling Prehistoric Occupation and Use of the Powder River Basin, Wyoming. Portland State University, Portland.

Enloe, James G, Francine David and Timothy S Hare

1994 Patterns of Faunal Processing at Section 27 of Pincevent: The Use of Spatial Analysis and Ethnoarchaeological Data in the Interpretation of Archaeological Site Structure. Journal of Anthropological Archaeology 13(2):105-124. 
Erlandson, Jon M

2001 The Archaeology of Aquatic Adaptations: Paradigms for a New Millennium. Journal of Archaeological Research 9(4):287-350.

Esdale, Julie A

2008 A Current Synthesis of the Northern Archaic. Arctic Anthropology 45(2):3-38.

Fejes, Claire

1966 People of the Noatak. Volcano. California: Volcano Press.

Fitzhugh, Ben

2003 The Evolution of Complex Hunter-Gatherers. Springer.

Fletcher, Mike and Gary R Lock

2005 Digging Numbers: Elementary Statistics for Archaeologists 33. Oxford Univ School of Archaeology.

Freeburg, Adam K and Shelby L Anderson

2012 Human-Environmental Dynamics at Cape Krusenstern, Two Hundred Generations: On the Beach of Their Time, Final Report.

Gerlach, Craig

1989 Models of Caribou Explotation, Butchery, and Processing at the Croxton Site, Tukuto Lake, Alaska. Dissertation, Brown University, Providence.

Gerlach, S Craig and Owen K Mason

1992 Calibrated Radiocarbon Dates and Cultural Interaction in the Western Arctic. Arctic Anthropology:54-81. 
Giddings, James L

1957 Round houses in the western Arctic. American Antiquity 23(2-1):121-135.

Giddings, James Louis

1952 The Arctic Woodland Culture of the Kobuk River. University Museum, University of Pennsylvania, Philadelphia.

Giddings, James Louis and Douglas D Anderson

1986 Beach Ridge Archeology of Cape Krusenstern: Eskimo and Pre-Eskimo Settlements Around Kotzebue Sound, Alaska. National Park Service, US Department of the Interior Washington, DC.

Goebel, Ted, Heather L Smith, Lyndsay DiPietro, Michael R Waters, Bryan Hockett, Kelly E Graf, Robert Gal, Sergei B Slobodin, Robert J Speakman and Steven G Driese

2013 Serpentine Hot Springs, Alaska: Results of Excavations and Implications for the Age and Significance of Northern Fluted Points. Journal of Archaeological Science 40(12):4222-4233.

Grier, Colin and James M Savelle

1994 Intrasite Spatial Patterning and Thule Eskimo Social Organization. Arctic Anthropology:95-107.

Hayden, Brian

1995 Pathways to Power: Principles for Creating Socioeconomic Inqualities. In Foundations of Social Inequality, ed. T.D. Price and G.M. Feinman. Plenum Press, New York.

Henrikson, Lael Suzann

2002 Ponds, Rivers and Bison Freezers: Evaluating a Behavioral Ecological Model of Hunter-Gatherer Mobility on Idaho's Snake River Plain, University of Oregon. 
Hoffecker, John F

2005 A Prehistory of the North: Human Settlement of the Higher Latitudes. Rutgers University Press, Piscataway.

Hoffecker, John F and Scott A Elias

2007 Human Ecology of Beringia. Columbia University Press.

Hoffecker, John F and Owen K Mason

2010 Human Response to Climate Change at Cape Espenberg: AD 800-1400:

Field Investigations at Cape Espenberg. Annual Report Sumbitted to the National Park Service, U.S. Department of Interior.

Holt, Michael J.

2012 Kuzitrin Lake and Twin Calderas: An Example of Optimal Land USe inthe Late Holocene in Seward Peninsula, Alaska. Thesis, School of Arcaheology and Ancient History, University of Leicester.

Ingold, Tim

1983 The Significance of Storage in Hunting Societies. Man. 553-571.

Kelly, Robert L

2007 The Foraging Spectrum: Diversity in Hunter-Gatherers Lifeways. Percheron Press, New York.

Kennett, Douglas J

2005 The Island Chumash: Behavioral Ecology of a Maritime Society. Univ of California Press.

Kennett, Douglas J, Bruce Winterhalder, Jacob Bartruff and Jon M Erlandson

2009 An Ecological Model for the Emergence of Institutionalized Social Hierarchies on California's Northern Channel Islands. In Pattern and Process in Cultural Evolution, pp. 297, S. J. Shennan, general editor. 
Koutsky, Kathryn

1981a Early Days on Norton Sound and Dering Strait: An Overview of Historic Sites in the BSNC Region, Vol. I The Shishmaref Area 1. Anthropology and Historic Preservation Cooperative Park Studies Unit University of Alaska, Fairbanks, Faribanks.

1981b Early Days on Norton Sound and Dering Strait: An Overview of Historic Sites in the BSNC Region, Vol. II The Wales Area 2. Anthropology and Historic Preservation Cooperative Park Studies Unit University of Alaska, Fairbanks, Faribanks.

1981c Early Days on Norton Sound and Dering Strait: An Overview of Historic Sites in the BSNC Region, Vol. III The Port Clarence and Kauwerak Areas 3. Anthropology and Historic Preservation Cooperative Park Studies Unit University of Alaska, Fairbanks, Faribanks.

1981d Early Days on Norton Sound and Dering Strait: An Overview of Historic Sites in the BSNC Region, Vol. IV The Nome, Fish River, and Golovin Areas 4. Anthropology and Historic Preservation Cooperative Park Studies Unit University of Alaska, Fairbanks, Faribanks.

1981e Early Days on Norton Sound and Dering Strait: An Overview of Historic Sites in the BSNC Region, Vol. V The Koyuk Area 5. Anthropology and Historic Preservation Cooperative Park Studies Unit University of Alaska, Fairbanks, Faribanks.

$1981 \mathrm{f}$ Early Days on Norton Sound and Dering Strait: An Overview of Historic Sites in the BSNC Region, Vol. VI The Shaktoolik Area 6. Anthropology and Historic Preservation Cooperative Park Studies Unit University of Alaska, Fairbanks, Faribanks.

Kvamme, Kenneth L

1999 Recent Directions and Developments in Geographical Information Systems. Journal of Archaeological Research 7(2):153-201. 
Larsen, Helge and Froelich Rainey

1948 Ipiutak and the Arctic whale hunting culture. American Museum of Natural History, New York.

Lovis, William A, Randolph E Donahue and Margaret B Holman

2005 Long-Distance Logistic Mobility as an Organizing Principle among Northern Hunter-Gatherers: A Great Lakes Middle Holocene Settlement System. American Antiquity:669-693.

Mann, Daniel H, Patricia A Heiser and Bruce P Finney

2002 Holocene History of the Great Kobuk Sand Dunes, Northwestern Alaska. Quaternary Science Reviews 21(4):709-731.

Martindale, Andrew, Bryn Letham, Duncan McLaren, David Archer, Meghan Burchell and Bernd R Schöne

2009 Mapping of Subsurface Shell Midden Components through Percussion Coring: Examples from the Dundas Islands. Journal of Archaeological Science 36(7):1565-1575.

Maschner, Herbert DG

1996 The Politics of Settlement Choice on the Northwest Coast: Cognition, GIS, and Coastal Landscapes. In Anthropology, Space, and Geographic Information Systems, pp. 175-189, M. Aldenderfer and H. D. Maschner, general editor. Oxford University Press, New York.

Mason, Owen K

1998 The Contest between the Ipiutak, Old Bering Sea, and Birnirk Polities and the Origin of Whaling during the First Millennium AD along Bering Strait. Journal of Anthropological Archaeology 17(3):240-325.

2006 Ipiutak Remains Mysterious: A Focal Place Still Out of Focus. Proceedings of the Dynamics of Northern Societies. Proceedings of a Symposium:106-120. Copenhagen.

2009a Flight From the Bering Strait: did Siberian Punuk/Thule Military Cadres Conquer Northwest Alaska. The Northern World AD 900 1400:76-128. 
2009b "The Multiplication of Forms:" Bering Strait Harpoon Heads as a Demic and Macroevolutionary Proxy. In Macroevolution in Human Prehistory, pp. 73107. Springer.

Mason, Owen K and S Craig Gerlach

1995a The Archaeological Imagination, Zooarchaeological Data, the Origins of Whaling in the Western Arctic, and "Old Whaling" and Choris Cultures. In Hunting the Largest Animals: Native Whaling in the Western Arctic and Subarctic, edited by A. P. McCartney, pp. 1-31. Studies in Whaling No. 3, Occasional Publication No. 36. The Canadian Circumpolar Institute, Calgary.

1995b Chukchi Hot Spots, Paleo-Polynyas, and Caribou Crashes: Climatic and Ecological Dimensions of North Alaska Prehistory. Arctic Anthropology:101-130.

Mason, Owen K and James W Jordan

1993 Heightened North Pacific Storminess During Synchronous Late Holocene Erosion of Northwest Alaska Beach Ridges. Quaternary Research 40(1):55-69.

2001 Minimal Late Holocene Sea Level Rise in the Chukchi Sea: Arctic Insensitivity to Global Change? Global and Planetary Change 32(1):13-23.

McClenahan, Patricia L and Douglas E Gibson

1990 Cape Krusenstern National Monument: An Archaeological Survey Vol. I. National Park Service, Alaska Regional Office, Anchorage.

Mitchel, Andy

2005 The ESRI Guide to GIS analysis, Volume 2: Spartial Measurements and Statistics. ESRI press.

Morgan, Christopher

2009 Climate Change, Uncertainty and Prehistoric Hunter-Gatherer Mobility. Journal of Anthropological Archaeology 28(4):382-396. 
O'Sullivan, David and David Unwin

2014 Geographic Information Analysis. John Wiley \& Sons.

O'Leary, Matthew

2007 A Roster of BIA ANCSA Radiocarbon Dates. Alaska Journal of Anthropology 5(1):123-145.

Odess, Dan

2003 An Early Arctic Small Tool tradition structure from interior Northwestern Alaska. Études/Inuit/Studies:13-27.

Potter, Ben A

2005 Site Structure and Organization in Central Alaska: Archaeological Investigations at Gerstle River. Dissertation, Department of Anthropology, University of Alaska Fairbanks, Fairbanks.

Powers, W Roger, Jo Anne Adams, Alicia Godfrey, James A Ketz and David C Plaskett 1982 Chukchi-Imuruk Report. Archaeological Investigations in the Bering Land Bridge National Preserve, Seward Peninsula, Alaska, 1974 and 1975. Occasional Paper, Anthropology and Historic Preservation, University of Alaska, Fairbanks.

Ray, Dorothy Jean

1975 The Eskimos of Bering Strait, 1650-1898. University of Washington Press Seattle.

Razali, Nornadiah Mohd and Yap Bee Wah

2011 Power Comparisons of Shapiro-Wilk, Kolmogorov-Smirnov, Lilliefors and Anderson-Darling Tests. Journal of Statistical Modeling and Analytics 2(1):21-33.

Reeder-Myers, Leslie A

2014 Multi-Scalar Foraging Decisions in the Santa Barbara Channel, Southern California. Journal of Anthropological Archaeology 35:202-219. 
Rogerson, Peter A

2015 Statistical methods for geography: a student's guide. Sage.

Schaaf, Jeanne M

1988 The Bering Land Bridge National Preserve: An Archeological Survey, Vol I. Archaeological Resources Report No. AR-14. National Park Service, Alaska Regional Office, Anchorage.

Shirar, Scott

2007 Maiyumerak Creek: Late Prehistoric Subsistence and Seasonality in Northwest Alaska, Anthropology, University of Alaska, Fairbanks.

2009 Subsistence and Seasonality at a Late Prehistoric House Pit in Northwest Alaska. Journal of Ecological Anthropology 13(1):6-25.

Tesart, Alain, Richard G. Forbis, Brian Hayden, Tim Ingold, Stephen M. Perlman, david L. Pokotylo, Peter Rowley-Conwy and David E. Stuart

1982 The Significance of Food Storage among Hunter-Gatherers: Residence Patterns, Population Densities, and Social Inequalities [and Comments and Reply]. Current Anthropology. 23(5): 523-537.

Thompson, Victor D and John A Turck

2009 Adaptive Cycles of Coastal Hunter-Gatherers. American Antiquity:255278.

Tremayne, Andrew Hale

2010 An Analysis of Faunal Remains from a Denbigh Flint Complex Camp at Matcharak Lake, Arctic Alaska. Thesis, University of Wyoming, Laramie.

2014 Investingating the Arctic Small Tool Tradition at Cape Espenberg, Bering Land Bridge National Preserve, Alaska. Report Sumbitted to the National Park Service, U.S. Department of Interior.

2015 The Origin and Development of Maritime Foraging Systems in Northern Alaska, Anthropology, University of California, Davis. 
Twiss, Katheryn

2012 The Archaeology of Food and Social Diversity. Journal of Archaeological Research. 20(4): 357-395.

VanStone, James W

1954 Archaeological Excavations at Kotzebue, Alaska. Dissertation, Anthroplogy, University of Pennsylvania.

Warren, Robert E and David L Asch

2003 A Predictive Model of Archaeological Site Location in the Eastern Prairie Peninsula. In Practical Applications of GIS for Archaeologists: A Predictive Modelling Toolkit, edited by K. L. Wescott and R. J. Brandon, pp. 6-36. Taylor and Francis, Hoboken.

Wesson, Cameron B.

1999 Chiefly Power and Food Storage in Southern North America. World Archaeology. 31(1): 145-164.

Wheatley, David and Mark Gillings

2003 Spatial Technology and Archaeology: The Archaeological Applications of GIS. CRC Press.

Winterhalder, Bruce, Douglas J Kennett, Mark N Grote and Jacob Bartruff

2010 Ideal Free Settlement of California's Northern Channel Islands. Journal of Anthropological Archaeology 29(4):469-490.

Yesner, David R

1980 Maritime Hunter-Gatherers: Ecology and Prehistory. Current Anthropology 21(6):727-750.

1998 Origins and Development of Maritime Adaptations in the Northwest Pacific Region of North America: A Zooarchaeological Perspective. Arctic Anthropology:204-222. 
Appendices 


\section{Appendix A: Settlement Data}

\begin{tabular}{|c|c|c|c|c|c|c|c|}
\hline $\begin{array}{l}\text { AHRS } \\
\text { Site } \\
\text { Number }\end{array}$ & Site Name & $\begin{array}{l}\text { Site } \\
\text { Type }\end{array}$ & $\begin{array}{l}\text { Number } \\
\text { of Houses }\end{array}$ & $\begin{array}{l}\text { Temporal } \\
\text { Period }\end{array}$ & $\begin{array}{l}\text { Temporal } \\
\text { Association }\end{array}$ & $\begin{array}{l}\text { Available } \\
\text { Radiocarbon Dates } \\
\text { Conventional Dates) }\end{array}$ & $\begin{array}{l}\text { AHRS site descriptions (AHRS } \\
\text { 2015). }\end{array}$ \\
\hline $\begin{array}{l}\text { AMR- } \\
00001\end{array}$ & $\begin{array}{l}\text { Onion Portage } \\
\text { (A) }\end{array}$ & $\begin{array}{l}\text { Small } \\
\text { Village }\end{array}$ & 3 & $\begin{array}{l}\text { Before } \\
500 \mathrm{BP}\end{array}$ & $\begin{array}{l}\text { Cultural } \\
\text { Association }\end{array}$ & 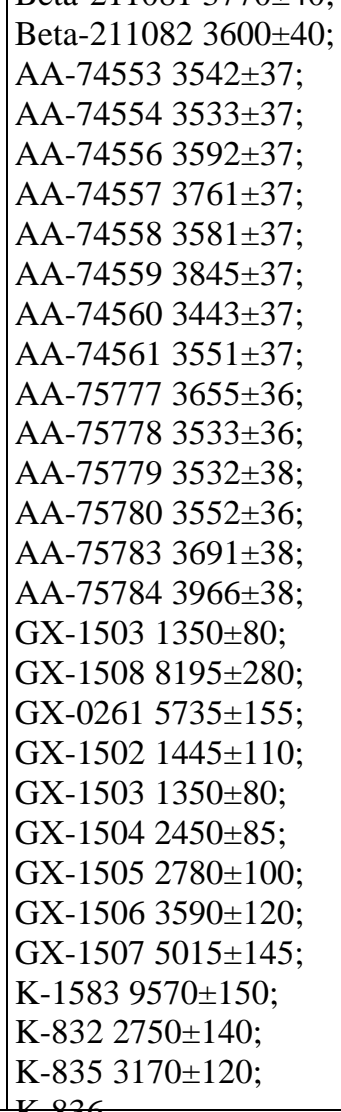 & $\begin{array}{l}\text { This is the Norton-Ipiutak-Thule } \\
\text { Phases of Onion Portage. The } \\
\text { principal site within the district, the } \\
\text { Onion Portage site (AMR-170) is a } \\
\text { deeply stratified series of river edge } \\
\text { occupation layers. Immediately } \\
\text { above the Onion Portage site is the } \\
\text { perhaps } 9000 \text { year old Akmak site } \\
\text { (AMR-169). Throughout the rest of } \\
\text { the 16,000 acre district are } \\
\text { numerous scattered settlement sites } \\
\text { and surface remains. Onion Portage } \\
\text { was first discovered by Louis } \\
\text { Giddings in 1941 and excavation } \\
\text { began in 1964. The results of his, } \\
\text { and other's, work revealed eight } \\
\text { stratigraphic occupation bands-- } \\
\text { each with subsidiary layers. [Sites } \\
\text { within the boundaries of this district } \\
\text { include the Jade Creek site } \\
\text { (AMR-007), the Kayak Site } \\
\text { (AMR-058), AMR-059, and }\end{array}$ \\
\hline
\end{tabular}




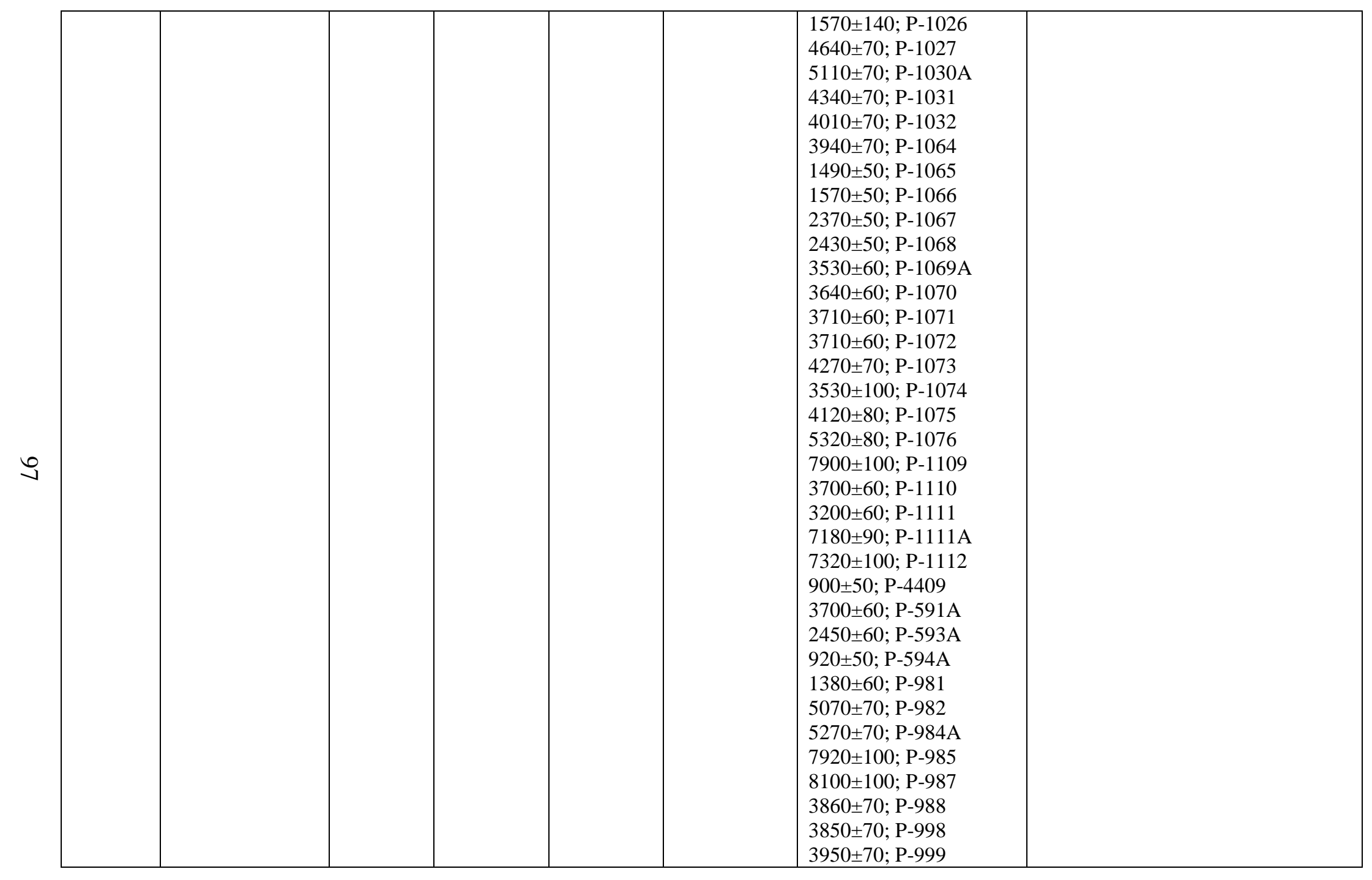




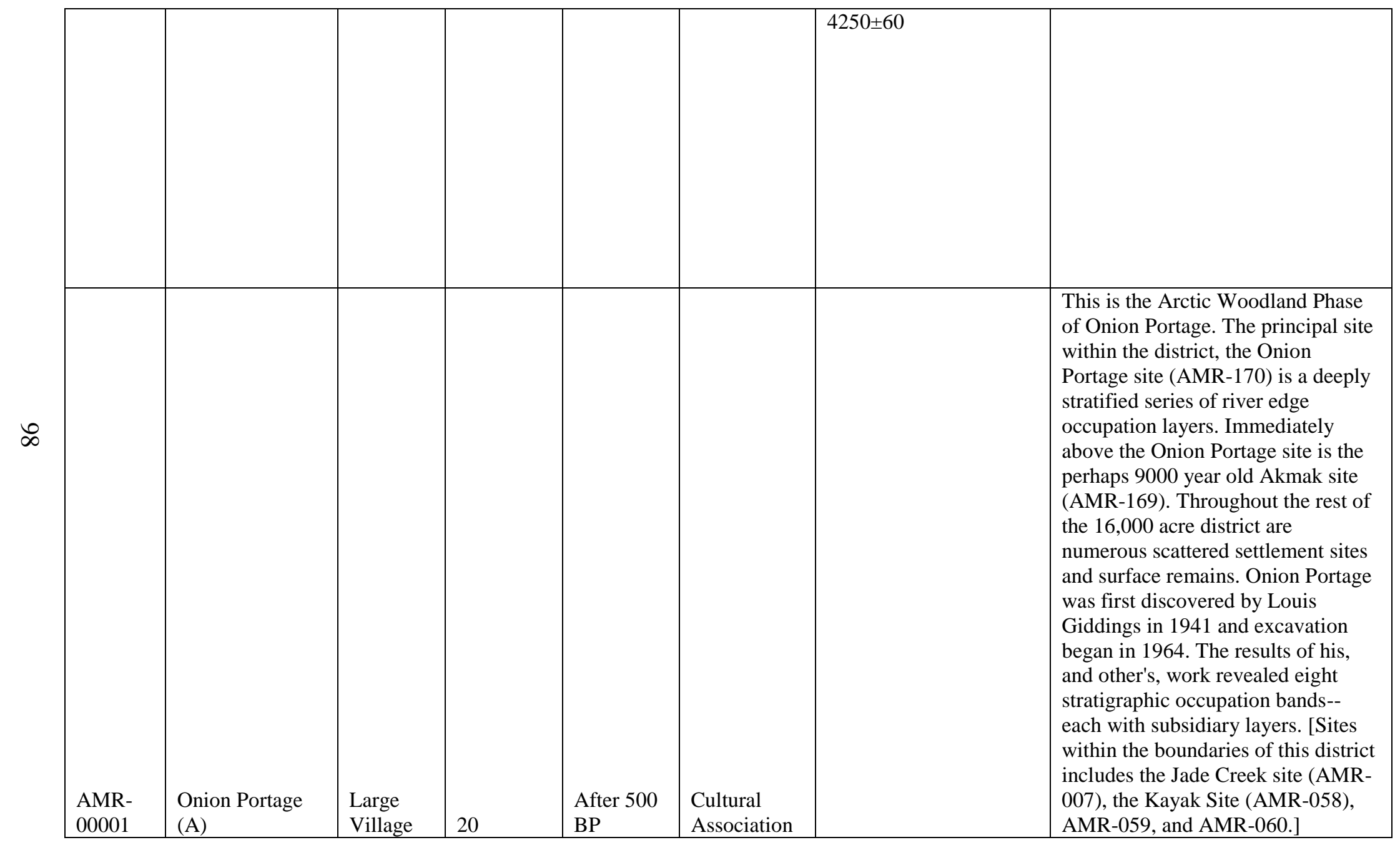




\begin{tabular}{|c|c|c|c|c|c|c|c|}
\hline $\begin{array}{l}\text { AMR- } \\
00002\end{array}$ & Ambler Island & $\begin{array}{l}\text { Large } \\
\text { Village }\end{array}$ & 15 & $\begin{array}{l}\text { After } 500 \\
\text { BP }\end{array}$ & $\begin{array}{l}\text { Occupation } \\
\text { Dates }\end{array}$ & 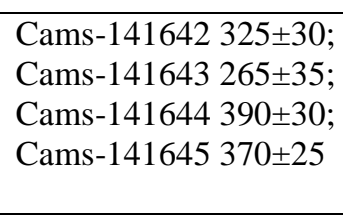 & $\begin{array}{l}\text { Giddings located this site of fifteen } \\
\text { house pits, all of which were } \\
\text { excavated, on a sand ridge near the } \\
\text { center of the island at the mouth of } \\
\text { Ambler River. }\end{array}$ \\
\hline $\begin{array}{l}\text { AMR- } \\
00066\end{array}$ & & $\begin{array}{l}\text { Small } \\
\text { Village }\end{array}$ & 2 & Unknown & N/A & & $\begin{array}{l}\text { This site consists of two } 4 \mathrm{~m} \times 4 \mathrm{~m} \\
\text { house depressions and accessory } \\
\text { pits (possible sod barrows). The } \\
\text { house pits, some } 50-70 \mathrm{~m} \text { apart, are } \\
\text { marked by disturbed vegetation and } \\
\text { some metal debris. Donald Smith } \\
\text { (Kiana) reported visiting the site } \\
\text { during the 1930s. }\end{array}$ \\
\hline $\begin{array}{l}\text { AMR- } \\
00083\end{array}$ & & $\begin{array}{l}\text { Small } \\
\text { Village }\end{array}$ & 4 & $\begin{array}{l}\text { Historic } \\
\text { Occupatio } \\
\mathrm{n}\end{array}$ & $\begin{array}{l}\text { Historic } \\
\text { Material }\end{array}$ & & $\begin{array}{l}\text { USNPS investigators noted historic } \\
\text { features in two loci on a sand ridge } \\
\text { feature. Locus A, just back from the } \\
\text { edge of a } 17 \mathrm{~m} \text { high erosion face, } \\
\text { consists of a } 6.3 \mathrm{~m} \times 4.3 \mathrm{~m} \text { raised } \\
\text { berm feature (about } 45 \mathrm{~cm} \text { deep), a } \\
4.5 \mathrm{~m} \times 2.6 \mathrm{~m} \text { sub rectangular pit, } \\
\text { and a } 1.9 \mathrm{~m} \text { in diameter pit. Locus B, } \\
\text { some } 45 \mathrm{~m} \text { to the southwest, consists } \\
\text { of the remains of two log cabins dug } \\
\text { into the hillside (5.4m } \times 3.5 \mathrm{~m} \text { and } \\
3 \mathrm{~m} \times 2.2 \mathrm{~m} \text { in size), three } \\
\text { rectangular pits }(1.2 \mathrm{~m} \times 1.2 \mathrm{~m}, 1.1 \mathrm{~m} \\
\times .8 \mathrm{~m} \text {, and } .9 \mathrm{~m} \times .9 \mathrm{~m}) \text {, a } 2.7 \mathrm{~m} \times 1 \mathrm{~m} \\
\text { rectangular trench, and a } .8 \mathrm{~m} \times .8 \mathrm{~m} \\
\text { possible feature corner. A } .9 \mathrm{~m} \text { in } \\
\text { diameter pit was also noted another } \\
30 \mathrm{~m} \text { to the southeast. A metal } \\
\text { detector scan yielded evidence of } \\
\text { metal in and around the Locus B } \\
\text { features, but not at Locus A. }\end{array}$ \\
\hline
\end{tabular}




\begin{tabular}{|c|c|c|c|c|c|}
\hline $\begin{array}{l}\text { AMR- } \\
00106\end{array}$ & $\begin{array}{l}\text { Small } \\
\text { Village }\end{array}$ & 2 & Unknown & N/A & $\begin{array}{l}\text { USNPS investigators noted two } \\
\text { house pits with tunnel entrances } \\
\text { extending from the long side, seven } \\
\text { circular cache pits and three } \\
\text { rectangular cache pits on the crest of } \\
\text { ridge rising } 7-8 \mathrm{~m} \text { above the river. } \\
\text { The houses measure } 6.6 \mathrm{~m} \times 3.7 \mathrm{~m} \\
\text { with a } 3.9 \mathrm{~m} \text { long entrance tunnel } \\
\text { and } 4.5 \mathrm{~m} \times 2.5 \mathrm{~m} \text { with a } 2.9 \mathrm{~m} \text { long } \\
\text { entrance tunnel. The caches } \\
\text { measure from } 1 \mathrm{~m} \text { in diameter to } \\
2.8 \mathrm{~m} \times 2.7 \mathrm{~m} \text { in size. A scan with a } \\
\text { metal detector yielded no evidence } \\
\text { of metal artifacts. }\end{array}$ \\
\hline $\begin{array}{l}\text { AMR- } \\
00107\end{array}$ & $\begin{array}{l}\text { Small } \\
\text { Village }\end{array}$ & 3 & Unknown & N/A & $\begin{array}{l}\text { USNPS investigators noted cultural } \\
\text { features extending for about } 200 \mathrm{~m} \\
\text { along the crest of a ridge, about } 8 \mathrm{~m} \\
\text { above the river. Features noted } \\
\text { include three house pits, a } 5 \mathrm{~m} \times \\
4.1 \mathrm{~m} \text { rectangular depression feature } \\
\text { (house?), two circular cache pits } \\
\text { (the largest } 1.5 \mathrm{~m} \text { in diameter), and } \\
\text { four rectangular cache pits (the } \\
\text { largest measuring } 2.3 \mathrm{~m} \times 2.6 \mathrm{~m} \text { ). } \\
\text { The house pit features include a } \\
3.5 \mathrm{~m} \times 2.7 \mathrm{~m} \text { house with a } 3.6 \mathrm{~m} \text { long } \\
\text { tunnel and a } 2.6 \mathrm{~m} \times 1.9 \mathrm{~m} \text { entry } \\
\text { room, a } 4.5 \mathrm{~m} \text { x } 3.6 \mathrm{~m} \text { house with a } \\
4.4 \mathrm{~m} \text { long entrance tunnel, and a } \\
3.5 \mathrm{~m} \times 3.3 \mathrm{~m} \text { house with a } 2.8 \mathrm{~m} \text { long } \\
\text { entrance tunnel. Structural elements } \\
\text { are still evident in the latter two } \\
\text { house features---several logs were } \\
\text { collected for possible } \\
\text { dendrochronological dating. A scan }\end{array}$ \\
\hline
\end{tabular}




\begin{tabular}{|c|c|c|c|c|c|}
\hline & & & & & $\begin{array}{l}\text { with a metal detector produced } \\
\text { evidence of metal at the three } \\
\text { northernmost house pits, but no } \\
\text { evidence at the rectangular feature } \\
\text { to the south. }\end{array}$ \\
\hline $\begin{array}{l}\text { AMR- } \\
00108\end{array}$ & $\begin{array}{l}\text { Single } \\
\text { House }\end{array}$ & 1 & Unknown & N/A & $\begin{array}{l}\text { USNPS investigators located a } 6.3 \mathrm{~m} \\
\text { x } 6.3 \mathrm{~m} \text { house pit with a } 4.5 \mathrm{~m} \text { long } \\
\text { entry tunnel at the edge of a } 9 \mathrm{~m} \\
\text { high erosion face. Two rectangular } \\
\text { cache pits ( } 2.9 \mathrm{~m} \times 2.7 \mathrm{~m} \text { and } 2.2 \mathrm{~m} \times \\
1.5 \mathrm{~m} \text { in size) and a circular cache } \\
\text { pit ( } 2.7 \mathrm{~m} \text { in diameter) were noted } \\
\text { adjacent to the house pit. }\end{array}$ \\
\hline $\begin{array}{l}\text { AMR- } \\
00109\end{array}$ & $\begin{array}{l}\text { Single } \\
\text { House }\end{array}$ & 1 & Unknown & N/A & $\begin{array}{l}\text { USNPS investigators located a } 5.7 \mathrm{~m} \\
\text { x } 4.1 \mathrm{~m} \text { house pit, with a } 3.9 \mathrm{~m} \text { long } \\
\text { entry tunnel, and a } 2.9 \mathrm{~m} \times 2.3 \mathrm{~m} \\
\text { cache pit approximately } 15 \mathrm{~m} \text { from } \\
\text { the edge of a } 7 \mathrm{~m} \text { high erosion face. }\end{array}$ \\
\hline $\begin{array}{l}\text { AMR- } \\
00111\end{array}$ & $\begin{array}{l}\text { Small } \\
\text { Village }\end{array}$ & 2 & $\begin{array}{l}\text { Historic } \\
\text { Occupatio } \\
\mathrm{n}\end{array}$ & $\begin{array}{l}\text { Occupation } \\
\text { Dates }\end{array}$ & $\begin{array}{l}\text { NPS investigators located a } 5 \mathrm{~m} \mathrm{x} \\
5 \mathrm{~m} \text { semi-subterranean, heavily } \\
\text { sodded depression built into the } \\
\text { hillside, with an entrance on the } \\
\text { downhill side. No metal was found } \\
\text { during detector survey. Cut spruce } \\
\text { within the pits were approximately } \\
70 \text { years of age when cut. Two } \\
\text { Inupiaq house features with entry }\end{array}$ \\
\hline
\end{tabular}




\begin{tabular}{|c|c|c|c|c|c|}
\hline & & & & & $\begin{array}{l}\text { tunnels were also noted, one with a } \\
\text { back room. Several cache pits were } \\
\text { also noted. A modern drying rack } \\
\text { was located just to the SW of the } \\
\text { features. Native allotment within the } \\
\text { NPS KOVA. }\end{array}$ \\
\hline $\begin{array}{l}\text { AMR- } \\
00112 \\
\end{array}$ & $\begin{array}{l}\text { Small } \\
\text { Village }\end{array}$ & 2 & $\begin{array}{l}\text { Historic } \\
\text { Occupatio } \\
\mathrm{n}\end{array}$ & $\begin{array}{l}\text { Occupation } \\
\text { Dates }\end{array}$ & $\begin{array}{l}\text { USNPS investigators located two } \\
\text { Inupiat house features with entrance } \\
\text { tunnels, a large rectangular dugout } \\
\text { area (possibly the lower Hanson } \\
\text { camp warehouse), several small pit } \\
\text { features, and a can dump. Hole-in- } \\
\text { top cans were present in the can } \\
\text { dump. }\end{array}$ \\
\hline $\begin{array}{l}\text { AMR- } \\
00115\end{array}$ & $\begin{array}{l}\text { Single } \\
\text { House }\end{array}$ & 1 & Unknown & N/A & $\begin{array}{l}\text { A single house pit and two cache } \\
\text { pits were located and mapped by } \\
\text { USNPS investigators in } 1998 \text {. The } \\
\text { site is situated on a slight terrace, } 5 \text { - } \\
\text { 10m above the river. }\end{array}$ \\
\hline $\begin{array}{l}\text { AMR- } \\
00116\end{array}$ & $\begin{array}{l}\text { Single } \\
\text { House }\end{array}$ & 1 & Unknown & N/A & $\begin{array}{l}\text { A single bermed historic house } \\
\text { feature }(6.1 \mathrm{~m} \times 3.85 \mathrm{~m}) \text { and two } \\
\text { rectangular cache pits were located } \\
\text { and mapped by USNPS } \\
\text { investigators in } 1998 \text {. The features } \\
\text { are situated on the slope of a hill on } \\
\text { the east side of a small drainage } \\
\text { ravine, about } 10 \mathrm{~m} \text { above Kobuk } \\
\text { River. }\end{array}$ \\
\hline $\begin{array}{l}\text { AMR- } \\
00117\end{array}$ & Village & 9 & Unknown & N/A & $\begin{array}{l}\text { USNPS investigators located and } \\
\text { mapped nine house pits and a } \\
\text { number of cache pits situated along } \\
\text { a } 600 \mathrm{~m} \text { long stretch of a terrace } \\
\text { overlooking Kobuk River. }\end{array}$ \\
\hline
\end{tabular}




\begin{tabular}{|c|c|c|c|c|c|c|}
\hline & & & & & & $\begin{array}{l}\text { Structural members were present in } \\
\text { several of the houses. }\end{array}$ \\
\hline $\begin{array}{l}\text { AMR- } \\
00170\end{array}$ & $\begin{array}{l}\text { Onion Portage } \\
\text { Site }\end{array}$ & Village & Unknown & $\begin{array}{l}\text { Outside } \\
\text { Study } \\
\text { Period }\end{array}$ & $\begin{array}{l}\text { Occupation } \\
\text { Dates }\end{array}$ & $\begin{array}{l}\text { The principal site within the district } \\
\text { (AMR-001), the Onion Portage site } \\
\text { is a deeply stratified series of river } \\
\text { edge occupation layers. } \\
\text { Immediately above the Onion } \\
\text { Portage site is the perhaps } 9000 \text { year } \\
\text { old Akmak site (AMR-169). Onion } \\
\text { Portage was first discovered by } \\
\text { Louis Giddings in } 1941 \text { and } \\
\text { excavation began in } 1964 \text {. The } \\
\text { results of his, and other's, work } \\
\text { revealed eight stratigraphic } \\
\text { occupation bands--each with } \\
\text { subsidiary layers. [NATREG] This } \\
\text { is the principle site within the } \\
\text { district. It is a deeply stratified } \\
\text { series of river edge occupation } \\
\text { layers. }\end{array}$ \\
\hline $\begin{array}{l}\text { AMR- } \\
00220\end{array}$ & & Village & Unknown & Unknown & N/A & $\begin{array}{l}\text { Cache pits, house depressions, } \\
\text { lithics, and wood charcoal }\end{array}$ \\
\hline $\begin{array}{l}\text { AMR- } \\
00221\end{array}$ & & Village & Unknown & Unknown & N/A & Depressions and cache pits \\
\hline $\begin{array}{l}\text { AMR- } \\
00222\end{array}$ & & Village & Unknown & Unknown & N/A & Depressions and cache pits \\
\hline $\begin{array}{l}\text { AMR- } \\
00223\end{array}$ & & Village & Unknown & Unknown & N/A & $\begin{array}{l}\text { House depression, cache pit, fire- } \\
\text { cracked rock, charcoal, wood, } \\
\text { fauna, lithics, and hearth }\end{array}$ \\
\hline $\begin{array}{l}\text { AMR- } \\
00224\end{array}$ & & Village & Unknown & Unknown & N/A & House depressions and lithics \\
\hline
\end{tabular}




\begin{tabular}{|c|c|c|c|c|c|c|c|}
\hline $\begin{array}{l}\text { BEN- } \\
00029\end{array}$ & Kuzitrin Lake \#1 & $\begin{array}{l}\text { Small } \\
\text { Village }\end{array}$ & 3 & Unknown & N/A & & $\begin{array}{l}\text { This site consists of three } \\
\text { rectangular house pits and a total of } \\
\text { six small depressions thought to be } \\
\text { storage pits. The house pits measure } \\
3 \mathrm{~m} \times 6 \mathrm{~m} \times .4 \mathrm{~m} \text { deep, } 4.5 \mathrm{~m} \times 2.5 \mathrm{~m} \times \\
.3 \mathrm{~m} \text { deep, and } 3 \mathrm{~m} \times 2 \mathrm{~m} \text { in size. One } \\
\text { of the depressions, which is partially } \\
\text { superimposed by another, was noted } \\
\text { to have an apparent entrance along } \\
\text { the long side. Pottery sherds, chert } \\
\text { flakes, a bifacially worked chert } \\
\text { object, and an abraded rock } \\
\text { fragment were collected from a test } \\
\text { pit in one of the houses. Schaaf } \\
\text { relocated the site. }\end{array}$ \\
\hline $\begin{array}{l}\text { BEN- } \\
00030\end{array}$ & Skeleton Butte & $\begin{array}{l}\text { Large } \\
\text { Village }\end{array}$ & 25 & Unknown & N/A & & $\begin{array}{l}\text { Old village site covers an area of } \\
120 \mathrm{~m} \text { x } 50 \mathrm{~m} \text {. Contains } 25 \text { stone- } \\
\text { lined house pits, } 37 \text { smaller stone- } \\
\text { lined depressions, three large, deep } \\
\text { rock structures, and several hunting } \\
\text { blinds. No artifacts were found; } \\
\text { some testing was conducted. }\end{array}$ \\
\hline $\begin{array}{l}\text { BEN- } \\
00033\end{array}$ & $\begin{array}{l}\text { Cloud Lake } \\
\text { Village }\end{array}$ & $\begin{array}{l}\text { Large } \\
\text { Village }\end{array}$ & 9 & Unknown & N/A & & $\begin{array}{l}\text { Nine stone-lined house pit structures } \\
\text { and two stone-lined cache pits. } \\
\text { Excavations produced pottery } \\
\text { sherds, stone and bone/antler } \\
\text { artifacts, beads and faunal remains. } \\
\text { D.M. Hopkins also tested here in } \\
\text { 1948. }\end{array}$ \\
\hline $\begin{array}{l}\text { BEN- } \\
00047\end{array}$ & $\begin{array}{l}\text { Gosling Cone } \\
\text { Site }\end{array}$ & $\begin{array}{l}\text { Large } \\
\text { Village }\end{array}$ & 9 & $\begin{array}{l}\text { After } 500 \\
\text { BP }\end{array}$ & $\begin{array}{l}\text { Occupation } \\
\text { Dates }\end{array}$ & Beta-264829 140 \pm 40 & $\begin{array}{l}\text { Nine house pits with low stone } \\
\text { walls around each, seven stone } \\
\text { rings, } 13 \text { storage pits, and nine } \\
\text { cairns. A large amount of antler was } \\
\text { found within the house pits. }\end{array}$ \\
\hline
\end{tabular}




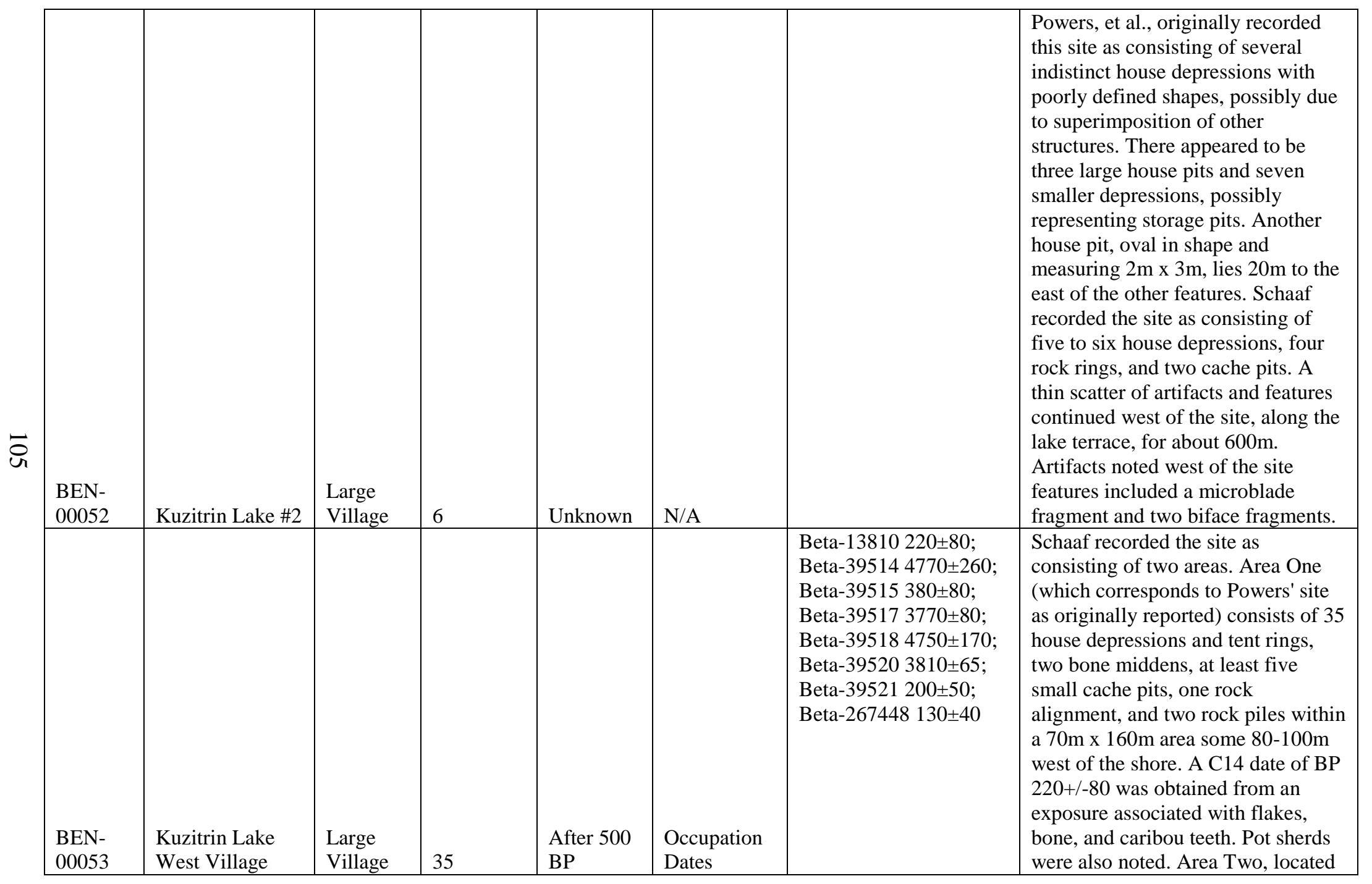




\begin{tabular}{|c|c|c|c|c|c|}
\hline & & & & & $\begin{array}{l}\text { in a blowout within a dune } \\
\text { formation } 40 \mathrm{~m} \text { to the north of Area } \\
\text { One, consists of a scatter of lithics } \\
\text { within a } 18 \mathrm{~m} \text { x } 23 \mathrm{~m} \text { area. Artifacts } \\
\text { noted include a side blade, burin } \\
\text { spalls, microblades, a biface } \\
\text { fragment, a mitten-shaped burin, } \\
\text { and numerous waste flakes. In } \\
\text { addition, a a m long stone arc was } \\
\text { located } 4 \mathrm{~m} \text { to the north and a } 6 \mathrm{~m} \text { in } \\
\text { diameter ring of cobbles was } \\
\text { located } 35 \mathrm{~m} \text { to the southeast of the } \\
\text { blowout. }\end{array}$ \\
\hline $\begin{array}{l}\text { BEN- } \\
00065\end{array}$ & $\begin{array}{l}\text { Small } \\
\text { Village }\end{array}$ & 3 & Unknown & N/A & $\begin{array}{l}\text { This site consists of a total of } 21 \\
\text { stone-lined features and depressions } \\
\text { situated within a } 130 \mathrm{~m} \times 70 \mathrm{~m} \text { area } \\
\text { in a boulder field which forms a } \\
\text { small point on the lakeshore, } 115 \mathrm{~m} \\
\text { east of BEN-053 and } 300 \mathrm{~m} \text { west of } \\
\text { BEN- }-107 \text {. The western portion of } \\
\text { this site consists of an } 8 \mathrm{~m} \text { in } \\
\text { diameter boulder ring associated } \\
\text { with caribou bone, a } 6 \mathrm{~m} \times 7 \mathrm{~m} \\
\text { rectangular boulder-lined enclosure, } \\
\text { four small depressions from } 1 \mathrm{~m} \text { to } \\
3 \mathrm{~m} \text { in diameter, a low rock wall } \\
\text { encircling a } 3 \mathrm{~m} \text { in diameter } \\
\text { depression, two or three possible } \\
\text { house depressions (from } 3 \mathrm{~m} \times 3 \mathrm{~m} \text { to } \\
4 \mathrm{~m} \times 4.5 \mathrm{~m} \text { in size), a } 3 \mathrm{~m} \times 4 \mathrm{~m} \\
\text { rectangular rock-lined depression, } \\
\text { and a bone midden with bone and } \\
\text { pot sherds exposed in the backdirt } \\
\text { of what may be a previous test pit. }\end{array}$ \\
\hline
\end{tabular}




\begin{tabular}{|c|c|c|c|c|c|c|c|}
\hline & & & & & & & $\begin{array}{l}\text { The eastern portion of the site (some } \\
30 \mathrm{~m} \text { away) consists of two hearths } \\
\text { associated with charcoal flecks, } \\
\text { burned and unburned bone, and pot } \\
\text { sherds, two boulder enclosures } \\
\text { caped by slabs, a } 3 \mathrm{~m} \text { in diameter } \\
\text { depression, three oval depressions } \\
\text { measuring from } 2.5 \mathrm{~m} \text { x } 2 \mathrm{~m} \text { to } 4.5 \mathrm{~m} \\
\times 3 \mathrm{~m} \text { in size, and a rectangular } 3 \mathrm{~m} \text { x } \\
5 \mathrm{~m} \text { depression. }\end{array}$ \\
\hline $\begin{array}{l}\text { BEN- } \\
00158\end{array}$ & Kogrupak & $\begin{array}{l}\text { Small } \\
\text { Village }\end{array}$ & 3 & Unknown & N/A & & $\begin{array}{l}\text { The site is composed of } 8 \text { features, } 3 \\
\text { of which appear to be house } \\
\text { remains. Other features may } \\
\text { represent fish caches, and one may } \\
\text { be a miner's assay pit. The location } \\
\text { was noted by Elders as a fishing site } \\
\text { that had been used for a long time. } \\
\text { Based on the number of features and } \\
\text { the proximity to the mouth of the } \\
\text { Kougarok River, this may be the } \\
\text { Village "Kogrupak" visited by } \\
\text { Hobson in } 1854 \text {. }\end{array}$ \\
\hline $\begin{array}{l}\text { BEN- } \\
00185\end{array}$ & & $\begin{array}{l}\text { Single } \\
\text { House }\end{array}$ & 1 & $\begin{array}{l}\text { Before } \\
500 \mathrm{BP}\end{array}$ & $\begin{array}{l}\text { Occupation } \\
\text { Dates }\end{array}$ & Beta-170273 1090 \pm 60 & $\begin{array}{l}\text { Habitation site remnant. Cutbank } \\
\text { section revealed nothced cobble } \\
\text { sink and a hide sinker fashioned } \\
\text { from air pump cylinder of a } 1897 \\
\text { brazing apparatus. Nearby test } \\
\text { yielded wire nails from } 15 \mathrm{~cm} \text { and } \\
\text { dated charcoal deposit from } 43- \\
48 \mathrm{~cm} \text {. These organic sediments } \\
\text { yielded a data of } 1090+/-60 \text { (Beta- } \\
170273 \text { ) and may represent a floor? }\end{array}$ \\
\hline
\end{tabular}




\begin{tabular}{|c|c|c|c|c|c|c|c|}
\hline $\begin{array}{l}\text { CAN- } \\
00004\end{array}$ & Iqalugruaq & $\begin{array}{l}\text { Small } \\
\text { Village }\end{array}$ & 2 & $\begin{array}{l}\text { After } 500 \\
\text { BP }\end{array}$ & $\begin{array}{l}\text { Occupation } \\
\text { Dates }\end{array}$ & Beta-127629 120 \pm 50 & $\begin{array}{l}\text { This site along the bank of the } \\
\text { Koyuk River consists of } 2 \text { sod house } \\
\text { ruins and } 3 \text { associated pits. A small } \\
\text { test inside one dwelling feature } \\
\text { yielded worked antler, fishbone, and } \\
\text { a ground slate blade. A radiocarbon } \\
\text { test was dated at } 120+/-50 \text { BP } \\
\text { (Beta-127629). }\end{array}$ \\
\hline $\begin{array}{l}\text { CAN- } \\
00025\end{array}$ & Kuluvachak & $\begin{array}{l}\text { Large } \\
\text { Village }\end{array}$ & 6 & $\begin{array}{l}\text { After } 500 \\
\text { BP }\end{array}$ & $\begin{array}{l}\text { Occupation } \\
\text { Dates }\end{array}$ & 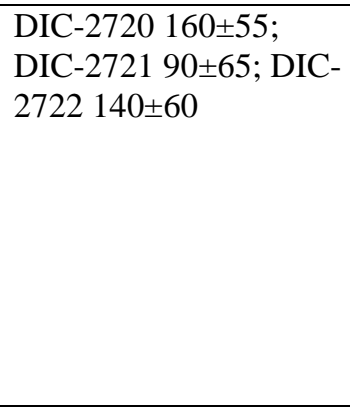 & $\begin{array}{l}\text { This is believed to be the site of the } \\
\text { 19th century settlement of } \\
\text { Culuvachak identified by Ray. In } \\
\text { 1978, H. Smith noted pieces of } \\
\text { pottery and bone implements } \\
\text { eroding from the river bank. In } \\
\text { 1991, Smith mapped } 6 \text { semi- } \\
\text { subterranean features in the now } \\
\text { stabilized area adjacent to the } \\
\text { Buckland River. }\end{array}$ \\
\hline $\begin{array}{l}\text { CAN- } \\
00044\end{array}$ & $\begin{array}{l}\text { Minie Thomas } \\
\text { Sod House }\end{array}$ & $\begin{array}{l}\text { Single } \\
\text { House }\end{array}$ & 1 & Unknown & N/A & & $\begin{array}{l}\text { Reported there was a sod covered } \\
\text { house to the S of the butchering } \\
\text { building. Location of house visible } \\
\text { on } 1966 \text { aerial photograph, but was } \\
\text { not observed during a walk over of } \\
\text { site. This was the home of Minnie } \\
\text { Thomas. }\end{array}$ \\
\hline $\begin{array}{l}\text { CAN- } \\
00046\end{array}$ & Candle Cabin \#1 & $\begin{array}{l}\text { Single } \\
\text { House }\end{array}$ & 1 & $\begin{array}{l}\text { Historic } \\
\text { Occupatio } \\
\mathrm{n}\end{array}$ & $\begin{array}{l}\text { Historic } \\
\text { Material }\end{array}$ & & $\begin{array}{l}\text { Historic cabin built in the 1950s in } \\
\text { Candle, moved to Buckland in the } \\
1960 \text { s. Vacant or no longer in use. }\end{array}$ \\
\hline $\begin{array}{l}\text { CAN- } \\
00054\end{array}$ & Unalitchuaq & $\begin{array}{l}\text { Large } \\
\text { Village }\end{array}$ & 19 & $\begin{array}{l}\text { Historic } \\
\text { Occupatio } \\
\mathrm{n}\end{array}$ & $\begin{array}{l}\text { Historic } \\
\text { Material }\end{array}$ & & $\begin{array}{l}\text { The site includes the remains of } 19 \\
\text { sod houses, } 1 \text { pole scatter, } 1 \text { sod } \\
\text { removal area, a possible grave, } 2 \\
\text { small pits and a latrine. May be } \\
\text { related to Ray, } 1964 \text { p. } 85 \text {, Kayuk. }\end{array}$ \\
\hline
\end{tabular}




\begin{tabular}{|c|c|c|c|c|c|c|}
\hline $\begin{array}{l}\text { CAN- } \\
00055\end{array}$ & Unalitchuaq & Village & Unknown & Unknown & N/A & $\begin{array}{l}\text { This site includes the remains of a } \\
\text { log school house and a log store } \\
\text { building, a log pile, a warm storage } \\
\text { shelter, a semi-subterranean cache, } \\
\text { and a garden area. May be related to } \\
\text { Ray, } 1964 \text { p. } 85 \text {, Kayuk. }\end{array}$ \\
\hline $\begin{array}{l}\text { CAN- } \\
00056\end{array}$ & Unalitchuaq & $\begin{array}{l}\text { Small } \\
\text { Village }\end{array}$ & 4 & $\begin{array}{l}\text { Historic } \\
\text { Occupatio } \\
\mathrm{n}\end{array}$ & $\begin{array}{l}\text { Historic } \\
\text { Material }\end{array}$ & $\begin{array}{l}\text { Four sod houses, two pits, and a } \\
\text { latrine. Ray recorded the } \\
\text { significance and history of the site. }\end{array}$ \\
\hline $\begin{array}{l}\text { CAN- } \\
00057\end{array}$ & Unalitchuaq & $\begin{array}{l}\text { Small } \\
\text { Village }\end{array}$ & 2 & Unknown & N/A & $\begin{array}{l}\text { Includes the remains of } 2 \text { sod } \\
\text { houses, } 2 \text { caches, a shed foundation, } \\
\text { and a tent-use area. May be related } \\
\text { to Ray, } 1964 \text { p. } 85 \text {, Kayuk. }\end{array}$ \\
\hline $\begin{array}{l}\text { CAN- } \\
00060\end{array}$ & Unalitchuaq & $\begin{array}{l}\text { Single } \\
\text { House }\end{array}$ & 1 & Unknown & N/A & $\begin{array}{l}\text { The profile of a single house and } \\
\text { associated living surfaces were } \\
\text { observed in the bank of the river } \\
\text { such as a vertical, axe cut post. A } \\
\text { variety of faunal remains were also } \\
\text { observed. }\end{array}$ \\
\hline $\begin{array}{l}\text { DEL- } \\
00239\end{array}$ & & Village & Unknown & Unknown & N/A & $\begin{array}{l}\text { A half-house, } 3.5 \mathrm{~m} \times 3 \mathrm{~m} \text {, with a } 2 \mathrm{~m} \\
\text { entrance passage, occupied by } \\
\text { Clinton Swan around } 1923 \text { (when } \\
\text { he was } 9-10 \text { ); and a large, } 6 \mathrm{~m} \times 5 \mathrm{~m} \text {, } \\
\text { semi-subterranean house with a } 2 \mathrm{~m} \\
\text { entrance passage, which was said to } \\
\text { have been abandoned prior to } \\
\text { Clinton Swan's time. A square } \\
\text { cache pit is located } 2 \mathrm{~m} \text { east of the } \\
\text { entrance to the earlier structure. BIA } \\
\text { ANCSA investigators recorded } 13 \\
\text { features. Nine were rectangular } \\
\text { bermed depressions, the remnants of } \\
\text { semi-subterranean dwellings, with } \\
\text { from } 1 \text { to } 6 \text { associated smaller }\end{array}$ \\
\hline
\end{tabular}




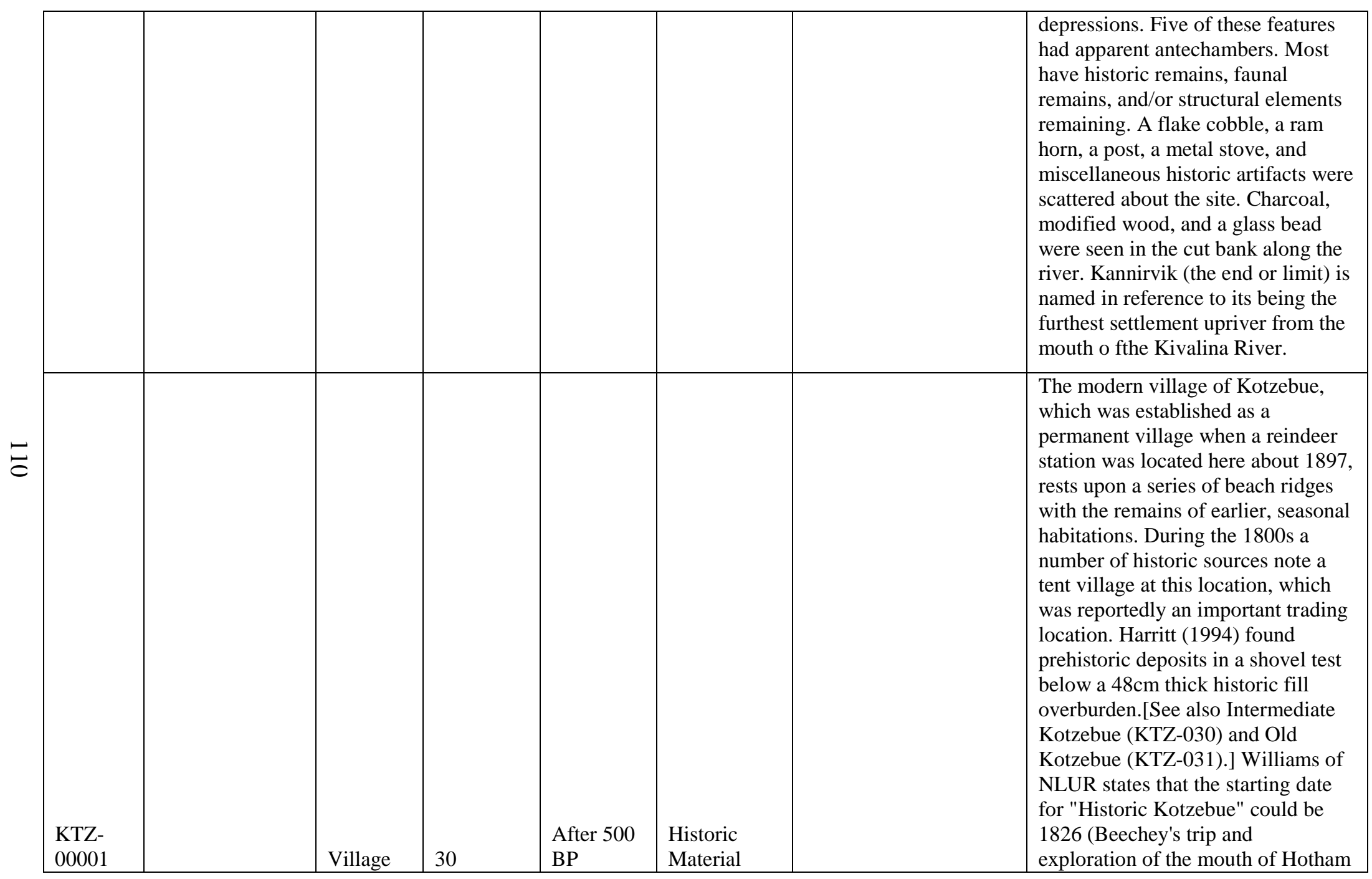




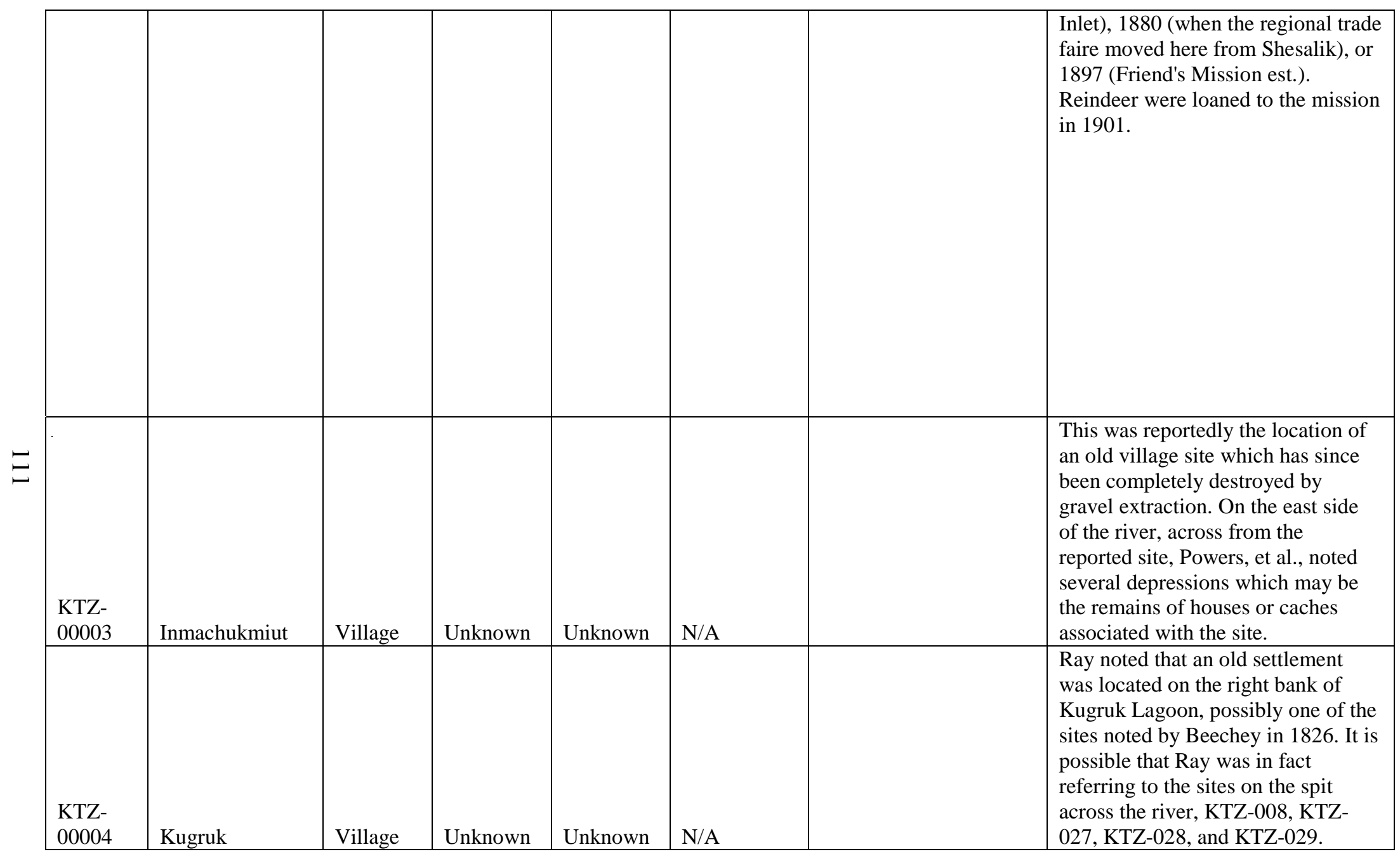




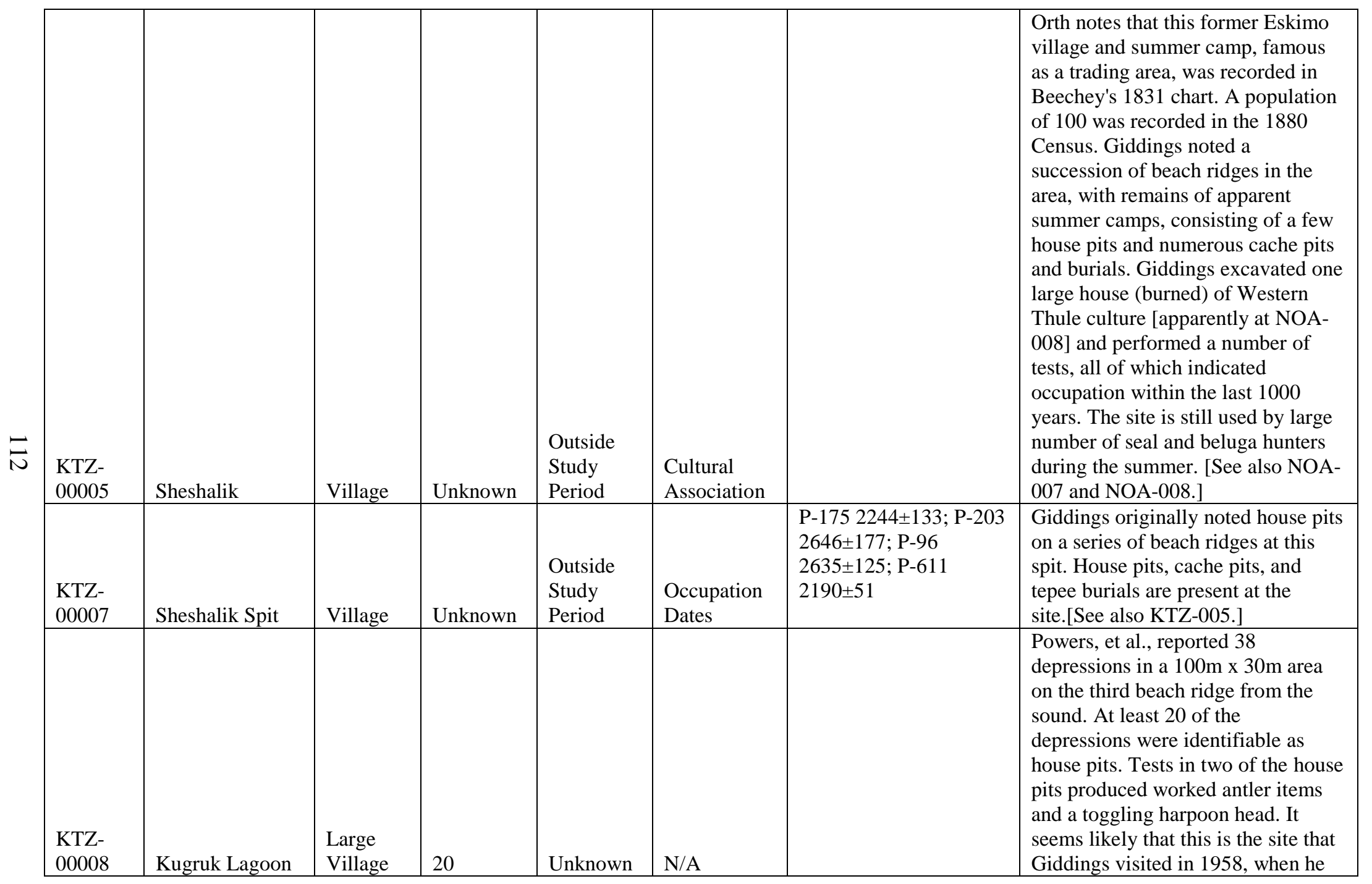




\begin{tabular}{|c|c|c|c|c|c|c|c|}
\hline & & & & & & & $\begin{array}{l}\text { noted that the earliest houses on the } \\
\text { series of beach ridges were } \\
\text { apparently more recent than Thule } \\
\text { age. [See also KTZ-004.] }\end{array}$ \\
\hline $\begin{array}{l}\text { KTZ- } \\
00009\end{array}$ & Kividluk & $\begin{array}{l}\text { Large } \\
\text { Village }\end{array}$ & 32 & $\begin{array}{l}\text { After } 500 \\
\text { BP }\end{array}$ & $\begin{array}{l}\text { Occupation } \\
\text { Dates }\end{array}$ & $\begin{array}{l}\text { Beta-17958 290 } \pm 70 ; \\
\text { Beta-17973 170 }\end{array}$ & $\begin{array}{l}\text { Ray notes that Kividluk had seven } \\
\text { houses in } 1892 \text { and possibly a kazgi } \\
\text { (Jackson, Sheldon 1895) [Ray's } \\
\text { map, however, locates the site on } \\
\text { the opposite bank (see KTZ-010)]. } \\
\text { Schaaf located four areas of cultural } \\
\text { occupation. Area A consists of two } \\
\text { intact house depressions, three } \\
\text { cache depressions, a large } \\
\text { rectangular depression with a } \\
\text { standing entryway arch constructed } \\
\text { of wood ship parts (the kazgi?), and } \\
12 \text { house and cache floors exposed } \\
\text { by erosion. A C14 date of BP } \\
170+/-70 \text { was obtained and a } \\
\text { number of artifacts were recovered. } \\
\text { Area B consists of nine house } \\
\text { depressions and } 13 \text { cache } \\
\text { depressions. Area C consists of a } \\
\text { group of } 11 \text { single and multi-room } \\
\text { house depressions and } 26 \text { cache } \\
\text { depressions. A C14 date of BP } \\
290+/-70 \text { was obtained and artifacts } \\
\text { were collected. Area D consists of } \\
\text { Harvey Pootoogooluk's abandoned } \\
\text { sod house, a raised cache, a grave, } \\
\text { and historic debris. }\end{array}$ \\
\hline
\end{tabular}




\begin{tabular}{|c|c|c|c|c|c|c|}
\hline $\begin{array}{l}\text { KTZ- } \\
00010 \\
\end{array}$ & Singyuk & $\begin{array}{l}\text { Small } \\
\text { Village }\end{array}$ & 5 & Unknown & N/A & $\begin{array}{l}\text { Ray notes that Singyak had only one } \\
\text { or two houses within memory, but } \\
\text { has ancient house depressions } \\
\text { [Ray's map, however, locates the } \\
\text { site on the opposite bank (see KTZ- } \\
\text { 009)]. Schaaf identified a standing } \\
\text { roofed cabin, an outbuilding or } \\
\text { small cabin, three sod house } \\
\text { foundations, four to five house } \\
\text { depressions, and a latrine trench on } \\
\text { the site shown is Singeak on the } \\
\text { USGS map.[See also KTZ-155 and } \\
\text { KTZ-156, sites just to the south, } \\
\text { which may represent or be } \\
\text { associated with Singyuk.] }\end{array}$ \\
\hline $\begin{array}{l}\text { KTZ- } \\
00012 \\
\end{array}$ & Nugnugaluktuk & $\begin{array}{l}\text { Single } \\
\text { House }\end{array}$ & 1 & Unknown & N/A & $\begin{array}{l}\text { Schaaf located an isolated sod house } \\
\text { mound on the north side of the } \\
\text { mouth of Kungealoruk Creek. The } \\
\text { feature measured } 4.65 \mathrm{~m} \text { x } 5.7 \mathrm{~m} \\
\text { with } 85 \mathrm{~cm} \text { high walls, and had three } \\
\text { intact corner posts inside. A circular } \\
\text { sod borrow area was noted on the } \\
\text { southwest side of the house and } \\
\text { about } 50 \mathrm{~m} \text { to the south was an } \\
\text { upright post and a scatter of reindeer } \\
\text { antlers. The site was reportedly the } \\
\text { winter camp of two reindeer } \\
\text { herders. There were reportedly two } \\
\text { sod houses at this location. } \\
\text { Nugnugaluktuk was noted by Ray to } \\
\text { be a seasonal fishing and/or sealing } \\
\text { site, located at the mouth of the } \\
\text { stream draining one of the lakes } \\
\text { called Kealik (ie., perhaps at the } \\
\text { mouth of the stream about } 3.8 \mathrm{~km} \\
\end{array}$ \\
\hline
\end{tabular}




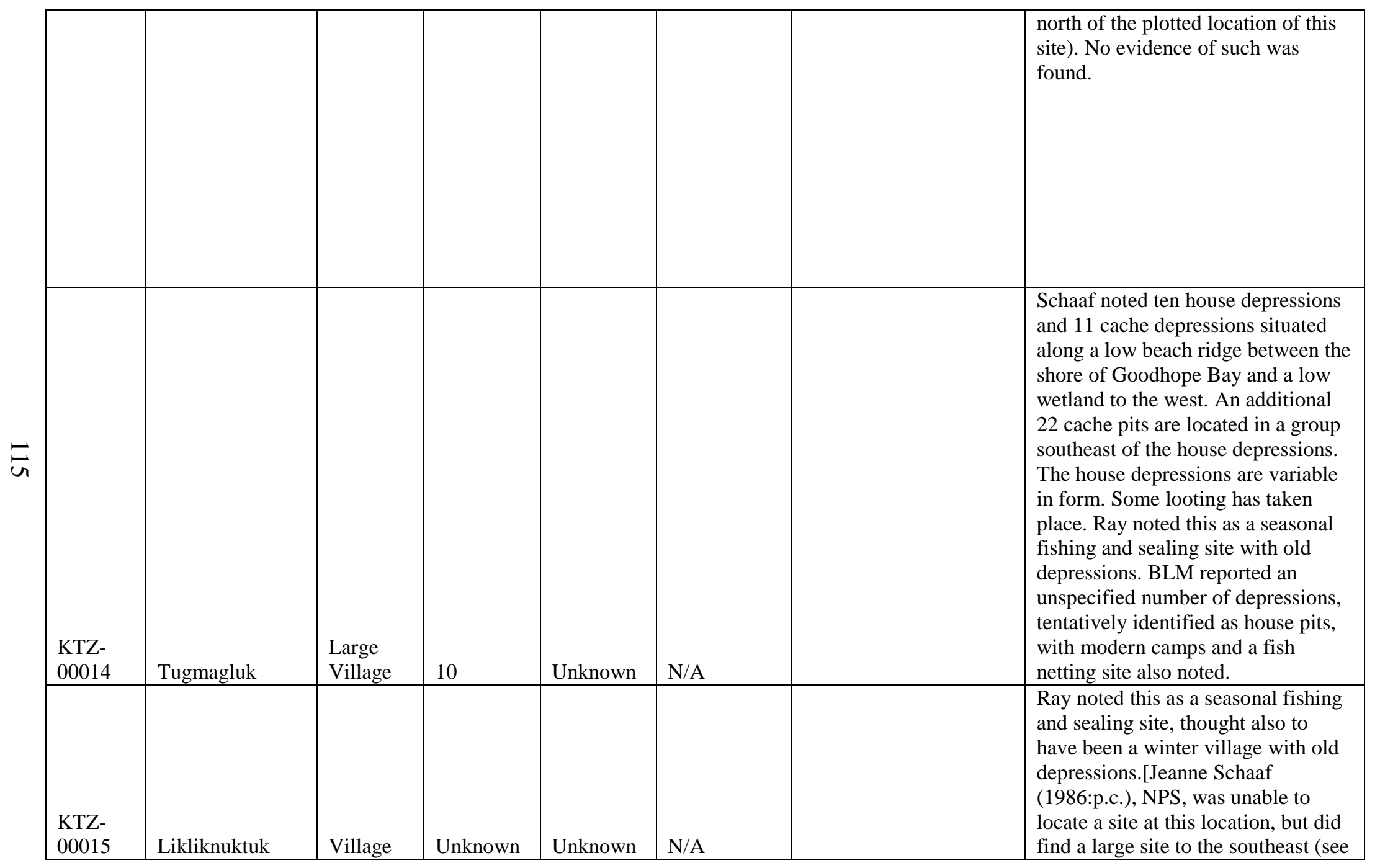




\begin{tabular}{|c|c|c|c|c|c|c|}
\hline & & & & & & KTZ-064).] \\
\hline $\begin{array}{l}\text { KTZ- } \\
00016 \\
\end{array}$ & Pittak & Village & Unknown & Unknown & N/A & $\begin{array}{l}\text { Ray noted this as a village site, } \\
\text { possibly that visited by Hobson in } \\
1854 .\end{array}$ \\
\hline $\begin{array}{l}\text { KTZ- } \\
00017\end{array}$ & Uyauks & $\begin{array}{l}\text { Single } \\
\text { House }\end{array}$ & 1 & Unknown & N/A & $\begin{array}{l}\text { A single } 5.1 \mathrm{~m} \times 4.9 \mathrm{~m} \text { rectangular } \\
\text { house depression was located on the } \\
\text { west side of the mouth of Clifford } \\
\text { Creek. The entry of the house } \\
\text { depression is eroding into the creek } \\
\text { and cultural material is exposed in } \\
\text { the cut bank. Items noted include } \\
\text { seal and caribou bone, fire cracked } \\
\text { rock, pot sherds, an octagonal rifle } \\
\text { barrel. Evidence of two other } \\
\text { apparent features was noted in the } \\
\text { cut bank northeast of the house } \\
\text { depression. An informant suggests } \\
\text { that the remaining feature may be } \\
\text { the remains of the sod house } \\
\text { occupied by Charlie Goodhope } \\
\text { during the early } 1930 \text { s. Ray noted } \\
\text { this as a small village site. }\end{array}$ \\
\hline $\begin{array}{l}\text { KTZ- } \\
00018\end{array}$ & Siknaugrurak & $\begin{array}{l}\text { Large } \\
\text { Village }\end{array}$ & 12 & Unknown & N/A & $\begin{array}{l}\text { Twelve house depressions and at } \\
\text { least four cache pits are situated } \\
\text { along the first beach ridge, about } \\
200 \mathrm{~m} \text { east of the mouth of Rex } \\
\text { Creek. All but two of the house } \\
\text { depressions are sub-rectangular and } \\
\text { single-roomed, with straight entry } \\
\text { tunnels. No artifacts or structural } \\
\text { members were noted. Ray noted this }\end{array}$ \\
\hline
\end{tabular}




\begin{tabular}{|c|c|c|c|c|c|c|}
\hline & & & & & & as a small village site. \\
\hline $\begin{array}{l}\text { KTZ- } \\
00019\end{array}$ & Toalavik & Village & Unknown & Unknown & N/A & $\begin{array}{l}\text { Ray noted this site, apparently a } \\
\text { small village, in an area of good } \\
\text { beluga hunting. }\end{array}$ \\
\hline $\begin{array}{l}\text { KTZ- } \\
00020 \\
\end{array}$ & Kiplaut & $\begin{array}{l}\text { Small } \\
\text { Village }\end{array}$ & 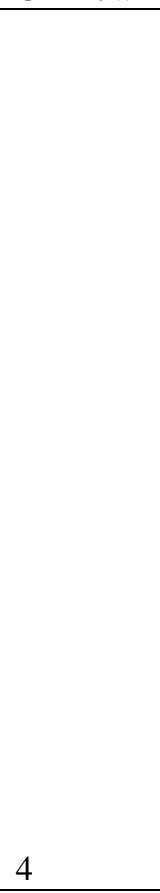 & Unknown & N/A & $\begin{array}{l}\text { When visited by Hobson in } 1854 \text {, } \\
\text { this village consisted of two good } \\
\text { huts (one inhabited) and two in poor } \\
\text { condition. Melchoir and Bennett } \\
\text { reported finding only two house pits } \\
\text { in } 1973 \text {. Powers, et al., visited the } \\
\text { site in } 1974 \text { and found it further } \\
\text { deteriorated. The surface was } \\
\text { littered with cultural debris and } \\
\text { pockmarked with shovel holes. The } \\
\text { original house pits were difficult to } \\
\text { observe. Approximately 50m to the } \\
\text { northwest an undisturbed house pit } \\
\text { was noted. Artifacts collected from } \\
\text { the surface include a chert end } \\
\text { scraper, an antler ice pick, an antler } \\
\text { wedge, and potsherds. This is } \\
\text { apparently the site investigated by } \\
\text { Townsend in } 1969 \text {. She noted } \\
\text { several house pits and recovered } \\
\text { artifacts suggesting a late Eskimo } \\
\text { occupation. }\end{array}$ \\
\hline
\end{tabular}




\begin{tabular}{|c|c|c|c|c|c|c|c|}
\hline $\begin{array}{l}\text { KTZ- } \\
00021\end{array}$ & & $\begin{array}{l}\text { Large } \\
\text { Village }\end{array}$ & 11 & Unknown & N/A & & $\begin{array}{l}\text { Melchoir and Bennett noted an } \\
\text { eastern group of five or six house } \\
\text { pits, separated by approximately } \\
500 \mathrm{~m} \text { from a western group of five } \\
\text { house pits. The western group } \\
\text { appeared much older than the } \\
\text { eastern group. A series of recent } \\
\text { burials was located between the two } \\
\text { groups of house pits. }\end{array}$ \\
\hline $\begin{array}{l}\text { KTZ- } \\
00023\end{array}$ & Deering Qualgi & $\begin{array}{l}\text { Single } \\
\text { House }\end{array}$ & 1 & $\begin{array}{l}\text { Before } \\
500 \text { BP }\end{array}$ & $\begin{array}{l}\text { Occupation } \\
\text { Dates }\end{array}$ & $\begin{array}{l}\text { C-260 } 973 \pm 170 ; \mathrm{K}- \\
2605 \mathrm{c} 1190 \pm 45 ; \mathrm{K}- \\
26061240 \pm 75 ; \mathrm{K}- \\
2607 \mathrm{c} 1400 \pm 55 ; \mathrm{K}- \\
2609 \mathrm{c} 320 \pm 55 ; \mathrm{K}-532 \\
1380 \pm 200 ; \mathrm{K}-537 \\
1290 \pm 200 ; \mathrm{K}-2608 \\
1250 \pm 75 ; \mathrm{K}-2605 \mathrm{a} \\
1180 \pm 55 ; \mathrm{K}-2605 \mathrm{~b} \\
1220 \pm 75 ; \mathrm{K}-2607 \mathrm{a} \\
1440 \pm 75 ; \mathrm{K}-2607 \mathrm{~b} \\
1370 \pm 75 ; \mathrm{K}-2609 \mathrm{a} \\
1290 \pm 75 ; \mathrm{K}-2609 \mathrm{~b} \\
1340 \pm 75\end{array}$ & $\begin{array}{l}\text { In } 1950 \text { Larsen excavated this } \\
\text { Ipiutak ceremonial house. The } 8 \mathrm{~m} \mathrm{x} \\
12 \mathrm{~m} \text { log structure had a large } \\
\text { rectangular fireplace in the center } \\
\text { and an apparent shed at one end. } \\
\text { Artifacts included sled and } \\
\text { snowshoe parts, in addition to } \\
\text { workshop items. Powers, et al., } \\
\text { reported in } 1982 \text { that the excavation } \\
\text { is visible at the W of Deering, along } \\
\text { the } \mathrm{S} \text { side of the airstrip. A local } \\
\text { resident found a Western Thule } \\
\text { style toggling harpoon head } \\
\text { associated with a hearth, while } \\
\text { excavating a storage pit behind his } \\
\text { house in the same location. In } 1994 \\
\text { Dixon revisited the site and found it } \\
\text { to consist only of a shallow hole in } \\
\text { the ground in a grass and willow } \\
\text { covered area. } 2 \text { new depressions } \\
\text { (1m in diameter X } 25 \mathrm{~cm} \text { deep; } 4 \mathrm{~m} x \\
2.5 \mathrm{~m} \text { x } 50 \mathrm{~cm} \text { deep) were found. A } \\
\text { test pit at the site produced } 70 \\
\text { items; including } 24 \text { Euroamerican } \\
\text { artifacts, } 17 \text { mammal bones, sawn } \\
\text { whale bone, decayed wood }\end{array}$ \\
\hline
\end{tabular}




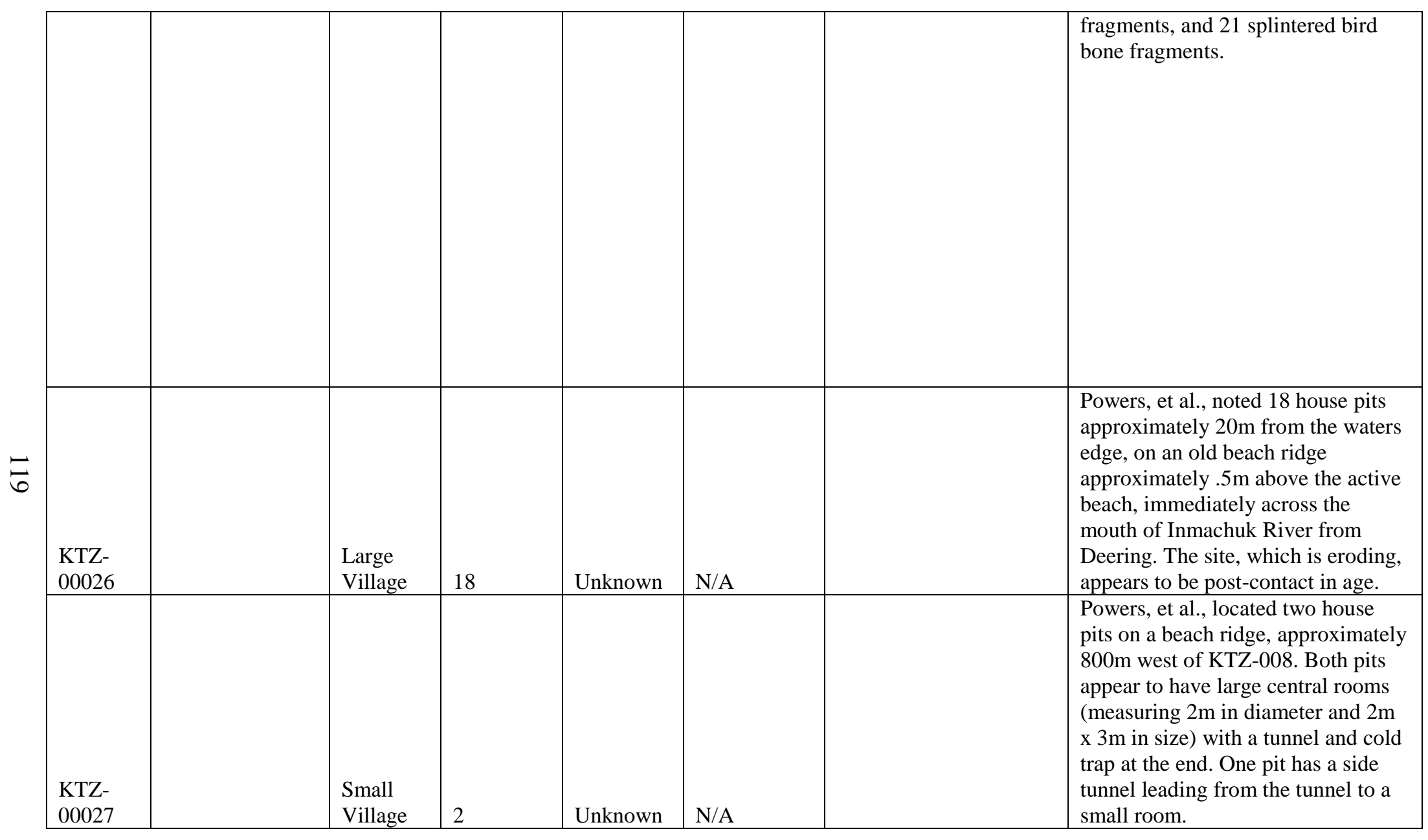




\begin{tabular}{|c|c|c|c|c|c|}
\hline $\begin{array}{l}\text { KTZ- } \\
00028\end{array}$ & $\begin{array}{l}\text { Small } \\
\text { Village } \\
\end{array}$ & 3 & Unknown & N/A & $\begin{array}{l}\text { Powers, et al., located three house } \\
\text { pits on a beach ridge near the tip of } \\
\text { the spit at the mouth of Kugruk } \\
\text { Lagoon. Each pit has several rooms } \\
\text { that are connected by tunnels. } \\
\text { Several small depressions nearby } \\
\text { appear to be cache pits. An area } \\
\text { approximately } 15 \mathrm{~m} \text { to the west had } \\
\text { a very irregular surface that } \\
\text { indicated some kind of disturbance, } \\
\text { possibly additional house pits } \\
\text { obscured by the vegetation. }\end{array}$ \\
\hline $\begin{array}{l}\text { KTZ- } \\
00029\end{array}$ & $\begin{array}{l}\text { Small } \\
\text { Village }\end{array}$ & 3 & Unknown & N/A & $\begin{array}{l}\text { Powers, et al., located three house } \\
\text { pits, six square depressions, a larger } \\
\text { rectangular depression, and a T- } \\
\text { shaped trench on the very tip of the } \\
\text { spit at the mouth of Kugruk Lagoon. } \\
\text { Each house pit has a large central } \\
\text { room (measuring } 3 \mathrm{~m}, 5 \mathrm{~m} \text {, and } 6 \mathrm{~m} \text { in } \\
\text { diameter) and an entrance tunnel } \\
\text { (two with apparent cold traps). The } \\
\text { large rectangular pit and the T- } \\
\text { shaped trench are the result of very } \\
\text { recent activity. }\end{array}$ \\
\hline
\end{tabular}




\begin{tabular}{|c|c|c|c|c|c|c|}
\hline $\begin{array}{l}\text { KTZ- } \\
00030 \\
\end{array}$ & $\begin{array}{l}\text { Intermediate } \\
\text { Kotzebue }\end{array}$ & $\begin{array}{l}\text { Large } \\
\text { Village }\end{array}$ & 30 & $\begin{array}{l}\text { Continuou } \\
\mathrm{s} \\
\text { Occupatio } \\
\mathrm{n}\end{array}$ & $\begin{array}{l}\text { Occupation } \\
\text { Dates }\end{array}$ & $\begin{array}{l}\text { Some } 30 \text { house pits are situated on } \\
\text { three beach ridges between the } \\
\text { beach and Issac Lake. Giddings } \\
\text { excavated five house pits here } \\
\text { during the 1940s, one of which was } \\
\text { a large kazigi. Dated from about AD } \\
\text { 1550, this site is more recent than } \\
\text { the remains at Old Kotzebue (KTZ- } \\
\text { 031). Historic items were recovered } \\
\text { from tests at the southernmost end } \\
\text { of the site. Scott excavated multiple } \\
\text { burials at the site in 1976. In } 2014 \\
\text { newly discovered cultural resources } \\
\text { and human remains found within } \\
\text { the Isaac Lake Material Site } \\
\text { construction area were discovered } \\
\text { and contributed to KTZ-030. The } \\
\text { boundary for the Kotzebue } \\
\text { Archaeological District (KTZ-036) } \\
\text { were revised according to the } \\
\text { findings. }\end{array}$ \\
\hline $\begin{array}{l}\text { KTZ- } \\
00031\end{array}$ & Old Kotzebue & $\begin{array}{l}\text { Large } \\
\text { Village }\end{array}$ & 200 & $\begin{array}{l}\text { Before } \\
500 \mathrm{BP}\end{array}$ & $\begin{array}{l}\text { Occupation } \\
\text { Dates }\end{array}$ & $\begin{array}{l}\text { Within, and at the outskirts of, the } \\
\text { modern village of Kotzebue (KTZ- } \\
001 \text { ) lie the remains of an older site } \\
\text { that Giddings called Old Kotzebue. } \\
\text { As many as } 200 \text { house features have } \\
\text { been estimated for the site, with the } \\
\text { majority within the confines of the } \\
\text { present village. Giddings excavated } \\
\text { three houses here during the } 1940 \text { s, } \\
\text { which he dated to AD 1400, } \\
\text { predating Intermediate Kotzebue } \\
\text { (KTZ-030). VanStone excavated } \\
\text { eight house pits here in 1951. [The } \\
\text { exact location of the excavations }\end{array}$ \\
\hline
\end{tabular}




\begin{tabular}{|c|c|c|c|c|c|c|}
\hline & & & & & & $\begin{array}{l}\text { conducted by Giddings and } \\
\text { VanStone is unknown.] Harritt } \\
\text { (1994) documented both surface and } \\
\text { subsurface cultural deposits of } \\
\text { fauna, pottery, and FCR beneath lot } \\
\text { 4601. }\end{array}$ \\
\hline $\begin{array}{l}\text { KTZ- } \\
00033\end{array}$ & $\begin{array}{l}\text { Kividluk Shelter } \\
\text { Cabin }\end{array}$ & Village & 7 & Unknown & N/A & $\begin{array}{l}\text { A } 12 \text { ' x } 16 \text { ' plywood shelter cabin, } \\
\text { numerous posts, and over } 37 \\
\text { depression features, at least some of } \\
\text { which are cultural in origin, were } \\
\text { noted during a brief reconnaissance. } \\
\text { The pits range from } 1 \mathrm{~m} \text { to } 3 \mathrm{~m} \text { in } \\
\text { diameter and are up to } 1 \mathrm{~m} \text { deep. The } \\
\text { house pits, perhaps about seven, } \\
\text { have entrance tunnels. Two } 50 \mathrm{~cm} \text { x } \\
\text { 50cm tests, placed adjacent to the } \\
\text { cabin, revealed no cultural material. } \\
\text { The cabin was built during the } \\
\text { 1980s. }\end{array}$ \\
\hline $\begin{array}{l}\text { KTZ- } \\
00038\end{array}$ & & $\begin{array}{l}\text { Single } \\
\text { House }\end{array}$ & 1 & Unknown & N/A & $\begin{array}{l}\text { Surface manifestations of this site } \\
\text { consist of the wooden structural } \\
\text { remains of a house wall. By the } \\
\text { angle of the logs it appears to be the } \\
\text { back wall, the rest of the house has } \\
\text { likely been destroyed by erosion. }\end{array}$ \\
\hline $\begin{array}{l}\text { KTZ- } \\
00040\end{array}$ & & $\begin{array}{l}\text { Small } \\
\text { Village }\end{array}$ & 2 & Unknown & N/A & $\begin{array}{l}\text { This site represents an occupational } \\
\text { area spanning two beach ridges, }\end{array}$ \\
\hline
\end{tabular}




\begin{tabular}{|c|c|c|c|c|c|}
\hline & & & & & $\begin{array}{l}\text { along an old channel. Two different } \\
\text { occupations or two residential areas } \\
\text { may be represented. Two possible } \\
\text { house depressions were noted, both } \\
\text { threatened by erosion. Numerous } \\
\text { cache pits were noted, and up to five } \\
\text { cache pits have eroded away, as } \\
\text { evidenced by large amounts of } \\
\text { cemented sands on the channel } \\
\text { beach and eroding support and } \\
\text { lining logs. Up to } 20 \text { posts, } \\
\text { representing at least two dog yards } \\
\text { and several rack structures, were } \\
\text { noted. A few feature depressions } \\
\text { were noted between the ridges. }\end{array}$ \\
\hline $\begin{array}{l}\text { KTZ- } \\
00048\end{array}$ & $\begin{array}{l}\text { Single } \\
\text { House }\end{array}$ & 1 & $\begin{array}{l}\text { Historic } \\
\text { Occupatio } \\
\text { n }\end{array}$ & $\begin{array}{l}\text { Occupation } \\
\text { Dates }\end{array}$ & $\begin{array}{l}\text { This site consists of a small sod } \\
\text { structure and a scatter of historic } \\
\text { artifacts and bone within a } 30 \mathrm{~m} x \\
60 \mathrm{~m} \text { area about } 23 \mathrm{~m} \text { from the } \\
\text { lakeshore. The sod walls are } 30 \mathrm{~cm} \\
\text { high and the bases of five posts are } \\
\text { present. The structure has two } \\
\text { rooms, measuring } 80 \mathrm{~cm} \text { x } 90 \mathrm{~cm} \text { and } \\
2.4 \mathrm{~m} \text { x } 2 \mathrm{~m} \text { (interior dimensions). } \\
\text { Artifacts noted include a star drill, a } \\
\text { curved } 1 \mathrm{~m} \text { section of iron pipe, a } \\
\text { large tree trunk chopping block, } \\
\text { stovepipe, an enamel coffee pot, and } \\
\text { rusted cans. The site is located } \\
\text { along a volcanic beach. A large ice } \\
\text { pressure berm buries some of the } \\
\text { artifacts. The site is reportedly a fox } \\
\text { hunting camp belonging to James } \\
\text { Moses and was occupied from the } \\
1930 \text { s to the } 1950 \mathrm{~s} \text {. }\end{array}$ \\
\hline
\end{tabular}




\begin{tabular}{|c|c|c|c|c|c|}
\hline $\begin{array}{l}\text { KTZ- } \\
00052 \\
\end{array}$ & $\begin{array}{l}\text { Large } \\
\text { Village }\end{array}$ & 47 & $\begin{array}{l}\text { Continuou } \\
\mathrm{s} \\
\text { Occupatio } \\
\mathrm{n}\end{array}$ & $\begin{array}{l}\text { Cultural } \\
\text { Association }\end{array}$ & $\begin{array}{l}\text { This site consists of } 47 \text { house } \\
\text { depressions and some small cache } \\
\text { pits within a } 520 \mathrm{~m} \times 50 \mathrm{~m} \text { area on } \\
\text { the second relict ridge from the } \\
\text { north shore of the lake. The } \\
\text { depressions are shallow and the } \\
\text { entryways open towards the lake. At } \\
\text { the west end of the site is a scatter } \\
\text { of historic artifacts, including the } \\
\text { remains of a tent camp (tent stakes, } \\
\text { door frame with leather hinges, } \\
\text { stovepipe, fuel cans, rusted cans, } \\
\text { and scrap lumber). A bone sled } \\
\text { runner was found in a test in one of } \\
\text { the house depressions. }\end{array}$ \\
\hline $\begin{array}{l}\text { KTZ- } \\
00053\end{array}$ & $\begin{array}{l}\text { Small } \\
\text { Village }\end{array}$ & 3 & $\begin{array}{l}\text { After } 500 \\
\text { BP }\end{array}$ & $\begin{array}{l}\text { Cultural } \\
\text { Association }\end{array}$ & $\begin{array}{l}\text { This site consists of three sub- } \\
\text { rectangular house depressions } \\
\text { within a } 120 \mathrm{~m} \times 30 \mathrm{~m} \text { area along } \\
\text { Kitluk River. The entryways have } \\
\text { enlargements at the end opposite the } \\
\text { house depression. Artifacts found } \\
\text { on the surface include a wooden } \\
\text { bow fragment and a small scatter of } \\
\text { pot sherds. The house pits measure } \\
4.5 \mathrm{~m} \times 2.15 \mathrm{~m} \times .45 \mathrm{~m}, 3.9 \mathrm{~m} \times 1.5 \mathrm{~m} \\
\times .25 \mathrm{~m} \text {, and } 4.36 \mathrm{~m} \times 2 \mathrm{~m} \times .35 \mathrm{~m} \text {. }\end{array}$ \\
\hline $\begin{array}{l}\text { KTZ- } \\
00054\end{array}$ & $\begin{array}{l}\text { Small } \\
\text { Village }\end{array}$ & 2 & $\begin{array}{l}\text { After } 500 \\
\text { BP }\end{array}$ & $\begin{array}{l}\text { Cultural } \\
\text { Association }\end{array}$ & $\begin{array}{l}\text { This site consists of two house } \\
\text { depressions and three cache pits } \\
\text { within a } 60 \mathrm{~m} \times 15 \mathrm{~m} \text { area on the } \\
\text { beach ridge above White Fish Lake. } \\
\text { Both houses have entryways, with } \\
\text { small entry rooms, oriented roughly } \\
\text { towards the lake. The house pits } \\
\text { measure } 3.1 \mathrm{~m} \times 1.7 \mathrm{~m} \times .7 \mathrm{~m} \text { and } \\
2.2 \mathrm{~m} \times 3.2 \mathrm{~m} \times 1.2 \mathrm{~m} \text {. The cache pits }\end{array}$ \\
\hline
\end{tabular}




\begin{tabular}{|c|c|c|c|c|c|}
\hline & & & & & $\begin{array}{l}\text { measure } .7 \mathrm{~m} \times .7 \mathrm{~m} \times .5 \mathrm{~m}, .9 \mathrm{~m} \times \\
1.1 \mathrm{~m} \times .4 \mathrm{~m} \text {, and } 1.8 \mathrm{~m} \times 1.1 \mathrm{~m} \times .5 \mathrm{~m} \text {. } \\
\text { The features appear to be relatively } \\
\text { recent in age, either late prehistoric } \\
\text { or early historic. }\end{array}$ \\
\hline $\begin{array}{l}\text { KTZ- } \\
00055 \\
\end{array}$ & $\begin{array}{l}\text { Large } \\
\text { Village }\end{array}$ & 12 & $\begin{array}{l}\text { After } 500 \\
\text { BP }\end{array}$ & $\begin{array}{l}\text { Cultural } \\
\text { Association }\end{array}$ & $\begin{array}{l}\text { This site consists of } 12 \text { house } \\
\text { depressions and five possible cache } \\
\text { pits within a } 40 \mathrm{~m} \times 150 \mathrm{~m} \text { area on an } \\
\text { old beach ridge. The round to sub- } \\
\text { rectangular house depressions range } \\
\text { in size from } 1.8 \mathrm{~m} \times 1.9 \mathrm{~m} \text { to } 4.1 \mathrm{~m} \times \\
2.3 \mathrm{~m} \text {, and have short entryways } \\
\text { oriented towards the lake. }\end{array}$ \\
\hline $\begin{array}{l}\text { KTZ- } \\
00056\end{array}$ & $\begin{array}{l}\text { Large } \\
\text { Village }\end{array}$ & 16 & $\begin{array}{l}\text { After } 500 \\
\text { BP }\end{array}$ & $\begin{array}{l}\text { Cultural } \\
\text { Association }\end{array}$ & $\begin{array}{l}\text { This site consists of } 16 \text { house } \\
\text { depressions and four possible cache } \\
\text { pits within a } 220 \mathrm{~m} \times 30 \mathrm{~m} \text { area along } \\
\text { an actively eroding beach ridge, } \\
\text { about } 500 \mathrm{~m} \text { ESE of KTZ- } 055 \text {. } \\
\text { Partially eroded depressions and } \\
\text { artifacts were noted in the cutbank, } \\
\text { as were bone, ash, and charcoal. } \\
\text { Several artifacts were collected } \\
\text { from the beach, including an ivory } \\
\text { ulu handle, a slate ulu blade, plain } \\
\text { ware pot sherds and a lamp } \\
\text { fragment, and a "lance" type } \\
\text { projectile point. }\end{array}$ \\
\hline $\begin{array}{l}\text { KTZ- } \\
00058\end{array}$ & $\begin{array}{l}\text { Small } \\
\text { Village }\end{array}$ & 4 & Unknown & N/A & $\begin{array}{l}\text { This site consists of four poorly- } \\
\text { defined possible house depressions } \\
\text { and two small cache pits within a } \\
40 \mathrm{~m} \text { x } 15 \mathrm{~m} \text { area along the edge of a } \\
\text { terrace stranded above a dry } \\
\text { meander of Singeakpuk River. No }\end{array}$ \\
\hline
\end{tabular}




\begin{tabular}{|c|c|c|c|c|c|}
\hline & & & & & $\begin{array}{l}\text { entryways were defined on the } \\
\text { house pits, which measured } 2 \mathrm{~m} \times \\
1.6 \mathrm{~m} \times .18 \mathrm{~m}, 2.3 \mathrm{~m} \times 2.1 \mathrm{~m} \times .25 \mathrm{~m} \text {, } \\
2 \mathrm{~m} \times 3.6 \mathrm{~m} \times .22 \mathrm{~m} \text {, and } 2.3 \mathrm{~m} \times 2.7 \mathrm{~m} \\
\times .32 \mathrm{~m} \text {. Several shovel tests yielded } \\
\text { negative results. }\end{array}$ \\
\hline $\begin{array}{l}\text { KTZ- } \\
00060\end{array}$ & $\begin{array}{l}\text { Single } \\
\text { House }\end{array}$ & 1 & $\begin{array}{l}\text { After } 500 \\
\text { BP }\end{array}$ & $\begin{array}{l}\text { Cultural } \\
\text { Association }\end{array}$ & $\begin{array}{l}\text { This site consists of a single } \\
\text { rectangular house depression } \\
\text { (measuring } 7.2 \mathrm{~m} \times 3.7 \mathrm{~m} \times .45 \mathrm{~m} \\
\text { deep) and a small cache pit located } \\
\text { on a small ridge on the west side of } \\
\text { the mouth of a small drainage. The } \\
\text { site is } 900 \mathrm{~m} \text { east of KTZ-061 and } \\
1.4 \mathrm{~km} \text { east of KTZ-018. The house } \\
\text { pit has been vandalized. A } \\
\text { unilaterally barbed ivory point, an } \\
\text { ivory object, and a pot sherd were } \\
\text { collected from the eroding beach } \\
\text { face. }\end{array}$ \\
\hline $\begin{array}{l}\text { KTZ- } \\
00061\end{array}$ & $\begin{array}{l}\text { Small } \\
\text { Village }\end{array}$ & 4 & Unknown & N/A & $\begin{array}{l}\text { This site consists of four house } \\
\text { depressions and three cache pits } \\
\text { along a low dune beach ridge about } \\
250 \mathrm{~m} \text { east of KTZ-018 and } 900 \mathrm{~m} \\
\text { west of KTZ- } 060 \text {. Three of the } \\
\text { house pits are rectangular, single- } \\
\text { roomed sod block features having } \\
\text { short, ocean oriented entryways } \\
\text { with enlarged entry chambers. One } \\
\text { of these features has exposed } \\
\text { structural members with round } \\
\text { nails. The fourth house pit is } \\
\text { vaguely defined, has an oval main } \\
\text { room measuring } 3.5 \mathrm{~m} \times 4.6 \mathrm{~m} \text {, with } \\
\text { a } 2 \mathrm{~m} \text { long entryway facing inland. }\end{array}$ \\
\hline
\end{tabular}




\begin{tabular}{|c|c|c|c|c|c|}
\hline $\begin{array}{l}\text { KTZ- } \\
00063 \\
\end{array}$ & $\begin{array}{l}\text { Small } \\
\text { Village }\end{array}$ & 5 & Unknown & N/A & $\begin{array}{l}\text { A total of five house depressions } \\
\text { and five cache pits were found on a } \\
\text { terrace about } 1 \mathrm{~km} \text { west of KTZ- } 013 \text {. } \\
\text { A small drainage bisects the site. } \\
\text { Three of the house depressions } \\
\text { average } 5 \mathrm{~m} \text { x } 3 \mathrm{~m} \text { in size and have } \\
\text { relatively short entryways facing } \\
\text { inland. Two vaguely defined house } \\
\text { depressions, on the opposite side of } \\
\text { the drainage, measure } 3.2 \mathrm{~m} \times 4.3 \mathrm{~m} \\
\text { and } 5 \mathrm{~m} \times 3.2 \mathrm{~m} \text { in size, and have } \\
\text { short entryways facing the water. A } \\
\text { pot sherd and a utilized flake were } \\
\text { noted on the beach. }\end{array}$ \\
\hline $\begin{array}{l}\text { KTZ- } \\
00064\end{array}$ & $\begin{array}{l}\text { Large } \\
\text { Village }\end{array}$ & 11 & Unknown & N/A & $\begin{array}{l}\text { Roughly } 11 \text { house depressions and } \\
\text { at least six cache depressions were } \\
\text { found along the back edge of a } \\
\text { gravel terrace, at the base of the } \\
\text { bluffs near a small point on the east } \\
\text { side of the Pish River estuary. In } \\
\text { general the houses are sub- } \\
\text { rectangular single-room features } \\
\text { with long straight entryways, } \\
\text { measuring on the average, } 7.5 \mathrm{~m} \mathrm{x} \\
5 \mathrm{~m} \text { x } 0.4 \mathrm{~m} \text { deep, with entrys } 2-4 \mathrm{~m} \\
\text { long. Occasionally there is evidence } \\
\text { of an axillary room off the } \\
\text { entry.[This may be the site of } \\
\text { Likliknuktuk (KTZ-015), which } \\
\text { Ray's map places to the northwest } \\
\text { of here, but which Schaaf was } \\
\text { unable to locate.] }\end{array}$ \\
\hline
\end{tabular}




\begin{tabular}{|c|c|c|c|c|c|}
\hline $\begin{array}{l}\text { KTZ- } \\
00065\end{array}$ & $\begin{array}{l}\text { Small } \\
\text { Village }\end{array}$ & 3 & Unknown & N/A & $\begin{array}{l}\text { The foundations of three sod } \\
\text { houses, one large cache, and six } \\
\text { small rectangular cache pits were } \\
\text { found on a terrace at the base of a } \\
\text { bluff on the east side of the mouth } \\
\text { of Francis Creek. A number of } \\
\text { historic artifacts were associated } \\
\text { with the site. Two of the houses } \\
\text { have suffered vandalism. }\end{array}$ \\
\hline $\begin{array}{l}\text { KTZ- } \\
00066\end{array}$ & $\begin{array}{l}\text { Small } \\
\text { Village }\end{array}$ & 2 & Unknown & N/A & $\begin{array}{l}\text { The standing walls of a two-room } \\
\text { sod house, one grave, four } \\
\text { rectangular cache pits, and two sod } \\
\text { borrow areas were found on a } \\
\text { terrace along the shore about } 300 \mathrm{~m} \\
\text { south of the mouth of Singeakpuk } \\
\text { River. The house measures } 3.2 \mathrm{~m} x \\
5.1 \mathrm{~m} \text { overall and its walls still stand } \\
\text { about } 40 \mathrm{~cm} \text { high. The house is } \\
\text { eroding along the lagoon shore. The } \\
\text { grave consists of the scattered } \\
\text { remains of a plank box and } \\
\text { miscellaneous skeletal members. } \\
\text { About } 200 \mathrm{~m} \text { NNE of the house is a } \\
\text { small mound with the remains of a } \\
\text { small wooden structure (possibly an } \\
\text { elevated cache or box burial) and a } \\
\text { rectangular, } 1 \mathrm{~m} \times 0.65 \mathrm{~m} \times 0.2 \mathrm{~m} \\
\text { depression. }\end{array}$ \\
\hline
\end{tabular}




\begin{tabular}{|c|c|c|c|c|c|}
\hline $\begin{array}{l}\text { KTZ- } \\
00067\end{array}$ & $\begin{array}{l}\text { Small } \\
\text { Village }\end{array}$ & 3 & Unknown & N/A & $\begin{array}{l}\text { This site consists of three } \\
\text { rectangular depressions, probably } \\
\text { cache pits, and one amorphous } \\
\text { feature at the base of the long sand } \\
\text { peninsula formed where Singeakpuk } \\
\text { River empties into Shismaref Inlet. } \\
\text { The site is situated on two adjacent } \\
\text { ridges on the west side of the river } \\
\text { mouth. The depressions range in } \\
\text { size from } 1-1.85 \mathrm{~m} \text { long, } 0.8-1.4 \mathrm{~m} \\
\text { wide, and are about } 0.25 \mathrm{~m} \text { deep. A } \\
\text { test in the other feature, a subtle } 3 \mathrm{~m} \\
\mathrm{x} 4 \mathrm{~m} \text { rectangular depression, } \\
\text { revealed clay, charcoal, and } \\
\text { pulverized fish bone lenses and a } \\
\text { single pot sherd. }\end{array}$ \\
\hline $\begin{array}{l}\text { KTZ- } \\
00068\end{array}$ & $\begin{array}{l}\text { Single } \\
\text { House }\end{array}$ & 1 & $\begin{array}{l}\text { Before } \\
500 \mathrm{BP}\end{array}$ & $\begin{array}{l}\text { Cultural } \\
\text { Association }\end{array}$ & $\begin{array}{l}\text { This site consists of a house } \\
\text { depression, a cache depression, and } \\
\text { a grave on a dune ridge on the } \\
\text { barrier bar between Shishmaref Inlet } \\
\text { and Chukchi Sea. The house feature } \\
\text { measures } 13.2 \mathrm{~m} \text { long, with a sub- } \\
\text { rectangular main room measuring } \\
4.1 \mathrm{~m} \times 3 \mathrm{~m} \times 0.55 \mathrm{~m} \text { deep. The house } \\
\text { entry descends the dune slope, } \\
\text { widening to a } 2 \mathrm{~m} \text { x } 5 \mathrm{~m} \text { room. An } \\
\text { axillary room may be present off the } \\
\text { east side of the entryway, but it is } \\
\text { poorly defined. Three upright posts } \\
\text { are present, one in each of the } \\
\text { rooms. An oval, } 2.85 \mathrm{~m} \text { x } 2.3 \mathrm{~m} x \\
0.3 \mathrm{~m} \text { deep cache depression is } \\
\text { located near the house. Also nearby } \\
\text { is a driftwood log pile, possibly a } \\
\text { collapsed rack or firewood cache. }\end{array}$ \\
\hline
\end{tabular}




\begin{tabular}{|c|c|c|c|c|c|c|}
\hline & & & & & & $\begin{array}{l}\text { About } 35 \mathrm{~m} \text { east of the house is a } \\
\text { wooden cross lying in a slight } \\
\text { depression on the crest of the dune. } \\
\text { Human skeletal members were } \\
\text { noted on the wet tundra below the } \\
\text { dune. }\end{array}$ \\
\hline $\begin{array}{l}\text { KTZ- } \\
00069\end{array}$ & $\begin{array}{l}\text { Large } \\
\text { Village }\end{array}$ & 27 & $\begin{array}{l}\text { Continuou } \\
\text { s } \\
\text { Occupatio } \\
\mathrm{n}\end{array}$ & $\begin{array}{l}\text { Occupation } \\
\text { Dates }\end{array}$ & Beta-17965 590 \pm 90 & $\begin{array}{l}\text { This site consists of a series of } 27 \\
\text { house depressions and } 18 \text { cache pits } \\
\text { situated along a narrow ridge, on } \\
\text { either sideo of a prominent drainage. } \\
\text { The houses include single-room } \\
\text { features, houses with one or two } \\
\text { axillary rooms off the entry tunnel, } \\
\text { and houses joined at the entry. } \\
\text { Thirteen houses are oriented toward } \\
\text { the sea, seven toward the mainland, } \\
\text { and four toward the channel } \\
\text { dividing the site. Cultural material } \\
\text { noted in deflation exposures and in } \\
\text { a subsurface test included shell, } \\
\text { burned and unburned bone, fire } \\
\text { cracked rock, pot sherds, a drilled } \\
\text { ivory item, and lithics. A C14 date } \\
\text { of BP } 590+/-90 \text { was obtained. }\end{array}$ \\
\hline
\end{tabular}




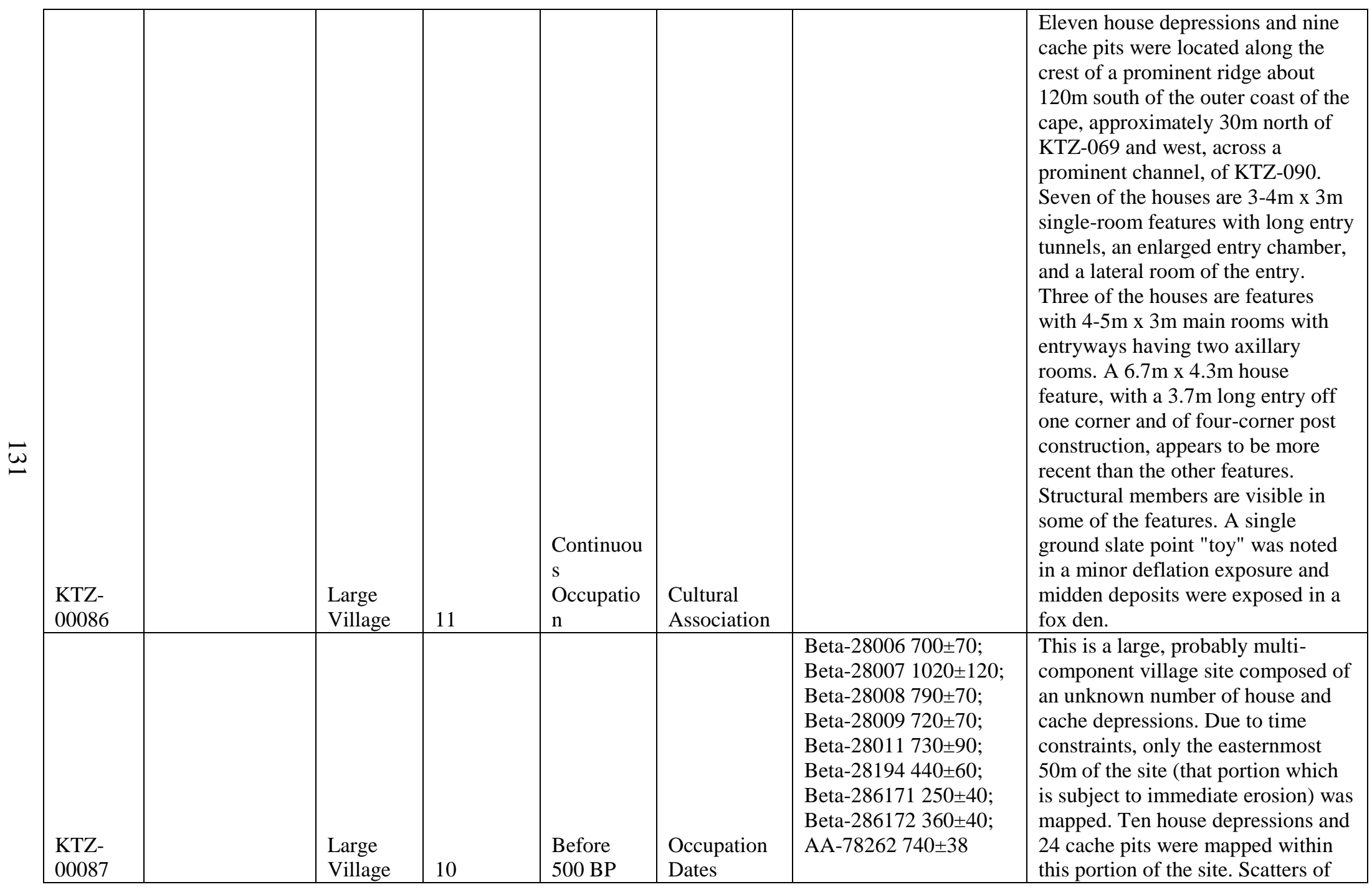




\begin{tabular}{|c|c|c|c|c|c|c|}
\hline & & & & & & $\begin{array}{l}\text { burned bone fragments, shell, } \\
\text { caribou/reindeer bone, small } \\
\text { mammal bone, fire cracked rock, } \\
\text { and the occasional artifact have } \\
\text { been exposed by deflation around } \\
\text { the houses. }\end{array}$ \\
\hline $\begin{array}{l}\text { KTZ- } \\
00088 \\
\end{array}$ & $\begin{array}{l}\text { Large } \\
\text { Village }\end{array}$ & 9 & $\begin{array}{l}\text { Continuou } \\
\mathrm{s} \\
\text { Occupatio } \\
\mathrm{n}\end{array}$ & $\begin{array}{l}\text { Occupation } \\
\text { Dates }\end{array}$ & 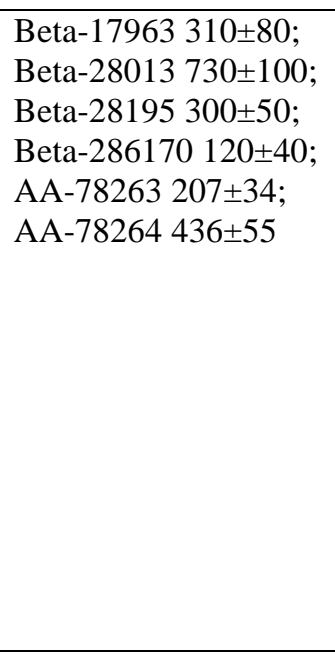 & $\begin{array}{l}\text { This site consists of an unknown } \\
\text { number of house and cache } \\
\text { depressions on a low ridge truncated } \\
\text { by erosion along the Kotzebue } \\
\text { Sound coast. Only the easternmost } \\
50 \mathrm{~m} \text { of the site, that most threatened } \\
\text { by erosion, was recorded. In that } \\
\text { portion, eight multi-room and } \\
\text { single-room house depressions and } \\
\text { three cache depressions were } \\
\text { mapped. Exposures of shell, bone, } \\
\text { and fire cracked rock were noted. } \\
\text { Artifacts noted include a straight- } \\
\text { stemmed triangular chipped point, } \\
\text { plain pot sherds, and a ground slate } \\
\text { punch. }\end{array}$ \\
\hline $\begin{array}{l}\text { KTZ- } \\
00089\end{array}$ & $\begin{array}{l}\text { Small } \\
\text { Village }\end{array}$ & 2 & $\begin{array}{l}\text { Continuou } \\
\mathrm{s} \\
\text { Occupatio } \\
\mathrm{n}\end{array}$ & $\begin{array}{l}\text { Cultural } \\
\text { Association }\end{array}$ & & $\begin{array}{l}\text { A series of six discrete artifact } \\
\text { scatters, two house depressions, and } \\
\text { a number of isolated artifacts were } \\
\text { found along a } 250 \mathrm{~m} \text { extent of a } \\
\text { relict beach ridge on the west side } \\
\text { of the prominent channel on the } \\
\text { outside coast of the cape, about } \\
110 \mathrm{~m} \text { south of KTZ-069, } 80 \mathrm{~m} \text { west } \\
\text { of KTZ-091, and } 270 \mathrm{~m} \text { east of } \\
\text { KTZ-092. Cultural material noted } \\
\text { include a bone arrow point, waste }\end{array}$ \\
\hline
\end{tabular}




\begin{tabular}{|c|c|c|c|c|c|c|}
\hline & & & & & & $\begin{array}{l}\text { flakes, slate flakes, an abrader, pot } \\
\text { sherds, fire cracked rock, shell } \\
\text { fragments, burned and unburned } \\
\text { bone fragments, and oil-soaked sand } \\
\text { chunks. The indistinct house } \\
\text { depressions resemble Western } \\
\text { Thule houses. }\end{array}$ \\
\hline $\begin{array}{l}\text { KTZ- } \\
00090\end{array}$ & $\begin{array}{l}\text { Large } \\
\text { Village }\end{array}$ & 10 & Unknown & N/A & & $\begin{array}{l}\text { Nine well-defined, very deep house } \\
\text { depressions, one less-defined house } \\
\text { depressions, and four cache pits } \\
\text { were located on relict beach ridges } \\
\text { east of the prominent channel on the } \\
\text { outer coast of the cape, about } 50 \mathrm{~m} \\
\text { north of KTZ-069 and east, across } \\
\text { the channel, of KTZ-086. Exposed } \\
\text { cultural material included shell, } \\
\text { bone, charcoal, cemented sand, iron } \\
\text { fragments, a bone point, a bone } \\
\text { harpoon socket with iron stains, and } \\
\text { a flake. }\end{array}$ \\
\hline $\begin{array}{l}\text { KTZ- } \\
00101\end{array}$ & $\begin{array}{l}\text { Large } \\
\text { Village } \\
\end{array}$ & 9 & $\begin{array}{l}\text { After } 500 \\
\text { BP }\end{array}$ & $\begin{array}{l}\text { Occupation } \\
\text { Dates }\end{array}$ & 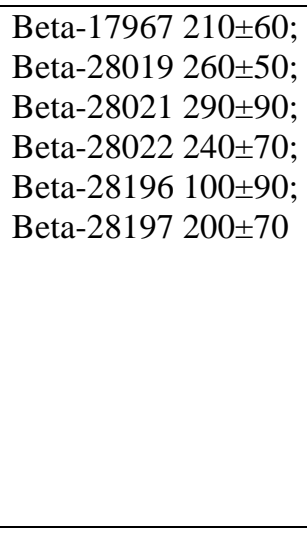 & $\begin{array}{l}\text { Nine house depressions and } 12 \\
\text { cache pits were found on the } \\
\text { eroding east end of a ridge on the } \\
\text { eastern tip of the cape, about } 100 \mathrm{~m} \\
\text { east of KTZ-088. Due to time } \\
\text { constraints, the further westward } \\
\text { extent of the site was not mapped. } \\
\text { The house depressions within the } \\
\text { eastern } 60 \mathrm{~m} \text { of the site are well- } \\
\text { defined, consisting of large } \\
\text { rectangular main rooms, long } \\
\text { entryways having chambers at the } \\
\text { terminus, and one or two rooms }\end{array}$ \\
\hline
\end{tabular}




\begin{tabular}{|c|c|c|c|c|c|c|}
\hline & & & & & & $\begin{array}{l}\text { connected to the entryway. Scatters } \\
\text { of burned bone, shell, and pot } \\
\text { sherds were exposed. A C14 date of } \\
\text { BP } 210+/-60 \text { was obtained from an } \\
\text { apparent eroded house floor. A } \\
\text { human skull cap and a fragment of a } \\
\text { ground slate artifact were found in } \\
\text { the mud flats below the site. }\end{array}$ \\
\hline $\begin{array}{l}\text { KTZ- } \\
00111\end{array}$ & $\begin{array}{l}\text { Large } \\
\text { Village }\end{array}$ & 22 & Unknown & N/A & & $\begin{array}{l}\text { At least } 22 \text { house depressions, } 27 \\
\text { cache depressions, and three graves } \\
\text { were found along the west bank of } \\
\text { Espenberg River, on the second and } \\
\text { third ridges inland from the Chukchi } \\
\text { Sea coast. Most of the house } \\
\text { depressions have vague outlines, } \\
\text { obscured either by the dense } \\
\text { vegetation or looter's diggings. } \\
\text { Artifactual material noted on the } \\
\text { surface include waffle-stamped pot } \\
\text { sherds, worked bone, waste flakes, } \\
\text { charcoal, and faunal material. }\end{array}$ \\
\hline $\begin{array}{l}\text { KTZ- } \\
00130 \\
\end{array}$ & $\begin{array}{l}\text { Large } \\
\text { Village }\end{array}$ & 25 & $\begin{array}{l}\text { Before } \\
500 \mathrm{BP}\end{array}$ & $\begin{array}{l}\text { Occupation } \\
\text { Dates }\end{array}$ & Beta-17970 500 \pm 80 & $\begin{array}{l}\text { This multi-component village site is } \\
\text { located on the second coastal ridge, } \\
\text { about } 100 \mathrm{~m} \text { south of the Chukchi } \\
\text { Sea coast. Twenty-five single-room } \\
\text { and multi-room house depressions } \\
\text { and } 10 \text { cache depressions were } \\
\text { noted. A C14 sample collected from } \\
\text { an eroding hearth yielded a date of } \\
\text { AD } 1422 \text { (calibrated). Cultural } \\
\text { materials noted in the blowout } \\
\text { below the hearth include a biface } \\
\text { fragment, waste flakes, pot sherds, }\end{array}$ \\
\hline
\end{tabular}




\begin{tabular}{|c|c|c|c|c|c|}
\hline & & & & & $\begin{array}{l}\text { bone, a steel trap, metal fragments, } \\
\text { and cemented sand. Recent graves } \\
\text { were noted about } 200 \mathrm{~m} \text { to the east } \\
\text { of the site. }\end{array}$ \\
\hline $\begin{array}{l}\text { KTZ- } \\
00131 \\
\end{array}$ & $\begin{array}{l}\text { Large } \\
\text { Village }\end{array}$ & 10 & $\begin{array}{l}\text { Before } \\
500 \mathrm{BP}\end{array}$ & $\begin{array}{l}\text { Cultural } \\
\text { Association }\end{array}$ & $\begin{array}{l}\text { Ten large house depressions, three } \\
\text { smaller possible house depressions, } \\
\text { and two caches were noted on the } \\
\text { fourth ridge inland from the } \\
\text { Chukchi Sea coast, on the west bank } \\
\text { of Espenberg River. Two of the } \\
\text { house depressions are eroding into } \\
\text { the river and a number of the } \\
\text { features have been severely } \\
\text { damaged by looting. Exposed } \\
\text { cultural material includes pot } \\
\text { sherds, slate fragments, fire cracked } \\
\text { rock, and faunal remains. }\end{array}$ \\
\hline $\begin{array}{l}\text { KTZ- } \\
00137\end{array}$ & $\begin{array}{l}\text { Single } \\
\text { House }\end{array}$ & 1 & Unknown & N/A & $\begin{array}{l}\text { This site is located on the east edge } \\
\text { of a ridge on the west side of } \\
\text { Espenberg River. The site was } \\
\text { incompletely recorded, but whale } \\
\text { bone, the remains of a possible } \\
\text { cache structure, pot sherds, a faint } \\
\text { house depression, and an adjacent } \\
\text { cache depression were noted. }\end{array}$ \\
\hline $\begin{array}{l}\text { KTZ- } \\
00138 \\
\end{array}$ & $\begin{array}{l}\text { Large } \\
\text { Village }\end{array}$ & 15 & $\begin{array}{l}\text { After } 500 \\
\text { BP }\end{array}$ & $\begin{array}{l}\text { Cultural } \\
\text { Association }\end{array}$ & $\begin{array}{l}\text { This large multi-component village } \\
\text { site is located on the second ridge } \\
\text { inland from the Chukchi Sea coast, } \\
\text { west of Espenberg River. The site } \\
\text { was only briefly examined, but } 15 \\
\text { house depressions, a number of }\end{array}$ \\
\hline
\end{tabular}




\begin{tabular}{|c|c|c|c|c|c|}
\hline & & & & & $\begin{array}{l}\text { cache depressions, whale bone, } \\
\text { waffle-stamped pot sherds, and an } \\
\text { ivory foreshaft were noted. }\end{array}$ \\
\hline $\begin{array}{l}\text { KTZ- } \\
00140\end{array}$ & $\begin{array}{l}\text { Large } \\
\text { Village }\end{array}$ & 9 & $\begin{array}{l}\text { Historic } \\
\text { Occupatio } \\
\mathrm{n}\end{array}$ & $\begin{array}{l}\text { Occupation } \\
\text { Dates }\end{array}$ & $\begin{array}{l}\text { Nine sod house depressions, an } \\
\text { elevated cabin (on wood posts), and } \\
\text { several associated caches were } \\
\text { located on the inland-most ridge of } \\
\text { the series of ridges just west of } \\
\text { Espenberg River, just south of the } \\
\text { Goodhope reindeer corral. This } \\
\text { settlement was associated with } \\
\text { reindeer herding and with early use } \\
\text { of the adjacent corral and was } \\
\text { occupied in the early } 1900 \text { s. The } \\
\text { cabin was used until } 1947 .\end{array}$ \\
\hline $\begin{array}{l}\text { KTZ- } \\
00145\end{array}$ & $\begin{array}{l}\text { Small } \\
\text { Village }\end{array}$ & 5 & Unknown & N/A & $\begin{array}{l}\text { The remains of five eroded house } \\
\text { features and at least two probable } \\
\text { caches are exposed in profile along } \\
\text { the severely eroding dune face on } \\
\text { the east side of the mouth of Kitluk } \\
\text { River. The houses are constructed of } \\
\text { driftwood posts and hewn planks. } \\
\text { Faunal remains, a ground slate ulu, } \\
\text { a retouched flake, a waste flake, } \\
\text { bone sled runners, decorated pot } \\
\text { sherds, a single notched pebble, and } \\
\text { trade items (a copper sheet and a } \\
\text { glass bead) were associated with the } \\
\text { features. Additionally, the remains } \\
\text { of a recent tent camp were noted. }\end{array}$ \\
\hline
\end{tabular}




\begin{tabular}{|c|c|c|c|c|c|c|c|}
\hline $\begin{array}{l}\text { KTZ- } \\
00148\end{array}$ & & $\begin{array}{l}\text { Large } \\
\text { Village }\end{array}$ & 11 & Unknown & $\begin{array}{l}\text { Occupation } \\
\text { Dates }\end{array}$ & Beta-17959 430 \pm 80 & $\begin{array}{l}\text { This site consists of two loci } \\
\text { situated on the west bank of an } \\
\text { unnamed drainage on the Chukchi } \\
\text { Sea coast. Loci A consists of five } \\
\text { eroded feature floors exposed in a } \\
\text { cut ridge face. Apparent rotted floor } \\
\text { remnants, charcoal, and bone were } \\
\text { noted, but no artifacts. Loci B } \\
\text { consists of six house depressions, } \\
\text { five cache depressions, and isolated } \\
\text { scatters of cultural material located } \\
\text { on ridges about } 150 \mathrm{~m} \text { southwest of } \\
\text { Loci A. Cultural material noted } \\
\text { included scatters of shell and bone, } \\
\text { decorated pot sherds, a bone blunt, } \\
\text { and a bone sled runner. An upright } \\
\text { configuration of posts and some } \\
\text { historic debris was also noted, 69- } \\
126 \mathrm{~m} \text { to the west of Loci B. }\end{array}$ \\
\hline $\begin{array}{l}\text { KTZ- } \\
00149\end{array}$ & Ullugsaun & $\begin{array}{l}\text { Large } \\
\text { Village }\end{array}$ & 25 & $\begin{array}{l}\text { After } 500 \\
\text { BP }\end{array}$ & $\begin{array}{l}\text { Cultural } \\
\text { Association }\end{array}$ & & $\begin{array}{l}\text { This site consists of at least } 25 \\
\text { cultural features extending for about } \\
500 \mathrm{~m} \text { along an eroding beach ridge } \\
\text { on the Chukchi Sea coast. The } \\
\text { features noted include six late } \\
\text { historic sod houses, with associated } \\
\text { racks and caches, and } 13 \text { eroded } \\
\text { structural features from earlier } \\
\text { occupations. A variety of } \\
\text { miscellaneous historic items were } \\
\text { noted, as were faunal remains, } \\
\text { decorated pot sherds, a bone sled } \\
\text { runner, and an apparent wooden } \\
\text { box. The more recent portion of the } \\
\text { site is reportedly the settlement of } \\
\text { Ullugsaum, and early } 1900 \text { s winter }\end{array}$ \\
\hline
\end{tabular}




\begin{tabular}{|c|c|c|c|c|c|c|}
\hline & & & & & & $\begin{array}{l}\text { village. } \\
\text { valla }\end{array}$ \\
\hline $\begin{array}{l}\text { KTZ- } \\
00155 \\
\end{array}$ & $\begin{array}{l}\text { Large } \\
\text { Village } \\
\end{array}$ & 6 & Unknown & N/A & & $\begin{array}{l}\text { Six historic period sod house } \\
\text { depressions, five cache depressions, } \\
\text { and unidentified feature remains } \\
\text { were located along a sand ridge, } \\
\text { about } 500 \mathrm{~m} \text { southwest of the } \\
\text { Singyuk cabins (KTZ-010). Two of } \\
\text { the features are partially eroded and } \\
\text { the others are very near the eroding } \\
\text { bank. A small amount of historic } \\
\text { debris was noted. A faint sub- } \\
\text { rectangular depression also noted } \\
\text { may represent an earlier house } \\
\text { depression. It is possible that this } \\
\text { site represents the late 1800s village } \\
\text { of Singyuk (see also KTZ-010). }\end{array}$ \\
\hline $\begin{array}{l}\text { KTZ- } \\
00157\end{array}$ & $\begin{array}{l}\text { Single } \\
\text { House }\end{array}$ & 1 & Unknown & $\begin{array}{l}\text { Occupation } \\
\text { Dates }\end{array}$ & $\begin{array}{l}\text { Beta-28024 1300 } \pm 70 ; \\
\text { Beta-28026 1410 } \pm 60 ; \\
\text { Beta-28198 1360 } \pm 90\end{array}$ & $\begin{array}{l}\text { This site consists of house pits and } \\
\text { cultural material (including human } \\
\text { remains eroding from blowouts on } \\
\text { a beach ridge (E-8). Extensive } \\
\text { testing of three house depressions } \\
\text { and an activity area was conducted, } \\
\text { yielding apparent Ipiutak artifacts } \\
\text { and C14 dates (uncalibrated) from } \\
\text { BP } 1300+/-70 \text { to BP } 1410+/-60 \text {. }\end{array}$ \\
\hline
\end{tabular}




\begin{tabular}{|c|c|c|c|c|c|c|c|}
\hline $\begin{array}{l}\text { KTZ- } \\
00158 \\
\end{array}$ & $\begin{array}{l}\text { Fletcher Gregg } \\
\text { Spit Site }\end{array}$ & Village & Unknown & $\begin{array}{l}\text { Outside } \\
\text { Study } \\
\text { Period } \\
\end{array}$ & $\begin{array}{l}\text { Cultural } \\
\text { Association }\end{array}$ & & $\begin{array}{l}\text { Several semi-subterranean houses } \\
\text { located on this gravel spit. A test } \\
\text { excavation in one of these yielded } \\
\text { numerous historic artifacts. The } \\
\text { finds included a toggle harpoon } \\
\text { head, worked bone, worked wood, } \\
\text { and forged iron. Another harpoon } \\
\text { head and a bone projectile point } \\
\text { were also found on the gravel road } \\
\text { on the property. }\end{array}$ \\
\hline $\begin{array}{l}\text { KTZ- } \\
00162\end{array}$ & & $\begin{array}{l}\text { Single } \\
\text { House }\end{array}$ & 1 & Unknown & N/A & & $\begin{array}{l}\text { A house depression, measuring } \\
\text { about } 4-5 \mathrm{~m} \text { square with } 50 \mathrm{~cm} \text { high } \\
\text { berms, was noted at the head of a } \\
\text { surge channel (Bf). No metal or } \\
\text { historic debris were noted during } \\
\text { cursory inspection. }\end{array}$ \\
\hline $\begin{array}{l}\text { KTZ- } \\
00171\end{array}$ & & $\begin{array}{l}\text { Small } \\
\text { Village }\end{array}$ & 4 & $\begin{array}{l}\text { After } 500 \\
\text { BP }\end{array}$ & $\begin{array}{l}\text { Cultural } \\
\text { Association }\end{array}$ & Beta-41833 100 \pm 70 & $\begin{array}{l}\text { USNPS investigators identified at } \\
\text { least four house pits during a brief } \\
\text { site visit to document a reported } \\
\text { looting incident. Four house pits } \\
\text { were noted at the site. Feature } 1 \\
\text { consists of three rooms connected } \\
\text { by long tunnels to an entrance room. } \\
\text { Feature } 2 \text { consists of a main room } \\
\text { and a possible kitchen connected by } \\
\text { tunnels to the entrance room. The } \\
\text { other two features are apparently } \\
\text { single room houses with long } \\
\text { entrance tunnels. }\end{array}$ \\
\hline
\end{tabular}




\begin{tabular}{|c|c|c|c|c|c|c|c|}
\hline $\begin{array}{l}\text { KTZ- } \\
00298 \\
\end{array}$ & Aklaq & $\begin{array}{l}\text { Large } \\
\text { Village }\end{array}$ & 11 & $\begin{array}{l}\text { After } 500 \\
\text { BP }\end{array}$ & $\begin{array}{l}\text { Occupation } \\
\text { Dates }\end{array}$ & Beta-304045 100 \pm 30 & $\begin{array}{l}\text { This site consists of a single grave } \\
\text { from } 1952 \text { marked with a white } \\
\text { painted cross, } 11 \text { probable house } \\
\text { depressions, } 59 \text { other depressions, } 6 \\
\text { tent-use areas, a scatter of poles and } \\
\text { a cluster of stakes. Modern debris } \\
\text { was found scattered throughout the } \\
\text { sites. Oral history documents } 3 \\
\text { occupations at Aklaq (brown bear): } \\
\text { a contact-period village which as } \\
\text { abandoned prior to } 1900 \text {, a fall fish } \\
\text { camp, and a reindeer herder's camp. }\end{array}$ \\
\hline $\begin{array}{l}\text { KTZ- } \\
00299\end{array}$ & & $\begin{array}{l}\text { Single } \\
\text { House }\end{array}$ & 1 & $\begin{array}{l}\text { Before } \\
500 \mathrm{BP}\end{array}$ & $\begin{array}{l}\text { Occupation } \\
\text { Dates }\end{array}$ & $\begin{array}{l}\text { Beta-138564 1620 } 180 ; \\
\text { Beta-138562 1250 } \\
\text { Beta-231493 } 1220 \pm 40\end{array}$ & $\begin{array}{l}\text { Buried Ipiutak house under what is } \\
\text { now the new Post Office building. } \\
\text { The house is semi-subterranean and } \\
\text { roughly rectangular in shape. The S } \\
\text { corner is replaced by a short } \\
\text { entrance tunnel. The cache pit is } \\
\text { about } 1 \mathrm{~m} \text { in diameter, with } \\
\text { irregularly sloping walls. The date } \\
\text { of the house features matches } \\
\text { remarkably closely with a } \\
\text { radiocarbon date from Ipiutak } \\
\text { Burial } 4 \text { (Reanier et al. 1998a) and } \\
\text { an Ipiutak Karigi or men's } \\
\text { ceremonial house excavated in the } \\
\text { early } 1950 \text { s by scientists from the } \\
\text { Danish National Museum in } \\
\text { Copenhagan (Larson 2001). } \\
\text { [Located within Deering } \\
\text { Archaeological District, KTZ-169]. }\end{array}$ \\
\hline
\end{tabular}




\begin{tabular}{|c|c|c|c|c|c|c|c|}
\hline $\begin{array}{l}\text { KTZ- } \\
00300\end{array}$ & $\begin{array}{l}\text { Deering Western } \\
\text { Thule House } 1\end{array}$ & $\begin{array}{l}\text { Single } \\
\text { House }\end{array}$ & 1 & $\begin{array}{l}\text { Before } \\
500 \mathrm{BP}\end{array}$ & $\begin{array}{l}\text { Occupation } \\
\text { Dates }\end{array}$ & 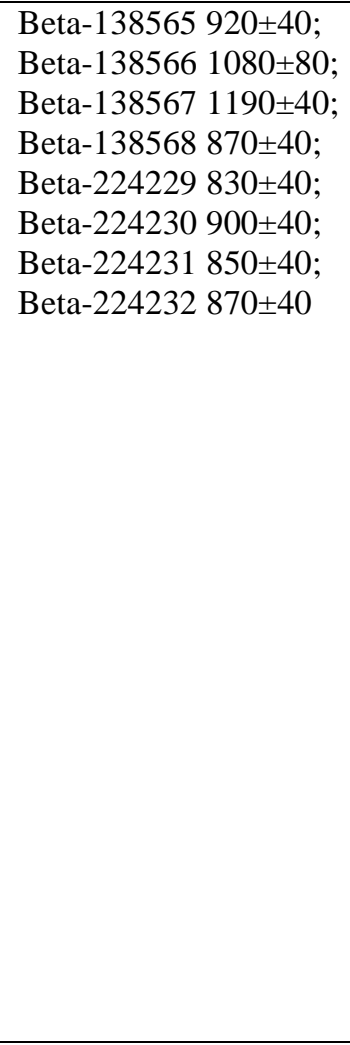 & $\begin{array}{l}\text { This feature is a } 2.5 \mathrm{~m} \text { square house } \\
\text { with a main room, } 6.4 \mathrm{~m} \text { long S- } \\
\text { facing entrance tunnel and a side } \\
\text { room presumably functioning as a } \\
\text { kitchen. It was constructed of } \\
\text { driftwood, whalebone, and sod. A } \\
\text { total of } 4 \text { C14 dates were obtained, } \\
\text { the most reliable date is from } \\
\text { charcoal beneath the main house } \\
\text { room floorboards, BP } 910+/-40 \\
\text { (Beta-138568). Charcoal from the } \\
\text { base of the house entrance tunnel } \\
\text { dates to BP } 940+/-40 \text { (Beta- } \\
138565 \text { ). Two additional C14 } \\
\text { samples from the house kitchen } \\
\text { antechamber may have been } \\
\text { contaminated by ancient sea } \\
\text { mammal oil. A single tree ring date } \\
\text { of AD } 1203 \text { was obtained from } \\
\text { analysis of structural wood from the } \\
\text { house timbers. This wood had a } \\
\text { growth span of } 163 \text { years between } \\
\text { AD } 1040-1203 \text { and was probably } \\
\text { obtained as driftwood. [Located } \\
\text { within Deering Archaeological } \\
\text { District, KTZ-169]. }\end{array}$ \\
\hline $\begin{array}{l}\text { KTZ- } \\
00301\end{array}$ & $\begin{array}{l}\text { Deering Western } \\
\text { Thule House } 2\end{array}$ & $\begin{array}{l}\text { Single } \\
\text { House }\end{array}$ & 1 & $\begin{array}{l}\text { Before } \\
500 \mathrm{BP}\end{array}$ & $\begin{array}{l}\text { Occupation } \\
\text { Dates }\end{array}$ & Beta-189091 790 \pm 40 & $\begin{array}{l}\text { Site consists of a main room } \\
\text { measuring } 3.7 \mathrm{~m} \times 3.2 \mathrm{~m} \text {. The length } \\
\text { of the entrance tunnel and } \\
\text { presence/absence of a side room are } \\
\text { unknown due to limits of test } \\
\text { excavations. An age estimate of } \mathrm{AD} \\
1260 \text { is assumed for the site. } \\
\text { [Located within the Deering } \\
\text { Archaeological District, KTZ-169]. }\end{array}$ \\
\hline
\end{tabular}




\begin{tabular}{|c|c|c|c|c|c|c|}
\hline $\begin{array}{l}\text { KTZ- } \\
00382\end{array}$ & & $\begin{array}{l}\text { Single } \\
\text { House }\end{array}$ & 1 & Unknown & N/A & $\begin{array}{l}\text { One multi-room house pit and one } \\
\text { cache pit. }\end{array}$ \\
\hline $\begin{array}{l}\text { KTZ- } \\
00383\end{array}$ & & $\begin{array}{l}\text { Large } \\
\text { Village }\end{array}$ & 8 & Unknown & N/A & At least eight house pits. \\
\hline $\begin{array}{l}\text { KTZ- } \\
00384\end{array}$ & & $\begin{array}{l}\text { Single } \\
\text { House }\end{array}$ & 1 & Unknown & N/A & $\begin{array}{l}\text { A cemented sediment feature and } \\
\text { possible hearth feature. }\end{array}$ \\
\hline $\begin{array}{l}\text { KTZ- } \\
00386\end{array}$ & $\begin{array}{l}\text { GCI Trench Site } \\
\# 1\end{array}$ & $\begin{array}{l}\text { Single } \\
\text { House }\end{array}$ & 1 & Unknown & N/A & $\begin{array}{l}\text { This site contains a pre-contact } \\
\text { buried semi-subterranean house } \\
\text { semi-subterranean house and } \\
\text { feature, either a cache pit or midden. } \\
\text { The site was identified by THRC } \\
\text { when a GCI trench cut through the } \\
\text { site in } 2013 \text { and disturbed the } \\
\text { deposits. The same trench also } \\
\text { disturbed site KTZ-347. THRC } \\
\text { conducted data recovery by } \\
\text { collecting artifacts and faunal } \\
\text { remains that were disturbed by } \\
\text { trenching from both sites. A count } \\
\text { of } 2329 \text { artifacts and unmodified } \\
\text { faunal remains are reported from the } \\
\text { two sites combined. GCI trench was } \\
\text { approximately } 1 \text { meter deep. The } \\
\text { cultural deposits were likely from } \\
\text { between } 75 \text { and } 100 \text { centimeters } \\
\text { below surface, consistent with what } \\
\text { was found in testing in KTZ-347, a } \\
\text { nearby site also consisting of a } \\
\text { prehistoric semi-subterranean house } \\
\text { semi-subterranean house. }\end{array}$ \\
\hline
\end{tabular}




\begin{tabular}{|c|c|c|c|c|c|c|c|}
\hline $\begin{array}{l}\text { MIS- } \\
00032\end{array}$ & Lake Kaiyak & $\begin{array}{l}\text { Large } \\
\text { Village }\end{array}$ & 8 & $\begin{array}{l}\text { After } 500 \\
\text { BP }\end{array}$ & $\begin{array}{l}\text { Occupation } \\
\text { Dates }\end{array}$ & 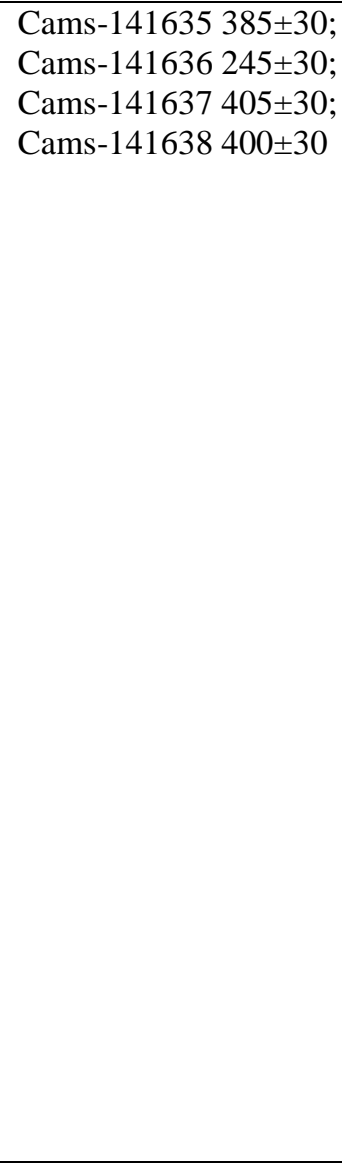 & $\begin{array}{l}\text { Hall reported locating eight } \\
\text { rectangular semi-subterranean house } \\
\text { pits, with medium length entrance } \\
\text { passages, on the lakeshore. No } \\
\text { karigi was noted. A small test in one } \\
\text { of the house pits produced } 33 \text { flint } \\
\text { flakes and a fragment of a large } \\
\text { leaf-shaped biface. A second test, in } \\
\text { another house pit, produced six } \\
\text { spalls and three biface fragments. } \\
\text { The condition of caribou bone } \\
\text { found in the test pits indicated that } \\
\text { the features are relatively older than } \\
\text { others found during the survey, } \\
\text { perhaps circa AD } 1500-1600 . \\
\text { Following the } 1995 \text { discovery of } \\
\text { vandalism at the site, in } 1996 \\
\text { excavations were conducted in the } \\
\text { two of the house features damaged. } \\
\text { Dating to circa AD } 1750 \text { is } \\
\text { anticipated. [Additional } \\
\text { sites/features were identified on the } \\
\text { nearby lake shore: } 13 \text { cache pits } \\
\text { located on the knoll } 425 \mathrm{~m} \text { to the } \\
\text { SSW; an apparent house pit with } \\
\text { tunnel and three cache pits located } \\
\text { on a knoll } 570 \mathrm{~m} \text { to the SSW; and a } \\
\text { cache of old Blazo cans on the shore } \\
575 \mathrm{~m} \text { to the southwest.] }\end{array}$ \\
\hline $\begin{array}{l}\text { MIS- } \\
00070\end{array}$ & & Village & Unknown & Unknown & N/A & & $\begin{array}{l}\text { Foote reported late prehistoric or } \\
\text { historic Eskimo winter houses. }\end{array}$ \\
\hline $\begin{array}{l}\text { MIS- } \\
00071\end{array}$ & Ninguqtutsiaq & Village & Unknown & Unknown & N/A & & $\begin{array}{l}\text { Burch (p.c. to Hall) noted this as a } \\
\text { fall concentration zone for families } \\
\text { from the Upper Noatak regional }\end{array}$ \\
\hline
\end{tabular}




\begin{tabular}{|c|c|c|c|c|c|c|}
\hline & & & & & & group. \\
\hline $\begin{array}{l}\text { MIS- } \\
00079\end{array}$ & Katyaak & Village & Unknown & Unknown & N/A & $\begin{array}{l}\text { Burch (p.c. to Hall) noted this as a } \\
\text { fall concentration zone for families } \\
\text { from the Upper Noatak regional } \\
\text { group. }\end{array}$ \\
\hline $\begin{array}{l}\text { MIS- } \\
00352\end{array}$ & & $\begin{array}{l}\text { Large } \\
\text { Village }\end{array}$ & 21 & Unknown & N/A & $\begin{array}{l}\text { Site found in approximately } 1951 \\
\text { by a geological survey group. } \\
\text { According to Mr. Mangus, the site } \\
\text { is located on a flat spot above the } \\
\text { lake on a moraine feature. The site } \\
\text { appears to represent a long } \\
\text { occupation as the artifacts ranged } \\
\text { from clear obsidian microburins and } \\
\text { microblades to decomposing } \\
\text { snowshoes that were half buried in } \\
\text { the soil. Also present at the site } 21 \\
\text { rectangular semi-subterranean } \\
\text { houses, midden deposits, and a } \\
\text { karigi/"council circle" consisting of } \\
13 \text { sets of seats. Near one seat was a } \\
\text { quartzite boulder decorated with a } \\
\text { starburst design. A number of other } \\
\text { quartzite boulders (ranging from } \\
18 \text { in. to } 24 \text { in. in diameter) are } \\
\text { present. These boulders are not } \\
\text { indigenous and must have been } \\
\text { transported into the area. Hall noted } \\
\text { that the karigi was U-shaped and } \\
\text { that the open end faced the lake. } \\
\text { Two small tests by Hall produced } \\
27 \text { flakes, } 6 \text { cut antler pieces, the } \\
\text { base of a hand drill, and } 1 \text { thick } \\
\text { potsherd.[Originally described as }\end{array}$ \\
\hline
\end{tabular}




\begin{tabular}{|c|c|c|c|c|c|c|}
\hline & & & & & & $\begin{array}{l}\text { part of MIS-077, on west side of } \\
\text { lake.] }\end{array}$ \\
\hline $\begin{array}{l}\text { MIS- } \\
00697\end{array}$ & & $\begin{array}{l}\text { Small } \\
\text { Village }\end{array}$ & 5 & Unknown & N/A & $\begin{array}{l}\text { Site consists of } 5 \text { semi-subterranean } \\
\text { houses and cache pits. }\end{array}$ \\
\hline $\begin{array}{l}\text { MIS- } \\
00698\end{array}$ & & Village & Unknown & Unknown & N/A & $\begin{array}{l}\text { Several house pits located on a knoll } \\
\text { directly south of MIS- } 00352 \text {. }\end{array}$ \\
\hline $\begin{array}{l}\text { NOA- } \\
00003\end{array}$ & Aniyak & $\begin{array}{l}\text { Large } \\
\text { Village }\end{array}$ & 7 & $\begin{array}{l}\text { After } 500 \\
\text { BP }\end{array}$ & $\begin{array}{l}\text { Cultural } \\
\text { Association }\end{array}$ & $\begin{array}{l}\text { Former Eskimo village recorded } \\
\text { with a population of } 25 \text { in the } 1880 \\
\text { Census and visited by Lt. D.H. } \\
\text { Jarvis, USRCS, in } 1898 \text {. Anderson } \\
\text { noted remains of winter house pits, } \\
\text { fish camps, fish racks, and cache } \\
\text { pits on the beach ridge spit at the } \\
\text { mouth of Tukrok River, with the } \\
\text { oldest apparently being located near } \\
\text { the base of the spit. NPS } \\
\text { investigators noted a total of } 197 \\
\text { features, including house pits, cache } \\
\text { pits, and other features, in the } \\
\text { vicinity of the current ranger station } \\
\text { and Shelter Cabin. The shelter cabin } \\
\text { is a mail run cabin built by the }\end{array}$ \\
\hline
\end{tabular}




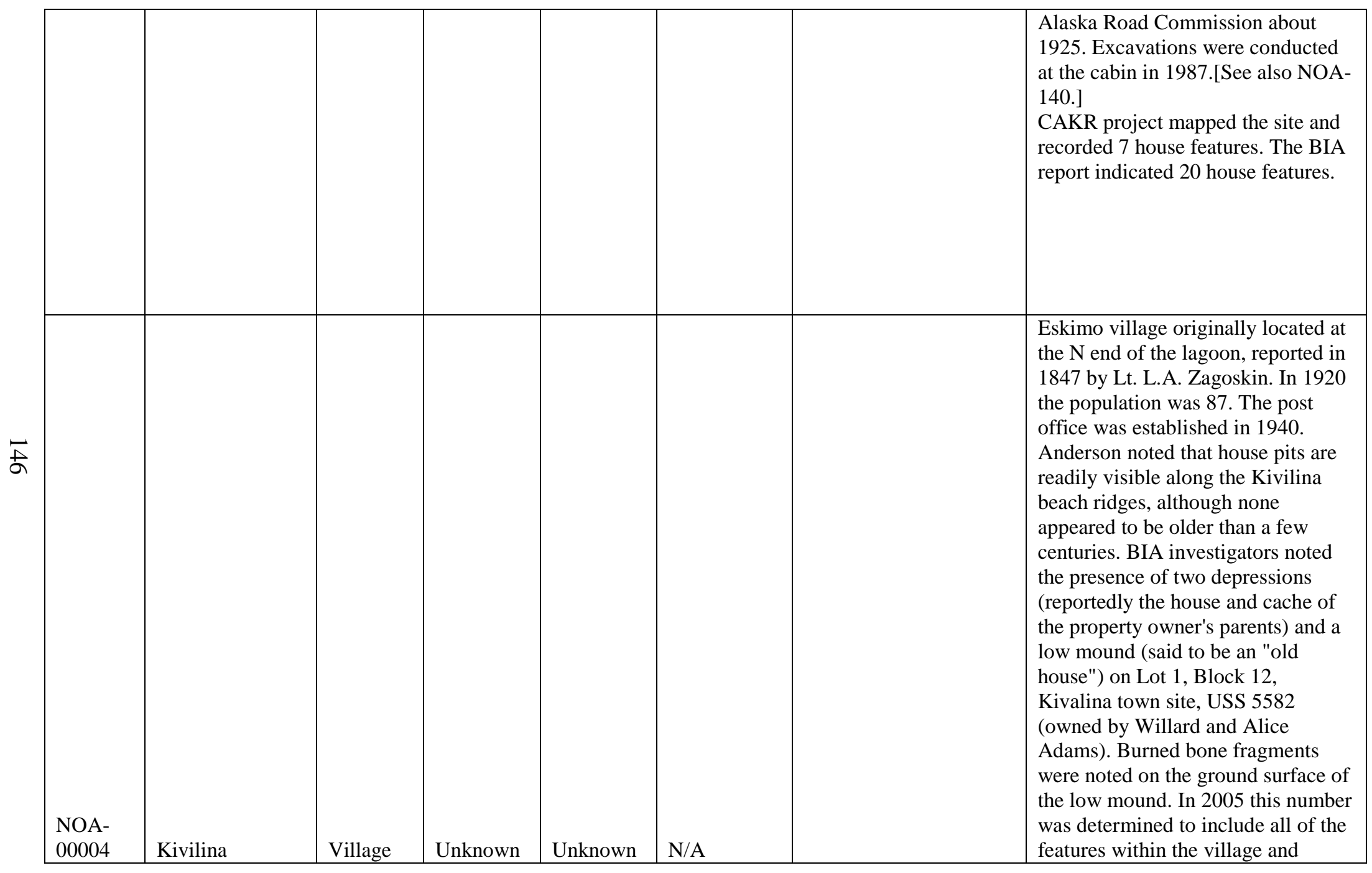




\begin{tabular}{|c|c|c|c|c|c|c|}
\hline & & & & & & $\begin{array}{l}\text { extending } \mathrm{N} \text { along the spit to at least } \\
\text { the } \mathrm{S} \text { end of the runway. Specific } \\
\text { areas/features within the village } \\
\text { have been given individual AHRS } \\
\text { numbers, including NOA-311 } \\
\text { through NOA-328. }\end{array}$ \\
\hline $\begin{array}{l}\text { NOA- } \\
00005\end{array}$ & Cape Sepping & Village & Unknown & Unknown & N/A & $\begin{array}{l}\text { Eskimo village or camp, now } \\
\text { abandoned, mentioned by P. } \\
\text { Tikhmeniev on his } 1861 \text { map as } \\
\text { "Kivalinag-miut." This may refer to } \\
\text { the present village of Kivalina } \\
\text { (NOA-004). On U.S. Navy } \\
\text { Hydrographic Office Chart } 68 \text {, } \\
\text { shown as "Kechemudluk." }\end{array}$ \\
\hline $\begin{array}{l}\text { NOA- } \\
00008\end{array}$ & & $\begin{array}{l}\text { Small } \\
\text { Village }\end{array}$ & 4 & $\begin{array}{l}\text { Before } \\
500 \mathrm{BP}\end{array}$ & $\begin{array}{l}\text { Cultural } \\
\text { Association }\end{array}$ & $\begin{array}{l}\text { Giddings noted four deep semi- } \\
\text { subterranean rectangular house pits } \\
\text { with long entrance passages here, } \\
\text { and excavated the one that had not } \\
\text { been rather extensively potted. } \\
\text { Excavation of the structure, which } \\
\text { had burned, produced evidence of a } \\
\text { Western Thule culture occupation } \\
\text { within the last } 1000 \text { years.[See also } \\
\text { KTZ-005 and NOA-007.] }\end{array}$ \\
\hline $\begin{array}{l}\text { NOA- } \\
00009\end{array}$ & Kitqlikquriaq & Village & Unknown & Unknown & N/A & $\begin{array}{l}\text { This willow and tundra covered } \\
\text { deltaic island was noted by E.S. } \\
\text { Burch, Jr. (p.c. to Hall) as a fall }\end{array}$ \\
\hline
\end{tabular}




\begin{tabular}{|c|c|c|c|c|c|c|}
\hline & & & & & & $\begin{array}{l}\text { concentration zone for families from } \\
\text { the Kotzebue regional group. } \\
\text { Probably the same as Hall's N } 13 \\
\text { site. }\end{array}$ \\
\hline $\begin{array}{l}\text { NOA- } \\
00010\end{array}$ & Qipisungnik & Village & Unknown & Unknown & N/A & $\begin{array}{l}\text { Giddings originally noted several } \\
\text { houses at this apparent location. } \\
\text { Hall noted a considerable number of } \\
\text { houses, at the willow-covered base } \\
\text { of the bluff in } 1965 \text {, and others } \\
\text { reported by Eskimos in } 1972 \text {. E.S. } \\
\text { Burch, Jr. (p.c. to Hall) the willow } \\
\text { covered point as a fall congretation } \\
\text { zone for families from the Kottzebue } \\
\text { regional group.[Previously this } \\
\text { location was given three AHRS } \\
\text { numbers; NOA-011 and NOA-012 } \\
\text { have since been subsumed.] }\end{array}$ \\
\hline $\begin{array}{l}\text { NOA- } \\
00015\end{array}$ & Kimmik & $\begin{array}{l}\text { Small } \\
\text { Village }\end{array}$ & 2 & Unknown & N/A & $\begin{array}{l}\text { Giddings located two houses and } \\
\text { tested at this apparent site of a } \\
\text { reindeer corral. E.S. Burch, Jr. (p.c. } \\
\text { to Hall) noted this as a fall } \\
\text { congregation zone for families from } \\
\text { the Kotzebue regional } \\
\text { group.[Subsumes NOA-016.] }\end{array}$ \\
\hline $\begin{array}{l}\text { NOA- } \\
00017\end{array}$ & Saniniq & Village & Unknown & Unknown & N/A & $\begin{array}{l}\text { E.S. Burch, Jr. (p.c. to Hall) noted } \\
\text { this as a fall concentration zone for } \\
\text { families from the Kotzebue regional } \\
\text { group. }\end{array}$ \\
\hline $\begin{array}{l}\text { NOA- } \\
00020\end{array}$ & & Village & Unknown & Unknown & N/A & $\begin{array}{l}\text { Giddings noted this as the site of an } \\
\text { old village reported by a Native on } \\
\text { hearsay. }\end{array}$ \\
\hline
\end{tabular}




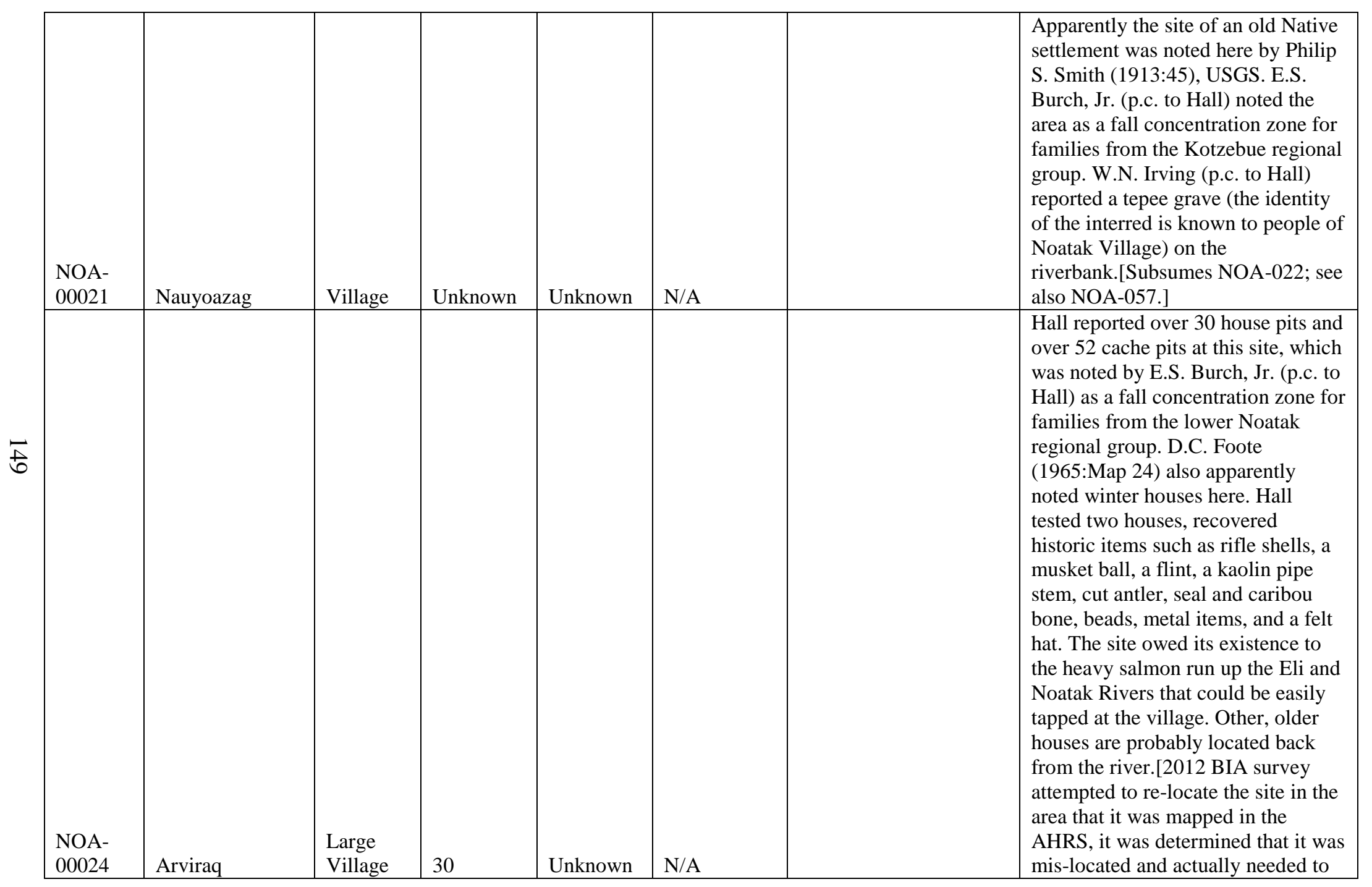




\begin{tabular}{|c|c|c|c|c|c|c|}
\hline & & & & & & $\begin{array}{l}\text { be approx } 2 \mathrm{mi} \text {. S of where it was, } \\
\text { although the site was not visited this } \\
\text { will be corrected] }\end{array}$ \\
\hline $\begin{array}{l}\text { NOA- } \\
00026\end{array}$ & Maraqtuq & $\begin{array}{l}\text { Large } \\
\text { Village }\end{array}$ & 7 & Unknown & N/A & $\begin{array}{l}\text { E.S. Burch, Jr. (p.c. to Hall) noted } \\
\text { this as a fall centration zone for } \\
\text { families from the lower Noatak } \\
\text { regional group. During survey in } \\
1974 \text { Hall noted a total of seven } \\
\text { major house features (including } \\
\text { collapsed log cabins and } \\
\text { depressions marking older houses), } \\
\text { cache pits, and historic debris. } \\
\text { Reportedly three of the cabins were } \\
\text { occupied in 1949, the others date } \\
\text { from earlier, perhaps around } \\
\text { 1900.[Subsumes NOA-043.] }\end{array}$ \\
\hline $\begin{array}{l}\text { NOA- } \\
00027\end{array}$ & Uninyuaq & Village & Unknown & Unknown & N/A & $\begin{array}{l}\text { E.S. Burch, Jr. (p.c. to Hall) noted } \\
\text { this as a fall concentration zone for } \\
\text { families from the lower Noatak } \\
\text { regional group. }\end{array}$ \\
\hline
\end{tabular}




\begin{tabular}{|c|c|c|c|c|c|c|}
\hline $\begin{array}{l}\text { NOA- } \\
00028 \\
\end{array}$ & Napaktusugruk & Village & Unknown & Unknown & N/A & $\begin{array}{l}\text { D.C. Foote (1965:Map 24) } \\
\text { apparently noted winter houses here } \\
\text { and E.S. Burch, Jr (p.c. to Hall) } \\
\text { noted it as a fall concentration zone } \\
\text { for families from the lower Noatak } \\
\text { regional group. During survey in } \\
\text { 1974, Hall noted a collapsed } 4 \mathrm{~m} x \\
4 \mathrm{~m} \text { historic cabin with axe cut logs } \\
\text { and a } 2 \mathrm{~m} \text { long entrance passage, } \\
\text { two } 1 \mathrm{~m} \times 1 \mathrm{~m} \text { cache pits, and } \\
\text { historic debris.[Subsumes NOA- } \\
046 .]\end{array}$ \\
\hline $\begin{array}{l}\text { NOA- } \\
00029\end{array}$ & Inilaq & Village & Unknown & Unknown & N/A & $\begin{array}{l}\text { E.S. Burch Jr. (p.c. to Hall) noted } \\
\text { this as a fall concentration zone for } \\
\text { families from the lower Noatak } \\
\text { regional group. }\end{array}$ \\
\hline $\begin{array}{l}\text { NOA- } \\
00030\end{array}$ & Kiiziq & Village & Unknown & Unknown & N/A & $\begin{array}{l}\text { E.S. Burch Jr. (p.c. to Hall) noted } \\
\text { this as a fall concentration zone for } \\
\text { families from the lower Noatak } \\
\text { regional group. }\end{array}$ \\
\hline $\begin{array}{l}\text { NOA- } \\
00031\end{array}$ & Kakiaq & Village & Unknown & Unknown & N/A & $\begin{array}{l}\text { E.S. Burch Jr. (p.c. to Hall) noted } \\
\text { this as a fall concentration zone for } \\
\text { families from the lower Noatak } \\
\text { regional group. D.C. Foote } \\
\text { (1965:Map 24) noted winter houses } \\
\text { in this vicinity. In } 1964 \text { Hall located } \\
\text { a house floor composed of spruce } \\
\text { logs and recovered } 44 \text { caliber } \\
\text { shells.[In } 1974 \text { Hall was unable to } \\
\text { relocate this site; see also NOA- } \\
044 .]\end{array}$ \\
\hline $\begin{array}{l}\text { NOA- } \\
00033\end{array}$ & Qamaniq & Village & Unknown & Unknown & N/A & $\begin{array}{l}\text { D.C. Foote (1965:Map } 23 \text { and p.c to } \\
\text { Hall) apparently noted the houses of } \\
\text { a winter village at this location. BIA }\end{array}$ \\
\hline
\end{tabular}




\begin{tabular}{|c|c|c|c|c|c|c|}
\hline & & & & & & $\begin{array}{l}\text { ANCSA investigators recorded } 15 \\
\text { features and } 6 \text { upright posts in a } \\
\text { clearing. The features include: the } \\
\text { remains of } 3 \text { log cabins, } 5 \text { small, } \\
\text { circular or square depressions } \\
\text { (possible storage pits), } 4 \text { small, } \\
\text { shallow, rectangular depressions } \\
\text { (possible storage pits, sod barrow } \\
\text { pits, etc.), and } 3 \text { piles of boards, } \\
\text { logs, and posts. Each house had one } \\
\text { of these woodpiles nearby. The } 6 \\
\text { upright posts extended from } 80 \mathrm{~cm} \\
\text { to } 95 \mathrm{~cm} \text { above the ground and were } \\
\text { cut with an axe. All had thinning in } \\
\text { the middle ("hourglass" shape) } \\
\text { which may indicate that these were } \\
\text { dogs stake outs. [Hall mentions } \\
\text { Kasmanik in a } 1966 \text { report, which } \\
\text { may be the same site]. }\end{array}$ \\
\hline $\begin{array}{l}\text { NOA- } \\
00035\end{array}$ & $\begin{array}{l}\text { Akaekkingyorru } \\
\mathrm{k}\end{array}$ & Village & Unknown & Unknown & N/A & $\begin{array}{l}\text { D.C. Foote (1965:Map } 25 \text { and p.c. } \\
\text { to Hall) apparently noted houses of } \\
\text { a winter village at this location. }\end{array}$ \\
\hline $\begin{array}{l}\text { NOA- } \\
00036 \\
\end{array}$ & Imarvik & Village & Unknown & Unknown & N/A & $\begin{array}{l}\text { E.S. Burch Jr. (p.c. to Hall) noted } \\
\text { this as a fall concentration zone for } \\
\text { families from the lower Noatak } \\
\text { regional group, however, as this } \\
\text { location is considerably upriver } \\
\text { from the other lower Noatak fall } \\
\text { activity zones, there is some } \\
\text { question as to its authenticity. }\end{array}$ \\
\hline $\begin{array}{l}\text { NOA- } \\
00037\end{array}$ & $\begin{array}{l}\text { Dr. Rabeau's } \\
\text { Cabin }\end{array}$ & Village & Unknown & Unknown & N/A & $\begin{array}{l}\text { Hall located and tested three } \\
\text { rectangular cache pits and a number } \\
\text { of possible houses on the tip of a } \\
\text { low spurr immediately behind Dr. } \\
\text { Rabeau's cabin. He also noted an }\end{array}$ \\
\hline
\end{tabular}




\begin{tabular}{|c|c|c|c|c|c|c|}
\hline & & & & & & $\begin{array}{l}\text { above ground burial box on the } \\
\text { spurr, } 300 \text { ' behind the cabin. }\end{array}$ \\
\hline $\begin{array}{l}\text { NOA- } \\
00038\end{array}$ & & $\begin{array}{l}\text { Large } \\
\text { Village }\end{array}$ & 20 & Unknown & N/A & $\begin{array}{l}\text { Hall noted a total of } 20 \text { semi- } \\
\text { subterranean houses and over } 52 \\
\text { circular cache pits scattered along } 2 \\
\text { miles of a beach ridge } 10 \text { ' above and } \\
20-100^{\prime} \text { north of the present water } \\
\text { line. Twelve houses and a number } \\
\text { of cache pits were in one cluster. } \\
\text { Hall performed a number of small } \\
\text { tests and recovered glass, chert, cut } \\
\text { antler, and ground slate. One house } \\
\text { pit was cruciform in outline. }\end{array}$ \\
\hline $\begin{array}{l}\text { NOA- } \\
00048\end{array}$ & Tununaaq & $\begin{array}{l}\text { Single } \\
\text { House }\end{array}$ & 1 & Unknown & N/A & $\begin{array}{l}\text { Hall noted a } 4 \mathrm{~m} \times 4 \mathrm{~m} \text { ground level } \\
\text { log cabin, a probable house with } \\
\text { five cache pits(?), a slight } 7 \mathrm{~m} \mathrm{x} \\
3.5 \mathrm{~m} \text { rectangular depression (with } \\
\text { apparent logs under the surface } \\
\text { running parallel to its long axis), } \\
\text { and a total of six more probably old } \\
\text { house depressions. E.S. Burch Jr. } \\
\text { (p.c. to Hall) noted this vicinity as a } \\
\text { fall concentration zone for families } \\
\text { from the lower Noatak regional } \\
\text { group.[See also NOA-047; } \\
\text { subsumes NOA-025.] }\end{array}$ \\
\hline $\begin{array}{l}\text { NOA- } \\
00055\end{array}$ & & $\begin{array}{l}\text { Small } \\
\text { Village }\end{array}$ & 2 & Unknown & N/A & $\begin{array}{l}\text { Hall noted two possible rectangular } \\
\text { house depressions, measuring } 4 \mathrm{~m} \times \\
3 \mathrm{~m} \text { and } 3 \mathrm{~m} \times 2 \mathrm{~m} \text { in size. }\end{array}$ \\
\hline $\begin{array}{l}\text { NOA- } \\
00062\end{array}$ & & $\begin{array}{l}\text { Single } \\
\text { House }\end{array}$ & 1 & Unknown & N/A & $\begin{array}{l}\text { This site consists of a } 4 \mathrm{~m} \times 3 \mathrm{~m} \\
\text { house pit with a short entrance } \\
\text { tunnel located at the southeast } \\
\text { corner of the depression. A wide }\end{array}$ \\
\hline
\end{tabular}




\begin{tabular}{|c|c|c|c|c|c|}
\hline & & & & & $\begin{array}{l}\text { berm surrounds the house pit, which } \\
\text { is about } 1.2 \mathrm{~m} \text { deep.[This site may } \\
\text { be a duplicate of NOA-165.] }\end{array}$ \\
\hline $\begin{array}{l}\text { NOA- } \\
00099 \\
\end{array}$ & Village & Unknown & Unknown & N/A & $\begin{array}{l}\text { This site consists of a large house } \\
\text { feature, a somewhat smaller house, } \\
\text { a number of cache pits, and two } \\
\text { possible graves. The larger house } \\
\text { feature measures } 7 \mathrm{~m} \times 5 \mathrm{~m} \text {, is a } \\
\text { typical winged semi-subterranean } \\
\text { structure with benches on either side } \\
\text { of a central hearth depression and a } \\
3 \mathrm{~m} \text { long entrance passage } \\
\text { terminating in an antechamber. The } \\
\text { second house feature measures } 4 \mathrm{~m} x \\
4 \mathrm{~m} \text { and is similarly constructed. }\end{array}$ \\
\hline $\begin{array}{l}\text { NOA- } \\
00100 \\
\end{array}$ & $\begin{array}{l}\text { Large } \\
\text { Village }\end{array}$ & 6 & Unknown & N/A & $\begin{array}{l}\text { A low bipartite mound contains } \\
\text { evidence of at least six sod houses, } \\
\text { with substantial sod walls still } \\
\text { standing to a height of } 1 \mathrm{~m} \text { and some } \\
\text { visible wall supports. The site is } \\
\text { probably of late prehistoric or early } \\
\text { historic age. }\end{array}$ \\
\hline $\begin{array}{l}\text { NOA- } \\
00104\end{array}$ & Village & Unknown & Unknown & N/A & $\begin{array}{l}\text { Several suspicious depressions, } \\
\text { including a possible semi- } \\
\text { subterranean house measuring } 4.5 \mathrm{~m} \\
\text { x } 3 \mathrm{~m} \text { with a } 3 \mathrm{~m} \text { long entrance } \\
\text { passage, were noted } 40 \mathrm{~m} \text { north of } \\
\text { an old river channel and } 400 \mathrm{~m} \text { north } \\
\text { and } 3 \mathrm{~m} \text { above the present river } \\
\text { channel. A test revealed only river } \\
\text { silt to frost at a depth of } 40 \mathrm{~cm} \text {. }\end{array}$ \\
\hline
\end{tabular}




\begin{tabular}{|c|c|c|c|c|c|c|}
\hline $\begin{array}{l}\text { NOA- } \\
00140\end{array}$ & Anigaaq & $\begin{array}{l}\text { Large } \\
\text { Village }\end{array}$ & 7 & $\begin{array}{l}\text { After } 500 \\
\text { BP }\end{array}$ & $\begin{array}{l}\text { Occupation } \\
\text { Dates }\end{array}$ & $\begin{array}{l}\text { USNPS investigators noted five } \\
\text { house pits and four grave sites (at } \\
\text { least five burials) distributed along } \\
1 \mathrm{~km} \text { of the bluff edge. The single } \\
\text { room house pits measure from } 4.4 \mathrm{~m} \\
\times 6 \mathrm{~m} \text { to } 6 \mathrm{~m} \times 7 \mathrm{~m} \text { in size, with entry } \\
\text { ways up to } 3 \mathrm{~m} \text { long. Wood coffins, } \\
\text { human bone, and a steamer rtrunk } \\
\text { were noted in the graves. The } \\
\text { village site was reportedly occupied } \\
\text { through } 1925 \text {.[See also NOA-003.] }\end{array}$ \\
\hline $\begin{array}{l}\text { NOA- } \\
00158\end{array}$ & & $\begin{array}{l}\text { Single } \\
\text { House }\end{array}$ & 1 & $\begin{array}{l}\text { Before } \\
500 \mathrm{BP}\end{array}$ & $\begin{array}{l}\text { Cultural } \\
\text { Association }\end{array}$ & $\begin{array}{l}\text { A possible house pit and two cache } \\
\text { pits were noted on the fourth beach } \\
\text { ridge back from the north shore of } \\
\text { Kotlik Lagoon, by USNPS } \\
\text { investigators in } 1987 \text {. The house } \\
\text { feature consists of an irregular } \\
\text { depression measuring about } 7.5 \mathrm{~m} \times \\
6.3 \mathrm{~m} \times .4 \mathrm{~m} \text { deep. Two large whale } \\
\text { vertebrae were noted in the } \\
\text { depression, which has been } \\
\text { disturbed by burrowing. About } 6 \mathrm{~m} \\
\text { east of the house feature, a } 30.5 \mathrm{~cm} \times \\
24 \mathrm{~cm} \text { wooden bowl was noted. Both } \\
\text { of the cache pits measure } \\
\text { approximately } 1.6 \mathrm{~m} \text { x } 1.4 \mathrm{~m} \times .7 \mathrm{~m} \\
\text { deep. USNPS investigators briefly } \\
\text { revisited the site in } 1995 \text { and } \\
\text { collected the wooden bowl (which } \\
\text { had moved about } 30 \mathrm{~m} \text { east of its } \\
\text { earlier location). }\end{array}$ \\
\hline
\end{tabular}




\begin{tabular}{|c|c|c|c|c|c|}
\hline $\begin{array}{l}\text { NOA- } \\
00161\end{array}$ & $\begin{array}{l}\text { Small } \\
\text { Village }\end{array}$ & 3 & $\begin{array}{l}\text { After } 500 \\
\text { BP }\end{array}$ & $\begin{array}{l}\text { Cultural } \\
\text { Association }\end{array}$ & $\begin{array}{l}\text { In } 1987 \text {, USNPS investigators } \\
\text { reported two well-defined house } \\
\text { pits, one possible house pit } \\
\text { (seriously disturbed by ground } \\
\text { squirrel burrowing), and two } \\
\text { probable cache pits on the third and } \\
\text { fourth beach ridges back from the } \\
\text { northern shore of Kotlik Lagoon. } \\
\text { The cache pits measure } 1.9 \mathrm{~m} \times 1.7 \mathrm{~m} \\
\text { x.24m deep and } 1.2 \mathrm{~m} \text { in diameter } \times \\
.25 \mathrm{~m} \text { deep. Feature } 3 \text {, a sub- } \\
\text { rectangular house pit, measures } \\
3.6 \mathrm{~m} \times 2.7 \mathrm{~m} \times .32 \mathrm{~m} \text { deep, with a } \\
1.8 \mathrm{~m} \times 1.4 \mathrm{~m} \text { entryway. Feature } 4 \text {, } \\
\text { another sub-rectangular house pit, } \\
\text { measures } 4.83 \mathrm{~m} \times 4 \mathrm{~m} \times .3 \mathrm{~m} \text { deep, } \\
\text { with a } 6.1 \mathrm{~m} \times 1.22 \mathrm{~m} \text { entryway. } \\
\text { USNPS investigators briefly } \\
\text { revisited the site in } 1995 \text {. }\end{array}$ \\
\hline $\begin{array}{l}\text { NOA- } \\
00162\end{array}$ & $\begin{array}{l}\text { Single } \\
\text { House }\end{array}$ & 1 & $\begin{array}{l}\text { After } 500 \\
\text { BP }\end{array}$ & $\begin{array}{l}\text { Cultural } \\
\text { Association }\end{array}$ & $\begin{array}{l}\text { As reported by USNPS investigators } \\
\text { in } 1987 \text {, this site consists of a single } \\
\text { house pit, situated on the first beach } \\
\text { ridge, approximately } 20 \mathrm{~m} \text { from the } \\
\text { shore of Kotlik Lagoon. The feature } \\
\text { measures } 7.7 \mathrm{~m} \times 4.5 \mathrm{~m} \times .46 \mathrm{~m} \text { deep, } \\
\text { with a } 2.7 \mathrm{~m} \times 2 \mathrm{~m} \text { entryway facing } \\
\text { the lagoon. In } 1995 \text {, USNPS } \\
\text { investigators excavated a } 50 \mathrm{~cm} \times \\
50 \mathrm{~cm} \text { test inside the house feature. } \\
\text { Although the stratigraphy indicated } \\
\text { the presence of roof fall and floor } \\
\text { material, no artifacts were } \\
\text { recovered. }\end{array}$ \\
\hline
\end{tabular}




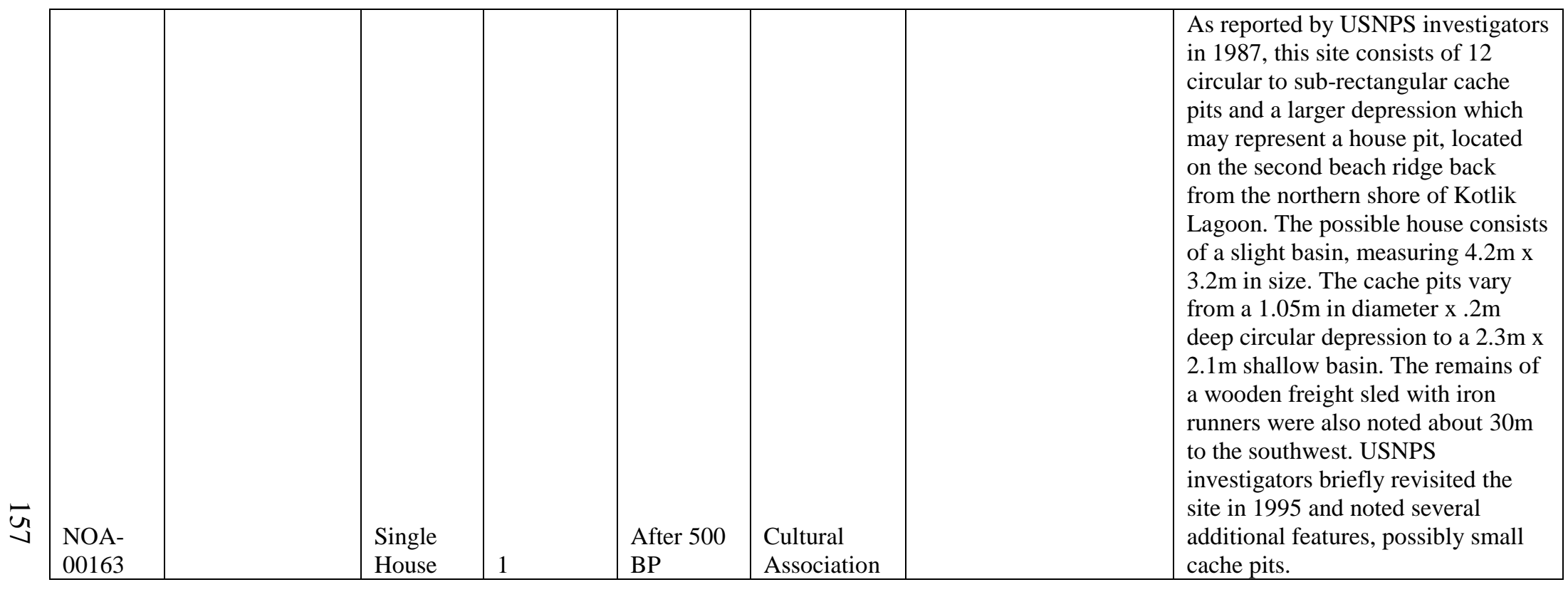




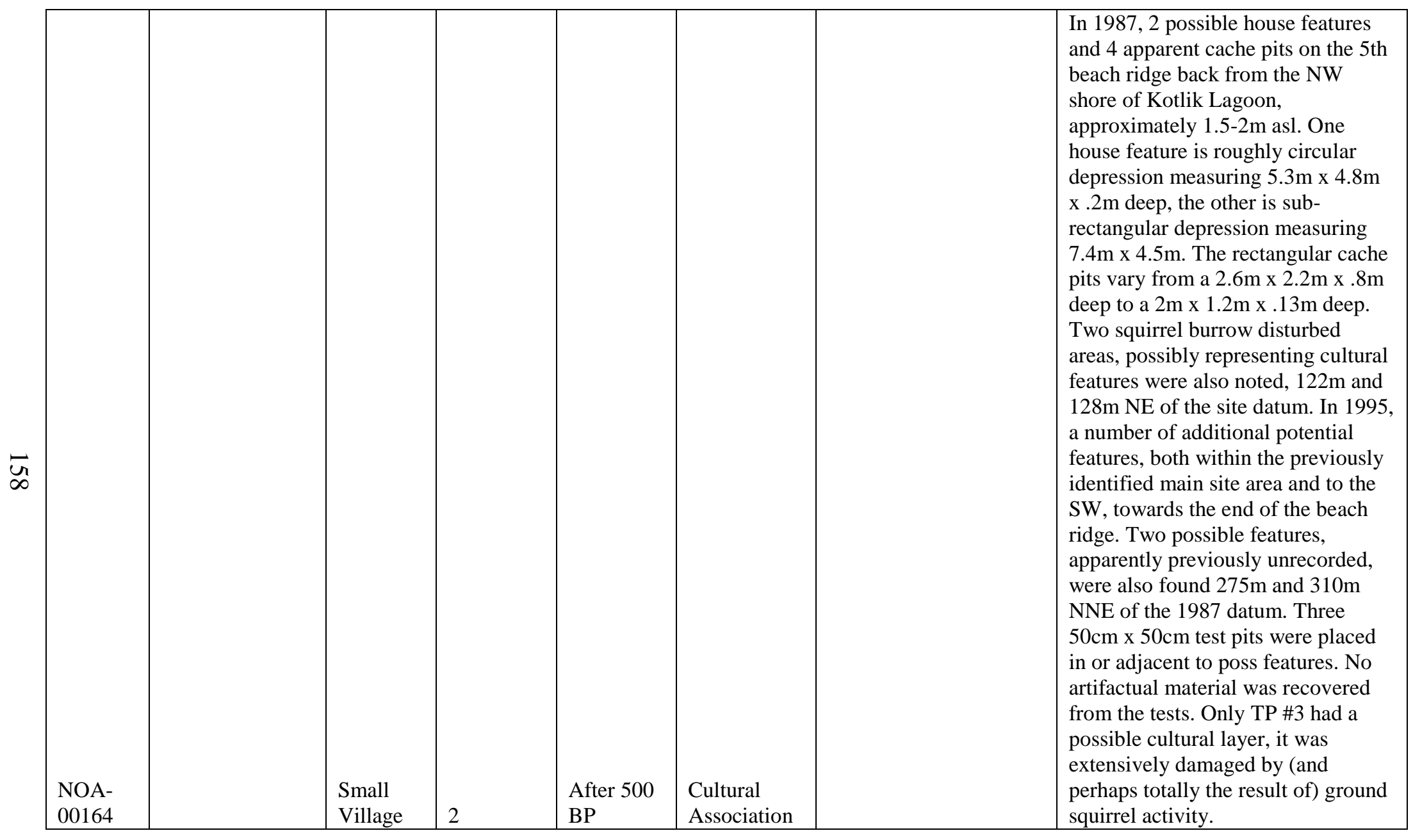




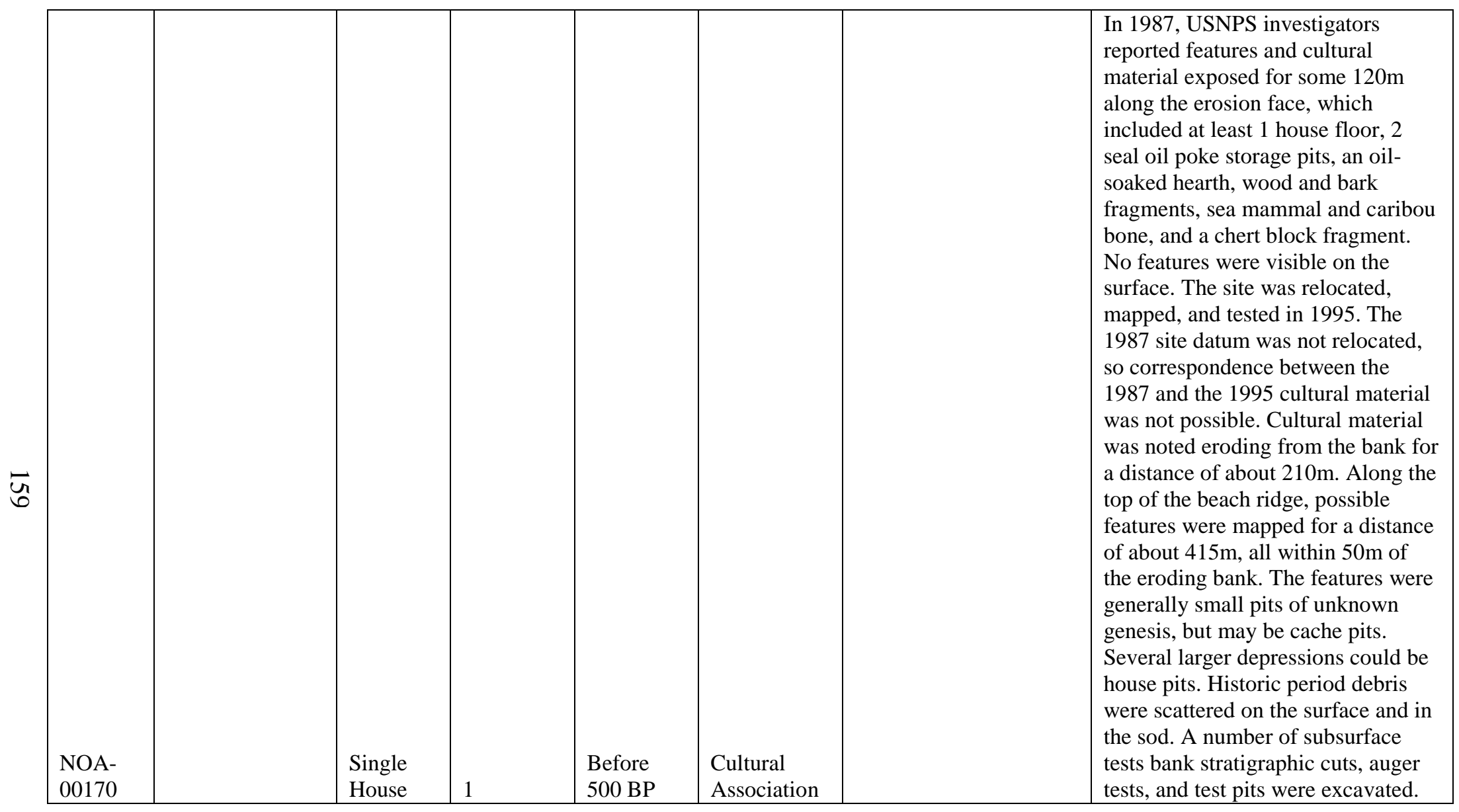




\begin{tabular}{|c|c|c|c|c|c|c|}
\hline $\begin{array}{l}\text { NOA- } \\
00188\end{array}$ & & $\begin{array}{l}\text { Single } \\
\text { House }\end{array}$ & 1 & $\begin{array}{l}\text { After } 500 \\
\text { BP }\end{array}$ & $\begin{array}{l}\text { Cultural } \\
\text { Association }\end{array}$ & $\begin{array}{l}\text { One house pit, five cache pits, a tent } \\
\text { ring, and two unidentified stone } \\
\text { features were located in a small } \\
\text { clearing. Oval house pit is } 4.8 \mathrm{~m} \mathrm{x} \\
2.7 \mathrm{~m} \times .22-.39 \mathrm{~m} \text { deep with a tunnel } \\
\text { measuring } 4.8 \mathrm{~m} \text { long and } 6 \mathrm{~m} \text { wide. } \\
\text { Large post, possibly whale bone, } \\
\text { found at each end of the entryway. } \\
\text { Tent ring measuring } 1.65 \mathrm{~m} \times 1.22 \mathrm{~m} \\
\text { in size made up of large cobbles and } \\
\text { small boulders. }\end{array}$ \\
\hline $\begin{array}{l}\text { NOA- } \\
00217\end{array}$ & Agiaguat & $\begin{array}{l}\text { Small } \\
\text { Village }\end{array}$ & 2 & $\begin{array}{l}\text { After } 500 \\
\text { BP }\end{array}$ & $\begin{array}{l}\text { Cultural } \\
\text { Association }\end{array}$ & $\begin{array}{l}\text { In } 1987,2 \text { house pits (a } 6.4 \mathrm{~m} \text { x } \\
5.5 \mathrm{~m} \text { depression with a } 3-3.5 \mathrm{~m} \text { x } \\
1.6 \mathrm{~m} \text { wide entry tunnel and a } 8.4 \mathrm{~m} \\
\text { x } 5.8 \mathrm{~m} \text { oval depression with a } 4.5 \mathrm{~m} \\
\text { long entry tunnel), } 2 \text { or more graves, } \\
\text { and a number depressions (some } \\
\text { cache pits) were noted. Remains of } \\
\text { crosses marking } 2 \text { of the shallow } \\
\text { grave depressions read KATHRINE } \\
\text { WEBSTER and ...TUCK. One } \\
\text { bifacial end or side blade, chert } \\
\text { flakes, pot sherds, and faunal } \\
\text { remains were also noted. This is } \\
\text { also this location that Burch records } \\
\text { as Agiagruat, a spring settlement of } \\
\text { the Napaaqtugmiut. In 1995, the site } \\
\text { was mapped. A number of } \\
\text { subsurface tests were excavated to } \\
\text { evaluate the damage to features } \\
\text { from recent vandalism and the total } \\
\text { site context. Cultural material } \\
\text { collected included chipped bifacial } \\
\text { and unifacial tools; waste, utilized, } \\
\text { and retouched flakes; ground slate }\end{array}$ \\
\hline
\end{tabular}




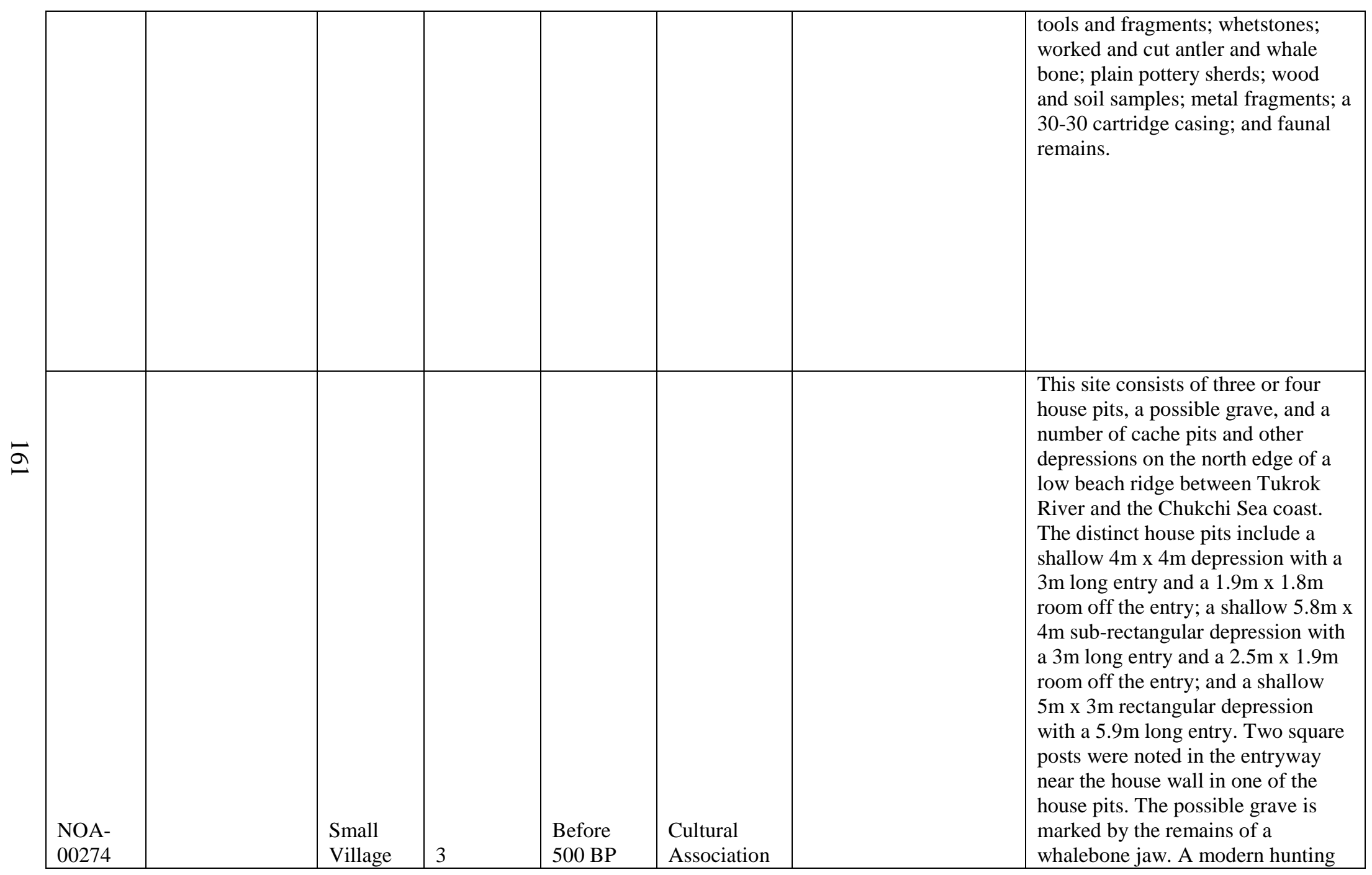




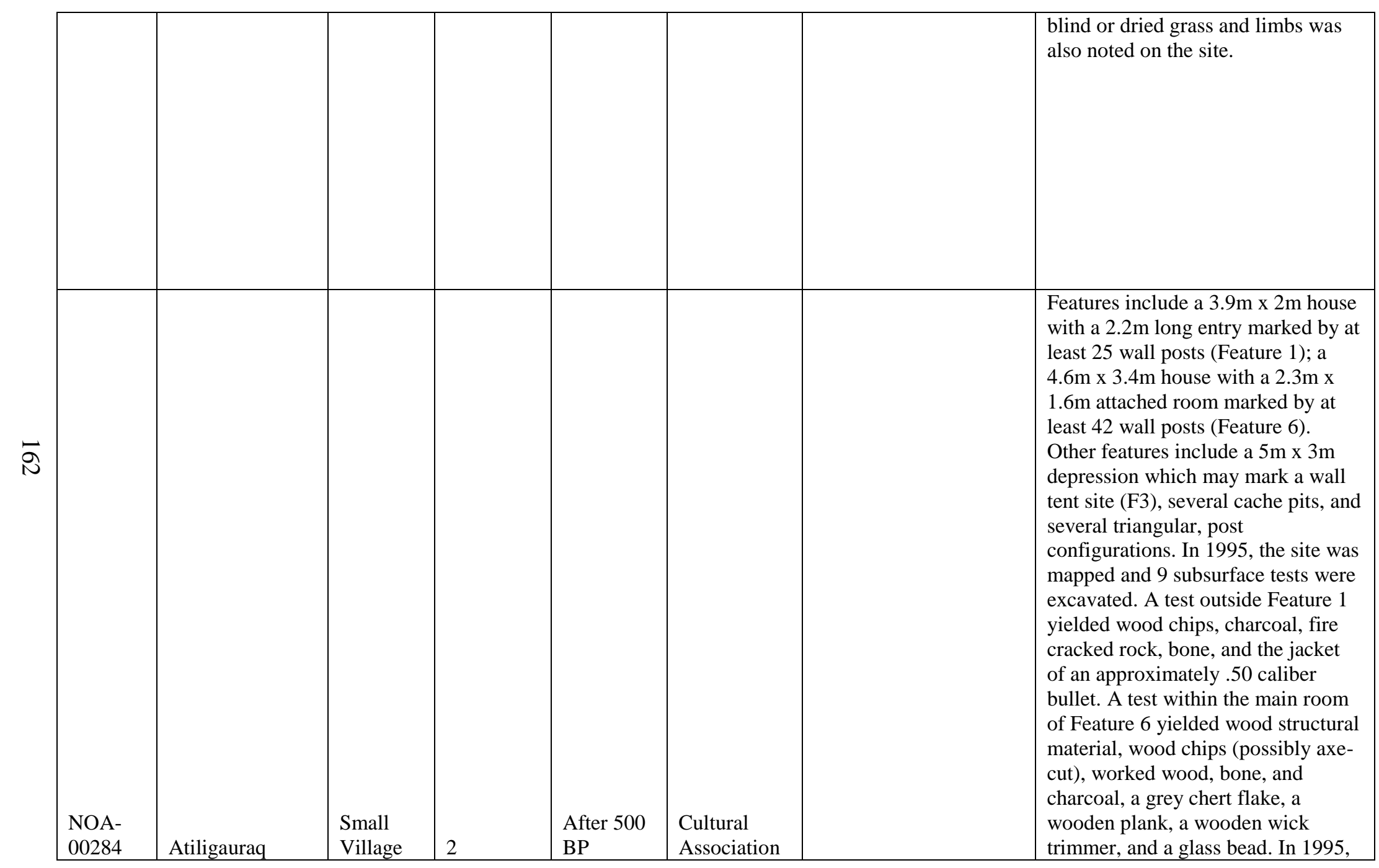




\begin{tabular}{|c|c|c|c|c|c|c|}
\hline & & & & & & $\begin{array}{l}\text { Feature } 9 \text { consisted of } 12 \text { posts } \\
\text { protruding from the beach (which } \\
\text { may be the remains of part of a } \\
\text { large house), aligned in two parallel } \\
\text { rows about } 1.7 \mathrm{~m} \text { apart and } \\
\text { perpendicular to the beach. The } \\
\text { additional posts exposed in } 1995 \\
\text { may be attributed to continued } \\
\text { erosion since } 1988 \text {. }\end{array}$ \\
\hline $\begin{array}{l}\text { NOA- } \\
00288\end{array}$ & $\begin{array}{l}\text { John Goodwin } \\
\text { Cabin Site }\end{array}$ & $\begin{array}{l}\text { Small } \\
\text { Village }\end{array}$ & 4 & Unknown & N/A & $\begin{array}{l}\text { Historic site. Remains include a } \\
\text { recent cabin, built of plywood and } \\
2 \times 4 \text {. The roof is gabled and has a } \\
\text { tarpaper covering. Furnishings and } \\
\text { clothing have been rummaged } \\
\text { through, presumably by bears, and } \\
\text { scattered for about } 20 \mathrm{~m} \text { upriver. } \\
\text { There is an outhouse, set on logs, } \\
\text { about } 30 \mathrm{~m} \text { to the SE. A sod } \\
\text { structure of traditional Eskimo } \\
\text { construction stands } 26 \mathrm{~m} \mathrm{~N} \text { of the } \\
\text { cabin. Its sloping walls are } \\
\text { constructed of trimmed spruce poles } \\
\text { and the roof is of plywood. Sod is } \\
\text { laid over all, but has mostly fallen } \\
\text { away, creating a wide berm around } \\
\text { the structure. The windows in the } \\
\text { walls and in the roof were covered } \\
\text { with plastic. Four semi-subterranean }\end{array}$ \\
\hline
\end{tabular}




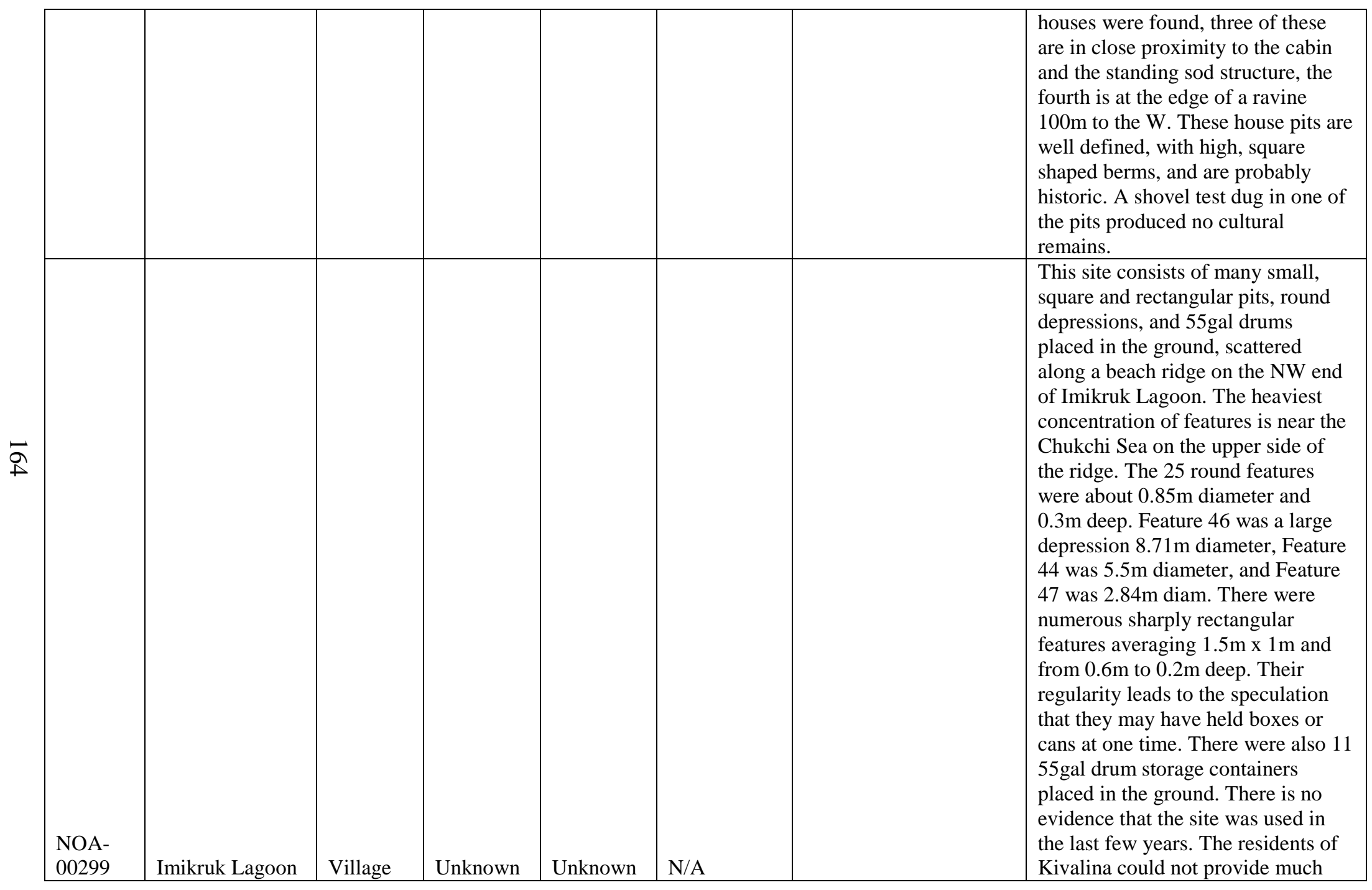




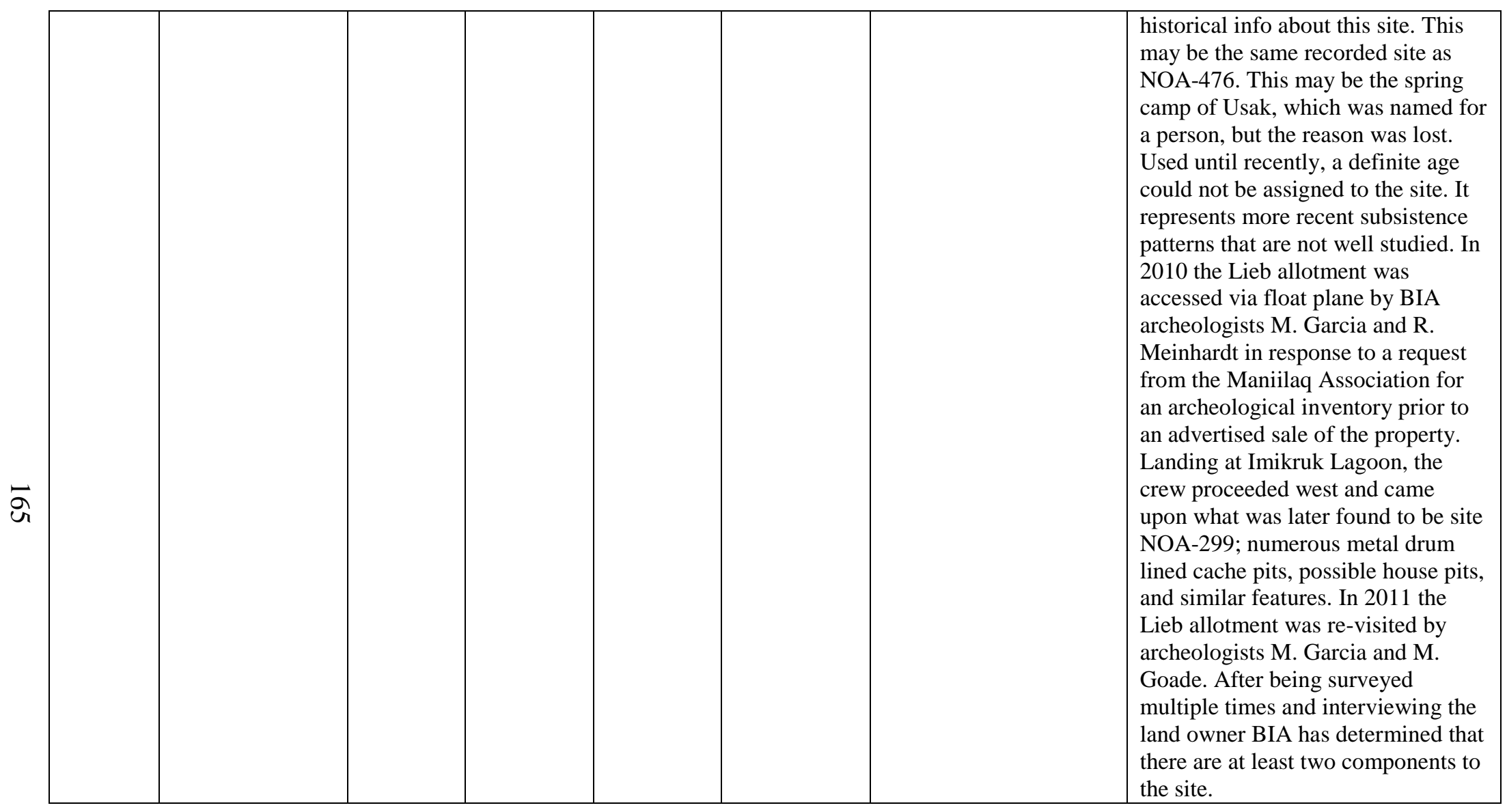




\begin{tabular}{|c|c|c|c|c|c|c|}
\hline $\begin{array}{l}\text { NOA- } \\
00301\end{array}$ & $\begin{array}{l}\text { Igrugaivik Creek } \\
\text { Camp }\end{array}$ & $\begin{array}{l}\text { Small } \\
\text { Village }\end{array}$ & 2 & $\begin{array}{l}\text { After } 500 \\
\text { BP }\end{array}$ & $\begin{array}{l}\text { Occupation } \\
\text { Dates }\end{array}$ & $\begin{array}{l}\text { This site (about } 120 \mathrm{~m} \times 140 \mathrm{~m}) \\
\text { consists of many small round and } \\
\text { rectangular depressions along } \\
\text { Igugaivik Creek bank. There are } \\
55 \text { gal barrels buried vertically into } \\
\text { the ground that may have served as } \\
\text { storage containers. There are } 34 \\
\text { round features } 1.2-0.5 \mathrm{~m} \text { in diameter } \\
\text { and } 16 \text { rectangular features } \\
\text { averaging } 1.5 \mathrm{~m} \text { x } 0.75 \mathrm{~m} \text { x } 0.6 \mathrm{~m} \\
\text { deep. The } 2 \text { large rectangular } \\
\text { features that may be the remains of } \\
\text { house pits or tent floors were } 6.2 \mathrm{~m} \times \\
3.5 \mathrm{~m} \text { and } 4.44 \mathrm{~m} \text { x } 2.06 \mathrm{~m} \text {. More } \\
\text { recent evidence of use were } 2 \\
\text { upright posts that served as a drying } \\
\text { rack with a folding table, and } \\
\text { plywood lying nearby, a wall tent } \\
\text { frame and an overturned couch in } \\
\text { poor condition. Camps closer to } \\
\text { Kivalina are still being used. This } \\
\text { spring camp may be part of } \\
\text { Kiniktuuraq, which means "little old } \\
\text { rise in the ground." During the } 18 \text { th } \\
\text { century, the major outlet of Kivalina } \\
\text { Lagoon was here. }\end{array}$ \\
\hline $\begin{array}{l}\text { NOA- } \\
00322 \\
\end{array}$ & & Village & Unknown & Unknown & N/A & $\begin{array}{l}\text { Site consists of possible house pits } \\
\text { visible on a } 1967 \text { aerial photo. }\end{array}$ \\
\hline $\begin{array}{l}\text { NOA- } \\
00323\end{array}$ & & $\begin{array}{l}\text { Single } \\
\text { House }\end{array}$ & 1 & Unknown & N/A & $\begin{array}{l}\text { Reported possible gravesite and } \\
\text { location of historic sod house. }\end{array}$ \\
\hline $\begin{array}{l}\text { NOA- } \\
00328\end{array}$ & & Village & Unknown & Unknown & N/A & $\begin{array}{l}\text { Local informant reported that } \\
\text { several families had occupied } \\
\text { several historic sod houses at the } \\
\text { extreme western end of town. Site }\end{array}$ \\
\hline
\end{tabular}




\begin{tabular}{|c|c|c|c|c|c|}
\hline & & & & & $\begin{array}{l}\text { may be the same as that located } \\
\text { during a BIA } 1989 \text { survey of the } \\
\text { Adams allotment. }\end{array}$ \\
\hline $\begin{array}{l}\text { NOA- } \\
00341\end{array}$ & Village & Unknown & Unknown & N/A & $\begin{array}{l}\text { The village of Noatak was listed by } \\
\text { Petroff in the } 1880 \text { Census as } \\
\text { Noatagamute. In } 1908 \text { the Friends } \\
\text { Church began a government } \\
\text { sponsored mission and school at the } \\
\text { present village site. In a } 1937 \\
\text { survey the school parcel consisted } \\
\text { of the Friends Manse, a log church, } \\
\text { a frame schoolhouse, a tramway and } \\
\text { track up the river bluff to the school, } \\
\text { a log cabin, a galvanized iron cache } \\
\text { and shed, and a frame outhouse. The } \\
\text { parcel is listed as USS 2037. The } \\
\text { surrounding buildings were listed as } \\
\text { Native built log cabins and caches. } \\
\text { A post office opened in } 1940 \text {. } \\
\text { Lithics possibly related to the } \\
\text { Northern Archaic tradition were } \\
\text { found on the ground surface in the } \\
\text { vicinity of Block 6, USS } 4486 \text { in } \\
1976 \text { prior to the installation of } \\
\text { water and sewer lines. }\end{array}$ \\
\hline $\begin{array}{l}\text { NOA- } \\
00342\end{array}$ & $\begin{array}{l}\text { Single } \\
\text { House }\end{array}$ & 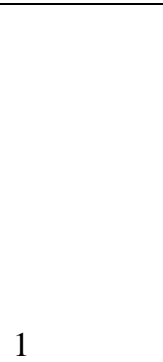 & Unknown & N/A & $\begin{array}{l}\text { Local informants report a house ruin } \\
\text { between the end of the existing } \\
\text { Noatak runway and the westernmost } \\
\text { channel of the Noatak River. The } \\
\text { ruin may be associated with the } \\
\text { Wendell Booth family and predate } \\
\text { the settlement of Noatak in } 1908 \text {. } \\
\text { May have been destroyed by river } \\
\text { erosion. }\end{array}$ \\
\hline
\end{tabular}




\begin{tabular}{|c|c|c|c|c|c|c|}
\hline $\begin{array}{l}\text { NOA- } \\
00343\end{array}$ & $\begin{array}{l}\text { Single } \\
\text { House }\end{array}$ & 1 & Unknown & N/A & & $\begin{array}{l}\text { The site consists of one semi- } \\
\text { subterranean house made from } \\
\text { spruce logs. Site was observed only } \\
\text { from the air and at a relatively high } \\
\text { altitude and speed. }\end{array}$ \\
\hline $\begin{array}{l}\text { NOA- } \\
00346\end{array}$ & Village & Unknown & Unknown & N/A & & $\begin{array}{l}\text { This is actually several sites strewn } \\
3 / 4 \mathrm{~km} \text { along the beach. The size of } \\
\text { each individual site was difficult to } \\
\text { determine from aerial inspection } \\
\text { alone. The site consists of several } \\
\text { semi-subterranean house } \\
\text { depressions and numerous cache } \\
\text { pits. The house pits could represent } \\
\text { any cultural affiliation and temporal } \\
\text { period over the past } 500 \text { years. Thus } \\
\text { these sites have the potential to } \\
\text { provide significant knowledge to the } \\
\text { regional prehistory. The site was } \\
\text { observed only from the air and so } \\
\text { no collections were made. }\end{array}$ \\
\hline $\begin{array}{l}\text { NOA- } \\
00383\end{array}$ & $\begin{array}{l}\text { Large } \\
\text { Village }\end{array}$ & 7 & $\begin{array}{l}\text { Before } \\
500 \mathrm{BP}\end{array}$ & $\begin{array}{l}\text { Occupation } \\
\text { Dates }\end{array}$ & $\begin{array}{l}\text { OS-93950 } 1190 \pm 25 \\
\text { OS-94051 } 1480 \pm 30\end{array}$ & $\begin{array}{l}\text { Site within the Cape Krusenstern } \\
\text { National Monument }\end{array}$ \\
\hline $\begin{array}{l}\text { NOA- } \\
00384\end{array}$ & $\begin{array}{l}\text { Small } \\
\text { Village }\end{array}$ & 2 & Unknown & N/A & & $\begin{array}{l}\text { Site within the Cape Krusenstern } \\
\text { National Monument }\end{array}$ \\
\hline $\begin{array}{l}\text { NOA- } \\
00397\end{array}$ & $\begin{array}{l}\text { Single } \\
\text { House }\end{array}$ & 1 & Unknown & N/A & & $\begin{array}{l}\text { Cape Krusenstern National } \\
\text { Monument }\end{array}$ \\
\hline $\begin{array}{l}\text { NOA- } \\
00398\end{array}$ & $\begin{array}{l}\text { Single } \\
\text { House }\end{array}$ & 1 & Unknown & N/A & & $\begin{array}{l}\text { Cape Krusenstern National } \\
\text { Monument }\end{array}$ \\
\hline $\begin{array}{l}\text { NOA- } \\
00408\end{array}$ & $\begin{array}{l}\text { Single } \\
\text { House }\end{array}$ & 1 & Unknown & N/A & & $\begin{array}{l}\text { Cape Krusenstern National } \\
\text { Monument }\end{array}$ \\
\hline $\begin{array}{l}\text { NOA- } \\
00425\end{array}$ & $\begin{array}{l}\text { Single } \\
\text { House }\end{array}$ & 1 & Unknown & N/A & & $\begin{array}{l}\text { Cape Krusenstern National } \\
\text { Monument }\end{array}$ \\
\hline
\end{tabular}




\begin{tabular}{|c|c|c|c|c|c|c|}
\hline $\begin{array}{l}\text { NOA- } \\
00427\end{array}$ & $\begin{array}{l}\text { Single } \\
\text { House }\end{array}$ & 1 & Unknown & N/A & & $\begin{array}{l}\text { Cape Krusenstern National } \\
\text { Monument }\end{array}$ \\
\hline $\begin{array}{l}\text { NOA- } \\
00434\end{array}$ & $\begin{array}{l}\text { Single } \\
\text { House }\end{array}$ & 1 & Unknown & N/A & & $\begin{array}{l}\text { Cape Krusenstern National } \\
\text { Monument }\end{array}$ \\
\hline $\begin{array}{l}\text { NOA- } \\
00440 \\
\end{array}$ & $\begin{array}{l}\text { Single } \\
\text { House }\end{array}$ & 1 & Unknown & N/A & & $\begin{array}{l}\text { Site within the Cape Krusenstern } \\
\text { National Monument }\end{array}$ \\
\hline $\begin{array}{l}\text { NOA- } \\
00453\end{array}$ & $\begin{array}{l}\text { Single } \\
\text { House }\end{array}$ & 1 & Unknown & N/A & & $\begin{array}{l}\text { Site within the Cape Krusenstern } \\
\text { National Monument }\end{array}$ \\
\hline $\begin{array}{l}\text { NOA- } \\
00454 \\
\end{array}$ & $\begin{array}{l}\text { Single } \\
\text { House }\end{array}$ & 1 & Unknown & N/A & & $\begin{array}{l}\text { Site within the Cape Krusenstern } \\
\text { National Monument }\end{array}$ \\
\hline $\begin{array}{l}\text { NOA- } \\
00456\end{array}$ & $\begin{array}{l}\text { Single } \\
\text { House }\end{array}$ & 1 & Unknown & N/A & & $\begin{array}{l}\text { Site within the Cape Krusenstern } \\
\text { National Monument }\end{array}$ \\
\hline $\begin{array}{l}\text { NOA- } \\
00457\end{array}$ & $\begin{array}{l}\text { Single } \\
\text { House }\end{array}$ & 1 & Unknown & N/A & & $\begin{array}{l}\text { Site within the Cape Krusenstern } \\
\text { National Monument }\end{array}$ \\
\hline $\begin{array}{l}\text { NOA- } \\
00468 \\
\end{array}$ & $\begin{array}{l}\text { Single } \\
\text { House } \\
\end{array}$ & 1 & $\begin{array}{l}\text { Before } \\
500 \mathrm{BP} \\
\end{array}$ & $\begin{array}{l}\text { Occupation } \\
\text { Dates }\end{array}$ & Beta-226688 1030 \pm 40 & $\begin{array}{l}\text { Site within the Cape Krusenstern } \\
\text { National Monument }\end{array}$ \\
\hline $\begin{array}{l}\text { NOA- } \\
00473 \\
\end{array}$ & $\begin{array}{l}\text { Large } \\
\text { Village } \\
\end{array}$ & 7 & $\begin{array}{l}\text { Before } \\
500 \mathrm{BP}\end{array}$ & $\begin{array}{l}\text { Cultural } \\
\text { Association } \\
\end{array}$ & & $\begin{array}{l}\text { Site within the Cape Krusenstern } \\
\text { National Monument }\end{array}$ \\
\hline $\begin{array}{l}\text { NOA- } \\
00474\end{array}$ & $\begin{array}{l}\text { Single } \\
\text { House }\end{array}$ & 1 & $\begin{array}{l}\text { After } 500 \\
\text { BP }\end{array}$ & $\begin{array}{l}\text { Occupation } \\
\text { Dates }\end{array}$ & $\begin{array}{l}\text { OS-93710 170 } \pm 25 \text {; OS- } \\
93686485 \pm 25 \text {; OS- } \\
93687 \text { 115 } \pm 25 \text {; OS- } \\
93688410 \pm 25 \text {; Beta- } \\
326114210 \pm 30\end{array}$ & $\begin{array}{l}\text { Site within the Cape Krusenstern } \\
\text { National Monument }\end{array}$ \\
\hline $\begin{array}{l}\text { NOA- } \\
00476\end{array}$ & Village & Unknown & Unknown & N/A & & $\begin{array}{l}\text { This site was first identified in } 2010 \\
\text { by BIA archaeologists. A revisit to } \\
\text { the site in } 2011 \text { revealed five areas } \\
\text { of cultural remains. Forty features } \\
\text { were identified along a } 197 \mathrm{~m} \text { stretch } \\
\text { of berms. This may be the same } \\
\text { recorded site as NOA- } 299 \text {. }\end{array}$ \\
\hline $\begin{array}{l}\text { NOA- } \\
00509\end{array}$ & $\begin{array}{l}\text { Small } \\
\text { Village }\end{array}$ & 2 & $\begin{array}{l}\text { Before } \\
500 \mathrm{BP}\end{array}$ & $\begin{array}{l}\text { Occupation } \\
\text { Dates }\end{array}$ & OS-93954 745 \pm 35 & $\begin{array}{l}\text { Site within the Cape Krusenstern } \\
\text { National Monument }\end{array}$ \\
\hline
\end{tabular}




\begin{tabular}{|c|c|c|c|c|c|c|c|}
\hline $\begin{array}{l}\text { NOA- } \\
00513\end{array}$ & & $\begin{array}{l}\text { Large } \\
\text { Village }\end{array}$ & 45 & $\begin{array}{l}\text { Continuou } \\
\text { s } \\
\text { Occupatio } \\
\mathrm{n}\end{array}$ & $\begin{array}{l}\text { Occupation } \\
\text { Dates }\end{array}$ & 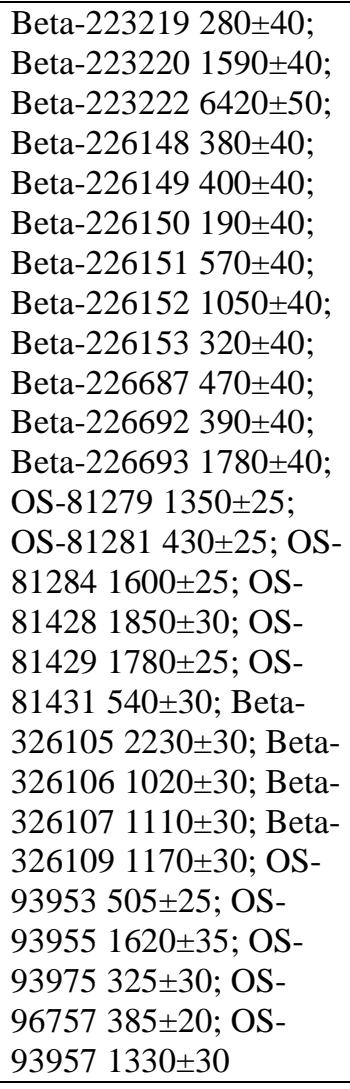 & $\begin{array}{l}\text { Site within the Cape Krusenstern } \\
\text { National Monument }\end{array}$ \\
\hline $\begin{array}{l}\text { NOA- } \\
00516\end{array}$ & $\begin{array}{l}\text { Associated with } \\
\text { NOA-00002 and } \\
\text { NOA-00242. }\end{array}$ & $\begin{array}{l}\text { Large } \\
\text { Village }\end{array}$ & 9 & $\begin{array}{l}\text { After } 500 \\
\text { BP }\end{array}$ & $\begin{array}{l}\text { Cultural } \\
\text { Association }\end{array}$ & & $\begin{array}{l}\text { Site within the Cape Krusenstern } \\
\text { National Monument }\end{array}$ \\
\hline $\begin{array}{l}\text { NOA- } \\
00519\end{array}$ & $\begin{array}{l}\text { Associated with } \\
\text { NOA-00002 and } \\
\text { NOA-00242. }\end{array}$ & $\begin{array}{l}\text { Single } \\
\text { House }\end{array}$ & 1 & $\begin{array}{l}\text { Outside } \\
\text { Study } \\
\text { Period }\end{array}$ & $\begin{array}{l}\text { Occupation } \\
\text { Dates }\end{array}$ & & $\begin{array}{l}\text { Site within the Cape Krusenstern } \\
\text { National Monument }\end{array}$ \\
\hline
\end{tabular}




\begin{tabular}{|c|c|c|c|c|c|c|c|}
\hline $\begin{array}{l}\text { NOA- } \\
00531\end{array}$ & $\begin{array}{l}\text { Associated with } \\
\text { NOA-00002 and } \\
\text { NOA-00242. }\end{array}$ & $\begin{array}{l}\text { Small } \\
\text { Village }\end{array}$ & 2 & $\begin{array}{l}\text { Before } \\
500 \mathrm{BP}\end{array}$ & $\begin{array}{l}\text { Cultural } \\
\text { Association }\end{array}$ & & $\begin{array}{l}\text { Site within the Cape Krusenstern } \\
\text { National Monument }\end{array}$ \\
\hline $\begin{array}{l}\text { NOA- } \\
00532\end{array}$ & $\begin{array}{l}\text { Associated with } \\
\text { NOA-00002 and } \\
\text { NOA-00242. }\end{array}$ & $\begin{array}{l}\text { Large } \\
\text { Village }\end{array}$ & 10 & Unknown & N/A & & $\begin{array}{l}\text { Site within the Cape Krusenstern } \\
\text { National Monument }\end{array}$ \\
\hline $\begin{array}{l}\text { NOA- } \\
00533\end{array}$ & $\begin{array}{l}\text { Associated with } \\
\text { NOA-00002 and } \\
\text { NOA-00242. }\end{array}$ & $\begin{array}{l}\text { Large } \\
\text { Village }\end{array}$ & 8 & $\begin{array}{l}\text { Continuou } \\
\mathrm{s} \\
\text { Occupatio } \\
\mathrm{n}\end{array}$ & $\begin{array}{l}\text { Occupation } \\
\text { Dates }\end{array}$ & 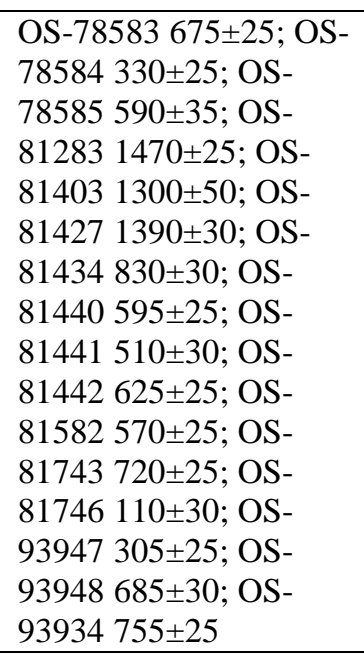 & $\begin{array}{l}\text { Site within the Cape Krusenstern } \\
\text { National Monument }\end{array}$ \\
\hline $\begin{array}{l}\text { NOA- } \\
00534\end{array}$ & $\begin{array}{l}\text { Associated with } \\
\text { NOA-00002 and } \\
\text { NOA-00242. }\end{array}$ & $\begin{array}{l}\text { Small } \\
\text { Village }\end{array}$ & 3 & $\begin{array}{l}\text { Before } \\
500 \mathrm{BP}\end{array}$ & $\begin{array}{l}\text { Occupation } \\
\text { Dates }\end{array}$ & 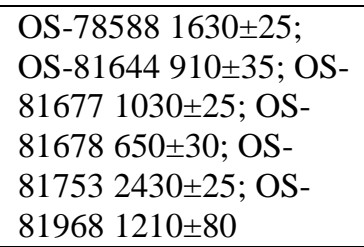 & $\begin{array}{l}\text { Site within the Cape Krusenstern } \\
\text { National Monument }\end{array}$ \\
\hline $\begin{array}{l}\text { NOA- } \\
00538\end{array}$ & $\begin{array}{l}\text { Associated with } \\
\text { NOA-00002 and } \\
\text { NOA-00242. }\end{array}$ & $\begin{array}{l}\text { Large } \\
\text { Village }\end{array}$ & 8 & Unknown & N/A & & $\begin{array}{l}\text { Site within the Cape Krusenstern } \\
\text { National Monument }\end{array}$ \\
\hline $\begin{array}{l}\text { NOA- } \\
00544\end{array}$ & $\begin{array}{l}\text { Associated with } \\
\text { NOA-00002 and } \\
\text { NOA-00242. }\end{array}$ & $\begin{array}{l}\text { Single } \\
\text { House }\end{array}$ & 1 & Unknown & N/A & & $\begin{array}{l}\text { Site within the Cape Krusenstern } \\
\text { National Monument }\end{array}$ \\
\hline
\end{tabular}




\begin{tabular}{|c|c|c|c|c|c|c|c|}
\hline $\begin{array}{l}\text { NOA- } \\
00553\end{array}$ & $\begin{array}{l}\text { Associated with } \\
\text { NOA-00002 and } \\
\text { NOA-00242. }\end{array}$ & $\begin{array}{l}\text { Large } \\
\text { Village }\end{array}$ & 7 & Unknown & N/A & & $\begin{array}{l}\text { Site within the Cape Krusenstern } \\
\text { National Monument }\end{array}$ \\
\hline $\begin{array}{l}\text { NOA- } \\
00554\end{array}$ & $\begin{array}{l}\text { Associated with } \\
\text { NOA-00002 and } \\
\text { NOA-00242. }\end{array}$ & $\begin{array}{l}\text { Small } \\
\text { Village }\end{array}$ & 2 & Unknown & N/A & & $\begin{array}{l}\text { Site within the Cape Krusenstern } \\
\text { National Monument }\end{array}$ \\
\hline $\begin{array}{l}\text { NOA- } \\
00555\end{array}$ & $\begin{array}{l}\text { Associated with } \\
\text { NOA-00002 and } \\
\text { NOA-00242. }\end{array}$ & $\begin{array}{l}\text { Single } \\
\text { House }\end{array}$ & 1 & $\begin{array}{l}\text { Before } \\
500 \mathrm{BP}\end{array}$ & $\begin{array}{l}\text { Occupation } \\
\text { Dates }\end{array}$ & OS-93938 1320 \pm 40 & $\begin{array}{l}\text { Site within the Cape Krusenstern } \\
\text { National Monument }\end{array}$ \\
\hline $\begin{array}{l}\text { NOA- } \\
00556\end{array}$ & $\begin{array}{l}\text { Associated with } \\
\text { NOA-00002 and } \\
\text { NOA-00242. }\end{array}$ & $\begin{array}{l}\text { Small } \\
\text { Village }\end{array}$ & 3 & $\begin{array}{l}\text { Before } \\
500 \mathrm{BP}\end{array}$ & $\begin{array}{l}\text { Occupation } \\
\text { Dates }\end{array}$ & 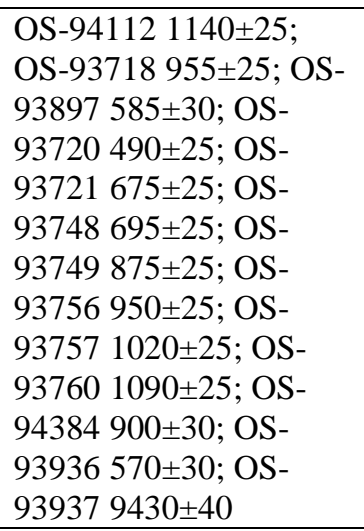 & $\begin{array}{l}\text { Site within the Cape Krusenstern } \\
\text { National Monument }\end{array}$ \\
\hline $\begin{array}{l}\text { NOA- } \\
00558\end{array}$ & $\begin{array}{l}\text { Associated with } \\
\text { NOA-00002 and } \\
\text { NOA-00242. }\end{array}$ & $\begin{array}{l}\text { Large } \\
\text { Village }\end{array}$ & 6 & $\begin{array}{l}\text { Continuou } \\
\mathrm{s} \\
\text { Occupatio } \\
\mathrm{n}\end{array}$ & $\begin{array}{l}\text { Occupation } \\
\text { Dates }\end{array}$ & $\begin{array}{l}\text { OS-93689 } 965 \pm 25 \text {; OS- } \\
93712975 \pm 25 \text {; OS- } \\
93713 \quad 810 \pm 25 \text {; OS- } \\
93714 \quad 830 \pm 30 \text {; OS- } \\
937151010 \pm 25 \text {; OS- } \\
93716910 \pm 30 \text {; OS- } \\
93717100 \pm 25 \text {; OS- } \\
93719630 \pm 25 \text {; OS- } \\
93750390 \pm 25 \text {; OS- } \\
93751920 \pm 25 \text {; OS- } \\
93753275 \pm 25 \text {; OS- } \\
93754665 \pm 25 \text {; OS- }\end{array}$ & $\begin{array}{l}\text { Site within the Cape Krusenstern } \\
\text { National Monument }\end{array}$ \\
\hline
\end{tabular}




\begin{tabular}{|c|c|c|c|c|c|c|c|}
\hline & & & & & & $\begin{array}{l}93755 \quad 715 \pm 25 \text {; OS- } \\
93758 \quad 745 \pm 25 \text {; OS- } \\
93759 \quad 370 \pm 25 \text {; OS- } \\
93761 \quad 925 \pm 35 \text {; OS- } \\
93763 \quad 290 \pm 35 \text {; Beta- } \\
326115 \quad 510 \pm 30 \text {; Beta- } \\
3261161450 \pm 30 \text {; OS- } \\
93764 \quad 160 \pm 25 \text {; OS- } \\
93879585 \pm 25 \text {; OS- } \\
93880740 \pm 25 \text {; OS- } \\
93932645 \pm 30 \text {; Beta- } \\
3261171410 \pm 30 \text {; OS- } \\
94064 \quad 490 \pm 30 \text {; OS- } \\
93940715 \pm 25 \text {; Beta- } \\
326118 \quad 1280 \pm 30 \text {; OS- } \\
96756 \quad 765 \pm 35 \text {; OS- } \\
93952 \quad 210 \pm 25 \text {; Beta- } \\
326120 \quad 640 \pm 30\end{array}$ & \\
\hline $\begin{array}{l}\text { NOA- } \\
00578\end{array}$ & $\begin{array}{l}\text { Associated with } \\
\text { NOA-00002 and } \\
\text { NOA-00242. }\end{array}$ & $\begin{array}{l}\text { Small } \\
\text { Village }\end{array}$ & 5 & $\begin{array}{l}\text { Before } \\
500 \mathrm{BP}\end{array}$ & $\begin{array}{l}\text { Cultural } \\
\text { Association }\end{array}$ & & $\begin{array}{l}\text { Site within the Cape Krusenstern } \\
\text { National Monument }\end{array}$ \\
\hline $\begin{array}{l}\text { NOB- } \\
00002\end{array}$ & Iyatayet & Village & Unknown & $\begin{array}{l}\text { Before } \\
500 \mathrm{BP}\end{array}$ & $\begin{array}{l}\text { Cultural } \\
\text { Association }\end{array}$ & & $\begin{array}{l}\text { Between } 1948 \text { and 1952, Giddings } \\
\text { conducted extensive excavations of } \\
\text { this large multi-component midden } \\
\text { site, which reached depths of over } \\
7 \text { '. The upper levels contained } \\
\text { Nukleet phase materials (AD } 1000 \\
\text { to AD 1700), the middle level } \\
\text { deposits contained Norton phase } \\
\text { materials (BC } 500 \text { to AD 400), and } \\
\text { the lower levels contained Denbigh } \\
\text { Flint complex materials (earlier than } \\
\text { BC } 2500 \text { ). }\end{array}$ \\
\hline
\end{tabular}




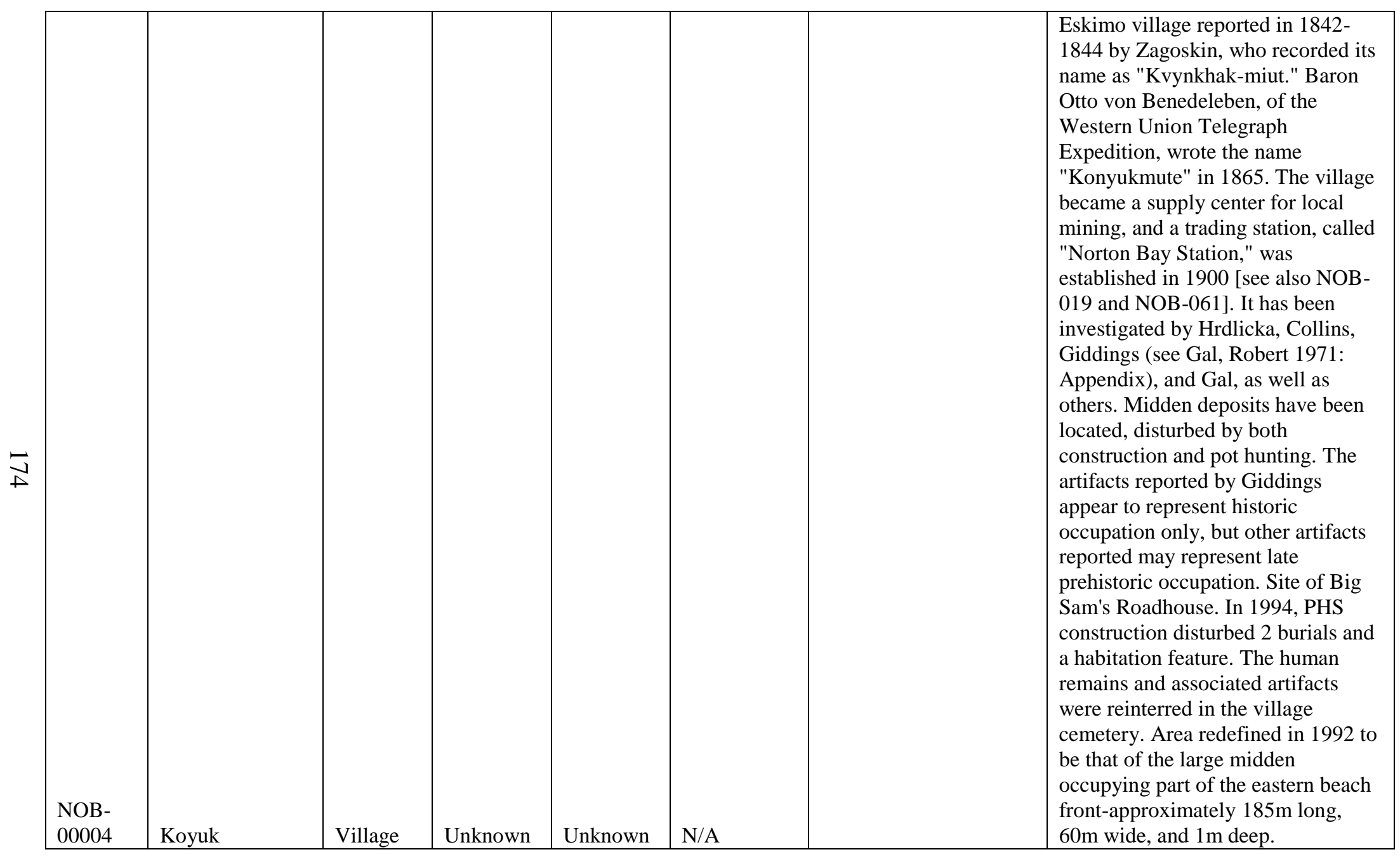




\begin{tabular}{|c|c|c|c|c|c|c|}
\hline $\begin{array}{l}\text { NOB- } \\
00013\end{array}$ & Kwighuk & Village & Unknown & Unknown & N/A & $\begin{array}{l}\text { Reported by Ray to be a summer } \\
\text { village for fishing and berry } \\
\text { picking. Though no tests were dug, } \\
\text { Gal thought the likely location of } \\
\text { the village was the grassy north } \\
\text { slope of the headland immediately } \\
\text { south of the mouth of Kuiuktulik } \\
\text { River, where a number of } \\
\text { depressions occur. }\end{array}$ \\
\hline $\begin{array}{l}\text { NOB- } \\
00017\end{array}$ & Maqluktuliq & $\begin{array}{l}\text { Small } \\
\text { Village }\end{array}$ & 3 & Unknown & N/A & $\begin{array}{l}\text { Gal noted an old village site } \\
\text { consisting of three house pits. Two } \\
\text { tests were attempted, but permafrost } \\
\text { conditions prevented the excavation } \\
\text { of cultural material. }\end{array}$ \\
\hline $\begin{array}{l}\text { NOB- } \\
00018\end{array}$ & & Village & Unknown & Unknown & N/A & $\begin{array}{l}\text { A house pit was reported to Gal as } \\
\text { being at this location. Gal did not } \\
\text { locate the house pit, though some } \\
\text { depressions were observed, which } \\
\text { he was unable to test due to } \\
\text { permafrost conditions. He did note a } \\
\text { rotted pile of wood, a broken sled } \\
\text { with metal shoeing, and a series of } \\
\text { upright posts presumed to be for } \\
\text { stretching nets. Johnson and } \\
\text { Sorensen relocated this site, } \\
\text { identifying the pile of wood as a } \\
\text { pre-Christian burial. }\end{array}$ \\
\hline $\begin{array}{l}\text { NOB- } \\
00023\end{array}$ & & Village & Unknown & $\begin{array}{l}\text { Before } \\
500 \mathrm{BP}\end{array}$ & $\begin{array}{l}\text { Cultural } \\
\text { Association }\end{array}$ & $\begin{array}{l}\text { Although Gal did not examine this } \\
\text { site, he received repeated reports of } \\
\text { its existence. Indeed, there may be } \\
\text { two settlements, on opposite banks } \\
\text { of the river. An informant also gave } \\
\text { Gal three artifacts (and he saw a } \\
\text { fourth) which could be placed } \\
\text { within Nukleet culture. }\end{array}$ \\
\hline
\end{tabular}




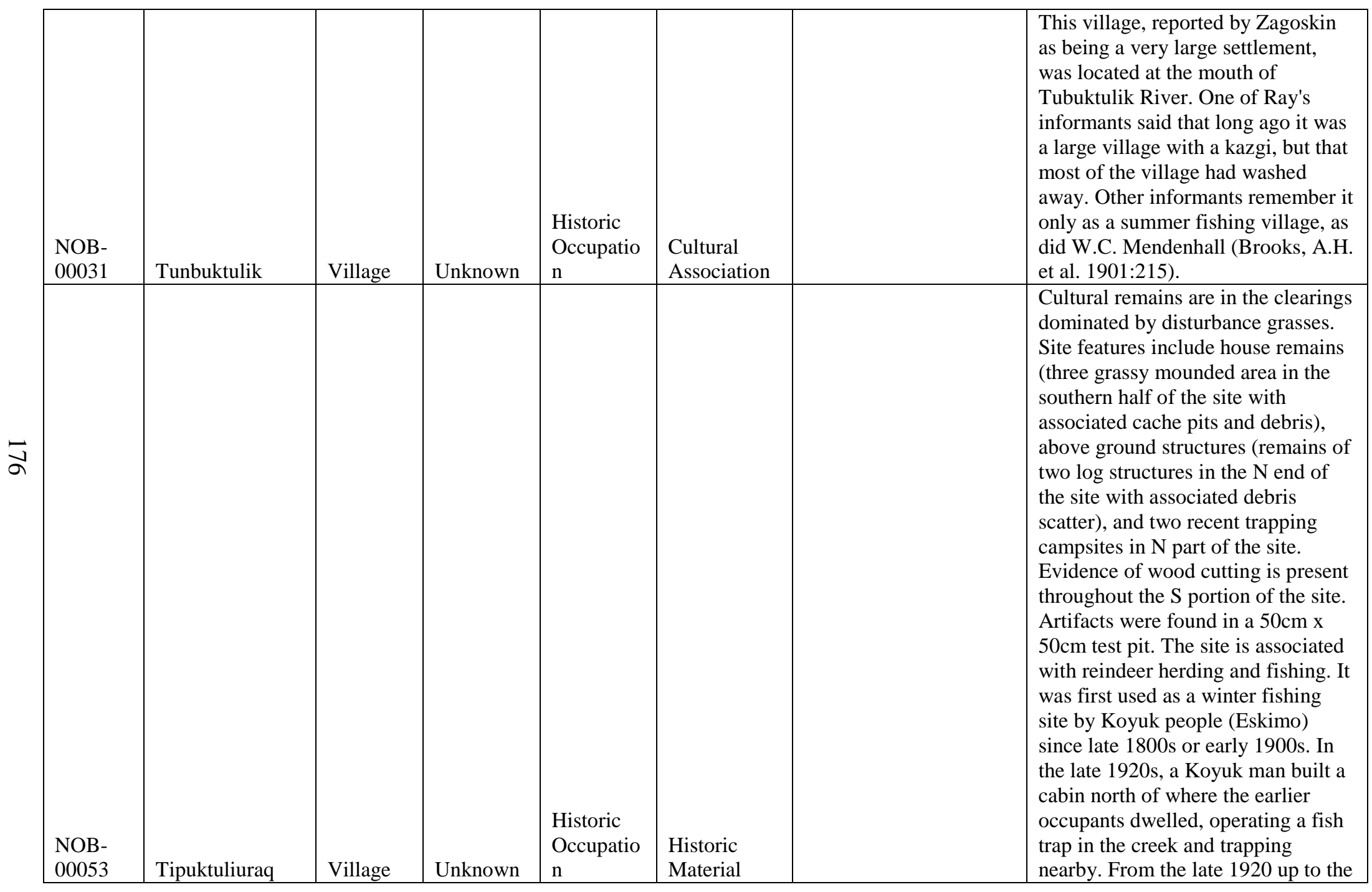




\begin{tabular}{|c|c|c|c|c|c|c|}
\hline & & & & & & $\begin{array}{l}\text { 1940s, other Koyuk residents also } \\
\text { used the site, but camped in tents. In } \\
1929 \text { or } 1930 \text { the Koyuk Reindeer } \\
\text { Co. built a shelter cabin at } \\
\text { Tipuktuliuraq, using the } \\
\text { surrounding area as winter grazing } \\
\text { land. }\end{array}$ \\
\hline $\begin{array}{l}\text { NOB- } \\
00063 \\
\end{array}$ & Ungalik & Village & Unknown & $\begin{array}{l}\text { Historic } \\
\text { Occupatio } \\
\text { n }\end{array}$ & $\begin{array}{l}\text { Cultural } \\
\text { Association }\end{array}$ & $\begin{array}{l}\text { Abandoned native village site on } \\
\text { Iditarod Trail. The Bonanza } \\
\text { Roadhouse (NOB-029), which is } \\
\text { associated with the Iditarod trail, } \\
\text { was located in the village site. }\end{array}$ \\
\hline $\begin{array}{l}\text { NOB- } \\
00067\end{array}$ & & $\begin{array}{l}\text { Large } \\
\text { Village }\end{array}$ & 15 & Unknown & N/A & $\begin{array}{l}\text { Site consists of at least } 15 \text { semi- } \\
\text { subterranean house depressions, } \\
\text { extending } 1,300 \text { ' along the narrow } \\
\text { beach ridge, immediately E of } \\
\text { village, across the river. }\end{array}$ \\
\hline $\begin{array}{l}\text { NOB- } \\
00069\end{array}$ & & Village & Unknown & Unknown & N/A & $\begin{array}{l}\text { Site consists of Rectangular and } \\
\text { square depressions. Most lie along } \\
\text { the beach ridge edge overlooking } \\
\text { the Tagoomenik River. }\end{array}$ \\
\hline $\begin{array}{l}\text { NOB- } \\
00084\end{array}$ & Utkusinnaq & Village & Unknown & Unknown & N/A & N/A \\
\hline
\end{tabular}




\begin{tabular}{|c|c|c|c|c|c|c|}
\hline $\begin{array}{l}\text { NOM- } \\
00004\end{array}$ & Salmon Lake & Village & Unknown & Unknown & N/A & $\begin{array}{l}\text { D. Sparks reported house pits on } \\
\text { high ground, about } 100 \text { yards back } \\
\text { of the beach, at the narrows between } \\
\text { the two portions of Salmon Lake. }\end{array}$ \\
\hline $\begin{array}{l}\text { NOM- } \\
00006\end{array}$ & Singigyak & $\begin{array}{l}\text { Large } \\
\text { Village }\end{array}$ & 6 & Unknown & N/A & $\begin{array}{l}\text { Ray reported this as a village of } \\
\text { about six houses which was } \\
\text { occupied until the } 1918 \text { influenza } \\
\text { epidemic wiped out the entire } \\
\text { village. A fox rancher, Peter X. } \\
\text { Peterson, reportedly lived on top of } \\
\text { the village site. This site is also } \\
\text { reportedly occupied by King } \\
\text { Islanders in the summer and the site } \\
\text { to which they would like to move to } \\
\text { permanently. }\end{array}$ \\
\hline $\begin{array}{l}\text { NOM- } \\
00007\end{array}$ & Pingo & Village & Unknown & Unknown & N/A & $\begin{array}{l}\text { Reported by Ray to "supposed to } \\
\text { have been a village of several } \\
\text { houses long ago, but no one has } \\
\text { lived there within memory." }\end{array}$ \\
\hline $\begin{array}{l}\text { NOM- } \\
00009\end{array}$ & Ayasayuk & Village & Unknown & $\begin{array}{l}\text { Before } \\
500 \mathrm{BP} \\
\end{array}$ & $\begin{array}{l}\text { Cultural } \\
\text { Association }\end{array}$ & $\begin{array}{l}\text { Bockstoce noted this as a still } \\
\text { inhabited small settlement, at a good } \\
\text { winter sea mammal hunting } \\
\text { location. Its midden was } \\
\text { approximately } 150 \mathrm{~m} \text { long and } \\
\text { showed the remains of many house } \\
\text { pits. The midden was eroding into } \\
\text { the sea. Excavations in the up to } 1 \mathrm{~m} \\
\text { deep midden in } 1974 \text { produced } \\
\text { evidence that the site was not more } \\
\text { than } 500 \text { years old. }\end{array}$ \\
\hline
\end{tabular}




\begin{tabular}{|c|c|c|c|c|c|c|}
\hline $\begin{array}{l}\text { NOM- } \\
00010\end{array}$ & Uinakhtaguik & Village & Unknown & Unknown & N/A & $\begin{array}{l}\text { Ray noted this as the name of Nome } \\
\text { River as well as a summer fish } \\
\text { camp, and possibly a winter } \\
\text { settlement of a family or two. The } \\
1880 \text { Census reported a population } \\
\text { of } 10 \text { for "Oo-innakhtagovik." } \\
\text { Today a dozen or more families } \\
\text { have summer fish camps here and } \\
\text { some are year-round residents. } \\
\text { Apparently the Lomen Brothers } \\
\text { slaughterhouse is also located here, } \\
\text { in the vicinity of the former site of } \\
\text { Fort Davis (NOM-002). }\end{array}$ \\
\hline $\begin{array}{l}\text { NOM- } \\
00015\end{array}$ & Ayak & Village & Unknown & Unknown & N/A & $\begin{array}{l}\text { The name applies to both the island } \\
\text { and the primary village on the } \\
\text { island. The island was visited by } \\
\text { E.W. Nelson in } 1881 \text {, and the site is } \\
\text { noted in both the } 1880 \text { Census and } \\
1890 \text { Census. The site was } \\
\text { occasionally reffered to, apparently } \\
\text { incorrectly, as Aziak. Sources } \\
\text { indicate that the site is located on } \\
\text { the east side of the island. } \\
\text { Reportedly, there is at least one } \\
\text { other village site on the island. }\end{array}$ \\
\hline $\begin{array}{l}\text { NOM- } \\
00025\end{array}$ & Sitnasuak & Village & Unknown & Unknown & N/A & $\begin{array}{l}\text { Ray noted that a formerly small } \\
\text { village existed at the mouth of } \\
\text { Snake River, now the site of Nome, } \\
\text { known for its King Crab fishery } \\
\text { offshore. Ray indicates that this is } \\
\text { the village of "Chitnashuak" of the } \\
1880 \text { Census, which had a } \\
\text { population of } 20 \text { [see also NOM- } \\
\text { 089, which is Orth's location for } \\
\text { "Chitnashuak"]. }\end{array}$ \\
\hline
\end{tabular}




\begin{tabular}{|c|c|c|c|c|c|c|}
\hline $\begin{array}{l}\text { NOM- } \\
00026\end{array}$ & Nagoluk & Village & Unknown & Unknown & N/A & $\begin{array}{l}\text { Noted by Ray as a small year-round } \\
\text { village at a stream mouth between } \\
\text { Snake River and Sinuk River. }\end{array}$ \\
\hline $\begin{array}{l}\text { NOM- } \\
00027\end{array}$ & Kailiosuak & $\begin{array}{l}\text { Small } \\
\text { Village }\end{array}$ & 5 & Unknown & N/A & $\begin{array}{l}\text { Noted by Ray as a small year-round } \\
\text { village, once with five houses. }\end{array}$ \\
\hline $\begin{array}{l}\text { NOM- } \\
00029\end{array}$ & Singuk & Village & Unknown & Unknown & N/A & $\begin{array}{l}\text { Noted by Ray as a very old, but } \\
\text { probably small, settlement } \\
\text { aboriginally, sometimes occupied } \\
\text { year-round, located on the left bank } \\
\text { of the river. In } 1895 \text { it became the } \\
\text { headquarters for the first Eskimo- } \\
\text { owned reindeer herd, that of Charlie } \\
\text { Antisarlook (Antesiluk). A } \\
\text { Methodist mission and a public } \\
\text { school were established on the right } \\
\text { bank of the river. The village was } \\
\text { wiped out by the influenza epidemic } \\
\text { of } 1918 \text {. }\end{array}$ \\
\hline $\begin{array}{l}\text { NOM- } \\
00045\end{array}$ & $\begin{array}{l}\text { Woolley Lagoon } \\
\text { Site }\end{array}$ & $\begin{array}{l}\text { Small } \\
\text { Village }\end{array}$ & 2 & Unknown & N/A & $\begin{array}{l}\text { Two circular house depressions and } \\
\text { a rectangular sod walled feature } \\
\text { front on the lagoon channel, } \\
\text { approximately } 170 \mathrm{~m} \text { south of the } \\
\text { turnaround at the end of Woolley } \\
\text { Lagoon Road. Directly across the } \\
\text { channel from the turnaround, on the } \\
\text { barrier beach, is the summer camp } \\
\text { of King Island Natives. A single } \\
\text { shovel probe within the } 8 \mathrm{~m} \times 10 \mathrm{~m} \\
\text { rectangular feature appeared to be } \\
\text { culturally sterile. A 50cm x } 50 \mathrm{~cm} \\
\text { test was placed within the } \\
\text { southernmost of the two } 4 \mathrm{~m} \text { in } \\
\text { diameter house depressions. An }\end{array}$ \\
\hline
\end{tabular}




\begin{tabular}{|c|c|c|c|c|c|c|}
\hline & & & & & & $\begin{array}{l}\text { apparent rock-lined hearth area and } \\
\text { structural timbers were noted. The } \\
\text { site is estimated to be a short-term, } \\
\text { perhaps single-season, occupation } \\
\text { of relatively recent age. }\end{array}$ \\
\hline $\begin{array}{l}\text { NOM- } \\
00089\end{array}$ & Sitnasuakak & Village & Unknown & Unknown & N/A & $\begin{array}{l}\text { Ray noted that a year-round village } \\
\text { was located at the mouth of Penny } \\
\text { River, where seal and duck hunting } \\
\text { and fishing were especially good, } \\
\text { and that it was still occupied during } \\
\text { the summer.[See also NOM-025.] }\end{array}$ \\
\hline $\begin{array}{l}\text { NOM- } \\
00092\end{array}$ & Rodney Creek & $\begin{array}{l}\text { Small } \\
\text { Village }\end{array}$ & 3 & Unknown & N/A & $\begin{array}{l}\text { Ray noted that Rodney Creek once } \\
\text { had three houses, supposedly for } \\
\text { hunting and fishing. }\end{array}$ \\
\hline $\begin{array}{l}\text { NOM- } \\
00093\end{array}$ & Kalulik & $\begin{array}{l}\text { Large } \\
\text { Village }\end{array}$ & 10 & Unknown & N/A & $\begin{array}{l}\text { Ray noted that, according to } \\
\text { informants, this village was very old } \\
\text { and had a kazgi. In } 1893 \text { it } \\
\text { reportedly had ten houses, in } 1867 \\
\text { there were two deserted houses and } \\
\text { one occupied house reported, and } \\
\text { after } 1900 \text { five houses were } \\
\text { reported. This location was, } \\
\text { apparently mistakenly, shown as } \\
\text { "Nook" on Nelson's } 1899 \text { map and } \\
\text { by Petroff in the } 1880 \\
\text { Census.[Formerly listed as TEL- } \\
\text { 003.] }\end{array}$ \\
\hline
\end{tabular}




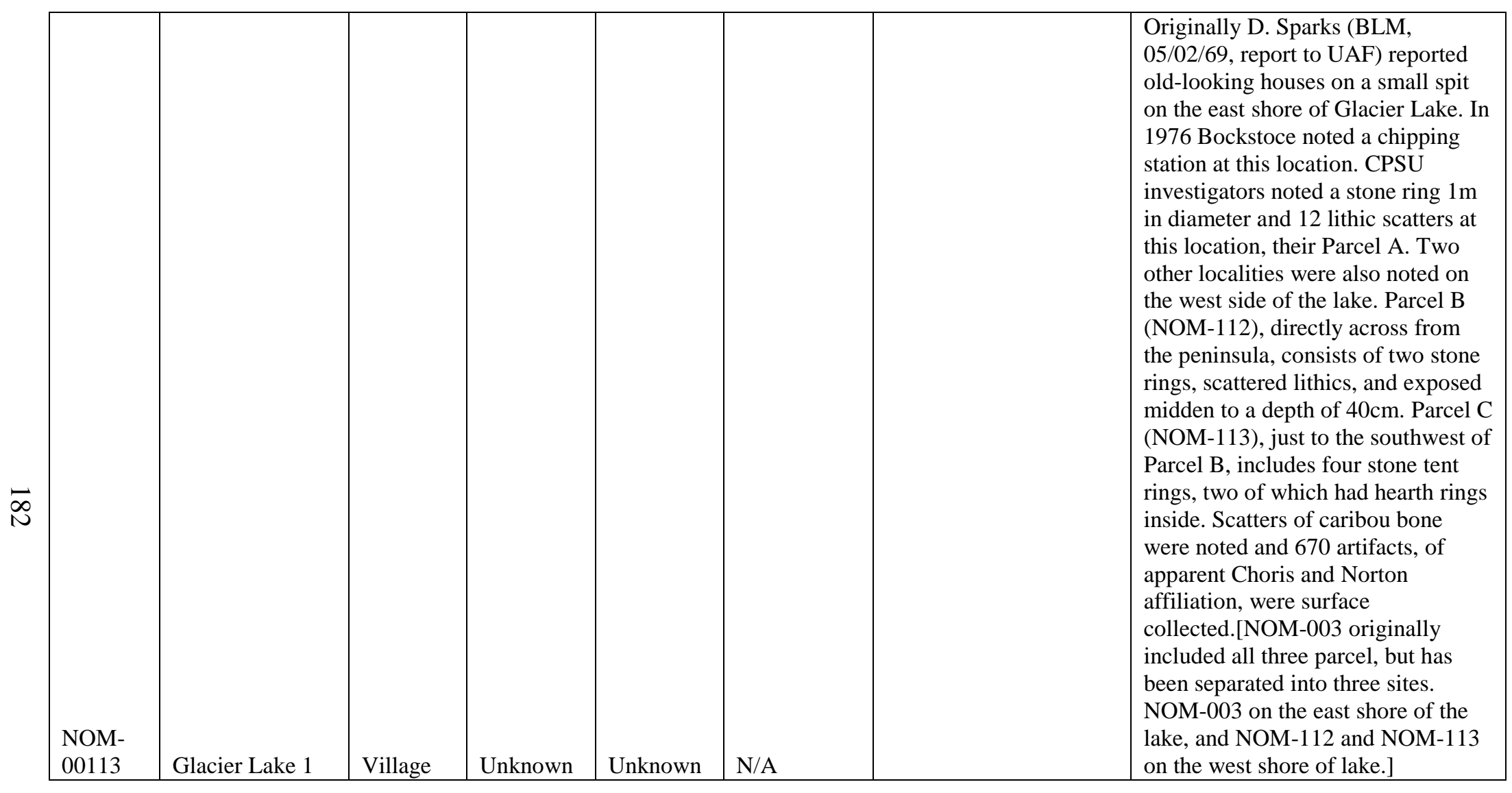




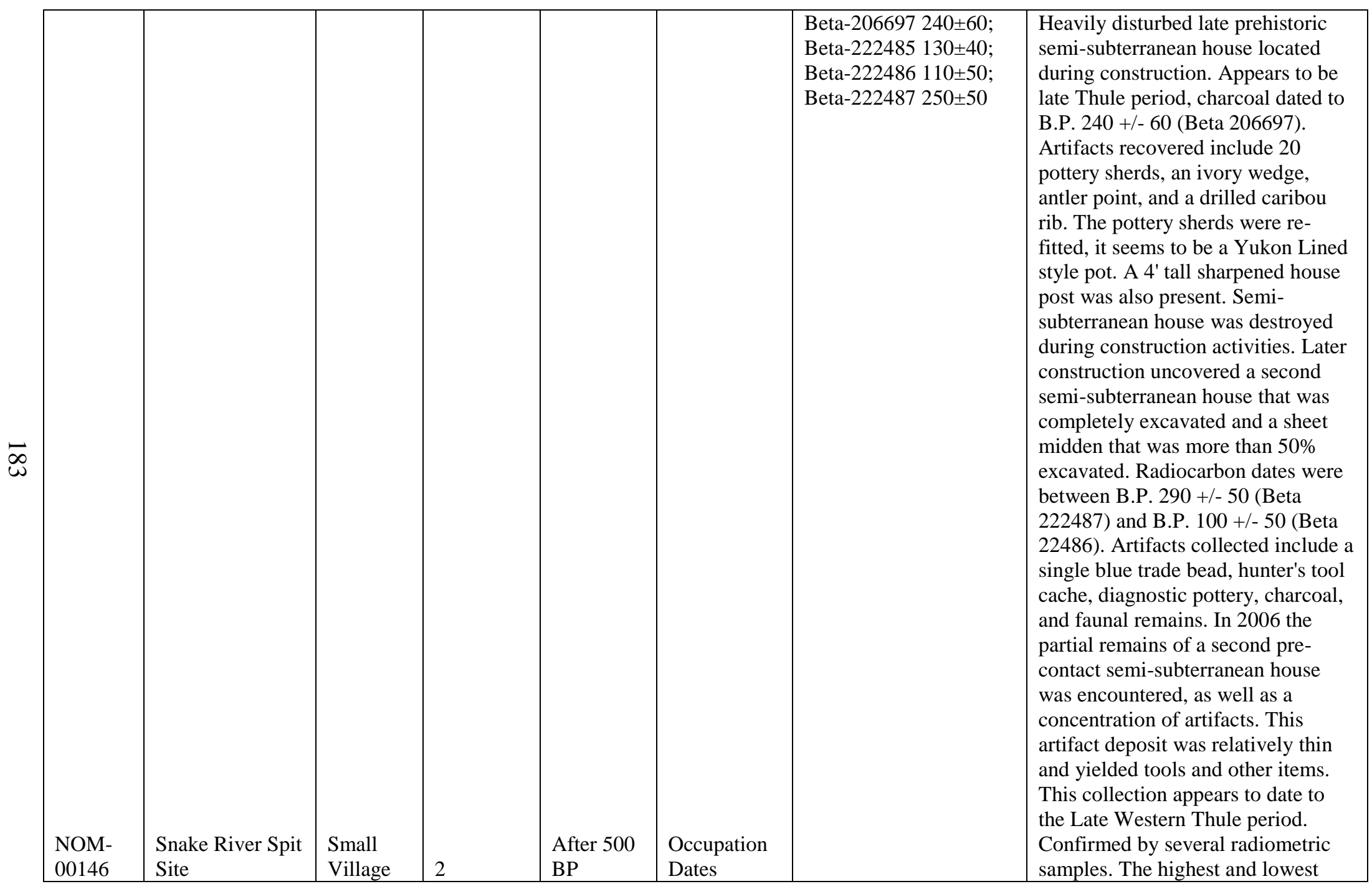




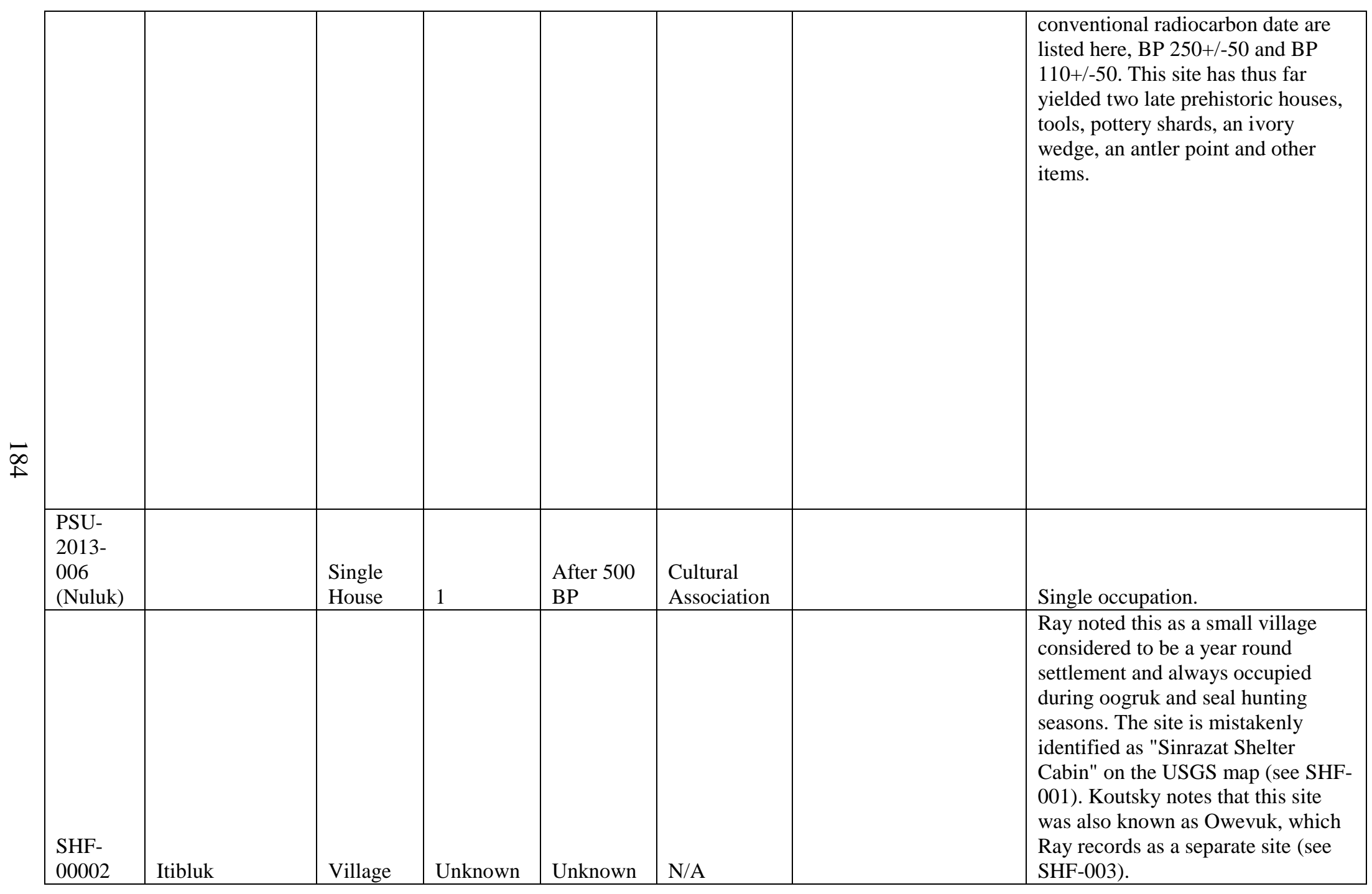




\begin{tabular}{|c|c|c|c|c|c|c|}
\hline $\begin{array}{l}\text { SHF- } \\
00003\end{array}$ & Owevuk & $\begin{array}{l}\text { Small } \\
\text { Village }\end{array}$ & 4 & $\begin{array}{l}\text { Historic } \\
\text { Occupatio } \\
\mathrm{n}\end{array}$ & $\begin{array}{l}\text { Occupation } \\
\text { Dates }\end{array}$ & $\begin{array}{l}\text { Ray noted that Owevuk had four } \\
\text { houses in } 1892 \text { (Jackson, Sheldon } \\
\text { 1895:97). At this location K. } \\
\text { Woodworth, BLM, noted several } \\
\text { depressions, probably house pits, } \\
\text { located on an elevated sand ridge, } \\
\text { approximately 700-800' south of the } \\
\text { outer shoreline; it is assumed that } \\
\text { these are the same site. Koutsky } \\
\text { associates the name of Owevuk with } \\
\text { Itibluk (SHF-002).[Previously also } \\
\text { listed as SHF-012.] }\end{array}$ \\
\hline $\begin{array}{l}\text { SHF- } \\
00004\end{array}$ & Kikiktuk & Village & Unknown & Unknown & N/A & $\begin{array}{l}\text { East of the Shishmaref runway are } \\
\text { the heavily disturbed ruins of the } \\
\text { original site of the present day } \\
\text { village of Shishmaref. First reported } \\
\text { by Otto von Kotzebue, who visited } \\
\text { the site in } 1816 \text {, it was the largest } \\
\text { village in the area. Hrdlicka visited } \\
\text { the site in } 1926 \text {, noted that it was } \\
\text { disturbed at that time by a fox farm. } \\
\text { Wiersum noted a large number of } \\
\text { house and cache pit depressions on } \\
\text { a series of parallel beach ridges and } \\
\text { evidence of human burials. }\end{array}$ \\
\hline $\begin{array}{l}\text { SHF- } \\
00006\end{array}$ & Nonatak & Village & Unknown & Unknown & N/A & $\begin{array}{l}\text { Ray noted this as a former fishing } \\
\text { village. }\end{array}$ \\
\hline $\begin{array}{l}\text { SHF- } \\
00007\end{array}$ & Lungyat & Village & Unknown & Unknown & N/A & $\begin{array}{l}\text { Ray noted this as a former fishing } \\
\text { village. }\end{array}$ \\
\hline
\end{tabular}




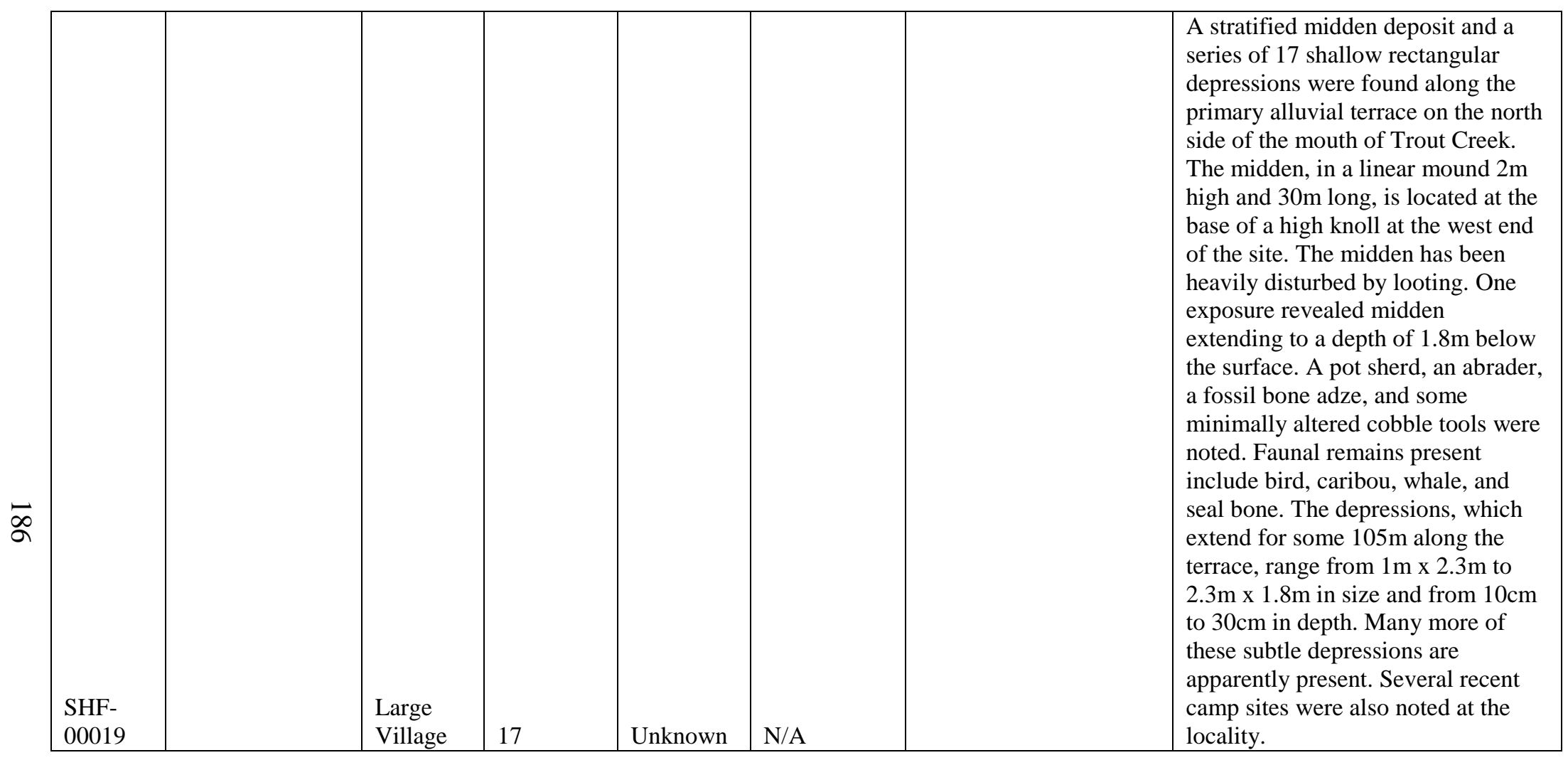




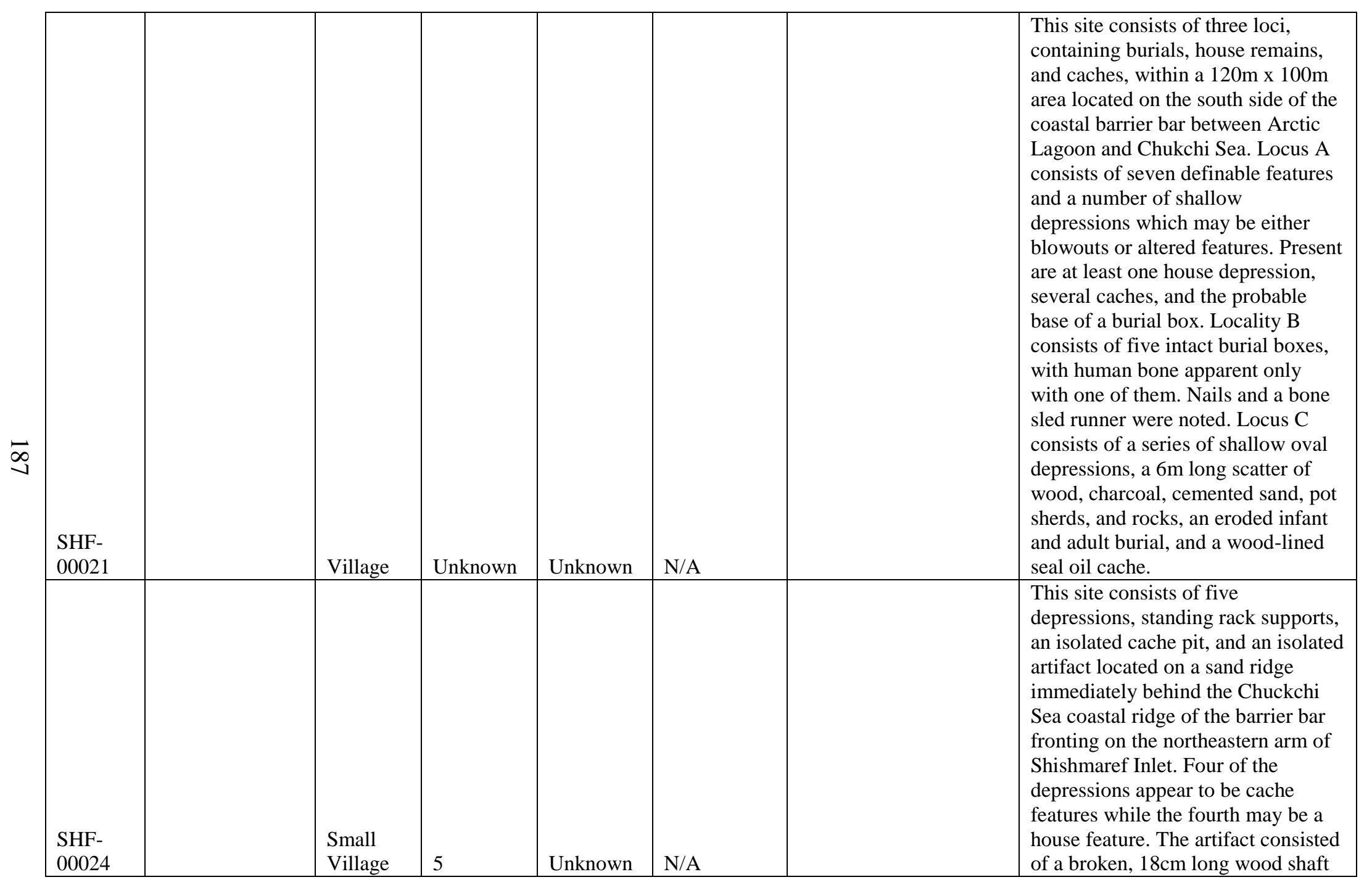




\begin{tabular}{|c|c|c|c|c|c|}
\hline & & & & & $\begin{array}{l}\text { with a piece of rawhide tied around } \\
\text { it. }\end{array}$ \\
\hline $\begin{array}{l}\text { SHF- } \\
00025\end{array}$ & $\begin{array}{l}\text { Single } \\
\text { House }\end{array}$ & 1 & Unknown & N/A & $\begin{array}{l}\text { A 20th Century sod house, an } \\
\text { earlier plank-lined house } \\
\text { depression, and a cache depression } \\
\text { were noted on the barrier bar } \\
\text { fronting on the northeastern arm of } \\
\text { Shishmaref Inlet, approximately } \\
750 \mathrm{~m} \text { west of VABM "Tart." The } \\
\text { sod house remains measure } 4.5 \mathrm{~m} \times \\
3.2 \mathrm{~m} \text {. Structural members, historic } \\
\text { debris, and faunal remains are } \\
\text { present. Several sod borrow areas } \\
\text { were also noted. The older house is } \\
\text { located in a blowout about } 66.5 \mathrm{~m} \text { to } \\
\text { the northwest of the sod house. It } \\
\text { has an oval or sub-rectangular main } \\
\text { room measuring } 2 \mathrm{~m} \times 1.7 \mathrm{~m}, \text { a } 3.9 \mathrm{~m} \\
\text { long straight entryway, and a } 1.7 \mathrm{~m} \times \\
1 \mathrm{~m} \text { axillary room off the entryway. } \\
\text { The } 2 \mathrm{~m} \times 1.1 \mathrm{~m} \times \mathrm{x} \text {. } \mathrm{m} \text { deep cache is } \\
\text { located about } 59 \mathrm{~m} \text { southeast of the } \\
\text { sod house. }\end{array}$ \\
\hline $\begin{array}{l}\text { SHF- } \\
00027\end{array}$ & $\begin{array}{l}\text { Small } \\
\text { Village }\end{array}$ & 2 & $\begin{array}{l}\text { Historic } \\
\text { Occupatio } \\
\mathrm{n}\end{array}$ & $\begin{array}{l}\text { Historic } \\
\text { Material }\end{array}$ & $\begin{array}{l}\text { A partially collapsed sod house, a } \\
\text { standing shelter cabin, a house } \\
\text { depression, two cache depressions, } \\
\text { and a scatter of metal and rubber } \\
\text { debris were found on a relict sand } \\
\text { ridge about } 35 \mathrm{~m} \text { south of the } \\
\text { Chukchi Sea coast, on the barrier }\end{array}$ \\
\hline
\end{tabular}




\begin{tabular}{|c|c|c|c|c|c|c|}
\hline & & & & & & $\begin{array}{l}\text { bar fronting the northeastern arm of } \\
\text { Shishmaref Inlet. The house } \\
\text { depression is a vaguely defined, } \\
\text { two-room feature measuring } 7 \mathrm{~m} \mathrm{x} \\
4 \mathrm{~m} \text {. A cache, which is } 2 \mathrm{~m} \text { from the } \\
\text { house depression, measures } 1.1 \mathrm{~m} \mathrm{x} \\
0.9 \mathrm{~m} \text { and has a driftwood pole } \\
\text { cover. The sod house measures } \\
4.3 \mathrm{~m} \text { x } 3.6 \mathrm{~m} \text { and has an entry room } \\
\text { attached via a short passageway. } \\
\text { The plank-lined walls and a portion } \\
\text { of the split log and sod roof are still } \\
\text { standing. The shelter cabin } \\
\text { measures } 2.75 \mathrm{~m} \times 2.09 \mathrm{~m} \text {. A number } \\
\text { of other, unidentified features were } \\
\text { noted. }\end{array}$ \\
\hline $\begin{array}{l}\text { SHF- } \\
00033\end{array}$ & South Sarichef & Village & Unknown & Unknown & N/A & $\begin{array}{l}\text { Wiersum noted a number of } \\
\text { rectangular house depressions with } \\
\text { their entrances facing a dry pond. } \\
\text { The site is situated on a sand dune. } \\
\text { There is some evidence of looting, } \\
\text { but the site generally appears to be } \\
\text { well preserved. }\end{array}$ \\
\hline $\begin{array}{l}\text { SHF- } \\
00036\end{array}$ & & $\begin{array}{l}\text { Single } \\
\text { House }\end{array}$ & 1 & Unknown & N/A & $\begin{array}{l}\text { A house depression, a log-lined } \\
\text { cache, and four cache depressions } \\
\text { were located within a } 40 \mathrm{~m} \times 30 \mathrm{~m} \\
\text { area on a small dune on the coastal } \\
\text { barrier bar fronting the northeastern } \\
\text { arm of Shishmaref Inlet, about } \\
120 \mathrm{~m} \text { south of the Chukchi Sea } \\
\text { coast. The house feature has a } 4.2 \mathrm{~m} \\
\text { x } 3 \mathrm{~m} \text { x .65m main room and a } 7 \mathrm{~m} \\
\text { long entryway with a small lateral } \\
\text { room off one side. A few upright } \\
\text { plank and post structural members }\end{array}$ \\
\hline
\end{tabular}




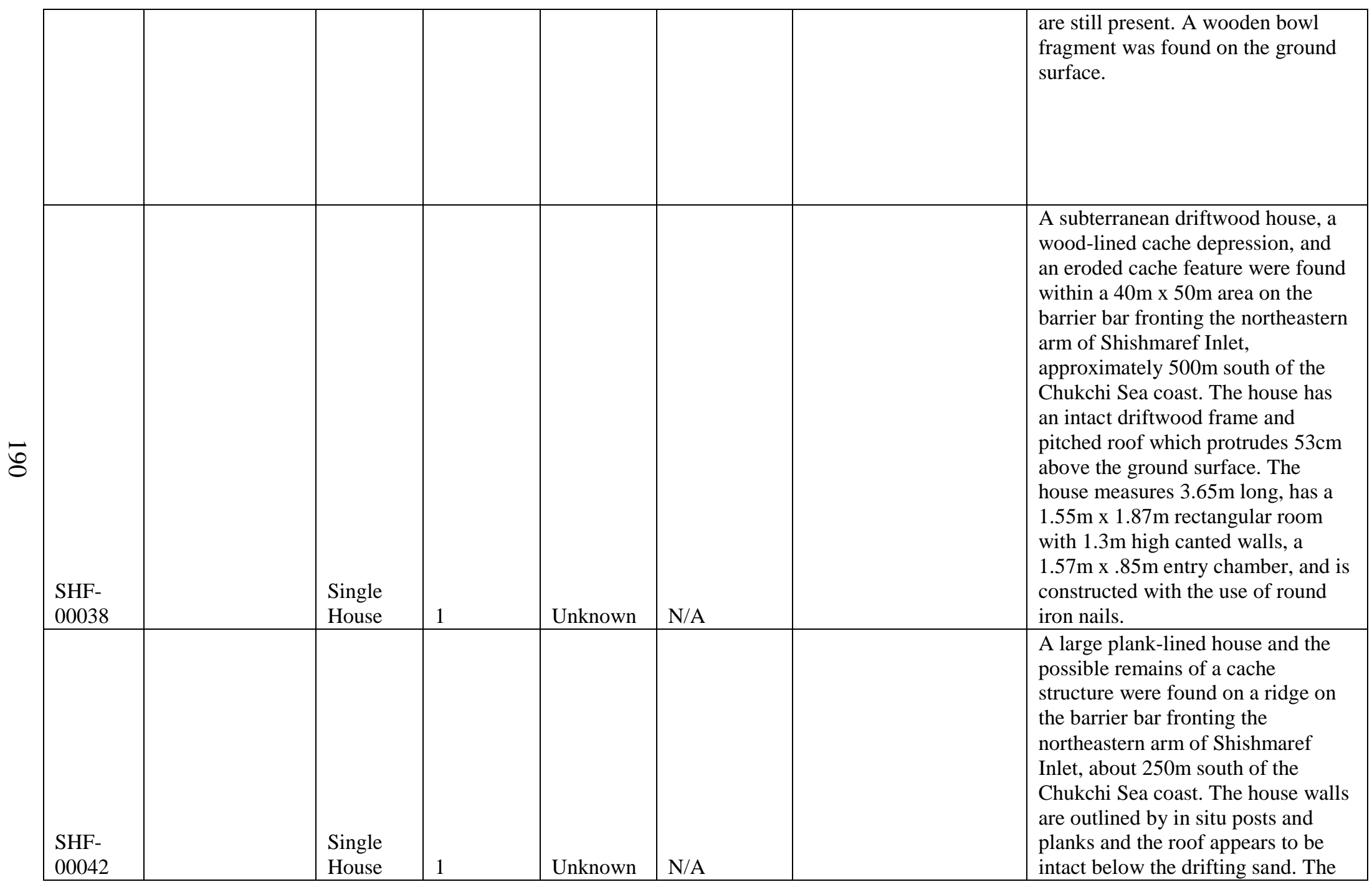




\begin{tabular}{|c|c|c|c|c|c|c|}
\hline & & & & & & $\begin{array}{l}\text { feature is } 13 \mathrm{~m} \text { long with a } \\
\text { trapezoidal main room measuring } \\
4 \mathrm{~m} \times 3.75 \mathrm{~m}, \text { a } 2.5 \mathrm{~m} \times 1 \mathrm{~m} \\
\text { passageway leading to a } 6.5 \mathrm{~m} \times \\
2.5 \mathrm{~m} \text { entry chamber, and another } \\
3 \mathrm{~m} \times 1.5 \mathrm{~m} \text { passage connecting to } \\
\text { another room or house measuring } \\
\text { about } 3 \mathrm{~m} \times 4 \mathrm{~m} \text {. Artifacts noted } \\
\text { include a bone harpoon foreshaft, } \\
\text { bone sled runner fragments, and a } \\
\text { decorated pot sherd. }\end{array}$ \\
\hline $\begin{array}{l}\text { SHF- } \\
00043\end{array}$ & & $\begin{array}{l}\text { Small } \\
\text { Village }\end{array}$ & 2 & $\begin{array}{l}\text { After } 500 \\
\text { BP }\end{array}$ & $\begin{array}{l}\text { Cultural } \\
\text { Association }\end{array}$ & $\begin{array}{l}\text { Two grass-covered house } \\
\text { depressions were found on the crest } \\
\text { of a low dune eroding along the } \\
\text { Chukchi Sea coast of the barrier bar } \\
\text { fronting the northeastern coast of } \\
\text { Shishmaref Inlet. One house has a } \\
5 \mathrm{~m} \times 3.5 \mathrm{~m} \text { main room, with an } \\
\text { entry way and an axillary room } \\
\text { measuring about } 3 \mathrm{~m} \text { in diameter. } \\
\text { The second feature has a } 4.1 \mathrm{~m} \times 4 \mathrm{~m} \\
\text { main room and a short passage } \\
\text { which connects to a } 5.5 \mathrm{~m} \times 2.5 \mathrm{~m} \\
\text { entry chamber. Structural members } \\
\text { are present. }\end{array}$ \\
\hline $\begin{array}{l}\text { SHF- } \\
00045\end{array}$ & Shishmaref & Village & Unknown & $\begin{array}{l}\text { Historic } \\
\text { Occupatio } \\
\mathrm{n}\end{array}$ & $\begin{array}{l}\text { Historic } \\
\text { Association }\end{array}$ & $\begin{array}{l}\text { The "modern" village site that dates } \\
\text { back to the } 1920 \text { s. The site is } \\
\text { marked by scattered and sporadic } \\
\text { midden deposits that appear to be } \\
\text { concentrated in the SW end of town. } \\
\text { The midden deposits are comprised } \\
\text { of sea mammal bone mixed with } \\
\text { other refuse. The deposits are } \\
\text { located along the eroding bluff } \\
\text { edge. }\end{array}$ \\
\hline
\end{tabular}




\begin{tabular}{|c|c|c|c|c|c|c|}
\hline $\begin{array}{l}\text { SHF- } \\
00052\end{array}$ & & $\begin{array}{l}\text { Single } \\
\text { House }\end{array}$ & 1 & Unknown & N/A & $\begin{array}{l}\text { Possible house pit, possible post, } \\
\text { three cemented sand lenses. }\end{array}$ \\
\hline $\begin{array}{l}\text { SHF- } \\
00053\end{array}$ & & $\begin{array}{l}\text { Small } \\
\text { Village }\end{array}$ & 2 & Unknown & N/A & $\begin{array}{l}\text { Two house pits, four caches, four } \\
\text { marine mammal bone scatters. }\end{array}$ \\
\hline $\begin{array}{l}\text { SHF- } \\
00054\end{array}$ & & $\begin{array}{l}\text { Small } \\
\text { Village }\end{array}$ & 5 & Unknown & N/A & $\begin{array}{l}\text { Five house pits, seven cache pits, } \\
\text { mammal cranium, contemporary } \\
\text { wooden feature, and nine posts. }\end{array}$ \\
\hline $\begin{array}{l}\text { SHF- } \\
00056\end{array}$ & & $\begin{array}{l}\text { Single } \\
\text { House }\end{array}$ & 1 & Unknown & N/A & $\begin{array}{l}\text { One multi-room house pit and one } \\
\text { cache pit. }\end{array}$ \\
\hline $\begin{array}{l}\text { SHF- } \\
00059\end{array}$ & & $\begin{array}{l}\text { Small } \\
\text { Village }\end{array}$ & 3 & Unknown & N/A & $\begin{array}{l}\text { Three house pits and seven cache } \\
\text { pits. }\end{array}$ \\
\hline $\begin{array}{l}\text { SHF- } \\
00065\end{array}$ & & $\begin{array}{l}\text { Small } \\
\text { Village }\end{array}$ & 3 & Unknown & N/A & $\begin{array}{l}\text { Three house pits, } 39 \text { cache pits, and } \\
\text { human remains. }\end{array}$ \\
\hline $\begin{array}{l}\text { SHU- } \\
00006\end{array}$ & Kuutchiaq & $\begin{array}{l}\text { Small } \\
\text { Village }\end{array}$ & 4 & Unknown & N/A & $\begin{array}{l}\text { Anderson and Anderson noted three } \\
\text { and possibly four house pits and at } \\
\text { least } 15 \text { cache pits on the northeast } \\
\text { side of the creek. This summer } \\
\text { camp was utilized into the 1900s. }\end{array}$ \\
\hline $\begin{array}{l}\text { SHU- } \\
00007\end{array}$ & Paniksigvik & $\begin{array}{l}\text { Small } \\
\text { Village }\end{array}$ & 2 & Unknown & N/A & $\begin{array}{l}\text { Anderson and Anderson located } \\
\text { grassy midden areas on both banks } \\
\text { of Kugarak River. Two house pits } \\
\text { are situated in the larger midden } \\
\text { area on the west bank of the river. } \\
\text { One house pit is on the east bank. } \\
\text { Further to the east of the eastern } \\
\text { locality is a 1930s reindeer corral } \\
\text { area. Several shallow pits, possibly } \\
\text { cache pits are located at the } \\
\text { confluence of Panuksigvik Creek. } \\
\text { There may be earlier houses } \\
\text { somewhat away from the eastern } \\
\text { bank. }\end{array}$ \\
\hline
\end{tabular}




\begin{tabular}{|c|c|c|c|c|c|c|}
\hline $\begin{array}{l}\text { SHU- } \\
00008\end{array}$ & Isigalik & $\begin{array}{l}\text { Large } \\
\text { Village }\end{array}$ & 15 & Unknown & N/A & $\begin{array}{l}\text { Anderson and Anderson reported } \\
\text { about } 15 \text { house pits facing Isragalik } \\
\text { Creek, which drains the largest lake } \\
\text { in the region. Additional cache pits } \\
\text { and shallow depressions which may } \\
\text { be house pits are located at the } \\
\text { mouth of the creek. Tests produced } \\
\text { a graphite nodule, a chert flake, and } \\
\text { some pottery lamp sherds. }\end{array}$ \\
\hline $\begin{array}{l}\text { SHU- } \\
00009\end{array}$ & Shungnak Site & $\begin{array}{l}\text { Small } \\
\text { Village }\end{array}$ & 5 & $\begin{array}{l}\text { After } 500 \\
\text { BP }\end{array}$ & $\begin{array}{l}\text { Cultural } \\
\text { Association }\end{array}$ & $\begin{array}{l}\text { Giddings excavated one of several } \\
\text { shallow pits concealed by willow } \\
\text { thickets, on the bank opposite the } \\
\text { present village of Shungnak. The } \\
9.5^{\prime} \times 15.5^{\prime} \text { house, with a } 12 \text { ' tunnel, } \\
\text { was built on the same plan as the } \\
\text { Ambler Island houses. A nearly 6' } \\
\text { long oval fireplace was outlined by } \\
\text { large stones. The house was } \\
\text { estimated to date from the mid- } \\
1800 \text { s, or perhaps a little earlier. }\end{array}$ \\
\hline $\begin{array}{l}\text { SHU- } \\
00010\end{array}$ & Pick River & $\begin{array}{l}\text { Small } \\
\text { Village }\end{array}$ & 2 & Unknown & N/A & $\begin{array}{l}\text { Giddings excavated the two houses } \\
\text { found at this site, both of which } \\
\text { differed from the Ambler Island } \\
\text { pattern only in having an apparent } \\
\text { entry chamber at the outer end of } \\
\text { the tunnel. }\end{array}$ \\
\hline $\begin{array}{l}\text { SHU- } \\
00013\end{array}$ & & $\begin{array}{l}\text { Single } \\
\text { House }\end{array}$ & 1 & Unknown & N/A & $\begin{array}{l}\text { Anderson noted a single } 4.5 \mathrm{~m} \times 2 \mathrm{~m} \\
\text { house pit, with a } 2 \mathrm{~m} \text { long entrance, } \\
\text { half way between a high cut bank of } \\
\text { Kugarak River and a lake, about } \\
\text { two bends above the mouth of } \\
\text { Rabbit River. A } 50 \mathrm{~cm} \times 50 \mathrm{~cm} \text { test } \\
\text { pit in the center of the depression } \\
\text { revealed the edge of a hearth at } \\
\text { about } 42 \mathrm{~cm} \text {. }\end{array}$ \\
\hline
\end{tabular}




\begin{tabular}{|c|c|c|c|c|c|c|}
\hline $\begin{array}{l}\text { SHU- } \\
00021\end{array}$ & Tekeahruguruk & $\begin{array}{l}\text { Small } \\
\text { Village }\end{array}$ & 5 & $\begin{array}{l}\text { After } 500 \\
\text { BP }\end{array}$ & $\begin{array}{l}\text { Cultural } \\
\text { Association }\end{array}$ & $\begin{array}{l}\text { Giddings excavated two of at least } \\
\text { five houses located at this willow } \\
\text { and alder covered site. The houses } \\
\text { were like those at Ambler Island. } \\
\text { Many jade fragments were noted. A } \\
\text { single blue bead indicated a } \\
\text { relatively recent age for one of the } \\
\text { houses. }\end{array}$ \\
\hline $\begin{array}{l}\text { SHU- } \\
00022\end{array}$ & Black River & $\begin{array}{l}\text { Large } \\
\text { Village }\end{array}$ & 8 & $\begin{array}{l}\text { After } 500 \\
\text { BP }\end{array}$ & $\begin{array}{l}\text { Cultural } \\
\text { Association }\end{array}$ & $\begin{array}{l}\text { Giddings noted eight house pits and } \\
\text { approximately } 30 \text { cache pits on a } \\
\text { sand ridge on the left bank of Black } \\
\text { River. All eight houses, one of } \\
\text { which may have been a kazgi, were } \\
\text { excavated. The houses differed from } \\
\text { the Ambler Island pattern only in } \\
\text { the apparent roof design. The site } \\
\text { may be slightly older than those at } \\
\text { Ambler Island. }\end{array}$ \\
\hline $\begin{array}{l}\text { SHU- } \\
00023\end{array}$ & $\begin{array}{l}\text { Slough Opposite } \\
\text { Black River } \\
\text { Mouth }\end{array}$ & Village & Unknown & Unknown & N/A & $\begin{array}{l}\text { Giddings noted several house pits } \\
\text { and tested at this site. }\end{array}$ \\
\hline $\begin{array}{l}\text { SHU- } \\
00024\end{array}$ & $\begin{array}{l}\text { River Bend } \\
\text { Below Black } \\
\text { River }\end{array}$ & Village & Unknown & Unknown & N/A & $\begin{array}{l}\text { Giddings noted several houses at } \\
\text { intervals. }\end{array}$ \\
\hline $\begin{array}{l}\text { SHU- } \\
00028\end{array}$ & $\begin{array}{l}\text { Cleveland } \\
\text { Homestead Site }\end{array}$ & $\begin{array}{l}\text { Small } \\
\text { Village }\end{array}$ & 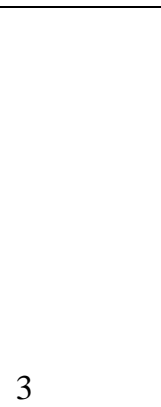 & Unknown & N/A & $\begin{array}{l}\text { BIA investigators noted a log cabin, } \\
\text { a standing cache, and posts for an } \\
\text { additional cache in a cleared area } \\
\text { and three large depressions just } E \text { of } \\
\text { the clearing. Depression } 1 \text { measures } \\
4.7 \mathrm{~m} \times 3.2 \mathrm{~m} \times 1 \mathrm{~m} \text { deep and has a } \\
2 \mathrm{~m} \text { long entryway. Two small cache } \\
\text { pits are associated with this } \\
\text { depression. Depression } 2 \text { measures } \\
4.7 \mathrm{~m} \times 3 \mathrm{~m} \times 1.2 \mathrm{~m} \text { deep, is well- }\end{array}$ \\
\hline
\end{tabular}




\begin{tabular}{|c|c|c|c|c|c|c|}
\hline & & & & & & $\begin{array}{l}\text { defined, and has a T-shaped } \\
\text { entryway. A rectangular pit lies off } \\
\text { one corner. Depression } 3 \text { measures } \\
3.1 \mathrm{~m} \times 3.5 \mathrm{~m} \times .6 \mathrm{~m} \text { deep, has well- } \\
\text { defined walls, but has no apparent } \\
\text { entryway. }\end{array}$ \\
\hline $\begin{array}{l}\text { SHU- } \\
00036\end{array}$ & Qimmin Akuniq & $\begin{array}{l}\text { Large } \\
\text { Village }\end{array}$ & 11 & $\begin{array}{l}\text { Historic } \\
\text { Occupatio } \\
\text { n }\end{array}$ & $\begin{array}{l}\text { Historic } \\
\text { Material }\end{array}$ & $\begin{array}{l}\text { Cultural remains consist of a } \\
\text { collapsed wooden cache, } 11 \text { small } \\
\text { pits, } 6 \text { log piles, and an arrangement } \\
\text { of stakes. }\end{array}$ \\
\hline $\begin{array}{l}\text { SLK- } \\
00006\end{array}$ & Inuktut & Village & Unknown & Unknown & N/A & $\begin{array}{l}\text { A former Eskimo village or camp } \\
\text { was reported on Igloo Point in } 1898 \\
\text { by Lt. E.P. Bertholf, USRCS. } \\
\text { Apparently Charles Lucier, UAF, } \\
\text { conducted excavations here. In } \\
\text { 1883, Jacobsen stayed at the house } \\
\text { of his guide, Inuktok, on a point of } \\
\text { land in the bay. Ray notes that the } \\
\text { village of Inuktok (Inyuktuk) on } \\
\text { Igloo Point refers to a deadly fight } \\
\text { with Selawik people. Keith } \\
\text { Woodworth, BLM, reported a site } \\
\text { consisting of several probable house } \\
\text { pits and what was identified as an } \\
\text { old cemetery site at this location. } \\
\text { Buckland informants stated that the } \\
\text { site represented a battleground } \\
\text { resulting from an attack by Selawik } \\
\text { residents, and also stated that some } \\
\text { excavations had been performed at } \\
\text { the site by Otto Geist. It is assumed } \\
\text { that all of this refers to the same } \\
\text { site, at this particular location. }\end{array}$ \\
\hline
\end{tabular}




\begin{tabular}{|c|c|c|c|c|c|c|}
\hline $\begin{array}{l}\text { SLK- } \\
00001\end{array}$ & Oksik & Village & Unknown & Unknown & N/A & $\begin{array}{l}\text { Giddings reported an extensive } \\
\text { village abandoned in historic times, } \\
\text { with structures partially standing. } \\
\text { Giddings' map location is as plotted; } \\
\text { see also Ten mile Post, some } 8 \mathrm{~km} \text { to } \\
\text { the east, which according to Orth is } \\
\text { also known as Oksik. }\end{array}$ \\
\hline $\begin{array}{l}\text { SLK- } \\
00002\end{array}$ & Kiana & Village & Unknown & $\begin{array}{l}\text { Before } \\
500 \mathrm{BP}\end{array}$ & $\begin{array}{l}\text { Cultural } \\
\text { Association }\end{array}$ & $\begin{array}{l}\text { Giddings reported that the area } \\
\text { about the mouth of Squirrel River } \\
\text { encompasses a large number of } \\
\text { house pits, most of them occurring } \\
\text { singly at intervals along sand ridges } \\
\text { near the present streams as well as } \\
\text { along an oxbow lake which was } \\
\text { once an open slough. One excavated } \\
\text { house pit, on the right limit of the } \\
\text { Squirrel, was built along Ambler } \\
\text { Island patterns. A second excavated } \\
\text { house pit, on the left limit of the } \\
\text { Squirrel, proved to be somewhat } \\
\text { older, combining some slate with } \\
\text { jade work and containing both } \\
\text { armor plate and sled shoes. By } \\
\text { inference it was dated in the early } \\
\text { 1600s. The village of Kiana became } \\
\text { a supply center for the Squirrel } \\
\text { River placer mines about } 1909 \text {. }\end{array}$ \\
\hline
\end{tabular}




\begin{tabular}{|c|c|c|c|c|c|c|}
\hline $\begin{array}{l}\text { SLK- } \\
00004\end{array}$ & Kiwalik & Village & Unknown & $\begin{array}{l}\text { Before } \\
500 \mathrm{BP}\end{array}$ & $\begin{array}{l}\text { Cultural } \\
\text { Association }\end{array}$ & $\begin{array}{l}\text { This village was first reported by } \\
\text { Zagoskin as being "large." In } 1881 \\
\text { crew members of the CORWIN saw } \\
\text { a deserted hut at the mouth, } \\
\text { probably the fishing site of } \\
\text { Kikkiktuak. About } 1890 \text { it became a } \\
\text { supply point for mining activities in } \\
\text { the Candle area. In 1950-1951 } \\
\text { Charles Lucier, UAF, excavated a } \\
\text { deep, probably early Thule, house } \\
\text { pit located well west of the tip of the } \\
\text { spit. The structure may have been } \\
\text { burned at abandonment. Of the } \\
\text { material found inside the house, a } \\
\text { headless human skeleton and a wolf } \\
\text { skull, minus the mandible, were of } \\
\text { especial note. Artifacts collected } \\
\text { included an open socketed barbed } \\
\text { harpoon with a blade slot opposite } \\
\text { the barb, concentric circle paddled } \\
\text { pottery fragments, and a bone lance } \\
\text { head with a sloping shouldered tang. }\end{array}$ \\
\hline $\begin{array}{l}\text { SLK- } \\
00005\end{array}$ & Chamisso Island & Village & Unknown & $\begin{array}{l}\text { After } 500 \\
\text { BP }\end{array}$ & $\begin{array}{l}\text { Cultural } \\
\text { Association }\end{array}$ & $\begin{array}{l}\text { A former Eskimo camp or } \\
\text { settlement was reported on } \\
\text { Chamisso Island by Beechey in } \\
\text { 1827. Apparently Charles Lucier, } \\
\text { UAF, conducted excavations here; } \\
\text { the site may be of later age, ranging } \\
\text { through the Kotzebue phase. }\end{array}$ \\
\hline
\end{tabular}




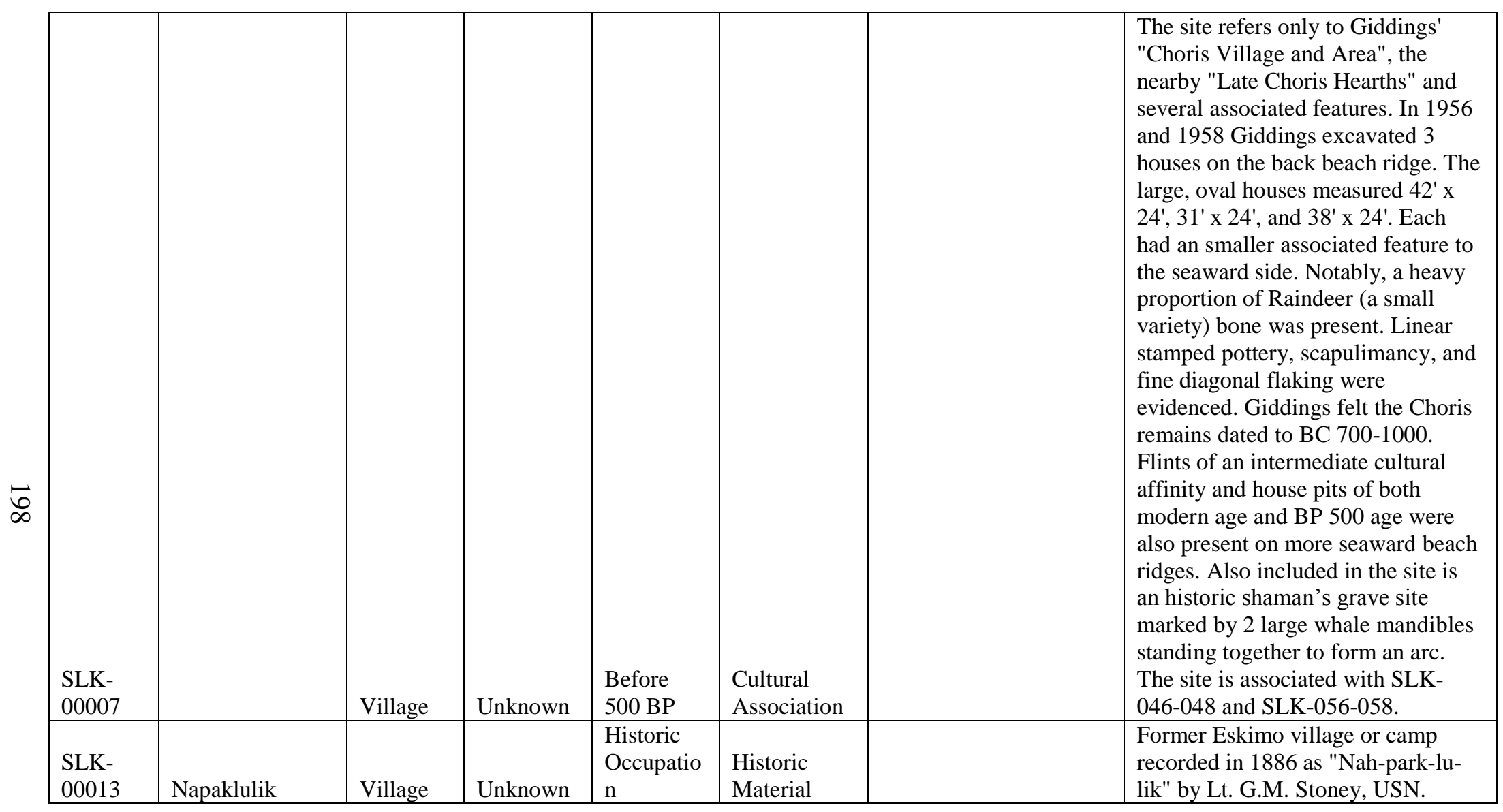




\begin{tabular}{|c|c|c|c|c|c|c|}
\hline $\begin{array}{l}\text { SLK- } \\
00016\end{array}$ & Katlisiguik & $\begin{array}{l}\text { Large } \\
\text { Village }\end{array}$ & 6 & Unknown & N/A & $\begin{array}{l}\text { Anderson and Anderson located thi } \\
\text { archaeological site and spring camp } \\
\text { on a grassy bank surrounded by } \\
\text { willow and alder. They reported six } \\
\text { house pits and at least five cache } \\
\text { pits on the east side of the stream } \\
\text { mouth and four cache pits and a } \\
\text { small midden-like mound on the } \\
\text { west side. The remains of a recent } \\
\text { spring muskrat hunting camp with a } \\
\text { camp stove and wash tub were also } \\
\text { located on the west side. }\end{array}$ \\
\hline $\begin{array}{l}\text { SLK- } \\
00017\end{array}$ & Ikaagiak & Village & Unknown & Unknown & N/A & $\begin{array}{l}\text { Anderson and Anderson located this } \\
\text { archaeological site and fall tent } \\
\text { camp on a high grass bank at the } \\
\text { mouth of a swift flowing stream } \\
\text { which drains a lake. Two house pits } \\
\text { and three cache pits were mapped } \\
\text { and other house pits were noted on } \\
\text { the river bank. Signs of recent } \\
\text { activity were noted. Reportedly a } \\
\text { traditional caribou crossing and an } \\
\text { excellent fall and winter fishing } \\
\text { spot, use continues today. The last } \\
\text { winter house was built here in } 1909 \\
\text { or } 1910 \text {. }\end{array}$ \\
\hline
\end{tabular}




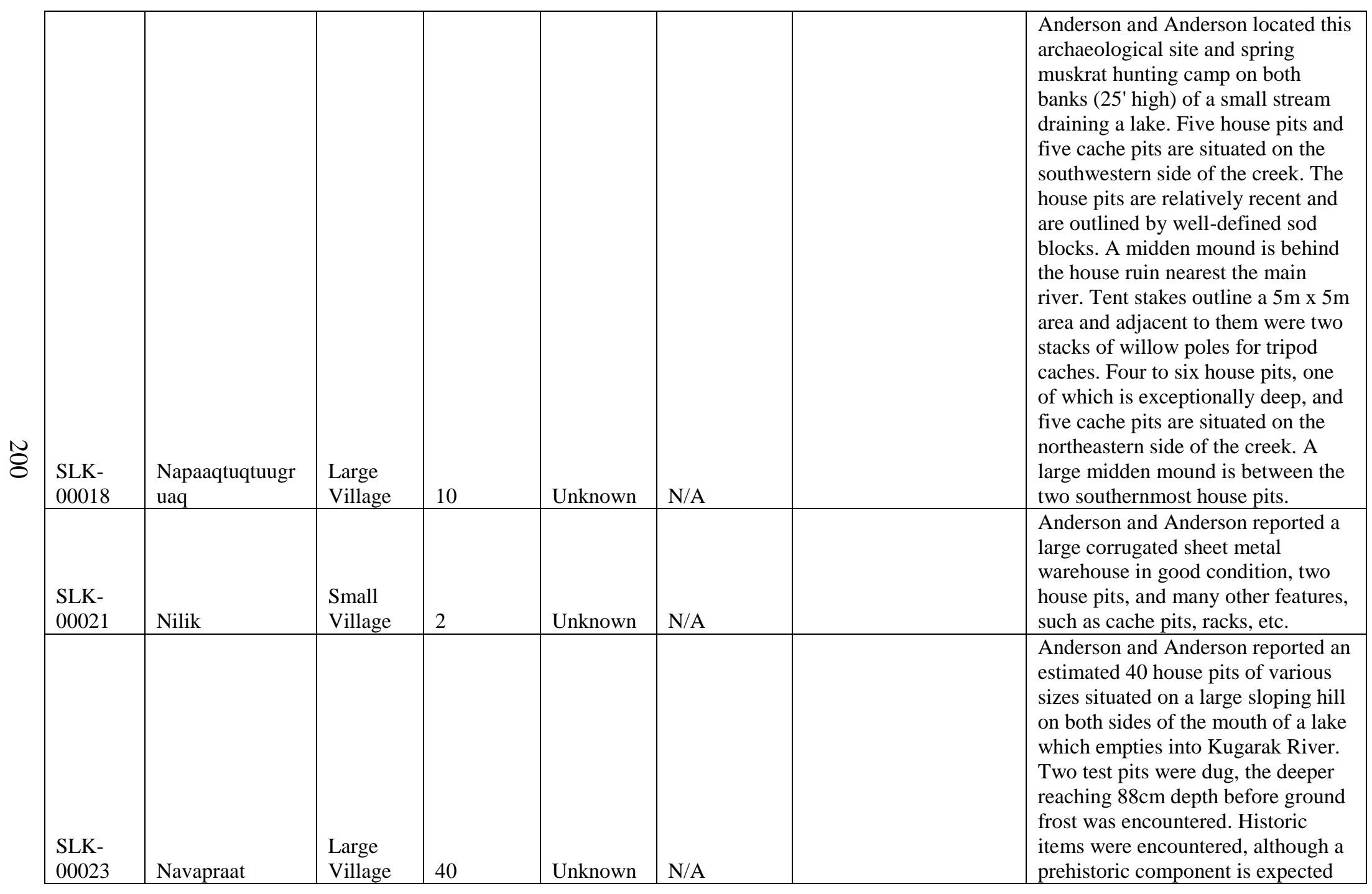




\begin{tabular}{|c|c|c|c|c|c|c|}
\hline & & & & & & $\begin{array}{l}\text { to be present. This is the largest } \\
\text { winter village site located in the } \\
\text { Selawik River drainage. }\end{array}$ \\
\hline $\begin{array}{l}\text { SLK- } \\
00024\end{array}$ & Niglaaqtuq & $\begin{array}{l}\text { Large } \\
\text { Village }\end{array}$ & 9 & Unknown & N/A & $\begin{array}{l}\text { Anderson and Anderson reported at } \\
\text { least six house pits on the north } \\
\text { bank and three house pits on the } \\
\text { south bank of the now almost dry } \\
\text { creek draining Niglaktok Lake, just } \\
\text { east of Selawik. The site has been } \\
\text { heavily potted by Selawik residents. } \\
\text { In } 1969 \text { Anderson and Anderson } \\
\text { excavated one of the house pits. The } \\
\text { apparently prehistoric dwelling was } \\
\text { formed of a } 14 \text { ' } 13 \text { ' room with a } \\
\text { short entrance tunnel. Numerous } \\
\text { artifacts, including organics, and } \\
\text { construction details were collected. }\end{array}$ \\
\hline $\begin{array}{l}\text { SLK- } \\
00025\end{array}$ & $\begin{array}{l}\text { Tuklomarak } \\
\text { River }\end{array}$ & $\begin{array}{l}\text { Large } \\
\text { Village }\end{array}$ & 7 & Unknown & N/A & $\begin{array}{l}\text { Anderson and Anderson noted a } \\
\text { total of seven house pits on the } \\
\text { north bank of "Tuklomarak River" } \\
\text { and on the tip of the peninsula at the } \\
\text { confluence of a lake outlet. A } \\
\text { graveyard is situated on the highest } \\
\text { ground of the peninsula. BLM } \\
\text { investigations noted two low } \\
\text { mounds, measuring 4m and } 3 \mathrm{~m} \text { in } \\
\text { diameter, at this location (between } \\
\text { the river channel and a shallow, } \\
\text { unnamed lake to the north). The } \\
\text { larger mound, which has apparently } \\
\text { been potted, has the remains of a }\end{array}$ \\
\hline
\end{tabular}




\begin{tabular}{|c|c|c|c|c|c|c|}
\hline & & & & & & raised burial box on one slope. \\
\hline $\begin{array}{l}\text { SLK- } \\
00026\end{array}$ & $\begin{array}{l}\text { Tuqlumaagruk } \\
\text { Paanga }\end{array}$ & $\begin{array}{l}\text { Small } \\
\text { Village }\end{array}$ & 3 & Unknown & N/A & $\begin{array}{l}\text { Anderson and Anderson noted three } \\
\text { house pits and a small metal shed on } \\
\text { the tip of the peninsula. Informants } \\
\text { reported that other house pits have } \\
\text { eroded away. }\end{array}$ \\
\hline $\begin{array}{l}\text { SLK- } \\
00028\end{array}$ & Kaiyuqtuq 1 & $\begin{array}{l}\text { Large } \\
\text { Village }\end{array}$ & 9 & Unknown & N/A & $\begin{array}{l}\text { Anderson and Anderson reported } \\
\text { three house pits on the east bank } \\
\text { and six house pits on the west bank } \\
\text { of a stream channel connecting a } \\
\text { small lake with Fox River. The } \\
\text { group of six house pits have } \\
\text { entrance tunnels facing a dried up } \\
\text { channel. BLM investigations noted } \\
\text { only a single } 2 \mathrm{~m} \text { x } 3 \mathrm{~m} \text { depression } \\
\text { on the west bank of the stream } \\
\text { channel and a low mound located in } \\
\text { grass covered area just } \mathrm{W} \text { of small } \\
\text { channel and } \mathrm{E} \text { o d dense alder } \\
\text { growth. Potting has been } \\
\text { considerable. Anderson and } \\
\text { Anderson (1977:20) make mention } \\
\text { of excavating a circa } 1900 \text { s house } \\
\text { pit tat this site in } 1976 \text { [but they may } \\
\text { have been refferring to SLK-030]. }\end{array}$ \\
\hline
\end{tabular}




\begin{tabular}{|c|c|c|c|c|c|c|}
\hline $\begin{array}{l}\text { SLK- } \\
00029\end{array}$ & Kaiyuqtuq 2 & $\begin{array}{l}\text { Small } \\
\text { Village }\end{array}$ & 5 & Unknown & N/A & $\begin{array}{l}\text { Anderson and Anderson located five } \\
\text { deep winter house pits on the south } \\
\text { bank of Fox River, opposite SLK- } \\
028 \text {. This site is likely that visited } \\
\text { by Purcell in } 1884 \text {, and that of one } \\
\text { of the old trading families whose } \\
\text { decendents moved to Selawik in } \\
1908 \text {. }\end{array}$ \\
\hline $\begin{array}{l}\text { SLK- } \\
00030\end{array}$ & Kaiyuqtuq 3 & $\begin{array}{l}\text { Large } \\
\text { Village }\end{array}$ & 7 & Unknown & N/A & $\begin{array}{l}\text { Anderson and Anderson located } \\
\text { seven house pits on the western } \\
\text { bank and three house pits on the } \\
\text { eastern bank of a former channel of } \\
\text { Fox River. On the opposite, } \\
\text { northern, bank of Fox River two } \\
\text { additional house pits and a tent site } \\
\text { were noted. Several of the house } \\
\text { pits are eroding into the river. Two } \\
\text { circa } 1900 \text { house pits were } \\
\text { excavated in } 1976 \text {. }\end{array}$ \\
\hline $\begin{array}{l}\text { SLK- } \\
00031\end{array}$ & Kaiyuqtuq 4 & Village & Unknown & Unknown & N/A & $\begin{array}{l}\text { Anderson and Anderson noted that } \\
\text { several depressions have been } \\
\text { reported on this high bank along the } \\
\text { former channel of Fox River, } \\
\text { approximately } 50-100 \mathrm{~m} \text { from the } \\
\text { channel. The site was noted from a } \\
\text { boat in passing. }\end{array}$ \\
\hline $\begin{array}{l}\text { SLK- } \\
00033\end{array}$ & Kaiyuqtuq 6 & $\begin{array}{l}\text { Small } \\
\text { Village }\end{array}$ & 4 & Unknown & N/A & $\begin{array}{l}\text { Anderson and Anderson reported } \\
\text { four house pits on a low gray } \\
\text { peninsula formed at a tight meander } \\
\text { of the old channel of Fox River. } \\
\text { Additional house pits may be } \\
\text { located at the mouth of a slough on } \\
\text { the opposite bank of the channel, } \\
\text { about } 200 \text { yards to the east. }\end{array}$ \\
\hline
\end{tabular}




\begin{tabular}{|c|c|c|c|c|c|c|}
\hline $\begin{array}{l}\text { SLK- } \\
00035\end{array}$ & Iggiaq & $\begin{array}{l}\text { Small } \\
\text { Village }\end{array}$ & 3 & Unknown & N/A & $\begin{array}{l}\text { Anderson and Anderson reported } \\
\text { three exceptionally large house pits, } \\
\text { two of which were over 5' deep. } \\
\text { Other possible house pits may be } \\
\text { located on the stream bank } \\
\text { opposite.[The locational description } \\
\text { provided by Anderson and } \\
\text { Anderson does not at all match the } \\
\text { map location provided in their } 1972 \\
\text { report.] }\end{array}$ \\
\hline $\begin{array}{l}\text { SLK- } \\
00036\end{array}$ & Imukgiatchiaq & $\begin{array}{l}\text { Large } \\
\text { Village }\end{array}$ & 13 & Unknown & N/A & $\begin{array}{l}\text { Anderson and Anderson reported } \\
\text { that at least } 13 \text { house pits and } \\
\text { probably more lie scattered around } \\
\text { this site, described as being situated } \\
\text { on high grassy terrain surrounding a } \\
\text { large marsh and lake area connected } \\
\text { to Selawik River. Six of the house } \\
\text { pits are on the peninsula facing } \\
\text { Selawik River and two are eroding } \\
\text { into the lake. Several fish drying } \\
\text { racks, tent frames, and a gravesite } \\
\text { are dispersed over an area between } \\
\text { two lakes. Some of the houses were } \\
\text { built since the 1930s. [The location } \\
\text { of this site is unclear. The locational } \\
\text { description could not match the map } \\
\text { location provided in their } 1972 \\
\text { report.] }\end{array}$ \\
\hline $\begin{array}{l}\text { SLK- } \\
00037\end{array}$ & Paalitkiing & $\begin{array}{l}\text { Small } \\
\text { Village }\end{array}$ & 4 & Unknown & N/A & $\begin{array}{l}\text { Anderson and Anderson reported } \\
\text { four and possibly five house pits on } \\
\text { the grassy bank of the stream } \\
\text { connecting Niglaiktok Lake to a } \\
\text { series of other lakes to the west. } \\
\text { Additionally, a garden plot, used in } \\
\text { 1968, and two disturbed areas, }\end{array}$ \\
\hline
\end{tabular}




\begin{tabular}{|c|c|c|c|c|c|}
\hline & & & & & $\begin{array}{l}\text { which may be tent sites, were noted. } \\
\text { Apparently the stream was created } \\
\text { by the digging of a ditch between } \\
\text { two waterways. }\end{array}$ \\
\hline $\begin{array}{l}\text { SLK- } \\
00038\end{array}$ & $\begin{array}{l}\text { Single } \\
\text { House }\end{array}$ & 1 & Unknown & N/A & $\begin{array}{l}\text { An apparent house pit was located } \\
\text { in a shallow swale between a } \\
\text { narrow stream channel and a small } \\
\text { cove of an unnamed lake. No } \\
\text { outline was apparent, but the area is } \\
\text { covered with grass as opposed to the } \\
\text { willow and alder in the surrounding } \\
\text { area. The site has been potted by the } \\
\text { allotment applicant and his family; } \\
\text { charcoal was noted in the back dirt. } \\
\text { During examination of the site, an } \\
\text { incised pottery vessel fragment, a } \\
\text { fragment of bone armor or sled } \\
\text { runner, birch bark, apparent ground } \\
\text { stone fragments, and a bone } \\
\text { implement were noted. }\end{array}$ \\
\hline $\begin{array}{l}\text { SLK- } \\
00042\end{array}$ & $\begin{array}{l}\text { Small } \\
\text { Village }\end{array}$ & 2 & Unknown & N/A & $\begin{array}{l}\text { This site consists of two (more or } \\
\text { less) depressions, possibly house } \\
\text { pits, located immediately adjacent } \\
\text { to Buckland River. A tent frame and } \\
\text { cache were located just to the north } \\
\text { of the depressions. }\end{array}$ \\
\hline
\end{tabular}




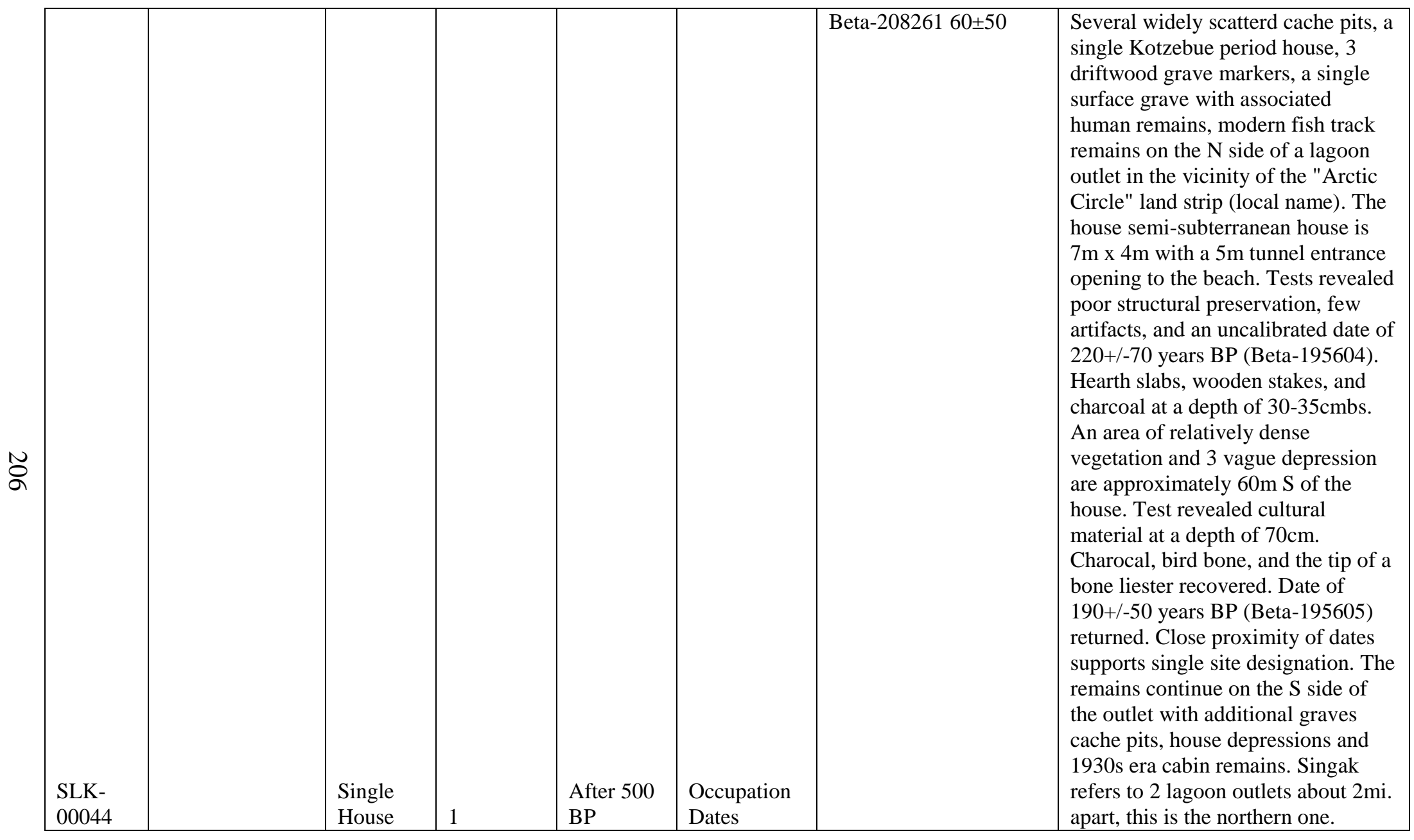




\begin{tabular}{|c|c|c|c|c|c|c|}
\hline $\begin{array}{l}\text { SLK- } \\
00045\end{array}$ & $\begin{array}{l}\text { Tommie Snyder } \\
\text { Allotment }\end{array}$ & $\begin{array}{l}\text { Small } \\
\text { Village }\end{array}$ & 2 & $\begin{array}{l}\text { Historic } \\
\text { Occupatio } \\
\mathrm{n}\end{array}$ & $\begin{array}{l}\text { Historic } \\
\text { Material } \\
\end{array}$ & $\begin{array}{l}\text { The site was used as a fish camp. } \\
\text { The site consists of two house } \\
\text { depressions, } 3.09 \mathrm{~m} \times 2.1 \mathrm{~m} \text { and } \\
0.85 \mathrm{~m} \times 2.35 \mathrm{~m} \text {, four other } \\
\text { depressions, a collapsed sod } \\
\text { structure, } 1.38 \mathrm{~m} \times 1.5 \mathrm{~m} \text {, and a } 2 \mathrm{~m} \times \\
4.67 \mathrm{~m} \text { cache with the height of the } \\
\text { ridge pole being } 2.15 \mathrm{~m} \text {. There is a } \\
\text { grave site located on the allotment, } \\
\text { marked by spruce-poles. The } \\
\text { upright posts represent the remains } \\
\text { of a fish rack. }\end{array}$ \\
\hline $\begin{array}{l}\text { SLK- } \\
00046\end{array}$ & Qutisugruk & Village & Unknown & $\begin{array}{l}\text { Continuou } \\
\mathrm{s} \\
\text { Occupatio } \\
\mathrm{n}\end{array}$ & $\begin{array}{l}\text { Cultural } \\
\text { Association }\end{array}$ & $\begin{array}{l}\text { A multi-component site along the } \\
\text { beach and on the bluffs above. It } \\
\text { includes the main "Choris Village } \\
\text { and Areas" and "Late Choris } \\
\text { Hearths" (SLK-007), the South } \\
\text { Bluff Locus (SLK-058), North Bluff } \\
\text { Locus (SLK-056), Thule-Kotzebue } \\
\text { Village (SLK-047), SLK-057, and } \\
\text { the historic Mendenhall Camp } \\
\text { (SLK-048). A total of } 225 \\
\text { prehistoric and historic features } \\
\text { have been identified, including } 2 \\
\text { standing structures, } 5 \text { tent pads, } 5 \\
\text { tent rings, } 5 \text { hearths, } 3 \text { rock cairns, } \\
\text { and } 4 \text { burials. }\end{array}$ \\
\hline $\begin{array}{l}\text { SLK- } \\
00047\end{array}$ & $\begin{array}{l}\text { Thule-Kotzebue } \\
\text { Village }\end{array}$ & $\begin{array}{l}\text { Large } \\
\text { Village }\end{array}$ & 6 & $\begin{array}{l}\text { Continuou } \\
\mathrm{s} \\
\text { Occupatio } \\
\mathrm{n}\end{array}$ & $\begin{array}{l}\text { Cultural } \\
\text { Association }\end{array}$ & $\begin{array}{l}\text { The site consists of } 2 \text { house features } \\
\text { along the beach N of Choris } \\
\text { Village. "House } 4 \text { " was a small } \\
\text { dwelling dating from the } 18 \text { th } \\
\text { century. "House } 5 " \text {, which is about } \\
150 \mathrm{~m} \text { S, dates to about the } 15 \text { th } \\
\text { century. The site is part of the } \\
\text { Choris Site (SLK-046). BIA }\end{array}$ \\
\hline
\end{tabular}




\begin{tabular}{|c|c|c|c|c|c|c|c|}
\hline & & & & & & & $\begin{array}{l}\text { ANCSA report indicates } 6 \text { houses in } \\
\text { the village. }\end{array}$ \\
\hline $\begin{array}{l}\text { SLK- } \\
00048\end{array}$ & $\begin{array}{l}\text { Mendenhall } \\
\text { Camp }\end{array}$ & $\begin{array}{l}\text { Small } \\
\text { Village }\end{array}$ & 2 & $\begin{array}{l}\text { Historic } \\
\text { Occupatio } \\
\mathrm{n}\end{array}$ & $\begin{array}{l}\text { Historic } \\
\text { Material } \\
\end{array}$ & & $\begin{array}{l}\text { The site includes } 2 \text { standing sod } \\
\text { houses and a probable Native grave } \\
\text { (features } 7,8,53-55 \text { of the Choris } \\
\text { site, SLK-046). Both houses are } \\
\text { rectangular, semi-subterranean, sod- } \\
\text { covered dwellings. Feature } 7 \text { has a } \\
\text { collapsed gable roof and measures } \\
16.6 \mathrm{~m} \text { x } 9.8 \mathrm{~m} \text {. Feature } 8 \text { has an } \\
\text { intact roof standing } 1.8 \mathrm{~m} \text { high and } \\
\text { measures } 9.9 \mathrm{~m} \times 9.3 \mathrm{~m} \text {. Features } 53 \\
\text { and } 54 \text { are depressions, roughly } 5 \mathrm{~m} \\
\text { square and } 5.4 \mathrm{~m} \times 5 \mathrm{~m} \text {, respectively. } \\
\text { Feature } 55 \text { is the possible grave } \\
\text { feature, which consists of a } \\
\text { depression } 2.2 \mathrm{~m} \times 1.5 \mathrm{~m} \text { with } \\
\text { associated wood and metal artifacts. }\end{array}$ \\
\hline $\begin{array}{l}\text { SLK- } \\
00049\end{array}$ & Sisiivik & $\begin{array}{l}\text { Large } \\
\text { Village }\end{array}$ & $160 ?$ & $\begin{array}{l}\text { Continuou } \\
\mathrm{s} \\
\text { Occupatio } \\
\mathrm{n}\end{array}$ & $\begin{array}{l}\text { Occupation } \\
\text { Dates }\end{array}$ & $\begin{array}{l}\text { Beta-23386 } 610 \pm 100 \\
\text { Beta-287532 } 300 \pm 40 \\
\text { Beta-287533 400 }\end{array}$ & $\begin{array}{l}\text { On two beach ridges a total of } 160 \\
\text { house and cache depressions, } 8 \\
\text { graves, a light chert lithic scatter, } \\
\text { and several cultural distribution } \\
\text { areas. A test pit was excavated } \\
\text { within a house depression. Cultural } \\
\text { material recovered from the test pit } \\
\text { included pottery pieces, burnt bone } \\
\text { fragments, numerous chert and } \\
\text { lithic debitage, and charcoal. }\end{array}$ \\
\hline
\end{tabular}




\begin{tabular}{|c|c|c|c|c|c|c|}
\hline $\begin{array}{l}\text { SLK- } \\
00054\end{array}$ & Katayaak & Village & Unknown & Unknown & N/A & $\begin{array}{l}\text { Anderson and Anderson located at } \\
\text { least one house pit and an old } \\
\text { willow frame (qaanaq) for a round } \\
\text { tent on the point bar formed at a } \\
\text { broad bend in Selawik River, where } \\
\text { it is joined by Taggagvik River. } \\
\text { Also noted were two large areas that } \\
\text { appear to have been disturbed } \\
\text { through digging.[Listed in report as } \\
\text { SHU-011.] }\end{array}$ \\
\hline $\begin{array}{l}\text { SLK- } \\
00055\end{array}$ & Anigulaaq & $\begin{array}{l}\text { Single } \\
\text { House }\end{array}$ & 1 & Unknown & N/A & $\begin{array}{l}\text { Anderson and Anderson located six } \\
\text { deep cache pits, one house pit, and } \\
\text { cut logs (apparently from a log } \\
\text { cabin) on a flat bench of a high cut } \\
\text { bank on the outer bend of a meander } \\
\text { of Tagagavik River, where a small } \\
\text { stream channel joins the main } \\
\text { river.[Listed in report as SHU-012.] }\end{array}$ \\
\hline $\begin{array}{l}\text { SLK- } \\
00060\end{array}$ & $\begin{array}{l}\text { Kivgalum } \\
\text { Kuuvgitchiam }\end{array}$ & $\begin{array}{l}\text { Single } \\
\text { House }\end{array}$ & 1 & Unknown & N/A & $\begin{array}{l}\text { Anderson and Anderson located } \\
\text { one, possibly two, house pits and } \\
\text { four cache pits on the east bank of } \\
\text { Fish River, near the mouth of a } \\
\text { small stream. }\end{array}$ \\
\hline $\begin{array}{l}\text { SLK- } \\
00063\end{array}$ & $\begin{array}{l}\text { Qusrimmaktuiaq } \\
2\end{array}$ & $\begin{array}{l}\text { Single } \\
\text { House }\end{array}$ & 1 & Unknown & N/A & $\begin{array}{l}\text { Anderson and Anderson located a } \\
\text { rapidly eroding house pit on a tiny } \\
\text { island in a lower channel of Selawik } \\
\text { River. }\end{array}$ \\
\hline
\end{tabular}




\begin{tabular}{|c|c|c|c|c|c|c|}
\hline $\begin{array}{l}\text { SLK- } \\
00064\end{array}$ & Qilagaq & $\begin{array}{l}\text { Small } \\
\text { Village }\end{array}$ & 4 & Unknown & N/A & $\begin{array}{l}\text { Anderson and Anderson located this } \\
\text { site at the mouth of a small stream } \\
\text { draining a lake into the lower } \\
\text { Selawik River and the area at the } \\
\text { bend in the main channel on the } \\
\text { opposite bank. One nearly complete } \\
\text { and two partially eroded house } \\
\text { depressions and two cache pits on } \\
\text { one bank inside the mouth of the } \\
\text { creek. Fish racks, a tent frame, and a } \\
\text { small fish storage house were } \\
\text { located at the mouth of the creek on } \\
\text { the same side of the channel and } \\
\text { fish racks and another tent frame } \\
\text { were located on the opposite bank } \\
\text { of the creek. One possible house pit, } \\
\text { one intact and two partially eroded } \\
\text { house pits were located on the } \\
\text { opposite bank of the main channel. }\end{array}$ \\
\hline $\begin{array}{l}\text { SLK- } \\
00067\end{array}$ & Sikanugan & $\begin{array}{l}\text { Single } \\
\text { House }\end{array}$ & 1 & Unknown & N/A & $\begin{array}{l}\text { Anderson and Anderson located one } \\
\text { large house pit with a tunnel, four } \\
\text { rectangular depressions of } \\
\text { undetermined function, and three } \\
\text { cache pits on a grassy peninsula at } \\
\text { the entrance to a lake. The walls of } \\
\text { the depressions are steep and appear } \\
\text { to have been made relatively } \\
\text { recently. The end of the tunnel and } \\
\text { one rectangular depression are } \\
\text { eroding. }\end{array}$ \\
\hline $\begin{array}{l}\text { SLK- } \\
00068\end{array}$ & Ayugrauq & $\begin{array}{l}\text { Small } \\
\text { Village }\end{array}$ & 2 & Unknown & N/A & $\begin{array}{l}\text { Anderson and Anderson located two } \\
\text { house pits, an old cache/storage pit, } \\
\text { and a recent tent frame and fish } \\
\text { racks on a grassy bank at the outlet } \\
\text { of a small stream into a tributary of }\end{array}$ \\
\hline
\end{tabular}




\begin{tabular}{|c|c|c|c|c|c|c|}
\hline & & & & & & the lower Selawik River. \\
\hline $\begin{array}{l}\text { SLK- } \\
00069\end{array}$ & Utqusriasaq & $\begin{array}{l}\text { Small } \\
\text { Village }\end{array}$ & 4 & Unknown & N/A & $\begin{array}{l}\text { Anderson and Anderson located } \\
\text { four house pits on the edge of a } \\
\text { large grassy bank along a waterway } \\
\text { leading from a large lake in the } \\
\text { lower part of Selawik River. Two of } \\
\text { the house pits are half gone through } \\
\text { erosion and the site is suffering } \\
\text { from local pot hunting. }\end{array}$ \\
\hline $\begin{array}{l}\text { SLK- } \\
00070\end{array}$ & Paaqliq & $\begin{array}{l}\text { Small } \\
\text { Village }\end{array}$ & 3 & Unknown & N/A & $\begin{array}{l}\text { Anderson and Anderson located at } \\
\text { least three house depressions and } \\
\text { numerous recent occupation } \\
\text { features (including deep cache pits, } \\
\text { a large lookout tower, a fish rack, } \\
\text { and a plank boat) on both sides of } \\
\text { Noyyatuuq River. About } 400 \mathrm{~m} \\
\text { upstream a grave box was noted. } \\
\text { The site has several high mounds on } \\
\text { it, apparently the result of a great } \\
\text { deal of digging for the house pits. }\end{array}$ \\
\hline $\begin{array}{l}\text { SLK- } \\
00071\end{array}$ & & $\begin{array}{l}\text { Small } \\
\text { Village }\end{array}$ & 4 & Unknown & N/A & $\begin{array}{l}\text { Anderson and Anderson located at } \\
\text { least four house pits and two } \\
\text { cache/storage pits in a grassy area } \\
\text { along the Kuutchiaq River, near the } \\
\text { outlet of a small lake. The largest } \\
\text { depression is trapezoidal in plan and } \\
\text { may be the result of two partially } \\
\text { superimposed house pits. At least } \\
\text { one house pit is eroding into the } \\
\text { river. }\end{array}$ \\
\hline SLK- & & Small & 4 & Unknown & N/A & Anderson and Anderson located \\
\hline
\end{tabular}




\begin{tabular}{|c|c|c|c|c|c|c|}
\hline 00072 & & Village & & & & $\begin{array}{l}\text { four house pits and three cache pits } \\
\text { on a high tundra covered knoll at a } \\
\text { sharp bend in Kuutchiaq River. Two } \\
\text { of the house pits are intact and two } \\
\text { are eroding. The intact house pits } \\
\text { have relatively long entrance } \\
\text { tunnels which apparently terminate } \\
\text { in storm sheds. }\end{array}$ \\
\hline $\begin{array}{l}\text { SLK- } \\
00074 \\
\end{array}$ & Milugiivik & $\begin{array}{l}\text { Large } \\
\text { Village }\end{array}$ & 6 & Unknown & N/A & $\begin{array}{l}\text { Anderson and Anderson located six } \\
\text { house pits and several cache pits on } \\
\text { a high tundra covered peninsula } \\
\text { between Kuutchiaq River and a } \\
\text { large lake. One of the depressions } \\
\text { lacks a tunnel and may be a karagi, } \\
\text { one appears to have two entrances } \\
\text { extending in opposite directions and } \\
\text { may be two superimposed houses, } \\
\text { and two other house pits have long } \\
\text { entrance tunnels with storm shed- } \\
\text { like areas at the outer end. }\end{array}$ \\
\hline $\begin{array}{l}\text { SLK- } \\
00076\end{array}$ & Kuutchiapaamiit & $\begin{array}{l}\text { Single } \\
\text { House }\end{array}$ & 1 & Unknown & N/A & $\begin{array}{l}\text { Anderson and Anderson located one } \\
\text { large sod-lined house depression } \\
\text { adjacent to a large grassy midden } \\
\text { area along a dense willow covered } \\
\text { bank of Kuutchiaq River, just } \\
\text { upstream of its first bend from } \\
\text { Inland Lake. A cache pit was noted } \\
\text { at the opposite of the midden. } \\
\text { Several other house pits are reported } \\
\text { to have eroded away. }\end{array}$ \\
\hline $\begin{array}{l}\text { SLK- } \\
00082\end{array}$ & & $\begin{array}{l}\text { Single } \\
\text { House }\end{array}$ & 1 & Unknown & N/A & $\begin{array}{l}\text { This site consists of } 4.5 \mathrm{~m} \times 3 \mathrm{~m} \\
\text { house depression, with a } 40 \mathrm{~cm} \text { high } \\
\text { berm and a } 2 \mathrm{~m} \text { long entry. Two } \\
\text { accessory pits are along the house } \\
\text { pit's SW and NE margins. Standing }\end{array}$ \\
\hline
\end{tabular}




\begin{tabular}{|c|c|c|c|c|c|c|}
\hline & & & & & & $\begin{array}{l}\text { wood structural elements and debris } \\
\text { were noted, as were large round } \\
\text { nails. }\end{array}$ \\
\hline $\begin{array}{l}\text { SLK- } \\
00086\end{array}$ & & $\begin{array}{l}\text { Single } \\
\text { House }\end{array}$ & 1 & $\begin{array}{l}\text { Continuou } \\
\text { s } \\
\text { Occupatio } \\
\mathrm{n}\end{array}$ & $\begin{array}{l}\text { Cultural } \\
\text { Association }\end{array}$ & $\begin{array}{l}\text { A } 5.5 \mathrm{~m} \times 2.8 \mathrm{~m} \times .35 \mathrm{~m} \text { deep } \\
\text { depression was noted at the base of } \\
\text { the bluff, about } 25 \mathrm{~m} \text { from the } \\
\text { modern beach. } 1 \times 1 \mathrm{~m} \text { unit was } \\
\text { excavated within the depression. } \\
\text { Vague stratigraphic contours, } \\
\text { structural members, and a nail were } \\
\text { recorded in the unit. }\end{array}$ \\
\hline $\begin{array}{l}\text { SLK- } \\
00088\end{array}$ & $\begin{array}{l}\text { Selawik House } \\
\text { Depression }\end{array}$ & $\begin{array}{l}\text { Single } \\
\text { House }\end{array}$ & 1 & $\begin{array}{l}\text { Historic } \\
\text { Occupatio } \\
\text { n }\end{array}$ & $\begin{array}{l}\text { Historic } \\
\text { Material }\end{array}$ & $\begin{array}{l}\text { The site consists of a well-defined } \\
\text { house depression with an expanse of } \\
\text { disturbance vegetation (150m x } \\
20 \mathrm{~m} \text { ) extending E to the shore of a } \\
\text { small lake. The depression is the } \\
\text { remains of a sod house built by } \\
\text { Annie Sun and the disturbance area } \\
\text { was the dog yard. }\end{array}$ \\
\hline $\begin{array}{l}\text { SLK- } \\
00095\end{array}$ & $\begin{array}{l}\text { House } \\
\text { Depressions } \\
\text { Above Okok } \\
\text { Poiny }\end{array}$ & $\begin{array}{l}\text { Small } \\
\text { Village }\end{array}$ & 4 & Unknown & N/A & $\begin{array}{l}\text { Consists of four regular house } \\
\text { depressions with entry tunnels and } \\
\text { several small circular depressions } \\
\text { that are probably cache pits. }\end{array}$ \\
\hline $\begin{array}{l}\text { SLK- } \\
00097\end{array}$ & $\begin{array}{l}\text { Johnson Fish } \\
\text { Camp }\end{array}$ & $\begin{array}{l}\text { Single } \\
\text { House }\end{array}$ & 1 & Unknown & N/A & $\begin{array}{l}\text { The site is a historic seasonal fish } \\
\text { camp. Features includes an ax- } \\
\text { notched log pole cache, split-log } \\
\text { shed, cache depression with two } \\
\text { rows of ax-notched foundation } \\
\text { posts, smokehouse, an old house } \\
\text { foundation, structural foundation, } \\
\text { and a rectangular house depression. }\end{array}$ \\
\hline
\end{tabular}




\begin{tabular}{|c|c|c|c|c|c|c|}
\hline $\begin{array}{l}\text { SLK- } \\
00100\end{array}$ & $\begin{array}{l}\text { Kiwalik Spit } \\
\text { Village }\end{array}$ & $\begin{array}{l}\text { Small } \\
\text { Village }\end{array}$ & 5 & $\begin{array}{l}\text { Continuou } \\
\mathrm{s} \\
\text { Occupatio } \\
\mathrm{n}\end{array}$ & $\begin{array}{l}\text { Cultural } \\
\text { Association }\end{array}$ & $\begin{array}{l}\text { This site contains at least } 5 \text { house } \\
\text { depressions and numerous cache } \\
\text { pits. Three of the house depressions } \\
\text { consist of one room with entrance } \\
\text { tunnels. The other } 2 \text { have } 2 \text { rooms } \\
\text { with no discernable entrance tunnel. } \\
\text { A test pit was done in } 3 \text { of the house } \\
\text { depressions. }\end{array}$ \\
\hline $\begin{array}{l}\text { SLK- } \\
00102\end{array}$ & Dobuk & $\begin{array}{l}\text { Single } \\
\text { House }\end{array}$ & 1 & $\begin{array}{l}\text { Historic } \\
\text { Occupatio } \\
\mathrm{n}\end{array}$ & $\begin{array}{l}\text { Historic } \\
\text { Material }\end{array}$ & $\begin{array}{l}\text { This site consists of a } 3.5 \mathrm{~m} \times 3.5 \mathrm{~m} \\
\text { house depression on a steep slope } \\
\text { adjacent to a small tributary stream. } \\
\text { Three associated pits were noted, at } \\
\text { the base of the slope and above the } \\
\text { house depression. A wooden box } \\
\text { with square nails was found near } \\
\text { one of the pits. The house was } \\
\text { estimated to be of 19th century age. } \\
\text { Donald Smith (Kiana) reported the } \\
\text { site name. [In Gannon's report this } \\
\text { site is referred to as SLK-093.] }\end{array}$ \\
\hline $\begin{array}{l}\text { SLK- } \\
00105\end{array}$ & $\begin{array}{l}\text { Kobuk House } \\
\text { Depressions }\end{array}$ & $\begin{array}{l}\text { Small } \\
\text { Village }\end{array}$ & 4 & $\begin{array}{l}\text { Historic } \\
\text { Occupatio } \\
\mathrm{n}\end{array}$ & $\begin{array}{l}\text { Cultural } \\
\text { Association }\end{array}$ & $\begin{array}{l}\text { The site consists of } 4 \text { house } \\
\text { depressions and a possible cache pit. } \\
\text { Tests on house depression revealed } \\
\text { burned wood and charcoal and } \\
\text { structural elements consisting of ax- } \\
\text { hewn wood which is beveled and } \\
\text { notched. Another house depression } \\
\text { consisted of } 3 \text { upright support poles, } \\
3 \text { rafter beams, and } 9 \text { wall and roof } \\
\text { poles. A third house depression } \\
\text { appeared more recent than the rest } \\
\text { of the site. Several remnants of } \\
\text { upright poles were noted at corners } \\
\text { and wall supports. }\end{array}$ \\
\hline
\end{tabular}




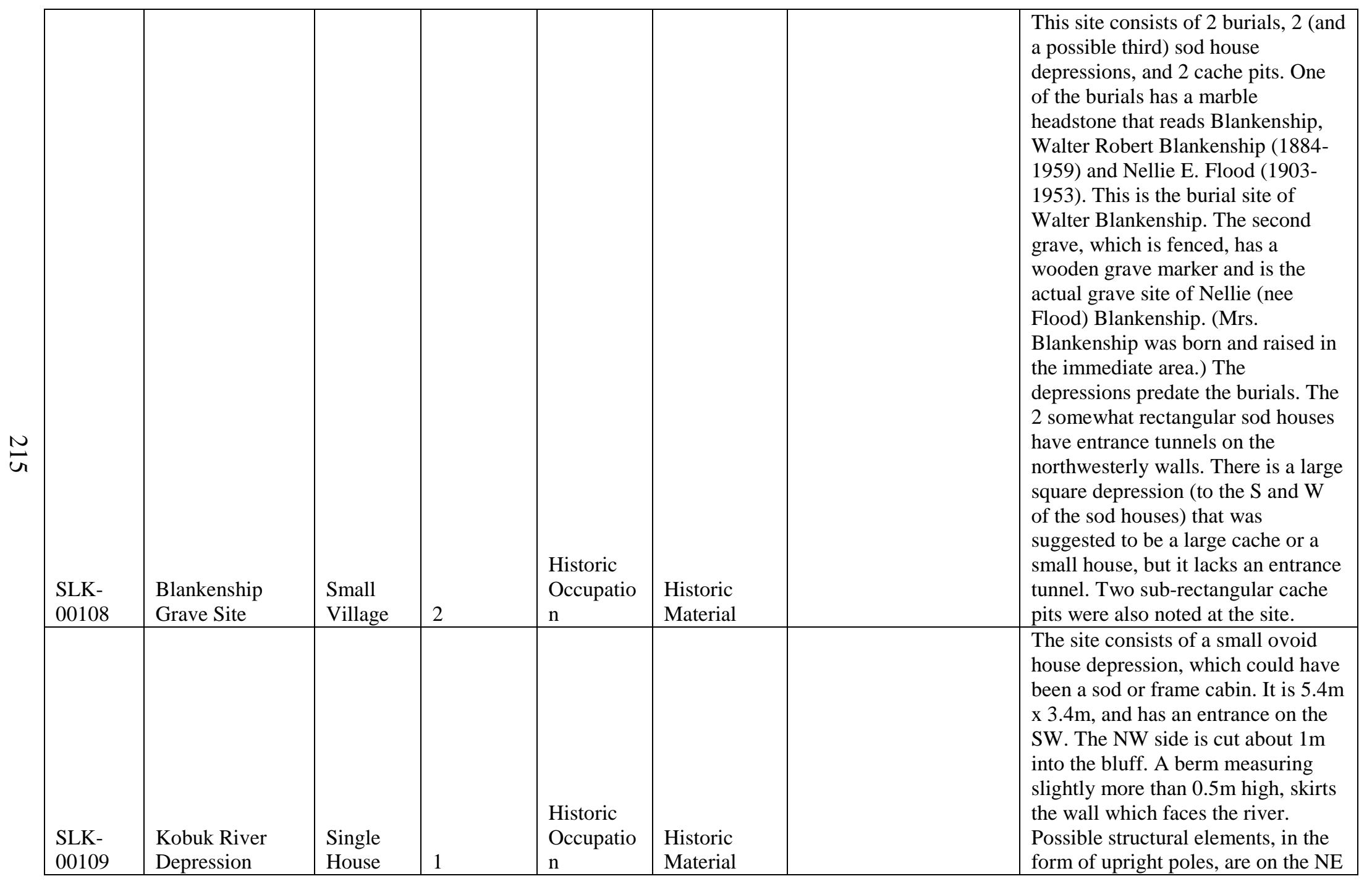




\begin{tabular}{|c|c|c|c|c|c|c|}
\hline & & & & & & $\begin{array}{l}\text { corner. Historic debris in the area } \\
\text { consists of coffee cans, kerosene } \\
\text { containers, and a square gallon can. }\end{array}$ \\
\hline $\begin{array}{l}\text { SLK- } \\
00111\end{array}$ & Saayou & Village & Unknown & Unknown & N/A & N/A \\
\hline $\begin{array}{l}\text { SLK- } \\
00118\end{array}$ & & $\begin{array}{l}\text { Single } \\
\text { House }\end{array}$ & 1 & $\begin{array}{l}\text { Historic } \\
\text { Occupatio } \\
\mathrm{n}\end{array}$ & $\begin{array}{l}\text { Historic } \\
\text { Material }\end{array}$ & $\begin{array}{l}\text { The site is composed of a collapsed } \\
\text { sod house approximately 9.5m long } \\
\text { x } 7 \mathrm{~m} \text { wide with the long axis } \\
\text { oriented parallel to the west bank of } \\
\text { the Selawik River. The house was } \\
\text { originally built by Phillip Carter in } \\
1940 \text { and is reported that he lived in } \\
\text { the house until 1971. The end of a } \\
\text { drum furnace (55gal?) can be seen } \\
\text { protruding from the surface, as well } \\
\text { as other unidentified metal objects. } \\
\text { A stick frame house, built on a } \\
\text { wood foundation, is on the northern } \\
\text { edge of the sod house. Overall site } \\
\text { integrity appears to be intact. }\end{array}$ \\
\hline $\begin{array}{l}\text { SLK- } \\
00175\end{array}$ & & Village & Unknown & Unknown & N/A & Semi-subterranean houses. \\
\hline
\end{tabular}




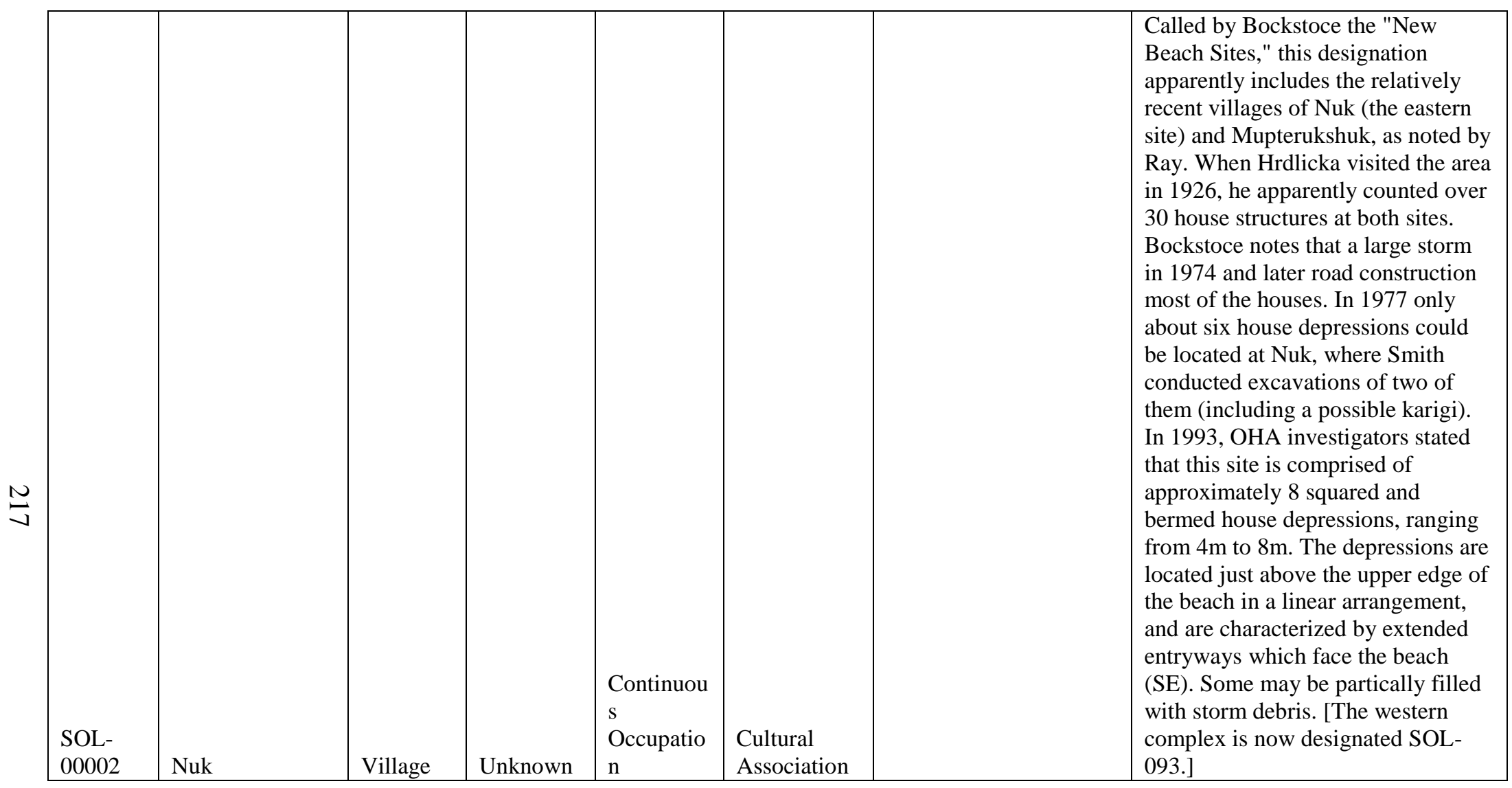




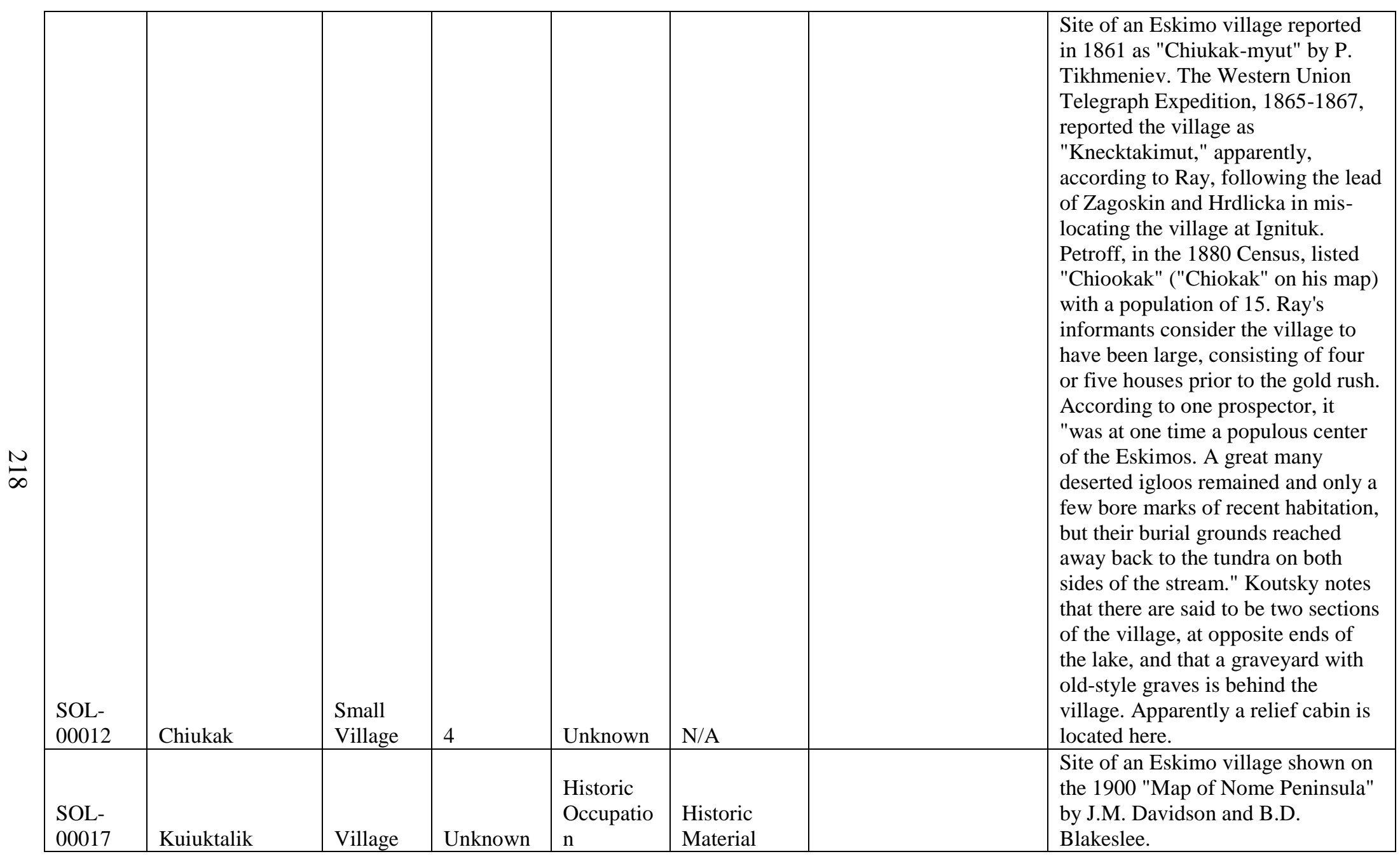




\begin{tabular}{|c|c|c|c|c|c|c|}
\hline $\begin{array}{l}\text { SOL- } \\
00024\end{array}$ & $\begin{array}{l}\text { Fish River } \\
\text { Village }\end{array}$ & Village & Unknown & Unknown & N/A & $\begin{array}{l}\text { This village, the main village in the } \\
\text { Fish River region, was visited by } \\
\text { Bourchier in } 1851 \text {. }\end{array}$ \\
\hline $\begin{array}{l}\text { SOL- } \\
00028\end{array}$ & Tapqaq & Village & Unknown & Unknown & N/A & $\begin{array}{l}\text { Former Eskimo village reported in } \\
\text { the } 1880 \text { Census as "Tup-ka-ak," } \\
\text { population 15, and listed in the } 1890 \\
\text { Census as "Taphok." A mining } \\
\text { camp appears to have been set up } \\
\text { here about } 1900 \text { and the } 1908 \text { "Map } \\
\text { of Seward Peninsula" by Arthur } \\
\text { Gibson shows a "Topkok } \\
\text { Roadhouse" at this site. The Alaska } \\
\text { Road Commission purchased the } \\
\text { Christianson Cabin at Tapqaq in } \\
\text { 1922 and repaired it for use as a } \\
\text { shelter cabin (ARC } \\
\text { 1922:90).[Formerly also listed as } \\
\text { SOL-067.] }\end{array}$ \\
\hline $\begin{array}{l}\text { SOL- } \\
00033\end{array}$ & Kuksuktapaga & $\begin{array}{l}\text { Small } \\
\text { Village }\end{array}$ & 2 & $\begin{array}{l}\text { Historic } \\
\text { Occupatio } \\
\mathrm{n}\end{array}$ & $\begin{array}{l}\text { Historic } \\
\text { Material }\end{array}$ & $\begin{array}{l}\text { CPSU investigators noted two } \\
\text { dwelling structures, one } 3.6 \mathrm{~m} \text { x } \\
8.4 \mathrm{~m} \text { above ground log structure } \\
\text { and one semi-subterranean structure } \\
\text { with sod around the framed walls. A } \\
1.5 \mathrm{~m} \text { in diameter pit, 12" deep, was } \\
\text { also noted, as were historic debris. } \\
\text { Kuksuktapaga was noted as early as } \\
1851 \text {, as both a winter and summer } \\
\text { settlement, and was reported to have } \\
\text { two houses. The remains noted } \\
\text { apparently relate to later use or } \\
\text { modification. }\end{array}$ \\
\hline
\end{tabular}




\begin{tabular}{|c|c|c|c|c|c|c|}
\hline $\begin{array}{l}\text { SOL- } \\
00043\end{array}$ & Kukuktaoluk & Village & Unknown & $\begin{array}{l}\text { Before } \\
500 \text { BP }\end{array}$ & $\begin{array}{l}\text { Cultural } \\
\text { Association }\end{array}$ & $\begin{array}{l}\text { This seasonal site reported by Ray } \\
\text { may be the site noted by Giddings, } \\
\text { where the "house pits were obscured } \\
\text { by a combination of soil creep and } \\
\text { thick moss, but we determined that } \\
\text { they also belonged to the Nukleet, } \\
\text { rather than an earlier, culture. This } \\
\text { site lies about fifty feet above sea } \\
\text { level, on a gentle slope at the top of } \\
\text { a bluff" [See also SOL-044 for } \\
\text { another candidate]. }\end{array}$ \\
\hline $\begin{array}{l}\text { SOL- } \\
00047\end{array}$ & Chauipak & Village & Unknown & Unknown & N/A & $\begin{array}{l}\text { Ray noted that there was a small } \\
\text { settlement on Fish River } 5 \text { miles } \\
\text { above the mouth of Niukluk River. }\end{array}$ \\
\hline $\begin{array}{l}\text { SOL- } \\
00051\end{array}$ & Chungauroktulik & Village & Unknown & $\begin{array}{l}\text { Historic } \\
\text { Occupatio } \\
\mathrm{n}\end{array}$ & $\begin{array}{l}\text { Historic } \\
\text { Material }\end{array}$ & $\begin{array}{l}\text { Ray noted this as a village which } \\
\text { was often occupied year round. It } \\
\text { was reportedly wiped out in a } \\
\text { landslide. It may be Jacobsen's } \\
\text { Singakloget, which was inhabited in } \\
1882 \text {. }\end{array}$ \\
\hline $\begin{array}{l}\text { SOL- } \\
00052\end{array}$ & Popikiuk & Village & Unknown & $\begin{array}{l}\text { Historic } \\
\text { Occupatio } \\
\text { n }\end{array}$ & $\begin{array}{l}\text { Historic } \\
\text { Material }\end{array}$ & $\begin{array}{l}\text { Ray notes this as a village which } \\
\text { was often occupied year round. Its } \\
\text { inhabitants died in the } 1900 \text { measles } \\
\text { epidemic. This may be Jacobsen's } \\
\text { Ojeralik, which was inhabited in } \\
1882 \text {. }\end{array}$ \\
\hline
\end{tabular}




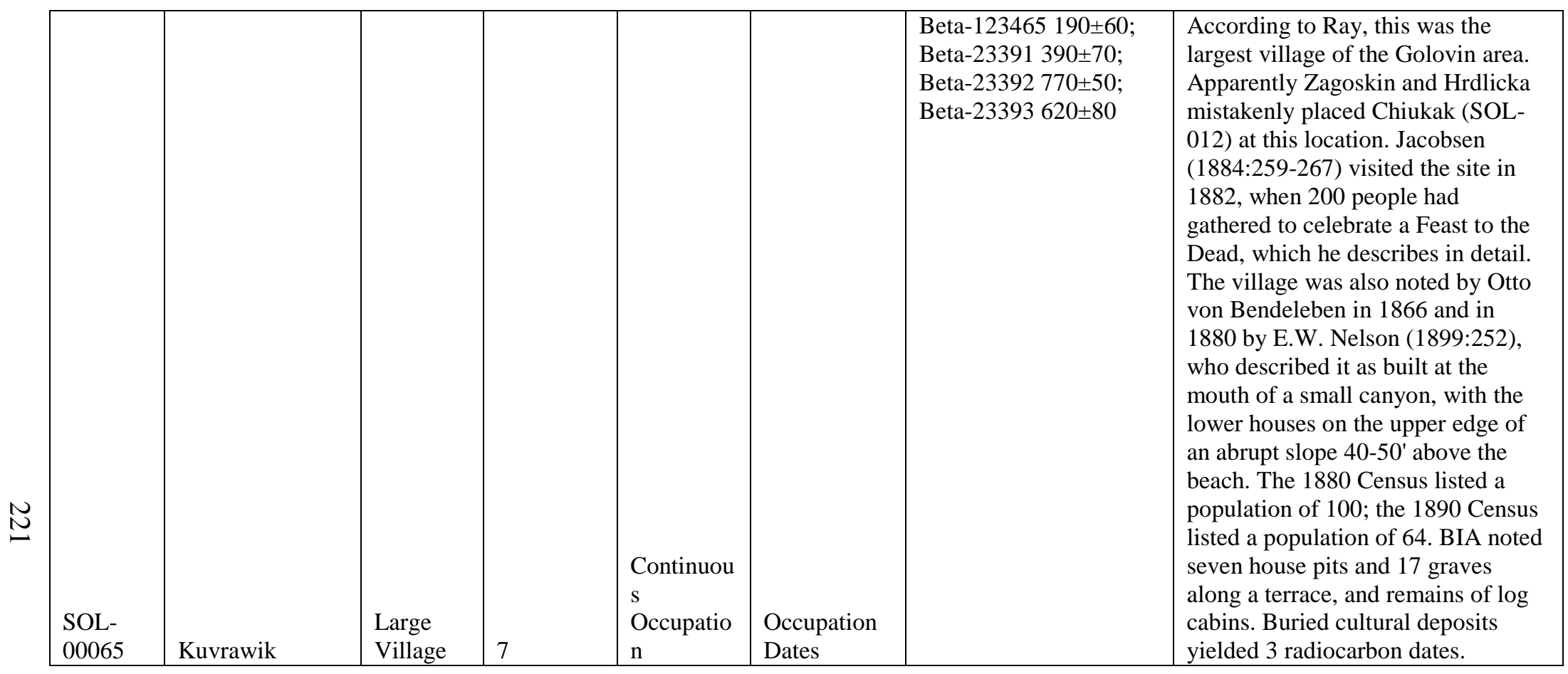




\begin{tabular}{|c|c|c|c|c|c|c|c|}
\hline $\begin{array}{l}\text { SOL- } \\
00068\end{array}$ & Okpiktulik & $\begin{array}{l}\text { Large } \\
\text { Village }\end{array}$ & 14 & $\begin{array}{l}\text { After } 500 \\
\text { BP }\end{array}$ & $\begin{array}{l}\text { Occupation } \\
\text { Dates }\end{array}$ & Beta-127628 $10 \pm 80$ & $\begin{array}{l}\text { According to Ray, this village, } \\
\text { situated at the mouth of Spruce } \\
\text { [Cache] Creek, is said by informants } \\
\text { to have had as many as } 10 \text { houses, } \\
\text { although Petroff reported only } 12 \\
\text { inhabitants in } 1880 \text {. Apparently } \\
\text { Zagoskin and Hrdlicka mistakenly } \\
\text { located the village at Topkok Head. } \\
\text { In } 1984, \text { BIA ANCSA } \\
\text { archaeologists reported documented } \\
\text { approximately } 124 \text { features } \\
\text { (numerous house pits and graves) } \\
\text { scattered over a } 600 \text { m long area, } \\
\text { extending westward from the } \\
\text { western end of Taylor Lagoon. This } \\
\text { site has recent remains (including a } \\
\text { portion of the Iditarod trail that } \\
\text { passes through the site), a late } \\
\text { mining era structure, the remains of } \\
\text { earlier cabins, depressions (some } \\
\text { multi-roomed structures) from } \\
\text { traditional semi-subterranean houses } \\
\text { and associated features and remains } \\
\text { of aboveground graves. }\end{array}$ \\
\hline $\begin{array}{l}\text { SOL- } \\
00070\end{array}$ & Setuk & Village & Unknown & Unknown & N/A & & $\begin{array}{l}\text { This was reported by Ray to have } \\
\text { been a permanent village site, } \\
\text { located on high dry ground on the } \\
\text { east side of Cape Nome. It was } \\
\text { apparently still inhabited as late as } \\
1899 \text {. Bockstoce was unable to } \\
\text { locate the site, which was perhaps } \\
\text { destroyed by road building and fill } \\
\text { collection. }\end{array}$ \\
\hline
\end{tabular}




\begin{tabular}{|c|c|c|c|c|c|c|c|}
\hline $\begin{array}{l}\text { SOL- } \\
00093\end{array}$ & Nuglene Site & $\begin{array}{l}\text { Large } \\
\text { Village }\end{array}$ & 9 & $\begin{array}{l}\text { After } 500 \\
\text { BP }\end{array}$ & $\begin{array}{l}\text { Occupation } \\
\text { Dates }\end{array}$ & 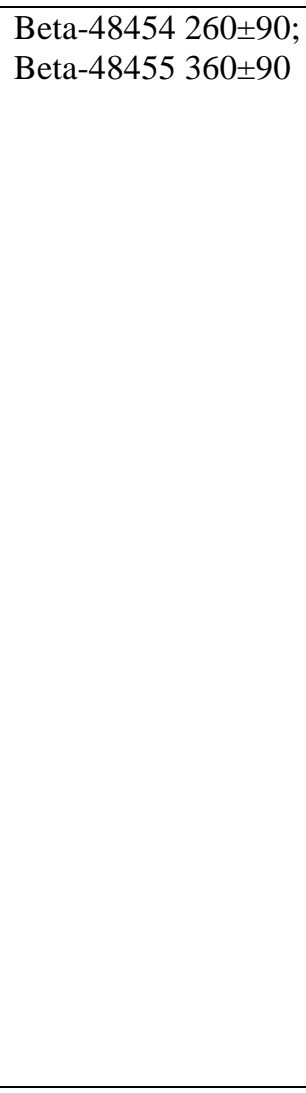 & $\begin{array}{l}\text { The site consists of a least } 9 \text { pit } \\
\text { features, including multi-room } \\
\text { house depression as well as smaller } \\
\text { features, on both side of the Nome- } \\
\text { Council Road. In } 1926 \text { Hrdlicka } \\
\text { found that the "Nook" site was } \\
\text { comprised of about } 30 \text { depressions } \\
\text { in two discrete areas. The eastern } \\
\text { locus is the Nuk site (SOL-002) } \\
\text { while the western locus is is the } \\
\text { settlement of Mupterukshuk. In } \\
1993 \text {, BIA archaeologists mapped } \\
\text { the features ( } 8 \text { major structures and } \\
6 \text { other surface features), recorded } \\
\text { vandalism, and conducted minor } \\
\text { excavations in the main room of one } \\
\text { of the multi-room structures. These } \\
\text { excavations revealed a collapsed } \\
\text { wooden structure and a sequence of } \\
\text { preserved wood floors in } \\
\text { stratigraphic context. The site is } \\
\text { thought to date around AD } 1700- \\
1750 \text {, at the beginning of European } \\
\text { influence. In } 1995 \text {, Feature } 12 \text { was } \\
\text { mitigated and found to contain } \\
\text { cultural materials only in the upper } \\
5 \mathrm{~cm} \text {. }\end{array}$ \\
\hline $\begin{array}{l}\text { SOL- } \\
00111\end{array}$ & Imaqliq & $\begin{array}{l}\text { Small } \\
\text { Village }\end{array}$ & 4 & Unknown & N/A & & $\begin{array}{l}\text { Between four and seven house pits } \\
\text { were noted, extensively disturbed } \\
\text { by erosion and vandalism. Sea } \\
\text { mammal remains and pottery were } \\
\text { scattered about the site. Reportedly, } \\
\text { Diomede Islanders returning home } \\
\text { from St. Michael encountered an } \\
\text { early winter storm and were forced }\end{array}$ \\
\hline
\end{tabular}




\begin{tabular}{|c|c|c|c|c|c|c|}
\hline & & & & & & $\begin{array}{l}\text { to build sod houses and winter over } \\
\text { here. Reportedly many died of } \\
\text { starvation. The site may have both } \\
\text { prehistoric and historic components } \\
\text { represented. }\end{array}$ \\
\hline $\begin{array}{l}\text { SOL- } \\
00130 \\
\end{array}$ & Ipnuchauk & Village & Unknown & Unknown & N/A & $\begin{array}{l}\text { Ray noted that this village was } \\
\text { thought by Eskimos to have been "a } \\
\text { pretty big village once, and } \\
\text { inhabited all year." This may be the } \\
\text { village of "Chaimut" reffered to by } \\
\text { Zagoskin. Koutsky reported that the } \\
\text { site was later used by reindeer } \\
\text { herders and that a corral built in the } \\
\text { early } 1900 \text { s still stands. }\end{array}$ \\
\hline $\begin{array}{l}\text { SOL- } \\
00131\end{array}$ & & $\begin{array}{l}\text { Small } \\
\text { Village }\end{array}$ & 2 & $\begin{array}{l}\text { Continuou } \\
\mathrm{s} \\
\text { Occupatio } \\
\mathrm{n}\end{array}$ & $\begin{array}{l}\text { Cultural } \\
\text { Association }\end{array}$ & $\begin{array}{l}\text { In } 1976 \text { Bockstoce carried out test } \\
\text { excavations on one of two house } \\
\text { pits noted here. Bockstoce estimated } \\
\text { that the house pit tested was } \\
\text { inhabited about } 500 \text { years ago.[In } \\
\text { passing Bockstoce mentions that } \\
\text { several house pit clusters were } \\
\text { noted on the lake.] }\end{array}$ \\
\hline $\begin{array}{l}\text { SOL- } \\
00138\end{array}$ & Kuvrawik & Village & Unknown & Unknown & N/A & $\begin{array}{l}\text { The site was investigated and } \\
\text { labeled a village, but no other } \\
\text { descriptions were given. }\end{array}$ \\
\hline
\end{tabular}




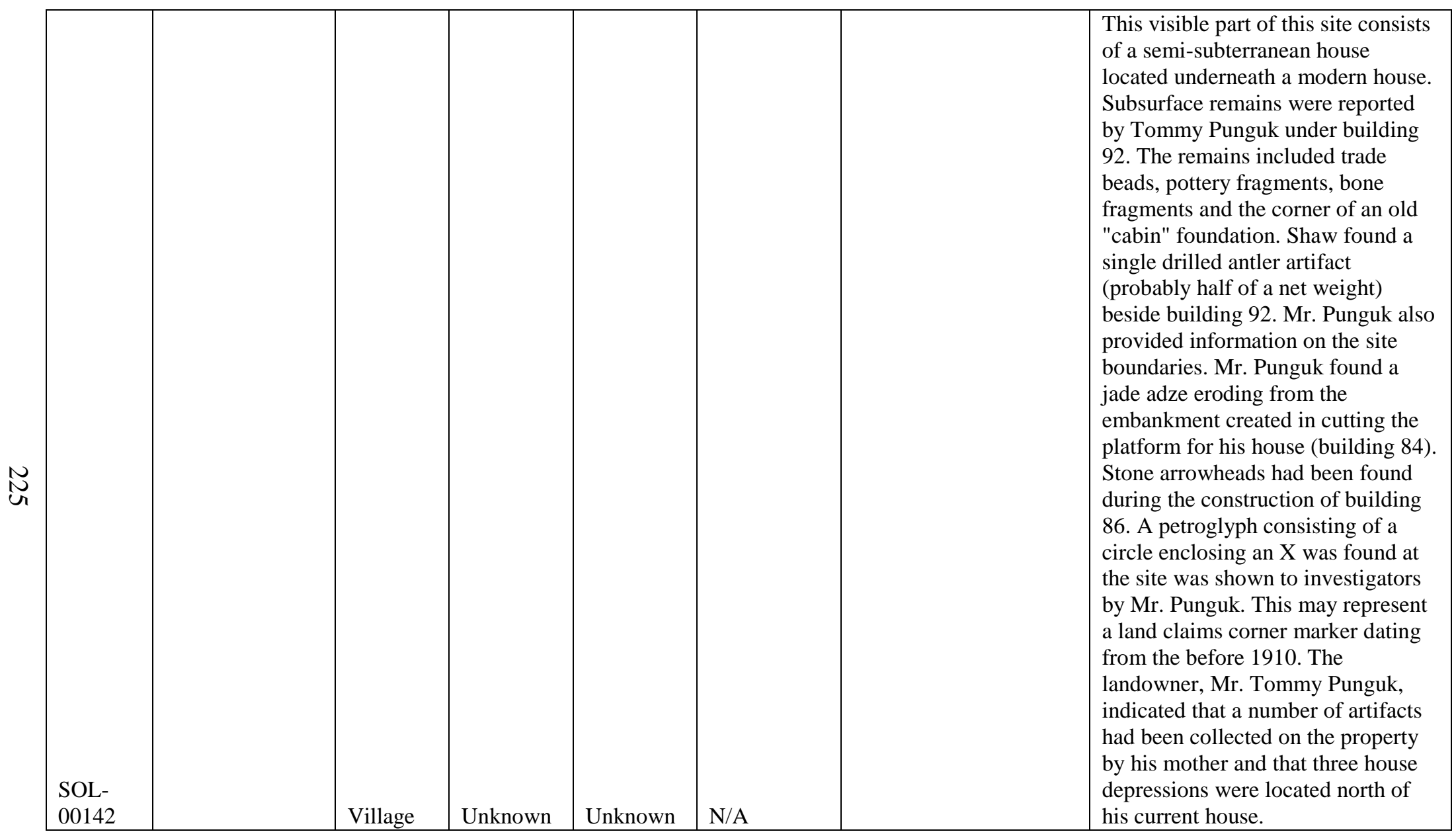




\begin{tabular}{|c|c|c|c|c|c|c|}
\hline $\begin{array}{l}\text { SOL- } \\
00143\end{array}$ & $\begin{array}{l}\text { Qitchauvik } \\
\text { Qargi }\end{array}$ & $\begin{array}{l}\text { Single } \\
\text { House }\end{array}$ & 1 & $\begin{array}{l}\text { Outside } \\
\text { Study } \\
\text { Period }\end{array}$ & $\begin{array}{l}\text { Occupation } \\
\text { Dates }\end{array}$ & $\begin{array}{l}\text { The site consists of single large } \\
\text { structure (>100 square m) with a } \\
\text { driftwood frame resembling the } \\
\text { Ipiutak qargi at Cape Krusenstern. } \\
\text { Wood was extensively used at this } \\
\text { site for construction and heating. } \\
\text { Caribou bones were abundant as } \\
\text { were caribou carvings. Artifacts are } \\
\text { similar to both Ipiutak and Norton. } \\
\text { Two ceramic oil lamps (made with a } \\
\text { pottery paddle) indicate oil was } \\
\text { burned. No iron was recovered but } \\
\text { cut marks on several ivory pieces } \\
\text { are typical of those made by iron } \\
\text { tools. Site was excavated } 1998 \text { as a } \\
\text { field school by the Golovin Native } \\
\text { Corp. }\end{array}$ \\
\hline $\begin{array}{l}\text { TEL- } \\
00001\end{array}$ & Sungiyorat & $\begin{array}{l}\text { Small } \\
\text { Village }\end{array}$ & 3 & $\begin{array}{l}\text { After } 500 \\
\text { BP }\end{array}$ & $\begin{array}{l}\text { Cultural } \\
\text { Association }\end{array}$ & $\begin{array}{l}\text { In } 1854 \text { Hobson noted } 30 \\
\text { inhabitants and two small dirty huts } \\
\text { on the old channel of Kuzitrin } \\
\text { River. Powers, et al. located three } \\
\text { house depressions, none larger than } \\
3 \mathrm{~m} \text { x } 3 \mathrm{~m} \text {, at this apparent location. }\end{array}$ \\
\hline
\end{tabular}




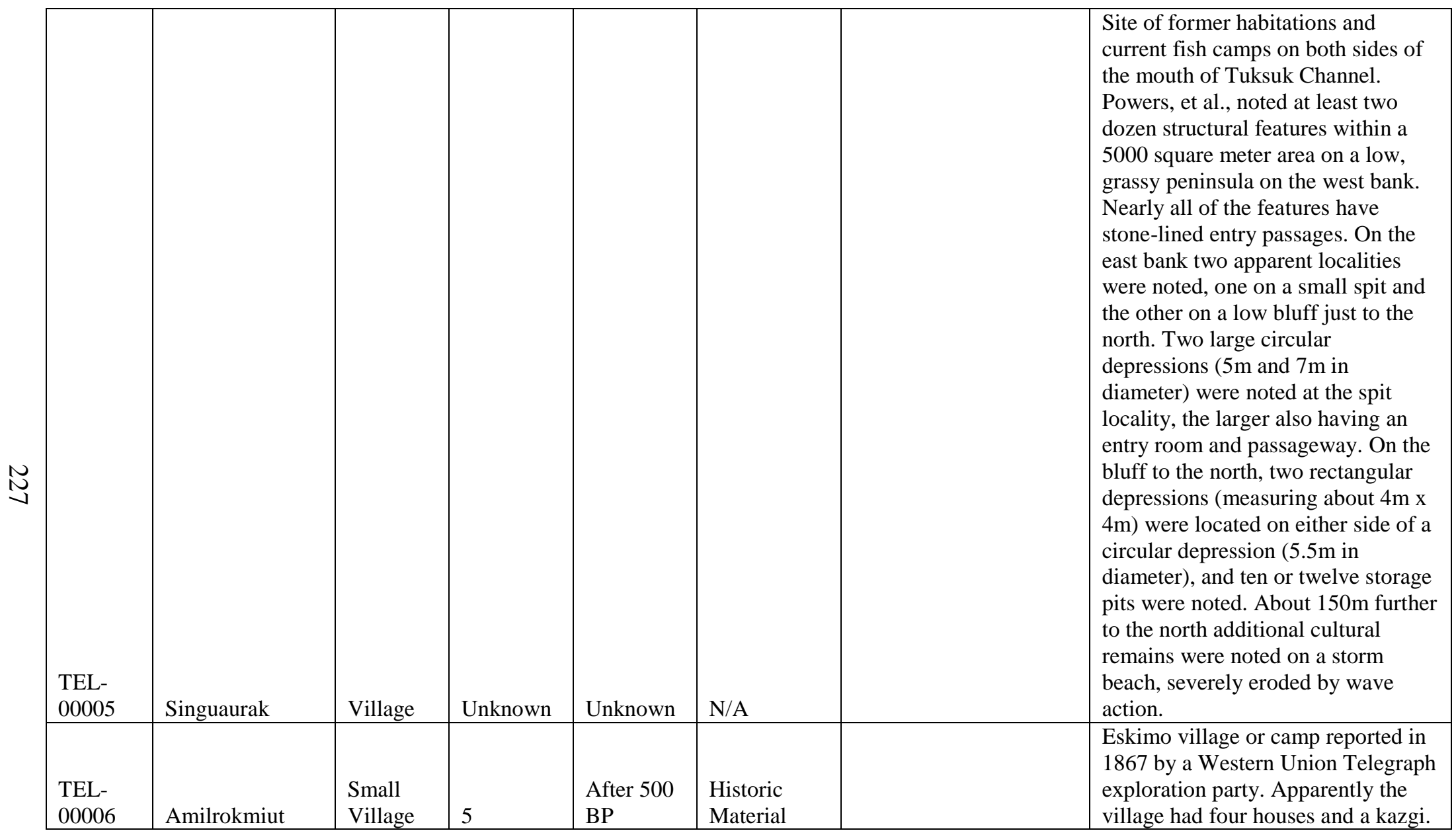




\begin{tabular}{|c|c|c|c|c|c|c|}
\hline $\begin{array}{l}\text { TEL- } \\
00007\end{array}$ & Kauwerak & $\begin{array}{l}\text { Large } \\
\text { Village }\end{array}$ & 29 & $\begin{array}{l}\text { After } 500 \\
\text { BP }\end{array}$ & $\begin{array}{l}\text { Historic } \\
\text { Material }\end{array}$ & $\begin{array}{l}\text { Establish by the late } 1700 \text { s, if not } \\
\text { earlier, this village was first noted } \\
\text { by Europeans in the } 1800 \text { s. In } 1854 \\
\text { Hobson noted it as having seven } \\
\text { large houses and a qargi. During an } \\
\text { archaeological survey in } 1929, \\
\text { Collins noted } 16 \text { house pits in what } \\
\text { his testing indicated was a relatively } \\
\text { late site. Collins also collected a } \\
\text { number of burials, all but one of } \\
\text { which were extended. Powers, et al., } \\
\text { mapped a total of } 29 \text { complete or } \\
\text { partially eroded large depressions at } \\
\text { the site, a number of which could be } \\
\text { interpreted as cache pits. A } 4 \mathrm{~m} \text { thick } \\
\text { section of eroding midden was } \\
\text { exposed along the river bank. In } \\
\text { general, the depressions are oriented } \\
\text { in two lines parallel to the river, } \\
\text { with their entrances for the most } \\
\text { part facing in opposite directions. } \\
\text { Cemetery areas were also noted. }\end{array}$ \\
\hline $\begin{array}{l}\text { TEL- } \\
00009 \\
\end{array}$ & Akavingayak & Village & Unknown & Unknown & N/A & $\begin{array}{l}\text { Ray notes that this settlement was } \\
\text { located on the southwest side of a } \\
\text { bluff between Fox Creek and Nickle } \\
\text { Creek. Koutsky reports that the } \\
\text { village was abandoned before the } \\
1918 \text { influenza epidemic. }\end{array}$ \\
\hline $\begin{array}{l}\text { TEL- } \\
00011\end{array}$ & $\begin{array}{l}\text { Singauruk } \\
\text { Channel }\end{array}$ & Village & Unknown & $\begin{array}{l}\text { Outside } \\
\text { Study } \\
\text { Period }\end{array}$ & $\begin{array}{l}\text { Cultural } \\
\text { Association }\end{array}$ & $\begin{array}{l}\text { Giddings noted cultural material in } \\
\text { three cross sections of old beach } \\
\text { ridges cut by Singauruk Channel. } \\
\text { Artifacts had eroded out and house } \\
\text { floors were visible in the banks. The } \\
\text { youngest beach ridge contained } \\
\text { items similar to Old Bering Sea }\end{array}$ \\
\hline
\end{tabular}




\begin{tabular}{|c|c|c|c|c|c|c|}
\hline & & & & & & $\begin{array}{l}\text { artifacts. The two older beach ridges } \\
\text { contained Norton culture stonework. }\end{array}$ \\
\hline $\begin{array}{l}\text { TEL- } \\
00020\end{array}$ & Mitletukeruk & Village & Unknown & $\begin{array}{l}\text { Before } \\
500 \mathrm{BP} \\
\end{array}$ & $\begin{array}{l}\text { Cultural } \\
\text { Association }\end{array}$ & $\begin{array}{l}\text { According to Ray an Eskimo } \\
\text { missionary was established at this } \\
\text { site in } 1897 \text {. The village was } \\
\text { abandoned following the } 1918 \\
\text { influenza epidemic. H.B. Collins } \\
\text { apparently excavated here in 1928, } \\
\text { making note of the house type as } \\
\text { being related to the Thule } \\
\text { type. [There is apparently some } \\
\text { confusion between this site and } \\
\text { another site also called "Mitletavik" } \\
\text { (TEL-147) shown as } \\
\text { "Mugistokivik" on the USGS map). }\end{array}$ \\
\hline $\begin{array}{l}\text { TEL- } \\
00025\end{array}$ & $\begin{array}{l}\text { Wales Hillside } \\
\text { Site }\end{array}$ & Village & Unknown & $\begin{array}{l}\text { Before } \\
500 \mathrm{BP}\end{array}$ & $\begin{array}{l}\text { Cultural } \\
\text { Association }\end{array}$ & $\begin{array}{l}\text { This } 200 \mathrm{~m} \text { long site is located on } \\
\text { the steep bank of the bluffs to the S } \\
\text { of the present village of Wales. Site } \\
\text { contains extensive and deeply } \\
\text { stratified deposits from at least the } \\
\text { Thule times. In } 1928 \text { Jenness } \\
\text { excavated two superimposed houses } \\
\text { on the brow of the bank. The floors } \\
\text { of these structures were 2'-6" and } 5 \text { ' } \\
\text { below the surface, respectively. A } \\
\text { more modern ruin, containing } \\
\text { several historic items, was also } \\
\text { excavated. In } 1936 \text { Collins also } \\
\text { conducted excavations at this site. } \\
\text { Site has been only superficially } \\
\text { investigated. }\end{array}$ \\
\hline
\end{tabular}




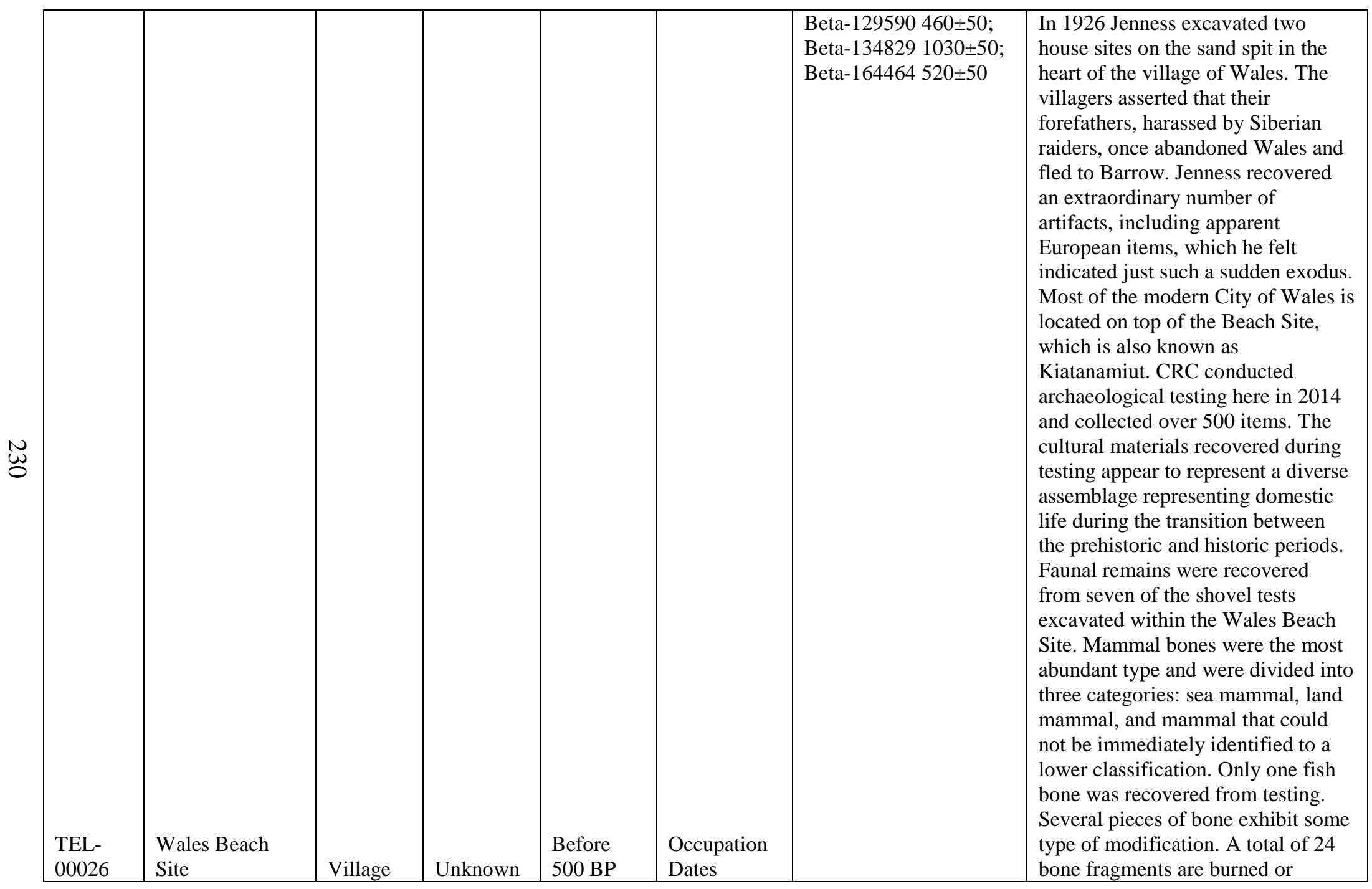




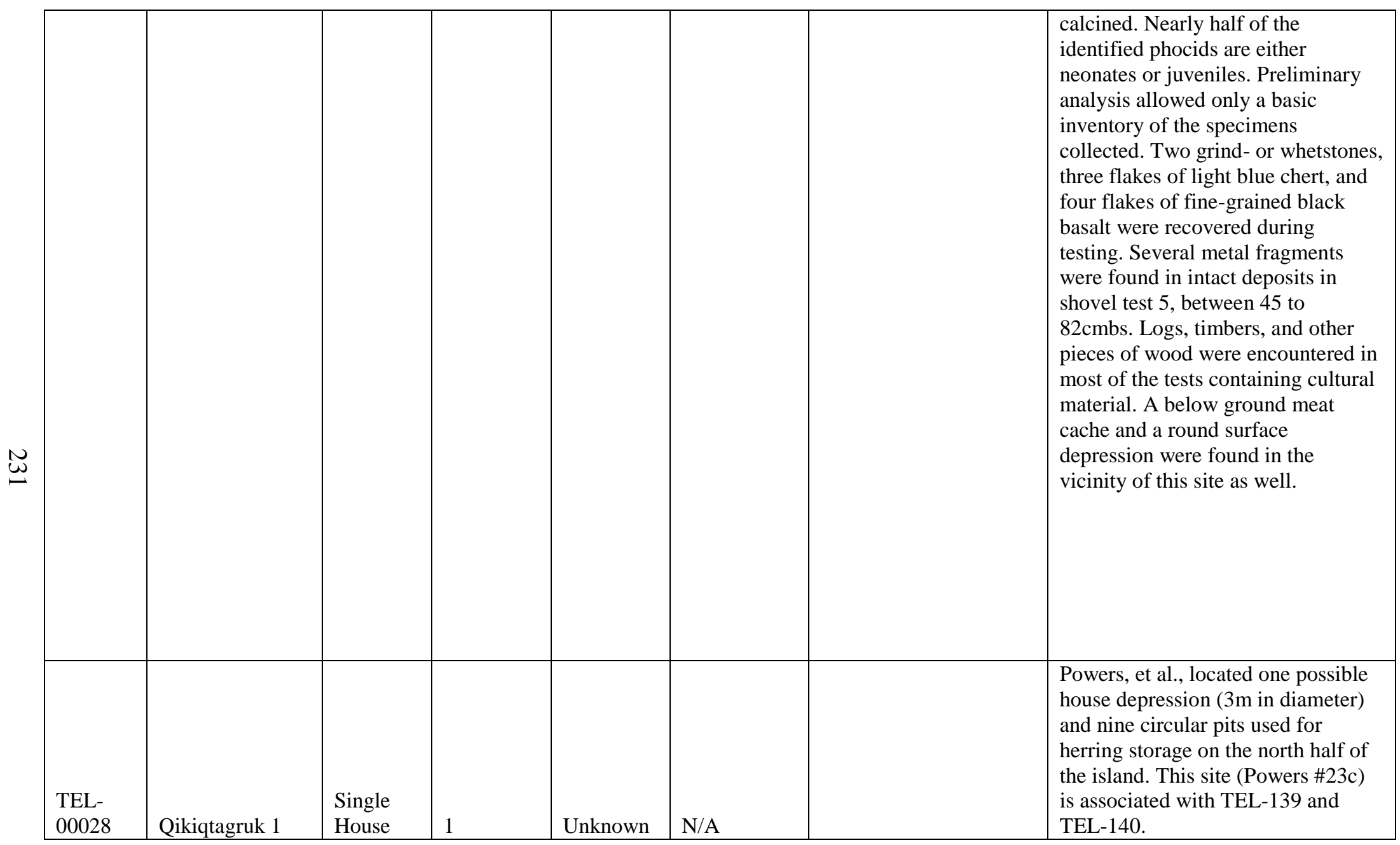




\begin{tabular}{|c|c|c|c|c|c|c|}
\hline $\begin{array}{l}\text { TEL- } \\
00033\end{array}$ & Ukuivuk & $\begin{array}{l}\text { Large } \\
\text { Village }\end{array}$ & 40 & Unknown & N/A & $\begin{array}{l}\text { Former Eskimo village, reported in } \\
\text { the } 1880 \text { Census as having a } \\
\text { population of } 200 \text {, and in the same } \\
\text { year as having about } 40 \text { houses. In } \\
\text { the summer the residents lived in } \\
\text { square parchment houses on stilts } \\
\text { and in the winter in rock houses. } \\
\text { The former residents have moved to } \\
\text { the mainland, returning to the island } \\
\text { only seasonally. A } 2005 \text { monitoring } \\
\text { project documented the removal of } \\
\text { the access stairs (from tidewater to } \\
\text { the village) and the moving of small } \\
\text { items to clear a trail through the } \\
\text { village. }\end{array}$ \\
\hline $\begin{array}{l}\text { TEL- } \\
00034\end{array}$ & Ikpiung & Village & Unknown & Unknown & N/A & $\begin{array}{l}\text { Ray notes that a settlement was } \\
\text { located here. }\end{array}$ \\
\hline $\begin{array}{l}\text { TEL- } \\
00035\end{array}$ & Mizek & Village & Unknown & Unknown & N/A & $\begin{array}{l}\text { According to Ray, "this settlement } \\
\text { on a spit near Point Jackson had } \\
\text { 'quite a few houses at one time,' but } \\
\text { they were in constant danger of } \\
\text { inundation. In the } 1890 \text { s Reverend } \\
\text { T.L. Brevig said that four families } \\
\text { lived at Point Jackson." }\end{array}$ \\
\hline $\begin{array}{l}\text { TEL- } \\
00036\end{array}$ & Sinramiut & Village & Unknown & Unknown & N/A & $\begin{array}{l}\text { This village was once the largest in } \\
\text { Port Clarence. Beechey noted a } \\
\text { kazgi and a burial ground when he } \\
\text { visited in } 1827 \text {. It was a short } \\
\text { distance to the east of here where } \\
\text { Sheldon Jackson established, in } \\
\text { 1892, the Teller Reindeer Station } \\
\text { (TEL-037, with which there is some } \\
\text { confusion). [TEL-153 may be } \\
\text { duplicate of this site.] }\end{array}$ \\
\hline
\end{tabular}




\begin{tabular}{|c|c|c|c|c|c|c|}
\hline $\begin{array}{l}\text { TEL- } \\
00039\end{array}$ & Ikpiumizua & Village & Unknown & Unknown & N/A & $\begin{array}{l}\text { Ray noted this as a small village } \\
\text { composed of a family or two. }\end{array}$ \\
\hline $\begin{array}{l}\text { TEL- } \\
00040\end{array}$ & Iklighilauk & $\begin{array}{l}\text { Single } \\
\text { House }\end{array}$ & 1 & Unknown & N/A & $\begin{array}{l}\text { Ray noted that one winter house and } \\
10 \text { or } 12 \text { summer fishing camps } \\
\text { were located on this sand spit in } \\
1894 \text {. }\end{array}$ \\
\hline $\begin{array}{l}\text { TEL- } \\
00042\end{array}$ & Kasilnuk & $\begin{array}{l}\text { Large } \\
\text { Village }\end{array}$ & 20 & Unknown & N/A & $\begin{array}{l}\text { Noted by Ray as a settlement often } \\
\text { inhabited in both winter and } \\
\text { summer, the name may have been } \\
\text { strictly applied to the group of } \\
\text { approximately } 20 \text { house pits just } \\
\text { west of the mouth of Offield Creek, } \\
\text { which were reported by Powers, et } \\
\text { al. These house pits are situated } \\
\text { along a } 200 \mathrm{~m} \text { extent of a beach } \\
\text { ridge some } 50 \mathrm{~m} \text { from the present } \\
\text { shoreline. The name, currently, is } \\
\text { also applied to the area between } \\
\text { Offield Creek and McKinley Creek, } \\
\text { where Powers, et al., noted } 12 \\
\text { isolated mounds running parallel to } \\
\text { the shore. The mounds are formed } \\
\text { of accumulated midden deposits, } \\
\text { backdirt from the excavation of } \\
\text { semi-subterranean houses, and } \\
\text { dense grass vegetation. The largest } \\
\text { mound covers an approximately } \\
1500 \text { square meter area. Each } \\
\text { mound contains surface features of } \\
\text { one or more house pits. }\end{array}$ \\
\hline
\end{tabular}




\begin{tabular}{|c|c|c|c|c|c|c|}
\hline $\begin{array}{l}\text { TEL- } \\
00045\end{array}$ & Kektoaschliuk & Village & Unknown & Unknown & N/A & $\begin{array}{l}\text { Powers, et al., noted at least } 39 \\
\text { depressions in four distinct groups, } \\
\text { on both banks of Kuzitrin River. } \\
\text { Twenty-two depressions were } \\
\text { located in one group on the north } \\
\text { bank of the river; on the south bank } \\
\text { groups of eight, three, and six } \\
\text { depressions were noted. The } \\
\text { depressions measured from } 2 \mathrm{~m} \mathrm{x} \\
2 \mathrm{~m} \text { to } 6 \mathrm{~m} \text { x } 5 \mathrm{~m} \text { in size, many with } \\
\text { passageways and several with entry } \\
\text { rooms. The house sits on the south } \\
\text { side of the river were larger, deeper, } \\
\text { and more clearly rectangular than } \\
\text { those on the north bank. A test of } \\
\text { one of the house pits on the north } \\
\text { side of the river produced historic } \\
\text { items. The first historic reports of } \\
\text { the village were during the early } \\
1850 \mathrm{~s} \text {. }\end{array}$ \\
\hline $\begin{array}{l}\text { TEL- } \\
00046\end{array}$ & Anaktkowatuk & Village & Unknown & Unknown & N/A & $\begin{array}{l}\text { Reportedly an old village, extinct in } \\
\text { the nineteenth century, was located } \\
\text { here. In } 1900 \text { a mining camp was } \\
\text { established here. A post office was } \\
\text { established here in } 1900 \text { and was } \\
\text { discontinued in } 1902 . \text { By } 1907 \text { York } \\
\text { was described as "a small collection } \\
\text { of cabins and tents." }\end{array}$ \\
\hline $\begin{array}{l}\text { TEL- } \\
00047\end{array}$ & Palazrak & $\begin{array}{l}\text { Large } \\
\text { Village }\end{array}$ & 6 & $\begin{array}{l}\text { Historic } \\
\text { Occupatio } \\
\mathrm{n}\end{array}$ & $\begin{array}{l}\text { Historic } \\
\text { Material } \\
\end{array}$ & $\begin{array}{l}\text { This small year-round village is said } \\
\text { to have had six or seven house at } \\
\text { one time. In } 1894 \text { the winter } \\
\text { population was } 40 \text {. One of Ray's } \\
\text { informants thought the village was } \\
\text { placed about } 2 \text { miles too far to the } \\
\text { northwest on the USGS map of }\end{array}$ \\
\hline
\end{tabular}




\begin{tabular}{|c|c|c|c|c|c|c|}
\hline & & & & & & 1950. \\
\hline $\begin{array}{l}\text { TEL- } \\
00049\end{array}$ & Umeveyuk & Village & Unknown & Unknown & N/A & $\begin{array}{l}\text { This place between Palazrak (TEL- } \\
\text { 047) and Tapkarak (TEL-048), } \\
\text { thought to have been an ancient } \\
\text { village site, was a reindeer herding } \\
\text { camp in the } 1890 \text { s. [The AHRS } \\
\text { maps have this site located in the } \\
\text { Tin City LRRS facility (TEL-141), } \\
\text { but an archaeological survey did not } \\
\text { locate the site within the facility. } \\
\text { Hoffecker did find a new site (TEL- } \\
\text { 155), which may be the same site.] }\end{array}$ \\
\hline $\begin{array}{l}\text { TEL- } \\
00051\end{array}$ & Aghudlawak & $\begin{array}{l}\text { Small } \\
\text { Village }\end{array}$ & 3 & $\begin{array}{l}\text { Historic } \\
\text { Occupatio } \\
\mathrm{n}\end{array}$ & $\begin{array}{l}\text { Historic } \\
\text { Material }\end{array}$ & $\begin{array}{l}\text { This village, in an area noted for its } \\
\text { goose hunting, reportedly had three } \\
\text { houses in } 1892 \text {. }\end{array}$ \\
\hline $\begin{array}{l}\text { TEL- } \\
00052\end{array}$ & Issak & $\begin{array}{l}\text { Small } \\
\text { Village }\end{array}$ & 4 & Unknown & N/A & $\begin{array}{l}\text { CPSU investigators reported finding } \\
\text { four house pits and a reindeer } \\
\text { corral. The driftwood corral } \\
\text { measures approximately } 200 \mathrm{~m} \times \\
100 \mathrm{~m} \text {. The house pits measure } 10 \mathrm{~m} \\
\text { x } 5.5 \mathrm{~m} \times 1 \mathrm{~m} \text { deep with and attached } \\
\text { room, } 14 \mathrm{~m} \times 8 \mathrm{~m} \times 1-2 \mathrm{~m} \text { deep, and } \\
12 \mathrm{~m} \times 5 \mathrm{~m} \times 1 \mathrm{~m} \text { deep (overlying a } \\
\text { smaller house pit, measuring } 4 \mathrm{~m} \times \\
3 \mathrm{~m} \times 1 \mathrm{~m} \text { deep). A bowl-shaped } \\
\text { wood artifact and pottery fragments } \\
\text { were noted. In } 1892 \text { three houses } \\
\text { were reportedly located here. }\end{array}$ \\
\hline $\begin{array}{l}\text { TEL- } \\
00053\end{array}$ & Imiengnak & Village & 1 & $\begin{array}{l}\text { Historic } \\
\text { Occupatio } \\
\mathrm{n}\end{array}$ & $\begin{array}{l}\text { Historic } \\
\text { Material }\end{array}$ & $\begin{array}{l}\text { Ray noted this as a small village } \\
\text { reportedly having one house in } \\
1892 \text {. }\end{array}$ \\
\hline
\end{tabular}




\begin{tabular}{|c|c|c|c|c|c|c|c|}
\hline $\begin{array}{l}\text { TEL- } \\
00055\end{array}$ & Singaurak & $\begin{array}{l}\text { Small } \\
\text { Village }\end{array}$ & 3 & $\begin{array}{l}\text { Historic } \\
\text { Occupatio } \\
\mathrm{n}\end{array}$ & $\begin{array}{l}\text { Historic } \\
\text { Material } \\
\end{array}$ & & $\begin{array}{l}\text { Ray noted that this village, reported } \\
\text { to have three houses in } 1892 \text {, was } \\
\text { said by informants to have had more } \\
\text { than ten houses and a kazgi before } \\
\text { that. The area was apparently noted } \\
\text { for its flounder fishing. K. } \\
\text { Woodworth, BLM, located three } \\
\text { house pits and three graves just } \\
\text { behind the beach here in } 1976 .\end{array}$ \\
\hline $\begin{array}{l}\text { TEL- } \\
00060\end{array}$ & Metoktu & $\begin{array}{l}\text { Large } \\
\text { Village }\end{array}$ & 17 & $\begin{array}{l}\text { After } 500 \\
\text { BP }\end{array}$ & $\begin{array}{l}\text { Occupation } \\
\text { Dates }\end{array}$ & Beta-325694 230 \pm 30 & $\begin{array}{l}\text { CPSU investigators reported } \\
\text { locating two loci, on opposite sides } \\
\text { of a slough. Parcel A consists of } \\
\text { some } 23 \text { features, including multi- } \\
\text { room house pits, squared house pits, } \\
\text { possible cache pits, and a } \\
\text { rectangular mound with posts. } \\
\text { Milled lumber and wire nails were } \\
\text { also found on the site. Parcel B } \\
\text { consists of some } 11 \text { burials. The site } \\
\text { was reportedly abandoned following } \\
\text { the } 1918 \text { influenza epidemic. } \\
\text { [CPSU reports that this is the site } \\
\text { reported, but they say incorrectly } \\
\text { located, by Powers, et al. } \\
\text { (1982:113-115; see TEL-129 for } \\
\text { that site/location entry).] }\end{array}$ \\
\hline $\begin{array}{l}\text { TEL- } \\
00061\end{array}$ & Igloo & $\begin{array}{l}\text { Small } \\
\text { Village }\end{array}$ & 4 & $\begin{array}{l}\text { After } 500 \\
\text { BP }\end{array}$ & $\begin{array}{l}\text { Historic } \\
\text { Material }\end{array}$ & & $\begin{array}{l}\text { CPSU investigators noted four } \\
\text { house pits, one sod structure, two } \\
\text { cache pits, a frame cabin, and recent } \\
\text { paraphernalia. The house pits } \\
\text { reportedly date to the early } 1800 \text { s. } \\
\text { The site was abandoned as a winter } \\
\text { village following the } 1918 \text { influenza } \\
\text { epidemic. The cabin, built during } \\
\text { the } 1920 \text { s by Lomen Company, is }\end{array}$ \\
\hline
\end{tabular}




\begin{tabular}{|c|c|c|c|c|c|c|}
\hline & & & & & & $\begin{array}{l}\text { associated with Igloo Corral (TEL- } \\
\text { 062). It was abandoned during the } \\
\text { 1930s. }\end{array}$ \\
\hline $\begin{array}{l}\text { TEL- } \\
00063 \\
\end{array}$ & Olanna Graves & $\begin{array}{l}\text { Large } \\
\text { Village }\end{array}$ & 46 & Unknown & N/A & $\begin{array}{l}\text { CPSU investigators located } \\
\text { approximately } 46 \text { house pits } \\
\text { (including multi-room features), six } \\
\text { reported graves, and miscellaneous } \\
\text { artifacts (historic and apparently } \\
\text { prehistoric) in three loci, and an } \\
\text { area possibly used for the staking } \\
\text { out of dogs. }\end{array}$ \\
\hline $\begin{array}{l}\text { TEL- } \\
00066\end{array}$ & Koksuktik B & $\begin{array}{l}\text { Large } \\
\text { Village }\end{array}$ & 11 & Unknown & N/A & $\begin{array}{l}\text { CPSU investigators noted } 11 \text { house } \\
\text { pits (from } 2.5 \mathrm{~m} \times 2.5 \mathrm{~m} \text { to } 4 \mathrm{~m} x \\
5.2 \mathrm{~m} \text { in size), five cache pits, and } \\
\text { miscellaneous historic debris. } \\
\text { Generally associated with reindeer } \\
\text { herding, the site may have a } \\
\text { prehistoric component associated } \\
\text { with caribou hunting. }\end{array}$ \\
\hline $\begin{array}{l}\text { TEL- } \\
00067\end{array}$ & Aveoltvik & $\begin{array}{l}\text { Small } \\
\text { Village }\end{array}$ & 5 & Unknown & N/A & $\begin{array}{l}\text { CPSU investigators reported a } \\
\text { village site consisting of five house } \\
\text { pits from } 4 \mathrm{~m} \times 3 \mathrm{~m} \text { to } 8.5 \mathrm{~m} \times 3 \mathrm{~m} \\
\text { (two rooms) in size and six mounds } \\
\text { measuring from } 1 \mathrm{~m} \text { to } 2.8 \mathrm{~m} \text { long, } \\
1 \mathrm{~m} \text { to } 2.5 \mathrm{~m} \text { wide, and } .6 \mathrm{~m} \text { to } 1.2 \mathrm{~m} \\
\text { high, all oriented along the terrace } \\
\text { edge. Vandalism was evident. }\end{array}$ \\
\hline
\end{tabular}




\begin{tabular}{|c|c|c|c|c|c|c|c|}
\hline $\begin{array}{l}\text { TEL- } \\
00078\end{array}$ & Nutaat & $\begin{array}{l}\text { Single } \\
\text { House }\end{array}$ & 1 & $\begin{array}{l}\text { After } 500 \\
\text { BP }\end{array}$ & $\begin{array}{l}\text { Cultural } \\
\text { Association }\end{array}$ & & $\begin{array}{l}\text { Semi-subterranean community } \\
\text { house structure of planks, drift logs, } \\
\text { and native stone, measuring about } \\
20 \text { ' x } 20 \text { '. Entrance is gained through } \\
\text { an underground tunnel and a hole in } \\
\text { the floor. Although deteriorating, } \\
\text { this traditional structure is in the } \\
\text { best condition of the three such } \\
\text { kazgi structures in the village. A } \\
2005 \text { monitoring survey found the } \\
\text { roof to be collapsed, although the } \\
\text { entrance tunnel appeared to be } \\
\text { intact. }\end{array}$ \\
\hline $\begin{array}{l}\text { TEL- } \\
00086 \\
\end{array}$ & & $\begin{array}{l}\text { Large } \\
\text { Village }\end{array}$ & 7 & $\begin{array}{l}\text { After } 500 \\
\text { BP }\end{array}$ & $\begin{array}{l}\text { Occupation } \\
\text { Dates }\end{array}$ & 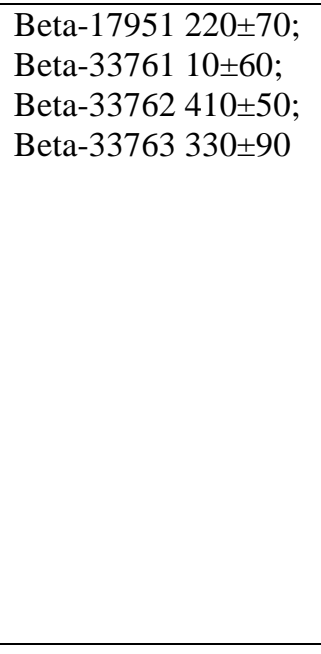 & $\begin{array}{l}\text { This village site consists of at least } \\
\text { six deep, multi-room house } \\
\text { depressions, one possible kazgi, six } \\
\text { cache depressions, and the posts of } \\
\text { an elevated rack or cache. The site } \\
\text { is located within a } 60 \mathrm{~m} \text { x } 70 \mathrm{~m} \text { area } \\
\text { on the tundra bluff about } 300 \mathrm{~m} \text { from } \\
\text { the shore, } 86.6 \mathrm{~m} \text { southwest and } \\
\text { across and old drainage from TEL- } \\
085 \text { and } 50 \mathrm{~m} \text { northeast of TEL-087. } \\
\text { Walrus, whale, and recent reindeer } \\
\text { bones are scattered across the site } \\
\text { and pot sherds were noted near one } \\
\text { of the features. The house features } \\
\text { appear to have from one to four } \\
\text { rooms each. }\end{array}$ \\
\hline $\begin{array}{l}\text { TEL- } \\
00087\end{array}$ & & $\begin{array}{l}\text { Small } \\
\text { Village }\end{array}$ & 2 & $\begin{array}{l}\text { After } 500 \\
\text { BP }\end{array}$ & $\begin{array}{l}\text { Cultural } \\
\text { Association }\end{array}$ & & $\begin{array}{l}\text { Two multi-room house depressions } \\
\text { and at least three cache pits were } \\
\text { found at the north end of a dune on } \\
\text { top of the tundra bluffs about } 250 \mathrm{~m} \\
\text { from the shore, about } 50 \mathrm{~m} \\
\text { southwest and across a small }\end{array}$ \\
\hline
\end{tabular}




\begin{tabular}{|c|c|c|c|c|c|}
\hline & & & & & $\begin{array}{l}\text { drainage from TEL- } 086 \text { and } 80 \mathrm{~m} \\
\text { northeast of TEL-088. The house } \\
\text { features appear to have three or four } \\
\text { rooms each. }\end{array}$ \\
\hline $\begin{array}{l}\text { TEL- } \\
00093\end{array}$ & $\begin{array}{l}\text { Small } \\
\text { Village }\end{array}$ & 3 & $\begin{array}{l}\text { Before } \\
500 \mathrm{BP}\end{array}$ & $\begin{array}{l}\text { Cultural } \\
\text { Association }\end{array}$ & $\begin{array}{l}\text { This site consists of a linear series } \\
\text { of features arranged along the crest } \\
\text { of a relict beach ridge, about } 150 \mathrm{~m} \\
\text { from the present shore, } \\
\text { approximately } 118 \mathrm{~m} \text { northeast of } \\
\text { TEL-092 and } 50 \mathrm{~m} \text { southwest of } \\
\text { TEL-094. The cultural features have } \\
\text { been modified by deflation and are } \\
\text { somewhat difficult to define, except } \\
\text { as diffuse scatters and indistinct } \\
\text { depressions. One plank lined, } \\
\text { Western Thule style house feature } \\
\text { and at least four cache depressions } \\
\text { are present. A variety of structural } \\
\text { members are present in the features, } \\
\text { and more than one house may be } \\
\text { represented. Fire cracked rock and } \\
\text { whale and walrus bone were also } \\
\text { noted. }\end{array}$ \\
\hline $\begin{array}{l}\text { TEL- } \\
00096\end{array}$ & $\begin{array}{l}\text { Small } \\
\text { Village }\end{array}$ & 4 & $\begin{array}{l}\text { After } 500 \\
\text { BP }\end{array}$ & $\begin{array}{l}\text { Cultural } \\
\text { Association }\end{array}$ & $\begin{array}{l}\text { Three or four house depressions, } \\
\text { five cache depressions, at least two } \\
\text { burials, and an extensiviv but sparse } \\
\text { scatter of isolated cultural material } \\
\text { were found in the dunes on top of } \\
\text { the tundra backed bluffs about } \\
300 \mathrm{~m} \text { inland from the present shore. } \\
\text { A bone arrow point with a single } \\
\text { lateral barb, pot sherds, and faunal } \\
\text { remains were noted in association }\end{array}$ \\
\hline
\end{tabular}




\begin{tabular}{|c|c|c|c|c|c|}
\hline & & & & & $\begin{array}{l}\text { with the multi-room house features. } \\
\text { The site has suffered some potting. } \\
\text { Additional burials and cultural } \\
\text { material were noted to the north, } \\
\text { within a Native allotment, which } \\
\text { USNPS was not permitted to } \\
\text { investigate. }\end{array}$ \\
\hline $\begin{array}{l}\text { TEL- } \\
00098\end{array}$ & $\begin{array}{l}\text { Small } \\
\text { Village }\end{array}$ & 5 & Unknown & N/A & $\begin{array}{l}\text { At least five historic or protohistoric } \\
\text { house depressions, } 12 \text { cache } \\
\text { depressions, and an extensive } \\
\text { scatter of bone, wood, enamelware, } \\
\text { grinding stones, and other cultural } \\
\text { remains were located on two sand } \\
\text { dunes on top of the tundra bluffs, } \\
\text { about } 150 \mathrm{~m} \text { southwest of TEL-100. } \\
\text { The house features are deep and } \\
\text { well-defined, with many structural } \\
\text { members visible. A variety of } \\
\text { artifacts were noted, including an } \\
\text { iron rifle barrel, a cast iron bucket, } \\
\text { wood bucket and wood bowl } \\
\text { fragments, wood barrel parts, bone } \\
\text { and iron sled runners, and a } \\
\text { decorated pot sherd. }\end{array}$ \\
\hline $\begin{array}{l}\text { TEL- } \\
00099\end{array}$ & $\begin{array}{l}\text { Small } \\
\text { Village }\end{array}$ & 4 & $\begin{array}{l}\text { After } 500 \\
\text { BP }\end{array}$ & $\begin{array}{l}\text { Cultural } \\
\text { Association }\end{array}$ & $\begin{array}{l}\text { Four house depressions and } 11 \\
\text { cache depressions were found on a } \\
\text { dune formation, adjacent to a thaw } \\
\text { lake outlet channel, on the tundra- } \\
\text { backed bluffs about } 150 \mathrm{~m} \text { inland } \\
\text { from the coast. The house features } \\
\text { consists of a rectangular main room, } \\
\text { connected to an entry chamber by a } \\
\text { long narrow entryway having one }\end{array}$ \\
\hline
\end{tabular}




\begin{tabular}{|c|c|c|c|c|c|c|}
\hline & & & & & & $\begin{array}{l}\text { axillary room. Whale and walrus } \\
\text { bone are associated with the } \\
\text { features. A bone, adze-like artifact } \\
\text { and decorated pot sherds were noted } \\
\text { in blowouts. Date inferred from the } \\
\text { cultural material found in } 1986 \text {. }\end{array}$ \\
\hline $\begin{array}{l}\text { TEL- } \\
00104\end{array}$ & $\begin{array}{l}\text { Large } \\
\text { Village }\end{array}$ & 7 & $\begin{array}{l}\text { Continuou } \\
\mathrm{s} \\
\text { Occupatio } \\
\mathrm{n}\end{array}$ & $\begin{array}{l}\text { Occupation } \\
\text { Dates }\end{array}$ & 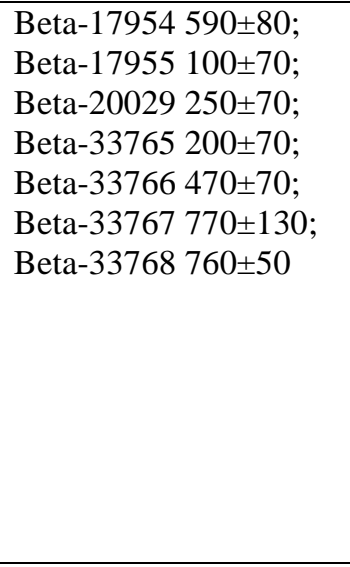 & $\begin{array}{l}\text { Seven single and multimulti-room } \\
\text { house depressions, } 18 \text { cache } \\
\text { depressions, three eroding wood- } \\
\text { framed seal oil caches, and deflation } \\
\text { exposed scatters of cultural material } \\
\text { were mapped at this site, which is } \\
\text { located in a sand dune formation } \\
\text { capping the high bluffs about } 150 \mathrm{~m} \\
\text { from the coast. Cultural material } \\
\text { noted includes structural members, } \\
\text { shell and bone remains, a bone sled } \\
\text { runner, a whetstone fragment, } \\
\text { decorated pot sherds, and rock } \\
\text { spalls. }\end{array}$ \\
\hline $\begin{array}{l}\text { TEL- } \\
00105\end{array}$ & $\begin{array}{l}\text { Large } \\
\text { Village }\end{array}$ & 8 & $\begin{array}{l}\text { Continuou } \\
\mathrm{s} \\
\text { Occupatio } \\
\mathrm{n}\end{array}$ & $\begin{array}{l}\text { Occupation } \\
\text { Dates }\end{array}$ & 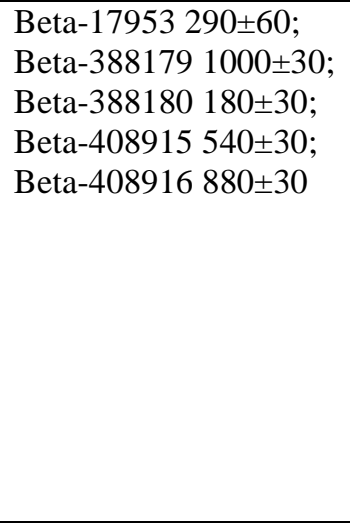 & $\begin{array}{l}\text { Seven multi-room house } \\
\text { depressions, at least } 15 \text { cache } \\
\text { depressions, and at least one burial } \\
\text { were found on two dune crests at } \\
\text { the edge of the bluffs, about } 175 \mathrm{~m} \\
\text { inland of the coast and } 250 \mathrm{~m} \\
\text { northeast of TEL-106. Cultural } \\
\text { material noted includes cobble } \\
\text { manuports, wood and cemented } \\
\text { sand scatters, a wood bowl } \\
\text { fragment, pot sherds, whale bone, } \\
\text { and a ground slate ulu blade. A C14 } \\
\text { date of BP } 290+/-60 \text { was obtained. }\end{array}$ \\
\hline
\end{tabular}




\begin{tabular}{|c|c|c|c|c|c|c|c|}
\hline & & & & & & & $\begin{array}{l}\text { Research in } 2012 \text { identified a } \\
\text { possible new house feature and } \\
\text { cache pit. Additional radiocarbon } \\
\text { samples collected and sent for } \\
\text { analysis. }\end{array}$ \\
\hline $\begin{array}{l}\text { TEL- } \\
00108\end{array}$ & & $\begin{array}{l}\text { Single } \\
\text { House }\end{array}$ & 1 & $\begin{array}{l}\text { Continuou } \\
\mathrm{s} \\
\text { Occupatio } \\
\mathrm{n}\end{array}$ & $\begin{array}{l}\text { Occupation } \\
\text { Dates }\end{array}$ & 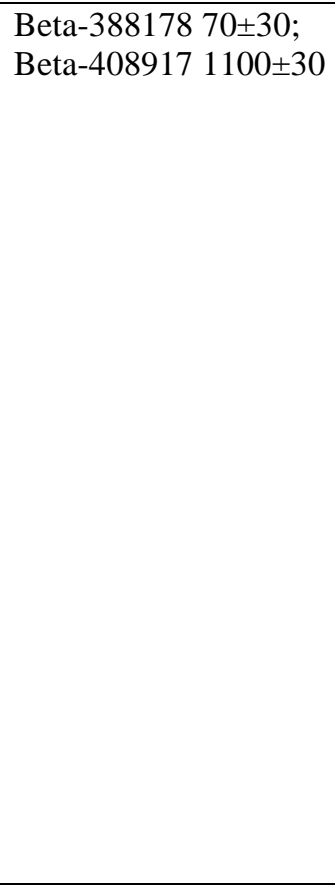 & $\begin{array}{l}\text { Four small cache-like depressions } \\
\text { and the subtle remains of a possible } \\
\text { house depression were found on the } \\
\text { edge of a vegetated dune, } \\
\text { overlooking a relict thaw lake } \\
\text { drainage, on the edge of the bluffs } \\
\text { about } 175 \mathrm{~m} \text { from the coast, } \\
\text { approximately } 300 \mathrm{~m} \text { northeast of } \\
\text { TEL-109 and } 200 \mathrm{~m} \text { southwest of } \\
\text { TEL-107. Two rectangular caches } \\
\text { measure } 1 \mathrm{~m} \times 1.5 \mathrm{~m} \text { and } 1.5 \mathrm{~m} \times \\
2.5 \mathrm{~m} \text {, a third is a } 2 \mathrm{~m} \times 1 \mathrm{~m} \text { oval, } \\
\text { while the fourth measures } 1 \mathrm{~m} \text { in } \\
\text { diameter. The possible house } \\
\text { depression consists of a shallow } 3 \mathrm{~m} \\
\text { x } 3 \mathrm{~m} \text { depression connected by a } \\
\text { subtle passage to a larger } \\
\text { rectangular depression, only } \\
\text { partially discernable. Two eroded, } \\
\text { wood-framed seal poke caches, } \\
\text { walrus bone, and some posts were } \\
\text { also noted. }\end{array}$ \\
\hline $\begin{array}{l}\text { TEL- } \\
00123\end{array}$ & Puibluk & $\begin{array}{l}\text { Large } \\
\text { Village }\end{array}$ & 38 & Unknown & N/A & & $\begin{array}{l}\text { Powers, et al., noted house } \\
\text { depressions concentrated in two } \\
\text { distinct localities at this site. A } \\
\text { series of } 20 \text { apparent house }\end{array}$ \\
\hline
\end{tabular}




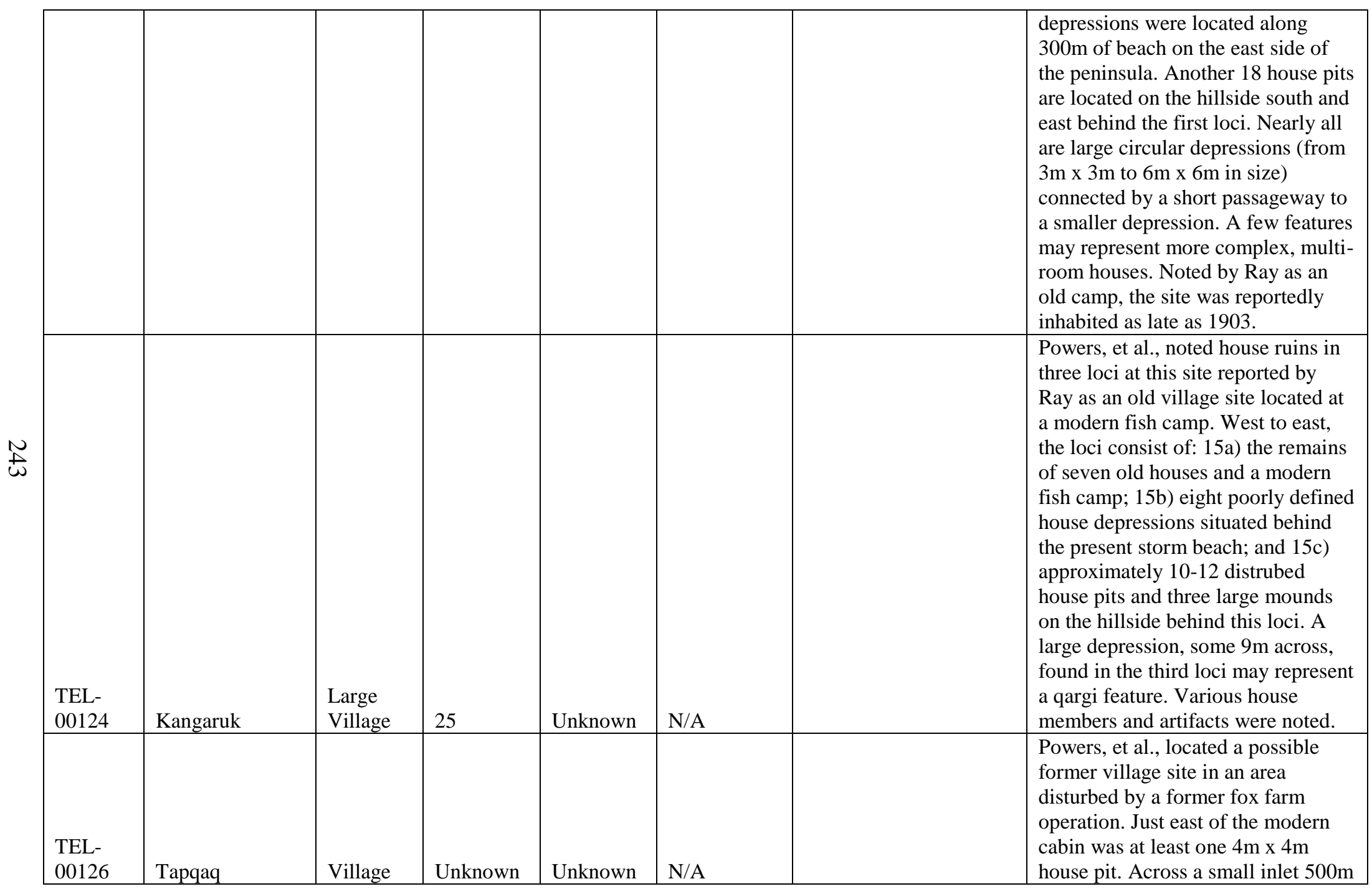




\begin{tabular}{|c|c|c|c|c|c|c|}
\hline & & & & & & $\begin{array}{l}\text { to the east, lush vegetation } \\
\text { suggested the location of another } \\
\text { site. An obscure rectangular } \\
\text { depression measuring } 3.5 \mathrm{~m} \times 4 \mathrm{~m} \\
\text { was noted, however it could be } \\
\text { interpreted as a natural feature. }\end{array}$ \\
\hline $\begin{array}{l}\text { TEL- } \\
00129\end{array}$ & Metuktuk & $\begin{array}{l}\text { Large } \\
\text { Village }\end{array}$ & 9 & Unknown & N/A & $\begin{array}{l}\text { Powers, et al., noted nine houses, } \\
\text { one with sod walls still standing. } \\
\text { Milled lumber and wire nails were } \\
\text { in evidence. Most were rectangular, } \\
\text { but one circular house was noted, as } \\
\text { were three small cache pits. A series } \\
\text { of modern fish racks were also } \\
\text { present. About } 1 \mathrm{~km} \text { to the north was } \\
\text { a recent cemetery with } 15 \text { burials. } \\
\text { On the west side of the river, west } \\
\text { of the village, rim sherds and bone } \\
\text { artifacts were collected from a } \\
\text { gravel bar, although their source } \\
\text { was not located.[CPSU reports that } \\
\text { Powers, et al., incorrectly located } \\
\text { the site, that it is instead located to } \\
\text { the north, at TEL-060.] }\end{array}$ \\
\hline $\begin{array}{l}\text { TEL- } \\
00130\end{array}$ & & $\begin{array}{l}\text { Small } \\
\text { Village }\end{array}$ & 2 & $\begin{array}{l}\text { Historic } \\
\text { Occupatio } \\
\mathrm{n}\end{array}$ & $\begin{array}{l}\text { Historic } \\
\text { Material }\end{array}$ & $\begin{array}{l}\text { Powers, et al., noted two house } \\
\text { depressions on a low bluff } \\
\text { overlooking the river. One was } \\
\text { rectangular and measured } 3 \mathrm{~m} \mathrm{x} \\
3.5 \mathrm{~m} \text { (Feature 1). The other (Feature } \\
\text { 2) was circular and measured 3m in } \\
\text { diameter. In 1993, BSNC } \\
\text { archaeologist noted historic debris } \\
\text { (barrel-type stove remains and a } 2.5 \\
\text { gallon galvanized bucket) } \\
\text { associated with Feature 1, which } \\
\text { was a sod cabin probably dating }\end{array}$ \\
\hline
\end{tabular}




\begin{tabular}{|c|c|c|c|c|c|c|}
\hline & & & & & & $\begin{array}{l}\text { from the first } 20 \text { years of this } \\
\text { century. Feature } 1 \text { appears to be } \\
\text { older than Feature } 2 \text {. Both features } \\
\text { have exposed, shallow }(<20 \mathrm{~cm}) \\
\text { shove probes, apparently the result } \\
\text { of pot hunting. [Powers had this site } \\
\text { located further downstream in the } \\
\text { SW quarter of Sec. } 20 .]\end{array}$ \\
\hline $\begin{array}{l}\text { TEL- } \\
00132 \\
\end{array}$ & Paniruhk & $\begin{array}{l}\text { Small } \\
\text { Village } \\
\end{array}$ & 3 & Unknown & N/A & $\begin{array}{l}\text { Powers, et al., reported a cluster of } \\
\text { three depressions, measuring } 4 \mathrm{~m} \text { in } \\
\text { diameter, on the tip of the spit. A } \\
\text { similar house pit, noted } 120 \mathrm{~m} \text { away, } \\
\text { had whale bone exposed. Twelve } \\
\text { apparent cache pits were also noted. } \\
\text { Ales Hrdlicka (1930:118) may have } \\
\text { visited the site in } 1926 \text {. }\end{array}$ \\
\hline $\begin{array}{l}\text { TEL- } \\
00133\end{array}$ & Isuktukpaga & $\begin{array}{l}\text { Small } \\
\text { Village }\end{array}$ & 5 & Unknown & N/A & $\begin{array}{l}\text { Powers, et al., located five house } \\
\text { pits on the south bank of the slough } \\
\text { entering the lake. Four were square } \\
\text { to rectangular in outline. One } \\
\text { measures } 4 \mathrm{~m} \times 5 \mathrm{~m} \text { and has a } 2 \mathrm{~m} \times \\
2 \mathrm{~m} \text { storm entrance; the others } \\
\text { measured } 3 \mathrm{~m} \text { to } 4 \mathrm{~m} \text { square. A fifth } \\
\text { depression, circular and } 2.5 \mathrm{~m} \text { in } \\
\text { diameter, was also noted. }\end{array}$ \\
\hline $\begin{array}{l}\text { TEL- } \\
00134\end{array}$ & Isuqtuq & $\begin{array}{l}\text { Large } \\
\text { Village }\end{array}$ & 11 & Unknown & N/A & $\begin{array}{l}\text { Powers, et al., noted } 11 \text { collapsed } \\
\text { houses group in two clusters, all but } \\
\text { three of which are eroding at the } \\
\text { slough edge. The southern loci } \\
\text { consists of six circular depressions, } \\
\text { one with a sod wall still standing } \\
\text { over } 1 \mathrm{~m} \text { high. The northern loci }\end{array}$ \\
\hline
\end{tabular}




\begin{tabular}{|c|c|c|c|c|c|c|}
\hline & & & & & & $\begin{array}{l}\text { consists of five house pits, in one of } \\
\text { which were found milled lumber } \\
\text { and a rusty tin can. All features } \\
\text { were no mere than } 3 \mathrm{~m} \text { in diameter. }\end{array}$ \\
\hline $\begin{array}{l}\text { TEL- } \\
00135 \\
\end{array}$ & Isuqtum Kania & Village & Unknown & Unknown & N/A & $\begin{array}{l}\text { Powers, et al., located several house } \\
\text { features situated on opposite sides } \\
\text { of a small inlet. The eastern locality } \\
\text { consists of a } 4 \mathrm{~m} \text { x } 4 \mathrm{~m} \text { depression } \\
\text { and a } 3 \mathrm{~m} \times 2 \mathrm{~m} \text { auxiliary depression } \\
\text { possibly used for storage. The } \\
\text { western locality consists of two, } 3 \mathrm{~m} \\
\text { in diameter, circular depressions. }\end{array}$ \\
\hline $\begin{array}{l}\text { TEL- } \\
00136\end{array}$ & Iglaurak 1 & $\begin{array}{l}\text { Small } \\
\text { Village }\end{array}$ & 4 & Unknown & N/A & $\begin{array}{l}\text { Powers, et al., located four house } \\
\text { depressions, measuring from } 3 \mathrm{~m} \times \\
3 \mathrm{~m} \text { to } 4 \mathrm{~m} \times 4 \mathrm{~m} \text { in size, on a } \\
\text { relatively high knoll within sight of } \\
\text { the associated sites, TEL-137 and } \\
\text { TEL-138. }\end{array}$ \\
\hline $\begin{array}{l}\text { TEL- } \\
00137\end{array}$ & Iglaurak 2 & $\begin{array}{l}\text { Small } \\
\text { Village }\end{array}$ & 3 & Unknown & N/A & $\begin{array}{l}\text { Powers, et al., located three large } \\
\text { house depressions, measuring } 7 \mathrm{~m} \\
\text { across, on a relatively high knoll } \\
\text { within sight of the associated sites, } \\
\text { TEL-136 and TEL-138. Within one } \\
\text { a post apparently shaped with a } \\
\text { stone adze was noted. Vandalism } \\
\text { has revealed potsherds of a thick- } \\
\text { walled, sand-tempered type. }\end{array}$ \\
\hline $\begin{array}{l}\text { TEL- } \\
00138\end{array}$ & Iglaurak 3 & $\begin{array}{l}\text { Single } \\
\text { House }\end{array}$ & 2 & Unknown & N/A & $\begin{array}{l}\text { Powers, et al., located a single } \\
\text { house depression, measuring } 3.5 \mathrm{~m} \\
\text { across, on a relatively high knoll } \\
\text { within sight of the associated sites, } \\
\text { TEL-136 and TEL-137. }\end{array}$ \\
\hline
\end{tabular}




\begin{tabular}{|c|c|c|c|c|c|c|}
\hline $\begin{array}{l}\text { TEL- } \\
00139 \\
\end{array}$ & Qikiqtagruk 2 & $\begin{array}{l}\text { Single } \\
\text { House }\end{array}$ & 1 & Unknown & N/A & $\begin{array}{l}\text { Powers, et al., reported a house pit } \\
\text { site on the mainland north of a small } \\
\text { island at the head of Imuruk Basin. } \\
\text { This site (23a) is associated with } \\
\text { TEL- } 028 \text { and TEL-140. }\end{array}$ \\
\hline $\begin{array}{l}\text { TEL- } \\
00140\end{array}$ & Qikiqtagruk 3 & $\begin{array}{l}\text { Single } \\
\text { House }\end{array}$ & 1 & Unknown & N/A & $\begin{array}{l}\text { Powers, et al., noted a } 3 \mathrm{~m} \times 5 \mathrm{~m} \\
\text { rectangular house depression and an } \\
\text { associated cache pit on the mainland } \\
\text { southwest of a small island at the } \\
\text { head of Imuruk Basin. This site } \\
\text { (23b) is associated with TEL-028 } \\
\text { and TEL-139. }\end{array}$ \\
\hline $\begin{array}{l}\text { TEL- } \\
00142 \\
\end{array}$ & Atnaq & $\begin{array}{l}\text { Small } \\
\text { Village }\end{array}$ & 3 & Unknown & N/A & $\begin{array}{l}\text { Powers, et al., noted one definite } 3 \mathrm{~m} \\
\text { x } 2 \mathrm{~m} \text { house depression, two possible } \\
\text { house depressions, and } 13 \text { small } \\
\text { circular and square depressions, } \\
\text { evidently used for whitefish } \\
\text { storage.[See also BEN-009.] }\end{array}$ \\
\hline $\begin{array}{l}\text { TEL- } \\
00143\end{array}$ & Qasigiat & $\begin{array}{l}\text { Small } \\
\text { Village }\end{array}$ & 3 & Unknown & N/A & $\begin{array}{l}\text { Powers, et al., noted three } \\
\text { depressions, and a possible fourth, } \\
\text { on a low sandy ridge on the east } \\
\text { side of the river. The area has been } \\
\text { heavily disturbed by fox denning } \\
\text { activity, and as no cultural remains } \\
\text { were noted in tests of three of the } \\
\text { depressions, their origin may be a } \\
\text { result of such activity. }\end{array}$ \\
\hline $\begin{array}{l}\text { TEL- } \\
00147\end{array}$ & Mitletavik & Village & Unknown & Unknown & N/A & $\begin{array}{l}\text { According to Orth, "Mugisitokiwik" } \\
\text { is the site of an Eskimo village or } \\
\text { camp reported about } 1940 \text { by } \\
\text { USC\&GS and published on Chart } \\
\text { 9380. According to Ray, this village } \\
\text { was unknown by that name. The } \\
\text { area was noted for its productive }\end{array}$ \\
\hline
\end{tabular}




\begin{tabular}{|l|l|l|l|l|l|l|}
\hline & & & & & & flounder fishery.[See also TEL- \\
020.]
\end{tabular}




\begin{tabular}{|c|c|c|c|c|c|c|}
\hline $\begin{array}{l}\text { TEL- } \\
00176\end{array}$ & $\begin{array}{l}\text { Port Clarence } \\
\text { House Pits }\end{array}$ & Village & 20 & $\begin{array}{l}\text { Outside } \\
\text { Study } \\
\text { Period }\end{array}$ & $\begin{array}{l}\text { Occupation } \\
\text { Dates }\end{array}$ & $\begin{array}{l}\text { This site consists of at least } 20 \text {, } \\
\text { possibly more, circular house } \\
\text { depressions on the shoreward beach } \\
\text { ridge slope above a marshy area. } \\
\text { They tend to occur in clusters of } 3 \\
\text { to } 5 \text {, in lineal fashion over a } \\
\text { distance of approximately } 1 \mathrm{mi} \text {. } \\
\text { (1.6km). There are no apparent } \\
\text { organic middens, but each } \\
\text { occupation site is marked by } \\
\text { quantities of sea mammal bone, in } \\
\text { stark contrast to the surrounding } \\
\text { areas. Observed artifacts include } \\
\text { pierced, sand tempered pottery } \\
\text { exhibiting a lineal pattern and an } \\
\text { ivory point with a triangular cross- } \\
\text { section (perhaps Choris period, } \\
2550 \text { to } 2000 \text { BP?). }\end{array}$ \\
\hline $\begin{array}{l}\text { TEL- } \\
00191\end{array}$ & & Village & Unknown & Unknown & N/A & $\begin{array}{l}\text { At south end of site is a small } \\
\text { depression and three parallel graves, } \\
\text { one with "Ailak Died Oct } 1908 \text { " } \\
\text { carved on the marker. East along the } \\
\text { Grantley Harbor shoreline is a } \\
\text { somewhat low and discontinuous } \\
\text { mound that parallels the shore for } \\
\text { about } 40 \mathrm{~m} \text {. Shallow and irregular } \\
\text { small mounds and depressions } \\
\text { continue more or less continuously } \\
\text { north of the graves, and there is also } \\
\text { a modern outhouse and a fairly } \\
\text { recent cold storage cache similar to } \\
\text { those seen along the bluff (TEL- } \\
\text { 00199). As the shoreline mound } \\
\text { ends, a cluster of larger mounds and } \\
\text { depressions occurs, including one }\end{array}$ \\
\hline
\end{tabular}




\begin{tabular}{|c|c|c|c|c|}
\hline & & & & $\begin{array}{l}\text { mound approximately } 10 \times 30 \mathrm{~m} \text { and } \\
\text { including several house pits with } \\
\text { multiple rooms. North of this is } \\
\text { another distinct mound with clear } \\
\text { potholing activity and several more } \\
\text { small but distinct pits. There has } \\
\text { been some disturbance at this site } \\
\text { but there are still mann undisturbed } \\
\text { features. The date on the grave and } \\
\text { the relative visibility of the features } \\
\text { imply that it is of proto-historic age. }\end{array}$ \\
\hline $\begin{array}{l}\text { TEL- } \\
00196\end{array}$ & $\begin{array}{l}\text { Small } \\
\text { Village }\end{array}$ & Unknown & N/A & $\begin{array}{l}\text { Consists of two mounds, one with } \\
\text { two house pits within it and the } \\
\text { other with one, several other pits } \\
\text { without mounds, and many smaller } \\
\text { irregular depressions. The trail runs } \\
\text { west of the site, removed by about } \\
20 \text { meters, and a distinct gravel } \\
\text { ridge runs near the east edge. } \\
\text { Another worked bone piece with a } \\
\text { drilled hole similar to the antler } \\
\text { artifacts observed at TEL-193 was } \\
\text { observed near the northern pit in the } \\
\text { larger mound. A large square hole } \\
\text { with modern trash near the north } \\
\text { end of the site is not considered } \\
\text { historic. There is little obvious } \\
\text { evidence of recent pot hunting at } \\
\text { this site, and it is considered to have } \\
\text { historic significance. Just south of } \\
\text { Allotment } 12585\end{array}$ \\
\hline
\end{tabular}




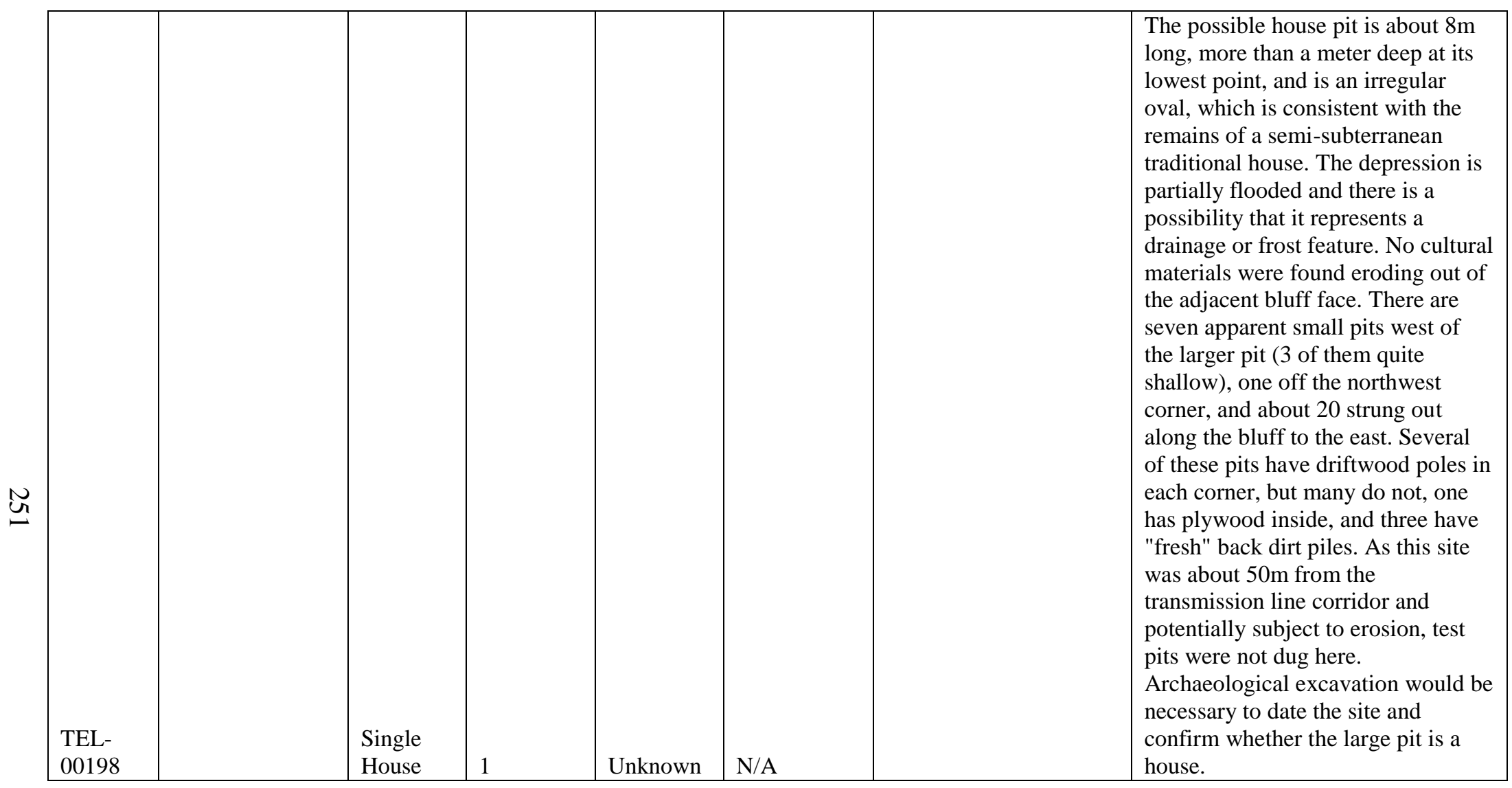




\begin{tabular}{|c|c|c|c|c|c|}
\hline $\begin{array}{l}\text { TEL- } \\
00216\end{array}$ & $\begin{array}{l}\text { Small } \\
\text { Village }\end{array}$ & 4 & $\begin{array}{l}\text { Before } \\
500 \mathrm{BP}\end{array}$ & $\begin{array}{l}\text { Cultural } \\
\text { Association }\end{array}$ & $\begin{array}{l}\text { Site consists of a cluster of } 4 \text { stone } \\
\text { house features. The floor plan may } \\
\text { have been rectangular with rounded } \\
\text { corners, there are no discernable } \\
\text { entryways. Feature KI-F002 has an } \\
\text { alcove with a partial wall visible on } \\
\text { the } \mathrm{W} \text { side. No other feature had } \\
\text { similar alcoves. House dimensions } \\
\text { range from } 7 \mathrm{~m} \times 8 \mathrm{~m} \text { to } 3.5 \mathrm{~m} \text { x } 4 \mathrm{~m} \text {. } \\
\text { Two test pits were dug using a soil } \\
\text { probe outside the features, each to } \\
\text { approximately } 50 \mathrm{~cm} \text { below surface. } \\
\text { Artifacts located in the test pits } \\
\text { include charcoal, pottery fragments, } \\
\text { and fragmentary sea mammal } \\
\text { bones. }\end{array}$ \\
\hline $\begin{array}{l}\text { TEL- } \\
00218\end{array}$ & $\begin{array}{l}\text { Single } \\
\text { House }\end{array}$ & 1 & Unknown & N/A & $\begin{array}{l}\text { Site is a semi-lunate stone } \\
\text { windbreak or house. The feature } \\
\text { commands a panoramic view of the } \\
\text { island and the ocean to the NW. } \\
\text { According to a local informant, an } \\
\text { "Isrigak" house was reported for this } \\
\text { locale. The Isrigak is a "hiding man" } \\
\text { or someone who has become } \\
\text { detached from the community of } \\
\text { humankind. }\end{array}$ \\
\hline $\begin{array}{l}\text { TEL- } \\
00232\end{array}$ & $\begin{array}{l}\text { Small } \\
\text { Village }\end{array}$ & 4 & Unknown & N/A & Several possible house features. \\
\hline $\begin{array}{l}\text { TEL- } \\
00233 \\
\end{array}$ & $\begin{array}{l}\text { Small } \\
\text { Village }\end{array}$ & 2 & Unknown & N/A & $\begin{array}{l}\text { Two probable house features } \\
\text { associated with cache pits and } \\
\text { activity area. }\end{array}$ \\
\hline $\begin{array}{l}\text { TEL- } \\
00237\end{array}$ & $\begin{array}{l}\text { Single } \\
\text { House }\end{array}$ & 1 & Unknown & N/A & $\begin{array}{l}\text { A single cemented sediment feature } \\
\text { with associated wood. }\end{array}$ \\
\hline
\end{tabular}




\begin{tabular}{|c|c|c|c|c|c|}
\hline $\begin{array}{l}\text { TEL- } \\
00238\end{array}$ & $\begin{array}{l}\text { Single } \\
\text { House }\end{array}$ & 1 & Unknown & N/A & $\begin{array}{l}\text { A single cemented sediment feature } \\
\text { with four wooden posts protruding } \\
\text { horizontally from sediment. A } \\
\text { ground slate tool was found } 5 \mathrm{~cm} \\
\text { from the feature. }\end{array}$ \\
\hline $\begin{array}{l}\text { TEL- } \\
00249\end{array}$ & $\begin{array}{l}\text { Small } \\
\text { Village }\end{array}$ & 5 & $\begin{array}{l}\text { After } 500 \\
\text { BP }\end{array}$ & $\begin{array}{l}\text { Cultural } \\
\text { Association }\end{array}$ & $\begin{array}{l}\text { PSU-2013-007 consists of five } \\
\text { features of cemented sediments with } \\
\text { associated vertical posts, two faunal } \\
\text { scatters, and a single piece of lithic } \\
\text { material. }\end{array}$ \\
\hline $\begin{array}{l}\text { TEL- } \\
00250\end{array}$ & $\begin{array}{l}\text { Single } \\
\text { House }\end{array}$ & 1 & $\begin{array}{l}\text { After } 500 \\
\text { BP }\end{array}$ & $\begin{array}{l}\text { Cultural } \\
\text { Association }\end{array}$ & $\begin{array}{l}\text { PSU-2013-008 consists of a feature } \\
\text { of cemented sediments, a buried } \\
\text { layer of cemented sediments, three } \\
\text { faunal scatters, two vertical posts, } \\
\text { and a glass scatter. }\end{array}$ \\
\hline $\begin{array}{l}\text { TEL- } \\
00251\end{array}$ & $\begin{array}{l}\text { Single } \\
\text { House }\end{array}$ & 1 & $\begin{array}{l}\text { After } 500 \\
\text { BP }\end{array}$ & $\begin{array}{l}\text { Cultural } \\
\text { Association }\end{array}$ & $\begin{array}{l}\text { PSU-2013-009 consists of a feature } \\
\text { of cemented sediments, three pieces } \\
\text { of structural wood, and burned } \\
\text { marine mammal bones. }\end{array}$ \\
\hline $\begin{array}{l}\text { TEL- } \\
00252\end{array}$ & $\begin{array}{l}\text { Single } \\
\text { House }\end{array}$ & 1 & $\begin{array}{l}\text { After } 500 \\
\text { BP }\end{array}$ & $\begin{array}{l}\text { Cultural } \\
\text { Association }\end{array}$ & $\begin{array}{l}\text { PSU-2013-011 consists of a single } \\
\text { feature of cemented sediments and } \\
\text { wood debris, thought to be the } \\
\text { remnants of a single occupation } \\
\text { feature. }\end{array}$ \\
\hline $\begin{array}{l}\text { TEL- } \\
00256\end{array}$ & $\begin{array}{l}\text { Single } \\
\text { House }\end{array}$ & 1 & $\begin{array}{l}\text { After } 500 \\
\text { BP }\end{array}$ & $\begin{array}{l}\text { Cultural } \\
\text { Association }\end{array}$ & $\begin{array}{l}\text { PSU-2013-015 consists of a feature } \\
\text { of cemented sediments, two wood } \\
\text { scatters, four vertical posts, and } \\
\text { faunal remains scattered across a } 30 \\
\mathrm{~m} \text { (north to south) by } 117 \text { meter } \\
\text { (east to west) dune blowout. The } \\
\text { site is thought to be the eroded } \\
\text { remains of a single occupation. }\end{array}$ \\
\hline
\end{tabular}




\begin{tabular}{|c|c|c|c|c|c|}
\hline $\begin{array}{l}\text { TEL- } \\
00257\end{array}$ & $\begin{array}{l}\text { Single } \\
\text { House }\end{array}$ & 1 & $\begin{array}{l}\text { After } 500 \\
\text { BP }\end{array}$ & $\begin{array}{l}\text { Cultural } \\
\text { Association }\end{array}$ & $\begin{array}{l}\text { PSU-2013-016 consists of a } \\
\text { concentration of eroding cemented } \\
\text { sediments. The site area is } \\
\text { approximately } 6 \text { meters in diameter. } \\
\text { No other cultural material or } \\
\text { artifacts were found in association } \\
\text { with the cemented sediments site. }\end{array}$ \\
\hline $\begin{array}{l}\text { TEL- } \\
00258\end{array}$ & $\begin{array}{l}\text { Small } \\
\text { Village }\end{array}$ & 2 & $\begin{array}{l}\text { After } 500 \\
\text { BP }\end{array}$ & $\begin{array}{l}\text { Cultural } \\
\text { Association }\end{array}$ & $\begin{array}{l}\text { PSU-2013-017 is likely the } \\
\text { remnants of a single house or small } \\
\text { settlement. Materials recorded at } \\
\text { the site include a house feature, a } \\
\text { concentration cemented sediments, } \\
\text { faunal remains, and other cultural } \\
\text { artifacts. The site area is } \\
\text { approximately } 108 \text { meters east to } \\
\text { west and } 22 \text { meters north to south. } \\
\text { Both the house and the tunnel have } \\
\text { been negatively impacted due to } \\
\text { erosion that caused the dune } \\
\text { blowout but there is an intact } \\
\text { occupation layer. Vertical posts } \\
\text { mark the possible boundary of the } \\
\text { house and the tunnel. On the surface } \\
\text { in the possible tunnel area are large } \\
\text { pieces of structural wood, mammoth } \\
\text { ivory, worked bone, pottery } \\
\text { fragments, and faunal remains all } \\
\text { disturbed from their original } \\
\text { position by dune erosion. A pottery } \\
\text { sherd, vertical posts, and terrestrial } \\
\text { mammal remains were noted on the } \\
\text { ground surface at the probable } \\
\text { junction of the house and tunnel. } \\
\text { Ground slate and other lithic raw } \\
\text { materials were noted on the dune }\end{array}$ \\
\hline
\end{tabular}




\begin{tabular}{|c|c|c|c|c|c|}
\hline & & & & & $\begin{array}{l}\text { surface in the house and tunnel } \\
\text { areas. A concentration of eroding of } \\
\text { cemented sediments and wood } \\
\text { debris located } 95 \text { meters west of the } \\
\text { first house feature are thought to be } \\
\text { the remnants of a second occupation } \\
\text { feature. }\end{array}$ \\
\hline $\begin{array}{l}\text { TEL- } \\
00260\end{array}$ & $\begin{array}{l}\text { Small } \\
\text { Village }\end{array}$ & 2 & $\begin{array}{l}\text { After } 500 \\
\text { BP }\end{array}$ & $\begin{array}{l}\text { Cultural } \\
\text { Association }\end{array}$ & $\begin{array}{l}\text { PSU-2013-019 is the remains of } \\
\text { what was probably once a small } \\
\text { settlement. The site consists of two } \\
\text { highly eroded occupation features; } \\
\text { all that remains of former } \\
\text { occupation are two concentrations } \\
\text { of cemented sediments. No } \\
\text { cultural material or artifacts were } \\
\text { found within the site area. }\end{array}$ \\
\hline $\begin{array}{l}\text { TEL- } \\
00263\end{array}$ & $\begin{array}{l}\text { Small } \\
\text { Village }\end{array}$ & 2 & $\begin{array}{l}\text { After } 500 \\
\text { BP }\end{array}$ & $\begin{array}{l}\text { Cultural } \\
\text { Association }\end{array}$ & $\begin{array}{l}\text { PSU-2013-023 consists of two small } \\
\text { features of cemented sediments and } \\
\text { associated wood debris that are } \\
\text { likely the remains of occupation } \\
\text { features. }\end{array}$ \\
\hline $\begin{array}{l}\text { TEL- } \\
00264\end{array}$ & $\begin{array}{l}\text { Small } \\
\text { Village }\end{array}$ & 3 & $\begin{array}{l}\text { After } 500 \\
\text { BP }\end{array}$ & $\begin{array}{l}\text { Cultural } \\
\text { Association }\end{array}$ & $\begin{array}{l}\text { PSU-2013-024 consists of three } \\
\text { former occupation features that have } \\
\text { been heavily eroded by wind and } \\
\text { water. All that remains are } \\
\text { cemented sediments, wood debris, } \\
\text { and pottery sherds. }\end{array}$ \\
\hline
\end{tabular}




\begin{tabular}{|c|c|c|c|c|c|}
\hline $\begin{array}{l}\text { TEL- } \\
00265\end{array}$ & $\begin{array}{l}\text { Small } \\
\text { Village }\end{array}$ & 2 & $\begin{array}{l}\text { After } 500 \\
\text { BP }\end{array}$ & $\begin{array}{l}\text { Cultural } \\
\text { Association }\end{array}$ & $\begin{array}{l}\text { PSU-2013-025 consists of two } \\
\text { occupation features with associated } \\
\text { cache pits and cultural material. } \\
\text { Feature } 1 \text { is a semi-subterranean } \\
\text { occupation feature or cache pit } \\
\text { located within a large blowout. The } \\
\text { feature consists of wooden } \\
\text { structural elements and fragments of } \\
\text { grass matting. The grass matting } \\
\text { was collected for further analysis. A } \\
\text { drilled wooden artifact was also } \\
\text { found in association with Feature } 1 . \\
\text { Cache Pit } 1 \text { is a small } 1.5 \text { meter by } 1 \\
\text { meter depression situated in a well- } \\
\text { vegetated area of the dune. A } \\
\text { sample of the grass mat was } \\
\text { collected for radiocarbon dating }\end{array}$ \\
\hline $\begin{array}{l}\text { TEL- } \\
00269\end{array}$ & $\begin{array}{l}\text { Small } \\
\text { Village }\end{array}$ & 4 & $\begin{array}{l}\text { After } 500 \\
\text { BP }\end{array}$ & $\begin{array}{l}\text { Occupation } \\
\text { Dates }\end{array}$ & $\begin{array}{l}\text { Site identified during field work in } \\
2013 \text { and } 2015 \text {. Possible subdivision } \\
\text { of TEL-00176. }\end{array}$ \\
\hline $\begin{array}{l}\text { TEL- } \\
00272\end{array}$ & $\begin{array}{l}\text { Small } \\
\text { Village }\end{array}$ & 2 & $\begin{array}{l}\text { After } 500 \\
\text { BP }\end{array}$ & $\begin{array}{l}\text { Occupation } \\
\text { Dates }\end{array}$ & $\begin{array}{l}\text { Site identified during field work in } \\
2013 \text { and 2015. Possible subdivision } \\
\text { of TEL-00176. }\end{array}$ \\
\hline $\begin{array}{l}\text { TEL- } \\
00273\end{array}$ & $\begin{array}{l}\text { Small } \\
\text { Village }\end{array}$ & 3 & $\begin{array}{l}\text { After } 500 \\
\text { BP }\end{array}$ & $\begin{array}{l}\text { Cultural } \\
\text { Association }\end{array}$ & $\begin{array}{l}\text { Site identified during field work in } \\
2013 \text { and } 2015 \text {. Possible subdivision } \\
\text { of TEL-00176. }\end{array}$ \\
\hline $\begin{array}{l}\text { TEL- } \\
00278\end{array}$ & $\begin{array}{l}\text { Small } \\
\text { Village }\end{array}$ & 3 & $\begin{array}{l}\text { After } 500 \\
\text { BP }\end{array}$ & $\begin{array}{l}\text { Cultural } \\
\text { Association }\end{array}$ & $\begin{array}{l}\text { Site identified during field work in } \\
2013 \text { and 2015. Possible subdivision } \\
\text { of TEL-00176. }\end{array}$ \\
\hline $\begin{array}{l}\text { TEL- } \\
00280\end{array}$ & $\begin{array}{l}\text { Small } \\
\text { Village }\end{array}$ & 3 & $\begin{array}{l}\text { After } 500 \\
\text { BP }\end{array}$ & $\begin{array}{l}\text { Occupation } \\
\text { Dates }\end{array}$ & $\begin{array}{l}\text { Site identified during field work in } \\
2013 \text { and } 2015 \text {. Possible subdivision } \\
\text { of TEL-00176. }\end{array}$ \\
\hline
\end{tabular}




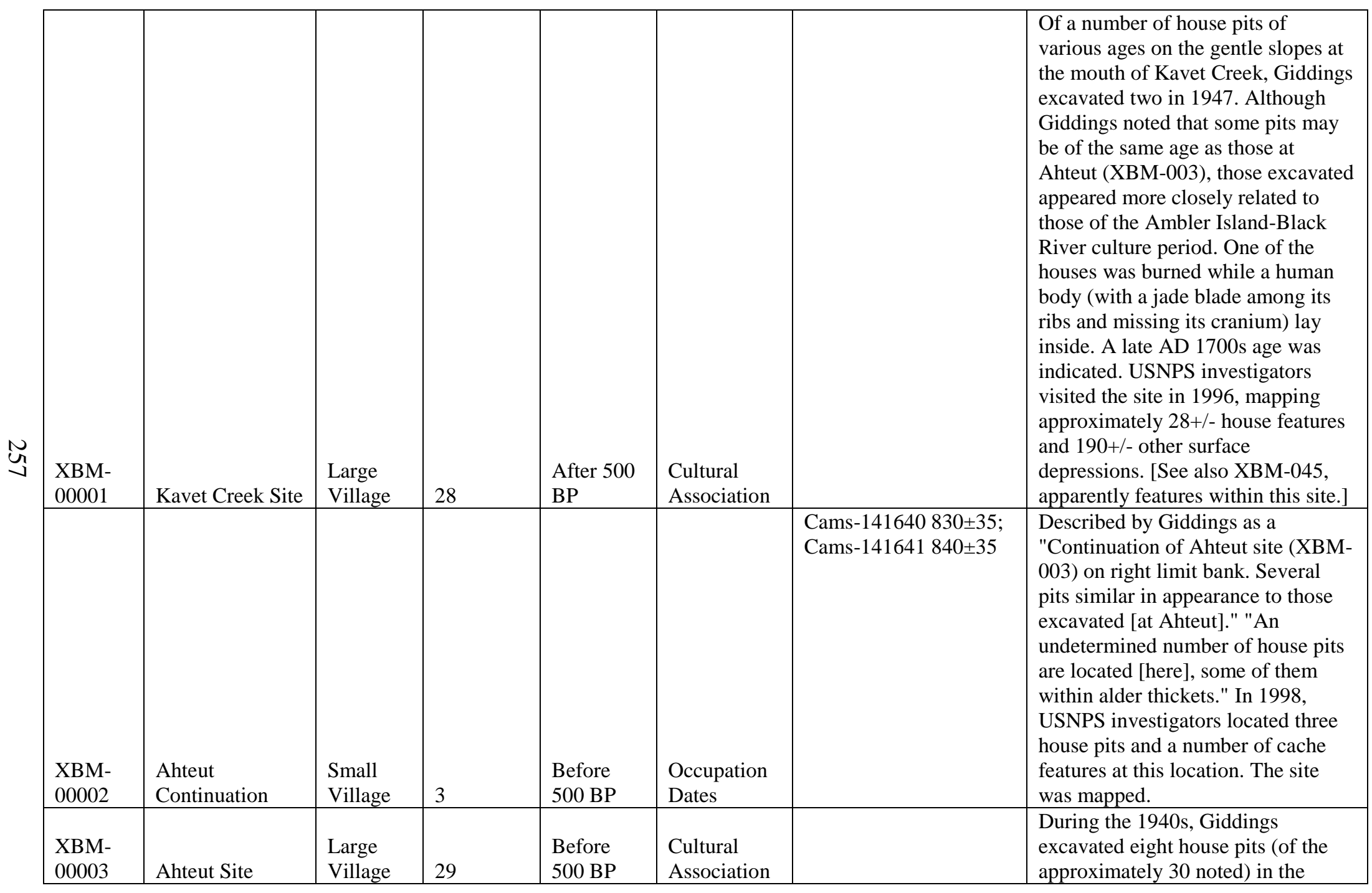




\begin{tabular}{|c|c|c|c|c|c|c|}
\hline & & & & & & $\begin{array}{l}\text { southern portion of the site and four } \\
\text { house pits (of the approximately } 10 \\
\text { noted) in the northern portion. } \\
\text { Dated at about AD } 1250 \text {, the houses } \\
\text { excavated were the earliest } \\
\text { Giddings found on Kobuk River. In } \\
\text { 1998, USNPS investigators mapped } \\
\text { the site. The southern loci consists } \\
\text { of a total of approximately } 29 \text { house } \\
\text { features and numerous cache pits. } \\
\text { The northern loci, separated by } \\
\text { some } 200 \mathrm{~m} \text {, consists of } \\
\text { approximately seven house features } \\
\text { and numerous cache pits. }\end{array}$ \\
\hline $\begin{array}{l}\text { XBM- } \\
00004\end{array}$ & $\begin{array}{l}\text { Kaligurickeark } \\
\text { River }\end{array}$ & Village & Unknown & Unknown & N/A & $\begin{array}{l}\text { Several house pits exposed in river } \\
\text { banks. Surface collection. AOHA } \\
2009\end{array}$ \\
\hline $\begin{array}{l}\text { XBM- } \\
00006\end{array}$ & $\begin{array}{l}\text { Salmon River } \\
\text { Village }\end{array}$ & Village & Unknown & Unknown & N/A & $\begin{array}{l}\text { Large village site occupied within } \\
\text { memory of living people. Reported } \\
\text { to Giddings. }\end{array}$ \\
\hline $\begin{array}{l}\text { XBM- } \\
00007\end{array}$ & $\begin{array}{l}\text { Kallarichuk } \\
\text { River }\end{array}$ & $\begin{array}{l}\text { Small } \\
\text { Village }\end{array}$ & 4 & Unknown & N/A & $\begin{array}{l}\text { Right limit bank above Kallarichuk } \\
\text { River. Four or more houses. }\end{array}$ \\
\hline $\begin{array}{l}\text { XBM- } \\
00008\end{array}$ & Kidway's Camp & Village & Unknown & $\begin{array}{l}\text { Before } \\
500 \mathrm{BP}\end{array}$ & $\begin{array}{l}\text { Cultural } \\
\text { Association }\end{array}$ & $\begin{array}{l}\text { Giddings noted house pits on both } \\
\text { sides of the river near Kidway's } \\
\text { Camp. Tests indicated that most } \\
\text { were late period ruins. Collections } \\
\text { from a steep bluff on the left bank } \\
\text { indicated that the eroding bank had } \\
\text { an Ahteut age (AD 1250) } \\
\text { occupation.[See also XBM-048 for } \\
\text { possible partial duplication.] }\end{array}$ \\
\hline
\end{tabular}




\begin{tabular}{|c|c|c|c|c|c|c|c|}
\hline $\begin{array}{l}\text { XBM- } \\
00009\end{array}$ & Ekseavik & $\begin{array}{l}\text { Large } \\
\text { Village }\end{array}$ & 20 & $\begin{array}{l}\text { Before } \\
500 \mathrm{BP}\end{array}$ & $\begin{array}{l}\text { Occupation } \\
\text { Dates }\end{array}$ & $\begin{array}{l}\text { P-16 780 } \pm 150 ; \text { P-29 } \\
720 \pm 200 ; \text { P- } 31 \\
820 \pm 220 ; \text { Cams- } 141646 \\
615 \pm 30 ; \text { Cams- } 141647 \\
735 \pm 20 ; \text { Cams-141648 } \\
710 \pm 25 ; \text { Cams- } 141649 \\
815 \pm 30\end{array}$ & $\begin{array}{l}\text { Giddings described this site as being } \\
\text { on a brush-covered knoll near a } \\
\text { small lake off a small slough of } \\
\text { Squirrel River, some } 8 \text { miles up } \\
\text { from Kiana. During the } 1940 \text { s, } 11 \text { of } \\
\text { the estimated } 20 \text { houses were } \\
\text { excavated. A date of AD } 1400 \text { was } \\
\text { assigned. [See also XMB-064 and } \\
\text { XBM-071.] }\end{array}$ \\
\hline $\begin{array}{l}\text { XBM- } \\
00010\end{array}$ & Kugururok River & Village & Unknown & $\begin{array}{l}\text { After } 500 \\
\text { BP }\end{array}$ & $\begin{array}{l}\text { Historic } \\
\text { Material }\end{array}$ & & $\begin{array}{l}\text { Site of old Native settlement located } \\
\text { by USGS party. Occupied between } \\
\text { AD } 1850-1900 \text {. }\end{array}$ \\
\hline $\begin{array}{l}\text { XBM- } \\
00012\end{array}$ & Kangiguksuk & $\begin{array}{l}\text { Single } \\
\text { House }\end{array}$ & 1 & $\begin{array}{l}\text { After } 500 \\
\text { BP }\end{array}$ & $\begin{array}{l}\text { Occupation } \\
\text { Dates }\end{array}$ & & $\begin{array}{l}\text { Rectangular, semi-subterranean } \\
\text { house with short entrance passage, } \\
\text { cache and hearth outside house. Hall } \\
\text { excavated approximately } 1100 \\
\text { square feet (about } 95 \% \text { of the site) } \\
\text { and recovered approximately } 2000 \\
\text { artifacts. These included projectile } \\
\text { points, arrowheads, adzes, spoons, a } \\
\text { harpoon head, fishing gear, labrets, } \\
1268 \text { pounds of faunal remains, } 359 \\
\text { pounds of spalls, and numerous } \\
\text { wood fragments. A } \\
\text { dendrochronological date of AD } \\
1578 \text { was obtained. Late prehistoric } \\
\text { Eskimo; most closely resembling } \\
\text { Intermediate Kotzebue site of } \\
\text { Giddings. }\end{array}$ \\
\hline $\begin{array}{l}\text { XBM- } \\
00027\end{array}$ & Kizuqtarvik & Village & Unknown & $\begin{array}{l}\text { Historic } \\
\text { Occupatio } \\
\mathrm{n}\end{array}$ & $\begin{array}{l}\text { Historic } \\
\text { Material }\end{array}$ & & $\begin{array}{l}\text { Fall concentration zone for families } \\
\text { from upper Noatak regional group. } \\
\text { Located by E.S. Burch (p.c. to } \\
\text { Hall). [See also XBM-028, XBM- } \\
\text { 029, XBM-030.] }\end{array}$ \\
\hline
\end{tabular}




\begin{tabular}{|c|c|c|c|c|c|c|}
\hline $\begin{array}{l}\text { XBM- } \\
00028\end{array}$ & Killiktavik 2 & $\begin{array}{l}\text { Large } \\
\text { Village }\end{array}$ & 12 & $\begin{array}{l}\text { After } 500 \\
\text { BP }\end{array}$ & $\begin{array}{l}\text { Historic } \\
\text { Material }\end{array}$ & $\begin{array}{l}\text { A dozen or more slightly semi- } \\
\text { subterranean, rectangular houses in } \\
\text { willows below bluff. Caribou bones } \\
\text { recovered. Probably post-AD } 1800 \text {; } \\
\text { late prehistoric Eskimo. [See also } \\
\text { XBM-027, XBM-029, XBM-030.] }\end{array}$ \\
\hline $\begin{array}{l}\text { XBM- } \\
00030\end{array}$ & & $\begin{array}{l}\text { Single } \\
\text { House }\end{array}$ & 1 & $\begin{array}{l}\text { After } 500 \\
\text { BP }\end{array}$ & $\begin{array}{l}\text { Cultural } \\
\text { Association }\end{array}$ & $\begin{array}{l}\text { Approximately one-half of an } \\
\text { eroded semi-subterranean house; } \\
\text { Hall excavated } 32 \text { square feet. A } \\
\text { harpoon foreshaft, projectile points, } \\
\text { arrow points, etc. were recovered. } \\
\text { Estimated date of AD 1600; late } \\
\text { prehistoric Eskimo: Kangigusuk and } \\
\text { Intermediate Kotzebue.[See also } \\
\text { XBM-027, XBM-028, XBM-029.] }\end{array}$ \\
\hline $\begin{array}{l}\text { XBM- } \\
00033\end{array}$ & Aayukalik & Village & Unknown & $\begin{array}{l}\text { Historic } \\
\text { Occupatio } \\
\mathrm{n}\end{array}$ & $\begin{array}{l}\text { Historic } \\
\text { Material }\end{array}$ & $\begin{array}{l}\text { Fall concentration zone for families } \\
\text { from upper Noatak regional group } \\
\text { (E.S. Burch p.c. to Hall). }\end{array}$ \\
\hline $\begin{array}{l}\text { XBM- } \\
00034\end{array}$ & Sisigak & Village & Unknown & $\begin{array}{l}\text { Historic } \\
\text { Occupatio } \\
\text { n }\end{array}$ & $\begin{array}{l}\text { Historic } \\
\text { Material }\end{array}$ & $\begin{array}{l}\text { Fall concentration zone for families } \\
\text { from upper Noatak regional group } \\
\text { (E.S. Burch p.c. to Hall).[See also } \\
\text { XBM-035.] }\end{array}$ \\
\hline $\begin{array}{l}\text { XBM- } \\
00035\end{array}$ & Siesieaijak & $\begin{array}{l}\text { Small } \\
\text { Village }\end{array}$ & 4 & $\begin{array}{l}\text { After } 500 \\
\text { BP }\end{array}$ & $\begin{array}{l}\text { Cultural } \\
\text { Association }\end{array}$ & $\begin{array}{l}\text { Four houses; two houses and } \\
\text { midden extensively tested. } \\
\text { Recovered cultural material } \\
\text { includes projectile points, } \\
\text { arrowheads, labrets, two metal } \\
\text { "tags," caribou bone, etc. Estimated } \\
\text { date of AD 1700: probable affinity } \\
\text { to Ambler Island on Kobuk River. } \\
\text { [See also XBM-034.] }\end{array}$ \\
\hline
\end{tabular}




\begin{tabular}{|c|c|c|c|c|c|c|}
\hline $\begin{array}{l}\text { XBM- } \\
00036\end{array}$ & & $\begin{array}{l}\text { Small } \\
\text { Village }\end{array}$ & 2 & $\begin{array}{l}\text { Historic } \\
\text { Occupatio } \\
\mathrm{n}\end{array}$ & $\begin{array}{l}\text { Historic } \\
\text { Material }\end{array}$ & $\begin{array}{l}\text { Two semi-subterranean houses (still } \\
\text { partially standing) and two hearths. } \\
\text { The two winter houses are in the } \\
\text { willows on the west side of the } \\
\text { creek; the hearths are one moss- } \\
\text { covered ground on the east side of } \\
\text { the creek. The hearth areas were } \\
\text { tested; material recovered includes } \\
.44 \text { shells, beads, antler tools, small } \\
\text { scrapers, and spalls. The houses } \\
\text { may not be as old as the hearth } \\
\text { areas: a Noatak informant told Hall } \\
\text { that Oscar Henry's family lived at } \\
\text { the mouth of Sapun (Sapoon) Creek } \\
\text { in } 1928 \text {. [See also XBM-037.] }\end{array}$ \\
\hline $\begin{array}{l}\text { XBM- } \\
00037\end{array}$ & Sapun & Village & Unknown & $\begin{array}{l}\text { Historic } \\
\text { Occupatio } \\
\mathrm{n}\end{array}$ & $\begin{array}{l}\text { Historic } \\
\text { Material }\end{array}$ & $\begin{array}{l}\text { Fall concentration zone for families } \\
\text { from upper Noatak regional group } \\
\text { (E.S. Burch p.c. to Hall). [See also } \\
\text { XBM-036.] }\end{array}$ \\
\hline $\begin{array}{l}\text { XBM- } \\
00038\end{array}$ & Aqlamagzuaq & Village & Unknown & $\begin{array}{l}\text { Historic } \\
\text { Occupatio } \\
\text { n }\end{array}$ & $\begin{array}{l}\text { Historic } \\
\text { Material }\end{array}$ & $\begin{array}{l}\text { Fall concentration zone for families } \\
\text { from Upper Noatak regional group. } \\
\text { Aklummayuak Creek sometimes } \\
\text { served as a route to Upper Noatak } \\
\text { River. Peterbourgh canoe, bobsled } \\
\text { frames, and umaypak parts. }\end{array}$ \\
\hline $\begin{array}{l}\text { XBM- } \\
00039 \\
\end{array}$ & Uliqsaun & Village & Unknown & $\begin{array}{l}\text { Historic } \\
\text { Occupatio } \\
\mathrm{n}\end{array}$ & $\begin{array}{l}\text { Historic } \\
\text { Material } \\
\end{array}$ & $\begin{array}{l}\text { Fall concentration zone for families } \\
\text { from Upper Noatak regional group. } \\
\text { Hall noted umaypak parts. }\end{array}$ \\
\hline $\begin{array}{l}\text { XBM- } \\
00040\end{array}$ & Isarukturvik & Village & Unknown & $\begin{array}{l}\text { Historic } \\
\text { Occupatio } \\
\mathrm{n}\end{array}$ & $\begin{array}{l}\text { Historic } \\
\text { Material }\end{array}$ & $\begin{array}{l}\text { Fall concentration zone for families } \\
\text { from Upper Noatak regional group } \\
\text { (E.S. Burch p.c. to Hall). }\end{array}$ \\
\hline
\end{tabular}




\begin{tabular}{|c|c|c|c|c|c|c|}
\hline $\begin{array}{l}\text { XBM- } \\
00041\end{array}$ & Mitkotaylyuk & $\begin{array}{l}\text { Single } \\
\text { House }\end{array}$ & 1 & $\begin{array}{l}\text { After } 500 \\
\text { BP }\end{array}$ & $\begin{array}{l}\text { Cultural } \\
\text { Association }\end{array}$ & $\begin{array}{l}\text { Portion of eroding rectangular house } \\
\text { on willow-covered river bank. Hall } \\
\text { excavated approximately } 40 \text { square } \\
\text { feet. Cultural material included } \\
\text { ground slate ulu blades, arrowheads, } \\
\text { caribou bones, etc. Probable affinity } \\
\text { with Ambler Island on Kobuk } \\
\text { River. }\end{array}$ \\
\hline $\begin{array}{l}\text { XBM- } \\
00045\end{array}$ & & $\begin{array}{l}\text { Small } \\
\text { Village }\end{array}$ & 2 & Unknown & N/A & $\begin{array}{l}\text { A } 4 \text { ' in diameter depression } \\
\text { connected to a 7' x 5' depression by } \\
\text { a } 10^{\prime} \text { x } 2 \text { ' tunnel and two 5' } \\
\text { depressions connected to a 7'x 5' } \\
\text { depression located } 45 \text { links [9.05m] } \\
\text { northeast of the first. These are } \\
\text { situated about } 100 \text { ' above the river } \\
\text { level overlooking a well-known } \\
\text { caribou crossing. Information from } \\
\text { Kenneth Ludy, BLM surveyor and } \\
\text { sketch map by Donovan Harris to } \\
\text { J.P. Cook, } 1974 \text {. [These reported } \\
\text { features appear to be within the } \\
\text { Kavet Creek Site (XBM-001).] }\end{array}$ \\
\hline $\begin{array}{l}\text { XBM- } \\
00047\end{array}$ & $\begin{array}{l}\text { Igliqtiqiugvigrua } \\
\mathrm{q}\end{array}$ & Village & Unknown & Unknown & N/A & $\begin{array}{l}\text { In } 1985 \text {, USNPS investigators noted } \\
\text { over } 40 \text { features, including house } \\
\text { pits and cache pits, along } \\
\text { approximately } 200 \text { m of point bar on } \\
\text { the south side of Kobuk River. } \\
\text { Artifacts noted eroding from the } \\
\text { adjacent river bank includes pottery } \\
\text { and worked bone and antler wedges, } \\
\text { net sinkers, and projectile points. } \\
\text { Possible test pits were noted in one } \\
\text { of the house pits. In } 1996 \text {, USNPS } \\
\text { investigators mapped the site, } \\
\text { recording approximately } 28 \text { houses }\end{array}$ \\
\hline
\end{tabular}




\begin{tabular}{|c|c|c|c|c|c|c|}
\hline & & & & & & $\begin{array}{l}\text { (many of complex form) in addition } \\
\text { to nearly } 200 \text { cache pits or other } \\
\text { features. At the eastern end of the } \\
\text { site, an eroding log feature yielded a } \\
\text { near-bark dendrochronology date of } \\
\text { A.D. 1908. [This is apparently a } \\
\text { duplication of XBM-058, a site } \\
\text { reported to, but not visited by, } \\
\text { Giddings.] }\end{array}$ \\
\hline $\begin{array}{l}\text { XBM- } \\
00048\end{array}$ & & $\begin{array}{l}\text { Small } \\
\text { Village }\end{array}$ & 2 & Unknown & N/A & $\begin{array}{l}\text { Two large depressions, associated } \\
\text { cache pits, and a dump site were } \\
\text { noted on a } 15-20 \mathrm{~m} \text { terrace. The } \\
\text { depressions, probably dwellings, } \\
\text { measured } 4 \mathrm{~m} \times 4 \mathrm{~m} \text { and } 4 \mathrm{~m} \times 5 \mathrm{~m} \text { in } \\
\text { size. The dump of tin cans was } \\
\text { situated about } 15 \mathrm{~m} \text { from the } \\
\text { depressions. Shee also XBM- } 008 \text { for } \\
\text { possible partial duplication.] }\end{array}$ \\
\hline $\begin{array}{l}\text { XBM- } \\
00064\end{array}$ & Canyon Creek & $\begin{array}{l}\text { Small } \\
\text { Village }\end{array}$ & 2 & Unknown & N/A & $\begin{array}{l}\text { Giddings excavated one of two } \\
\text { obscure pits noted at the mouth of } \\
\text { Canyon Creek, about } 2 \text { miles from } \\
\text { Ekseavik (XBM-009). The house } \\
\text { excavated appeared to be closely } \\
\text { related to those at Ekseavik. } \\
\text { Additionally, Giddings noted that } \\
\text { several house pits were discovered } \\
\text { along the banks of a former slough } \\
\text { betwen Ekseavik and Squirrel } \\
\text { River, which tests showed to be of a } \\
\text { late period. [See also XBM-009 and } \\
\text { XBM-071.] }\end{array}$ \\
\hline
\end{tabular}




\begin{tabular}{|c|c|c|c|c|c|}
\hline $\begin{array}{l}\text { XBM- } \\
00065\end{array}$ & $\begin{array}{l}\text { Small } \\
\text { Village }\end{array}$ & 3 & $\begin{array}{l}\text { Historic } \\
\text { Occupatio } \\
\mathrm{n}\end{array}$ & $\begin{array}{l}\text { Historic } \\
\text { Material }\end{array}$ & $\begin{array}{l}\text { Oswalt briefly notes excavating one } \\
\text { of three fallen and partly buried } \\
\text { Eskimo houses on a dead slough } \\
\text { across from Archie's Landing, about } \\
12 \text { miles up Squirrel River. The } \\
\text { excavated house measured } 14 \text { ' x } \\
122.5^{\prime} \text { with a straight } 2^{2} \text { x } 8 \text { ' tunnel, } \\
\text { and resembled Giddings' Ambler } \\
\text { Island house dated to the early } \\
1700 \text { s. The tree-ring dates indicate } \\
\text { that the structures were built circa } \\
\text { AD } 1879 \text {. }\end{array}$ \\
\hline $\begin{array}{l}\text { XBM- } \\
00067\end{array}$ & $\begin{array}{l}\text { Single } \\
\text { House }\end{array}$ & 1 & Unknown & N/A & $\begin{array}{l}\text { In 1989, a house pit-shaped } \\
\text { depression was noted on the north } \\
\text { edge of a forested terrace on the } \\
\text { south side of Kobuk River. Roughly } \\
\text { oval in outline, with a diffuse, } \\
\text { discontinuous berm, the feature is } \\
\text { about } 30 \mathrm{~cm} \text { deep. This feature, and } \\
\text { two others, was relocated by } \\
\text { USNPS investigators in } 1998 \text {. } \\
\text { Subsurface of the features, thought } \\
\text { to be thaw features, yielded negative } \\
\text { results. }\end{array}$ \\
\hline $\begin{array}{l}\text { XBM- } \\
00071\end{array}$ & $\begin{array}{l}\text { Large } \\
\text { Village }\end{array}$ & 6 & Unknown & N/A & $\begin{array}{l}\text { This site consists of at least six } \\
\text { house pits and over } 25 \text { cache pits on } \\
\text { top of a } 3 \mathrm{~m} \text { high cut bank just west } \\
\text { of a low, } 2-3 \mathrm{~m} \text { high sand ridge. The } \\
\text { house pits near the river have } \\
\text { entryways of variable length and } \\
\text { orientation. The site was reported to } \\
\text { Mason as having been tested by J.L. } \\
\text { Giddings during the } 1940 \text { s. [See } \\
\text { also XBM-064 (possible } \\
\text { duplication).] }\end{array}$ \\
\hline
\end{tabular}




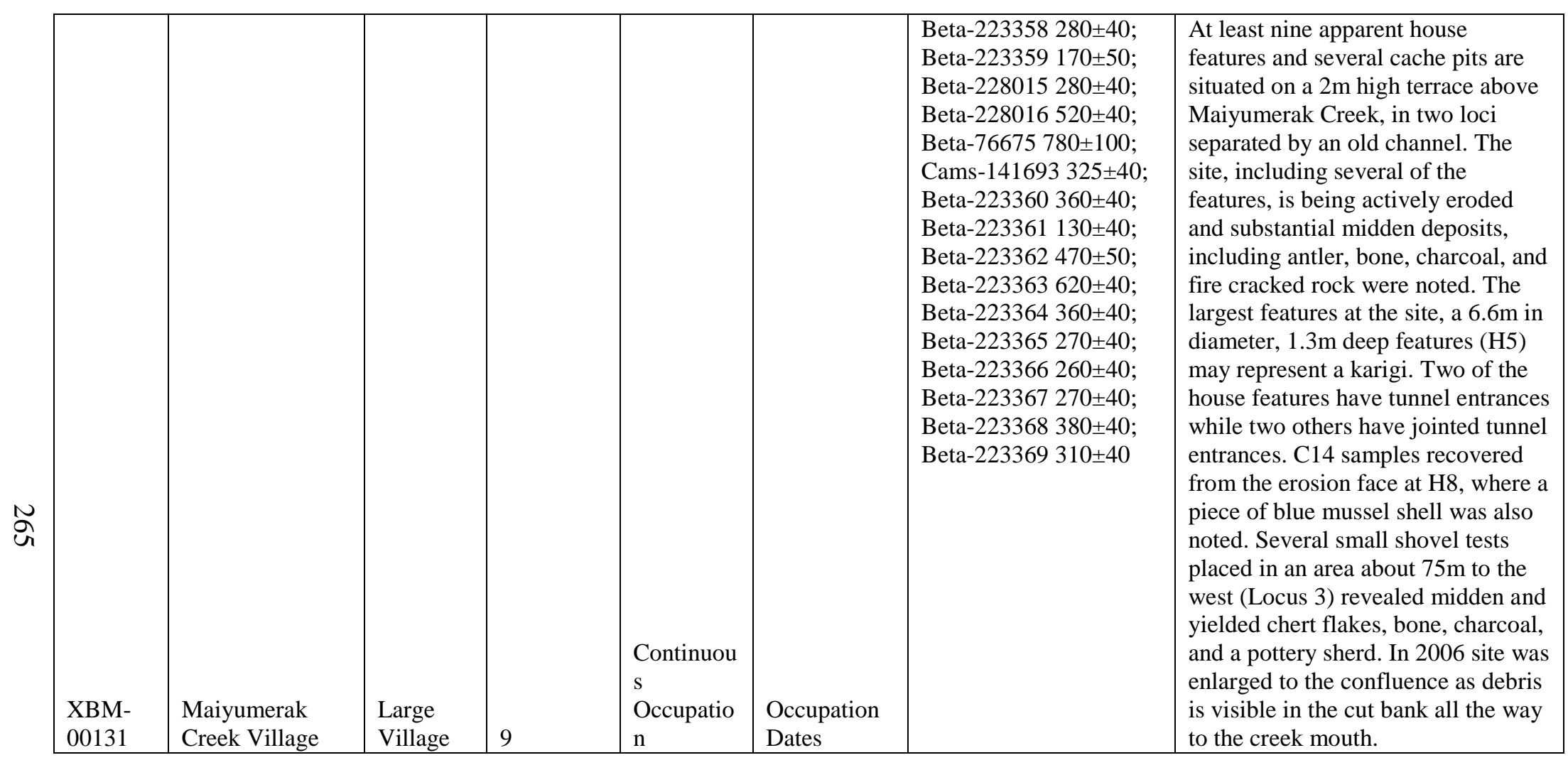




\begin{tabular}{|c|c|c|c|c|c|c|}
\hline $\begin{array}{l}\text { XBM- } \\
00144\end{array}$ & $\begin{array}{l}\text { Ruth B. Sandvik } \\
\text { Allotment Site }\end{array}$ & Village & Unknown & Unknown & N/A & $\begin{array}{l}\text { In 1996, during a brief rest stop, } \\
\text { USNPS investigators noted two } \\
\text { house pits on the terrace in front of } \\
\text { a modern frame cabin on an } \\
\text { allotment. One of the house pits } \\
\text { appeared to be of late prehistoric } \\
\text { age (rectangular structure with a } \\
\text { long entrance tunnel off the long } \\
\text { wall), while the other may be of } \\
\text { historic age (larger rectangular } \\
\text { structure with a long entrance } \\
\text { tunnel). USNPS investigators } \\
\text { revisited and mapped the site in } \\
1998 \text {. A total of } 12 \text { house pits and } \\
\text { numerous cache pits were noted } \\
\text { along a } 450 \mathrm{~m} \text { stretch of eroding } \\
\text { bank. Several of the features are } \\
\text { eroding and cultural material is } \\
\text { evident along portions of the } \\
\text { erosion face. AOHA } 2009 \text {. }\end{array}$ \\
\hline $\begin{array}{l}\text { XBM- } \\
00145\end{array}$ & Oolyak's Camp & $\begin{array}{l}\text { Small } \\
\text { Village }\end{array}$ & 3 & Unknown & N/A & $\begin{array}{l}\text { USNPS investigators noted the } \\
\text { remains of a } 4.6 \mathrm{~m} \times 4 \mathrm{~m} \text { log cabin, } \\
\text { two rectangular depression features } \\
\text { without tunnel entrances ( } 4.8 \mathrm{~m} \times \\
3.6 \mathrm{~m} \text { and } 5.6 \mathrm{~m} \times 2.9 \mathrm{~m} \text { in size), a } \\
4.4 \mathrm{~m} \times 3.4 \mathrm{~m} \text { rectangular depression } \\
\text { feature with a } 1.9 \mathrm{~m} \text { long tunnel } \\
\text { entrance, three cache pits, a number } \\
\text { of posts, and historic debris. } \\
\text { Possibly the camp of Oolyak } \\
\text { (Stonewall Jackson), a key } \\
\text { informant of J. Louis Giddings } \\
\text { during the early 1940s (rather than } \\
\text { XBM-046, as reported previously). }\end{array}$ \\
\hline
\end{tabular}




\begin{tabular}{|c|c|c|c|c|c|}
\hline $\begin{array}{l}\text { XBM- } \\
00147\end{array}$ & $\begin{array}{l}\text { Single } \\
\text { House }\end{array}$ & 1 & Unknown & N/A & $\begin{array}{l}\text { USNPS investigators noted the } \\
\text { remains of a } 4.1 \mathrm{~m} \text { x } 2.85 \mathrm{~m} \text { house pit } \\
\text { with a } 3.2 \mathrm{~m} \text { long entrance tunnel } \\
\text { and four large cache pits (two } \\
\text { rectangular and two circular). The } \\
\text { house pit is located less than } 6 \mathrm{~m} \\
\text { from the edge of the eroding bank. } \\
\text { A metal detector scan yielded } \\
\text { evidence of metal. A } 1 \mathrm{~m} \times .5 \mathrm{~m} \text { test } \\
\text { within the house pit yielded a coffee } \\
\text { can in the fill of a shallow (later) pit } \\
\text { and a small birch bark basket from } \\
\text { the house interior. }\end{array}$ \\
\hline $\begin{array}{l}\text { XBM- } \\
00148 \\
\end{array}$ & $\begin{array}{l}\text { Large } \\
\text { Village }\end{array}$ & 10 & Unknown & N/A & $\begin{array}{l}\text { USNPS investigators and mapped } \\
\text { about } 10 \text { house pits and } 27+ \\
\text { additional depression features } \\
\text { within a } 200 \mathrm{~m} \times 80 \mathrm{~m} \text { area, on } 5 \text { of a } \\
\text { series of small ridges/knobs and } \\
\text { swales projecting to the S from the } \\
\text { end of a major ridge overlooking the } \\
\text { right bank of Kobuk River. Most of } \\
\text { the houses are on or near the tops of } \\
\text { the knobs. The semi-subterranean } \\
\text { houses vary from almost round to } \\
\text { sub-rectangular and trapezoidal, but } \\
\text { are all from } 3-5 \mathrm{~m} \text { wide and less than } \\
.5 \mathrm{~m} \text { deep. Several show suggestions } \\
\text { of structural wood under obscuring } \\
\text { vegetation and in one (H6), many } \\
\text { logs, split logs, and hewn planks } \\
\text { survive, although in an entirely } \\
\text { collapsed state. A metal detector } \\
\text { scan of this house was entirely } \\
\text { negative. Surface indications in } \\
\text { several houses suggest the presence }\end{array}$ \\
\hline
\end{tabular}




\begin{tabular}{|c|c|c|c|c|c|c|}
\hline & & & & & & $\begin{array}{l}\text { of side benches and central fire pits. } \\
\text { Other features at the site include a } \\
\text { variety of round and rectilinear pits } \\
\text { from } 1 \mathrm{~m} \text { diameter to } 2 \mathrm{~m} \text { sq. Tests } \\
\text { conducted in } 1998 \text { revealed a late } \\
\text { prehistoric cultural inventory with } \\
\text { no Euroamerican trade goods. The } \\
\text { house floors were frozen and } \\
\text { contained a rich assemblage of } \\
\text { faunal material. }\end{array}$ \\
\hline $\begin{array}{l}\text { XBM- } \\
00149\end{array}$ & $\begin{array}{l}\text { Ranger Reported } \\
\text { Site }\end{array}$ & $\begin{array}{l}\text { Single } \\
\text { House }\end{array}$ & 1 & Unknown & N/A & $\begin{array}{l}\text { Originally reported by a USNPS } \\
\text { Park ranger in 1995, this site was } \\
\text { mapped by USNPS investigators in } \\
\text { 1998. The site consists of a single } \\
\text { house pit and two cache pits } \\
\text { adjacent to the confluence of a small } \\
\text { drainage with Kobuk River and four } \\
\text { cache pits on a small hill behind the } \\
\text { site. }\end{array}$ \\
\hline $\begin{array}{l}\text { XBM- } \\
00155\end{array}$ & & $\begin{array}{l}\text { Large } \\
\text { Village }\end{array}$ & 6 or 7 & Unknown & N/A & $\begin{array}{l}\text { Six to seven houses and numerous } \\
\text { cache feature in two loci. Mapped } \\
\text { by NPS in } 1998 .\end{array}$ \\
\hline $\begin{array}{l}\text { XBM- } \\
00156\end{array}$ & & $\begin{array}{l}\text { Small } \\
\text { Village }\end{array}$ & 3 & Unknown & N/A & $\begin{array}{l}\text { Three house pits and numerous } \\
\text { cache pits were noted in three loci. } \\
\text { Mapped by NPS in } 1998 \text {. }\end{array}$ \\
\hline $\begin{array}{l}\text { XBM- } \\
00157\end{array}$ & & $\begin{array}{l}\text { Single } \\
\text { House }\end{array}$ & 1 & Unknown & N/A & $\begin{array}{l}\text { In 1998, USNPS investigators } \\
\text { located and mapped a single house } \\
\text { pit and seven cache features situated }\end{array}$ \\
\hline
\end{tabular}




\begin{tabular}{|c|c|c|c|c|c|c|}
\hline & & & & & & $\begin{array}{l}\text { on a hilltop/terrace about } 15-20 \mathrm{~m} \\
\text { above the river. }\end{array}$ \\
\hline $\begin{array}{l}\text { XBM- } \\
00158\end{array}$ & & $\begin{array}{l}\text { Small } \\
\text { Village }\end{array}$ & 3 & Unknown & N/A & $\begin{array}{l}\text { USNPS investigators located and } \\
\text { mapped three or four house pits and } \\
10 \text { cache features situated on a high, } \\
\text { dry ridge about } 150 \mathrm{~m} \text { back from the } \\
\text { river beach. [This may be, or be a } \\
\text { part of, the site identified by } \\
\text { Giddings as Ahteut Continuation } \\
\text { (XBM-002).] }\end{array}$ \\
\hline $\begin{array}{l}\text { XBM- } \\
00159\end{array}$ & $\begin{array}{l}\text { Grace Outwater } \\
\text { Allotement Site }\end{array}$ & $\begin{array}{l}\text { Large } \\
\text { Village }\end{array}$ & 6 & Unknown & N/A & $\begin{array}{l}\text { USNPS investigators located and } \\
\text { mapped this site in } 1998 \text {. In addition } \\
\text { to an allotment cabin, the site } \\
\text { consists of six house pits, three } \\
\text { bermed wall tent features, and the } \\
\text { ruins of a log cabin. As well as an } \\
\text { apparent Inupiat site, the site } \\
\text { appears to be the remains of the } \\
1898 \text { gold rush period "Jessy Lou } \\
\text { Camp." }\end{array}$ \\
\hline $\begin{array}{l}\text { XBM- } \\
00177\end{array}$ & & Village & Unknown & Unknown & N/A & $\begin{array}{l}\text { Reported to John Cook as a large } \\
\text { area with pits and mounds. USGS } \\
\text { map with a hand written note that } \\
\text { "pits and mounds found in this } \\
\text { area." Not field verified by } \\
\text { archaeologists but a fallen log cache } \\
\text { is noted on the western end of US } \\
\text { Survey No. 5151, Lot } 2 \text { (1973). }\end{array}$ \\
\hline $\begin{array}{l}\text { XHP- } \\
00004\end{array}$ & Feniak Lake & $\begin{array}{l}\text { Large } \\
\text { Village }\end{array}$ & 14 & Unknown & N/A & $\begin{array}{l}\text { Hall located, but did not test, a total } \\
\text { of seven rectangular semi- } \\
\text { subterranean houses with entrance } \\
\text { passages, a small, apparently } \\
\text { circular, stone-lined karigi, and } \\
\text { midden deposits. Moving north }\end{array}$ \\
\hline
\end{tabular}




\begin{tabular}{|c|c|c|c|c|c|c|}
\hline & & & & & & $\begin{array}{l}\text { along the east shore of the lake they } \\
\text { were encountered in the order of } \\
\text { two houses, then five houses and the } \\
\text { karigi. }\end{array}$ \\
\hline $\begin{array}{l}\text { XHP- } \\
00010\end{array}$ & & $\begin{array}{l}\text { Single } \\
\text { House }\end{array}$ & 1 & $\begin{array}{l}\text { Outside } \\
\text { Study } \\
\text { Period }\end{array}$ & $\begin{array}{l}\text { Occupation } \\
\text { Dates }\end{array}$ & $\begin{array}{l}\text { Hall located and excavated a } \\
\text { rectangular, semi-subterranean } \\
\text { house with an entrance passage and } \\
\text { an interior hearth located on a small } \\
\text { knoll near a creek about } 3 / 4 \text { mile up } \\
\text { the east shore of the lake from the } \\
\text { outlet stream. Two cache pits were } \\
\text { also noted. Approximately } 1500 \\
\text { artifacts were recovered, including } \\
\text { adze heads, side and end blades, } \\
\text { incised pebbles, worked antler, } \\
\text { discoidals, ground slate, waste } \\
\text { flakes, bone, and birch bark. The } \\
\text { house apparently represents a } \\
\text { Norton-Ipiutak occupation. }\end{array}$ \\
\hline $\begin{array}{l}\text { XHP- } \\
00011\end{array}$ & Anisaiaq & $\begin{array}{l}\text { Large } \\
\text { Village }\end{array}$ & 6 & Unknown & N/A & $\begin{array}{l}\text { Irving (p.c. to Hall) located six } \\
\text { readily visible semi-subterranean } \\
\text { houses and over } 12 \text { cache pits } \\
\text { amongst the willows and } \\
\text { cottonwood at the base of the bluff. } \\
\text { Pottery and spalls were recovered. } \\
\text { Hall visited the site in } 1970 \text {. Burch } \\
\text { (p.c. to Hall) noted this as a fall } \\
\text { concentration zone for families from } \\
\text { the Upper Noatak regional group. }\end{array}$ \\
\hline
\end{tabular}




\begin{tabular}{|c|c|c|c|c|c|c|}
\hline $\begin{array}{l}\text { XHP- } \\
00013\end{array}$ & Uivaqsaat & Village & Unknown & Unknown & N/A & $\begin{array}{l}\text { Burch (p.c. to Hall) noted a fall } \\
\text { concentration zone for families from } \\
\text { the Upper Noatak regional groups } \\
\text { south of Desperation Lake, where } \\
\text { Fry (Uivaksak) Creek joins another } \\
\text { westward flowing stream before } \\
\text { becoming the Anisak River. D.C. } \\
\text { Foote (1965: Map 24) apparently } \\
\text { noted winter houses just west of } \\
\text { Desperation Lake in the Anisak } \\
\text { River drainage, possibly the same } \\
\text { locality. }\end{array}$ \\
\hline $\begin{array}{l}\text { XHP- } \\
00016 \\
\end{array}$ & & $\begin{array}{l}\text { Small } \\
\text { Village }\end{array}$ & 2 & Unknown & N/A & $\begin{array}{l}\text { Irving (p.c. to Hall) reported } \\
\text { locating two shallow rectangular } \\
\text { houses on the storm beach near the } \\
\text { late prehistoric/historic village } \\
\text { (XHP-017) on the south shore of } \\
\text { Desperation Lake. The house } \\
\text { features were different from those in } \\
\text { the village. }\end{array}$ \\
\hline $\begin{array}{l}\text { XHP- } \\
00017\end{array}$ & & $\begin{array}{l}\text { Large } \\
\text { Village }\end{array}$ & 24 & Unknown & N/A & $\begin{array}{l}\text { Irving located about two dozen } \\
\text { large rectangular houses of a winter } \\
\text { village site on the south shore of } \\
\text { Desperation Lake. Two house pits } \\
\text { and midden, up to } 2.5 \text { ' thick, were } \\
\text { tested. Pottery of recent appearance } \\
\text { and ground jade and slate were } \\
\text { noted throughout the midden, } \\
\text { leading to speculation that the } \\
\text { village was founded in the late } \\
\text { prehistoric period. Saw-cut bones } \\
\text { were also noted. Around the village } \\
\text { a great number of tent rings were } \\
\text { noted, but no associated artifacts } \\
\text { other than caribou bones. Of special }\end{array}$ \\
\hline
\end{tabular}




\begin{tabular}{|c|c|c|c|c|c|c|}
\hline & & & & & & $\begin{array}{l}\text { note was an oval karigi, some } 35 \text { ' in } \\
\text { its longest interior dimension, } \\
\text { marked by wall boulders up to } 5 \text { ' in } \\
\text { diameter, some of which bear } \\
\text { petroglyphs. }\end{array}$ \\
\hline $\begin{array}{l}\text { XHP- } \\
00022 \\
\end{array}$ & $\begin{array}{l}\text { Tupichalik } \\
\text { Creek }\end{array}$ & Village & Unknown & Unknown & N/A & $\begin{array}{l}\text { D.C. Foote (1965:Map 24) } \\
\text { apparently locates winter houses in } \\
\text { the upper reaches of Tupichalik } \\
\text { Creek, which drains into } \\
\text { Desperation Lake. }\end{array}$ \\
\hline $\begin{array}{l}\text { XHP- } \\
00024\end{array}$ & Nanirailik & Village & Unknown & Unknown & N/A & $\begin{array}{l}\text { Burch (p.c. to Hall) noted this } \\
\text { locality as a fall concentration zone } \\
\text { for families from the Upper Noatak } \\
\text { regional group. }\end{array}$ \\
\hline $\begin{array}{l}\text { XHP- } \\
00026\end{array}$ & Makpik & $\begin{array}{l}\text { Large } \\
\text { Village }\end{array}$ & 7 & Unknown & N/A & $\begin{array}{l}\text { Seven or more semi-subterranean } \\
\text { houses and numerous cache pits } \\
\text { were located at this site. T.D. } \\
\text { Hamilton (p.c. to Hall) reported that } \\
\text { the site was stratified, but Hall } \\
\text { found no evidence to support this } \\
\text { contention. Spalls were noted but } \\
\text { apparently not retained. Burch (p.c. } \\
\text { to Hall) noted this locality as a fall } \\
\text { concentration zone for families from } \\
\text { the Upper Naotak regional group. }\end{array}$ \\
\hline $\begin{array}{l}\text { XHP- } \\
00028\end{array}$ & Nazvarzug & Village & Unknown & Unknown & N/A & $\begin{array}{l}\text { Burch (p.c. to Hall) noted this as a } \\
\text { fall concentration zone for families } \\
\text { from the Upper Noatak regional } \\
\text { group. This locality is represented }\end{array}$ \\
\hline
\end{tabular}




\begin{tabular}{|c|c|c|c|c|c|c|}
\hline & & & & & & $\begin{array}{l}\text { by a number of recorded sites } \\
\text { (XPH-004, XPH-008, XPH-009, } \\
\text { XPH-010, XPH-029, and XPH- } \\
\text { 399). }\end{array}$ \\
\hline $\begin{array}{l}\text { XHP- } \\
00029\end{array}$ & & $\begin{array}{l}\text { Small } \\
\text { Village }\end{array}$ & 2 & Unknown & N/A & $\begin{array}{l}\text { Hall located two semi-subterranean } \\
\text { houses on a willow-cloaked hillside } \\
\text { about } 400 \text { yards east of the } \\
\text { southeast corner of Feniak Lake. } \\
\text { The house are similar to, but more } \\
\text { compact than, others at the lake. A } \\
\text { midden deposit was noted south of } \\
\text { the houses. A small test yielded } \\
\text { caribou bone. }\end{array}$ \\
\hline $\begin{array}{l}\text { XHP- } \\
00031\end{array}$ & & Village & Unknown & $\begin{array}{l}\text { Historic } \\
\text { Occupatio } \\
\mathrm{n}\end{array}$ & $\begin{array}{l}\text { Occupation } \\
\text { Dates }\end{array}$ & $\begin{array}{l}\text { S.B. McLenegan (1887) apparently } \\
\text { noted houses on the north bank of } \\
\text { Noatak River, just upstream from } \\
\text { the mouth of Makpik Creek } \\
\text { (location not exact). }\end{array}$ \\
\hline $\begin{array}{l}\text { XHP- } \\
00033\end{array}$ & Okak Bend & Village & Unknown & Unknown & N/A & $\begin{array}{l}\text { Irving (p.c. to Hall) reported a } \\
\text { summer camp of } 8-10 \text { willow tent } \\
\text { frames, bow pieces, and wooden } \\
\text { dish fragments on the south side of } \\
\text { the river, at Okak Bend. Irving } \\
\text { suggested that the stream had been } \\
\text { dammed for a weir. Burch (p.c. to } \\
\text { Hall) noted Okak Bend as a fall } \\
\text { concentration zone for families from } \\
\text { the Upper Noatak regional group. } \\
\text { Apparently D.C. Foote (1965:Map } \\
\text { 24) also noted winter houses at this } \\
\text { location.[See also XHP-034.] }\end{array}$ \\
\hline $\begin{array}{l}\text { XHP- } \\
00034\end{array}$ & & Village & Unknown & Unknown & N/A & $\begin{array}{l}\text { S.B. McLenegan (1887) apparently } \\
\text { noted houses on the north side of } \\
\text { Okak Bend. }\end{array}$ \\
\hline
\end{tabular}




\begin{tabular}{|c|c|c|c|c|c|c|}
\hline $\begin{array}{l}\text { XHP- } \\
00035 \\
\end{array}$ & & $\begin{array}{l}\text { Small } \\
\text { Village }\end{array}$ & 5 & Unknown & N/A & $\begin{array}{l}\text { P.S. Smith (1913:45) apparently } \\
\text { noted several abandoned huts and } \\
\text { boat frames and covers on the } \\
\text { willow-covered stream bank. Hall } \\
\text { investigated the site in 1962, noting } \\
\text { one rectangular semi-subterranean } \\
\text { house and four hearths, and } \\
\text { excavated one house completely and } \\
\text { one house partially. Three other } \\
\text { summer houses were not disturbed. } \\
\text { Thirty artifacts and caribou bones } \\
\text { were recovered and a collection of } \\
\text { pottery was made from the } \\
\text { riverbank. }\end{array}$ \\
\hline $\begin{array}{l}\text { XHP- } \\
00036\end{array}$ & Kiingyak Lake & $\begin{array}{l}\text { Single } \\
\text { House }\end{array}$ & 1 & Unknown & N/A & $\begin{array}{l}\text { Hall originally located } 14 \text { cache pits } \\
\text { and caribou bone on a beach ridge } \\
\text { at the north end of the lake. Davis, } \\
\text { et al., later investigated the area, } \\
\text { noting } 14 \text { cache pits, a possible } \\
\text { house pit, a scatter of modern } \\
\text { garbage, and Hall's test pits. A test } \\
\text { of the } 5 \mathrm{~m} \text { x } 2 \mathrm{~m} \text { possible house pit } \\
\text { failed to produce evidence of } \\
\text { cultural activity. A second area, } \\
\text { about } 49 \mathrm{~m} \text { to the southeast, } \\
\text { consisted of a } 10 \mathrm{~cm} \text { thick bone layer } \\
\text { exposed in the eroded } 1 \mathrm{~m} \text { high } \\
\text { bluff. A late prehistoric antler } \\
\text { projectile point was recovered from } \\
\text { below the bluff layer. Behind this } \\
\text { bluff, on a small knoll, an apparent } \\
\text { tent ring and hearth were noted. }\end{array}$ \\
\hline
\end{tabular}




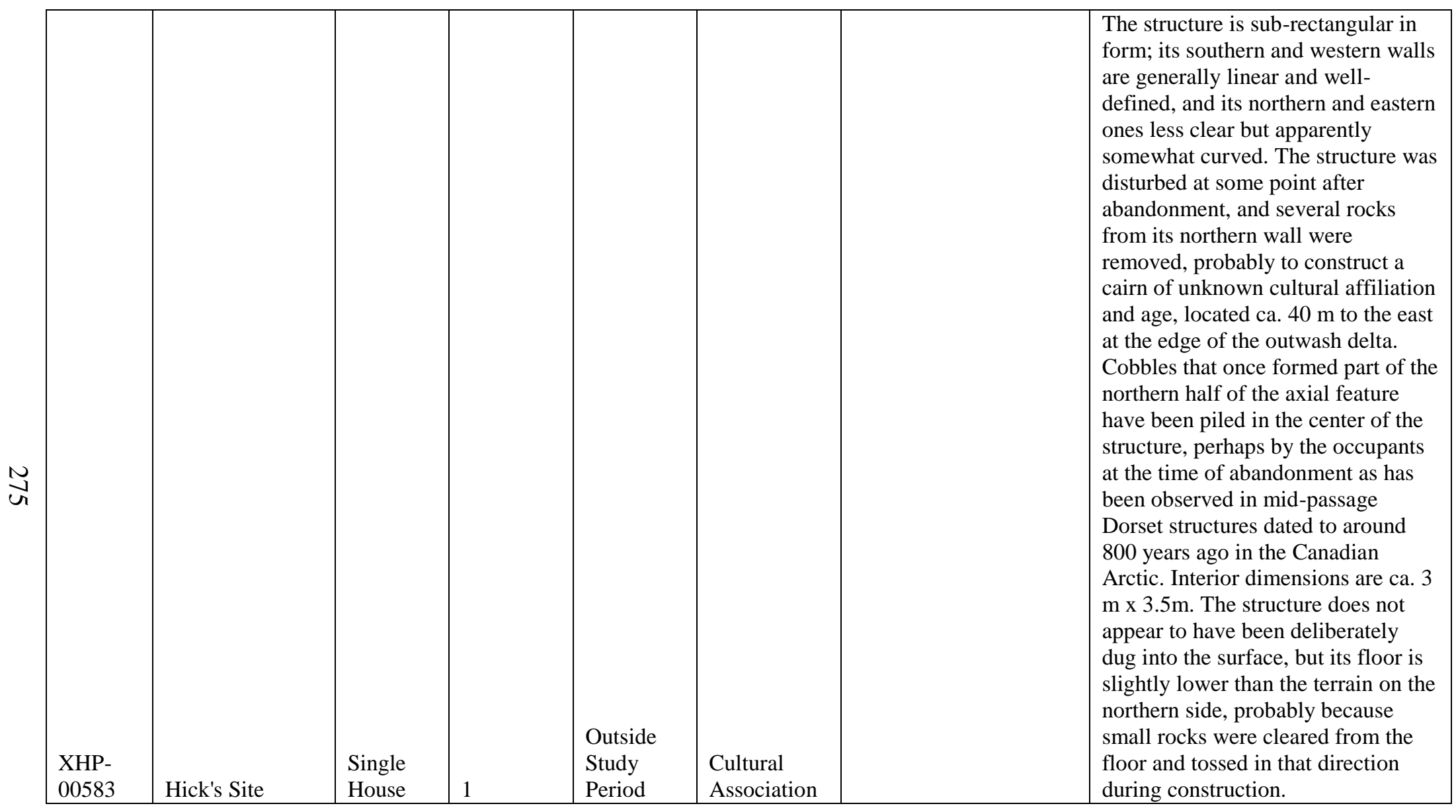


Appendix B: House Size Data

\begin{tabular}{|c|c|c|c|c|c|c|c|}
\hline $\begin{array}{l}\text { AHRS Site } \\
\text { Number }\end{array}$ & Site Name & $\begin{array}{l}\text { Temporal } \\
\text { Period }\end{array}$ & $\begin{array}{l}\text { Feature } \\
\text { Number }\end{array}$ & $\begin{array}{l}\text { Main Room } \\
\text { Area (sq m) }\end{array}$ & House Type & Reference & $\begin{array}{l}\text { Available } \\
\text { Measurements }\end{array}$ \\
\hline BEN-00185 & & $\begin{array}{l}\text { Before } 500 \\
\text { BP }\end{array}$ & 1 & 10.50000000000 & $\begin{array}{l}\text { Single } \\
\text { Room }\end{array}$ & BIA; Powers 1982 & Data presented \\
\hline KTZ-00008 & & $\begin{array}{l}\text { Before } 500 \\
\text { BP }\end{array}$ & 1 & 12.00000000000 & $\begin{array}{l}\text { Single } \\
\text { Room }\end{array}$ & Powers 1982 & Data table \\
\hline KTZ-00008 & & $\begin{array}{l}\text { Before } 500 \\
\text { BP }\end{array}$ & 2 & 36.79000000000 & Multi-Room & Powers 1982 & Data table \\
\hline KTZ-00008 & & $\begin{array}{l}\text { Before } 500 \\
\text { BP }\end{array}$ & 3 & 13.00000000000 & Multi-Room & Powers 1982 & Data table \\
\hline KTZ-00008 & & $\begin{array}{l}\text { Before } 500 \\
\text { BP }\end{array}$ & 4 & 18.00000000000 & $\begin{array}{l}\text { Single } \\
\text { Room }\end{array}$ & Powers 1982 & Data table \\
\hline KTZ-00008 & & $\begin{array}{l}\text { Before } 500 \\
\text { BP }\end{array}$ & 5 & 32.50000000000 & Multi-Room & Powers 1982 & Data table \\
\hline KTZ-00008 & & $\begin{array}{l}\text { Before } 500 \\
\text { BP }\end{array}$ & 6 & 3.14000000000 & $\begin{array}{l}\text { Single } \\
\text { Room }\end{array}$ & Powers 1982 & Data table \\
\hline KTZ-00008 & & $\begin{array}{l}\text { Before } 500 \\
\text { BP }\end{array}$ & 7 & 19.00000000000 & Multi-Room & Powers 1982 & Data table \\
\hline KTZ-00008 & & $\begin{array}{l}\text { Before } 500 \\
\text { BP }\end{array}$ & 8 & 13.75000000000 & Multi-Room & Powers 1982 & Data table \\
\hline KTZ-00008 & & $\begin{array}{l}\text { Before } 500 \\
\text { BP }\end{array}$ & 9 & 44.58000000000 & Multi-Room & Powers 1982 & Data table \\
\hline KTZ-00008 & & $\begin{array}{l}\text { Before } 500 \\
\text { BP }\end{array}$ & 10 & 21.00000000000 & $\begin{array}{l}\text { Single } \\
\text { Room }\end{array}$ & Powers 1982 & Data table \\
\hline KTZ-00008 & & $\begin{array}{l}\text { Before } 500 \\
\text { BP }\end{array}$ & 11 & 6.00000000000 & $\begin{array}{l}\text { Single } \\
\text { Room }\end{array}$ & Powers 1982 & Data table \\
\hline KTZ-00008 & & $\begin{array}{l}\text { Before } 500 \\
\text { BP }\end{array}$ & 12 & 20.00000000000 & Multi-Room & Powers 1982 & Data table \\
\hline KTZ-00008 & & $\begin{array}{l}\text { Before } 500 \\
\text { BP }\end{array}$ & 13 & 16.50000000000 & Multi-Room & Powers 1982 & Data table \\
\hline KTZ-00008 & & Before 500 & 14 & 7.00000000000 & Single & Powers 1982 & Data table \\
\hline
\end{tabular}




\begin{tabular}{|c|c|c|c|c|c|c|c|}
\hline & & $\mathrm{BP}$ & & & Room & & \\
\hline KTZ-00008 & & $\begin{array}{l}\text { Before } 500 \\
\text { BP }\end{array}$ & 15 & 16.14000000000 & Multi-Room & Powers 1982 & Data table \\
\hline KTZ-00008 & & $\begin{array}{l}\text { Before } 500 \\
\text { BP }\end{array}$ & 16 & 30.020000000000 & Multi-Room & Powers 1982 & Data table \\
\hline KTZ-00008 & & $\begin{array}{l}\text { Before } 500 \\
\text { BP }\end{array}$ & 17 & 25.000000000000 & Multi-Room & Powers 1982 & Data table \\
\hline KTZ-00008 & & $\begin{array}{l}\text { Before } 500 \\
\text { BP }\end{array}$ & 18 & 7.18750000000 & Multi-Room & Powers 1982 & Data table \\
\hline KTZ-00008 & & $\begin{array}{l}\text { Before } 500 \\
\text { BP }\end{array}$ & 19 & 10.07000000000 & $\begin{array}{l}\text { Single } \\
\text { Room }\end{array}$ & Powers 1982 & Data table \\
\hline KTZ-00008 & & $\begin{array}{l}\text { Before } 500 \\
\text { BP }\end{array}$ & 20 & 10.50000000000 & Multi-Room & Powers 1982 & Data table \\
\hline KTZ-00023 & & $\begin{array}{l}\text { Before } 500 \\
\text { BP }\end{array}$ & N/A & 96.00000000000 & $\begin{array}{l}\text { Single } \\
\text { Room }\end{array}$ & Larson 1950 & Data presented \\
\hline KTZ-00031 & Old Kotzebue & $\begin{array}{l}\text { Before } 500 \\
\text { BP }\end{array}$ & House 1 & 18.21000000000 & $\begin{array}{l}\text { Single } \\
\text { Room }\end{array}$ & VanStone 1955 & Data presented \\
\hline KTZ-00031 & Old Kotzebue & $\begin{array}{l}\text { Before } 500 \\
\text { BP }\end{array}$ & House 2 & 14.86000000000 & $\begin{array}{l}\text { Single } \\
\text { Room }\end{array}$ & VanStone 1955 & Data presented \\
\hline KTZ-00031 & Old Kotzebue & $\begin{array}{l}\text { Before } 500 \\
\text { BP }\end{array}$ & House 3 & 13.47000000000 & $\begin{array}{l}\text { Single } \\
\text { Room }\end{array}$ & VanStone 1955 & Data presented \\
\hline KTZ-00031 & Old Kotzebue & $\begin{array}{l}\text { Before } 500 \\
\text { BP }\end{array}$ & House 4 & 14.86000000000 & $\begin{array}{l}\text { Single } \\
\text { Room }\end{array}$ & VanStone 1955 & Data presented \\
\hline KTZ-00031 & Old Kotzebue & $\begin{array}{l}\text { Before } 500 \\
\text { BP }\end{array}$ & House 5 & 13.24000000000 & $\begin{array}{l}\text { Single } \\
\text { Room }\end{array}$ & VanStone 1955 & Data presented \\
\hline KTZ-00031 & Old Kotzebue & $\begin{array}{l}\text { Before } 500 \\
\text { BP }\end{array}$ & House 6 & 13.94000000000 & $\begin{array}{l}\text { Single } \\
\text { Room }\end{array}$ & VanStone 1955 & Data presented \\
\hline KTZ-00031 & Old Kotzebue & $\begin{array}{l}\text { Before } 500 \\
\text { BP }\end{array}$ & House 7 & 13.94000000000 & $\begin{array}{l}\text { Single } \\
\text { Room }\end{array}$ & VanStone 1955 & Data presented \\
\hline KTZ-00031 & Old Kotzebue & $\begin{array}{l}\text { Before } 500 \\
\text { BP }\end{array}$ & House 8 & 20.07000000000 & $\begin{array}{l}\text { Single } \\
\text { Room }\end{array}$ & VanStone 1955 & Data presented \\
\hline KTZ-00068 & & $\begin{array}{l}\text { Before } 500 \\
\text { BP }\end{array}$ & Feature 1 & 12.30000000000 & Multi-Room & Schaaf 1988 & Data presented \\
\hline KTZ-00087 & & Before 500 & Feature 1 & 15.54000000000 & Single & Schaaf 1988 & Data presented \\
\hline
\end{tabular}




\begin{tabular}{|c|c|c|c|c|c|c|}
\hline & $\mathrm{BP}$ & & & Room & & \\
\hline KTZ-00087 & $\begin{array}{l}\text { Before } 500 \\
\text { BP }\end{array}$ & Feature $2 \mathrm{a}$ & 26.60000000000 & $\begin{array}{l}\text { Single } \\
\text { Room }\end{array}$ & Schaaf 1988 & Data presented \\
\hline KTZ-00087 & $\begin{array}{l}\text { Before } 500 \\
\text { BP }\end{array}$ & Feature 2a & 18.13000000000 & $\begin{array}{l}\text { Single } \\
\text { Room }\end{array}$ & Schaaf 1988 & Data presented \\
\hline KTZ-00087 & $\begin{array}{l}\text { Before } 500 \\
\text { BP }\end{array}$ & Feature 3 & 18.50000000000 & $\begin{array}{l}\text { Single } \\
\text { Room }\end{array}$ & Schaaf 1988 & Data presented \\
\hline KTZ-00087 & $\begin{array}{l}\text { Before } 500 \\
\text { BP }\end{array}$ & Feature 4 & 31.32000000000 & $\begin{array}{l}\text { Single } \\
\text { Room }\end{array}$ & Schaaf 1988 & Data presented \\
\hline KTZ-00087 & $\begin{array}{l}\text { Before } 500 \\
\text { BP }\end{array}$ & Feature 5 & 17.17000000000 & $\begin{array}{l}\text { Single } \\
\text { Room }\end{array}$ & Schaaf 1988 & Data presented \\
\hline KTZ-00087 & $\begin{array}{l}\text { Before } 500 \\
\text { BP }\end{array}$ & Feature 13 & 14.35000000000 & $\begin{array}{l}\text { Single } \\
\text { Room }\end{array}$ & Schaaf 1988 & Data presented \\
\hline KTZ-00087 & $\begin{array}{l}\text { Before } 500 \\
\text { BP }\end{array}$ & Feature 14 & 10.80000000000 & $\begin{array}{l}\text { Single } \\
\text { Room }\end{array}$ & Schaaf 1988 & Data presented \\
\hline KTZ-00087 & $\begin{array}{l}\text { Before } 500 \\
\text { BP }\end{array}$ & Feature 15 & 9.30000000000 & $\begin{array}{l}\text { Single } \\
\text { Room }\end{array}$ & Schaaf 1988 & Data presented \\
\hline KTZ-00087 & $\begin{array}{l}\text { Before } 500 \\
\text { BP }\end{array}$ & Feature 16 & 11.70000000000 & $\begin{array}{l}\text { Single } \\
\text { Room }\end{array}$ & Schaaf 1988 & Data presented \\
\hline KTZ-00087 & $\begin{array}{l}\text { Before } 500 \\
\text { BP }\end{array}$ & $\begin{array}{l}\text { Feature } \\
17 \mathrm{a}\end{array}$ & 8.50500000000 & $\begin{array}{l}\text { Single } \\
\text { Room }\end{array}$ & Schaaf 1988 & Data presented \\
\hline KTZ-00087 & $\begin{array}{l}\text { Before } 500 \\
\text { BP }\end{array}$ & $\begin{array}{l}\text { Feature } \\
17 \mathrm{~b}\end{array}$ & 9.67250000000 & $\begin{array}{l}\text { Single } \\
\text { Room }\end{array}$ & Schaaf 1988 & Data presented \\
\hline KTZ-00130 & $\begin{array}{l}\text { Before } 500 \\
\text { BP }\end{array}$ & Feature $1 \mathrm{~b}$ & 11.37500000000 & Multi-Room & Schaaf 1988 & Data presented \\
\hline KTZ-00130 & $\begin{array}{l}\text { Before } 500 \\
\text { BP }\end{array}$ & Feature $4 \mathrm{a}$ & 18.06000000000 & Multi-Room & Schaaf 1988 & Data presented \\
\hline KTZ-00130 & $\begin{array}{l}\text { Before } 500 \\
\text { BP }\end{array}$ & Feature 5 & 15.60000000000 & Multi-Room & Schaaf 1988 & Data presented \\
\hline KTZ-00130 & $\begin{array}{l}\text { Before } 500 \\
\text { BP }\end{array}$ & Feature 6 & 11.55000000000 & Multi-Room & Schaaf 1988 & Data presented \\
\hline KTZ-00130 & $\begin{array}{l}\text { Before } 500 \\
\text { BP }\end{array}$ & Feature 7 & 15.21000000000 & Multi-Room & Schaaf 1988 & Data presented \\
\hline KTZ-00130 & Before 500 & Feature 11 & 15.05000000000 & Multi-Room & Schaaf 1988 & Data presented \\
\hline
\end{tabular}




\begin{tabular}{|c|c|c|c|c|c|c|}
\hline & $\mathrm{BP}$ & & & & & \\
\hline KTZ-00130 & $\begin{array}{l}\text { Before } 500 \\
\text { BP }\end{array}$ & Feature 12 & 10.92000000000 & Multi-Room & Schaaf 1988 & Data presented \\
\hline KTZ-00130 & $\begin{array}{l}\text { Before } 500 \\
\text { BP }\end{array}$ & Feature 15 & 10.35000000000 & Multi-Room & Schaaf 1988 & Data presented \\
\hline KTZ-00130 & $\begin{array}{l}\text { Before } 500 \\
\text { BP }\end{array}$ & Feature 16 & 17.60000000000 & Multi-Room & Schaaf 1988 & Data presented \\
\hline KTZ-00130 & $\begin{array}{l}\text { Before } 500 \\
\text { BP }\end{array}$ & Feature 17 & 12.18000000000 & Multi-Room & Schaaf 1988 & Data presented \\
\hline KTZ-00130 & $\begin{array}{l}\text { Before } 500 \\
\text { BP }\end{array}$ & Feature 18 & 10.30000000000 & Multi-Room & Schaaf 1988 & Data presented \\
\hline KTZ-00130 & $\begin{array}{l}\text { Before } 500 \\
\text { BP }\end{array}$ & Feature 19 & 8.25000000000 & Multi-Room & Schaaf 1988 & Data presented \\
\hline KTZ-00130 & $\begin{array}{l}\text { Before } 500 \\
\text { BP }\end{array}$ & Feature 20 & 21.07000000000 & Multi-Room & Schaaf 1988 & Data presented \\
\hline KTZ-00130 & $\begin{array}{l}\text { Before } 500 \\
\text { BP }\end{array}$ & Feature 21 & 12.76500000000 & Multi-Room & Schaaf 1988 & Data presented \\
\hline KTZ-00130 & $\begin{array}{l}\text { Before } 500 \\
\text { BP }\end{array}$ & Feature 22 & 8.75000000000 & Multi-Room & Schaaf 1988 & Data presented \\
\hline KTZ-00130 & $\begin{array}{l}\text { Before } 500 \\
\text { BP }\end{array}$ & Feature 23 & 24.15000000000 & Multi-Room & Schaaf 1988 & Data presented \\
\hline KTZ-00130 & $\begin{array}{l}\text { Before } 500 \\
\text { BP }\end{array}$ & Feature 24 & 28.80000000000 & Multi-Room & Schaaf 1988 & Data presented \\
\hline KTZ-00130 & $\begin{array}{l}\text { Before } 500 \\
\text { BP }\end{array}$ & Feature 1a & 10.23000000000 & $\begin{array}{l}\text { Single } \\
\text { Room }\end{array}$ & Schaaf 1988 & Data presented \\
\hline KTZ-00130 & $\begin{array}{l}\text { Before } 500 \\
\text { BP }\end{array}$ & Feature 3 & 22.55000000000 & $\begin{array}{l}\text { Single } \\
\text { Room }\end{array}$ & Schaaf 1988 & Data presented \\
\hline KTZ-00130 & $\begin{array}{l}\text { Before } 500 \\
\text { BP }\end{array}$ & Feature $4 \mathrm{~b}$ & 24.18000000000 & $\begin{array}{l}\text { Single } \\
\text { Room }\end{array}$ & Schaaf 1988 & Data presented \\
\hline KTZ-00130 & $\begin{array}{l}\text { Before } 500 \\
\text { BP }\end{array}$ & Feature 8 & 8.96000000000 & $\begin{array}{l}\text { Single } \\
\text { Room }\end{array}$ & Schaaf 1988 & Data presented \\
\hline KTZ-00130 & $\begin{array}{l}\text { Before } 500 \\
\text { BP }\end{array}$ & Feature 9 & 11.40000000000 & $\begin{array}{l}\text { Single } \\
\text { Room }\end{array}$ & Schaaf 1988 & Data presented \\
\hline KTZ-00130 & Before 500 & Feature 10 & 14.44000000000 & Single & Schaaf 1988 & Data presented \\
\hline
\end{tabular}




\begin{tabular}{|c|c|c|c|c|c|c|}
\hline & $\mathrm{BP}$ & & & Room & & \\
\hline KTZ-00130 & $\begin{array}{l}\text { Before } 500 \\
\text { BP }\end{array}$ & Feature 13 & 14.70000000000 & $\begin{array}{l}\text { Single } \\
\text { Room }\end{array}$ & Schaaf 1988 & Data presented \\
\hline KTZ-00131 & $\begin{array}{l}\text { Before } 500 \\
\text { BP }\end{array}$ & Feature 4 & 24.08000000000 & Multi-Room & Schaaf 1988 & Data presented \\
\hline KTZ-00131 & $\begin{array}{l}\text { Before } 500 \\
\text { BP }\end{array}$ & Feature 6 & 12.25000000000 & Multi-Room & Schaaf 1988 & Data presented \\
\hline KTZ-00131 & $\begin{array}{l}\text { Before } 500 \\
\text { BP }\end{array}$ & Feature 9 & 18.75000000000 & Multi-Room & Schaaf 1988 & Data presented \\
\hline KTZ-00131 & $\begin{array}{l}\text { Before } 500 \\
\text { BP }\end{array}$ & Feature 10 & 13.20000000000 & Multi-Room & Schaaf 1988 & Data presented \\
\hline KTZ-00131 & $\begin{array}{l}\text { Before } 500 \\
\text { BP }\end{array}$ & Feature 11 & 31.02000000000 & Multi-Room & Schaaf 1988 & Data presented \\
\hline KTZ-00131 & $\begin{array}{l}\text { Before } 500 \\
\text { BP }\end{array}$ & Feature 12 & 28.60000000000 & Multi-Room & Schaaf 1988 & Data presented \\
\hline KTZ-00131 & $\begin{array}{l}\text { Before } 500 \\
\text { BP }\end{array}$ & Feature 7 & 7.56000000000 & $\begin{array}{l}\text { Single } \\
\text { Room }\end{array}$ & Schaaf 1988 & Data presented \\
\hline KTZ-00299 & $\begin{array}{l}\text { Before } 500 \\
\text { BP }\end{array}$ & AU 34 & 17.57500000000 & $\begin{array}{l}\text { Single } \\
\text { Room }\end{array}$ & Bowers 2009 & $\begin{array}{l}\text { Data and map } \\
\text { measured }\end{array}$ \\
\hline KTZ-00300 & $\begin{array}{l}\text { Before } 500 \\
\text { BP }\end{array}$ & House 1 & 18.65000000000 & Multi-Room & Bowers 2009 & $\begin{array}{l}\text { Data and map } \\
\text { measured }\end{array}$ \\
\hline KTZ-00301 & $\begin{array}{l}\text { Before } 500 \\
\text { BP }\end{array}$ & House 2 & 11.84000000000 & $\begin{array}{l}\text { Single } \\
\text { Room }\end{array}$ & Bowers 2009 & Data presented \\
\hline NOA-00158 & $\begin{array}{l}\text { Before } 500 \\
\text { BP }\end{array}$ & N/A & 47.25000000000 & $\begin{array}{l}\text { Single } \\
\text { Room }\end{array}$ & $\begin{array}{l}\text { McClenahan and Gibson } \\
\text { 1990II }\end{array}$ & $\begin{array}{l}\text { Data and map } \\
\text { measured }\end{array}$ \\
\hline NOA-00274 & $\begin{array}{l}\text { Before } 500 \\
\text { BP }\end{array}$ & 6 & 22.42000000000 & Multi-Room & $\begin{array}{l}\text { McClenahan and Gibson } \\
1990 \text { II }\end{array}$ & $\begin{array}{l}\text { Data and map } \\
\text { measured }\end{array}$ \\
\hline NOA-00274 & $\begin{array}{l}\text { Before } 500 \\
\text { BP }\end{array}$ & 10 & 32.45000000000 & Multi-Room & $\begin{array}{l}\text { McClenahan and Gibson } \\
1990 \text { II }\end{array}$ & $\begin{array}{l}\text { Data and map } \\
\text { measured }\end{array}$ \\
\hline NOA-00274 & $\begin{array}{l}\text { Before } 500 \\
\text { BP }\end{array}$ & 13 & 26.21000000000 & $\begin{array}{l}\text { Single } \\
\text { Room }\end{array}$ & $\begin{array}{l}\text { McClenahan and Gibson } \\
\text { 1990II }\end{array}$ & $\begin{array}{l}\text { Data and map } \\
\text { measured }\end{array}$ \\
\hline NOA-00383 & $\begin{array}{l}\text { Before } 500 \\
\text { BP }\end{array}$ & $4 \mathrm{~A}$ & 6.92286929658 & $\begin{array}{l}\text { Single } \\
\text { Room }\end{array}$ & CAKR Project & GIS measurements \\
\hline NOA-00383 & Before 500 & $6 \mathrm{~A}$ & 9.10146901234 & Single & CAKR Project & GIS measurements \\
\hline
\end{tabular}




\begin{tabular}{|c|c|c|c|c|c|c|}
\hline & $\mathrm{BP}$ & & & Room & & \\
\hline NOA-00383 & $\begin{array}{l}\text { Before } 500 \\
\text { BP }\end{array}$ & $1 \mathrm{~A}$ & 9.78832854229 & $\begin{array}{l}\text { Single } \\
\text { Room }\end{array}$ & CAKR Project & GIS measurements \\
\hline NOA-00383 & $\begin{array}{l}\text { Before } 500 \\
\text { BP }\end{array}$ & $5 \mathrm{~A}$ & 13.70862706360 & $\begin{array}{l}\text { Single } \\
\text { Room }\end{array}$ & CAKR Project & GIS measurements \\
\hline NOA-00383 & $\begin{array}{l}\text { Before } 500 \\
\text { BP }\end{array}$ & $3 \mathrm{~A}$ & 14.19956757160 & $\begin{array}{l}\text { Single } \\
\text { Room }\end{array}$ & CAKR Project & GIS measurements \\
\hline NOA-00383 & $\begin{array}{l}\text { Before } 500 \\
\text { BP }\end{array}$ & Unknown & 77.85282400000 & $\begin{array}{l}\text { Single } \\
\text { Room }\end{array}$ & CAKR Project & GIS measurements \\
\hline NOA-00383 & $\begin{array}{l}\text { Before } 500 \\
\text { BP }\end{array}$ & Unknown & $\begin{array}{l}118.1980430000 \\
0\end{array}$ & $\begin{array}{l}\text { Single } \\
\text { Room }\end{array}$ & CAKR Project & GIS measurements \\
\hline NOA-00468 & $\begin{array}{l}\text { Before } 500 \\
\text { BP }\end{array}$ & 2 & 33.91073441210 & $\begin{array}{l}\text { Single } \\
\text { Room }\end{array}$ & CAKR Project & GIS measurements \\
\hline NOA-00473 & $\begin{array}{l}\text { Before } 500 \\
\text { BP }\end{array}$ & $1 \mathrm{~A}$ & 8.97990795452 & $\begin{array}{l}\text { Single } \\
\text { Room }\end{array}$ & CAKR Project & GIS measurements \\
\hline NOA-00473 & $\begin{array}{l}\text { Before } 500 \\
\text { BP }\end{array}$ & 1 & 26.69562000390 & Multi-Room & CAKR Project & GIS measurements \\
\hline NOA-00473 & $\begin{array}{l}\text { Before } 500 \\
\text { BP }\end{array}$ & 3 & 41.11413500000 & $\begin{array}{l}\text { Single } \\
\text { Room }\end{array}$ & CAKR Project & GIS measurements \\
\hline NOA-00473 & $\begin{array}{l}\text { Before } 500 \\
\text { BP }\end{array}$ & 1 & $\begin{array}{l}112.5331440000 \\
0\end{array}$ & Multi-Room & CAKR Project & GIS measurements \\
\hline NOA-00473 & $\begin{array}{l}\text { Before } 500 \\
\text { BP }\end{array}$ & 3 & 66.69711800000 & Multi-Room & CAKR Project & GIS measurements \\
\hline NOA-00473 & $\begin{array}{l}\text { Before } 500 \\
\text { BP }\end{array}$ & 1 & 87.21116400000 & Multi-Room & CAKR Project & GIS measurements \\
\hline NOA-00473 & $\begin{array}{l}\text { Before } 500 \\
\text { BP }\end{array}$ & 2 & 95.91951400000 & $\begin{array}{l}\text { Single } \\
\text { Room }\end{array}$ & CAKR Project & GIS measurements \\
\hline NOA-00509 & $\begin{array}{l}\text { Before } 500 \\
\text { BP }\end{array}$ & $1 \mathrm{~A}$ & 37.31861544000 & $\begin{array}{l}\text { Single } \\
\text { Room }\end{array}$ & CAKR Project & GIS measurements \\
\hline NOA-00509 & $\begin{array}{l}\text { Before } 500 \\
\text { BP }\end{array}$ & $2 \mathrm{~A}$ & $\begin{array}{l}116.8753553180 \\
0\end{array}$ & $\begin{array}{l}\text { Single } \\
\text { Room }\end{array}$ & CAKR Project & GIS measurements \\
\hline NOA-00531 & $\begin{array}{l}\text { Before } 500 \\
\text { BP }\end{array}$ & 1 & 38.05476854300 & $\begin{array}{l}\text { Single } \\
\text { Room }\end{array}$ & CAKR Project & GIS measurements \\
\hline NOA-00531 & Before 500 & 2 & 49.85900849670 & Single & CAKR Project & GIS measurements \\
\hline
\end{tabular}




\begin{tabular}{|c|c|c|c|c|c|c|c|}
\hline & & $\mathrm{BP}$ & & & Room & & \\
\hline NOA-00534 & & $\begin{array}{l}\text { Before } 500 \\
\text { BP }\end{array}$ & Unknown & 9.31076900000 & $\begin{array}{l}\text { Single } \\
\text { Room }\end{array}$ & CAKR Project & GIS measurements \\
\hline NOA-00534 & & $\begin{array}{l}\text { Before } 500 \\
\text { BP }\end{array}$ & Unknown & 39.98657900000 & $\begin{array}{l}\text { Single } \\
\text { Room }\end{array}$ & CAKR Project & GIS measurements \\
\hline NOA-00534 & & $\begin{array}{l}\text { Before } 500 \\
\text { BP }\end{array}$ & Unknown & 72.28651700000 & $\begin{array}{l}\text { Single } \\
\text { Room }\end{array}$ & CAKR Project & GIS measurements \\
\hline NOA-00555 & & $\begin{array}{l}\text { Before } 500 \\
\text { BP }\end{array}$ & $1 \mathrm{~B}$ & 45.80259389280 & $\begin{array}{l}\text { Single } \\
\text { Room }\end{array}$ & CAKR Project & GIS measurements \\
\hline NOA-00556 & & $\begin{array}{l}\text { Before } 500 \\
\text { BP }\end{array}$ & $1 \mathrm{~B}$ & 13.47628743770 & $\begin{array}{l}\text { Single } \\
\text { Room }\end{array}$ & CAKR Project & GIS measurements \\
\hline NOA-00556 & & $\begin{array}{l}\text { Before } 500 \\
\text { BP }\end{array}$ & 1B & 18.57947589540 & $\begin{array}{l}\text { Single } \\
\text { Room }\end{array}$ & CAKR Project & GIS measurements \\
\hline NOA-00556 & & $\begin{array}{l}\text { Before } 500 \\
\text { BP }\end{array}$ & Unknown & 14.84406000000 & $\begin{array}{l}\text { Single } \\
\text { Room }\end{array}$ & CAKR Project & GIS measurements \\
\hline NOA-00578 & & $\begin{array}{l}\text { Before } 500 \\
\text { BP }\end{array}$ & Unknown & $\begin{array}{l}170.9883270000 \\
0\end{array}$ & Multi-Room & CAKR Project & GIS measurements \\
\hline NOA-00578 & & $\begin{array}{l}\text { Before } 500 \\
\text { BP }\end{array}$ & Unknown & 92.75229000000 & $\begin{array}{l}\text { Single } \\
\text { Room }\end{array}$ & CAKR Project & GIS measurements \\
\hline NOA-00578 & & $\begin{array}{l}\text { Before } 500 \\
\text { BP }\end{array}$ & Unknown & $\begin{array}{l}186.6273230000 \\
0\end{array}$ & $\begin{array}{l}\text { Single } \\
\text { Room }\end{array}$ & CAKR Project & GIS measurements \\
\hline NOA-00578 & & $\begin{array}{l}\text { Before } 500 \\
\text { BP }\end{array}$ & Unknown & 41.06903100000 & $\begin{array}{l}\text { Single } \\
\text { Room }\end{array}$ & CAKR Project & GIS measurements \\
\hline NOA-00578 & & $\begin{array}{l}\text { Before } 500 \\
\text { BP }\end{array}$ & Unknown & 32.42737200000 & $\begin{array}{l}\text { Single } \\
\text { Room }\end{array}$ & CAKR Project & GIS measurements \\
\hline TEL-00093 & & $\begin{array}{l}\text { Before } 500 \\
\text { BP }\end{array}$ & 3 & 48.45000000000 & $\begin{array}{l}\text { Single } \\
\text { Room }\end{array}$ & Schaaf 1988 & Data presented \\
\hline TEL-00093 & & $\begin{array}{l}\text { Before } 500 \\
\text { BP }\end{array}$ & 5 & 49.50000000000 & $\begin{array}{l}\text { Single } \\
\text { Room }\end{array}$ & Schaaf 1988 & Data presented \\
\hline XBM-00003 & Ahteut & $\begin{array}{l}\text { Before } 500 \\
\text { BP }\end{array}$ & House $3 \mathrm{~S}$ & 8.88000000000 & Multi-Room & Unpublished NPS data & GIS measurements \\
\hline XBM-00003 & Ahteut & $\begin{array}{l}\text { Before } 500 \\
\text { BP }\end{array}$ & $\begin{array}{l}\text { House } \\
14 \mathrm{~S}\end{array}$ & 14.04000000000 & Multi-Room & Unpublished NPS data & GIS measurements \\
\hline XBM-00003 & Ahteut & Before 500 & House & 5.40000000000 & Multi-Room & Unpublished NPS data & GIS measurements \\
\hline
\end{tabular}




\begin{tabular}{|c|c|c|c|c|c|c|c|}
\hline & & $\mathrm{BP}$ & $15 \mathrm{~S}$ & & & & \\
\hline XBM-00003 & Ahteut & $\begin{array}{l}\text { Before } 500 \\
\text { BP }\end{array}$ & House a & 20.12500000000 & Multi-Room & Unpublished NPS data & GIS measurements \\
\hline XBM-00003 & Ahteut & $\begin{array}{l}\text { Before } 500 \\
\text { BP }\end{array}$ & House c & 16.25000000000 & Multi-Room & Unpublished NPS data & GIS measurements \\
\hline XBM-00003 & Ahteut & $\begin{array}{l}\text { Before } 500 \\
\text { BP }\end{array}$ & House d & 12.21000000000 & Multi-Room & Unpublished NPS data & GIS measurements \\
\hline XBM-00003 & Ahteut & $\begin{array}{l}\text { Before } 500 \\
\text { BP }\end{array}$ & House e & 11.76000000000 & Multi-Room & Unpublished NPS data & GIS measurements \\
\hline XBM-00003 & Ahteut & $\begin{array}{l}\text { Before } 500 \\
\text { BP }\end{array}$ & House $\mathrm{f}$ & 9.00000000000 & Multi-Room & Unpublished NPS data & GIS measurements \\
\hline XBM-00003 & Ahteut & $\begin{array}{l}\text { Before } 500 \\
\text { BP }\end{array}$ & House $\mathrm{g}$ & 6.90000000000 & Multi-Room & Unpublished NPS data & GIS measurements \\
\hline XBM-00003 & Ahteut & $\begin{array}{l}\text { Before } 500 \\
\text { BP }\end{array}$ & House $\mathrm{h}$ & 12.03500000000 & Multi-Room & Unpublished NPS data & GIS measurements \\
\hline XBM-00003 & Ahteut & $\begin{array}{l}\text { Before } 500 \\
\text { BP }\end{array}$ & House i & 12.06000000000 & Multi-Room & Unpublished NPS data & GIS measurements \\
\hline XBM-00003 & Ahteut & $\begin{array}{l}\text { Before } 500 \\
\text { BP }\end{array}$ & House j & 15.12500000000 & Multi-Room & Unpublished NPS data & GIS measurements \\
\hline XBM-00003 & Ahteut & $\begin{array}{l}\text { Before } 500 \\
\text { BP }\end{array}$ & House $\mathrm{k}$ & 12.64000000000 & Multi-Room & Unpublished NPS data & GIS measurements \\
\hline XBM-00003 & Ahteut & $\begin{array}{l}\text { Before } 500 \\
\text { BP }\end{array}$ & House 1 & 9.60000000000 & Multi-Room & Unpublished NPS data & GIS measurements \\
\hline XBM-00003 & Ahteut & $\begin{array}{l}\text { Before } 500 \\
\text { BP }\end{array}$ & House a & 4.00000000000 & $\begin{array}{l}\text { Single } \\
\text { Room }\end{array}$ & Unpublished NPS data & GIS measurements \\
\hline XBM-00003 & Ahteut & $\begin{array}{l}\text { Before } 500 \\
\text { BP }\end{array}$ & House b & 13.80000000000 & $\begin{array}{l}\text { Single } \\
\text { Room }\end{array}$ & Unpublished NPS data & GIS measurements \\
\hline XBM-00003 & Ahteut & $\begin{array}{l}\text { Before } 500 \\
\text { BP }\end{array}$ & House $\mathrm{c}$ & 14.40000000000 & $\begin{array}{l}\text { Single } \\
\text { Room }\end{array}$ & Unpublished NPS data & GIS measurements \\
\hline XBM-00003 & Ahteut & $\begin{array}{l}\text { Before } 500 \\
\text { BP }\end{array}$ & House 7S & 8.12000000000 & $\begin{array}{l}\text { Single } \\
\text { Room }\end{array}$ & Unpublished NPS data & GIS measurements \\
\hline XBM-00003 & Ahteut & $\begin{array}{l}\text { Before } 500 \\
\text { BP }\end{array}$ & House 8S & 14.26000000000 & $\begin{array}{l}\text { Single } \\
\text { Room }\end{array}$ & Unpublished NPS data & GIS measurements \\
\hline XBM-00003 & Ahteut & Before 500 & House 9S & 9.66000000000 & Single & Unpublished NPS data & GIS measurements \\
\hline
\end{tabular}




\begin{tabular}{|c|c|c|c|c|c|c|c|}
\hline & & $\mathrm{BP}$ & & & Room & & \\
\hline XBM-00003 & Ahteut & $\begin{array}{l}\text { Before } 500 \\
\text { BP }\end{array}$ & $\begin{array}{l}\text { House } \\
13 \mathrm{~S} \\
\end{array}$ & 17.22000000000 & $\begin{array}{l}\text { Single } \\
\text { Room }\end{array}$ & Unpublished NPS data & GIS measurements \\
\hline XBM-00003 & Ahteut & $\begin{array}{l}\text { Before } 500 \\
\text { BP }\end{array}$ & House b & 27.28000000000 & $\begin{array}{l}\text { Single } \\
\text { Room }\end{array}$ & Unpublished NPS data & GIS measurements \\
\hline XBM-00009 & Ekseavik & $\begin{array}{l}\text { Before } 500 \\
\text { BP }\end{array}$ & House 1 & 24.42715970000 & $\begin{array}{l}\text { Single } \\
\text { Room }\end{array}$ & Giddings, JL 1952 & Data presented \\
\hline XBM-00009 & Ekseavik & $\begin{array}{l}\text { Before } 500 \\
\text { BP }\end{array}$ & House 2 & 22.69955330000 & $\begin{array}{l}\text { Single } \\
\text { Room }\end{array}$ & Giddings, JL 1952 & Data presented \\
\hline XBM-00009 & Ekseavik & $\begin{array}{l}\text { Before } 500 \\
\text { BP }\end{array}$ & House 3 & 21.39981070000 & $\begin{array}{l}\text { Single } \\
\text { Room }\end{array}$ & Giddings, JL 1952 & Data presented \\
\hline XBM-00009 & Ekseavik & $\begin{array}{l}\text { Before } 500 \\
\text { BP }\end{array}$ & House 4 & 21.39891070000 & $\begin{array}{l}\text { Single } \\
\text { Room }\end{array}$ & Giddings, JL 1952 & $\begin{array}{l}\text { Data and map } \\
\text { measured }\end{array}$ \\
\hline XBM-00009 & Ekseavik & $\begin{array}{l}\text { Before } 500 \\
\text { BP }\end{array}$ & House 5 & 24.14293580000 & $\begin{array}{l}\text { Single } \\
\text { Room }\end{array}$ & Giddings, JL 1952 & $\begin{array}{l}\text { Data and map } \\
\text { measured }\end{array}$ \\
\hline XBM-00009 & Ekseavik & $\begin{array}{l}\text { Before } 500 \\
\text { BP }\end{array}$ & House 6 & 25.47518400000 & $\begin{array}{l}\text { Single } \\
\text { Room }\end{array}$ & Giddings, JL 1952 & $\begin{array}{l}\text { Data and map } \\
\text { measured }\end{array}$ \\
\hline XBM-00009 & Ekseavik & $\begin{array}{l}\text { Before } 500 \\
\text { BP }\end{array}$ & House 7 & 18.50745600000 & $\begin{array}{l}\text { Single } \\
\text { Room }\end{array}$ & Giddings, JL 1952 & Data presented \\
\hline XBM-00009 & Ekseavik & $\begin{array}{l}\text { Before } 500 \\
\text { BP }\end{array}$ & House 8 & 25.68549600000 & $\begin{array}{l}\text { Single } \\
\text { Room }\end{array}$ & Giddings, JL 1952 & Data presented \\
\hline XBM-00009 & Ekseavik & $\begin{array}{l}\text { Before } 500 \\
\text { BP }\end{array}$ & House 11 & 39.01927680000 & $\begin{array}{l}\text { Single } \\
\text { Room }\end{array}$ & Giddings, JL 1952 & Data presented \\
\hline AMR-00002 & Ambler Island & $\begin{array}{l}\text { After } 500 \\
\text { BP }\end{array}$ & House 1 & 81.84000000000 & $\begin{array}{l}\text { Single } \\
\text { Room }\end{array}$ & Giddings, JL 1952 & Data presented \\
\hline AMR-00002 & Ambler Island & $\begin{array}{l}\text { After } 500 \\
\text { BP }\end{array}$ & House 2 & 20.88000000000 & $\begin{array}{l}\text { Single } \\
\text { Room }\end{array}$ & Giddings, JL 1952 & Data presented \\
\hline AMR-00002 & Ambler Island & $\begin{array}{l}\text { After } 500 \\
\text { BP }\end{array}$ & House 3 & 17.84000000000 & $\begin{array}{l}\text { Single } \\
\text { Room }\end{array}$ & Giddings, JL 1952 & Data presented \\
\hline AMR-00002 & Ambler Island & $\begin{array}{l}\text { After } 500 \\
\text { BP }\end{array}$ & House 4 & 13.01000000000 & $\begin{array}{l}\text { Single } \\
\text { Room }\end{array}$ & Giddings, JL 1952 & Data presented \\
\hline AMR-00002 & Ambler Island & $\begin{array}{l}\text { After } 500 \\
\text { BP }\end{array}$ & House 5 & 12.63000000000 & $\begin{array}{l}\text { Single } \\
\text { Room }\end{array}$ & Giddings, JL 1952 & Data presented \\
\hline AMR-00002 & Ambler Island & After 500 & House 6 & 14.86000000000 & Single & Giddings, JL 1952 & Data presented \\
\hline
\end{tabular}




\begin{tabular}{|c|c|c|c|c|c|c|c|}
\hline & & $\mathrm{BP}$ & & & Room & & \\
\hline AMR-00002 & Ambler Island & $\begin{array}{l}\text { After } 500 \\
\text { BP }\end{array}$ & House 7 & 16.35000000000 & $\begin{array}{l}\text { Single } \\
\text { Room }\end{array}$ & Giddings, JL 1952 & Data presented \\
\hline AMR-00002 & Ambler Island & $\begin{array}{l}\text { After } 500 \\
\text { BP }\end{array}$ & House 8 & 14.31000000000 & $\begin{array}{l}\text { Single } \\
\text { Room }\end{array}$ & Giddings, JL 1952 & Data presented \\
\hline AMR-00002 & Ambler Island & $\begin{array}{l}\text { After } 500 \\
\text { BP }\end{array}$ & House 9 & 15.61000000000 & $\begin{array}{l}\text { Single } \\
\text { Room }\end{array}$ & Giddings, JL 1952 & Data presented \\
\hline AMR-00002 & Ambler Island & $\begin{array}{l}\text { After } 500 \\
\text { BP }\end{array}$ & House 10 & 18.95000000000 & $\begin{array}{l}\text { Single } \\
\text { Room }\end{array}$ & Giddings, JL 1952 & Data presented \\
\hline AMR-00002 & Ambler Island & $\begin{array}{l}\text { After } 500 \\
\text { BP }\end{array}$ & House 11 & 13.01000000000 & $\begin{array}{l}\text { Single } \\
\text { Room }\end{array}$ & Giddings, JL 1952 & Data presented \\
\hline AMR-00002 & Ambler Island & $\begin{array}{l}\text { After } 500 \\
\text { BP }\end{array}$ & House 12 & 16.72000000000 & $\begin{array}{l}\text { Single } \\
\text { Room }\end{array}$ & Giddings, JL 1952 & Data presented \\
\hline AMR-00002 & Ambler Island & $\begin{array}{l}\text { After } 500 \\
\text { BP }\end{array}$ & House 13 & 20.07000000000 & $\begin{array}{l}\text { Single } \\
\text { Room }\end{array}$ & Giddings, JL 1952 & Data presented \\
\hline AMR-00002 & Ambler Island & $\begin{array}{l}\text { After } 500 \\
\text { BP }\end{array}$ & House 14 & 11.71000000000 & $\begin{array}{l}\text { Single } \\
\text { Room }\end{array}$ & Giddings, JL 1952 & Data presented \\
\hline AMR-00002 & Ambler Island & $\begin{array}{l}\text { After } 500 \\
\text { BP }\end{array}$ & House 15 & 19.42000000000 & $\begin{array}{l}\text { Single } \\
\text { Room }\end{array}$ & Giddings, JL 1952 & Data presented \\
\hline BEN-00029 & & $\begin{array}{l}\text { After } 500 \\
\text { BP }\end{array}$ & House 1 & 18.00000000000 & $\begin{array}{l}\text { Single } \\
\text { Room }\end{array}$ & Schaaf 1988 & Data presented \\
\hline BEN-00029 & & $\begin{array}{l}\text { After } 500 \\
\text { BP }\end{array}$ & House 2 & 11.25000000000 & $\begin{array}{l}\text { Single } \\
\text { Room }\end{array}$ & Schaaf 1988 & Data presented \\
\hline BEN-00033 & $\begin{array}{l}\text { Cloud Lake } \\
\text { Village }\end{array}$ & $\begin{array}{l}\text { After } 500 \\
\text { BP }\end{array}$ & Feature 6 & 241.2500000000 & $\begin{array}{l}\text { Single } \\
\text { Room }\end{array}$ & Adams 1977 & Data presented \\
\hline BEN-00033 & $\begin{array}{l}\text { Cloud Lake } \\
\text { Village }\end{array}$ & $\begin{array}{l}\text { After } 500 \\
\text { BP }\end{array}$ & Feature 7 & 27.50000000000 & $\begin{array}{l}\text { Single } \\
\text { Room }\end{array}$ & Adams 1977 & Data presented \\
\hline BEN-00033 & $\begin{array}{l}\text { Cloud Lake } \\
\text { Village }\end{array}$ & $\begin{array}{l}\text { After } 500 \\
\text { BP }\end{array}$ & Feature 8 & 36.00000000000 & $\begin{array}{l}\text { Single } \\
\text { Room }\end{array}$ & Adams 1977 & Data presented \\
\hline BEN-00053 & & $\begin{array}{l}\text { After } 500 \\
\text { BP }\end{array}$ & Feature 1 & 12.54000000000 & $\begin{array}{l}\text { Single } \\
\text { Room }\end{array}$ & Schaaf 1988 & Data presented \\
\hline BEN-00053 & & $\begin{array}{l}\text { After } 500 \\
\text { BP }\end{array}$ & Feature 2 & 27.88000000000 & $\begin{array}{l}\text { Single } \\
\text { Room }\end{array}$ & Schaaf 1988 & Data presented \\
\hline BEN-00053 & & After 500 & Feature 3 & 16.32000000000 & Single & Schaaf 1988 & Data presented \\
\hline
\end{tabular}




\begin{tabular}{|c|c|c|c|c|c|c|c|}
\hline & & $\mathrm{BP}$ & & & Room & & \\
\hline BEN-00053 & & $\begin{array}{l}\text { After } 500 \\
\text { BP }\end{array}$ & Feature 4 & 14.40000000000 & $\begin{array}{l}\text { Single } \\
\text { Room }\end{array}$ & Schaaf 1988 & Data presented \\
\hline BEN-00053 & & $\begin{array}{l}\text { After } 500 \\
\text { BP }\end{array}$ & Feature 6 & 11.56000000000 & $\begin{array}{l}\text { Single } \\
\text { Room }\end{array}$ & Schaaf 1988 & Data presented \\
\hline BEN-00053 & & $\begin{array}{l}\text { After } 500 \\
\text { BP }\end{array}$ & Feature 7 & 64.60000000000 & $\begin{array}{l}\text { Single } \\
\text { Room }\end{array}$ & Schaaf 1988 & Data presented \\
\hline BEN-00053 & & $\begin{array}{l}\text { After } 500 \\
\text { BP }\end{array}$ & Feature 9 & 26.40000000000 & $\begin{array}{l}\text { Single } \\
\text { Room }\end{array}$ & Schaaf 1988 & Data presented \\
\hline BEN-00053 & & $\begin{array}{l}\text { After } 500 \\
\text { BP }\end{array}$ & Feature 13 & 27.84000000000 & $\begin{array}{l}\text { Single } \\
\text { Room }\end{array}$ & Schaaf 1988 & Data presented \\
\hline BEN-00053 & & $\begin{array}{l}\text { After } 500 \\
\text { BP }\end{array}$ & Feature 14 & 17.16000000000 & $\begin{array}{l}\text { Single } \\
\text { Room }\end{array}$ & Schaaf 1988 & Data presented \\
\hline CAN-00004 & Iqalugruaq & $\begin{array}{l}\text { After } 500 \\
\text { BP }\end{array}$ & $\mathrm{B}$ & 15.12000000000 & $\begin{array}{l}\text { Single } \\
\text { Room }\end{array}$ & BIA Report (F22908) & Data presented \\
\hline CAN-00004 & Iqalugruaq & $\begin{array}{l}\text { After } 500 \\
\text { BP }\end{array}$ & $\mathrm{D}$ & 10.88000000000 & $\begin{array}{l}\text { Single } \\
\text { Room }\end{array}$ & BIA Report (F22908) & Data presented \\
\hline KTZ-00009 & $\begin{array}{l}\text { Kividluk, } \\
\text { Kividlo }\end{array}$ & $\begin{array}{l}\text { After } 500 \\
\text { BP }\end{array}$ & $\begin{array}{l}\text { Feature } 1 \\
\text { Locality } \\
\text { A }\end{array}$ & 26.24000000000 & $\begin{array}{l}\text { Single } \\
\text { Room }\end{array}$ & Schaaf 1988 & Data presented \\
\hline KTZ-00009 & $\begin{array}{l}\text { Kividluk, } \\
\text { Kividlo }\end{array}$ & $\begin{array}{l}\text { After } 500 \\
\text { BP }\end{array}$ & $\begin{array}{l}\text { Feature } 2 \\
\text { Locality } \\
\text { A }\end{array}$ & 25.37000000000 & $\begin{array}{l}\text { Single } \\
\text { Room }\end{array}$ & Schaaf 1988 & Data presented \\
\hline KTZ-00009 & $\begin{array}{l}\text { Kividluk, } \\
\text { Kividlo }\end{array}$ & $\begin{array}{l}\text { After } 500 \\
\text { BP }\end{array}$ & $\begin{array}{l}\text { Feature } 3 \\
\text { Locality } \\
\text { A }\end{array}$ & 21.84000000000 & $\begin{array}{l}\text { Single } \\
\text { Room }\end{array}$ & Schaaf 1988 & Data presented \\
\hline KTZ-00009 & $\begin{array}{l}\text { Kividluk, } \\
\text { Kividlo }\end{array}$ & $\begin{array}{l}\text { After } 500 \\
\text { BP }\end{array}$ & $\begin{array}{l}\text { Feature } 5 \\
\text { Locality C } \\
\end{array}$ & 26.64000000000 & Multi-Room & Schaaf 1988 & Data presented \\
\hline KTZ-00009 & $\begin{array}{l}\text { Kividluk, } \\
\text { Kividlo }\end{array}$ & $\begin{array}{l}\text { After } 500 \\
\text { BP }\end{array}$ & $\begin{array}{l}\text { Feature } 6 \\
\text { Locality C }\end{array}$ & 10.08000000000 & Multi-Room & Schaaf 1988 & Data presented \\
\hline KTZ-00009 & $\begin{array}{l}\text { Kividluk, } \\
\text { Kividlo }\end{array}$ & $\begin{array}{l}\text { After } 500 \\
\text { BP }\end{array}$ & $\begin{array}{l}\text { Feature } 9 \\
\text { Locality C }\end{array}$ & 4.56000000000 & Multi-Room & Schaaf 1988 & Data presented \\
\hline
\end{tabular}




\begin{tabular}{|c|c|c|c|c|c|c|c|}
\hline KTZ-00009 & $\begin{array}{l}\text { Kividluk, } \\
\text { Kividlo }\end{array}$ & $\begin{array}{l}\text { After } 500 \\
\text { BP }\end{array}$ & $\begin{array}{l}\text { Feature } 10 \\
\text { Locality C }\end{array}$ & 7.04000000000 & Multi-Room & Schaaf 1988 & Data presented \\
\hline KTZ-00009 & $\begin{array}{l}\text { Kividluk, } \\
\text { Kividlo } \\
\end{array}$ & $\begin{array}{l}\text { After } 500 \\
\text { BP }\end{array}$ & $\begin{array}{l}\text { Feature } 13 \\
\text { Locality C }\end{array}$ & 14.10000000000 & Multi-Room & Schaaf 1988 & Data presented \\
\hline KTZ-00009 & $\begin{array}{l}\text { Kividluk, } \\
\text { Kividlo }\end{array}$ & $\begin{array}{l}\text { After } 500 \\
\text { BP }\end{array}$ & $\begin{array}{l}\text { Feature } 14 \\
\text { Locality C }\end{array}$ & 26.17500000000 & Multi-Room & Schaaf 1988 & Data presented \\
\hline KTZ-00009 & $\begin{array}{l}\text { Kividluk, } \\
\text { Kividlo }\end{array}$ & $\begin{array}{l}\text { After } 500 \\
\text { BP }\end{array}$ & $\begin{array}{l}\text { Feature } 1 \\
\text { Locality C }\end{array}$ & 18.50000000000 & $\begin{array}{l}\text { Single } \\
\text { Room }\end{array}$ & Schaaf 1988 & Data presented \\
\hline KTZ-00009 & $\begin{array}{l}\text { Kividluk, } \\
\text { Kividlo }\end{array}$ & $\begin{array}{l}\text { After } 500 \\
\text { BP }\end{array}$ & $\begin{array}{l}\text { Feature } 3 \\
\text { Locality C }\end{array}$ & 9.60000000000 & $\begin{array}{l}\text { Single } \\
\text { Room }\end{array}$ & Schaaf 1988 & Data presented \\
\hline KTZ-00009 & $\begin{array}{l}\text { Kividluk, } \\
\text { Kividlo }\end{array}$ & $\begin{array}{l}\text { After } 500 \\
\text { BP }\end{array}$ & $\begin{array}{l}\text { Feature } 4 \\
\text { Locality C }\end{array}$ & 38.28000000000 & $\begin{array}{l}\text { Single } \\
\text { Room }\end{array}$ & Schaaf 1988 & Data presented \\
\hline KTZ-00009 & $\begin{array}{l}\text { Kividluk, } \\
\text { Kividlo }\end{array}$ & $\begin{array}{l}\text { After } 500 \\
\text { BP }\end{array}$ & $\begin{array}{l}\text { Feature } 7 \\
\text { Locality C }\end{array}$ & 33.77500000000 & $\begin{array}{l}\text { Single } \\
\text { Room }\end{array}$ & Schaaf 1988 & Data presented \\
\hline KTZ-00009 & $\begin{array}{l}\text { Kividluk, } \\
\text { Kividlo }\end{array}$ & $\begin{array}{l}\text { After } 500 \\
\text { BP }\end{array}$ & $\begin{array}{l}\text { Feature } 11 \\
\text { Locality C }\end{array}$ & 17.28000000000 & $\begin{array}{l}\text { Single } \\
\text { Room }\end{array}$ & Schaaf 1988 & Data presented \\
\hline KTZ-00009 & $\begin{array}{l}\text { Kividluk, } \\
\text { Kividlo }\end{array}$ & $\begin{array}{l}\text { After } 500 \\
\text { BP }\end{array}$ & $\begin{array}{l}\text { Feature } 1 \\
\text { Locality B }\end{array}$ & 17.00000000000 & Multi-Room & Schaaf 1988 & Data presented \\
\hline KTZ-00009 & $\begin{array}{l}\text { Kividluk, } \\
\text { Kividlo }\end{array}$ & $\begin{array}{l}\text { After } 500 \\
\text { BP }\end{array}$ & $\begin{array}{l}\text { Feature } 3 \\
\text { Locality B } \\
\end{array}$ & 14.44000000000 & Multi-Room & Schaaf 1988 & Data presented \\
\hline KTZ-00009 & $\begin{array}{l}\text { Kividluk, } \\
\text { Kividlo }\end{array}$ & $\begin{array}{l}\text { After } 500 \\
\text { BP }\end{array}$ & $\begin{array}{l}\text { Feature } 7 \\
\text { Locality B }\end{array}$ & 9.45000000000 & Multi-Room & Schaaf 1988 & Data presented \\
\hline KTZ-00009 & $\begin{array}{l}\text { Kividluk, } \\
\text { Kividlo }\end{array}$ & $\begin{array}{l}\text { After } 500 \\
\text { BP }\end{array}$ & $\begin{array}{l}\text { Feature } 8 \\
\text { Locality B }\end{array}$ & 13.17500000000 & Multi-Room & Schaaf 1988 & Data presented \\
\hline KTZ-00009 & $\begin{array}{l}\text { Kividluk, } \\
\text { Kividlo }\end{array}$ & $\begin{array}{l}\text { After } 500 \\
\text { BP }\end{array}$ & $\begin{array}{l}\text { Feature } 10 \\
\text { Locaity B }\end{array}$ & 13.97200000000 & Multi-Room & Schaaf 1988 & Data presented \\
\hline KTZ-00009 & $\begin{array}{l}\text { Kividluk, } \\
\text { Kividlo }\end{array}$ & $\begin{array}{l}\text { After } 500 \\
\text { BP }\end{array}$ & $\begin{array}{l}\text { Feature } 12 \\
\text { Locality B } \\
\end{array}$ & 11.55000000000 & Multi-Room & Schaaf 1988 & Data presented \\
\hline KTZ-00009 & $\begin{array}{l}\text { Kividluk, } \\
\text { Kividlo }\end{array}$ & $\begin{array}{l}\text { After } 500 \\
\text { BP }\end{array}$ & $\begin{array}{l}\text { Feature } 13 \\
\text { Locality B }\end{array}$ & 10.56000000000 & Multi-Room & Schaaf 1988 & Data presented \\
\hline
\end{tabular}




\begin{tabular}{|c|c|c|c|c|c|c|c|}
\hline KTZ-00009 & $\begin{array}{l}\text { Kividluk, } \\
\text { Kividlo }\end{array}$ & $\begin{array}{l}\text { After } 500 \\
\text { BP }\end{array}$ & $\begin{array}{l}\text { Feature } 2 \\
\text { Locality B } \\
\end{array}$ & 30.82000000000 & $\begin{array}{l}\text { Single } \\
\text { Room }\end{array}$ & Schaaf 1988 & Data presented \\
\hline KTZ-00009 & $\begin{array}{l}\text { Kividluk, } \\
\text { Kividlo }\end{array}$ & $\begin{array}{l}\text { After } 500 \\
\text { BP }\end{array}$ & $\begin{array}{l}\text { Feature } 11 \\
\text { Locality B }\end{array}$ & 5.13000000000 & $\begin{array}{l}\text { Single } \\
\text { Room }\end{array}$ & Schaaf 1988 & Data presented \\
\hline KTZ-00009 & $\begin{array}{l}\text { Kividluk, } \\
\text { Kividlo }\end{array}$ & $\begin{array}{l}\text { After } 500 \\
\text { BP }\end{array}$ & $\begin{array}{l}\text { Feature } 2 \\
\text { Locality } \\
\text { D }\end{array}$ & 28.48000000000 & $\begin{array}{l}\text { Single } \\
\text { Room }\end{array}$ & Schaaf 1988 & Data presented \\
\hline KTZ-00030 & $\begin{array}{l}\text { Intermediate } \\
\text { Kotzebue }\end{array}$ & $\begin{array}{l}\text { After } 500 \\
\text { BP }\end{array}$ & House 1 & 12.64000000000 & $\begin{array}{l}\text { Single } \\
\text { Room }\end{array}$ & Giddings 1952 & Data presented \\
\hline KTZ-00030 & $\begin{array}{l}\text { Intermediate } \\
\text { Kotzebue }\end{array}$ & $\begin{array}{l}\text { After } 500 \\
\text { BP }\end{array}$ & House 3 & 9.20000000000 & $\begin{array}{l}\text { Single } \\
\text { Room }\end{array}$ & Giddings 1952 & Data presented \\
\hline KTZ-00030 & $\begin{array}{l}\text { Intermediate } \\
\text { Kotzebue }\end{array}$ & $\begin{array}{l}\text { After } 500 \\
\text { BP }\end{array}$ & House 7 & 49.05000000000 & $\begin{array}{l}\text { Single } \\
\text { Room }\end{array}$ & Giddings 1952 & Data presented \\
\hline KTZ-00030 & $\begin{array}{l}\text { Intermediate } \\
\text { Kotzebue }\end{array}$ & $\begin{array}{l}\text { After } 500 \\
\text { BP }\end{array}$ & House 8 & 8.36000000000 & $\begin{array}{l}\text { Single } \\
\text { Room }\end{array}$ & Giddings 1952 & Data presented \\
\hline KTZ-00030 & $\begin{array}{l}\text { Intermediate } \\
\text { Kotzebue }\end{array}$ & $\begin{array}{l}\text { After } 500 \\
\text { BP }\end{array}$ & House 12 & 15.33000000000 & $\begin{array}{l}\text { Single } \\
\text { Room }\end{array}$ & Giddings 1952 & Data presented \\
\hline KTZ-00054 & & $\begin{array}{l}\text { After } 500 \\
\text { BP }\end{array}$ & Feature 2 & 7.04000000000 & Multi-Room & Schaaf 1988 & Data presented \\
\hline KTZ-00054 & & $\begin{array}{l}\text { After } 500 \\
\text { BP }\end{array}$ & Feature 1 & 5.27000000000 & $\begin{array}{l}\text { Single } \\
\text { Room }\end{array}$ & Schaaf 1988 & Data presented \\
\hline KTZ-00055 & & $\begin{array}{l}\text { After } 500 \\
\text { BP }\end{array}$ & Feature 1 & 4.41000000000 & $\begin{array}{l}\text { Single } \\
\text { Room }\end{array}$ & Schaaf 1988 & Data presented \\
\hline KTZ-00055 & & $\begin{array}{l}\text { After } 500 \\
\text { BP }\end{array}$ & Feature 2 & 8.75000000000 & $\begin{array}{l}\text { Single } \\
\text { Room }\end{array}$ & Schaaf 1988 & Data presented \\
\hline KTZ-00055 & & $\begin{array}{l}\text { After } 500 \\
\text { BP }\end{array}$ & Feature 3 & 5.04000000000 & $\begin{array}{l}\text { Single } \\
\text { Room }\end{array}$ & Schaaf 1988 & Data presented \\
\hline KTZ-00055 & & $\begin{array}{l}\text { After } 500 \\
\text { BP }\end{array}$ & Feature 4 & 9.43000000000 & $\begin{array}{l}\text { Single } \\
\text { Room }\end{array}$ & Schaaf 1988 & Data presented \\
\hline KTZ-00055 & & $\begin{array}{l}\text { After } 500 \\
\text { BP }\end{array}$ & Feature 5 & 9.75000000000 & $\begin{array}{l}\text { Single } \\
\text { Room }\end{array}$ & Schaaf 1988 & Data presented \\
\hline KTZ-00055 & & $\begin{array}{l}\text { After } 500 \\
\text { BP }\end{array}$ & Feature 6 & 4.48000000000 & $\begin{array}{l}\text { Single } \\
\text { Room }\end{array}$ & Schaaf 1988 & Data presented \\
\hline
\end{tabular}




\begin{tabular}{|c|c|c|c|c|c|c|}
\hline KTZ-00055 & $\begin{array}{l}\text { After } 500 \\
\text { BP }\end{array}$ & Feature 7 & 3.99000000000 & $\begin{array}{l}\text { Single } \\
\text { Room }\end{array}$ & Schaaf 1988 & Data presented \\
\hline KTZ-00055 & $\begin{array}{l}\text { After } 500 \\
\text { BP }\end{array}$ & Feature 8 & 7.36000000000 & $\begin{array}{l}\text { Single } \\
\text { Room }\end{array}$ & Schaaf 1988 & Data presented \\
\hline KTZ-00055 & $\begin{array}{l}\text { After } 500 \\
\text { BP }\end{array}$ & Feature 9 & 5.52000000000 & $\begin{array}{l}\text { Single } \\
\text { Room }\end{array}$ & Schaaf 1988 & Data presented \\
\hline KTZ-00055 & $\begin{array}{l}\text { After } 500 \\
\text { BP }\end{array}$ & Feature 10 & 6.00000000000 & $\begin{array}{l}\text { Single } \\
\text { Room }\end{array}$ & Schaaf 1988 & Data presented \\
\hline KTZ-00055 & $\begin{array}{l}\text { After } 500 \\
\text { BP }\end{array}$ & Feature 11 & 3.42000000000 & $\begin{array}{l}\text { Single } \\
\text { Room }\end{array}$ & Schaaf 1988 & Data presented \\
\hline KTZ-00055 & $\begin{array}{l}\text { After } 500 \\
\text { BP }\end{array}$ & Feature 12 & 7.56000000000 & $\begin{array}{l}\text { Single } \\
\text { Room }\end{array}$ & Schaaf 1988 & Data presented \\
\hline KTZ-00056 & $\begin{array}{l}\text { After } 500 \\
\text { BP }\end{array}$ & Feature 2 & 14.00000000000 & Multi-Room & Schaaf 1988 & Data presented \\
\hline KTZ-00056 & $\begin{array}{l}\text { After } 500 \\
\text { BP }\end{array}$ & Feature 1 & 8.41000000000 & $\begin{array}{l}\text { Single } \\
\text { Room }\end{array}$ & Schaaf 1988 & Data presented \\
\hline KTZ-00056 & $\begin{array}{l}\text { After } 500 \\
\text { BP }\end{array}$ & Feature 3 & 4.75000000000 & $\begin{array}{l}\text { Single } \\
\text { Room }\end{array}$ & Schaaf 1988 & Data presented \\
\hline KTZ-00056 & $\begin{array}{l}\text { After } 500 \\
\text { BP }\end{array}$ & Feature 4 & 5.44000000000 & $\begin{array}{l}\text { Single } \\
\text { Room }\end{array}$ & Schaaf 1988 & Data presented \\
\hline KTZ-00056 & $\begin{array}{l}\text { After } 500 \\
\text { BP }\end{array}$ & Feature 5 & 5.27000000000 & $\begin{array}{l}\text { Single } \\
\text { Room }\end{array}$ & Schaaf 1988 & Data presented \\
\hline KTZ-00056 & $\begin{array}{l}\text { After } 500 \\
\text { BP }\end{array}$ & Feature 6 & 5.44000000000 & $\begin{array}{l}\text { Single } \\
\text { Room }\end{array}$ & Schaaf 1988 & Data presented \\
\hline KTZ-00056 & $\begin{array}{l}\text { After } 500 \\
\text { BP }\end{array}$ & Feature 7 & 4.20000000000 & $\begin{array}{l}\text { Single } \\
\text { Room }\end{array}$ & Schaaf 1988 & Data presented \\
\hline KTZ-00056 & $\begin{array}{l}\text { After } 500 \\
\text { BP }\end{array}$ & Feature 8 & 6.51000000000 & $\begin{array}{l}\text { Single } \\
\text { Room }\end{array}$ & Schaaf 1988 & Data presented \\
\hline KTZ-00056 & $\begin{array}{l}\text { After } 500 \\
\text { BP }\end{array}$ & Feature 10 & 4.16000000000 & $\begin{array}{l}\text { Single } \\
\text { Room }\end{array}$ & Schaaf 1988 & Data presented \\
\hline KTZ-00056 & $\begin{array}{l}\text { After } 500 \\
\text { BP }\end{array}$ & Feature 11 & 4.32000000000 & $\begin{array}{l}\text { Single } \\
\text { Room }\end{array}$ & Schaaf 1988 & Data presented \\
\hline KTZ-00056 & $\begin{array}{l}\text { After } 500 \\
\text { BP }\end{array}$ & Feature 12 & 8.40000000000 & $\begin{array}{l}\text { Single } \\
\text { Room }\end{array}$ & Schaaf 1988 & Data presented \\
\hline
\end{tabular}




\begin{tabular}{|c|c|c|c|c|c|c|}
\hline KTZ-00056 & $\begin{array}{l}\text { After } 500 \\
\text { BP }\end{array}$ & Feature 13 & 7.20000000000 & $\begin{array}{l}\text { Single } \\
\text { Room }\end{array}$ & Schaaf 1988 & Data presented \\
\hline KTZ-00056 & $\begin{array}{l}\text { After } 500 \\
\text { BP }\end{array}$ & Feature 14 & 9.02000000000 & $\begin{array}{l}\text { Single } \\
\text { Room }\end{array}$ & Schaaf 1988 & Data presented \\
\hline KTZ-00056 & $\begin{array}{l}\text { After } 500 \\
\text { BP }\end{array}$ & Feature 15 & 4.42000000000 & $\begin{array}{l}\text { Single } \\
\text { Room }\end{array}$ & Schaaf 1988 & Data presented \\
\hline KTZ-00056 & $\begin{array}{l}\text { After } 500 \\
\text { BP }\end{array}$ & Feature 16 & 5.40000000000 & $\begin{array}{l}\text { Single } \\
\text { Room }\end{array}$ & Schaaf 1988 & Data presented \\
\hline KTZ-00060 & $\begin{array}{l}\text { After } 500 \\
\text { BP }\end{array}$ & Feature 1 & 26.64000000000 & $\begin{array}{l}\text { Single } \\
\text { Room }\end{array}$ & Schaaf 1988 & Data presented \\
\hline KTZ-00088 & $\begin{array}{l}\text { After } 500 \\
\text { BP }\end{array}$ & Feature 2 & 9.36000000000 & Multi-Room & Schaaf 1988 & Data presented \\
\hline KTZ-00088 & $\begin{array}{l}\text { After } 500 \\
\text { BP }\end{array}$ & Feature 6 & 14.40000000000 & Multi-Room & Schaaf 1988 & Data presented \\
\hline KTZ-00088 & $\begin{array}{l}\text { After } 500 \\
\text { BP }\end{array}$ & Feature 1 & 8.50500000000 & $\begin{array}{l}\text { Single } \\
\text { Room }\end{array}$ & Schaaf 1988 & Data presented \\
\hline KTZ-00088 & $\begin{array}{l}\text { After } 500 \\
\text { BP }\end{array}$ & Feature 3 & 11.10000000000 & $\begin{array}{l}\text { Single } \\
\text { Room }\end{array}$ & Schaaf 1988 & Data presented \\
\hline KTZ-00088 & $\begin{array}{l}\text { After } 500 \\
\text { BP }\end{array}$ & Feature 4 & 14.21000000000 & $\begin{array}{l}\text { Single } \\
\text { Room }\end{array}$ & Schaaf 1988 & Data presented \\
\hline KTZ-00088 & $\begin{array}{l}\text { After } 500 \\
\text { BP }\end{array}$ & Feature 5a & 10.56000000000 & $\begin{array}{l}\text { Single } \\
\text { Room }\end{array}$ & Schaaf 1988 & Data presented \\
\hline KTZ-00088 & $\begin{array}{l}\text { After } 500 \\
\text { BP }\end{array}$ & Feature $5 b$ & 8.74000000000 & $\begin{array}{l}\text { Single } \\
\text { Room }\end{array}$ & Schaaf 1988 & Data presented \\
\hline KTZ-00088 & $\begin{array}{l}\text { After } 500 \\
\text { BP }\end{array}$ & Feature 7 & 10.44000000000 & $\begin{array}{l}\text { Single } \\
\text { Room }\end{array}$ & Schaaf 1988 & Data presented \\
\hline KTZ-00088 & $\begin{array}{l}\text { After } 500 \\
\text { BP }\end{array}$ & Feature 8 & 14.35000000000 & $\begin{array}{l}\text { Single } \\
\text { Room }\end{array}$ & Schaaf 1988 & Data presented \\
\hline KTZ-00090 & $\begin{array}{l}\text { After } 500 \\
\text { BP }\end{array}$ & Feature 1 & 18.52500000000 & Multi-Room & Schaaf 1988 & Data presented \\
\hline KTZ-00090 & $\begin{array}{l}\text { After } 500 \\
\text { BP }\end{array}$ & Feature 2 & 27.84000000000 & Multi-Room & Schaaf 1988 & Data presented \\
\hline KTZ-00090 & $\begin{array}{l}\text { After } 500 \\
\text { BP }\end{array}$ & Feature 3 & 13.60000000000 & Multi-Room & Schaaf 1988 & Data presented \\
\hline
\end{tabular}




\begin{tabular}{|c|c|c|c|c|c|c|}
\hline KTZ-00090 & $\begin{array}{l}\text { After } 500 \\
\text { BP }\end{array}$ & Feature 4 & 16.66000000000 & Multi-Room & Schaaf 1988 & Data presented \\
\hline KTZ-00090 & $\begin{array}{l}\text { After } 500 \\
\text { BP }\end{array}$ & Feature 6 & 30.38000000000 & Multi-Room & Schaaf 1988 & Data presented \\
\hline KTZ-00090 & $\begin{array}{l}\text { After } 500 \\
\text { BP }\end{array}$ & Feature 8 & 26.10000000000 & Multi-Room & Schaaf 1988 & Data presented \\
\hline KTZ-00090 & $\begin{array}{l}\text { After } 500 \\
\text { BP }\end{array}$ & Feature 9 & 21.85500000000 & Multi-Room & Schaaf 1988 & Data presented \\
\hline KTZ-00090 & $\begin{array}{l}\text { After } 500 \\
\text { BP }\end{array}$ & Feature 5 & 21.24000000000 & $\begin{array}{l}\text { Single } \\
\text { Room }\end{array}$ & Schaaf 1988 & Data presented \\
\hline KTZ-00090 & $\begin{array}{l}\text { After } 500 \\
\text { BP }\end{array}$ & Feature 7 & 40.71000000000 & $\begin{array}{l}\text { Single } \\
\text { Room }\end{array}$ & Schaaf 1988 & Data presented \\
\hline KTZ-00090 & $\begin{array}{l}\text { After } 500 \\
\text { BP }\end{array}$ & Feature 11 & 27.29500000000 & $\begin{array}{l}\text { Single } \\
\text { Room }\end{array}$ & Schaaf 1988 & Data presented \\
\hline KTZ-00101 & $\begin{array}{l}\text { After } 500 \\
\text { BP }\end{array}$ & Feature 1 & 21.60000000000 & Multi-Room & Schaaf 1988 & Data presented \\
\hline KTZ-00101 & $\begin{array}{l}\text { After } 500 \\
\text { BP }\end{array}$ & Feature 2 & 15.48000000000 & Multi-Room & Schaaf 1988 & Data presented \\
\hline KTZ-00101 & $\begin{array}{l}\text { After } 500 \\
\text { BP }\end{array}$ & Feature 4 & 14.00000000000 & Multi-Room & Schaaf 1988 & Data presented \\
\hline KTZ-00101 & $\begin{array}{l}\text { After } 500 \\
\text { BP }\end{array}$ & Feature 5 & 17.55000000000 & Multi-Room & Schaaf 1988 & Data presented \\
\hline KTZ-00101 & $\begin{array}{l}\text { After } 500 \\
\text { BP }\end{array}$ & Feature 6 & 17.50000000000 & Multi-Room & Schaaf 1988 & Data presented \\
\hline KTZ-00101 & $\begin{array}{l}\text { After } 500 \\
\text { BP }\end{array}$ & Feature 9 & 17.72000000000 & Multi-Room & Schaaf 1988 & Data presented \\
\hline KTZ-00101 & $\begin{array}{l}\text { After } 500 \\
\text { BP }\end{array}$ & Feature 10 & 6.60000000000 & Multi-Room & Schaaf 1988 & Data presented \\
\hline KTZ-00101 & $\begin{array}{l}\text { After } 500 \\
\text { BP }\end{array}$ & Feature 3 & 12.25000000000 & $\begin{array}{l}\text { Single } \\
\text { Room }\end{array}$ & Schaaf 1988 & Data presented \\
\hline KTZ-00101 & $\begin{array}{l}\text { After } 500 \\
\text { BP }\end{array}$ & Feature 7 & 15.64000000000 & $\begin{array}{l}\text { Single } \\
\text { Room }\end{array}$ & Schaaf 1988 & Data presented \\
\hline KTZ-00148 & $\begin{array}{l}\text { After } 500 \\
\text { BP }\end{array}$ & Feature 3 & 19.35000000000 & Multi-Room & Schaaf 1988 & Data presented \\
\hline
\end{tabular}




\begin{tabular}{|c|c|c|c|c|c|c|}
\hline KTZ-00148 & $\begin{array}{l}\text { After } 500 \\
\text { BP }\end{array}$ & Feature 4 & 26.40000000000 & Multi-Room & Schaaf 1988 & Data presented \\
\hline KTZ-00148 & $\begin{array}{l}\text { After } 500 \\
\text { BP }\end{array}$ & Feature 10 & 24.20000000000 & Multi-Room & Schaaf 1988 & Data presented \\
\hline KTZ-00148 & $\begin{array}{l}\text { After } 500 \\
\text { BP }\end{array}$ & Feature 1 & 27.00000000000 & $\begin{array}{l}\text { Single } \\
\text { Room }\end{array}$ & Schaaf 1988 & Data presented \\
\hline KTZ-00148 & $\begin{array}{l}\text { After } 500 \\
\text { BP }\end{array}$ & Feature 9 & 23.00000000000 & $\begin{array}{l}\text { Single } \\
\text { Room }\end{array}$ & Schaaf 1988 & Data presented \\
\hline KTZ-00148 & $\begin{array}{l}\text { After } 500 \\
\text { BP }\end{array}$ & Feature 11 & $\begin{array}{l}131.0400000000 \\
0\end{array}$ & $\begin{array}{l}\text { Single } \\
\text { Room }\end{array}$ & Schaaf 1988 & Data presented \\
\hline KTZ-00171 & $\begin{array}{l}\text { After } 500 \\
\text { BP }\end{array}$ & 3 & 9.45248765800 & $\begin{array}{l}\text { Single } \\
\text { Room }\end{array}$ & Darwent et al. 2012 & Data presented \\
\hline KTZ-00171 & $\begin{array}{l}\text { After } 500 \\
\text { BP }\end{array}$ & 1 & 14.16579864000 & $\begin{array}{l}\text { Single } \\
\text { Room }\end{array}$ & Darwent et al. 2012 & Data presented \\
\hline KTZ-00171 & $\begin{array}{l}\text { After } 500 \\
\text { BP }\end{array}$ & 2 & 20.96926316000 & Multi-Room & Darwent et al. 2012 & Data presented \\
\hline KTZ-00171 & $\begin{array}{l}\text { After } 500 \\
\text { BP }\end{array}$ & 7 & 11.66212230000 & Multi-Room & Darwent et al. 2012 & Data presented \\
\hline KTZ-00171 & $\begin{array}{l}\text { After } 500 \\
\text { BP }\end{array}$ & 6 & 17.24431918000 & Multi-Room & Darwent et al. 2012 & Data presented \\
\hline KTZ-00171 & $\begin{array}{l}\text { After } 500 \\
\text { BP }\end{array}$ & 5 & 10.52851791000 & Multi-Room & Darwent et al. 2012 & Data presented \\
\hline KTZ-00171 & $\begin{array}{l}\text { After } 500 \\
\text { BP }\end{array}$ & 9 & 14.74659501000 & Multi-Room & Darwent et al. 2012 & Data presented \\
\hline KTZ-00171 & $\begin{array}{l}\text { After } 500 \\
\text { BP }\end{array}$ & 11 & 20.12622107000 & Multi-Room & Darwent et al. 2012 & Data presented \\
\hline KTZ-00171 & $\begin{array}{l}\text { After } 500 \\
\text { BP }\end{array}$ & 13 & 12.74086604000 & Multi-Room & Darwent et al. 2012 & Data presented \\
\hline KTZ-00171 & $\begin{array}{l}\text { After } 500 \\
\text { BP }\end{array}$ & 15 & 14.39506670000 & Multi-Room & Darwent et al. 2012 & Data presented \\
\hline KTZ-00298 & $\begin{array}{l}\text { After } 500 \\
\text { BP }\end{array}$ & 2 & 16.07000000000 & $\begin{array}{l}\text { Single } \\
\text { Room }\end{array}$ & BIA F-22301 & Data presented \\
\hline KTZ-00298 & $\begin{array}{l}\text { After } 500 \\
\text { BP }\end{array}$ & 4 & 17.00000000000 & Multi-Room & BIA F-22301 & Data presented \\
\hline
\end{tabular}




\begin{tabular}{|c|c|c|c|c|c|c|c|}
\hline KTZ-00298 & & $\begin{array}{l}\text { After } 500 \\
\text { BP }\end{array}$ & 6 & 9.50000000000 & $\begin{array}{l}\text { Single } \\
\text { Room }\end{array}$ & BIA F-22301 & Data presented \\
\hline KTZ-00298 & & $\begin{array}{l}\text { After } 500 \\
\text { BP }\end{array}$ & 11 & 11.16000000000 & $\begin{array}{l}\text { Single } \\
\text { Room }\end{array}$ & BIA F-22301 & Data presented \\
\hline KTZ-00298 & & $\begin{array}{l}\text { After } 500 \\
\text { BP }\end{array}$ & 17 & 21.04000000000 & Multi-Room & BIA F-22301 & Data presented \\
\hline KTZ-00298 & & $\begin{array}{l}\text { After } 500 \\
\text { BP }\end{array}$ & 20 & 26.95000000000 & $\begin{array}{l}\text { Single } \\
\text { Room }\end{array}$ & BIA F-22301 & Data presented \\
\hline KTZ-00298 & & $\begin{array}{l}\text { After } 500 \\
\text { BP }\end{array}$ & 31 & 11.53000000000 & $\begin{array}{l}\text { Single } \\
\text { Room }\end{array}$ & BIA F-22301 & Data presented \\
\hline KTZ-00298 & & $\begin{array}{l}\text { After } 500 \\
\text { BP }\end{array}$ & 53 & 50.46000000000 & Multi-Room & BIA F-22301 & Data presented \\
\hline KTZ-00298 & & $\begin{array}{l}\text { After } 500 \\
\text { BP }\end{array}$ & $54 \mathrm{~A} / \mathrm{B}$ & 24.80000000000 & Multi-Room & BIA F-22301 & Data presented \\
\hline NOA-00003 & Aniyak & $\begin{array}{l}\text { After } 500 \\
\text { BP }\end{array}$ & Unknown & 30.78992300000 & $\begin{array}{l}\text { Single } \\
\text { Room }\end{array}$ & CAKR Project & GIS measurements \\
\hline NOA-00003 & Aniyak & $\begin{array}{l}\text { After } 500 \\
\text { BP }\end{array}$ & Unknown & 20.99588100000 & $\begin{array}{l}\text { Single } \\
\text { Room }\end{array}$ & CAKR Project & GIS measurements \\
\hline NOA-00003 & Aniyak & $\begin{array}{l}\text { After } 500 \\
\text { BP }\end{array}$ & Unknown & 29.12839800000 & $\begin{array}{l}\text { Single } \\
\text { Room }\end{array}$ & CAKR Project & GIS measurements \\
\hline NOA-00003 & Aniyak & $\begin{array}{l}\text { After } 500 \\
\text { BP }\end{array}$ & Unknown & 15.59010900000 & $\begin{array}{l}\text { Single } \\
\text { Room }\end{array}$ & CAKR Project & GIS measurements \\
\hline NOA-00003 & Aniyak & $\begin{array}{l}\text { After } 500 \\
\text { BP }\end{array}$ & Unknown & 15.06170200000 & $\begin{array}{l}\text { Single } \\
\text { Room }\end{array}$ & CAKR Project & GIS measurements \\
\hline NOA-00003 & Aniyak & $\begin{array}{l}\text { After } 500 \\
\text { BP }\end{array}$ & Unknown & 22.89644400000 & $\begin{array}{l}\text { Single } \\
\text { Room }\end{array}$ & CAKR Project & GIS measurements \\
\hline NOA-00003 & Aniyak & $\begin{array}{l}\text { After } 500 \\
\text { BP }\end{array}$ & Unknown & 18.91865300000 & $\begin{array}{l}\text { Single } \\
\text { Room }\end{array}$ & CAKR Project & GIS measurements \\
\hline NOA-00003 & Aniyak & $\begin{array}{l}\text { After } 500 \\
\text { BP }\end{array}$ & Unknown & 32.31866500000 & $\begin{array}{l}\text { Single } \\
\text { Room }\end{array}$ & CAKR Project & GIS measurements \\
\hline NOA-00003 & Aniyak & $\begin{array}{l}\text { After } 500 \\
\text { BP }\end{array}$ & Unknown & 17.73475500000 & $\begin{array}{l}\text { Single } \\
\text { Room }\end{array}$ & CAKR Project & GIS measurements \\
\hline NOA-00003 & Aniyak & $\begin{array}{l}\text { After } 500 \\
\text { BP }\end{array}$ & Unknown & 14.37435800000 & $\begin{array}{l}\text { Single } \\
\text { Room }\end{array}$ & CAKR Project & GIS measurements \\
\hline
\end{tabular}




\begin{tabular}{|c|c|c|c|c|c|c|c|}
\hline NOA-00003 & Aniyak & $\begin{array}{l}\text { After } 500 \\
\text { BP }\end{array}$ & Unknown & 8.50591700000 & $\begin{array}{l}\text { Single } \\
\text { Room }\end{array}$ & CAKR Project & GIS measurements \\
\hline NOA-00003 & Aniyak & $\begin{array}{l}\text { After } 500 \\
\text { BP }\end{array}$ & Unknown & 23.63868900000 & $\begin{array}{l}\text { Single } \\
\text { Room }\end{array}$ & CAKR Project & GIS measurements \\
\hline NOA-00140 & Anigaaq $\mathrm{C}$ & $\begin{array}{l}\text { After } 500 \\
\text { BP }\end{array}$ & 1 & 12.00000000000 & $\begin{array}{l}\text { Single } \\
\text { Room }\end{array}$ & BIA F21237 C & Data presented \\
\hline NOA-00140 & Anigaaq $\mathrm{C}$ & $\begin{array}{l}\text { After } 500 \\
\text { BP }\end{array}$ & 2 & 9.00000000000 & $\begin{array}{l}\text { Single } \\
\text { Room }\end{array}$ & BIA F21237 C & Data presented \\
\hline NOA-00140 & Anigaaq C & $\begin{array}{l}\text { After } 500 \\
\text { BP }\end{array}$ & 3 & 14.00000000000 & $\begin{array}{l}\text { Single } \\
\text { Room }\end{array}$ & BIA F21237 C & Data presented \\
\hline NOA-00140 & Anigaaq C & $\begin{array}{l}\text { After } 500 \\
\text { BP }\end{array}$ & 4 & 30.00000000000 & $\begin{array}{l}\text { Single } \\
\text { Room }\end{array}$ & BIA F21237 C & Data presented \\
\hline NOA-00140 & Anigaaq C & $\begin{array}{l}\text { After } 500 \\
\text { BP }\end{array}$ & 5 & 8.10000000000 & $\begin{array}{l}\text { Single } \\
\text { Room }\end{array}$ & BIA F21237 C & Data presented \\
\hline NOA-00140 & Anigaaq $\mathrm{C}$ & $\begin{array}{l}\text { After } 500 \\
\text { BP }\end{array}$ & 6 & 17.60000000000 & $\begin{array}{l}\text { Single } \\
\text { Room }\end{array}$ & BIA F21237 C & Data presented \\
\hline NOA-00140 & Anigaaq $\mathrm{C}$ & $\begin{array}{l}\text { After } 500 \\
\text { BP }\end{array}$ & 7 & 38.50000000000 & $\begin{array}{l}\text { Single } \\
\text { Room }\end{array}$ & BIA F21237 C & Data presented \\
\hline NOA-00161 & & $\begin{array}{l}\text { After } 500 \\
\text { BP }\end{array}$ & 3 & 12.24000000000 & $\begin{array}{l}\text { Single } \\
\text { Room }\end{array}$ & $\begin{array}{l}\text { McClenahan and Gibson } \\
\text { 1990II }\end{array}$ & Data presented \\
\hline NOA-00161 & & $\begin{array}{l}\text { After } 500 \\
\text { BP }\end{array}$ & 4 & 26.76200000000 & $\begin{array}{l}\text { Single } \\
\text { Room }\end{array}$ & $\begin{array}{l}\text { McClenahan and Gibson } \\
1990 \text { II }\end{array}$ & Data presented \\
\hline NOA-00162 & & $\begin{array}{l}\text { After } 500 \\
\text { BP }\end{array}$ & 1 & 34.65000000000 & $\begin{array}{l}\text { Single } \\
\text { Room }\end{array}$ & $\begin{array}{l}\text { McClenahan and Gibson } \\
\text { 1990II }\end{array}$ & Data presented \\
\hline NOA-00163 & & $\begin{array}{l}\text { After } 500 \\
\text { BP }\end{array}$ & 10 & 26.25000000000 & $\begin{array}{l}\text { Single } \\
\text { Room }\end{array}$ & $\begin{array}{l}\text { McClenahan and Gibson } \\
\text { 1990II }\end{array}$ & Data presented \\
\hline NOA-00164 & & $\begin{array}{l}\text { After } 500 \\
\text { BP }\end{array}$ & 3 & 25.44000000000 & $\begin{array}{l}\text { Single } \\
\text { Room }\end{array}$ & $\begin{array}{l}\text { McClenahan and Gibson } \\
\text { 1990II }\end{array}$ & Data presented \\
\hline NOA-00164 & & $\begin{array}{l}\text { After } 500 \\
\text { BP }\end{array}$ & 6 & 33.30000000000 & $\begin{array}{l}\text { Single } \\
\text { Room }\end{array}$ & $\begin{array}{l}\text { McClenahan and Gibson } \\
1990 \text { II }\end{array}$ & Data presented \\
\hline NOA-00188 & & $\begin{array}{l}\text { After } 500 \\
\text { BP }\end{array}$ & 1 & 12.96000000000 & $\begin{array}{l}\text { Single } \\
\text { Room }\end{array}$ & $\begin{array}{l}\text { McClenahan and Gibson } \\
\text { 1990II }\end{array}$ & Data presented \\
\hline NOA-00217 & Agiaguat & $\begin{array}{l}\text { After } 500 \\
\text { BP }\end{array}$ & 6 & 40.40000000000 & $\begin{array}{l}\text { Single } \\
\text { Room }\end{array}$ & $\begin{array}{l}\text { McClenahan and Gibson } \\
\text { 1990II }\end{array}$ & Data presented \\
\hline
\end{tabular}




\begin{tabular}{|c|c|c|c|c|c|c|c|}
\hline NOA-00217 & Agiaguat & $\begin{array}{l}\text { After } 500 \\
\text { BP }\end{array}$ & 10 & 57.45000000000 & $\begin{array}{l}\text { Single } \\
\text { Room }\end{array}$ & $\begin{array}{l}\text { McClenahan and Gibson } \\
\text { 1990II }\end{array}$ & Data presented \\
\hline NOA-00284 & Aitiligauraq & $\begin{array}{l}\text { After } 500 \\
\text { BP }\end{array}$ & House 1 & 10.83000000000 & $\begin{array}{l}\text { Single } \\
\text { Room }\end{array}$ & Giddings 1952 & Data presented \\
\hline NOA-00284 & Aitiligauraq & $\begin{array}{l}\text { After } 500 \\
\text { BP }\end{array}$ & House 2 & 18.00000000000 & $\begin{array}{l}\text { Single } \\
\text { Room }\end{array}$ & Giddings 1952 & Data presented \\
\hline NOA-00301 & $\begin{array}{l}\text { Igrugaivik } \\
\text { Creek Camp }\end{array}$ & $\begin{array}{l}\text { After } 500 \\
\text { BP }\end{array}$ & 1 & 21.70000000000 & $\begin{array}{l}\text { Single } \\
\text { Room }\end{array}$ & Grover, M. 2001 & Data presented \\
\hline NOA-00301 & $\begin{array}{l}\text { Igrugaivik } \\
\text { Creek Camp }\end{array}$ & $\begin{array}{l}\text { After } 500 \\
\text { BP }\end{array}$ & 2 & 9.14640000000 & $\begin{array}{l}\text { Single } \\
\text { Room }\end{array}$ & Grover, M. 2001 & Data presented \\
\hline NOA-00474 & & $\begin{array}{l}\text { After } 500 \\
\text { BP }\end{array}$ & $1 \mathrm{~B}$ & 11.61247192890 & $\begin{array}{l}\text { Single } \\
\text { Room }\end{array}$ & CAKR Project & GIS measurements \\
\hline $\begin{array}{l}\text { PSU-2013-06 } \\
\text { (Nuluk) }\end{array}$ & & $\begin{array}{l}\text { After } 500 \\
\text { BP }\end{array}$ & 1 & 2.90722000000 & $\begin{array}{l}\text { Single } \\
\text { Room }\end{array}$ & Nuluk Project & GIS measurements \\
\hline SHF-00043 & & $\begin{array}{l}\text { After } 500 \\
\text { BP }\end{array}$ & Feature 1 & 17.50000000000 & Multi-Room & Schaaf 1988 & Data presented \\
\hline SHF-00043 & & $\begin{array}{l}\text { After } 500 \\
\text { BP }\end{array}$ & Feature 2 & 16.40000000000 & Multi-Room & Schaaf 1988 & Data presented \\
\hline SHU-00009 & Shungnak & $\begin{array}{l}\text { After } 500 \\
\text { BP }\end{array}$ & $\mathrm{n} / \mathrm{a}$ & 13.68000000000 & $\begin{array}{l}\text { Single } \\
\text { Room }\end{array}$ & Giddings 1952 & Data presented \\
\hline SLK-00044 & & $\begin{array}{l}\text { After } 500 \\
\text { BP }\end{array}$ & 8 & 12.00000000000 & $\begin{array}{l}\text { Single } \\
\text { Room }\end{array}$ & BIA FF17627B & Data presented \\
\hline SLK-00102 & Dobuk & $\begin{array}{l}\text { After } 500 \\
\text { BP }\end{array}$ & 1 & 12.25000000000 & $\begin{array}{l}\text { Single } \\
\text { Room }\end{array}$ & AHRS & Data presented \\
\hline SOL-00068 & Okpiktulik & $\begin{array}{l}\text { After } 500 \\
\text { BP }\end{array}$ & A & 90.60000000000 & $\begin{array}{l}\text { Single } \\
\text { Room }\end{array}$ & BIA F-21889 & Data presented \\
\hline SOL-00068 & Okpiktulik & $\begin{array}{l}\text { After } 500 \\
\text { BP }\end{array}$ & $\mathrm{B}$ & 34.36000000000 & Multi-Room & BIA F-21889 & Data presented \\
\hline SOL-00068 & Okpiktulik & $\begin{array}{l}\text { After } 500 \\
\text { BP }\end{array}$ & $\mathrm{F}$ & 48.87000000000 & Multi-Room & BIA F-21889 & Data presented \\
\hline SOL-00068 & Okpiktulik & $\begin{array}{l}\text { After } 500 \\
\text { BP }\end{array}$ & $\mathrm{L}$ & 35.60500000000 & Multi-Room & BIA F-21889 & Data presented \\
\hline SOL-00068 & Okpiktulik & $\begin{array}{l}\text { After } 500 \\
\text { BP }\end{array}$ & $\mathrm{M}$ & 58.96000000000 & Multi-Room & BIA F-21889 & Data presented \\
\hline
\end{tabular}




\begin{tabular}{|c|c|c|c|c|c|c|c|}
\hline SOL-00068 & Okpiktulik & $\begin{array}{l}\text { After } 500 \\
\text { BP }\end{array}$ & Q & 52.41500000000 & Multi-Room & BIA F-21889 & Data presented \\
\hline SOL-00068 & Okpiktulik & $\begin{array}{l}\text { After } 500 \\
\text { BP }\end{array}$ & $S$ & 55.80000000000 & Multi-Room & BIA F-21889 & Data presented \\
\hline SOL-00068 & Okpiktulik & $\begin{array}{l}\text { After } 500 \\
\text { BP }\end{array}$ & $\mathrm{Z}$ & 19.08000000000 & $\begin{array}{l}\text { Single } \\
\text { Room }\end{array}$ & BIA F-21889 & Data presented \\
\hline SOL-00068 & Okpiktulik & $\begin{array}{l}\text { After } 500 \\
\text { BP }\end{array}$ & $\mathrm{CC}$ & 94.17000000000 & Multi-Room & BIA F-21889 & Data presented \\
\hline SOL-00068 & Okpiktulik & $\begin{array}{l}\text { After } 500 \\
\text { BP }\end{array}$ & GG & 54.22000000000 & Multi-Room & BIA F-21889 & Data presented \\
\hline SOL-00068 & Okpiktulik & $\begin{array}{l}\text { After } 500 \\
\text { BP }\end{array}$ & $\mathrm{HH}$ & $\begin{array}{l}133.2300000000 \\
0\end{array}$ & $\begin{array}{l}\text { Single } \\
\text { Room }\end{array}$ & BIA F-21889 & Data presented \\
\hline SOL-00068 & Okpiktulik & $\begin{array}{l}\text { After } 500 \\
\text { BP }\end{array}$ & II & 68.73000000000 & Multi-Room & BIA F-21889 & Data presented \\
\hline SOL-00068 & Okpiktulik & $\begin{array}{l}\text { After } 500 \\
\text { BP }\end{array}$ & SS & 88.33000000000 & Multi-Room & BIA F-21889 & Data presented \\
\hline SOL-00068 & Okpiktulik & $\begin{array}{l}\text { After } 500 \\
\text { BP }\end{array}$ & $X X$ & 48.28000000000 & $\begin{array}{l}\text { Single } \\
\text { Room }\end{array}$ & BIA F-21889 & Data presented \\
\hline TEL-00007 & & $\begin{array}{l}\text { After } 500 \\
\text { BP }\end{array}$ & 1 & 15.00000000000 & $\begin{array}{l}\text { Single } \\
\text { Room }\end{array}$ & Powers 1982 & Data presented \\
\hline TEL-00007 & & $\begin{array}{l}\text { After } 500 \\
\text { BP }\end{array}$ & 2 & 61.50000000000 & Multi-Room & Powers 1982 & Data presented \\
\hline TEL-00007 & & $\begin{array}{l}\text { After } 500 \\
\text { BP }\end{array}$ & 3 & 45.70000000000 & Multi-Room & Powers 1982 & Data presented \\
\hline TEL-00007 & & $\begin{array}{l}\text { After } 500 \\
\text { BP }\end{array}$ & 4 & 67.00000000000 & Multi-Room & Powers 1982 & Data presented \\
\hline TEL-00007 & & $\begin{array}{l}\text { After } 500 \\
\text { BP }\end{array}$ & 5 & 68.15000000000 & Multi-Room & Powers 1982 & Data presented \\
\hline TEL-00007 & & $\begin{array}{l}\text { After } 500 \\
\text { BP }\end{array}$ & 6 & 16.00000000000 & Multi-Room & Powers 1982 & Data presented \\
\hline TEL-00007 & & $\begin{array}{l}\text { After } 500 \\
\text { BP }\end{array}$ & 7 & 45.00000000000 & Multi-Room & Powers 1982 & Data presented \\
\hline TEL-00007 & & $\begin{array}{l}\text { After } 500 \\
\text { BP }\end{array}$ & 8 & 23.00000000000 & Multi-Room & Powers 1982 & Data presented \\
\hline
\end{tabular}




\begin{tabular}{|c|c|c|c|c|c|c|}
\hline TEL-00007 & $\begin{array}{l}\text { After } 500 \\
\text { BP }\end{array}$ & 9 & 38.50000000000 & Multi-Room & Powers 1982 & Data presented \\
\hline TEL-00007 & $\begin{array}{l}\text { After } 500 \\
\text { BP }\end{array}$ & 10 & 25.00000000000 & $\begin{array}{l}\text { Single } \\
\text { Room }\end{array}$ & Powers 1982 & Data presented \\
\hline TEL-00007 & $\begin{array}{l}\text { After } 500 \\
\text { BP }\end{array}$ & 11 & 42.75000000000 & Multi-Room & Powers 1982 & Data presented \\
\hline TEL-00007 & $\begin{array}{l}\text { After } 500 \\
\text { BP }\end{array}$ & 12 & 40.50000000000 & Multi-Room & Powers 1982 & Data presented \\
\hline TEL-00007 & $\begin{array}{l}\text { After } 500 \\
\text { BP }\end{array}$ & 13 & 35.00000000000 & Multi-Room & Powers 1982 & Data presented \\
\hline TEL-00007 & $\begin{array}{l}\text { After } 500 \\
\text { BP }\end{array}$ & 15 & 68.00000000000 & Multi-Room & Powers 1982 & Data presented \\
\hline TEL-00007 & $\begin{array}{l}\text { After } 500 \\
\text { BP }\end{array}$ & 16 & 27.50000000000 & Multi-Room & Powers 1982 & Data presented \\
\hline TEL-00007 & $\begin{array}{l}\text { After } 500 \\
\text { BP }\end{array}$ & 17 & 36.00000000000 & Multi-Room & Powers 1982 & Data presented \\
\hline TEL-00007 & $\begin{array}{l}\text { After } 500 \\
\text { BP }\end{array}$ & 18 & 20.00000000000 & $\begin{array}{l}\text { Single } \\
\text { Room }\end{array}$ & Powers 1982 & Data presented \\
\hline TEL-00007 & $\begin{array}{l}\text { After } 500 \\
\text { BP }\end{array}$ & 19 & 9.00000000000 & $\begin{array}{l}\text { Single } \\
\text { Room }\end{array}$ & Powers 1982 & Data presented \\
\hline TEL-00007 & $\begin{array}{l}\text { After } 500 \\
\text { BP }\end{array}$ & 20 & 79.00000000000 & Multi-Room & Powers 1982 & Data presented \\
\hline TEL-00007 & $\begin{array}{l}\text { After } 500 \\
\text { BP }\end{array}$ & 21 & 25.00000000000 & Multi-Room & Powers 1982 & Data presented \\
\hline TEL-00007 & $\begin{array}{l}\text { After } 500 \\
\text { BP }\end{array}$ & 22 & 48.00000000000 & Multi-Room & Powers 1982 & Data presented \\
\hline TEL-00007 & $\begin{array}{l}\text { After } 500 \\
\text { BP }\end{array}$ & 23 & 56.00000000000 & Multi-Room & Powers 1982 & Data presented \\
\hline TEL-00007 & $\begin{array}{l}\text { After } 500 \\
\text { BP }\end{array}$ & 24 & 84.00000000000 & Multi-Room & Powers 1982 & Data presented \\
\hline TEL-00007 & $\begin{array}{l}\text { After } 500 \\
\text { BP }\end{array}$ & 25 & 82.00000000000 & Multi-Room & Powers 1982 & Data presented \\
\hline TEL-00007 & $\begin{array}{l}\text { After } 500 \\
\text { BP }\end{array}$ & 26 & 36.50000000000 & Multi-Room & Powers 1982 & Data presented \\
\hline
\end{tabular}




\begin{tabular}{|c|c|c|c|c|c|c|}
\hline TEL-00007 & $\begin{array}{l}\text { After } 500 \\
\text { BP }\end{array}$ & 27 & 66.75000000000 & Multi-Room & Powers 1982 & Data presented \\
\hline TEL-00007 & $\begin{array}{l}\text { After } 500 \\
\text { BP }\end{array}$ & 28 & 46.50000000000 & Multi-Room & Powers 1982 & Data presented \\
\hline TEL-00007 & $\begin{array}{l}\text { After } 500 \\
\text { BP }\end{array}$ & 29 & 42.25000000000 & $\begin{array}{l}\text { Single } \\
\text { Room }\end{array}$ & Powers 1982 & Data presented \\
\hline TEL-00060 & $\begin{array}{l}\text { After } 500 \\
\text { BP }\end{array}$ & 1 & 38.25000000000 & $\begin{array}{l}\text { Single } \\
\text { Room }\end{array}$ & BIA F-21978A & Data presented \\
\hline TEL-00060 & $\begin{array}{l}\text { After } 500 \\
\text { BP }\end{array}$ & 2 & 57.76000000000 & $\begin{array}{l}\text { Single } \\
\text { Room }\end{array}$ & BIA F-21978A & Data presented \\
\hline TEL-00060 & $\begin{array}{l}\text { After } 500 \\
\text { BP }\end{array}$ & 3 & 11.88000000000 & $\begin{array}{l}\text { Single } \\
\text { Room }\end{array}$ & BIA F-21978A & Data presented \\
\hline TEL-00060 & $\begin{array}{l}\text { After } 500 \\
\text { BP }\end{array}$ & 4 & 19.63000000000 & $\begin{array}{l}\text { Single } \\
\text { Room }\end{array}$ & BIA F-21978A & Data presented \\
\hline TEL-00060 & $\begin{array}{l}\text { After } 500 \\
\text { BP }\end{array}$ & 5 & 31.80000000000 & $\begin{array}{l}\text { Single } \\
\text { Room }\end{array}$ & BIA F-21978A & Data presented \\
\hline TEL-00060 & $\begin{array}{l}\text { After } 500 \\
\text { BP }\end{array}$ & 6 & 59.17000000000 & Multi-Room & BIA F-21978A & Data presented \\
\hline TEL-00060 & $\begin{array}{l}\text { After } 500 \\
\text { BP }\end{array}$ & 7 & 28.00000000000 & $\begin{array}{l}\text { Single } \\
\text { Room }\end{array}$ & BIA F-21978A & Data presented \\
\hline TEL-00060 & $\begin{array}{l}\text { After } 500 \\
\text { BP }\end{array}$ & 8 & $\begin{array}{l}105.7900000000 \\
0\end{array}$ & Multi-Room & BIA F-21978A & Data presented \\
\hline TEL-00060 & $\begin{array}{l}\text { After } 500 \\
\text { BP }\end{array}$ & 9 & 67.28000000000 & Multi-Room & BIA F-21978A & Data presented \\
\hline TEL-00060 & $\begin{array}{l}\text { After } 500 \\
\text { BP }\end{array}$ & 10 & 43.00000000000 & Multi-Room & BIA F-21978A & Data presented \\
\hline TEL-00060 & $\begin{array}{l}\text { After } 500 \\
\text { BP }\end{array}$ & 12 & 53.50000000000 & Multi-Room & BIA F-21978A & Data presented \\
\hline TEL-00060 & $\begin{array}{l}\text { After } 500 \\
\text { BP }\end{array}$ & 13 & 37.84000000000 & Multi-Room & BIA F-21978A & Data presented \\
\hline TEL-00060 & $\begin{array}{l}\text { After } 500 \\
\text { BP }\end{array}$ & 14 & 45.20000000000 & Multi-Room & BIA F-21978A & Data presented \\
\hline TEL-00060 & $\begin{array}{l}\text { After } 500 \\
\text { BP }\end{array}$ & 15 & 38.00000000000 & Multi-Room & BIA F-21978A & Data presented \\
\hline
\end{tabular}




\begin{tabular}{|c|c|c|c|c|c|c|}
\hline TEL-00060 & $\begin{array}{l}\text { After } 500 \\
\text { BP }\end{array}$ & 17 & 26.18000000000 & $\begin{array}{l}\text { Single } \\
\text { Room }\end{array}$ & BIA F-21978A & Data presented \\
\hline TEL-00060 & $\begin{array}{l}\text { After } 500 \\
\text { BP }\end{array}$ & 18 & 54.59000000000 & Multi-Room & BIA F-21978A & Data presented \\
\hline TEL-00060 & $\begin{array}{l}\text { After } 500 \\
\text { BP }\end{array}$ & 19 & 43.70000000000 & Multi-Room & BIA F-21978A & Data presented \\
\hline TEL-00086 & $\begin{array}{l}\text { After } 500 \\
\text { BP }\end{array}$ & Feature $7 \mathrm{a}$ & 24.50000000000 & Multi-Room & Schaaf 1988 & Data presented \\
\hline TEL-00086 & $\begin{array}{l}\text { After } 500 \\
\text { BP }\end{array}$ & Feature 8 & 7.36000000000 & Multi-Room & Schaaf 1988 & Data presented \\
\hline TEL-00086 & $\begin{array}{l}\text { After } 500 \\
\text { BP }\end{array}$ & Feature 12 & 19.50000000000 & Multi-Room & Schaaf 1988 & Data presented \\
\hline TEL-00086 & $\begin{array}{l}\text { After } 500 \\
\text { BP }\end{array}$ & Feature 14 & 17.55000000000 & Multi-Room & Schaaf 1988 & Data presented \\
\hline TEL-00086 & $\begin{array}{l}\text { After } 500 \\
\text { BP }\end{array}$ & Feature 3 & 22.00000000000 & Multi-Room & Schaaf 1988 & Data presented \\
\hline TEL-00086 & $\begin{array}{l}\text { After } 500 \\
\text { BP }\end{array}$ & Feature 4 & 8.19000000000 & $\begin{array}{l}\text { Single } \\
\text { Room }\end{array}$ & Schaaf 1988 & Data presented \\
\hline TEL-00087 & $\begin{array}{l}\text { After } 500 \\
\text { BP }\end{array}$ & $\begin{array}{l}\text { Feature 2- } \\
5\end{array}$ & 16.80000000000 & Multi-Room & Schaaf 1988 & Data presented \\
\hline TEL-00087 & $\begin{array}{l}\text { After } 500 \\
\text { BP }\end{array}$ & $\begin{array}{l}\text { Feature } \\
7,9,10\end{array}$ & 16.10000000000 & Multi-Room & Schaaf 1988 & Data presented \\
\hline TEL-00096 & $\begin{array}{l}\text { After } 500 \\
\text { BP }\end{array}$ & Feature 1 & 13.50000000000 & Multi-Room & Schaaf 1988 & Data presented \\
\hline TEL-00096 & $\begin{array}{l}\text { After } 500 \\
\text { BP }\end{array}$ & Feature 10 & 12.00000000000 & Multi-Room & Schaaf 1988 & Data presented \\
\hline TEL-00096 & $\begin{array}{l}\text { After } 500 \\
\text { BP }\end{array}$ & Feature $5 \mathrm{a}$ & 15.20000000000 & $\begin{array}{l}\text { Single } \\
\text { Room }\end{array}$ & Schaaf 1988 & Data presented \\
\hline TEL-00096 & $\begin{array}{l}\text { After } 500 \\
\text { BP }\end{array}$ & Feature $5 b$ & 10.08000000000 & $\begin{array}{l}\text { Single } \\
\text { Room }\end{array}$ & Schaaf 1988 & Data presented \\
\hline TEL-00099 & $\begin{array}{l}\text { After } 500 \\
\text { BP }\end{array}$ & Feature 3 & 7.00000000000 & Multi-Room & Schaaf 1988 & Data presented \\
\hline TEL-00099 & $\begin{array}{l}\text { After } 500 \\
\text { BP }\end{array}$ & Feature 5 & 10.89000000000 & Multi-Room & Schaaf 1988 & Data presented \\
\hline
\end{tabular}




\begin{tabular}{|c|c|c|c|c|c|c|}
\hline TEL-00099 & $\begin{array}{l}\text { After } 500 \\
\text { BP }\end{array}$ & Feature 6 & 17.28000000000 & $\begin{array}{l}\text { Single } \\
\text { Room }\end{array}$ & Schaaf 1988 & Data presented \\
\hline TEL-00099 & $\begin{array}{l}\text { After } 500 \\
\text { BP }\end{array}$ & $\begin{array}{l}\text { Feature 1- } \\
14\end{array}$ & 11.78000000000 & $\begin{array}{l}\text { Single } \\
\text { Room }\end{array}$ & Schaaf 1988 & Data presented \\
\hline TEL-00232 & $\begin{array}{l}\text { After } 500 \\
\text { BP }\end{array}$ & $1 \mathrm{~A}$ & 8.44323000000 & $\begin{array}{l}\text { Single } \\
\text { Room }\end{array}$ & Nuluk Project & GIS measurements \\
\hline TEL-00232 & $\begin{array}{l}\text { After } 500 \\
\text { BP }\end{array}$ & $2 \mathrm{~A}$ & 7.39544000000 & $\begin{array}{l}\text { Single } \\
\text { Room }\end{array}$ & Nuluk Project & GIS measurements \\
\hline TEL-00232 & $\begin{array}{l}\text { After } 500 \\
\text { BP }\end{array}$ & $3 \mathrm{~A}$ & 13.89940000000 & $\begin{array}{l}\text { Single } \\
\text { Room }\end{array}$ & Nuluk Project & GIS measurements \\
\hline TEL-00232 & $\begin{array}{l}\text { After } 500 \\
\text { BP }\end{array}$ & $4 \mathrm{~A}$ & 8.12271000000 & $\begin{array}{l}\text { Single } \\
\text { Room }\end{array}$ & Nuluk Project & GIS measurements \\
\hline TEL-00233 & $\begin{array}{l}\text { After } 500 \\
\text { BP }\end{array}$ & $1 \mathrm{~A}$ & $\begin{array}{l}111.2220000000 \\
0\end{array}$ & $\begin{array}{l}\text { Single } \\
\text { Room }\end{array}$ & Nuluk Project & GIS measurements \\
\hline TEL-00233 & $\begin{array}{l}\text { After } 500 \\
\text { BP }\end{array}$ & $2 \mathrm{~A}$ & 45.63680000000 & $\begin{array}{l}\text { Single } \\
\text { Room }\end{array}$ & Nuluk Project & GIS measurements \\
\hline TEL-00249 & $\begin{array}{l}\text { After } 500 \\
\text { BP }\end{array}$ & $1 \mathrm{~A}$ & 14.42540000000 & $\begin{array}{l}\text { Single } \\
\text { Room }\end{array}$ & Nuluk Project & GIS measurements \\
\hline TEL-00249 & $\begin{array}{l}\text { After } 500 \\
\text { BP }\end{array}$ & $2 \mathrm{~A}$ & 11.09900000000 & $\begin{array}{l}\text { Single } \\
\text { Room }\end{array}$ & Nuluk Project & GIS measurements \\
\hline TEL-00249 & $\begin{array}{l}\text { After } 500 \\
\text { BP }\end{array}$ & $3 \mathrm{~A}$ & 10.54930000000 & $\begin{array}{l}\text { Single } \\
\text { Room }\end{array}$ & Nuluk Project & GIS measurements \\
\hline TEL-00249 & $\begin{array}{l}\text { After } 500 \\
\text { BP }\end{array}$ & $4 \mathrm{~A}$ & 0.67460000000 & $\begin{array}{l}\text { Single } \\
\text { Room }\end{array}$ & Nuluk Project & GIS measurements \\
\hline TEL-00250 & $\begin{array}{l}\text { After } 500 \\
\text { BP }\end{array}$ & $1 \mathrm{~A}$ & 5.31187000000 & $\begin{array}{l}\text { Single } \\
\text { Room }\end{array}$ & Nuluk Project & GIS measurements \\
\hline TEL-00251 & $\begin{array}{l}\text { After } 500 \\
\text { BP }\end{array}$ & $1 \mathrm{~A}$ & 1.46389000000 & $\begin{array}{l}\text { Single } \\
\text { Room }\end{array}$ & Nuluk Project & GIS measurements \\
\hline TEL-00252 & $\begin{array}{l}\text { After } 500 \\
\text { BP }\end{array}$ & $1 \mathrm{~A}$ & 3.13391000000 & $\begin{array}{l}\text { Single } \\
\text { Room }\end{array}$ & Nuluk Project & GIS measurements \\
\hline TEL-00256 & $\begin{array}{l}\text { After } 500 \\
\text { BP }\end{array}$ & & 13.77320000000 & $\begin{array}{l}\text { Single } \\
\text { Room }\end{array}$ & Nuluk Project & GIS measurements \\
\hline TEL-00257 & $\begin{array}{l}\text { After } 500 \\
\text { BP }\end{array}$ & & 3.02080000000 & $\begin{array}{l}\text { Single } \\
\text { Room }\end{array}$ & Nuluk Project & GIS measurements \\
\hline
\end{tabular}




\begin{tabular}{|c|c|c|c|c|c|c|}
\hline TEL-00258 & $\begin{array}{l}\text { After } 500 \\
\text { BP }\end{array}$ & & 3.29509000000 & $\begin{array}{l}\text { Single } \\
\text { Room }\end{array}$ & Nuluk Project & GIS measurements \\
\hline TEL-00260 & $\begin{array}{l}\text { After } 500 \\
\text { BP }\end{array}$ & $1 \mathrm{~A}$ & 6.85063000000 & $\begin{array}{l}\text { Single } \\
\text { Room }\end{array}$ & Nuluk Project & GIS measurements \\
\hline TEL-00260 & $\begin{array}{l}\text { After } 500 \\
\text { BP }\end{array}$ & $2 \mathrm{~A}$ & 3.44095000000 & $\begin{array}{l}\text { Single } \\
\text { Room }\end{array}$ & Nuluk Project & GIS measurements \\
\hline TEL-00263 & $\begin{array}{l}\text { After } 500 \\
\text { BP }\end{array}$ & $1 \mathrm{~A}$ & 5.57867000000 & $\begin{array}{l}\text { Single } \\
\text { Room }\end{array}$ & Nuluk Project & GIS measurements \\
\hline TEL-00263 & $\begin{array}{l}\text { After } 500 \\
\text { BP }\end{array}$ & $2 \mathrm{~A}$ & 4.96776000000 & $\begin{array}{l}\text { Single } \\
\text { Room }\end{array}$ & Nuluk Project & GIS measurements \\
\hline TEL-00264 & $\begin{array}{l}\text { After } 500 \\
\text { BP }\end{array}$ & $1 \mathrm{~A}$ & 14.46940000000 & $\begin{array}{l}\text { Single } \\
\text { Room }\end{array}$ & Nuluk Project & GIS measurements \\
\hline TEL-00264 & $\begin{array}{l}\text { After } 500 \\
\text { BP }\end{array}$ & $2 \mathrm{~A}$ & 2.31564000000 & $\begin{array}{l}\text { Single } \\
\text { Room }\end{array}$ & Nuluk Project & GIS measurements \\
\hline TEL-00264 & $\begin{array}{l}\text { After } 500 \\
\text { BP }\end{array}$ & $3 \mathrm{~A}$ & 2.05634000000 & $\begin{array}{l}\text { Single } \\
\text { Room }\end{array}$ & Nuluk Project & GIS measurements \\
\hline TEL-00269 & $\begin{array}{l}\text { After } 500 \\
\text { BP }\end{array}$ & 1 & 9.89934000000 & $\begin{array}{l}\text { Single } \\
\text { Room }\end{array}$ & Port Clarence Project & GIS measurements \\
\hline TEL-00269 & $\begin{array}{l}\text { After } 500 \\
\text { BP }\end{array}$ & 2 & 27.49700000000 & $\begin{array}{l}\text { Single } \\
\text { Room }\end{array}$ & Port Clarence Project & GIS measurements \\
\hline TEL-00269 & $\begin{array}{l}\text { After } 500 \\
\text { BP }\end{array}$ & 3 & 17.55140000000 & $\begin{array}{l}\text { Single } \\
\text { Room }\end{array}$ & Port Clarence Project & GIS measurements \\
\hline TEL-00269 & $\begin{array}{l}\text { After } 500 \\
\text { BP }\end{array}$ & 4 & 26.43860000000 & $\begin{array}{l}\text { Single } \\
\text { Room }\end{array}$ & Port Clarence Project & GIS measurements \\
\hline TEL-00272 & $\begin{array}{l}\text { After } 500 \\
\text { BP }\end{array}$ & 3 & 13.34460000000 & $\begin{array}{l}\text { Single } \\
\text { Room }\end{array}$ & Port Clarence Project & GIS measurements \\
\hline TEL-00272 & $\begin{array}{l}\text { After } 500 \\
\text { BP }\end{array}$ & 1 & 12.11100000000 & $\begin{array}{l}\text { Single } \\
\text { Room }\end{array}$ & Port Clarence Project & GIS measurements \\
\hline TEL-00273 & $\begin{array}{l}\text { After } 500 \\
\text { BP }\end{array}$ & 5 & 32.65190000000 & $\begin{array}{l}\text { Single } \\
\text { Room }\end{array}$ & Port Clarence Project & GIS measurements \\
\hline TEL-00273 & $\begin{array}{l}\text { After } 500 \\
\text { BP }\end{array}$ & 8 & 16.99770000000 & $\begin{array}{l}\text { Single } \\
\text { Room }\end{array}$ & Port Clarence Project & GIS measurements \\
\hline TEL-00272 & $\begin{array}{l}\text { After } 500 \\
\text { BP }\end{array}$ & 10 & 46.59770000000 & $\begin{array}{l}\text { Single } \\
\text { Room }\end{array}$ & Port Clarence Project & GIS measurements \\
\hline
\end{tabular}




\begin{tabular}{|c|c|c|c|c|c|c|c|}
\hline TEL-00278 & & $\begin{array}{l}\text { After } 500 \\
\text { BP }\end{array}$ & 1 & 27.11730000000 & $\begin{array}{l}\text { Single } \\
\text { Room }\end{array}$ & Port Clarence Project & GIS measurements \\
\hline TEL-00278 & & $\begin{array}{l}\text { After } 500 \\
\text { BP }\end{array}$ & 2 & 20.37500000000 & $\begin{array}{l}\text { Single } \\
\text { Room }\end{array}$ & Port Clarence Project & GIS measurements \\
\hline TEL-00278 & & $\begin{array}{l}\text { After } 500 \\
\text { BP }\end{array}$ & 6 & 10.77090000000 & $\begin{array}{l}\text { Single } \\
\text { Room }\end{array}$ & Port Clarence Project & GIS measurements \\
\hline TEL-00278 & & $\begin{array}{l}\text { After } 500 \\
\text { BP }\end{array}$ & 1 & 27.15880000000 & $\begin{array}{l}\text { Single } \\
\text { Room }\end{array}$ & Port Clarence Project & GIS measurements \\
\hline TEL-00278 & & $\begin{array}{l}\text { After } 500 \\
\text { BP }\end{array}$ & 2 & 20.43860000000 & $\begin{array}{l}\text { Single } \\
\text { Room }\end{array}$ & Port Clarence Project & GIS measurements \\
\hline TEL-00278 & & $\begin{array}{l}\text { After } 500 \\
\text { BP }\end{array}$ & 3 & 15.69160000000 & $\begin{array}{l}\text { Single } \\
\text { Room }\end{array}$ & Port Clarence Project & GIS measurements \\
\hline XBM-00001 & Kavet Creek & $\begin{array}{l}\text { After } 500 \\
\text { BP }\end{array}$ & House $\mathrm{f}$ & 17.32000000000 & Multi-Room & Unpublished NPS data & GIS measurements \\
\hline XBM-00001 & Kavet Creek & $\begin{array}{l}\text { After } 500 \\
\text { BP }\end{array}$ & House $\mathrm{g}$ & 21.88000000000 & Multi-Room & Unpublished NPS data & GIS measurements \\
\hline XBM-00001 & Kavet Creek & $\begin{array}{l}\text { After } 500 \\
\text { BP }\end{array}$ & House $p$ & 24.94000000000 & Multi-Room & Unpublished NPS data & GIS measurements \\
\hline XBM-00001 & Kavet Creek & $\begin{array}{l}\text { After } 500 \\
\text { BP }\end{array}$ & House $\mathrm{r}$ & 28.67000000000 & Multi-Room & Unpublished NPS data & GIS measurements \\
\hline XBM-00001 & Kavet Creek & $\begin{array}{l}\text { After } 500 \\
\text { BP }\end{array}$ & House u & 35.06000000000 & Multi-Room & Unpublished NPS data & GIS measurements \\
\hline XBM-00001 & Kavet Creek & $\begin{array}{l}\text { After } 500 \\
\text { BP }\end{array}$ & House $\mathrm{v}$ & 15.04000000000 & Multi-Room & Unpublished NPS data & GIS measurements \\
\hline XBM-00001 & Kavet Creek & $\begin{array}{l}\text { After } 500 \\
\text { BP }\end{array}$ & House $\mathrm{z}$ & 4.94000000000 & Multi-Room & Unpublished NPS data & GIS measurements \\
\hline XBM-00001 & Kavet Creek & $\begin{array}{l}\text { After } 500 \\
\text { BP }\end{array}$ & House a & 13.15000000000 & $\begin{array}{l}\text { Single } \\
\text { Room } \\
\end{array}$ & Unpublished NPS data & GIS measurements \\
\hline XBM-00001 & Kavet Creek & $\begin{array}{l}\text { After } 500 \\
\text { BP }\end{array}$ & House $\mathrm{b}$ & 10.01000000000 & $\begin{array}{l}\text { Single } \\
\text { Room }\end{array}$ & Unpublished NPS data & GIS measurements \\
\hline XBM-00001 & Kavet Creek & $\begin{array}{l}\text { After } 500 \\
\text { BP }\end{array}$ & House c & 9.76000000000 & $\begin{array}{l}\text { Single } \\
\text { Room }\end{array}$ & Unpublished NPS data & GIS measurements \\
\hline XBM-00001 & Kavet Creek & $\begin{array}{l}\text { After } 500 \\
\text { BP }\end{array}$ & House d & 10.51000000000 & $\begin{array}{l}\text { Single } \\
\text { Room }\end{array}$ & Unpublished NPS data & GIS measurements \\
\hline
\end{tabular}




\begin{tabular}{|c|c|c|c|c|c|c|c|}
\hline XBM-00001 & Kavet Creek & $\begin{array}{l}\text { After } 500 \\
\text { BP }\end{array}$ & House e & 17.28000000000 & $\begin{array}{l}\text { Single } \\
\text { Room }\end{array}$ & Unpublished NPS data & GIS measurements \\
\hline XBM-00001 & Kavet Creek & $\begin{array}{l}\text { After } 500 \\
\text { BP }\end{array}$ & House $\mathrm{h}$ & 29.27000000000 & $\begin{array}{l}\text { Single } \\
\text { Room }\end{array}$ & Unpublished NPS data & GIS measurements \\
\hline XBM-00001 & Kavet Creek & $\begin{array}{l}\text { After } 500 \\
\text { BP }\end{array}$ & House i & 26.69000000000 & $\begin{array}{l}\text { Single } \\
\text { Room }\end{array}$ & Unpublished NPS data & GIS measurements \\
\hline XBM-00001 & Kavet Creek & $\begin{array}{l}\text { After } 500 \\
\text { BP }\end{array}$ & House $\mathrm{j}$ & 15.72000000000 & $\begin{array}{l}\text { Single } \\
\text { Room }\end{array}$ & Unpublished NPS data & GIS measurements \\
\hline XBM-00001 & Kavet Creek & $\begin{array}{l}\text { After } 500 \\
\text { BP }\end{array}$ & House $\mathrm{k}$ & 7.29000000000 & $\begin{array}{l}\text { Single } \\
\text { Room }\end{array}$ & Unpublished NPS data & GIS measurements \\
\hline XBM-00001 & Kavet Creek & $\begin{array}{l}\text { After } 500 \\
\text { BP }\end{array}$ & House 1 & 7.77000000000 & $\begin{array}{l}\text { Single } \\
\text { Room }\end{array}$ & Unpublished NPS data & GIS measurements \\
\hline XBM-00001 & Kavet Creek & $\begin{array}{l}\text { After } 500 \\
\text { BP }\end{array}$ & House $\mathrm{m}$ & 17.72000000000 & $\begin{array}{l}\text { Single } \\
\text { Room }\end{array}$ & Unpublished NPS data & GIS measurements \\
\hline XBM-00001 & Kavet Creek & $\begin{array}{l}\text { After } 500 \\
\text { BP }\end{array}$ & House $\mathrm{n}$ & 9.65000000000 & $\begin{array}{l}\text { Single } \\
\text { Room }\end{array}$ & Unpublished NPS data & GIS measurements \\
\hline XBM-00001 & Kavet Creek & $\begin{array}{l}\text { After } 500 \\
\text { BP }\end{array}$ & House o & 14.71000000000 & $\begin{array}{l}\text { Single } \\
\text { Room }\end{array}$ & Unpublished NPS data & GIS measurements \\
\hline XBM-00001 & Kavet Creek & $\begin{array}{l}\text { After } 500 \\
\text { BP }\end{array}$ & House q & 15.82000000000 & $\begin{array}{l}\text { Single } \\
\text { Room }\end{array}$ & Unpublished NPS data & GIS measurements \\
\hline XBM-00001 & Kavet Creek & $\begin{array}{l}\text { After } 500 \\
\text { BP }\end{array}$ & House $\mathrm{s}$ & 11.36000000000 & $\begin{array}{l}\text { Single } \\
\text { Room }\end{array}$ & Unpublished NPS data & GIS measurements \\
\hline XBM-00001 & Kavet Creek & $\begin{array}{l}\text { After } 500 \\
\text { BP }\end{array}$ & House $t$ & 16.51000000000 & $\begin{array}{l}\text { Single } \\
\text { Room }\end{array}$ & Unpublished NPS data & GIS measurements \\
\hline XBM-00001 & Kavet Creek & $\begin{array}{l}\text { After } 500 \\
\text { BP }\end{array}$ & House $\mathrm{x}$ & 10.55000000000 & $\begin{array}{l}\text { Single } \\
\text { Room }\end{array}$ & Unpublished NPS data & GIS measurements \\
\hline XBM-00001 & Kavet Creek & $\begin{array}{l}\text { After } 500 \\
\text { BP }\end{array}$ & House y & 23.07000000000 & $\begin{array}{l}\text { Single } \\
\text { Room }\end{array}$ & Unpublished NPS data & GIS measurements \\
\hline
\end{tabular}

